Faculdade de Arquitetura e Urbanismo da Universidade de São Paulo Dissertação de Mestrado

\title{
Arte e Paisagem
}

Estudo de obras contemporâneas brasileiras

\author{
Cristiana Bernardi Isaac
}


EXEMPLAR REVISADO E ALTERADO EM RELAÇÃO À VERSÃO ORIGINAL, SOB RESPONSABILIDADE DO AUTOR E ANUÊNCIA DO ORIENTADOR.

O original se encontra disponível na sede do programa

São Paulo, 11 de julho de 2013. 



\section{Cristiana Bernardi Isaac}

\section{Arte e Paisagem}

\section{Estudo de obras contemporâneas brasileiras.}

Dissertação apresentada ao Programa de Pós-graduação da Faculdade de Arquitetura e Urbanismo da Universidade de São Paulo para obtenção do título de Mestre em Arquitetura e Urbanismo.

Área de Concentração:

Projeto, Espaço e Cultura.

Orientadora: Profa. Dra.

Maria Angela Faggin Pereira Leite 


\title{
São Paulo
}

2013

\begin{abstract}
AUTORIZO A REPRODUÇÃO E DIVULGAÇÃO TOTAL OU PARCIAL DESTE TRABALHO, POR QUALQUER MEIO CONVENCIONAL OU ELETRÔNICO, PARA FINS DE ESTUDO E PESQUISA, DESDE QUE CITADA A FONTE.
\end{abstract}

E-MAIL DA AUTORA: criisaac@uol.com.br

\begin{tabular}{|l}
\hline I73a \\
Isaac, Cristiana Bernardi \\
Arte e paisagem. Estudo de obras contemporâneas brasileiras. / \\
Cristiana Bernardi Isaac. --São Paulo, 2013. \\
336 p. : il. \\
Dissertação (Mestrado - Área de Concentração: Projeto, Espaço \\
e Cultura) - FAUUSP. \\
Orientadora: Maria Angela Faggin Pereira Leite \\
1.Paisagem 2.Arte contemporânea - Brasil 3.Land art 4.Arte \\
ambiental 4.Projeto Fronteiras, 1998-2001 6.Projeto Margem, 2009- \\
2010 I.Título \\
CDU 712
\end{tabular}


Nome: ISAAC, Cristiana Bernardi

Título:

Arte e Paisagem. Estudo de obras contemporâneas brasileiras

Dissertação apresentada à Faculdade de Arquitetura e Urbanismo da Universidade de São Paulo para obtenção do título de Mestre em Arquitetura e Urbanismo.

Aprovado em:

Banca Examinadora:

Prof. Dr.

Instituição:

Assinatura:

Prof. Dr.

Instituição:

Assinatura:

Prof. Dr.

Instituição:

Assinatura: 
gráfica Multiofício 
ao meu amado Matheus

que acompanhou este trabalho desde a barriga. 



\section{Agradecimentos}

À Universidade de São Paulo e à Faculdade de Arquitetura e Urbanismo.

Em especial, sou grata à Profa. Dra. Maria Angela Faggin Pereira Leite, pela orientação exigente em todas as etapas deste trabalho e pela confiança, com profunda admiração. Aos professores Dra. Vera Pallamin e Dr. Vladimir Bartalini, integrantes da banca para o exame de qualificação, cujas considerações ajudaram enormemente no amadurecimento desta pesquisa.

Aos artistas que, em entrevistas para esta dissertação, a tornaram mais concreta. A Nelson Félix e Carlos Fajardo, cujas conversas são aulas de arte. À atenção de Eliane Prolik, pelo material que me enviou. A Carmela Gross, Angelo Venosa e José Resende que compartilharam outras de suas obras a fim de ajudar no desenvolvimento deste trabalho e pelas perspicazes observações sobre arte e sobre paisagens. À fala sucinta, e muito relevante para a compreensão da arte em relação à paisagem brasileira, de Nuno Ramos e por apresentar a esta dissertação o seu projeto Cabaré Chinelo. Ao curador Guilherme Wisnik e ao artista Hector Zamora que lançaram luz sobre o projeto Margem. Em especial, à Profa. Dra. Sônia Salzstein pela entrevista e por ter registrado as obras no catálogo Fronteiras (2005), meu ponto de partida para esta pesquisa.

Ao José Francisco Alves de Almeida que compartilhou seus artigos e sua tese de doutoramento, pelos quais pude ter mais acesso às obras, por ter desbravado caminhos.

Ao apoio financeiro da CAPES. Ao prestativo Fernando Galante, da Midiateca do Itaú Cultural.

Também agradeço aos professores da Pós-graduação, com quem cursei disciplinas e que nortearam muitas das ideias aqui presentes: Jorge Bassani, Euler Sandeville Jr., Fábio Mariz Gonçalves, Sérgio Régis Moreira Martins, Agnaldo Aricê Caldas Farias, Carlos Alberto Fajardo e Carlos Roberto Zibel da Costa. 

A vacant white room with lights is still a submission to the neutral [...] Also, I am not interested in art works that suggest "process" within the metaphysical limits of the neutral room. There is no freedom in that kind of behavioral game playing.

[...] Apart from the ideal gardens of the past, and their modern counterparts national and large urban parks, there are the more infernal regions - slag heaps, strip mines, and polluted rivers. Because of the great tendency toward idealism, both pure and abstract, society is confused as to what to do with such places. Nobody wants to go on vacation to a garbage dump. Our land ethic, especially in that never-never land called the "art world" has become clouded with abstractions and concepts.

(Robert Smithson. Cultural Confinement, 1972) 
Uma sala branca, vazia e iluminada é ainda uma submissão à neutralidade [...] Além disso, eu não me interesso por obras que sugerem "processo" dentro dos limites metafísicos da sala neutra. Não existe liberdade neste tipo de comportamento em jogo.

Além dos parques ideais do passado, e suas modernas cópias - grandes parques urbanos e nacionais, existem regiões mais infernais - morros de lixo industrial ou de mineração, áreas descobertas de mineração, rios poluídos. Devido à grande tendência ao idealismo, igualmente puro e abstrato, a sociedade fica confusa sobre o que fazer com tais lugares. Ninguém quer sair de férias em um depósito de lixo. Nossa ética em relação à terra [ao lugar], especialmente neste lugar dos sonhos que se chama "mundo da arte", se tornou confuso com abstrações e conceitos.

(Robert Smithson. Confinamento Cultural, 1972) [tradução nossa] 


\section{RESUMO}

Este trabalho disserta sobre as relações entre a arte contemporânea brasileira e a paisagem, através de algumas obras que nela intervieram diretamente, assim como de projetos que se propunham a intervir, mas não foram executados. Tais obras, ao incorporarem os elementos naturais e culturais que constituem a paisagem, a evidenciam e fazem-nos refletir sobre sua formação, transformação e apreciação.

Foram escolhidas duas exposições que, a princípio, seriam realizadas em escala nacional e que propuseram de modo mais efetivo a intervenção da arte brasileira na paisagem, estimulando discussões sobre o tema. São elas: projeto Fronteiras (1998-2001), que abordou as referências geográficas da paisagem, e projeto Margem (2009-2010), cujas referências eram as urbanas.

Com Fronteiras, a partir do tema que dá nome ao projeto, abre-se o debate sobre território, região, escala geográfica e modos de ocupação territorial; a arte, por sua vez, introduz nele a necessidade da paisagem. Já com Margem, vêm à tona questões da paisagem urbana, em específico, como os rios são apropriados e percebidos.

Esta é uma amostragem de obras que, abordando referências distintas da paisagem, fazem-nos refletir sobre a produção artística nacional que tem na paisagem mais do que uma inspiração, mas um elemento constitutivo; assim como de que modos a paisagem é, possivelmente, uma influência para estas obras.

\section{Palavras-chave}

Paisagem; arte; arte contemporânea brasileira; land art; projeto Fronteiras (19982001); projeto Margem (2009-2010); arte ambiental. 


\section{ABSTRACT}

This research disserts about the relationship between brazilian contemporary art and landscape, regarding some works of art that interfered directly in it, as well as projects that intended to do it, but were not accomplished. These works, as they incorporate natural and cultural aspects of the landscape, they emphasize it and raise a debate on its development, transformation and appreciation.

Two expositions - which were to be taken, at first, in national scale - more effectively proposed the intervention of brazilian contemporary art into the landscape and stimulated discussions on these matters. They are: Fronteiras (1998-2001), which approached the geographical landscape references, and Margem (2009-2010), which focused the urban ones.

Within Fronteiras, from the boundary theme, the discussion arises on territory, region, geographical scale and models of territorial occupation; nevertheless, art introduces the need of landscape in this debate. Margem brings up issues related to the urban landscape, specifically how rivers are appropriated and apprehended by people.

This is a sample of works of art that approach landscape in different ways, which lead us to consider how brazilian contemporary art handles landscape, not only as an inspiration, but as a constitutive component of the work; they also highlight how landscape might be, possibly, an influence on them.

\section{Key words}

Landscape; art; brazilian contemporary art; land art; projeto Fronteiras (1998-2001); projeto Margem (2009-2010); environmental art. 


\section{Lista de imagens}

\section{CAPÍTULO 1. Relações arte e paisagem. Campo de influências mútuas}

01. Programação Cromática do Complexo Viário João Jorge Saad.

Parque das Cores do Escuro, 2002.

02. Double Negative, $1969-70$. 16,70

03. 12 hours Tide Objects with Correction of Perspective, 1969.

04. Running Fence, 1972-76.

20,34

05. Wool Spread Over Short Sheep-Grazed Grass, 1997. 22

06. Mono Lake, Filme Super 8, 1968. 23

07. 7000 Carvalhos, 1982-86. 24,66

08. Cartaz Documenta $7,1982$. 25

09. Do It Yourself (Seascape), 1962. 26

10. Noturno: azul e dourado, 1872-75. 27

11. A condução de volta ao lar, 1973. 27

12. Paisagem com sacrifício a Apolo, 1662. 33

13. The Blue Rigi, Sunrise, 1842. 33

14. Passagem do Cortejo Real na Ponte do Maracanã, 1817-20. 38

15. Floresta Reduzida a Carvão, 1830. 38

16. Vista do Pontal de Icaraí, 1884. 40

17. Paisagem com Rio e Barco ao Seco em São Paulo "Ponte Grande", 1895. 40

18. Leste Maravilhosa, 2003. 42

19. Camiri, Helka, 2009. 43

20. Sun Tunnels, 1973-76

21. The Lightning Field, 1977. 44

22. Idem 44

23. A line made by walking, 1967. 45

24. Oolite island, 1971. 45

25. Levitated Mass, 1969-2012. 


\section{CAPÍTULO 2. A arte contemporânea da paisagem.}

26. Spiral Jetty, $1970 . \quad 59,70$,

\begin{tabular}{lr} 
27. Perimeters/Pavillions/Decoys, 1978. & 103 \\
\hline 28. Alpi Marittime, 1968 & 71 \\
\hline 29. A Ten Mile Walk, England, 1968. & 78 \\
\hline 30. Las Vegas Piece, 1969. & 79 \\
\hline 31. Accumulation Cut, 1969. & 85 \\
\hline 32. Ash Dome, $1977-2006$. & 85 \\
\hline 33. Maple leaves, 1991. & 86 \\
\hline 34. Annual Rings, 1968. & 86 \\
\hline 35. Observatory, 1971 & 86 \\
\hline 36. Valley Curtain, $1970-72$ & 87 \\
\hline 37. Dissipate, 1968. & 87 \\
\hline 38. Complex One /City, $1972-76$. & 88 \\
\hline 39. Non-site (Franklin, New Jersey), 1968 & 88 \\
\hline 40. A Line of 682 stones, 1976 & 88 \\
\hline 41. A Line in The Himalayas, 1975. & 88 \\
\hline 42. One Hour Run, 1968 . & 89 \\
\hline 43. Mile Long Drawing (ou Two Parallel Lines), 1968 & 89 \\
\hline
\end{tabular}

44. No Talking for Seven Days (walking for seven days in a wood Januart Full Moon Cairngorms, Scotland, 1993)

45. Land, Sea and Air II, 1982

46. Time Landscape, 1969-78. 91

47. Wheatfield, 1982. 92

48. Intervenção em King Country, 1979.

49. Revival Fields. 1992-atual 93

50. Tate Thames Dig, 1999-2000. 94

51. Pool of Virgin Earth, 1975.

52. Perspective Correction (Square with two diagonals) 96

53. A Metre of Jungle, 1992

54. Double Sunset, 2000. 97

55. A Tour of the Monuments of Passaic, 1967.

56. Asphalt Rundown, $1969 . \quad 102$ 
CAPÍTULO 2. A arte contemporânea da paisagem. (continuação)

\begin{tabular}{|c|c|}
\hline 57. Broken Circle, 1971 & 104 \\
\hline 58. Spiral Hill, 1971 & 105 \\
\hline 59. Croqui de Broken Circle e Spiral Hill, 1971 & 105 \\
\hline 60. Bingham Copper Mining Pit-Utah / Reclamation Project, 1973 & 106 \\
\hline 61. Paisagismo Martha Schwartz. Recuperação de Terras de Mineração. & 107 \\
\hline 62. A Line in Scotland, Cul Mor, 1981. & 110 \\
\hline 63. Sahara Line, 1988. & 111 \\
\hline 64. São Paulo, 1924 & 118 \\
\hline 65. Rio de Janeiro, 1923. & 118 \\
\hline 66. Paisagem de Minas, década de 1940 & 119 \\
\hline 67. Noite de São João, 1961 & 119 \\
\hline 68. Projeto Paisagismo Residencial Burle Marx, 1948. Califórnia EUA & 120 \\
\hline 69. Paisagismo Burle Marx Banco Safra, São Paulo, 1982 & 120 \\
\hline 70. Calçadão de Copacabana & 121 \\
\hline 71. Intervenção na Rua Gaspar Lourenço, Vila Mariana, São Paulo. 1972. & 122 \\
\hline 72. Ensacamento, 1979 . & 124 \\
\hline 73. Situação T.E. - trouxas ensanguentadas, 1970 & 124,195 \\
\hline $\begin{array}{l}\text { 74. Pedra fundamental para implantar Pavilhão Krajcberg, Parque do } \\
\text { Carmo, } 2009 \text {. }\end{array}$ & 130 \\
\hline 75. Esculturas no Instituto Frans Krajcberg Curitiba, em 2006 & 130 \\
\hline 76. Floração, 1968. & 130 \\
\hline 77. Flor do Mangue, 1970 . & 130 \\
\hline 78. Fotografias de queimadas, 2008 & 131 \\
\hline 79. Tropicália PN2 e PN3, 1967 & 131 \\
\hline 80. Tropicália, montagem em 1969. & 133 \\
\hline 81. Éden, montagem 1969. & 133 \\
\hline 82. Tropicália, montagem 2005. & 134 \\
\hline 83. Projeto Éden, 1969 & 135 \\
\hline 84. Maquete Magic Square, 1978. & 135 \\
\hline 85. Magic Square \# 5, DeLuxe, 1977 & 135,136 \\
\hline 86. Pets, 2008 & 139 \\
\hline 87. Suco Gástrico, 2008 & 140 \\
\hline
\end{tabular}




\section{CAPÍTULO 2. A arte contemporânea da paisagem. (continuação)}

88. Olhos Atentos, 2005

140,141

89. Reportagem sobre a obra Olhos Atentos.

90. Espelho Rápido, 2005

91. Paisagem, 2005

92. Cascata, 2005

93. Projeto Paredes Pintura, Jardim Santo André, 2009.

94. Projeto Paredes Pintura, Jardim Miriam, 2002.

95. Natureza Urbana \#2. Caçambas Verdes, 2008.

96. Eu só vendo a vista, 1999.

\section{CAPÍTULO 3. Projetos Fronteiras e Margem: lugares de transição}

97. Fotografia Rio Uruguai, Itapiranga, SC.

98. Errante, 2010

272,277 ,

99. Apresentação rojeto Fronteiras, sítio eletrônico. 1998

100. Fotografias de Barra do Quaraí, 1998 156

101. Rura mihi et silentium, 1612. 160

102. Fotografia índios Tapuias, Manaus, AM. C1865 161

103. Fotografia Rio de Janeiro, RJ. 1885. 161

104. Fotografia de Cruzeiro do Sul, Acre. 1998. 162

105. Fotografia de São Borja, RS. 1998 162

106. Fotografias de Santana do Livramento, RS. 1998 162

107. Cordões $30 \mathrm{Km}, 1969$ 178

108. Mutações Geográficas: Fronteira Rio-São Paulo, 1969. 178

109. Condensado II - Mutações Geográficas: Rio-São Paulo, 1970. 179

110. Dirty Water Initiative, 2005. 180

111. Time Line, 1968.

112. Illegal Border Crossing Between Austria and the Principality of Liechtenstein, 1993.

113. Left and opposite, 1968.

114. Green-River Project, 1998-2001. 
CAPÍTULO 3. Projetos Fronteiras e Margem: lugares de transição. (continuação)

115. Waterfalls Project, 2008-2012.

188,189

116. Beacon Point, 1999-2007.

117. Ritual de Entrega de uma Zona de Sensibilidade Imaterial, 1962.

118. Floating Island to Travel Around Manhattan Island, 1970-2005.

119. Estação de Tratamento de Água do Reno, 1972.

120. Badeschiff, 2004-atual.

121. Caiaques, 2008.

122. MMMM7, 2006.

CAPÍTULO 4. As obras de Fronteiras (1998-2001)e de Margem (2009-2010).

123. Minuano, 2000

124. O Aleph, 1999.

125. Projeto de O Aleph, 1999.

126. Fotografia Obra em Execução, 1999 215

127. Fotografia Parque do Batuva, 2010. 216

128. Foto Aérea do Parque do Batuva. Santana do Livramento, RS, 2003 217

129. Pavilhão Brasileiro. $45^{\mathrm{a}}$ Bienal de Veneza, 1993 218

130. Croqui Cruz na América, 2012 220

131. Mesa, 1999. 220, 221, 223, 228

132. Cruz na América, anotações do artista, 2011. 222

133. O Grande Budha, 1985-2000. 223

134. Vazio Coração / Deserto do Atacama, s.d. 224

135. Vazio Coração / Litoral, S.D. 224

136. Projeto de Sem título, 2000. 228

137. Sem título, 1993-2001. 229,236

284

138. Sem título (maquete), 1999. 231

139. Imagens Google Earth, Praia do Mar Grosso, Laguna, SC. 2009 e 2012 E vista aérea Praia do Mar Grosso, Laguna, 2003. 


\section{CAPÍTULO 4. As obras de Fronteiras (1998-2001)e de Margem (2009-2010). (continuação)}

140. Minuano, fotografia em 2010.

141. Projeto de Momento de fronteira (escultura), 2000. 243

142. Livro-objeto Momento de fronteira, 2000. 244

143. Momento de fronteira, $2000.244,247$,

\begin{tabular}{lr} 
144. Pálio I , 1996-1999. & 285 \\
\hline
\end{tabular}

145. Canteiro entre Avenida Brasileira e Paraguaia. Ponta Porã, MS. 2012.

146. Pálio I, Canteiro de Obras, 1999.

$\begin{array}{ll}\text { 147. Pálio II, 1996-1999. 253, } 254 & \end{array}$

148. Projeto de Fronteira, Fonte, Foz, 2000

149. Imagens Google Earth, Laguna, SC, 2009 e 2012.

150. Fronteira, Fonte, Foz, $2001 . \quad 257,258$,

$\begin{array}{r}266 \\ \hline\end{array}$

151. Estudos para Fronteira, Fonte, Foz. 261

152. O Evanescente, 2001.

153. Projetos de José Resende para Fronteiras. 264

154. A L'Heure de L'Observatoire Les Amoureux, 1933.

$\begin{array}{ll}\text { 155. Três livros e meio, } 2000 & 267,268\end{array}$

156. Folder MARGEM - Errante, 2010

157. Ruínas do Casarão, à margem do Rio Negro, Manaus, 2009.

158. Projeto Cabaré Chinelo. Desenhos e fotos (arquivo Nuno Ramos) $\quad 280$ a 282

159. Baleia, $1990 \quad 286$

160. Escultura para o Rio, 1996.

161. Canteiro de Operações, $2012 . \quad 287,288$

162. Cubo de Tijolos. Bienal de Veneza, 1993

163. Marécaixão, 2000.

164. Canto I, 1992

165. BLEUJAUNEROUGEROUGE, $2004 \quad 289$

166. Topografia Volátil, 2006.

167. Ao Ar Livre. Projeto de Ocupação de Outdoors.

R. da Consolação, São Paulo. 1981-82. 


\section{SUMÁRIO}

\section{APRESENTAÇÃO}

\section{INTRODUÇÃO}

Por uma paisagem receptiva à arte. Por uma arte possível na paisagem.........01

\section{CAPÍTULO 1}

Relações arte e paisagem. Campo de influências mútuas. .09

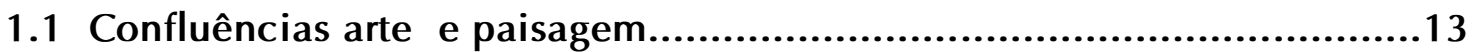

1.2 Influências da paisagem na arte ou quando a arte vai rumo à paisagem..28

1.3 Paisagem-Natureza.

\section{CAPÍTULO 2}

A arte contemporânea da paisagem.......................................................59

2.1 Land Art: arte da paisagem nos EUA e Europa.....................................62

Diferentes formas da arte da paisagem.

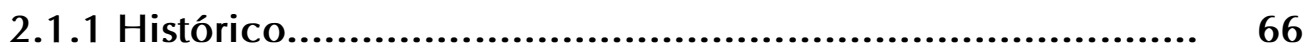

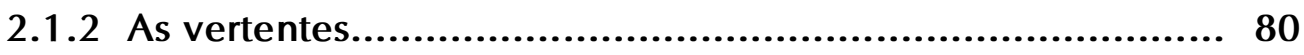

2.2 Arte contemporânea da paisagem no Brasil: um breve histórico...........113

2.2.1 A ideia de paisagem na arte moderna brasileira e a ida à paisagem na arte contemporânea....................................................116

2.2.2 Precursores: Frans Krajcberg e Hélio Oiticica...................... 127

2.2.3 Iniciativas no Brasil: Fronteiras, 5ª Bienal do Mercosul, Quase

Líquido, Margem......................................................................136

\section{CAPÍTULO 3}

Projetos Fronteiras (1998-2001) e Margem (2009-2010): lugares de transição

3.1 Fronteiras nas Artes Plásticas (1998-2001): seu contexto no projeto

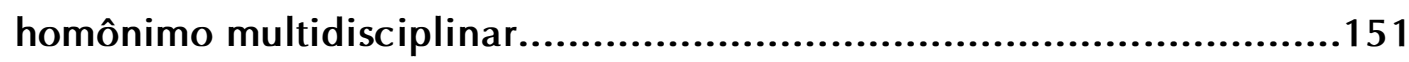

3.1.1 Descolando espaços: território e paisagem; geografia e paisagem......163 
3.2 Projeto Margem (2009-2010): seu contexto no projeto multidisciplinar..171

3.3 Fronteiras e territórios na arte contemporânea da paisagem.

3.4 Rios na arte contemporânea da paisagem.................................. 184

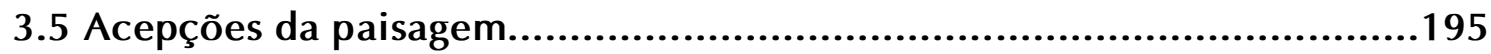

\section{CAPÍTULO 4}

As obras de Fronteiras (1998-2001) e de Margem (2009-2010)..........203

4.1. As obras do projeto Fronteiras (1998-2001) e como os artistas abordaram a paisagem.......................................................208

4.1.1 Angelo Venosa. O Aleph, 1999...................................210

4.1.2 Nelson Felix. Mesa, 1999..........................................218

4.1.3 Carlos Fajardo. Sem Título, 1993/2001..........................228

4.1.4 Nuno Ramos. Minuano, 2000......................................237

4.1.5 Waltércio Caldas. Momento de fronteira, 2000..................243

4.1.6 Eliane Prolik. Pálio I e II, 1996/1999...............................249

4.1.7 Carmela Gross. Fronteira, Fonte, Foz, 2001.....................255

4.1.8 José Resende. O Evanescente, 2001 ................................262

4.1.9 Artur Barrio. Três livros e meio, 2000...............................266

4.2. As obras do projeto Margem (2009-2010) e como os artistas abordaram a

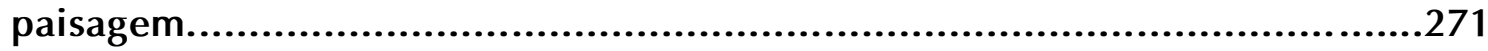

4.2.1 Hector Zamora. Errante, 2010.................................272

4.2.2 Nuno Ramos. Cabaré Chinelo, 2009..............................278

CONSIDERAÇÕES FINAIS. A paisagem em debate na arte.................291

ANEXO I

Entrevistas.

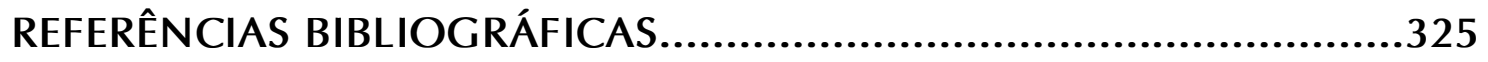




\section{Apresentação}

Esta dissertação teve, desde o início, o propósito de estudar as aproximações e afinidades entre arte e paisagem através de obras da arte pública contemporânea brasileira. No entanto, a princípio, abordava obras cuja relação com a paisagem passava pelas semelhanças e ambiguidades com o projeto de paisagismo.

Com o desenvolvimento deste trabalho, foi essencial rever a compreensão e amplitude do conceito de paisagem que não mais cabia àqueles exemplos. As questões naturais e culturais da paisagem - da forma às condições socioeconômicas - tornaram-se visíveis em outros exemplos da nossa arte contemporânea, assim como, com intensidades diversas, interferiram na concepção ou na leitura das obras.

Diante deste quadro, ampliou-se a possibilidade de escolha das obras, sendo que minha seleção se deu a partir do acesso às suas informações em catálogos e livros. Muitas obras são tão efêmeras que nada deixam como registro, quase como as metamorfoses das nossas paisagens.

Sempre me interessei pela land art, essa arte que nos leva em direção à paisagem. Busquei, então, estudar obras brasileiras que, de modo correlato, também abarcassem a paisagem como referência e como o seu próprio suporte.

Se antes desta pesquisa eu a apreciava por suas formas, por sua liberdade de se inserir

além dos lugares convencionados da arte - galerias e museus - e através dela admirava e imaginava transformações em paisagens; no decorrer deste trabalho, passei a compreendê-la também por seus significados que derivam da história, dos símbolos, e do imaginário da paisagem em que intervêm, assim como pela complexidade desta arte de se formular em meio à trama social e política de suas paisagens.

No Capítulo 01, serão abordados pontos de convergência nas acepções da arte e da paisagem e as similaridades de suas apreciações. Antes de nos atermos aos exemplos brasileiros e contemporâneos é importante revermos como a arte influenciou - direta e indiretamente - na formação de paisagens, assim também, como a paisagem nutriu a arte como tema, como espelhamento da organização social ou das emoções humanas e como meio 
direto da obra. Serão abordados os processos de "artialização": a percepção e formação da paisagem segundo valores artísticos. Neste capítulo, como um panorama das artializações, são comentados exemplos estrangeiros e brasileiros a fim de ampliar o debate sobre as representações, idealizações e intervenções diretas da arte na paisagem. Também veremos que, em muitas narrativas, os sentidos de paisagem e natureza convergem, e por isso nos deteremos nestas tangências. A natureza parece ser, muitas vezes, o grande elo da arte com a paisagem. Em Fronteiras, por exemplo, boa parte das obras foca nos elementos naturais e, em Margem, são os rios que servem de tema.

No Capítulo 02, será apresentado o histórico da arte contemporânea da paisagem - da land e environmental art. Um fenômeno que surge na década de 1960 em diferentes países que, a partir de então, não deixaram de produzir e pensar uma arte engajada com questões da natureza e transformações da paisagem, uma arte que apresenta diferentes formas. Assim também, de que modo surgem exemplos similares desta arte no Brasil. Para tanto, sob o viés da história da arte, veremos os antecedentes e as vertentes desta arte, que se faz a partir da paisagem, tanto nos países que promoveram a land art quanto no Brasil.

No Capítulo 03, analisaremos as duas exposições brasileiras que integraram projetos multidisciplinares com a intenção de relacionar a arte contemporânea com todo o território nacional. São elas: Fronteiras (1998-2001) e Margem (2009-2010). Para a análise de Fronteiras, cuja referência conceitual é o território, vamos discorrer sobre as diferenças entre território e paisagem e suas respectivas acepções. Principalmente, como as obras instauraram a paisagem em lugares e circunstâncias limites nas áreas da nossa fronteira continental. Já para a análise de Margem (2009-2010), o debate sobre as interações entre sociedade e natureza evidenciaram, através dos rios, a paisagem. Paralelamente, serão comentadas algumas obras estrangeiras para visualizarmos que estas referências - geográficas e urbanas - da paisagem têm motivado, há décadas, a arte contemporânea da paisagem. Neste ponto, tendo definido a arte contemporânea ligada às questões da paisagem, e como ela se manifesta, nos deteremos às acepções da paisagem.

Após compreendermos as premissas destas exposições, no Capítulo 04 serão abordadas as obras e projetos que delas participaram, incluindo a fala dos artistas sobre suas obras e sobre a paisagem, em narrativas que, por vezes, se interceptam. Veremos através da diversidade de formas que as obras assumem e das poéticas em que se inspiram, alguns modos de a arte incorporar ou abordar a paisagem, quer seja como uma totalidade em sua experiência sensível, quer seja através de alguns de seus elementos, indo da contemplação à crítica ao seu processo de produção. 
Em Considerações Finais, veremos que o tema da paisagem e da natureza esteve em destaque em recentes exposições das artes plásticas no Brasil. Nossos exemplos da arte contemporânea da paisagem compartilham similaridades com obras da land art, mas também apresentam aspectos distintos em relação a ela. Tais aspectos serão aqui retomados, uma vez que incluem o debate sobre o quão significativos são os lugares na qualificação da paisagem e da arte contemporânea da paisagem. 



\section{Introdução}

\section{Por uma paisagem receptiva à arte. Por uma arte possível na paisagem.}

Este trabalho investiga os modos pelos quais a arte brasileira contemporânea ${ }^{1}$ aborda as questões da paisagem - da apreciação à experiência da paisagem - ou reflete sobre seus modos de produção. Em específico, serão analisadas obras que se relacionam diretamente com a paisagem, e não por representação ${ }^{2}$, tomando partido tanto de suas características físicas (morfologia, materialidade) quanto das características humanas (histórica, cultural).

Tais obras fazem parte de uma arte que teve início na década de 1960 intervindo em lugares, que não galerias ou museus e, principalmente, refletindo a complexidade de nossas relações com a paisagem ${ }^{3}$. Na década de 1970, ela foi batizada de land art. No Brasil, não houve um agrupamento de obras sob este (ou similar) título, no entanto há obras que compartilham afinidades ao incorporarem a paisagem para a obra em si ou para seu discurso. Por isso, as tratarei por arte contemporânea da paisagem.

Tufnell (2006) apresenta que a paisagem para a land art não é um cenário, mas um componente ativo: a obra enfatiza a paisagem em que se situa.

Land art is primarily physical and non-representational [...] It's not simply sculpture placed in the landscape but encompasses an attitude to the site and experience that goes beyond the object, emphasizing the landscape in wich it is sited, often bringing it within the compass of the work and so rendering it an active component rather than merely a setting. (TUFNELL, Land Art. 2006, p. 16). ${ }^{4}$

\footnotetext{
1 Por arte contemporânea entende-se uma produção artística, que tem início na década de 1960, que rompe com as categorias pintura, desenho, escultura e aproxima-se dos objetos e ações cotidianos. Tal expansão dos contornos da arte, em especial da escultura, é analisada por Rosalind Krauss em Sculpture in the expanded field (1979) e é levada às últimas consequências pela Land Art, em que a arte abarca a exterioridade, a totalidade da paisagem. Este assunto será abordado no Capítulo 02.

2 Não serão abordadas obras que ilustram a paisagem, o que exclui uma produção vasta de pinturas, desenhos e fotografias, uma vez que "paisagem" já era um tema caro à arte brasileira desde o início do século XIX com o início da Academia de Arte no Brasil. Um histórico faria até mesmo remontarmos ao século XVII, com as pinturas de paisagem de Frans Post, as primeiras da América.

3 TUFNELL, Ben. Land Art. London: Tate Publishing, 2006, p.15.

4 "A arte da paisagem é essencialmente física e não-representacional [...]Não é simplesmente a escultura situada na paisagem, mas abarca uma atitude em relação ao lugar e uma experiência que vai além do
} 
A experiência da paisagem é abarcada pela obra assim como podem ser suas representações, aspectos físicos, simbólicos ou históricos. Em suma, a paisagem torna-se para esta arte um elemento constitutivo, indissociável.

Esta produção artística não é autorreferencial, a exemplo de monumentos, murais, graffiti e esculturas inseridos no espaço público e que dialogam com processos que são próprios da arte, de sua história, técnica ou linguagem. A arte da paisagem, diferentemente, parece estar atenta ao que lhe circunda. Ela apresenta um olhar paysagère, nos termos de Berque $^{5}$. Por vezes ela se torna híbrida em relação aos elementos do lugar e do entorno, ao se diluir ou abarcar as ações, objetos e a natureza que formam a paisagem. Por vezes, se insere mais marcadamente na paisagem, mas, do mesmo modo, acaba por ressaltá-la. A obra é parte daquele lugar e seu entorno não como adição, mas como continuidade da paisagem.

Sua ação na paisagem pode ser tanto temporária como permanente. Pode ser intervencionista - através de uma relação dialética ${ }^{6}$ entre tecnologia e natureza - ou de natureza efêmera e sutil, fazendo prevalecer ações na escala e com a força humana. De todos os modos, faz nossa percepção se voltar para o lugar, talvez de maneira renovada, assim como traz para a arte o repertório cultural da paisagem.

A fim de delimitar os exemplos da nossa arte contemporânea da paisagem, serão analisadas as obras que integraram as exposições Fronteiras (1998-2001) e Margem (2009-10), atentando em como cada obra comenta a paisagem enquanto composição, valoriza seus elementos naturais e/ou faz críticas quanto às condições sociais, políticas e culturais do lugar que ocupa, tornando-nos mais conscientes dos aspectos factuais e sensíveis da paisagem que habitamos ou daquela que desejamos.

objeto, enfatizando a paisagem em que se situa, frequentemente trazendo-a para dentro dos limites (do contorno) da obra e, então, tornando-a um componente ativo mais que um mero pano-de-fundo"

5 Para os propósitos deste trabalho, adotarei o termo "paysagère", de Augustin Berque, ao invés de "paisagístico" referindo-me ao olhar impregnado de paisagem, com a intencionalidade de vê-la, "[...] um pensamento paysagère não necessita necessariamente de palavras. Prova é que na Europa, as primeiras populações vindas da África até a Renascença, viveram de uma maneira tão paysagère que nos deixaram paisagens admiráveis, isso na total ausência de um pensamento sobre a paisagem" BERQUE, Augustin. La Pensée Paysagère. Paris: Archibooks, 2008, p. 9. apud MARIA, Yanci L., 2010, p. 125)

6 Segundo Crawford, a relação dialética entre tecnologia e paisagem nasce de uma tensão de forças que cria um terceiro objeto, este sim alvo da apreciação estética e, como exemplos, cita as obras americanas Running Fence (1972-76) de Christo Jeanne-Claude e a Spiral Jetty (1970) de Robert Smithson. CRAWFORD, Donald W. Comparing natural and artistic beauty. In: KEMAL, S.; GASKELL, I. (org.) Landscape, natural beauty and the arts, 1995, p. 194. 
Em relação à paisagem, como fonte de interesse para a arte brasileira, parece haver um certo descompasso na passagem da arte moderna para a arte contemporânea. Os movimentos emancipatórios da arte nacional, desde o Romantismo, durante o Brasil Império, até a Semana de Arte Moderna de 1922, liderada pelas vanguardas modernistas, buscaram na natureza e na paisagem a essência para se (re)descobrir uma nação com identidade e linguagem artística próprias. Assim, vemos paisagens brasileiras nas pinturas de Tarsila do Amaral ou de Alberto da Veiga Guignard (para não citar os outros tantos pintores do período). Já com os artistas precursores da arte contemporânea, como Frans Krajcberg e Helio Oiticica, a natureza e a paisagem continuam a ser temas de grande destaque, contudo, deixam de representar aspirações do futuro, evidenciando de maneira crítica processos culturais de apropriação da natureza e produção da paisagem.

Sobretudo, é com estes artistas que a paisagem e a natureza tornam-se suporte para a arte. Suas obras já lançavam olhares críticos sobre o disparate de a "natureza" incorporar, ao mesmo tempo, o mote da identidade nacional e ser objeto de extrativismo e devastação. Mas, no decorrer da formação da arte contemporânea brasileira, a paisagem e a natureza aparecem menos presentes e, talvez, menos importantes diante da prioridade dos debates artísticos que se voltavam para questões de enfrentamento político ou focavam nos fenômenos da urbanização, industrialização e dos novos meios de comunicação. Fronteiras e Margem são exposições sintomáticas neste sentido, pois se referem à paisagem mas não a abordam em suas premissas.

Surge, então, o questionamento desta investigação, uma inquietude por não compreender por que nesta passagem da arte moderna para a contemporânea, a paisagem perde sua força, sua presença no imaginário. Seriam nossas paisagens mais mitificadas e menos vivenciadas?

Quando da passagem da arte tridimensional (escultura) à espacial (a exemplo de obras que são específicas de um lugar [site-specific]), momento propício para a realização da arte através da paisagem, esta arte parece, contudo, se dispersar.

O questionamento referido é intensificado se considerarmos que, em meados da década de 1960, momento de formação da arte contemporânea tanto estrangeira quanto nacional, os expoentes tradicionais da arte ocidental, Europa e EUA, e também o Japão - a 
partir de 1968, com o Movimento Mono- $h a^{7}$ - voltavam-se para a expansão de territórios na arte (territórios reais e virtuais) ocupando ou tratando dos temas paisagem natural, paisagem periférica, paisagens em processo de urbanização e urbana. Enquanto isso, o Brasil, com sua vastidão territorial e sendo foco de interesses ambientais parece não ter sido um campo fecundo para pesquisas ou experimentações da arte na paisagem.

Tufnell $^{8}$ ressalta que, no surgimento da land art (em particular a partir de 1968), questões ecológicas ganharam espaço e organizações em prol do meio ambiente se formaram dentro de setores da sociedade e tornaram-se proeminentes, como o Friends of The Earth (1969). Interesses sociais, políticos e culturais espelham-se na arte, assim como neste período. Wallis ${ }^{9}$, ao introduzir "Land and Environmental Art" cita o evento de alcance mundial, a ECO 92, no Rio de Janeiro, como um ponto de inflexão sobre como, até então, se davam os interesses por questões da paisagem e do ambiente e como, a partir daí, atitudes mais engajadas com estas questões são assumidas por alguns artistas que passaram a ser chamados de environmental artists.

Podemos dizer que, de certo modo, a arte contemporânea da paisagem no Brasil, desperta a partir deste evento e, talvez não por coincidência, é a partir dos anos 1990 que o tema da paisagem - já adentrando questões ecológicas e ambientais - aparece em exposições temáticas. ${ }^{10}$ Saltamos de uma reflexão continuada de como nossas paisagens têm se formado para questões ambientais mundiais através da arte.

Questões da paisagem despertaram o interesse das ciências sociais em diferentes países, colocando sob uma lente de aumento - evidenciando, criticando, refletindo ou apenas recriando - a relação entre a sociedade e a natureza através de diferentes formas e procedimentos. No Brasil, o estudo da paisagem também ganhou a simpatia das ciências humanas, como antropologia, arquitetura, história e psicologia. A arte nunca esteve fora destas reflexões sociais.

\footnotetext{
7 O Movimento Mono-ha se inicia em 1968 no Japão e incorpora conceitos do xintoísmo à natureza.Os artistas trabalham com elementos da natureza em galerias ou agem transgredindo a ocupação do espaço público. Vide Sekine Nobuo "Phase 1 - Mother Earth".
}

8 TUFNELL, 2006, p. 13.

9 KASTNER, Jeffrey; WALLIS, Brian. Land and Environmental Art. Londres: Phaidon Press, 1998, p. 22.

10 Poéticas da Natureza, Arte e Natureza, Ecológica, Arte Frágil Resistências - que serão abordadas em Considerações Finais. É a partir da década de 1990 que exposições tratariam da arte na paisagem a partir de diretrizes de instituições, como o projeto Fronteiras que faz a mediação entre os projetos de nove artistas em locais diversos na fronteira Brasil e Mercosul, e o projeto Margem. 
O termo "arte contemporânea da paisagem" tem como referência conceitual definições encontradas na bibliografia sobre land e environmental art. Esta arte foi mais intensa em alguns países - EUA, Inglaterra, Alemanha e Holanda - a partir do final dos anos 1960, e foi nomeada de earthworks, earth art, landscape art, land art. ${ }^{11}$ Posteriormente surgiram ramificações como a Environmental Art e até Eco Art. Tomarei o seu significado de modo abrangente: uma arte que atenta para a paisagem, que tem nela sua inspiração ou motivação crítica, e que sugere uma reflexão sobre a interação entre a sociedade e a natureza e sobre os processos econômicos, políticos e culturais que direcionam e, em certa medida, moldam a paisagem.

Este trabalho se apoiou em uma bibliografia norte-americana e inglesa sobre a arte da paisagem e se nutriu das obras apresentadas por ela. Mas, se apresento referências estrangeiras não é com a intenção de estabelecer comparações com a produção nacional e, sim, de buscar nos estudos já realizados certos contornos e afinidades compartilhadas com a produção nacional.

Como declarou o artista mexicano Zamora, do projeto Margem, a paisagem paulistana do Tamanduateí também tem um pouco da paisagem densamente construída e caótica da Cidade do México. ${ }^{12}$ A paisagem industrial e sem identidade de Passaic (que Robert Smithson nos descreve entre revolta e poesia) também pode ser vista em São Paulo, Madrid ou Bombaim, como bem escreve Farias. ${ }^{13}$ Analogias possíveis à parte, a arte da paisagem nos faz atentar para as diferenças das paisagens / países $^{14}$ que se formam a partir das mesmas marcas ou matrizes. ${ }^{15}$

É recorrente atrelarmos a arte contemporânea da paisagem com "natureza" e a imaginarmos em paisagens ermas ou onde predominam os elementos naturais. As suas

11 TUFNELL, 2006, p. 15.

12 Entrevista com o artista, vide em Anexo I.

13 FARIAS, Agnaldo. Robert Smithson: o artista como viajante. Revista Espaço e Debates, São Paulo, v.23, jan/dez, p 120-128, 2003.

14 ROGER, Alain. O Nascimento da Paisagem no Ocidente. In: 1ํㅡ을 COLOIO INTERNACIONAL DE HISTÓRIA DA ARTE, 1999. Tradução Prof. Dr. Vladimir Bartalini para disciplina AUP 5834, do curso de Pós-graduação da FAU-USP, São Paulo, 2009. In: SALGUEIRO, Helena Angotti (org.). Paisagem e Arte: a invenção da natureza, a evolução do olhar. São Paulo: CNPq/FAPESP/CBHA, 1999 - 2000."Um país não é, de entrada, uma paisagem, é que entre um e outro se encontra toda uma elaboração da arte, essa mediação que chama artialização.

15 Nos termos de BERQUE, 1984 In: CORRÊA, Roberto Lobato \& ROSENDAHL, Zeny (org.) Paisagem, Tempo e Cultura. Rio de Janeiro: EdUERJ, 1998. Série Geografia Cultural, no2, p. 84. Marca como a grafia sobre a superfície da Terra, como conjunto de transformações do meio. E matrizes, as condicionantes culturais que direcionam tais transformações. 
primeiras e emblemáticas obras se fizeram, de fato, neste contexto: nos desertos norteamericanos, nos bosques italianos e ingleses. No entanto, ela também se faz em paisagens praticamente destituídas de belezas naturais. Não obstante, a natureza permanece como um elemento estruturador e simbólico da paisagem e é por isso que recorremos a ela, quer seja com um pedaço de céu para compor uma paisagem emoldurando edifícios, ou desejando ver através da barreira construída uma amplitude, o horizonte. A arte contemporânea da paisagem permanece evocando os elementos naturais e suas transformações como importantes fontes de sentido.

Veremos que algumas obras de Fronteiras (1998-2001) e as de Margem (2009-2010) sublinham os elementos e fenômenos da natureza e fazem convergir a experiência da paisagem com a experiência estética da obra. Contudo, a experiência da paisagem evocada por estas obras não é necessariamente aquela que Appleton ${ }^{16}$ traduz como única, que abarca a apreciação estética da natureza e que nos é em parte inata, pois as obras da nossa arte da paisagem trazem à tona conflitos ao se inserirem em lugares de passagem, de "pouca afetividade"17, em não lugares.

Dado este pano de fundo com exemplos de obras em que a transformação, apreciação e apropriação da paisagem são propulsoras, será necessário delimitar com mais precisão o termo essencial desta investigação: a paisagem. Para este estudo, ela possui os significados trazidos pela Geografia Humana e Cultural, e é compreendida não só como forma, mas também como a interação entre a sociedade e a natureza que alcança, além do visível, a "trama parcialmente invisível da estrutura social”. ${ }^{18}$

Por isso, sincronicamente, a arte contemporânea da paisagem adentra questões que vão além da visualidade, dos aspectos físicos ou dos recursos naturais, mas, principalmente, promove a reflexão sobre os modos de produção da paisagem.

A acepção poética, ou mais subjetiva, que a paisagem assume no discurso da arte será somada àquela de sentido histórico-geográfico, uma vez que me detenho a analisar através de

\footnotetext{
$16 \mathrm{O}$ autor descreve que em parte a satisfação resultante de apreendermos uma composição equilibrada entre panoramas e refúgios, que naturalmente nos dá referenciais de onde estamos, seguros, ao mesmo tempo que desfrutamos da amplitude. Ver APPLETON, Jay. The experience of Landscape. London: John Wiley \& Sons, 1975.

17 É a expressão utilizada pelo artista Carlos Fajardo para descrever o lugar de sua obra em Fronteiras.

18 LEITE, Maria Angela Faggin Pereira. Destruição ou Desconstrução? Questões da paisagem e tendências de regionalização. São Paulo: Hucitec, 2006, p. 82.
} 
obras brasileiras contemporâneas de que maneira a paisagem é palco para ações criativas, sendo apropriada, transformada, ou imaginada através da arte.

O interesse desta pesquisa está em descobrir de que modos nossa arte que ocupa os "espaços da vida"19 estabelece contatos com a paisagem. E ao estabelecê-los, de que maneira esta arte - que abarca os elementos e características do lugar - nos faz refletir sobre nossas paisagens.

19 SALZSTEIN, Sônia. Fronteiras. Rio de Janeiro/são Paulo: Contra Capa, 2005, p. 24. 

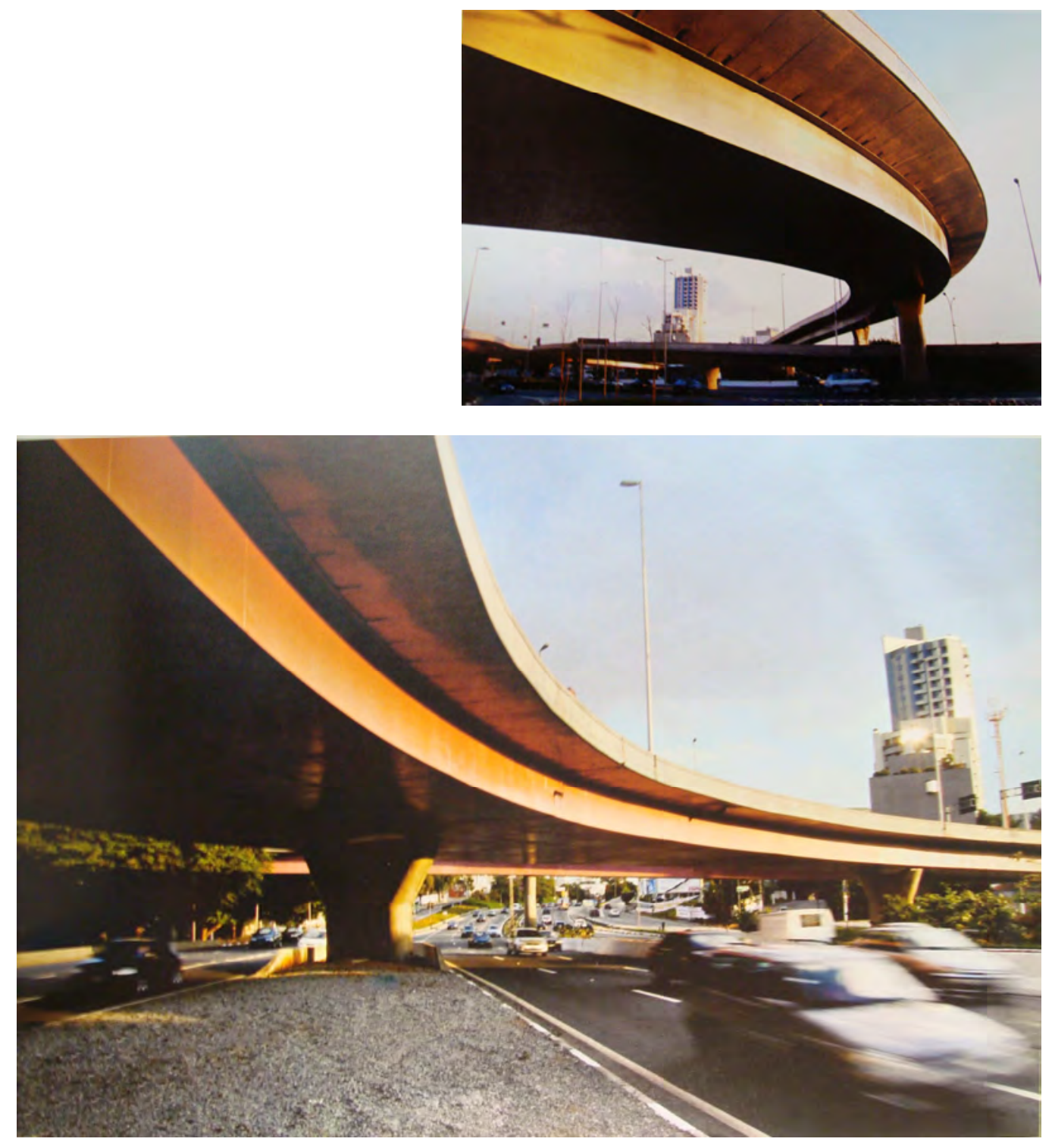

CAPÍTULO 1

Relações arte e paisagem. Campo de influências mútuas. 
01. Pág. anterior: Amélia Toledo. Programação Cromática do Complexo Viário João Jorge Saad. Parque das Cores do Escuro, Parque Ibirapuera, São Paulo, 2002. (Fonte: FARIAS, Agnaldo. Amélia Toledo: As naturezas do artifício. São Paulo: W11, 2004).

A pintura da estrutura de aço dos viadutos foi imaginada com a intenção de aliviar visualmente o volume da construção e criar ao mesmo tempo faixas de luz sobre a avenida 23 de Maio. Por indicação do nosso consultor técnico, o engenheiro Alfredo Nogueira, empregamos uma tinta de alta resistência com adição de pigmentos de reflexo, que acentuam a natureza metálica da estrutura e fazem a cor variar conforme a incidência da luz ou a posição do observador. (Amélia Toledo) 
Arte e paisagem compartilham ao longo da história modos de ver e de representar que se inter-relacionam. Também compartilham semelhanças em suas gêneses quanto à composição, identidade e singularidade, além de sublinharem valores e ideais de uma sociedade ou época. Mais especificamente, a arte contemporânea da paisagem se vale da simbologia e dos aspectos culturais da paisagem para com eles ressignificar, projetar, refletir.

Compreendendo paisagem como a interação entre a sociedade e a natureza ao longo do tempo e, imbuída de intencionalidade estética, como produção cultural que, para ser apreendida, deve ser considerada além da sua forma em seus fatores políticos, sociais e culturais. E por arte, me atenho à arte da paisagem - que nesta dissertação limita-se ao período contemporâneo ${ }^{20}$ - como obra ${ }^{21}$ ou ação que se relaciona diretamente com a paisagem, e não de modo representacional, abarcando seus elementos naturais e/ou culturais, e sensibilizando-nos para as questões da apreciação da produção da paisagem.

A obra, por vezes, apenas rearranja e ressignifica os próprios elementos que constituem a paisagem. Assim, ela não se atém a regras, processos ou técnicas exclusivos da arte, como o fez, por exemplo, a pintura de paisagem. A obra contemporânea se elabora de modo singular em relação ao lugar e entorno onde intervém, incorporando a história, símbolos, valores e a dinâmica de produção da paisagem.

Há, nesse segmento da arte, mais que influências recíprocas e espelhamentos entre paisagem e arte, há similaridades nos modos como o indivíduo se insere nelas ou diante delas - da composição visível e sensível - traçando relações entre os elementos que as compõem e o lugar, seu entorno e história.

Diante da paisagem e de obras da arte contemporânea da paisagem, podemos perceber ações e pensamentos que moldam sua composição, ${ }^{22}$ ou seja, aspectos da trama parcialmente

\footnotetext{
20 A partir dos anos 1960, a arte passa a adquirir características mais relacionais e menos autônomas quanto à forma e à leitura, o que, de um modo geral, compreende-se como pós-vanguarda, pós-moderno e contemporâneo. Archer (2001, p. x) aponta o Conceitualismo, a Land Art, a Performance, e a Body Art como artes que, a partir desta década, desafiam "o reconhecimento de que o significado de uma obra de arte não estava necessariamente contido nela, mas às vezes emergia do contexto em que ela existia." ARCHER, Michael. Arte Contemporânea: uma história concisa. São Paulo: Martins Fontes, 2001.

21 Embora o termo "trabalho" seja muito compatível com a arte contemporânea que desmistifica o objeto para contemplação, ao se infiltrar no cotidiano por meio de ações e ao hibridar-se com objetos não artísticos, adoto o termo obra, uma vez que me refiro a exemplos apresentados na bibliografia da História da Arte.

22 Composição como um arranjo de formas. "Forma é a configuração visível do conteúdo." (SHAN, Ben apud ARNHEIM, Rudolf. Arte e Percepção Visual: uma Psicologia da visão criadora. São Paulo: Ed. Pioneira, 1991, p.89).
} 
invisível $^{23}$ - heranças e dinâmicas de produção da paisagem - que na arte se condensam como indícios da cultura. A arte é hábil em revelar tais elementos, não tão visíveis mas sensíveis, que amalgamam a identidade da paisagem.

Perceberemos que, ao longo dos tempos, as tangências entre arte e paisagem passam a abarcar, além da forma e do resultado da composição, cada vez mais os aspectos culturais que influenciam ou determinam a produção da paisagem. Eles são, inclusive, o mote essencial de muitas destas obras contemporâneas que se inclinam a uma visão crítica da interação entre sociedade e natureza, tratando de questões sociopolíticas, culturais e ambientais.

Assim, ao analisarmos a arte contemporânea da paisagem, devemos observar além das relações formais entre a obra e o lugar, ou seu entorno - aspectos físicos, proporção ou mesmo aspectos expressivos da arte -, pois, invariavelmente, as matrizes culturais que formam aquela paisagem vêm à tona através da obra e do seu discurso. A paisagem já contém em si uma narrativa e uma atmosfera que emana através da arte com ela relacionada.

Antes de abordarmos as obras de Fronteiras (1998-2001) e de Margem (2009-10), vejamos exemplos da arte que evocam a paisagem e paisagens que nos remetem à arte. Observaremos semelhanças que parecem nutrir algumas das definições de paisagem e de arte, pois estas tangências é que são potencializadas na arte contemporânea da paisagem.

23 LEITE, 2006, p.82. 


\subsection{Confluências arte e paisagem.}

Arte e paisagem possuem um núcleo comum que é densamente tecido, uma vez que ambas apresentam similaridades quanto aos processos do fazer (como são produzidas) e quanto ao lugar em que, diante delas, o observador é lançado. O campo de influências mútuas vai além das reverberações de uma representando a outra.

Partir do princípio de que arte e paisagem são maneiras de ver e de compor, é uma das aproximações, talvez a primeira ou a de superfície, que nos leva a percorrer as histórias justapostas da paisagem e das artes, ${ }^{24}$ principalmente a da pintura. Tal princípio nos remonta à invenção da perspectiva linear no Renascimento, que permitiu, através da ordem (forma atrelada à lógica), representar o espaço e logo se estendeu - tanto intelectualmente quanto de modo concreto - ao mundo exterior. Esta maneira de ver apoiava-se na organização do mundo em regras geométricas, primando pela composição, e se fazia visível tanto nas paisagens do período como nas suas representações.

A perspectiva nos permite reproduzir em duas dimensões a ilusão realista de um espaço composto racionalmente de três dimensões. Ordem e forma consistentes podem ser impostas intelectual e praticamente ao mundo externo. Não é de se espantar que, no mesmo período, a pintura das paisagens tenha aparecido pela primeira vez na Europa como uma expressão popular, acompanhada por uma arte florescente de incluir a paisagem na poesia, representação teatral, jardins e na concepção de parques. (COSGROVE, 1989 apud CORRÊA, ROSENDAHL, $1998)^{25}$

Alguns autores, ao abordarem a paisagem, focam a percepção, o modo de ver como fator que inventa ou faz nascer a paisagem. Cauquelin $(2007)^{26}$ ressalta o quanto a construção do olhar, a partir da pintura de paisagem, se enraizou em nós de modo a tomarmos como natural uma paisagem planejada e construída. Ao contemplarmos uma exterioridade dada pela paisagem, estamos reproduzindo "esquemas mentais, plenos de uma evidência longínqua, e milhares de projeções anteriores".

\footnotetext{
24 Aqui estendo o termo para artes, para abranger a diversidade de manifestações que inclui as categorias de Artes Plásticas, Literatura, os Desenhos de Jardins, entre outras.

25 COSGROVE, Denis. A Geografia está em toda parte: cultura e simbolismo nas paisagens humanas. 1989. In: CORRÊA, Roberto Lobato \& ROSENDAHL, Zeny (Orgs.) Paisagem, Tempo e Cultura. Rio de Janeiro: Ed. UERJ, 1998. Série Geografia Cultural, no2, p. 98
}

26 CAUQUELIN, Anne. A Invenção da Paisagem. São Paulo: Martins Fontes, 2007, p. 26. 
Roger (1999) discorre sobre a influência da pintura de paisagem e da fotografia como decisivas para nossa percepção e aceitação da paisagem. Estas são "artializações" (transformações através da arte) in visu; que somadas às artializações in situ, moldam ou instruem nossa percepção do mundo.

Considero, de um modo geral, que toda a nossa experiência, visual ou não, é modelada por modelos artísticos. A percepção histórica e cultural, de todas as nossas paisagens - campo, montanha, mar, deserto, etc. - não requer qualquer intervenção mística (como se elas descessem do céu) ou misteriosa (como se elas saíssem do chão), ela se opera segundo o que denomino, retomando uma palavra de Montaigne, uma artialização. (ROGER, 1999)

Este olhar instruído, ou a intencionalidade no modo de ver, é também necessário para apreender uma obra de arte, dar-lhe contornos, mesmo nos exemplos da arte da paisagem que se hibridam ao lugar e ao entorno. Não por menos, algumas das obras que analisaremos fazem referências a outras formas de "artializar" - direta ou indiretamente - por exemplo, o paisagismo, os monumentos do Neolítico como um princípio de ordenação do espaço, ou a própria fotografia. Arte e paisagem requerem a pausa do olhar, um olhar com intencionalidade orientado por imagens da cultura; um olhar que é matriz, formador e produtor da paisagem, pois é nutrido e moldado pelos "esquemas de percepção, de concepção e de ação - ou seja da cultura."27

Mas também, as artes buscariam abarcar os elementos não visíveis da paisagem, às vezes, até considerando-os como elementos principais: as sensações que despertam e as emoções que podem provocar. A filosofia passa a investigar as diferentes formas do belo, sublime e pitoresco. Novas paisagens são produzidas pela cultura como o mar, a montanha ${ }^{28}$ e a floresta; outras, pela sedimentação no imaginário, tornam-se emblemáticas, como as campestres - composições que "significam" paisagem. Pensadores da filosofia, literatura e ciências $^{29}$ passam a dedicar-se à compreensão das emoções únicas despertadas por estas paisagens e pela natureza.

27 BERQUE, 1984. In: CORRÊA; ROSENDAHL, 1998, p. 85.

28 A montanha como paisagem foi uma conquista de escritores, pintores-gravadores e, a partir de 1850, de fotógrafos. "O exemplo da montanha é particularmente instrutivo, porque ele nos confirma que a paisagem jamais é uma realidade natural, mas sempre uma criação cultural, e que ela nasce nas artes antes de fecundar nossos olhares". ROGER, 1999.

29 "Paisagem é um tema caro ao pensamento alemão como vemos com Goethe (1749-1832) e Humboldt (1769 - 1859), assim como ao europeu". SILVEIRA, Flávio Leonel Abreu da Silveira. A paisagem como fenômeno complexo, relações sobre um tema interdisciplinar. In: __ ; CANCELA, Cristina Donza (orgs.). Paisagem e cultura: dinâmica do patrimônio e da memória na atualidade. Belém: UFPA, 2009, p. 73. 
A partir do século XIX, o olhar expande sua capacidade em abarcar noções de tempo e de espaço, cada vez mais extensos, através das novas tecnologias, a começar com a fotografia e depois com o vídeo, a imagem por satélite e outros. As artes, valendo-se destes novos meios, refletem sobre as transformações, ao longo do tempo, das ocupações espaciais e da percepção humana.

Tais questões, que inter-relacionam tempo, espaço e percepção, compõem o mote essencial da escultura contemporânea, que se desprende de sua estrutura e lógica internas para hibridar-se com o lugar e o entorno, ${ }^{30}$ desde praças públicas até lugares banais do cotidiano, das Cordilheiras do Himalaia ao deserto norte-americano, de campos agrícolas a um bosque. Soma-se à necessidade interna da arte de reagir contra a condição de objeto de determinado mercado, a expansão de ocupação e contatos relacionais que reverberam significados. Nesta expansão, a arte abarca a paisagem, cuja leitura, produção, elementos naturais e culturais unem-se à obra. É esta a arte da paisagem no contemporâneo, uma expansão radical da arte em busca de referenciais mais amplos da organização social.

Alguns dos trabalhos embrionários da land art nos EUA nascem de experiências com fotografias aéreas. Em 1969, promove-se na Alemanha uma exposição sobre arte da paisagem via canal de televisão, para que muitos pudessem "ver ao mesmo tempo". ${ }^{31}$ Meios tecnológicos passam a ser - junto com meios de representação, como os mapas - explorados pelos artistas ligados à paisagem, que os utilizam como possibilidades do alcance do discurso da arte, assim como para investigar relações possíveis do homem com seus lugares de existência, paisagem e meio.

A arte contemporânea da paisagem dá corpo a esta nova maneira de ver: ela pode trabalhar com o registro fotográfico, com a imagem de satélite ou com o registro em mapas. Assim, incorpora as ferramentas de trabalho e os meios de comunicação da cultura de sua época e, portanto, incorpora também suas questões político-sociais.

O modo de ver da arte, há muito revestido de imagens e influenciado pela possibilidade de alcance das mesmas, parece tornar-se menos compositivo (no sentido de dar

\footnotetext{
30 Se no Minimalismo a arte se envolve com o lugar e entorno, mas em galerias ou museus, na Land Art esse lugar exterior adquire a dimensão da paisagem. A exterioridade é expandida em escala, assim como nas relações internas à própria obra. No Capítulo 2, veremos o surgimento da land art.
}

31Ver em KASTNER; WALLIS, 1998, p. 181. Artista Jan Dibbets. Exibido em TV, 15/04/1969. 
forma a um conjunto que adquire significado autônomo) e mais relacional entre as dimensões da cultura. ${ }^{32}$
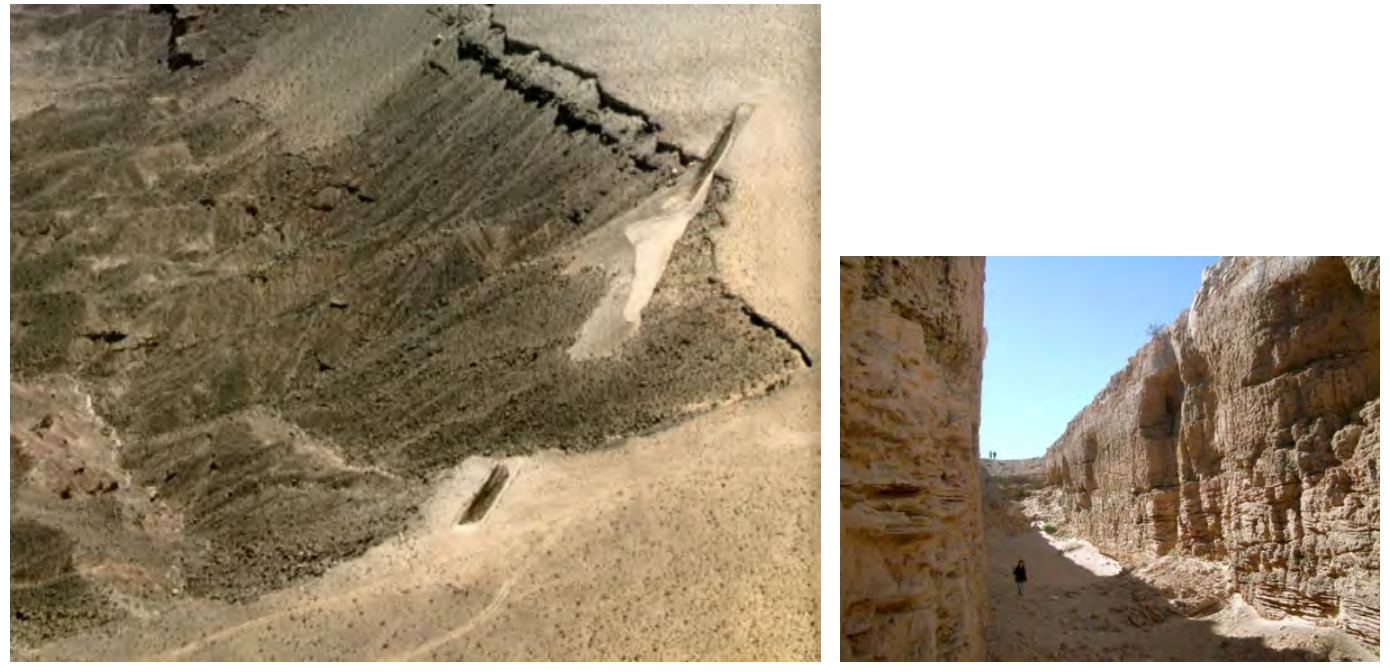

02. Michael Heizer. Double Negative, 1969-70. Mormom Mesa, Nevada, EUA.

Vista aérea e na escala humana

(Fonte imagem: http://artwelove.com/artwork/-id/42d1b37a )

à direita:

03. Jan Dibbets. 12 hours Tide Objects with Correction of Perspective. Gerry Schum's Land Art, Exibição para a TV, 1969.

"enquanto as pessoas estiverem assistindo, elas terão uma obra original de Dibbets" (Fonte: KASTNER; WALLIS, 1998, p.

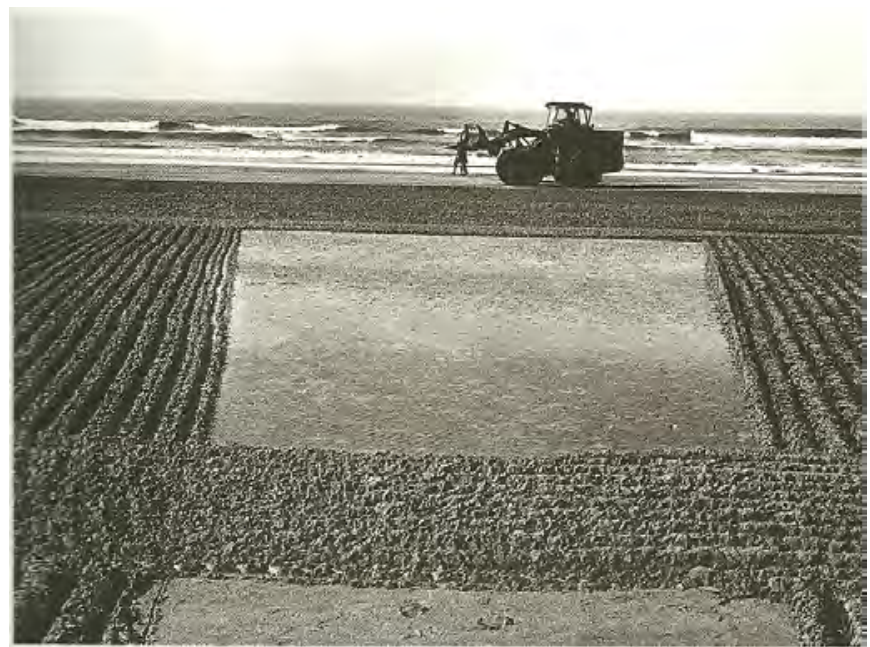

32 Cultura compreendida como organização da vida social e política e de sentimentos e pensamentos presentes no mito, na religião, nas ciências, linguagem e arte. "A cultura humana está dividida em várias atividades que procedem segundo linhas diferentes e perseguem fins diferentes". CASSIRER, Ernst. Ensaio sobre o homem. Introdução a uma filosofia da cultura humana. São Paulo: Martins Fontes, 1994, p. 119. 
Mas a paisagem não é necessariamente construída pela arte, pelo seu "modo de ver" e interagir. A arte, quando presente na produção da paisagem, reafirma-a ou modela-a em sua "atmosfera", pode até mesmo promover identidades nacionais, ou ainda fornecer padrões estéticos que alimentem o repertório de outras produções culturais.

As paisagens não cultivadas ou transformadas pela arte, ${ }^{33}$ pelo olhar estético, parecem carecer de referenciais da tessitura humana e simbólica para estabelecer contatos e se inserir. É, então, através da ausência ou negação da composição, que a arte reage ou dialoga com estas paisagens tecnicamente produzidas "que não acompanharam o ritmo natural e cultural de um lugar", ${ }^{34}$ trazendo reflexões ou buscando indícios para interferir no meio e estabelecer novos paradigmas - formas ou relações entre elementos - não encontrados nestas paisagens.

Tal reflexão nos leva a Cosgrove, ${ }^{35}$ para ele, a paisagem está ligada a uma maneira de ver o mundo como "criação racionalmente ordenada, designada e harmoniosa", pois, mesmo a arte contemporânea prescindindo da apreciação estética ${ }^{36}$ da forma, encontra resistências para se efetivar em uma paisagem tecnocrata. São exemplos disto os projetos de Robert Smithson para áreas de refugo industrial que não se concretizaram, assim como exemplos da arte brasileira - como Errante (2010) dentro do projeto Margem - e outras tentativas de exposições de arte abordando diretamente a produção de nossas paisagens que não se realizaram. ${ }^{37}$

Assim, a paisagem está intimamente ligada a uma nova maneira de ver o mundo como uma criação racionalmente ordenada, designada e harmoniosa, cuja estrutura e mecanismo são acessíveis à mente humana, assim como ao olho, e agem como guias para os seres humanos em suas ações de alterar e aperfeiçoar o meio ambiente [...] Tal intervenção, deve ser ressaltado, não é indiferente, exploradora ou destrutiva, mas uma relação que harmonizaria a vida humana com a ordem ou modelo inerente da própria natureza. (COSGROVE, 1989. In: CORREA; ROSENDAHL, 1998, p. 89, grifo nosso)

33 "Artlializadas" como apresenta Roger (1999) seja diretamente (in situ), seja na percepção e julgamento estético (in visu).

34 LEITE, 2006, p. 18.

35 COSGROVE, Denis, In: CORRÊA, ROSENDAHL, 1998, p.99.

36 Desde as Vanguardas Modernistas, a arte passa a questionar sua finalidade estética. A arte para contemplação dá lugar àquela que intensifica a consciência de sua época, problematizando questões além da forma.

37 Na entrevista com Carmela Gross, tomei conhecimento de uma exposição que aconteceria em 2005 no Rio Tietê, em São Paulo, em que dezesseis artistas ocupariam suas pontes, margens e o leito chamando a atenção para o rio, forçando-o a ser visível. Esta exposição, organizada por Cacilda Teixeira da Costa junto à Pinacoteca e que se chamaria "Olha o Tietê", não aconteceu por falta de patrocínio. Disponível em: http://www1.folha.uol.com.br/fsp/cotidian/ff0511200501.htm). 
Mesmo não sendo uma condição para a existência da paisagem, ao estudar a arte da paisagem no contemporâneo, vemos que a composição, valores estéticos e simbólicos inerentes à harmonia ${ }^{38}$ que o autor menciona como sua formadora - são fundamentais para que haja uma efetiva e espontânea aproximação entre a arte e a paisagem.

Assim como Clark $(1961)^{39}$ comenta sobre o desejo humano em "criar harmonia com aquilo que o rodeia", no período quando desponta a pintura de paisagem, na arte contemporânea da paisagem há também obras que intentam a disposição ordenada dos elementos, integração e coerência formal com o lugar e o entorno. Contudo, há outras que refletem sobre as questões da paisagem sem intenção de compor com ela, sem concordâncias formais. A composição (neste segmento específico da arte) não produz padrões ou modelos capazes de nortear nosso modo de olhar. Isto porque as obras se integram, em sua maioria, às características da paisagem - assim como às características daquele período e tempo resultando em inúmeras formas. Assim também, elas não se fazem a partir da ideia de composição, o que pressupõe o trabalho com determinadas regras da sintaxe visual que regeram a pintura de paisagem e influenciaram na artialização in visu de jardins e parques. Elas se "moldam" ao lugar e ao entorno de acordo com intenções ou certas atitudes que Kastner $^{40}$ agrupa como integração, envolvimento, implementação, imaginação ou interrupção. ${ }^{41}$ Em suma, suas formas respondem ao modo de aproximação com a paisagem: mais ou menos idealizado, mais ou menos permanente, funcionalista ou intervencionista.

Mais adiante, para que a obra seja concebida, construída, mantida ou divulgada, a arte contemporânea da paisagem, em específico, envolve uma ampla rede de ações políticas, sociais e econômicas (além daquelas comumente ligadas à arte), uma vez que ocupa territórios, espaços públicos ou privados. Vemos em exemplos estrangeiros que as Administrações Públicas, em diferentes instâncias junto aos particulares, participam da obra, mais ou menos diretamente, evidenciando aspectos políticos, sociais, econômicos e culturais que formam a paisagem. Estes aspectos, nem sempre visíveis, são apontados por Leite ${ }^{42}$ como essenciais para a compreensão da paisagem.

38 "A harmonia diz respeito à disposição formal bem organizada no todo ou entre as partes de um todo. $\mathrm{Na}$ harmonia predominam os fatores de equilíbrio, de ordem e de regularidade visual inscritos no objeto ou na composição possibilitando, geralmente, uma leitura simples e clara. A harmonia é, em síntese, o resultado de uma perfeita articulação visual na integração e coerência formal das unidades ou partes daquilo que é apresentado, que é visto".In: GOMES FILHO, João. Gestalt do Objeto: sistema de leitura visual da forma. São Paulo: Escrituras, 2000, p. 51.

39 CLARK, Kenneth. Paisagem na arte. Lisboa: Ulisseia, 1961.

40 KASTNER; WALLIS, 1998, p. 17.

41 Ibidem. Tais vertentes serão analisadas no Capítulo 02.

42 LEITE, 2006, p. 82

18 
A paisagem é, portanto, composta de formas visíveis, duráveis, que lhe conferem certa estabilidade temporal e pela trama parcialmente invisível da estrutura social. [...] No plano do projeto e da intervenção na paisagem, as questões mais relevantes não se referem, portanto, apenas à leitura, identificação e atribuição de valores aos elementos naturais ou construídos que lhe conferem forma $\mathrm{e}$ caráter. É necessário buscar nos processos econômicos, políticos e culturais da sociedade os fatos que explicam e justificam essa forma e esse caráter. (LEITE, 2006, p. 82-3)

Atentarmos para os processos econômicos, políticos e culturais é extremamente necessário para o estudo da arte contemporânea da paisagem, em especial no caso brasileiro, uma vez que nossas paisagens nesta arte não são, na maioria das vezes, aquelas que primam pela "composição" ou pela harmonia nos termos de Cosgrove (1989). A relevância de contextualizar a arte contemporâmea da paisagem em um espectro mais amplo da cultura tornou-se um ponto chave para este trabalho.

No encontro com este pensamento, Beardsley $(1998)^{43}$ exemplifica, através da obra Running Fence (1972-76), dos artistas Christo e Jeanne Claude, a importância das determinantes ou condicionantes políticas e culturais para a land art. Esta obra, que durou duas semanas, despendeu quatro anos de negociações, com audiências públicas, incluindo o Superior Tribunal de Justiça da Califórnia, para que se pudesse atravessar cinquenta e nove propriedades particulares e catorze estradas. A obra ainda requereu a declaração sobre seu impacto ambiental, compilada em 450 páginas. Estes documentos legais integram a obra plástica: uma extensa cortina de nylon que atravessa a paisagem de colinas recortadas por rodovias, terminando no Pacífico. Os artistas arquivaram toda a documentação junto aos projetos e imagens. Beardsley ressalta que as negociações não são dados externos à obra, mas parte integrante da leitura da obra. Em uma leitura formalista da arte, estes aspectos da trama cultural, política e social poderiam passar despercebidos, contudo, a leitura da arte da paisagem no contemporâneo exige a compreensão além da sua forma. ${ }^{44}$

Just as religion was important to the Quattrocento artist, so are economics, social problems and politics today... the greatest drama. Knowledge of these areas should

\footnotetext{
43 BEARDSLEY, John. Earthworks and Beyond: contemporary art in the landscape. Nova York: Abeville, 1998, p. 31-34

44 KRAUSS, Rosalind.Caminhos da Escultura Moderna. São Paulo: Martins Fontes, 2007, 2a edição (Texto original, 1977). A autora apresenta uma análise formal das obras da land art: Spiral Jetty (1970) e Double Negative (1969-71). São examinadas a forma, a simetria, a proporção, os eixos, os percursos táteis e visíveis na obra, o peso visual, enfim, a sintaxe da linguagem visual. Tal análise é própria da Arte. A arte contemporânea da paisagem, no entanto, exige uma leitura que incorpore os termos da paisagem em mesmo grau (como veremos no Capítulo 02).
} 
be an important part of one's work. (CHRISTO, 1976 apud BEARDSLEY, 1998, p. 34)

Estas são as estruturas sociais que ajudam a evidenciar a forma visível das intervenções humanas na paisagem, revelá-las era, pelo menos, tão importante quanto a "barreira" [fence] para Christo em sua configuração física. Elas foram elaboradamente documentadas em um livro e em um filme sobre o projeto. (BEARDSLEY, 1998. p. 34)

04. Christo e Jeanne-Claude. Running Fence, 1972-76. Sonoma e Marin Counties, California, EUA.

\section{(Fonte:}

http://www.artnet.com/magazineus/f eatures/cone/jeanne-claude5-6-

10_detail.asp)

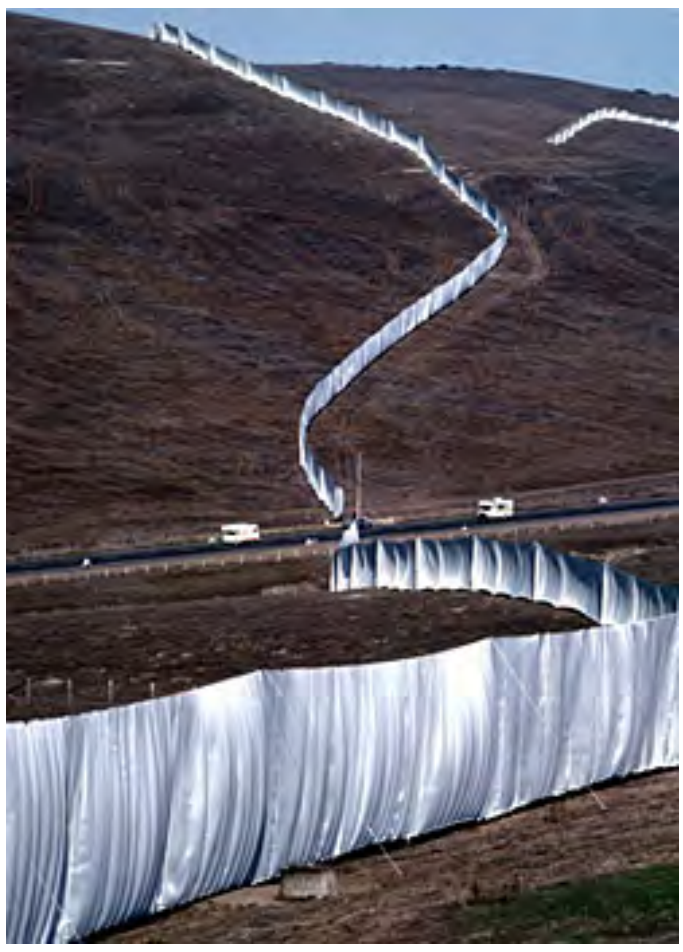

Ao analisarmos os aspectos formais e as condicionantes culturais tanto da paisagem como da arte, percebemos outra semelhança entre ambas: a simultaneidade. A simultaneidade e a íntima inter-relação destas ações e pensamentos com a forma produzida são a síntese da abordagem de Berque ${ }^{45}$ sobre a paisagem. $\mathrm{O}$ autor trata a paisagem como objeto plurimodal que é tanto a grafia humana sobre a superfície da Terra, forma e resultado, marca; assim como também é matriz que determina o olhar, a experiência, o juízo estético e moral. Assim, a paisagem e o sujeito são cointegrados.

A paisagem é uma marca, pois expressa uma civilização, mas é também matriz, porque participa dos esquemas da percepção, de concepção e de ação - ou seja, da cultura - que canalizam, em um certo sentido, a relação de uma sociedade

45 BERQUE, 1984 In: CORRÊA; ROSENDAHL, 1998, p. 86. 
com o espaço e com a natureza e, portanto, a paisagem do seu ecúmeno. (BERQUE, 1984 In: CORRÊA; ROSENDAHL, 1998, p. 84)

Esta simultaneidade entre forma e os "esquemas de percepção, de concepção e de ação - ou seja, da cultura" é também característica da arte contemporânea da paisagem, uma vez que, igualmente, não apreendemos a obra como uma composição fechada, ou como uma realidade que diz respeito apenas à sua categoria de arte, mas, sim, de modo relacional com os aspectos físicos, históricos e simbólicos da paisagem.

Compreender a arte contemporânea da paisagem e a paisagem em simultaneidade entre forma - que se manifesta visível na composição de elementos físicos e humanos, naturais e culturais - e ação e reação à trama política, social e cultural nos faz mergulhar nos reais significados das obras. Este é o ponto de partida para se analisar a produção brasileira.

Podemos também falar da unidade ou totalidade da paisagem e da arte. A paisagem se revela como totalidade ao traduzir a relação homem e natureza unificada por um caráter identitário ou sentido de unidade perceptível, que, para Simmel $(1913)^{46}$ é o stimmung da paisagem:

Quanto à paisagem, é justamente sua delimitação, sua captura em um raio visual efêmero ou duradouro que a definem essencialmente; sua base material ou pedaços isolados podem sempre passar por natureza - a paisagem reivindica um ser-per-si ótico, ou estético, ou atmosférico, em suma uma singularidade, um caráter que a separa da unidade indivisível da natureza, onde cada parte não pode ser senão um lugar de passagem para as forças universais do ser-ali [...]

Para a paisagem, este caráter identitário promove contornos da nação. Mesmo distantes de intenções nacionalistas, artistas da paisagem, nas décadas de 1960 e 1970, por trabalharem suas paisagens já simbólicas, acabaram por representar seus países, promovendo a singularidade, valores estéticos e éticos de como suas culturas lidam com a natureza e como transformam-na (ou gostariam de transformar). A fusão da arte da paisagem com questões nacionalistas é anterior ao contemporâneo. A pintura de paisagem recebeu, ao longo dos tempos, a incumbência de representar a identidade de um povo, suas qualidades éticas e estéticas, se adequando a projetos políticos. No Brasil, tanto a pintura Romântica do final do século XIX quanto a pintura Modernista do início do século XX se envolveram em descobrir e divulgar imagens que simbolizassem a identidade brasileira.

\footnotetext{
46 SIMMEL, Georg. Filosofia da Paisagem. 1913. Tradução Prof. Dr. Vladimir Bartalini, para uso exclusivo da disciplina da AUP 5882 Paisagem e Arte, Pós-graduação FAU-USP, 2011.
} 
A arte contemporânea da paisagem abarca suas dimensões sócio-cultural, estética e identitária. São exemplos os trabalhos dos artistas norte-americanos Robert Smithson e Michael Heizer no deserto de Nevada - como se reconquistassem os territórios ermos do Oeste - ou os trabalhos do artista inglês Richard Long em intervenções mínimas diante de paisagens inglesas já muito "artializadas". O artista Joseph Beuys com 7.000 carvalhos, em Kassel, 1982, resgatou uma árvore que é um símbolo presente em fábulas alemãs, assim como uma espécie já rara na paisagem da cidade. O artista inglês Andy Goldsworthy delicadamente interfere em campos escoceses, seja simplesmente acompanhando uma topografia ou ruínas, seja "apenas" evidenciando a história e o processo de produção da paisagem. É ela, no caso deste artista, a própria obra de arte.

Abaixo vemos algumas destas obras que fazem convergir o "país-paisagem", e que nos fazem compreender, como emblemas, que questões identitárias nacionais não dificilmente emergem, na arte contemporânea da paisagem. ${ }^{47}$

O país é, de algum modo, o grau zero da paisagem, aquilo que precede sua artialização, seja ela direta, (in situ) ou indireta (in visu). Eis o que nos ensina a história. No entanto, nossas paisagens se tornaram tão familiares para nós, tão "naturais", que tendemos a crer que sua beleza é natural; e são os artistas que nos evocam esta verdade primeira, mas esquecida: um país não é de imediato, uma paisagem; há entre um e outro, toda a elaboração da arte. (ROGER, 1999, grifo nosso)

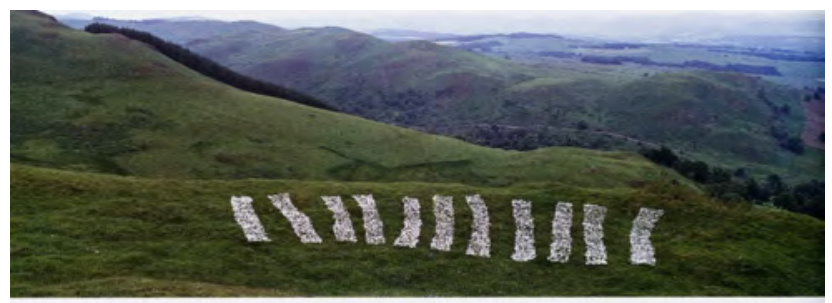

05. Andy Goldsworthy. Wool Spread Over Short Sheep-Grazed Grass, $1997 .{ }^{48}$

(Fonte:

http://www.cavetocanvas.com/post/180494846 56/andy-goldsworthy-wool-spread-over-short)

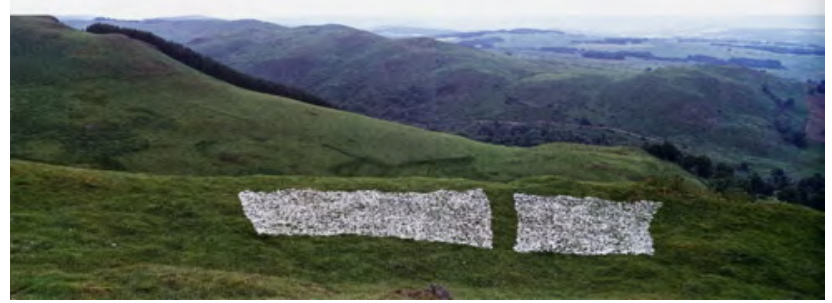

47 Uma das particularidades da arte contemporânea brasileira ligada à paisagem é seu distanciamento de contornos identitários nacionais; ao contrário, ela se relaciona com lugares "generalizantes". (como veremos no Capítulo 03).

48 Goldsworthy utilizou lã de ovelha diretamente sobre paisagens escocesas. Sua ação reforça o olhar sobre uma natureza transformada pela criação de ovelhas, que foi fator determinante para a configuração daquelas paisagens. Ao expor a lã sob a forma de um plano branco, $o$ artista também remete à tela de pintura "em branco" como espaço para criação, em uma composição já há muito cultivada. 


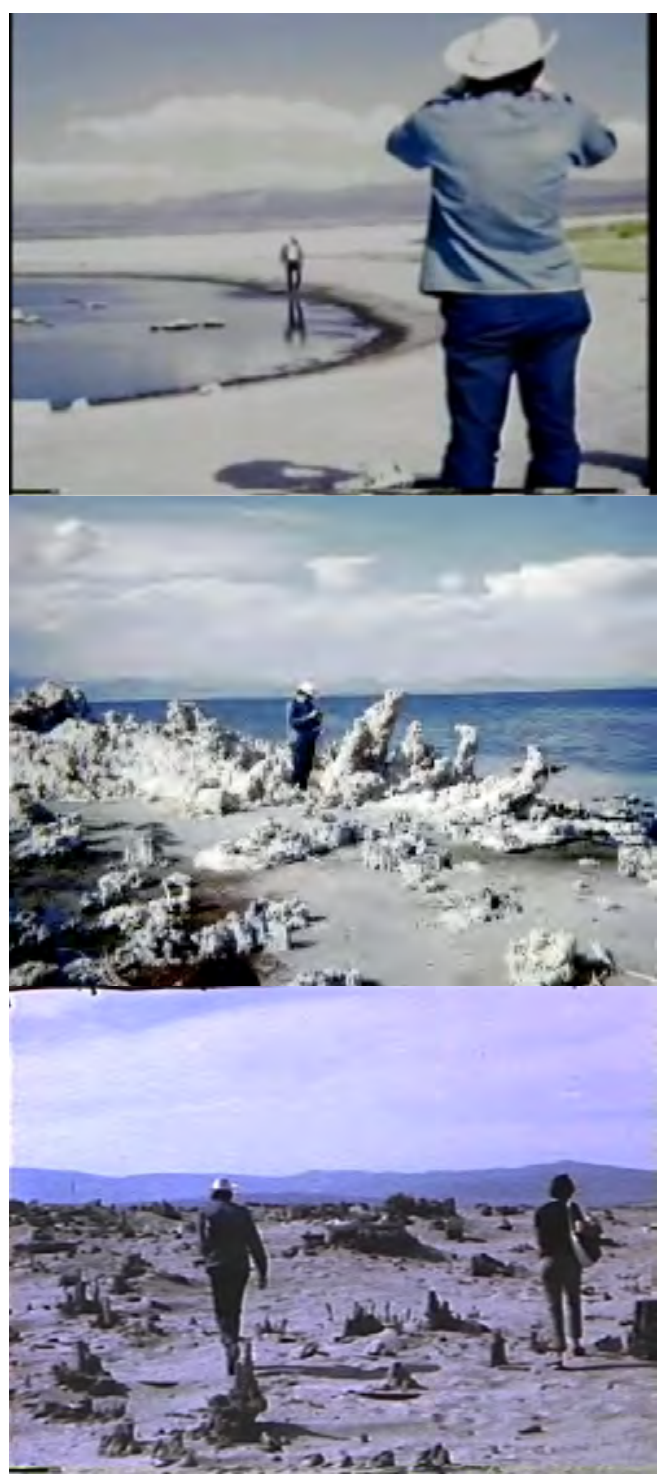

06. Michael Heizer, Nancy Holt, Robert Smithson. Mono Lake, California. Filme Super 8, 1968. ${ }^{49}$

(Fonte: http://arttorrents.blogspot.com.br/2008/06/nancy-holt-robert-smithson-mono-lake.html)

Meneses $^{50}$ explica que o tema dos espaços selvagens nos EUA é um "mito fundador que desempenhou o papel de fixar as virtudes da jovem nação". Robert Smithson e Michael Heizer são fotografados com botas e chapéus de cowboy em Mono Lake. O imaginário do mito americano, intrinsecamente ligado à sua paisagem, está presente nas atitudes dos artistas, no

49 "Mono Lake, de modo inocente, apresenta os três artistas enquanto eles exploram a paisagem de um dos mais inconfundíveis lagos da América do Norte. Heizer e Smithson são ouvidos narrando fatos sobre os fenômenos naturais do lago alcalino. As vozes foram sobrepostas às imagens de fantástica beleza do lugar ..." (Disponível em: http://www.eai.org/title.htm?id=11669).

50 MENESES, Ulpiano Bezerra. A paisagem como fato cultural. In: YÁZIGI, Eduardo (org.) Paisagem e Turismo. São Paulo: Contexto, 2002, p.44. 
desbravamento deste "novo território" da arte. E a relação entre imaginário e paisagem é de grande importância para compreendermos a land art nos diferentes países.

Intimamente imbricado com o conceito de espaço selvagem está o de paisagem de fronteira (o já referido Oeste americano, o faroeste), que carrega consigo questões relativas à democracia (versus aristocracia) ou à natureza/barbárie (versus civilização), transformando-se em espaço simbólico, ideológico e material de grande eficácia. ${ }^{51}$

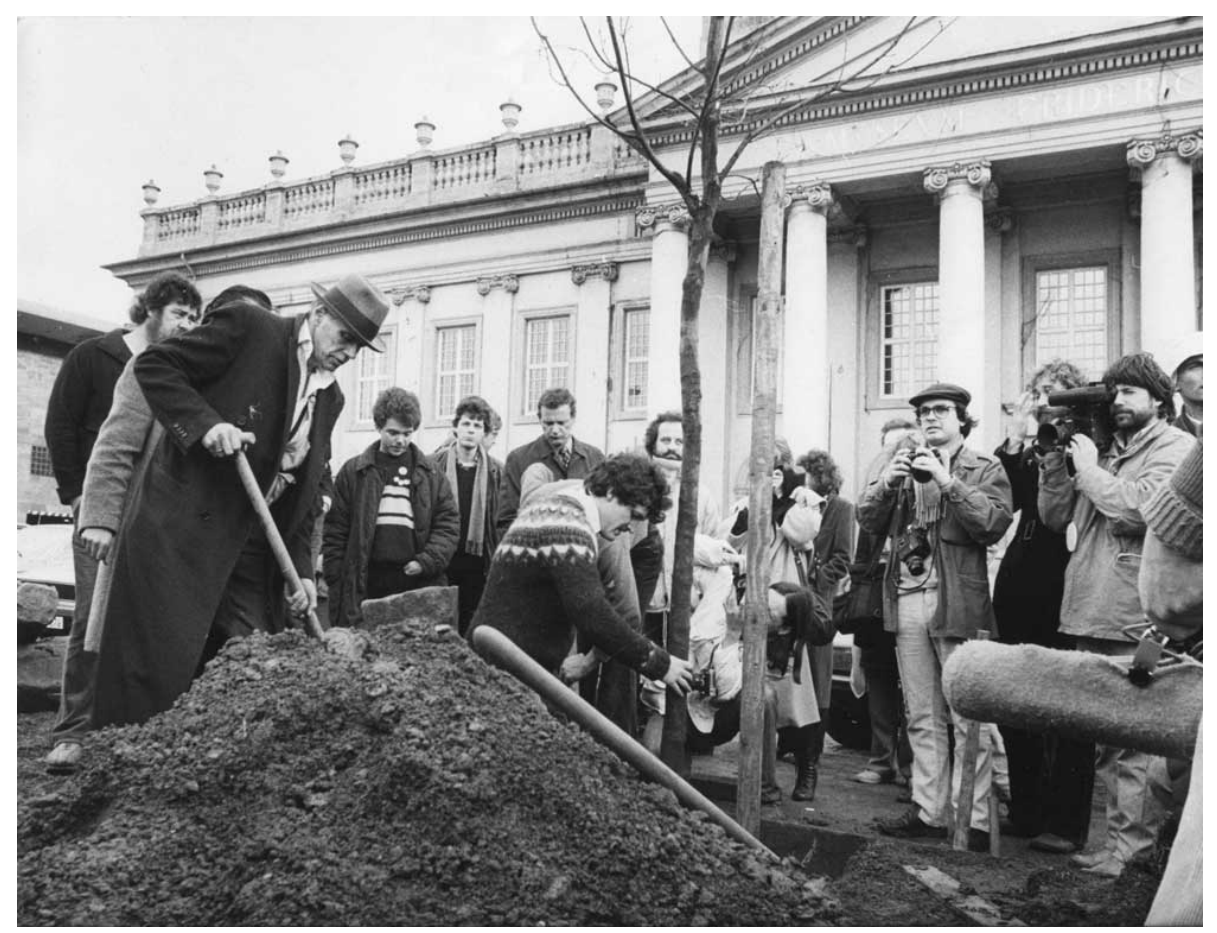

07. Joseph Beuys. 7.000 carvalhos. Documenta 7, Kassel, Alemanha. 1982-86.

(Fonte: http://www.kassel.de/kultur/documenta/kunstwerke/objekte /08259/index.html). ${ }^{52}$

O carvalho escolhido como unidade da "escultura social" - obra a ser realizada por muitos, através do plantio em diferentes pontos da cidade de Kassel - já era uma espécie em extinção na paisagem alemã, além de estar presente em contos e mitos. Beuys atenta, ao mesmo tempo, para o aspecto ambiental e histórico. Ele comenta sobre a obra: "uma coisa muito simples... a imagem mais básica"*. (Fonte: Catálogo A Revolução Somos Nós. Joseph Beuys. SESC-SP 2010)

\footnotetext{
51 Ibidem, p.44.

52 "...Come to Kassel, the 'Capital of the German Fairy Tale Route' where art and nature are equally important." (Fonte:http://www.kassel.de/kultur/documenta/kunstwerke/objekte/08259/index.html).
} 


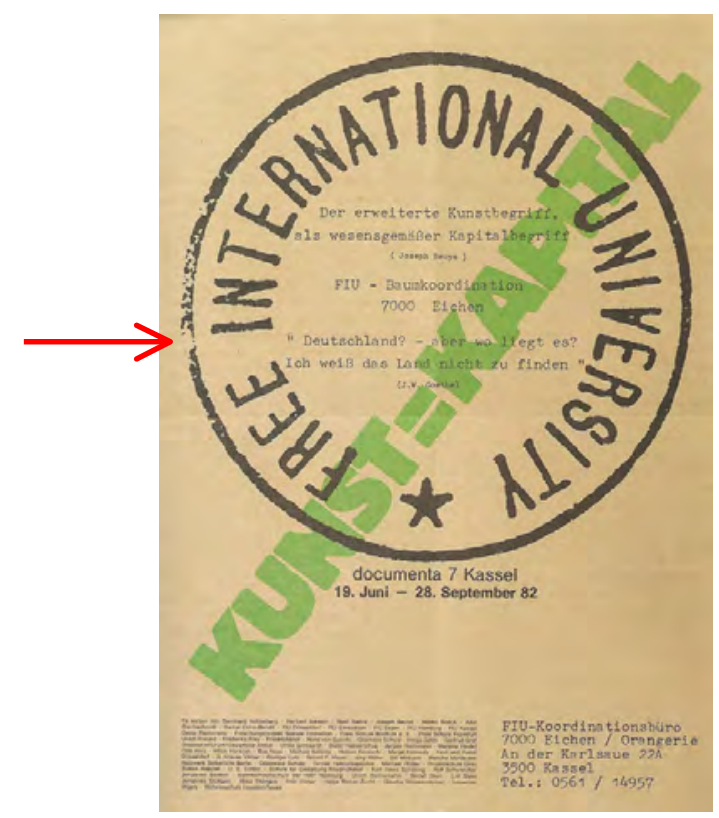

08. No cartaz-programa de debate Documenta 7 (1982), a obra 7.000 Carvalhos traz a questão identitária do "paíspaisagem":

"Deutschland? aber wo liegt es? Ich weiß das land nicht zu finden" (J.W.Goethe). [Alemanha? Mas onde está? Eu não encontro o país].

(Fonte: A Revolução Somos Nós. Joseph Beuys. *

Entrevista em vídeo "Theo Altenberg - Joseph Beuys, Documenta 7, 1982)

Em contrapartida, ao trabalhar com "ambiente" ao invés de paisagem, a environmental art atenua esta característica identitária, cedendo lugar a um discurso e preocupação compartilhados de maneira homogênea por diversos países. O "ambiente", abstração do espaço, ${ }^{53}$ não está revestido da atmosfera ou identidade que unifica a paisagem.

$\mathrm{Na}$ arte da paisagem no Brasil, veremos que esta característica identitária nacional se mostra pouco presente, uma vez que ela floresce em lugares cujas preocupações paisagísticas, além da arte, interligam-se mais firmemente entre os setores político, social e cultural, que produzem e transformam a paisagem, agindo em sinergia. Assim, a paisagem na arte contemporânea brasileira aparece mais como ambiente ou meio, ou é resquício de natureza. Não que tenhamos ido diretamente rumo à arte ambiental - aquela engajada em questões ambientais - mas, por não termos como simbólicas certas paisagens e não nos vermos espelhados nelas. Este não reconhecimento da paisagem (ou de nós mesmos por meio da paisagem) - através de um elo histórico - é, possivelmente, um dos fatores que problematizam esta arte no Brasil, dificultando o pertencimento de algumas das obras de Fronteiras e Margem na paisagem, no lugar e no entorno.

Por outro lado, ao mesmo tempo em que a paisagem e a arte podem suscitar "o espírito de um povo"54 em que a paisagem se estrutura e se organiza de acordo com os desígnios

53 COSGROVE, Denis, 1989 In: CORRÊA; ROSENDAHL, 1998:, p. 108.

49" $\mathrm{Na}$ interação com as paisagens, há uma espécie de reforçamento do ser que está vinculado à representação, atingindo dimensões sutis da alma e, mesmo, do espírito de um povo". SILVEIRA, 2009, p. 77. 
humanos, ela "tende a conservar uma autonomia, posto que se recusa - pelo menos parcialmente - a entregar-se ao humano, mantendo uma originalidade-alteridade" ${ }^{55} \mathrm{Na}$ essência desta ideia está outra semelhança entre arte e paisagem, pois mesmo uma obra que se confunde e se hibrida com a paisagem possui sua configuração própria. A obra se distingue e não parece nascer dali naturalmente ou, ao menos, pode gerar dúvidas. ${ }^{56}$

A arte contemporânea se hibrida às ações, símbolos e objetos do cotidiano, pois uma de suas essências é inter-relacionar arte e vida. Ela começou por incorporar matérias-primas e objetos do cotidiano, para então se apropriar das características e elementos do lugar e logo abarcaria toda a paisagem.

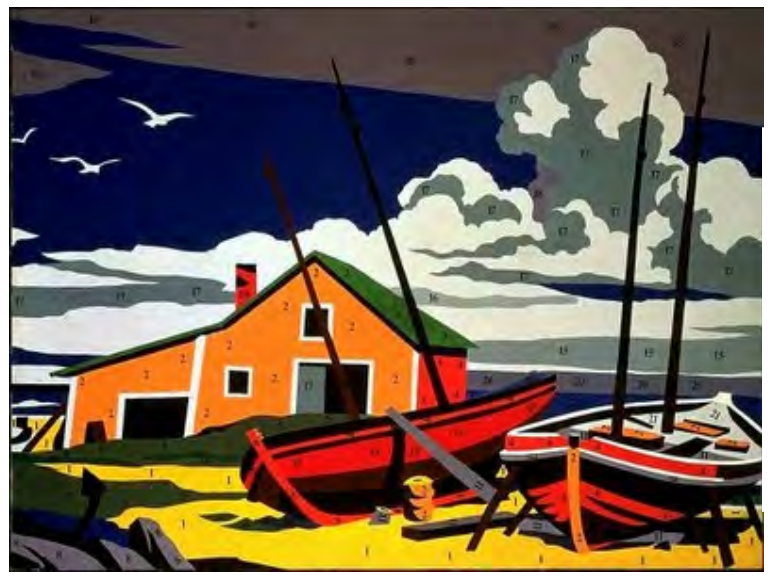

Ações, Símbolos e Objetos

Elementos do cotidiano rearranjados e ressignificados na arte contemporânea. A arte estaria a um passo de rearranjar diretamente a paisagem.

09. Andy Warhol. Do It Yourself(Seascape), 1962

(Fonte: HONNEF, Arte Contemporânea. 1992)

* Honnef (1992, p. 42), a partir dos anos 1970, qualifica como ativadores de "conceito alargado de arte" os artistas Joseph Beuys e Andy Warhol, por unirem arte e vida, cada qual com posturas muito distintas, contudo, ambos se valendo dos objetos, dos mitos, dos meios da realidade.

55 SANSOT, 1983 apud SILVEIRA, 2009, p. 78.

56 Acompanhando sites de turismo e blogs sobre a Spiral Jetty (1970) de Robert Smithson li a pergunta de um turista que viu a obra quando ela estava em parte submersa: "isso é da natureza ou alguém que fez?". Muitas obras da land art tensionam este limiar entre o que é natural e o que é construído. 

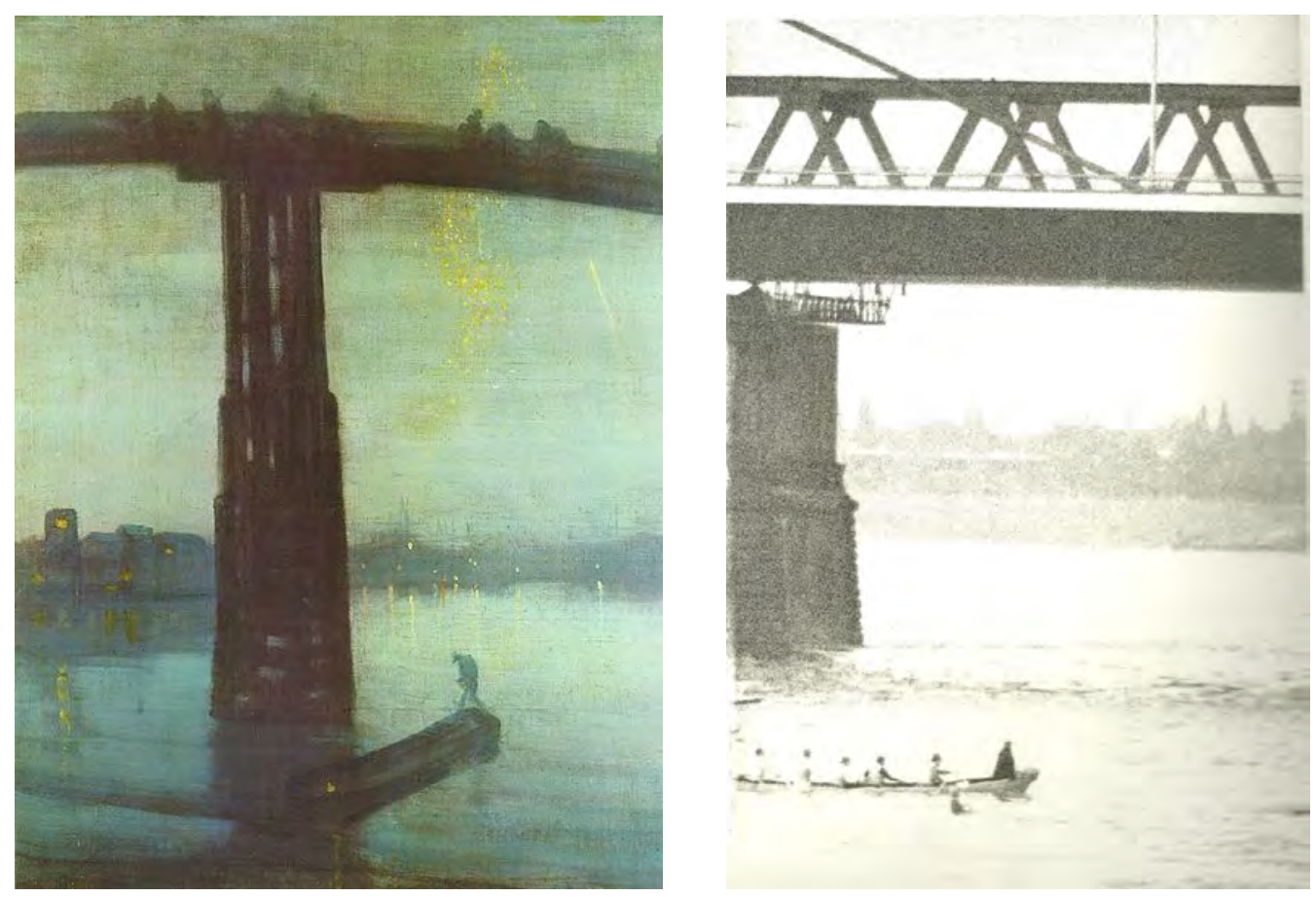

10. (esq.) James A.M. Whistler. Noturno: azul e dourado, 1872-75.

(Fonte: http://www.bbc.co.uk/portuguese/especial/1227_turnermonet/page9.shtml)

11. (dir.) Joseph Beuys. A condução de volta ao lar ,1973.

(Fonte: BORER, Joseph Beuys, 2001)

Por último, destacamos semelhanças no processo de apreciação da paisagem e da arte. Diante delas, o observador torna-se mais presente no lugar enquanto abarca uma composição - harmônica ou não - que exprime uma mensagem e é, portanto, simbólica. Os elementos visíveis da paisagem e da arte, que os olhos apreendem, são costurados em um conjunto e, nesta ação, tecemos uma lógica: no instante em que os abarcamos, rememoramos uma história, fazemos analogias entre os elementos visíveis e entre o visível e o sensível, vemos um pouco de nós, do subjetivo ao antropológico, de nossa cultura e época espelhadas na arte e na paisagem. Neste espelhamento do indivíduo inserido na paisagem ou na arte, há uma intensificação do ser.

Neste espelhamento entre a escala social e a do indivíduo, entre identidade e alteridade, há permeabilidade entre aquele que vê e a obra ou a paisagem, criando um campo dialético. Não há paisagem sem o sujeito formando "um conjunto unitário, que se autoproduz e se autorreproduz" ${ }^{57} \mathrm{~A}$ paisagem traz consigo os tempos presente e o passado, enquanto a arte da paisagem tece possibilidades de um futuro, vivificando os elementos da paisagem, fazendo ecoar seus símbolos e histórias.

57 BERQUE In: CORRÊA; ROSENDAHL, 1998, p.86. 
Arte e paisagem despertam a reação do encantamento, da percepção sutil de algo que é único, ou, contrariamente, a reação de alheamento ou não pertencimento. Ambas requerem uma pausa para estar diante do lugar e do entorno e diferenciá-los: não são lugares de passagem, exigem de quem as vê que se reconheça ali. Sobretudo, podem revelar sensações que, numa emoção única, envolvem o indivíduo em um processo de estetização do mundo, sendo, deste modo, incorporadas por ele, o que resulta em certa indistinção entre ambos.

\subsection{Influências da paisagem na arte ou quando a arte vai rumo à paisagem.}

Antes de poder ser um repouso para os sentidos, a paisagem é obra da mente. Compõe-se tanto de camadas de lembranças quanto de estratos de rochas" (SCHAMA, Simon. Paisagem e memória, 1996, p. 17)

Só vemos o que já foi visto e o vemos como deve ser visto... O mesmo se dá com a paisagem, sua "realidade" social, uma construção que é passada por filtros simbólicos, antigas heranças. (CAUQUELIN, Anne. A invenção da Paisagem, 2007, p. 96)

Ao abordar questões compartilhadas pela arte e pela paisagem, é significativo revermos a pintura de paisagem, uma das artes que mais influenciou diretamente a percepção do meio, transformando-o em paisagem, pois emprestava suas regras de composição para modelar e interpretar o mundo real. Assim, remontamos ao período em que o termo paisagem designava um gênero da pintura, no qual a idealização ou representação de um sítio ao ar livre constituía o argumento principal. ${ }^{58}$ Neste período, para alguns autores, dá-se a invenção ou o nascimento da paisagem; é quando surge a noção de paisagem "que no decorrer das práticas sociais, representações artísticas e reflexões religiosas, filosóficas e científicas, configurou-se como esquema de percepção da realidade, até parecer algo originário, preexistente a nós mesmos." ${ }^{159}$

58 Definição de paisagem encontrada na Pinacoteca do Estado de São Paulo : "representação pictórica de um sítio ao ar livre, no qual a natureza desempenha o papel exclusivo ou preponderante". MYANAKI, Jacqueline. A paisagem no ensino de geografia: uma estratégia didática a partir da arte. Dissertação de Mestrado FFLCH-USP, São Paulo, 2003, p. 23.

59 MARIA, 2010, p. 17. 
No Brasil, tais representações e idealizações também influenciaram os modos de ver e de aceitar a paisagem brasileira, mas também geraram embates pela incongruência entre os padrões da pintura europeia e a realidade brasileira. É por este embate que a arte contemporânea brasileira rompe com os padrões estrangeiros e é, talvez, pela herança de paisagem como gênero de pintura ${ }^{60}$ que a nossa arte contemporânea da paisagem se envolve com ela com certa reserva e crítica. ${ }^{61}$

Ao tornar-se objeto perceptível e revestido de identidade e unidade, o termo paisagem se desprende de país, e de terra e território iniciando na arte o seu desenvolvimento. Os termos paysage, paesaggio, paisasaje e paisagem são contemporâneos ao momento em que a paisagem, como gênero de pintura, começa a ser explorada por artistas, portanto, muito mais próximo das artes plásticas do que da geografia. (MYANAKI, 2003, p. 13)

Este desenvolvimento também pode ser compreendido como etapas em que a paisagem ganha autonomia na arte. Primeiramente, desprendendo-se de temas religiosos onde figurava como pano de fundo. Depois, ao ser objeto de estudo específico, a paisagem foi tema para se exercitar a composição das formas visíveis. Não tardaria à composição também transmitir os fenômenos interiores do indivíduo ou da sociedade - das emoções humanas metaforizadas na paisagem aos projetos políticos difundidos através dela. Mais adiante, na arte contemporânea da paisagem, esta é abarcada como parte constitutiva da obra que, além das questões estéticas, passa a abordar questões políticas, culturais e ambientais.

É com a finalidade de melhor analisarmos as influências entre a arte e paisagem no contemporâneo, que propomos referenciar o histórico da pintura de paisagem, ${ }^{62}$ usando

60 Besse (2006, p. 20) apresenta a etimologia de paisagem, explicando que antes do desenvolvimento do gênero de pintura dos séculos XVII e XVIII, quando então a paisagem adquiriria uma "significação principalmente estética", os termos landchap, Landschaft e paese - do neerlandês, alemão e italiano remetiam ao espaço objetivo uma "significação que se pode dizer territorial e geográfica". Roger (1999) indica ainda que o termo, nas línguas ocidentais, data do século XVI, do francês paysage, e o surgimento da paisagem na pintura data do século XV com "as aquarelas e guaches de Dürer (nos anos 1490)."

61 A artista Carmela Gross, em entrevista, explica sobre a herança da pintura de paisagem brasileira que desde o século XIX promoveu uma política de exploração da natureza acrítica em relação aos processos de produção da paisagem, além de ser representada como um souvenir. A paisagem estaria, assim, revestida deste histórico. Nuno Ramos e Carlos Fajardo não interpretam a land art como ligada à paisagem, mas, sim, que as obras intervieram em paisagens ermas para, radicalmente, se oporem à mercantilização da arte. Tais interpretações são relevantes para compreendermos que, no Brasil, a paisagem aparece mais como uma ideia, e menos como um meio construído pela sociedade, que também interfere sobre ela.

62 Esta dissertação não poderia adentrar o histórico da pintura de paisagem - quer seja a europeia que nos influenciou, quer seja a nacional - mas é importante que seja apresentado um breve panorama da pintura de paisagem para salientar que desta pintura também herdamos padrões, "esquemas de percepção" - nos termos de Berque (1998). Portanto, vale atentarmos para obras e artistas formadores de "visões de paisagem". 
alguns exemplos, a fim de compreendermos que, desde então, há um encadeamento de ações da arte em relação à paisagem.

Ao apreender, estetizar, intervir, representar, projetar e modelar a realidade objetiva o meio - a pintura de paisagem do Renascimento até as intervenções in loco da arte contemporânea da paisagem seguem aprofundando nossa percepção da paisagem e alargando nossa relação e compreensão com o meio e a natureza.

A pintura da paisagem marca as fases da nossa concepção de Natureza. O seu aparecimento e desenvolvimento desde a Idade Média é parte de um ciclo, no qual o espírito humano tenta mais uma vez criar harmonia com aquilo que o rodeia. (Clark, Kenneth. Paisagem e Arte, 1961, p. 19)

Podemos entender que, além da pintura de paisagem, a arte contemporânea da paisagem igualmente incita uma melhor observação e reflexão sobre as relações de uma sociedade com seu meio. Quando Clark nos fala desse segmento da pintura como um índice que revela como as sociedades conceberam seu meio ou sua natureza - interpretaram-na, idearam-na, imaginaram-na -, ele ainda não havia presenciado o fenômeno da arte da paisagem que, a partir de meados dos anos 1960, passou a imprimir diretamente sobre a paisagem, natureza, ou meio, suas concepções. Tufnell, ${ }^{63}$ sobre a arte contemporânea da paisagem, explica que este gênero propõe debater, por meio de propostas às vezes divergentes, a complexidade de nossa relação com a paisagem, com a terra (land) e com a natureza.

[Land art] propose a cohesive argument, or rather arguments, a set of propositions about our relationships with the land and nature, about the way in wich art can articulate the experience of landscape and nature. [...] Broadly, Land art is characterised by an immediate and visceral interaction with landscape, nature and the environment. (TUFNELL, 2006, p. 15)

A pintura de paisagem (na sua tradição europeia) talvez não tenha inventado a paisagem, ${ }^{64}$ mas influenciou os modos de vê-la e de produzi-la e, para o Brasil, de aceitá-la e reconhecê-la.

63 TUFNELL, 2006, p. 15."A arte contemporânea da paisagem expõe um debate coerente, ou melhor debates, uma série de sugestões sobre nossas relações com a terra, com a natureza [...] De modo geral, esta arte é caracterizada por uma imediata e visceral interação com a paisagem, natureza e meio ambiente". (tradução nossa)

64 BERQUE, 2001 apud MARIA, 2010, p. 124. Berque não concorda em compreender a paisagem como construção do olhar apenas, pois ela é também um dado externo a ele. "Porque 'nascimento', por exemplo, ao invés de invenção da paisagem? Porque eu não gosto desse vocabulário construtivista, que leva a pensar que a paisagem seria pura criação do olhar humano. A paisagem não está no olhar sobre os objetos, ele está na realidade das coisas, ou seja dentro da relação que temos com o nosso ambiente": 
Quando Roger (1999) ressalta a influência da arte na produção e aceitação da paisagem, através dos processos que chama de artialização, ele agrupa "a arte milenar dos jardins, o landscape gardening a partir do século XVIII e , mais próxima de nós, a Land Art", como modos de artializar in situ, pois inscrevem "diretamente o código artístico na materialidade do lugar, sobre o terreno, a base natural"; e na arte que influencia indiretamente - in visu -, a produção da paisagem opera "sobre o olhar coletivo, fornecendo-lhe modelos de visão, esquemas de percepção e de deleite". Neste último grupo, estão as pinturas de paisagem que serviram como inspiração e modelo para a criação de parques, a fotografia, a paisagem descrita e imaginada na literatura, assim como a paisagem divulgada em filmes, entre outros.

Deste modo, a arte, em relação à paisagem, configura-a (ou reconfigura-a) - no sentido de configurar junto -, e, não menos capaz de moldá-la, também pode influenciar na elaboração do nosso olhar sobre ela, fornecendo "modelos de visão", de percepção e apreciação estética. As imagens da arte, da fotografia e dos meios de comunicação reiteram paisagens simbólicas, perpetuam uma tradição ou lançam olhares para novas paisagens a serem assimiladas.

Besse (2006) expõe o quão potente foi a influência da pintura como repertório de imagens e de padrões estéticos para Goethe em sua viagem à Itália. Através das descrições de Goethe, as paisagens são "evocações pitorescas" onde se pode reconhecer na paisagem real os padrões da paisagem pictórica de Claude Lorrain. A Itália, para Goethe, é uma "pintura viva", é através de uma cultura herdada que ele reencontra o que já sabia desde sempre e, por isso, diz sentir-se em casa e não mais como um estrangeiro exilado.

Se a paisagem é um quadro, Goethe, [...] olha a natureza com os olhos do artista. Ele fala em Veneza, deste 'dom que tenho há tempos de ver o mundo pelos olhos do pintor cujas imagens eu acabo de gravar no meu espírito' (8 de outubro de 1786). A referência pictórica contém diversos fins: ela guia o olhar do viajante sobre os lugares que ele atravessa, ela dá a tonalidade das suas descrições e permite apresentar a fisionomia particular da região, determinando a impressão que o viajante tem dela. ${ }^{65}$

A pintura de Claude Lorrain não norteou apenas o olhar de Goethe. Gombrich $(1988)^{66}$ descreve os desdobramentos das pinturas do artista, que traduziam composições agradáveis entre o cultural e o natural. Veremos ainda, que a influência deste pintor chegou

65 BESSE, Jean-Marc. Vapores no céu. A paisagem italiana na viagem de Goethe. In: .Ver a Terra: Seis ensaios sobre a paisagem e a geografia. São Paulo: Perspectiva, 2006, p. 48.

66 GOMBRICH, Ernst Hans. A história da Arte. Rio de Janeiro: Ed. Guanabara, 1988, p. 309 
até o Brasil, por intermédio do primeiro pintor paisagista, vindo com a Missão Francesa, incumbido de representar o país durante o vice-reinado.

Foi Claude Lorrain quem primeiro abriu os olhos das pessoas para a beleza sublime da natureza e por quase um século após sua morte os viajantes costumavam julgar um trecho de paisagem real de acordo com os padrões por ele fixados em suas telas. Se o cenário natural lhes recordava as visões do artista, consideravam-no adorável e ali se instalavam para seus piqueniques. Os ingleses ricos foram ainda mais longe e decidiram modelar os trechos de natureza que consideravam seus, os jardins em suas propriedades, de acordo com os sonhos de beleza de Lorrain. (GOMBRICH, 1988, p. 309).

A paisagem, como já vimos, não é mera representação ou imagem, é realidade factual e produto cultural que evidencia os modos de uma sociedade transformar e se adaptar ao meio. No entanto, dada a influência da pintura de paisagem, capaz de promover a realidade à condição de paisagem, alguns autores, como Denis Cosgrove, ressaltam sua essência artística, sublinhando sua natureza simbólica e sua condição de ser uma composição.

A landscape is a cultural image, a pictorial way of a representing, struturing or symbolizing surroundings. This is not to say that landscapes are immaterial. They may be represented in a variety of materials and on many surfaces - in paint on canvas, in writing on paper, in earth, stone, water and vegetation on the ground.$^{67}$ (DANIELS \& COSGROVE, 1988, p. 1 apud MYANAKI, 2003, p. 17)

67 "A paisagem é uma imagem cultural, um modo pictórico de representar, estruturar e simbolizar o entorno (o meio). Isto não quer dizer que as paisagens sejam imateriais. Elas podem estar representadas em uma variedade de materiais e superfícies - na pintura, na tela, na escrita sobre o papel, na terra, pedra, água e na vegetação sobre o solo".

DANIELS \& COSGROVE. Iconography and Landscape. Great Britain: Cambridge Univ. Press, 1988, p. 1 (tradução nossa) apud MYANAKI, 2003, p.17. 


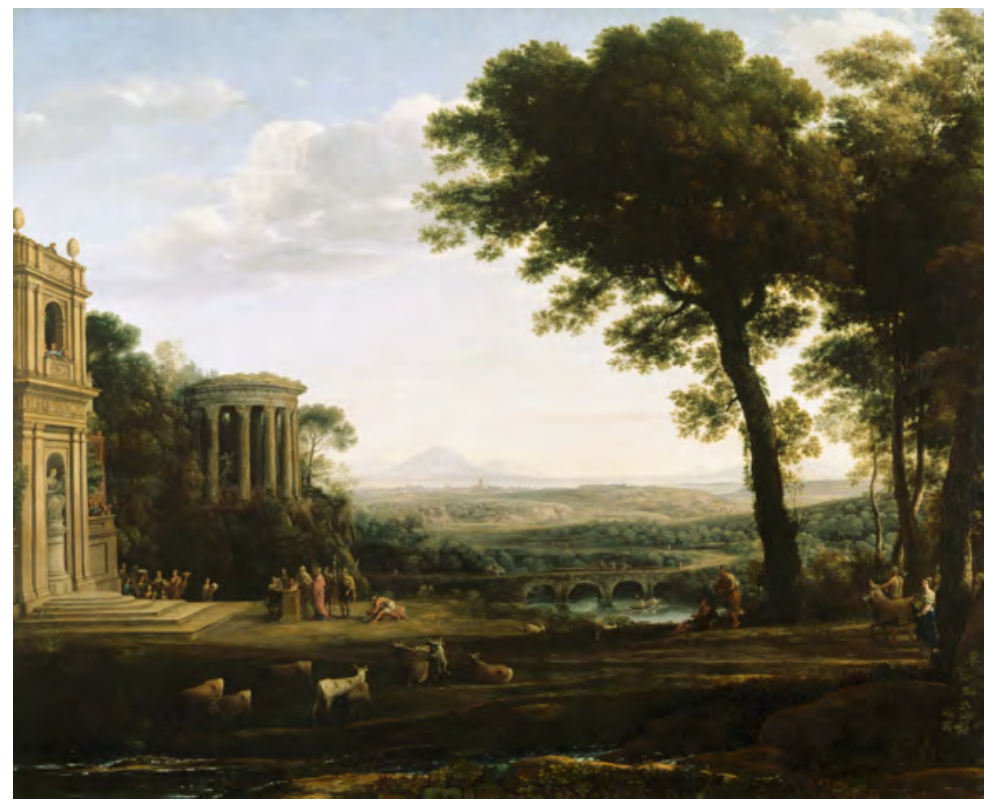

12. Claude Lorrain (1600-1682). Paisagem com sacrifício a Apolo, 1662. (Fonte: http://londonist.com/2012/03/art-review-turner-inspired-in-the-light-of-claude.php/the-father-ofpsyche-sacrificing-at-the-temple-of-apollo-1662)
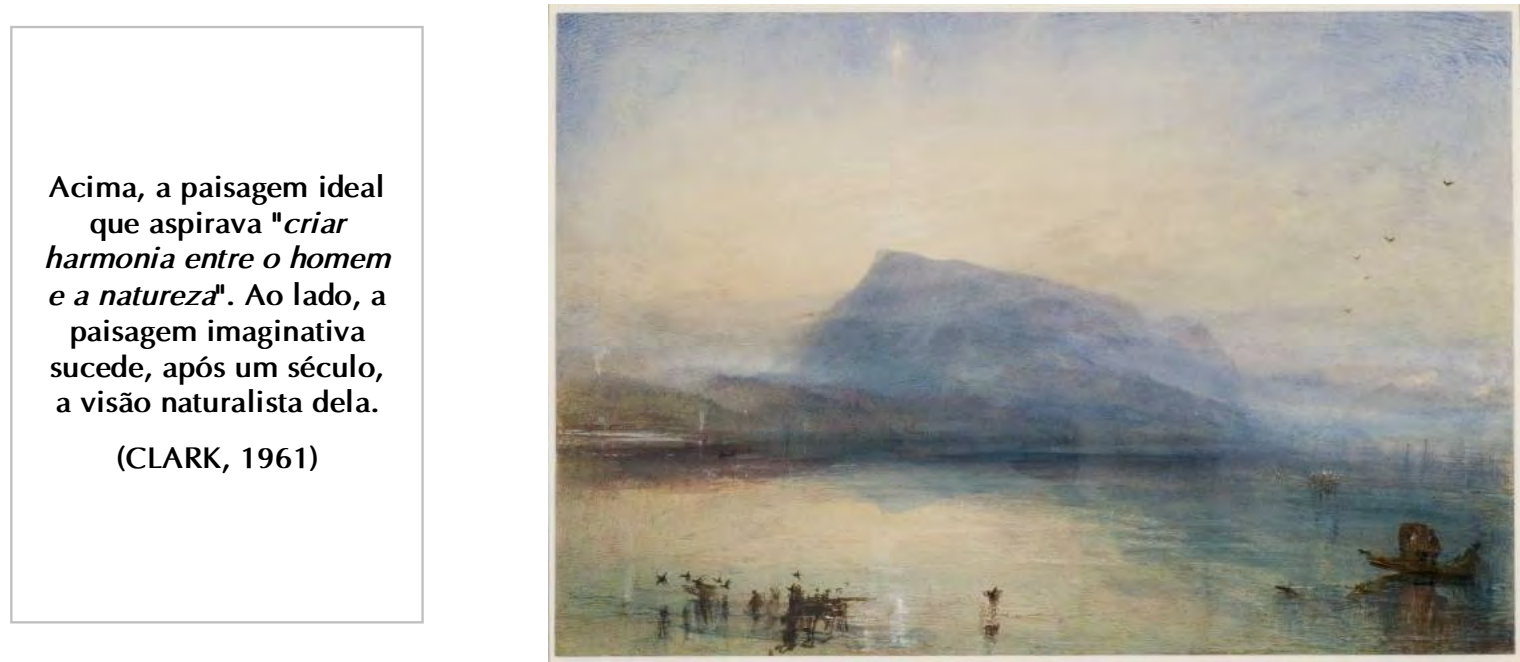

13. Joseph Mallord WilliamTurner (1789-1862). The Blue Rigi, Sunrise. 1842. Aquarela, $29,7 \times 45 \mathrm{~cm}$. (Fonte: http://www.tate.org.uk/art/artworks/turner-the-blue-rigi-sunrise-t12336) 
Acting as an artificial barrier, the work connected the land to the sea and sky surrounding it, making explicit the arbitrary nature of political and geographic boundaries.

(KASTNER; WALLIS, 1998, p. 72)

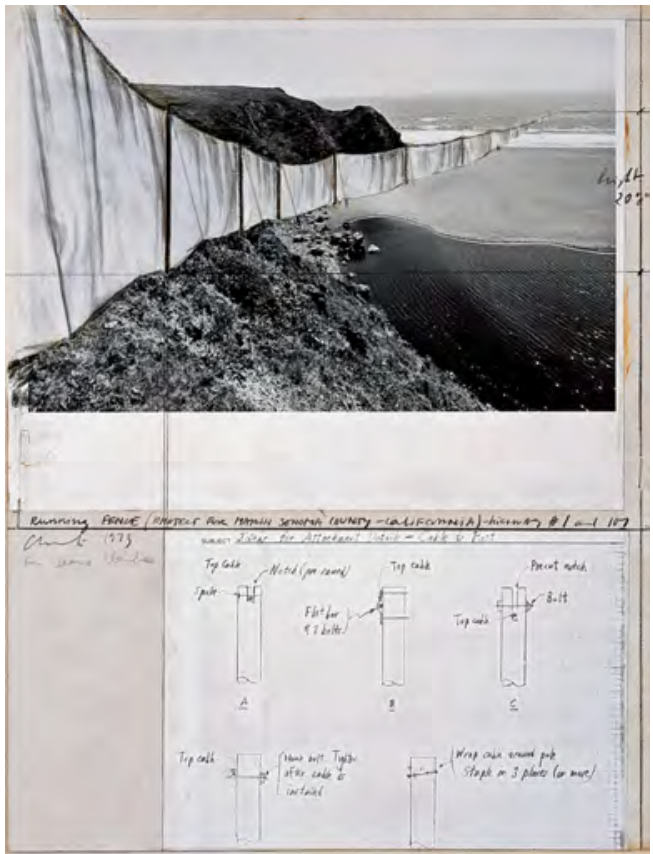

Funcionando como uma barreira artificial, o trabalho conectou o terreno ao mar e ao céu, delimitando-o, tornando explícita a natureza arbitrária dos limites políticos e geográficos. (tradução nossa)
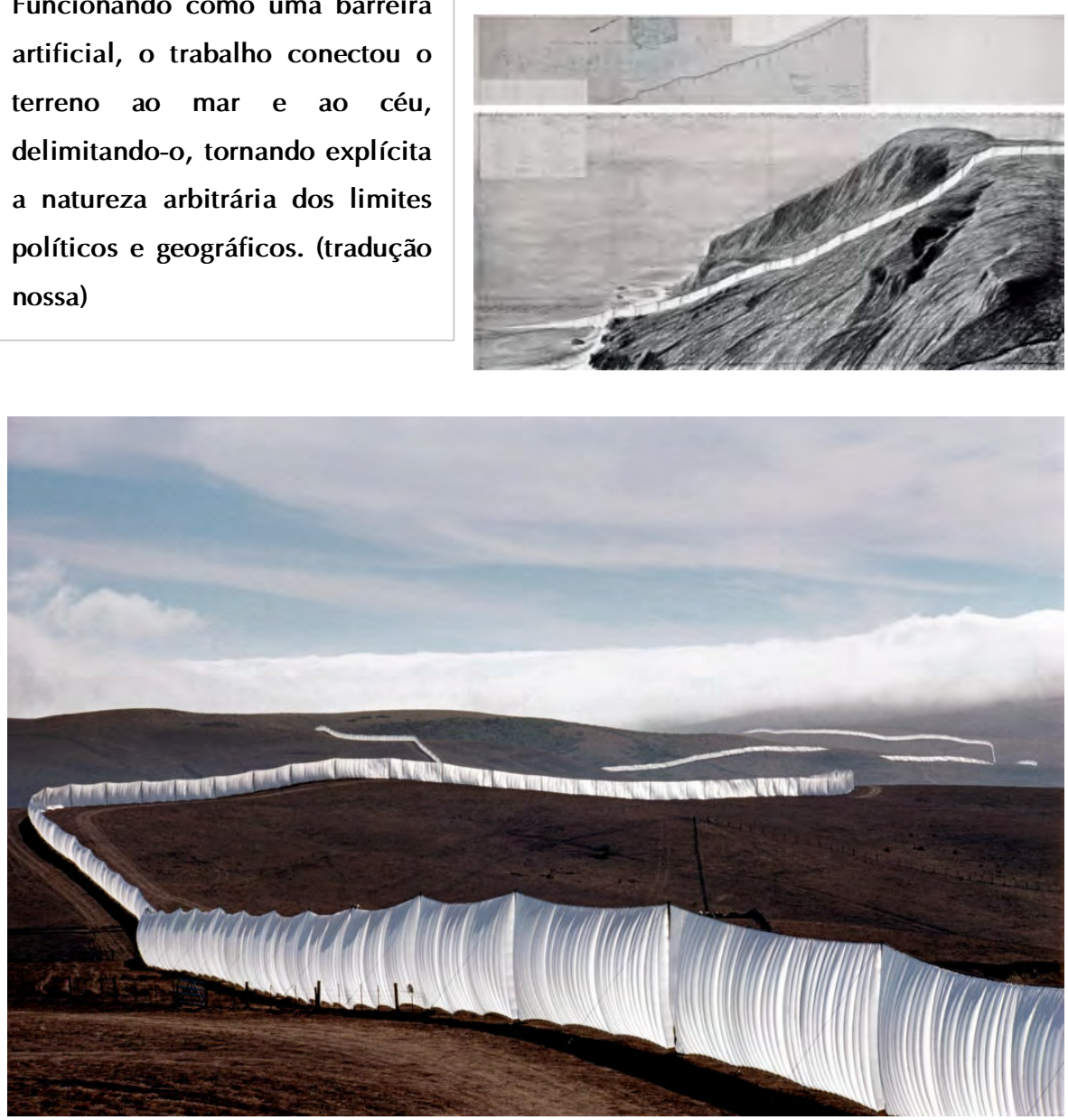

(04). Christo e Jeanne-Claude. Running Fence (Project for Marin Sonoma County - California)

Colagem, 1973; Desenho em duas partes, 1976 e Fotografia de Wolfgang Volz, 1976. 
Antes de a paisagem ser mote para a pintura, ela precisou se desprender de temas religiosos e políticos, entre outros, para ganhar a frente ou totalidade da tela - e da visão deixando de ser apenas cenário até tornar-se autônoma, como uma entidade por si só simbólica.

Vejamos como a paisagem foi sendo abarcada pela arte, em um processo que durou séculos, traduzindo o envolvimento da sociedade e sua capacidade, cada vez maior, de interferir no meio em que está inserida. Ao compreendermos este processo de autonomia da paisagem na arte, ganhamos outra perspectiva para analisarmos a arte contemporânea da paisagem no Brasil.

Nas pinturas da Idade Média, os elementos da natureza, ordenados e compondo uma cena de fundo, simbolizavam o divino. Tanto os elementos naturais representados na pintura quanto os modelados diretamente nos jardins, em uma concepção idílica, eram projetados de modo a reconfortar o homem, que habitava um mundo e natureza perturbadores.

Estas composições da natureza, adquirindo autonomia, deixaram de representar apenas paisagens celestiais ou estar a serviço da pintura religiosa, e passaram a construir-se de fato, incidindo sobre a realidade que poderia, então, vislumbrar a condição de paraíso terrestre "onde a harmonia entre o homem e a natureza, dentro dos limites da nação, traria como resultado uma vida terrena espiritual e materialmente gratificante". ${ }^{68}$

Nos séculos XVI e XVII, as descobertas do Renascimento influenciaram ainda mais as representações da paisagem e os artistas passaram a se interessar por ela "como imitação do mundo real. ${ }^{69}$ A partir "da laicização dos elementos naturais, árvores, rochas, rios, etc." (ROGER, 1999), os elementos naturais ganharam a atenção, quando, descolados de ícones centrais que compunham, passaram a organizar-se a si próprios.

Em suma, a paisagem adquiriria a consistência de uma realidade para além do quadro, de uma realidade completamente autônoma, ao passo que, de início, era apenas uma parte, um ornamento da pintura. (CAUQUELIN, 2007, p. 37)

68 LEITE, 2006, p. 61.

69 MYANAKE, 2003, p. 26. 
É no século XVIII, quando a organização da paisagem em jardins e parques havia se estabelecido como interesse político-social, que a paisagem adquiriu o status de gênero da pintura e passou a ser ensinada nas academias. Segundo Clark (1961, p. 78), a partir do Renascimento, seguiram-se trezentos anos até que "a pintura de paisagem pudesse constituir um fim em si”. As artes se envolveram com a paisagem real, visível, com a relação homem e natureza através da pintura, na literatura, bem como nos jardins e parques públicos. Neles, buscava-se ordenar e compreender os elementos naturais a partir das emoções estéticas que suscitavam e das normas de composição da pintura: a paisagem e os elementos da natureza eram então valorizados esteticamente tanto quanto a arte.

Já no século XIX, a pintura de paisagem, em mais de uma corrente estilística, aproximou-se da natureza e de seus fenômenos, sob a visão naturalista. Artistas como John Constable (1776-1837) desejavam observar a natureza e se aproximar da realidade ao máximo; enquanto artistas como Turner (1775-1851) evocavam da natureza o sublime, ressaltando nela o incomensurável, afinados com a estética romântica. Paisagens grandiosas e desconhecidas passaram a ser fonte de interesse, incluindo as selvagens e aquelas do Novo Mundo. Assim, ampliava-se o repertório de paisagens na pintura, primeiramente moldadas no equilíbrio entre o natural e o construído, natureza e civilização, ou que representassem campos e jardins. $^{70}$

A partir daí, a apreciação estética da paisagem (e da natureza) se disseminaria, muitas vezes, associada a posturas éticas traduzidas nas imagens do campo como repouso ${ }^{71}$ ou da natureza como alívio dos males urbanos. Tal fato é relevante para chegarmos à arte da paisagem no contemporâneo, pois é com ela que a apreciação estética da arte e da paisagem se reaproximam, em acordo ou não, sendo objetos para contemplação ou para reflexão crítica, mas quando não caberia mais a polaridade campo e cidade ou natureza e cultura.

A partir de meados do século XIX até a primeira metade do século XX, a paisagem urbana também ganhou a atenção de artistas, incluindo brasileiros. A representação figurativa e narrativa de paisagens já ficara a cargo da fotografia, libertando a pintura da geometria perspectivista que passa, então, a focar o caráter simbólico e o contexto sócio-político da paisagem.

Entre 1850 et 1950, les paysages urbains occupant une place importante dans les diffèrents arts. La rue, le boulevard, le mouvement des hommes et des choses, les

\footnotetext{
70 MYANAKI, 2003, p. 28.

71 Durante séculos, a paisagem era sinônimo de campos, de "países tranquilos" [pays sage]. ROGER, 1999. 
reclámes et le vitrines, les terrasses de café, le luxe et la pauvretè s'y deéclinent sous leurs nombreuses facettes diurnes et nocturnes. (BÉGUIN, 1995, p. 17 apud MYANAKI, 2003, p. 28)

No Brasil, a pintura de paisagem e da natureza recebeu a atenção dos naturalistas e artistas viajantes, desde Frans Post (1612-1680), perdurando até os séculos XVIII e XIX. Há desenhos e pinturas de paisagens brasileiras anteriores à Academia Real de Belas Artes ${ }^{72}$, provavelmente influenciados pelos exemplos dos viajantes estrangeiros. Mas o tema da paisagem e da natureza nas artes plásticas se inicia por intermédio dos artistas da Missão Francesa. Deles herdamos um imaginário de paisagens já sedimentado, com regras de composição e gostos temáticos estabelecidos, que se configurava há, pelo menos, quatro séculos.

Nossas paisagens - mesmo com outras luzes e formas, e, principalmente, moldadas a partir de uma apropriação da natureza, cuja urgência pela exploração opõe-se ao tempo e aos recursos necessários para se elaborar a composição e seu desfrute estético - foram adequadas e reelaboradas por estas visões de paisagem precedentes, que também foram, alternadamente, motivo para se buscar novos meios de se desprender das referências estrangeiras.

É relevante notar a existência, desde a Academia Real, de uma base comum e uma confusão entre reconhecimento de território e linguagem artística, o que se repetirá na proposta contemporânea do projeto Fronteiras (1998-2001).

A aprendizagem do desenho era a base comum para pintores, gravadores e cartógrafos. Essas profissões ligadas à prática administrativa e militar, tinham prioridade para o novo regime que acabava por considerar secundária a formação de artistas, cujo prestígio era pouco na sociedade da época. (MIGLIACCIO, 2000, p. 50)

Nicolas-Antoine Taunay (1755-1830), o primeiro pintor paisagista da Academia, bem amoldou a paisagem brasileira às lições da academia europeia. O pintor francês retrata os reis portugueses, mesclando elementos característicos do cenário brasileiro - a vegetação, escravos, frades e a arquitetura peculiar da casa grande portuguesa - com "a tradição da

\footnotetext{
72 Em 1820, criou-se a Real Academia de Desenho, Escultura e Arquitetura Civil que, no ano seguinte, passou a se chamar Academia Real de Belas Artes. A Missão Artística Francesa foi composta "pelo arquiteto Grandjean de Montigny, pelo pintor histórico Jean Batiste Debret, pelo paisagista NicolasAntoine Taunay, seu irmão o escultor Auguste-Marie Taunay, pelo gravador Pradier e por alguns especialistas em mecânica". MIGLIACCIO, Luciano. O Século XIX In: FUNDAÇÃO BIENAL DE SÃO PAULO. Arte do Século XIX. Mostra do Redescobrimento. Brasil +500: Catálogo, São Paulo: Fundação Bienal de São Paulo, 2000, p. 48
} 
paisagem pastoral inspirada em Claude Lorrain". Dessa forma, uma atmosfera campestre e idílica é construída com "leve toque da cor local, aquela característica das edificações e da vegetação local."73

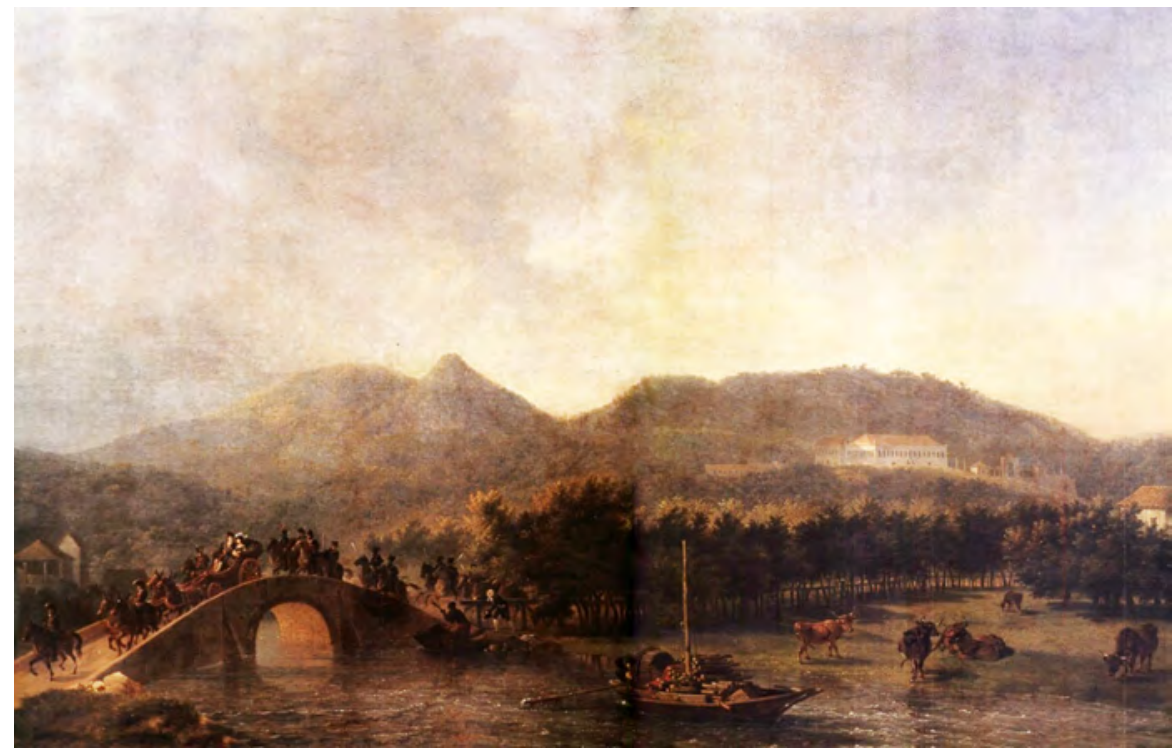

14. Nicolas-Antoine Taunay. Passagem do Cortejo Real na Ponte do Maracanã,1817-20. (Fonte:http://commons.wikimedia.org/wiki/File:NicolasAntoine_Taunay_Passagem_do_Cortejo_Real_na_P onte_do_Maracan\%).

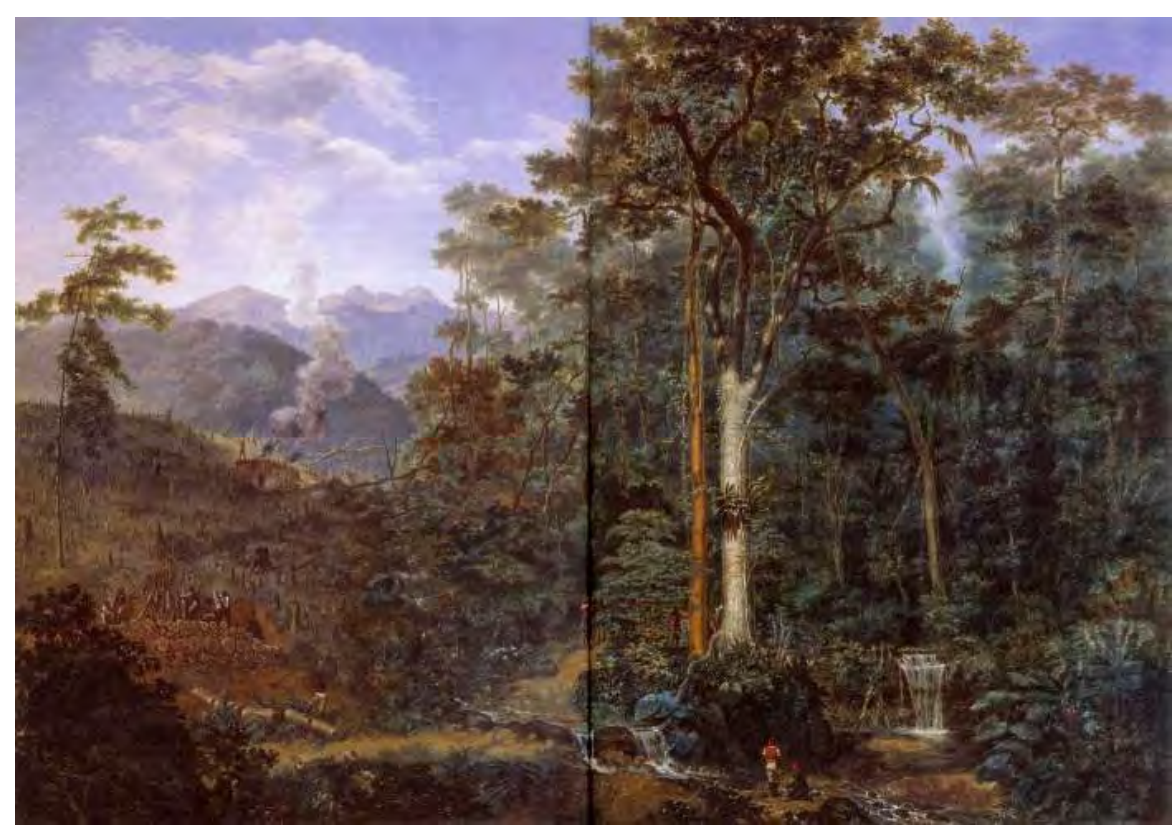

15. Félix-Emile Taunay. Floresta Reduzida a Carvão, 1830. (Fonte: http://topicos.estadao.com.br/fotos-sobre-tauney/1843-taunay)

Uma vez implantada a escola de artes, a pintura de paisagem passa a se desenvolver como conhecimento e divulgação do país. Com Félix-Emile Taunay, almejou-se "um gênero

\footnotetext{
73 Ibidem, p. 52
} 
de paisagem histórica capaz de superar os limites da ilustração científica e do panorama". ${ }^{74}$ No final do século XIX, quando ela é ensinada ao ar livre por Georg Grimm, a pintura de paisagem se liberta da condição de ilustração e pintura de história, deixando de ter intenção didática ou narrativa. Ao dar este primeiro passo de autonomia, a paisagem na arte logo se incumbiria de comentar a própria natureza humana, suas angústias e anseios. Castagneto, aluno de Grimm, exemplifica com suas marinas, que representam estados da alma, a pintura de paisagem como exercício do olhar e da liberdade. Esta aproximação menos narrativa da arte com a paisagem retornaria em obras contemporâneas.

Entre a pintura acadêmica inaugurada por Taunay e os precursores da arte da paisagem contemporânea, não há como desconsiderar que a pintura brasileira buscou por uma natureza e uma paisagem identitárias, originando um profundo exercício de reflexão para se encontrar tanto o repertório de imagens, o vocabulário da paisagem brasileira, quanto sua essência ou atmosfera. Na pintura moderna, a paisagem alcançou destaque com Tarsila do Amaral (1886-1973), que a propôs entre o lúdico e o simbólico de uma identidade brasileira; com Alberto da Veiga Guignard (1896-1962), que elegeu as paisagens coloniais brasileiras, em pleno ápice do desenvolvimentismo do projeto Moderno; ${ }^{75}$ assim também com Francisco Rebolo (1902-80), cujas paisagens, mais despidas de elementos naturais, foram atentas ao processo de urbanização desde a década de 1930 até 1970.

À pintura de paisagem no Brasil mesclaram-se interesses em dar visibilidade à paisagem e à natureza como símbolos de riqueza e recurso. Artistas estrangeiros e brasileiros, desbravando e propagandeando paisagens do Novo Mundo, transformaram a floresta e o índio, o bom selvagem, em ícones da nação. A natureza exuberante era, desde os retratos de Albert Eckhout (1610-1665), para ser apropriada, era uma natureza como sinônimo de riqueza. Já no Modernismo, as paisagens simbolizavam a identidade nacional, dando forma à ideia de tropical ou de um futuro a se construir. Esta herança de interesses políticos e econômicos que se sobrepuseram à arte da paisagem brasileira, somada ao fato de paisagem ainda significar pintura em que principalmente reina a natureza - mesmo diante de paisagens cujas construções se adensavam e se verticalizavam vertiginosamente -, parece ter distanciado o interesse da arte contemporânea brasileira da paisagem de fato.

\footnotetext{
74 Ibidem.

75 No Capítulo 2, será abordada a paisagem nas pinturas de Tarsila do Amaral e de Guignard para introduzir a passagem para a nossa arte contemporânea.
} 


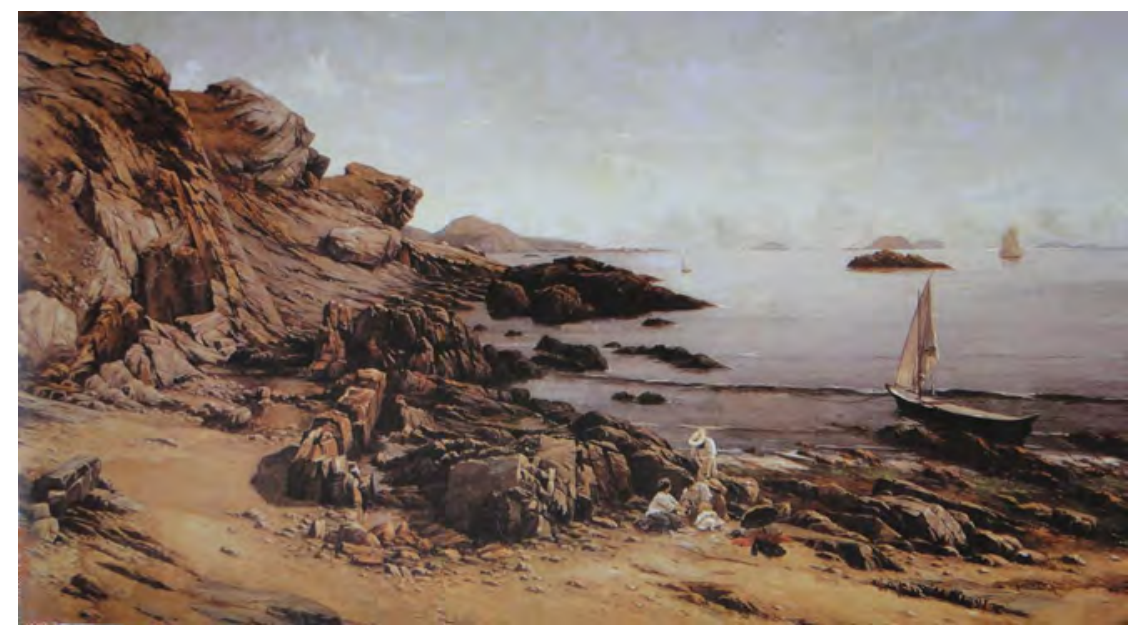

16. Johann Georg Grimm. Vista da Ponta de Icaraí, 1884. (Fonte: Catálogo Olhar distante, 2000, p. 132-133)

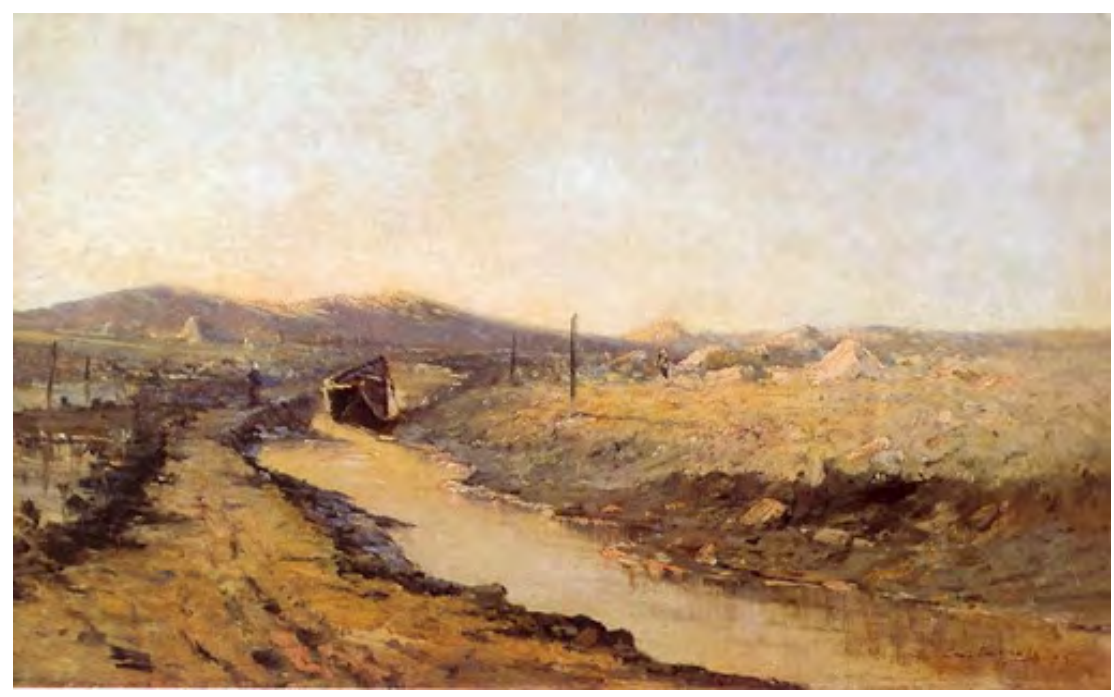

17. Giovanni Battista F. Castagneto. Paisagem com Rio e Barco ao Seco em São Paulo "Ponte Grande", 1895. Óleo sobre madeira. $33 \times 55 \mathrm{~cm}$ (Fonte: http://www.arcasdearte.com/2011/06/giovanni-battista-castagneto-pintor-e.html)

Carregando a herança dos tempos de pintura e ainda reduzida unicamente a esta categoria da arte, a paisagem alcança os debates da arte contemporânea, não sem dificuldades. ${ }^{76}$ Além disso, há a questão de identificação da obra ou do artista com o lugar, que nem sempre foi alcançada em Fronteiras, por exemplo. Nuno Ramos, com Minuano, 2000, diz sobre o lugar onde inseriu a obra: "não é natureza, não é o pampa. É apenas um pasto". 77 Podemos entender que não há uma herança no nosso imaginário de reconhecimento daqueles

\footnotetext{
76 Sônia Salzstein, em entrevista para esta dissertação, expõe que seria anacrônico aproximar "paisagem" da arte contemporânea (referindo-se a seu significado como pintura).
}

77 RAMOS, Nuno. Ensaio Geral, 2007, p.222 
campos como paisagem significativa. Nélson Félix, com Mesa (1999), elege o lugar da obra a partir de coordenadas geográficas, para evitar a composição; ele deseja lançar luz a um novo olhar, e não lidar com as heranças de composição.

As camadas de lembrança que compõem a paisagem, como expõe Schama (1996), tornam-se mais interligadas na arte contemporânea da paisagem, e podemos melhor compreendê-las a partir do próprio histórico da arte que aborda a paisagem. A arte contemporânea da paisagem no Brasil também não se desenvolveu alheia ao histórico da pintura do gênero - tampouco às artializações, que lhe deram referências formais e conceituais, in visu ou in situ - como se pode notar na referência às remotas transformações do meio através da arte do Neolítico, que veremos nas obras de Fronteiras (1998-2001) O aleph (1999) e Minuano (2000), ou no paisagismo, como veremos em Fronteira, Fonte, Foz (2001).

Podemos dizer que a paisagem exerce influência em determinado segmento da arte, cujo início está na pintura de paisagem do século XV, prosseguindo até as obras da land art, no século XX, e seus desdobramentos, cada vez mais atuais, como a environmental ou eco art. Tal influência ultrapassa a simples inspiração ou tema (como mimese da natureza), uma vez que a arte da paisagem a idealiza, projeta, transforma ou questiona seus modos de produção, de acordo com padrões estéticos e intenções que evidenciam valores sociais de uma época. Isso se justifica, talvez, pelo fato de a paisagem ser nossa mediação frente ao mundo, à natureza.

A arte se nutriu da paisagem como repertório e como tema, seja por suas formas e objetos, sua composição; seja pela sua atmosfera que inspira sentimentos; seja ainda por sua história e o que ela representa para nós. E disto a arte contemporânea da paisagem parece não diferir. 


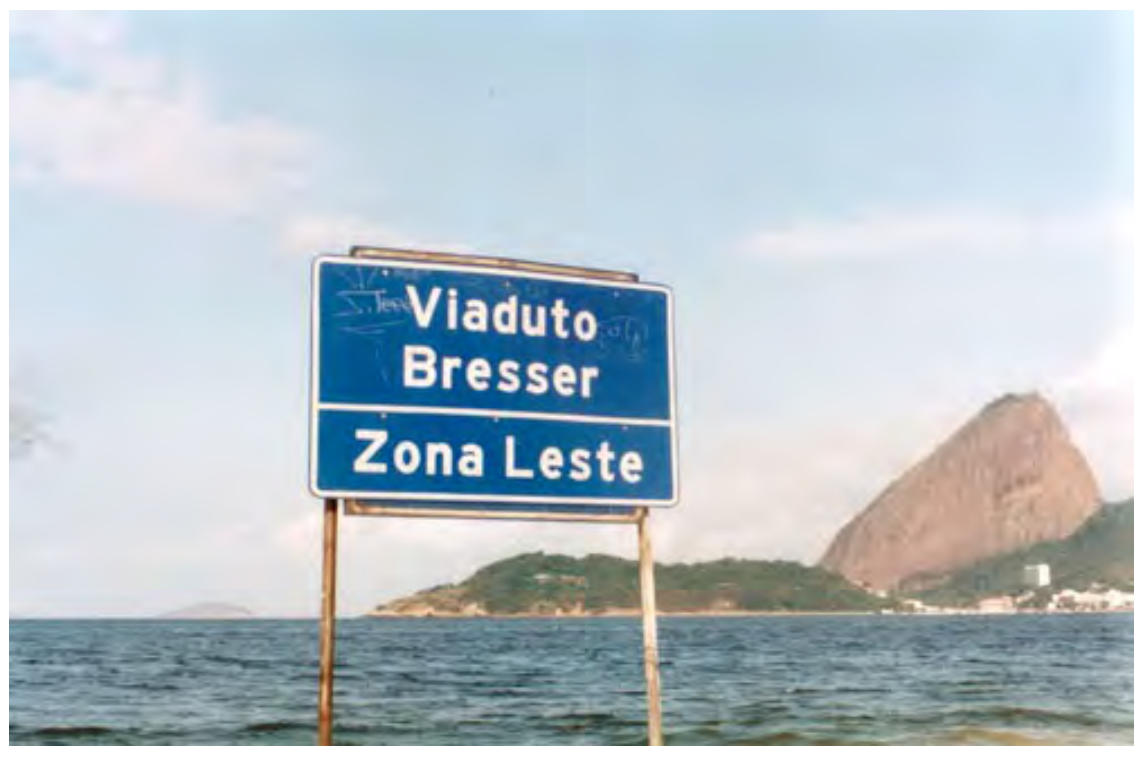

18. Marcelo Cidade. Leste Maravilhosa (2003). Intervenção. Fotografia e passagem de ônibus. (Fonte: < http://revistatrip.uol.com.br/fotos/galeria-vermelho.html\#18) 


\subsection{Paisagem-Natureza.}

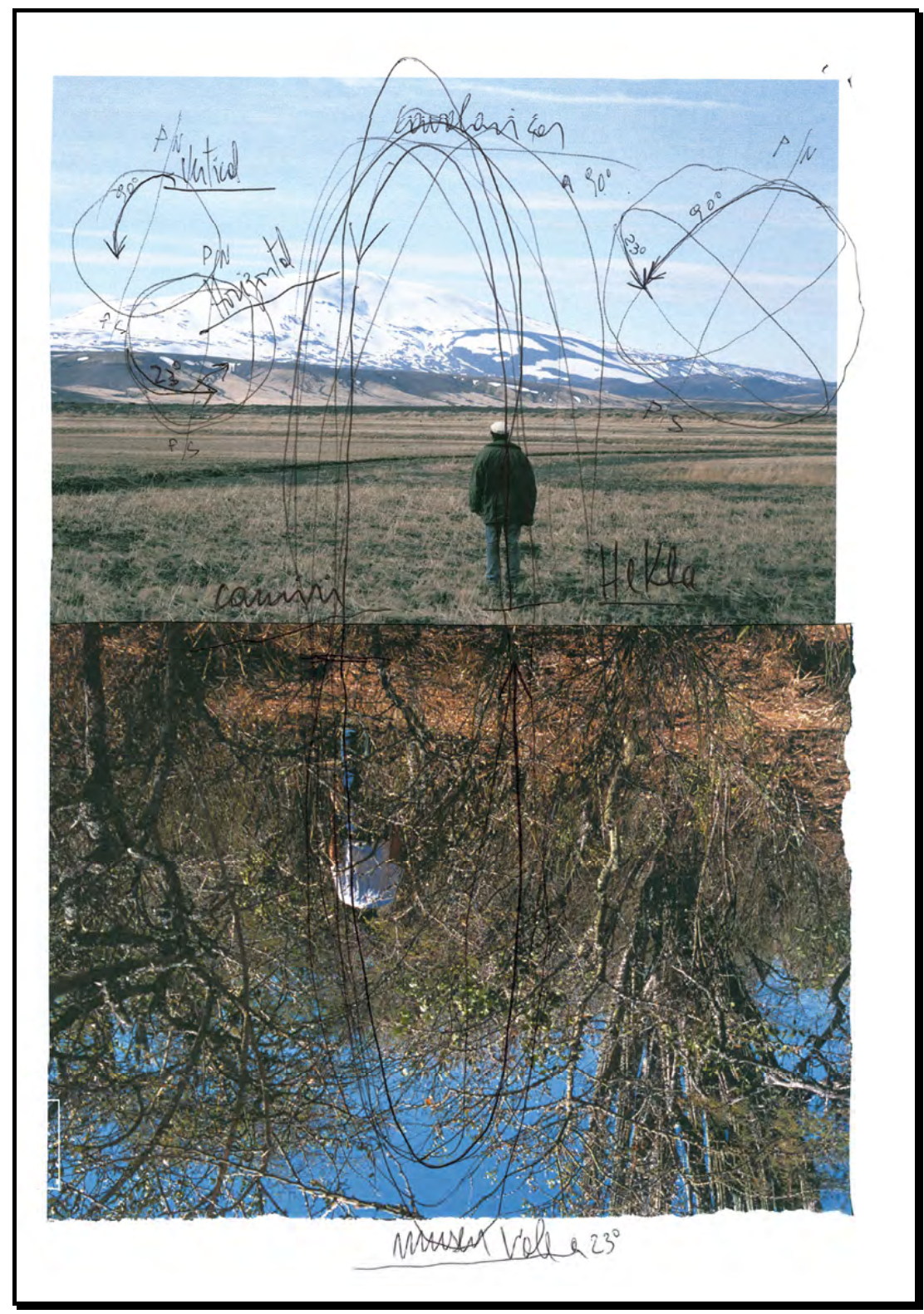

19. Nelson Félix. Camiri, Hekla, 2009.

"...reinstaurar um olhar primeiro, sem questões, sem direção. Olhar a escultura e só - estamos carregados de história,

mas ainda creio em voltar a um olhar limpo, sem discurso, informação, um olhar não cívico, sem texto -

UM OLHAR DE OLHAR".

(FELIX, Nelson. anotações no aeroporto, Paris, 2008. In: Concerto para encanto e anel, 2011) 


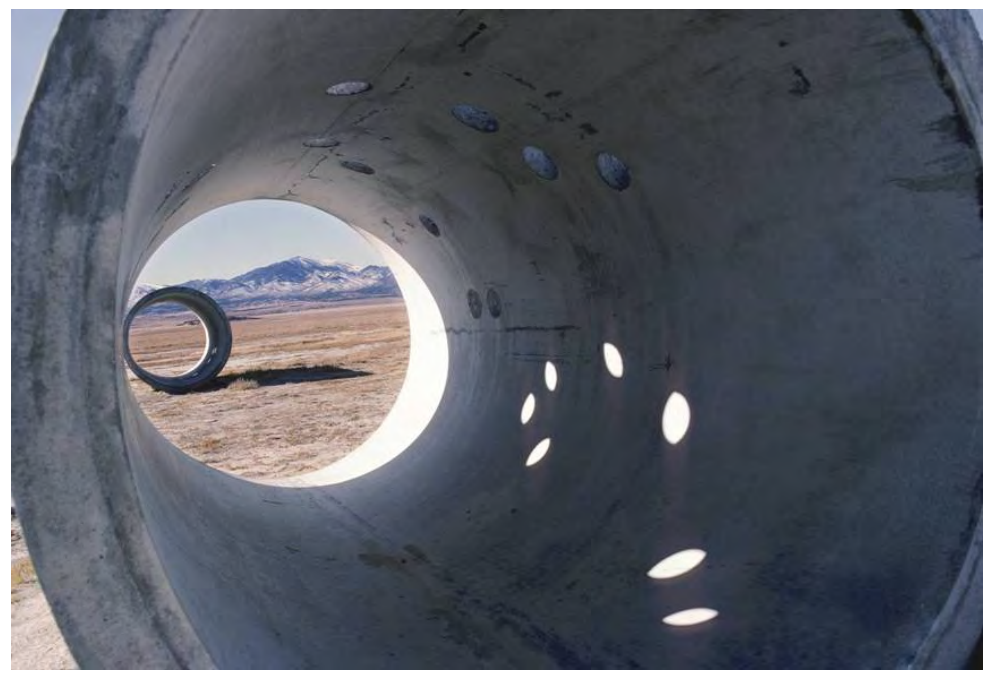

20. Nancy Holt. Sun Tunnels, 1973-76.

Tubos de concreto alinhados com o nascer e pôr-do-sol em dias de solstício, os raios do sol "desenham" na obra.

A experiência do trabalho diretamente na natureza, os efeitos das mudanças de luzes, o espaço "deslocado" [shifting], o calor e a espera por um evento específico intensificam o sentimento de tempo e escala do observador. (KASTNER; WALLIS, 1998, p. 109)

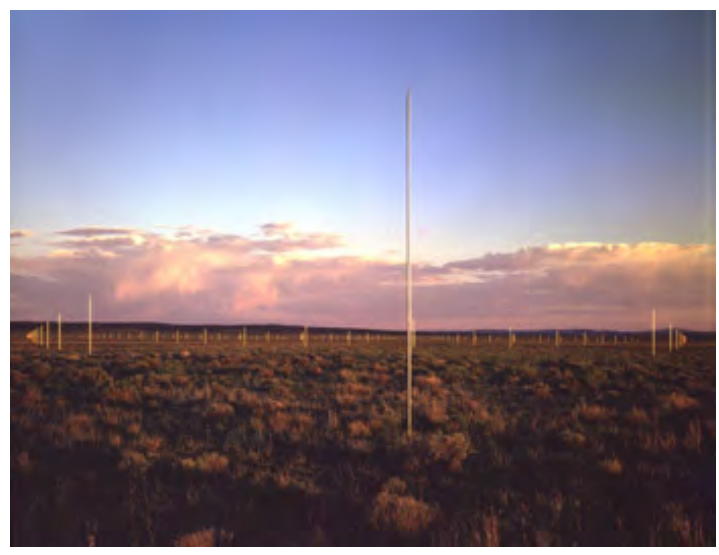

21 e 22. Walter De Maria. Lightning Field, 1977. New Mexico, EUA (Fonte: http://www.diaart.org/sites/main/lightningfield

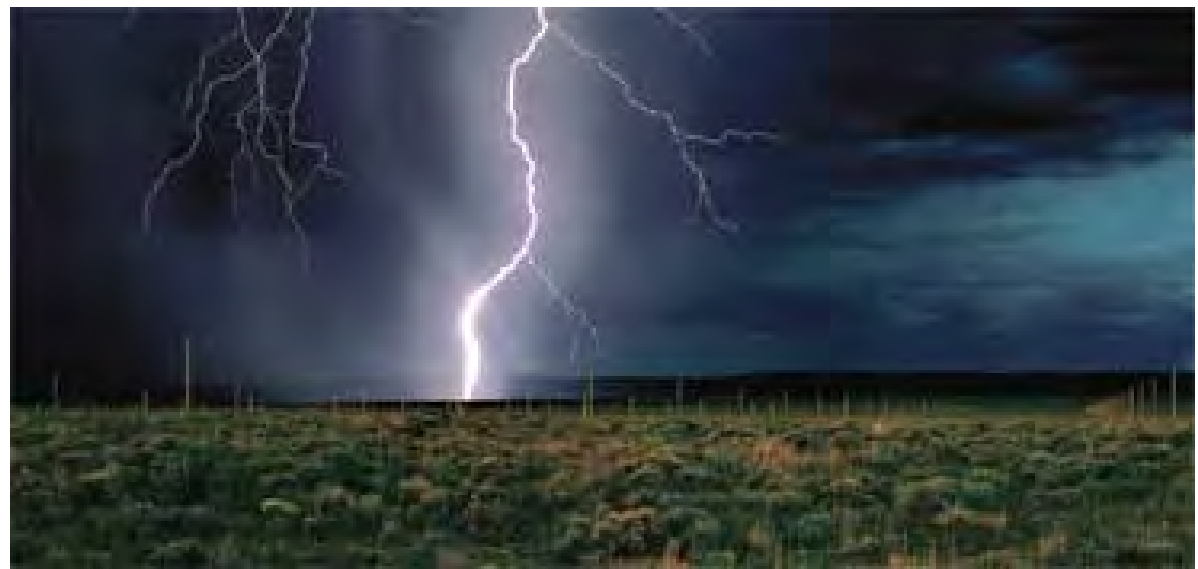




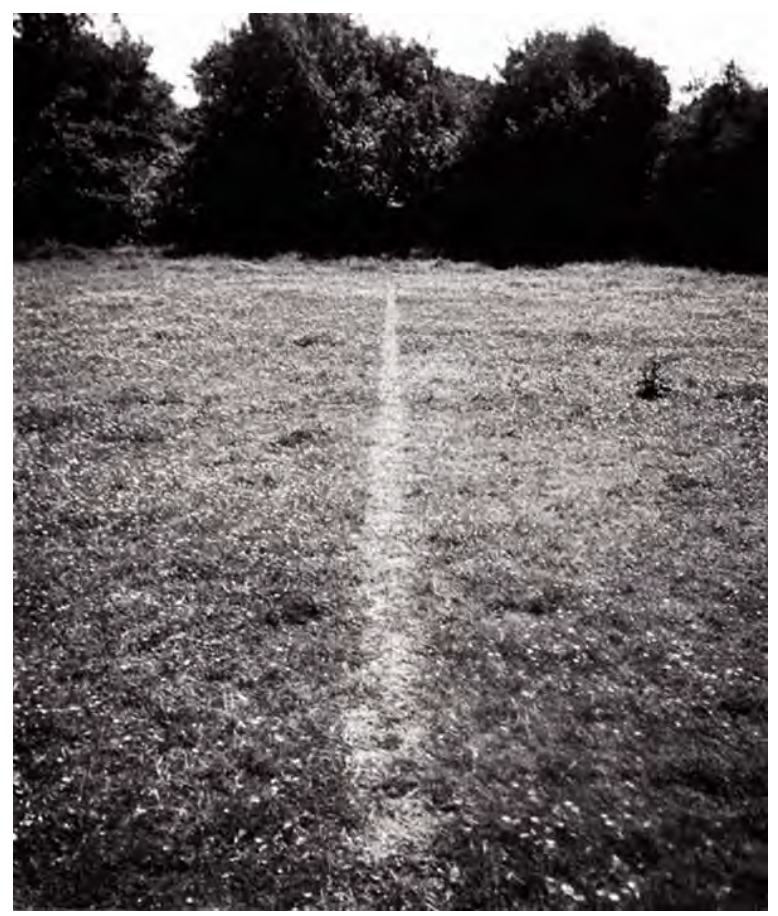

23. Richard Long. A line made by walking, 1967. Somerset, Inglaterra

O desenho traçado com a caminhada do artista durará até a grama nascer novamente.

(KASTNER; WALLIS, 1998, p. 125)

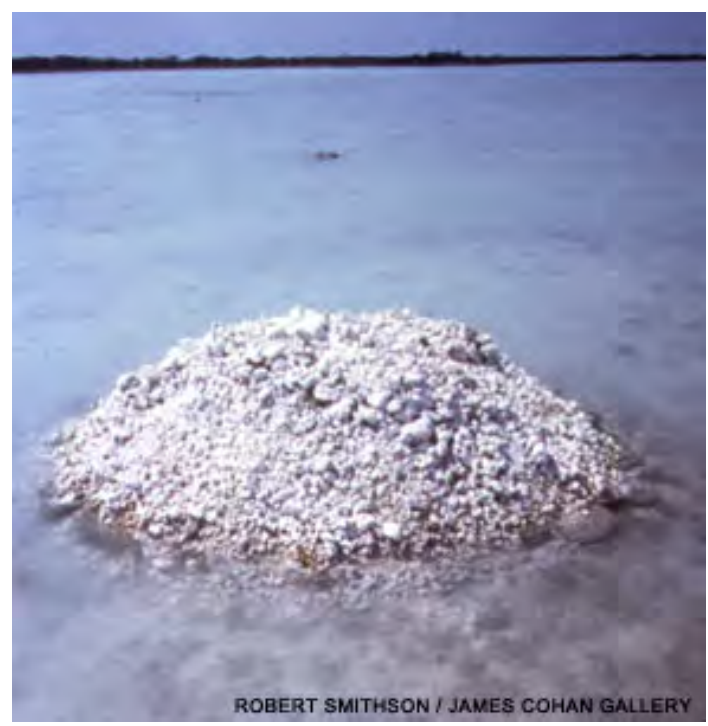

24. Robert Smithson. Oolite island, 1971. Florid

Smithson em entrevista a Gregoire Müller, 1971, diz trabalhar com água, terra, ar e fogo (luz solar) como um todo, como um fenômeno interligado. (FLAM, 1996, p. 261) 78 $^{7}$

78 FLAM, Jack. Robert Smithson: The Collected Writtings. Berkeley: University of California Press, 1996. 
Uma ideia foi se moldando no decorrer deste estudo: a de que a arte da paisagem parece ter como espinha dorsal a aproximação ou apropriação da natureza pelo indivíduo ou sociedade. Quando as obras não são os próprios elementos da natureza rearranjados, elas comumente se referem ao tempo e às forças de desenvolvimento ou entropia, que pertencem à escala do incomensurável. A arte da paisagem, no contemporâneo, parece focar os elementos e fenômenos da natureza (mesmo que estejam ocultados na paisagem). São exemplos disso desde os primeiros earthworks remodelando terra, pedras e relevos, até as obras que se valem da magnitude de trovões ou da incidência dos raios solares.

Também em Fronteiras (1998-2001), veremos obras que dialogam com elementos da natureza e algumas delas incorporam seus processos vitais. Já em Errante (2010), de Margem (2009-2010), é ressaltada uma natureza subjugada às diretrizes tecnocratas. Assim, endossando tal desconforto, as árvores, presença da natureza tão desejada em cidades como São Paulo, são inseridas em uma situação de tensão: atirantadas sobre o rio.

A arte contemporânea da paisagem nos desperta para os elementos da natureza e, deste modo, suscita reflexões sobre valores até então paralelos à arte, como o questionamento da natureza condicionada a interesses econômicos; ou sobre o valor da arte como "natureza" e não mais como objeto; até reflexões sobre as limitações da nossa percepção, que requer meios tecnológicos para abarcá-la.

Sobretudo, esta arte reflete os modos como uma sociedade, em determinado período, se apropria e interpreta a natureza. Não por menos, ao estudar as obras da land art e da arte da paisagem nacional, esbarramos nas noções e acepções de paisagem e natureza que, por vezes, se sobrepõem. E, por este mesmo motivo, autores da paisagem como Simmel, Cauquelin e Berque definem e refletem sobre natureza, paisagem e as tangências entre elas.

Natureza e Paisagem não são sinônimos, mas, nas falas dos artistas, por vezes, assim aparecerão, fazendo lembrar as colocações de Cauquelin (2007), que aborda as sobreposições entre ambas, discorrendo sobre um antigo aprendizado da percepção, o de moldar ou domesticar a natureza como paisagem. Sobre esta convergência entre paisagem e natureza, a autora expõe: 
A natureza-paisagem: um só termo, um só conceito - tocar a paisagem, modelála ou destruí-la, é tocar a própria natureza. [...] A paisagem participa da eternidade da natureza, um constante existir, antes do homem e, sem dúvida, depois dele. Em suma a paisagem é uma substância. (Ibidem, 2007:39)

Um fato chama nossa atenção ao estudarmos as obras da land art: não bastou a escultura contemporânea se inserir e incorporar os espaços públicos urbanos (lugares seus por excelência). Ela rumou para as paisagens menos habitadas, como que desejando esvaziar-se de seu repertório histórico, e com isso (re)aproximou-se da natureza. Tal aproximação merece uma atenção especial, pois, ao focar nos elementos naturais,- seja na sua apreciação estética ou na experiência da paisagem - a arte da paisagem aponta para a apropriação, interpretação, transformação da natureza. Deste modo, nos mostra anseios e críticas da sociedade quanto à influência da natureza na produção da paisagem.

Refletir em como, através da arte, a natureza é transformada, interpretada e simbolizada parece ajudar a compreender singularidades de uma arte da paisagem que se molda junto às produções culturais de sua época; uma arte que, diante da grandiosidade da natureza - seja esta temida ou venerada -, parecerá alheia ou mais "interiorizada", apontando para "um outro lugar". ${ }^{79}$

Assim também, os autores da arte da paisagem Tufnell, Beardsley, Kastner e Wallis não desvencilham a obra do modo como ela interage com os elementos da natureza. Ao contrário, eles apontam que nesta arte convergem os elementos naturais - seus fenômenos e a experiência da paisagem -, o pensamento e a obra de arte. Este fato reforçaria um novo olhar sobre a paisagem, pelo qual se entrelaçam natureza e cultura, sob perspectivas estéticas e éticas. $^{80}$

Para Simmel (1913), a paisagem é delimitação da natureza, enquanto esta seria o continuum da vida, indivisível. O sentimento da natureza, para o autor, precede o moderno, o que não ocorre com o sentimento de paisagem, concomitante a ele. $\mathrm{O}$ autor diz que "olhar um trecho do solo e o que há sobre ele como paisagem é conferir unidade a algo que, por sua vez, foi extraído da natureza - o que já se afasta completamente da noção de natureza."

79 SALZSTEIN, 2005, p. 12. Referindo-se à arte pública contemporânea brasileira.

80 Por essa essência da natureza na paisagem, por vezes, a arte da paisagem assume ou é utilizada por discursos ambientalistas, deslocando-se o foco das questões da produção da paisagem para os problemas ambientais. Dessa forma, a paisagem parece assumir um "esteticismo inútil". (CAUQUELIN, 2007, p. 10). 
Mas por que essa tendência (que se torna tão visível na arte da paisagem contemporânea) a associar paisagem e natureza, ou melhor, de focar na paisagem os elementos naturais? Cauquelin (2007), ao explicar que nosso imaginário de natureza e paisagem é herdado de moldes - seja da pintura, da reprodução literária, fílmica -, aborda que esta aparente "insistência" advém de um aprendizado que há muito nos influencia. Um aprendizado de vermos a natureza moldada na paisagem. E se a paisagem não pode ser vista, como no caso de algumas obras de Fronteiras, os elementos naturais tomam a cena e tornamse a ligação da arte com o meio. "Porque se a paisagem responde 'ausente', a natureza está lá." (Cauquelin, 2007, p. 45)

A autora explica ainda que esta aproximação paisagem-natureza nem sempre existiu e, sobretudo, que ela nos cria armadilhas, pois tendemos a interpretar uma paisagem como "natural". Assim, fica encoberta a complexidade de sua produção, ou ainda, com o uso do termo "paisagem urbana", reiteramos a oposição à suposta paisagem natural.

As paisagens de Fronteiras e de Margem evocam a natureza. A maioria dos artistas de Fronteiras constitui a paisagem moldando e ressaltando elementos da natureza. Comentemos algumas obras:

Angelo Venosa, com a obra $\boldsymbol{O}$ aleph (1999), explica em entrevista para esta dissertação, que a apreciação da natureza e da obra não se somam, "não são duas partes", mas uma unidade. Carlos Fajardo, por sua vez, pensou, primeiramente, em trabalhar com uma paisagem em que a natureza e o som (das Cataratas de Iguaçu) se sobressaíssem fortemente. Em Laguna, onde implanta Sem Título (1993/2001), também imperam os elementos da natureza, como "as dunas, uma linha do horizonte com o mar aberto" ${ }^{1}$, e são eles que imprimem uma atmosfera de dispersão à paisagem.

Para Nélson Félix os elementos da natureza não são tomados como partes de uma composição para apreciação estética, mas seriam indícios de um tempo e espaço que transbordam de nossa percepção. Assim, será o crescimento das figueiras (que pode levar duzentos anos) que desenvolverá Mesa (1999), quando as árvores erguerem a chapa de aço. Os processos da natureza e o acaso constituem a obra. Para Nuno Ramos, Minuano (2000) funciona se conseguir "captar o circuito do sol". Ramos comenta ainda sobre a escala da obra na paisagem, onde "a natureza continua resistindo firmemente". ${ }^{82}$ Waltércio Caldas escolheu a

81 FAJARDO, 2005, p. 89.

82 RAMOS, 2005, p. 193. 
fronteira como rio para instalar Momento de fronteira (2000), ressaltando as forças equivalentes dos elementos naturais que compõem aquela paisagem: o rio, o céu e a mata ${ }^{83}$. Ele também chama a atenção para o som: "o céu se ampliando com o ruído do rio, o ruído do rio se ampliando com a mata".

Já Fronteira, Fonte, Foz (2001), de Carmela Gross, sutilmente tangencia a natureza na referência do título "é um híbrido entre água e terra, fixidez e mobilidade, paisagem e desenho"; mas para por aí, pois a artista associa a arte ao fenômeno urbano, e não ao “pitoresco" da natureza. Pálio I e II (1996/8), de Eliane Prolik, não referencia os elementos da natureza e é a obra que está mais inserida em um contexto urbano vivo, área de comércio e circulação. Contudo, quando instalada anteriormente em São Paulo, a escultura remetia às formas orgânicas ou da natureza, em contraste com a paisagem densamente construída.

Para o projeto Margem (2009-2010), é através dos resquícios da natureza - os rios urbanos - que buscamos uma segunda chance para instaurar a paisagem. Errante (2010) se vale de uma ideia de jardim de árvores suspenso sobre o rio canalizado. Cabaré Chinelo, propôs levar as águas do rio Negro para dentro de um casarão em ruína, transformando-as em fonte, e o que une estes fluxos é a história da extração da borracha. A proposta de Ana Maria Tavares teve como princípio como as pessoas próximas ao Guaíba se relacionam com a água.

Há na paisagem um apelo à contemplação e uma necessidade de promover ou fundirse à natureza. Na paisagem, equivalem-se natureza e arte. ${ }^{84}$

[...] parece que se deu um salto que leva mais longe que a mera possibilidade de representação gráfica dos lugares e dos objetos, que é um salto de uma outra espécie: uma ordem que se instaura, a da equivalência entre um artifício e a natureza. Para os ocidentais que somos, a paisagem, é, com efeito, justamente "da natureza". A imagem, construída sobre a ilusão da perspectiva, confunde-se com aquilo de que ela seria imagem. (CAUQUELIN, 2007, p. 38)

Em vista dos exemplos mencionados, vemos que apontar para os elementos naturais da paisagem, enfatizá-los, ou até mesmo comentar sua ausência, são características da arte contemporânea da paisagem que também podem ser encontradas no Brasil. ${ }^{85}$ Ao abarcarmos

83 SALZSTEIN, 2005, p. 219.

84 Ressaltando a equivalência entre natureza e arte, CAUQUELIN $(2007$, p. 41) apresenta a definição de paisagem elaborada pelo Ministério da Instrução Pública e das Belas-Artes francês, em 1930, como "monumento natural de caráter artístico", no qual a floresta, por exemplo, é uma "galeria de quadros naturais, um museu verde".

85 A partir da land e environmental art, a Estética voltou novamente sua atenção para o elemento natureza, que havia desde o século XVIII se tornado menor, em relação à arte. Uma considerável 
"uma vista", um todo, procuramos por referenciais naturais que podem ser, desde a sutil luminosidade do céu à vastidão do mar, ou ainda a presença de um rio que, mesmo canalizado, é uma reserva de natureza.

A visão de natureza de Euclides da Cunha, citada por Nuno Ramos, ${ }^{86}$ - uma natureza dominadora e que resiste ao homem, como metáfora desse meio físico pouco maleável ou difícil de lidar - ou ainda, como vimos no item anterior, natureza e paisagem como gênero de pintura atrelado a uma história de interesses de apropriação, são algumas das lembranças da natureza nos campos da arte brasileira, memórias que, provavelmente, contagiam as aproximações da nossa arte contemporânea com a paisagem.

Para não abordar "natureza" como termo amplo e genérico, o que dificultaria este estudo ao invés de focá-lo, vamos circunscrevê-la a partir de alguns autores que analisam natureza e paisagem. A natureza na paisagem - ou como paisagem - está inserida no panorama da cultura e, se abordamos a natureza na arte, é pela necessidade desta de moldá-la, reproduzi-la, extingui-la, ${ }^{87}$ ou ainda dar-lhe voz. Nesse sentido, não poderíamos iniciar o assunto sem citar Robert Lenoble em História da Ideia de Natureza, $1990 .{ }^{88}$ Valemo-nos da analogia com "leque" que o autor faz, ao explicar que os campos do saber - a ciência, a moral, a ética e a arte - compartilham, em dada época, uma mesma compreensão e experiência de realidade e de natureza, sendo que esta, observada ao longo da história, não foi sempre a mesma.

Também ela ainda não é olhada por si mesma, mas permanece carregada dos rogos e dos desejos do homem. Uma paisagem, dir-se-ia no século XIX, é um estado de alma. Mas foi em primeiro lugar a Natureza na sua inteireza, Natureza do físico, do moralista e do artista que foi pintada sob os traços e que sempre serviu ao homem para falar de si para consigo, pelo menos tanto quanto lhe serviu para se assenhorear do objetos. (LENOBLE, 1969, p. 198)

Igualmente, para introduzir o assunto na arte contemporânea, é referência a fala de Robert Smithson quando, ao ser perguntado sobre expor em galeria ou na "natureza", responde que não há diferença entre fazer uma obra fora ou dentro da galeria, pois a galeria

bibliografia sobre Environmental Aesthetics vem sendo publicada e foram as obras da land art que reintroduziram o debate sobre a apreciação estética da natureza.

86 Os comentários dos artistas sobre paisagem e suas obras serão abordados no Capítulo 04.

87 "a natureza existe para ser violada", frase de Pablo Picasso que expressa a tendência das Vanguardas Modernistas à sua autonomia como linguagem, livre da mimesis da natureza.(Ver em ROSENTHAL, Mark In: SONFIST, Alan (org.). Art in The Land. New York: Dutton, 1983, p. 60)

88 LENOBLE, Robert. História da Ideia de Natureza. Lisboa: Edições 70, 1990. 
está na paisagem, e tal aproximação - fusão entre cultura e natureza - não pretende romantizar a "natureza" como algo distante da realidade, da cidade e mesmo do mercado.

Acho que todos nós vemos a paisagem como sendo coextensiva à galeria. Não acho que estejamos lidando com o assunto em termos de um movimento de volta à natureza [back to nature movement] (SMITHSON, 1970. Apud FERREIRA; COTRIM, 2006, p. 280) $)^{89}$

Berque alarga a compreensão de natureza, ao dizer que ela, além de ser criação do homem a partir de sua interação com o ambiente, é também realidade objetiva e preexistente à humanidade.

Dizer o que é natureza, no fundo, é justamente afirmar o que ela não é: uma concepção humana. A natureza é de fato aquilo que em si não é definido nem para nem pelo homem, mas sim que é definido no homem e em torno dele. Pelo homem e para ele, a natureza é traduzida obrigatoriamente em termos próprios a uma cultura; ela é integrada ao mundo que o homem é capaz de conceber, de perceber e organizar. Ao mesmo tempo, a natureza em si não deixa de existir, em seu próprio sentido, que é irredutível aos termos humanos, ou seja, não somente em relação ao homem (em seu ambiente, do mais próximo ao mais distante), mas também no próprio homem (em sua fisiologia). A natureza, essa entidade que é por vezes inconcebível, incomensurável, mas na qual o homem está imerso, que ele carrega em si mesmo e que ele não cessa de humanizar, de cultivar, a natureza portanto, por sua ambivalência, é o exemplo de uma realidade mesológica: indissoluvelmente factual e sensível, física e fenomenal, a natureza é bipolar. (BERQUE, 2000, p. 51-52 apud MARIA, 2010, p. 124) (90 $^{90}$

Mesmo em paisagens densamente construídas, onde pouco notamos a presença dos elementos da natureza, a arte contemporânea da paisagem tem a extrema habilidade de trazêlos à tona, evidenciando os processos de seu crescimento, ou sua transformação, e aqueles processos sociais de apropriação da mesma. São assim os exemplos do projeto Margem (2010), e os projetos para áreas de refugo industrial de Robert Smithson. Em ambos os exemplos, vemos que a falta de referenciais naturais na paisagem, ${ }^{91}$ ou esta como resultado de uma produção tecnocrata, instiga uma aproximação crítica e ácida da arte - como se ela

89 SMITHSON. Discussões com Heizer, Oppenheim e Smithson. In: FERREIRA, Glória; COTRIM, Cecília. Escrito dos artistas. Anos 60/70. Rio de Janeiro: Editora Zahar, 2006.

90 BERQUE, Augustin. Médiance. De Milieux en Paysages. 2.ed. Paris:Belin/Reclus 2000.In: MARIA, 2010, p. 124

91 Paisagem como composição com intenção estética. Nos termos de Cosgrove (apud CORRÊA; ROSENDAHL, 1998, p. 99): "criação racionalmente ordenada, designada e harmoniosa, cuja estrutura e mecanismo são acessíveis à mente humana, assim como ao olho, e agem como guias para os seres humanos em suas ações de alterar e aperfeiçoar o meio ambiente". 
reagisse ao meio hostil, e também poderia instigar uma arte engajada à criação de projetos para a transformação desta realidade.

Ferriolo, em Landscape Ethics $(2004)^{92}$, busca diferenciar natureza e paisagem, que são corriqueiramente confundidas, ainda mais no momento atual pelos "debates ecológicos e por aqueles devotados às políticas ambientalistas". Para tanto, ele ressalta os aspectos históricos e éticos da paisagem, sendo que o seu caráter ético ganharia o primeiro plano, pois a paisagem é consequência de façanhas e ações humanas. Esta, segundo o autor, é resultado da totalidade complexa do pensamento e ideias de uma dada sociedade - no sentido original de "ethos" -, que com a liberdade humana utiliza a arte e a tecnologia para criar, construir, projetar ou modificar a natureza, fazendo-a útil ou bela. "O homem moderno sai para a natureza, procura e a encontra novamente como paisagem, que é a característica de uma nova relação entre o homem e a natureza em sua totalidade". Compreendemos, então, a dimensão histórica das interpretações da natureza e a qualidade humana e artística da paisagem.

Tais premissas se afinam com a acepção de paisagem da geografia cultural - como transformações da natureza pela sociedade ao longo do tempo. Por isso, quando nos reportamos a uma arte ligada à natureza, ou mesmo a uma arte ambiental estamos apenas mudando os termos, a nomenclatura, da arte da paisagem. No entanto, esta mudança de foco para o meio ambiente pode, como observou o autor, esconder interesses políticos, a fim de mesclar-se em outros debates que não os da arte, da estética e dos projetos para formação da paisagem.

Se para o homem moderno a paisagem é o resultado de uma divisão - de um lado existe o homem, de outro a natureza -, então, de certa forma, a beleza natural sugere uma perda que ele compensa através da apreciação e da experiência da paisagem, como uma possibilidade de retorno à perfeição ou à unidade perdida. No contemporâneo, apesar dos limites menos rígidos entre cultura e natureza e da compreensão mais ou menos difundida de que uma natureza pura ${ }^{93}$ não existe mais, esta ainda permanece como uma compensação, uma promessa de integração.

92 FERRIOLO, Massimo Venturi. Landscape Ethics. In: STRELOW, Heike; DAVID, Vera (Orgs.). Ecological Aesthetics. Art in Environmental Design: Theory and Practic. Berlin, Basel: Birkhäuser, 2004, pág. 16-19.

93 “Natureza, no sentido da Terra [earth] desassociada da intervenção humana em sua maior parte já desapareceu, uma vez que as ações humanas afetam e afetaram desde as vastidões mais ermas, 0 rearranjo de espécies da fauna e flora dos seus habitats naturais, incluindo a alteração da configuração, do contorno da superfície terrestre em conjunto com seu clima e atmosfera." BERLEANT, Arnold. The Aesthetics of art and nature. In: KEMAL, S.; GASKELL, I. (org.) Landscape, natural beauty and the arts, 1995 , p. 228 
Neste ponto, ao nos aprofundarmos na convergência da natureza e da cultura que a arte contemporânea da paisagem suscita, é relevante ressaltarmos que suas primeiras manifestações na década de 1960 não apenas se voltavam contra a política, ou contra o mercado da arte, indo, então, desbravar outros meios além do museu, galeria ou espaço público. Não é mera consequência o uso de materiais naturais como oposição à indústria, é também porque a arte quis se distanciar do mercado que elegeu a paisagem como seu meio e lugar. ${ }^{94}$ Esta e a natureza que a constitui são simbólicas e, por isso, são meios fecundos para a arte. Nesta escolha há a busca por novos valores, entre éticos e estéticos, que são atribuídos à natureza, à paisagem e à arte.

Considerando o caso brasileiro das exposições Fronteiras e Margem, não é tão clara essa escolha da arte pela paisagem ou pela natureza. Isso porque tais aproximações ocorrem por meio de exposições temáticas, e cujos temas parecem até distanciarem-se da essência da paisagem, ao propor reflexões sobre território ou fronteira geográfica ou ainda sobre rios urbanos, em meio ao discurso da sustentabilidade. Soma-se à falta de nitidez dessa escolha da arte brasileira pela paisagem a não execução ou conclusão de projetos, o que concorre para subtrair a visibilidade da arte e da paisagem.

Quando a arte contemporânea da paisagem adquire visibilidade é porque, entre outros fatores, a apreciação estética lhe conferiu qualidades e a cultura lhe atribuiu valores. Vejamos algumas definições de como a apreciação estética da natureza e da arte - justapostas na arte da paisagem - ocorre, de acordo com a corrente da filosofia contemporânea que se designa "estética ambiental" e que tem investigado a partir das obras da land art e environmental art se apreciamos esteticamente a natureza e a arte de mesmo modo, e se não, de que modos.

Crawford ${ }^{95}$ apresenta três relações estéticas entre arte e natureza. A primeira ele chama de simbiótica e ocorreria entre o natural e o artefato. Por meio desta, estabelece-se uma relação harmônica, em que arte e natureza se beneficiam mutuamente. A arte chama a atenção para as qualidades naturais da paisagem, podendo ressaltar suas qualidades estéticas naturais e, ao mesmo tempo, ganhar foco, "emoldurar-se" e se destacar. Seria como se a paisagem adquirisse um certo "status" através da arte nela inserida.

\footnotetext{
94 A compreensão de "expandir o campo" na arte da paisagem foi literal e abrupta, na medida em que incorpora diversas questões da cultura, até mesmo a natureza.

95 CRAWFORD, Donald W. Comparing natural and artistic beauty. In: KEMAL, S.; GASKELL, I. (org.) Landscape, natural beauty and the arts, 1995, p. 183-198.
} 
A segunda relação entre o artefato e o natural seria dialética. Nela, os dois elementos são forças conflitantes, cuja interação traz um terceiro objeto: o produto desta interação. Aqui, Crawford cita como exemplos a Spiral Jetty (1970) de Robert Smithson, as obras Valley Curtain (1970-72), Running Fence (1972-76) e Surrounded Islands (1980-83) de Christo e Jeanne-Claude. ${ }^{96}$ Este terceiro objeto que emerge é o alvo da apreciação estética e resulta da síntese de forças opostas: artefato e natural. Às vezes, ambos os elementos mantêm seus contornos - suas identidades - que a aproximação não nega ou dissolve.

Uma terceira dinâmica se estabeleceria através da dominação da natureza pela arte ou vice-versa (ele exemplifica como uma bomba que destrói o meio). Porém, esta não traz um resultado estético, "pelo menos não no sentido que é compreendido desde o passado". ${ }^{97}$ Para tal, imagina uma obra que subordinasse ou erradicasse a natureza, mas, caso isso ocorresse, uma análise puramente formalista seria imprópria.

Assim, a apreciação estética da arte que se relaciona com a natureza implicaria em uma postura ética, possível na dinâmica simbiótica, que se traduz na coexistência harmônica, ou na dialética, com a interação de antagonismos que convergem em um objeto estético. $\mathrm{O}$ autor ainda aponta que, em muitos casos, a arte da paisagem (land art) tem êxito estético devido à paisagem ou porque um aspecto da natureza atua como parte da obra.

We need to recognize, however, that in many cases of contemporary environmental sculpture the work succeeds only because of the natural setting or an aspect of nature functions as a part of the work. In such cases, nature is used to refer to that very relationship (whether harmonious, dialectical or parasitic). These complex relationships between art and nature preclude direct comparisons with natural or artistic beauty, at least on traditional models of aesthetics evaluation. (CRAWFORD, 1995, p. 195)

Berleant, ${ }^{98}$ em The aesthetics of art and nature, apresenta algumas posturas da estética, ao analisar a aproximação entre arte e natureza presente na arte da paisagem. Uma primeira corrente nos diz que um mesmo valor estético existiria nos domínios da natureza e da arte, mas o tipo de apreciação suscitada por cada um seria diferente. Outra, tomando como exemplos a land e environmental art, assim como os jardins dos séculos XVII e XVIII, nos diz

96 Crawford, ao denominar uma das aproximações entre arte e natureza como dialética, indica que nem a arte nem os aspectos naturais se sobressaem. Este agrupamento se assemelha ao que Kastner (1998, p. 72) trata por interrupção:" these projects...use manufactured susbstances and structures, or machine and technology... they both participate in and critique the kind of terrestrial exploitation".

97 Ibidem, p. 195.

98 BERLEANT, Arnold. The aesthetics of art and nature. In: KEMAL \& GASKELL (org.). Landscape, natural beauty and the arts. Cambridge: Cambridge University Press, 1995, p. 228. 
que arte e natureza compartilhariam a mesma estética, pois se tornariam uma unidade. Uma terceira, acredita que a apreciação do meio ambiente serviria como modelo (critério) para se reinterpretar a estética artística que se liga à natureza.

De um modo geral, o autor analisa que a apreciação se traduz em admiração e reverência e isto se relaciona ao fato de não sabermos os limites entre o natural e o não natural em nós mesmos; tampouco sabemos os limites e a compreensão do domínio que chamamos natureza, pois não vamos além do nosso campo cognitivo. São experimentados sentimentos de magnitude, influência, potência, extensão, mistério e o ilimitado - o incompreensível efeito da natureza. Estas percepções fazem parte da poética da arte da paisagem.

Ao apreciar a natureza, o autor prossegue, vivenciamos uma agudeza sensorial, pois entrelaça-se a este sentimento de reverência o envolvimento do indivíduo, percebendo-se em unidade com a natureza. Tal experiência é imediata, direta na paisagem, e presentifica tempo e espaço. Obras que propõem tal agudeza sensorial são, por exemplo, The Lightning Field (1977) e Spiral Jetty (1970), que suscitam uma forte apreciação estética da paisagem e da natureza seus elementos ou fenômenos -, assim como o envolvimento do observador, conforme a definição de Berleant.

A ideia de que o mundo natural é também um "artefato cultural"99 é recente. Não só a natureza é afetada universalmente - de modo global - pelas ações humanas, como nossa concepção de natureza é histórica e difere, em termos de tradições culturais.

What we mean by nature, our beliefs about wilderness, the recognition of landscape, our very sense of environment have all made an historical appearance and have been understood differently at different times and places. No wonder that an aesthetics that aspires like the sciences to universality has difficulty in accommodating nature. ${ }^{100}$

Crawford e Berleant chamam a atenção para o cruzamento das intenções estéticas e éticas que a arte, que incorpora ou ressalta a natureza, suscita. No Brasil, por exemplo, apesar de não haver um grupo de obras ou artistas que recebam a denominação de "arte ambiental", algumas exposições buscaram engajar-se em questões de "qualidade urbana" e “sustentabilidade”. É o caso das que envolveram os rios urbanos - Margem (2010) e Quase Líquido (2008).

99 BERLEANT, 1995, p. 234.

100 Ibidem, p. 23. 
A arte que abarca a natureza "cultural" - a arte da paisagem - é facilmente fisgada por discursos políticos e sociais que, por vezes, desejam falar mais alto que a experiência estética.

Um bom exemplo desta perda de contornos entre o natural e a arte, desta "consciência" possível na pedra ${ }^{101}$, tanto quanto na escultura, é notável em Levitated Mass (1985-2012), de Michael Heizer. A obra consiste em um megalito de granito de trezentas e quarenta toneladas transportado para o Museu de Arte Contemporânea de Los Angeles (LACMA) e posto sobre uma vala por onde passam os visitantes. Tanto a pedra e sua inserção, quanto o seu transporte, a engenharia e a logística para sua colocação, assim como a mídia que tornou a obra popular a ponto de encontrarmos centenas de imagens da "pedra" registradas por particulares e lançadas na internet - constituem, também, a "obra". O silêncio geológico ou a referência remota aos megalitos do Neolítico se perdem na eloquência da informação e da imagem, em uma época e lugar em que a obra, longe de ser uma pedra em estado bruto, se transforma em desejos da cultura. ${ }^{102}$
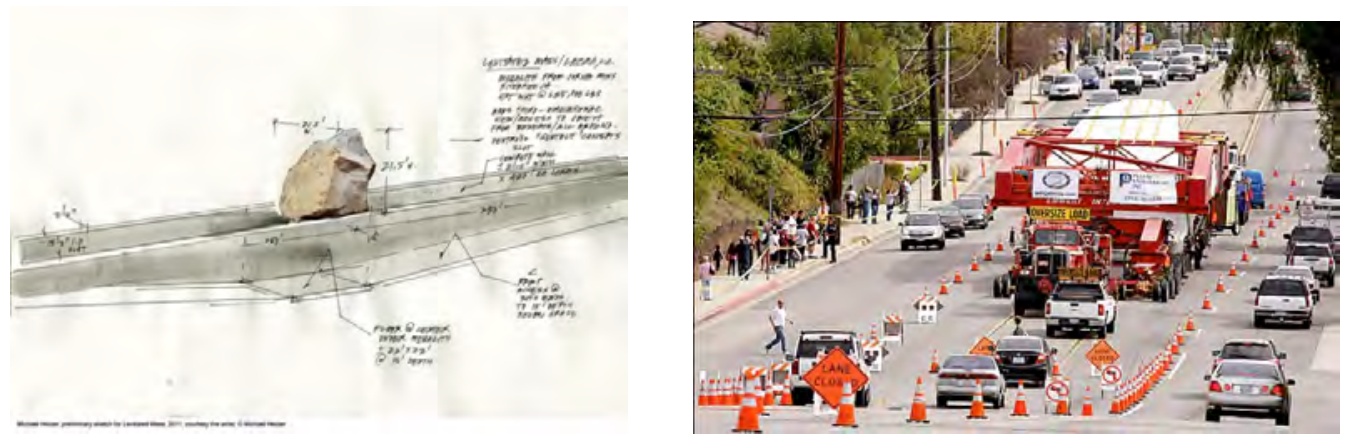

25. Michael Heizer. Croqui Levitaded Mass. (1969-2012)

(Fonte Imagem:<http://www.lacma.org/art/exhibition/levitated-mass/)

101 A pedra é uma referência à diferenciação entre arte e natureza exemplificada por Hegel (1770-1831). A escultura - a pedra transformada em arte - seria superior a uma simples pedra encontrada na paisagem pois, segundo o ponto de vista hegeliano, estes elementos seriam por demais diversos quanto à sua consciência ("self- consciousness").Ver CRAWFORD, 1995, p. 192. Hegel, cuja influência perduraria até o século $\mathrm{XX}$, ocupou-se apenas da arte como objeto da estética, pois esta seria a expressão mais elevada do ("Absolute Spirit") espírito (ou da mente vivificada, nos termos de Kant), de modo a ser única, original, resultado da genialidade e não de condições que ritmadamente se perpetuam, como ocorre com a beleza natural. Hegel emancipou a arte da natureza, uma ação necessária à arte, uma vez que esta mantinha-se subordinada como mimesis ou como figuração, na obrigatoriedade de seguir os modelos naturais.

$102 \mathrm{Na}$ inauguração da obra, o diretor do museu LACMA se pronuncia orgulhoso pelo novo monumento ali instalado que representa sua cidade, povo e época: "For me, it's better than those ancient monuments because it is not an expression of the power of gods and kings, but rather of people - of the museum visitor that descends into an empty abstract space defined by linear concrete walls to see the monolith from below, virtually levitating in our beautiful California sky."(GOVAN, Michael. Disponível em: <http://lacma.wordpress.com/2012/06/26/michael-govan-on-levitated-mass/>. Acesso em: 11/08/2012) 

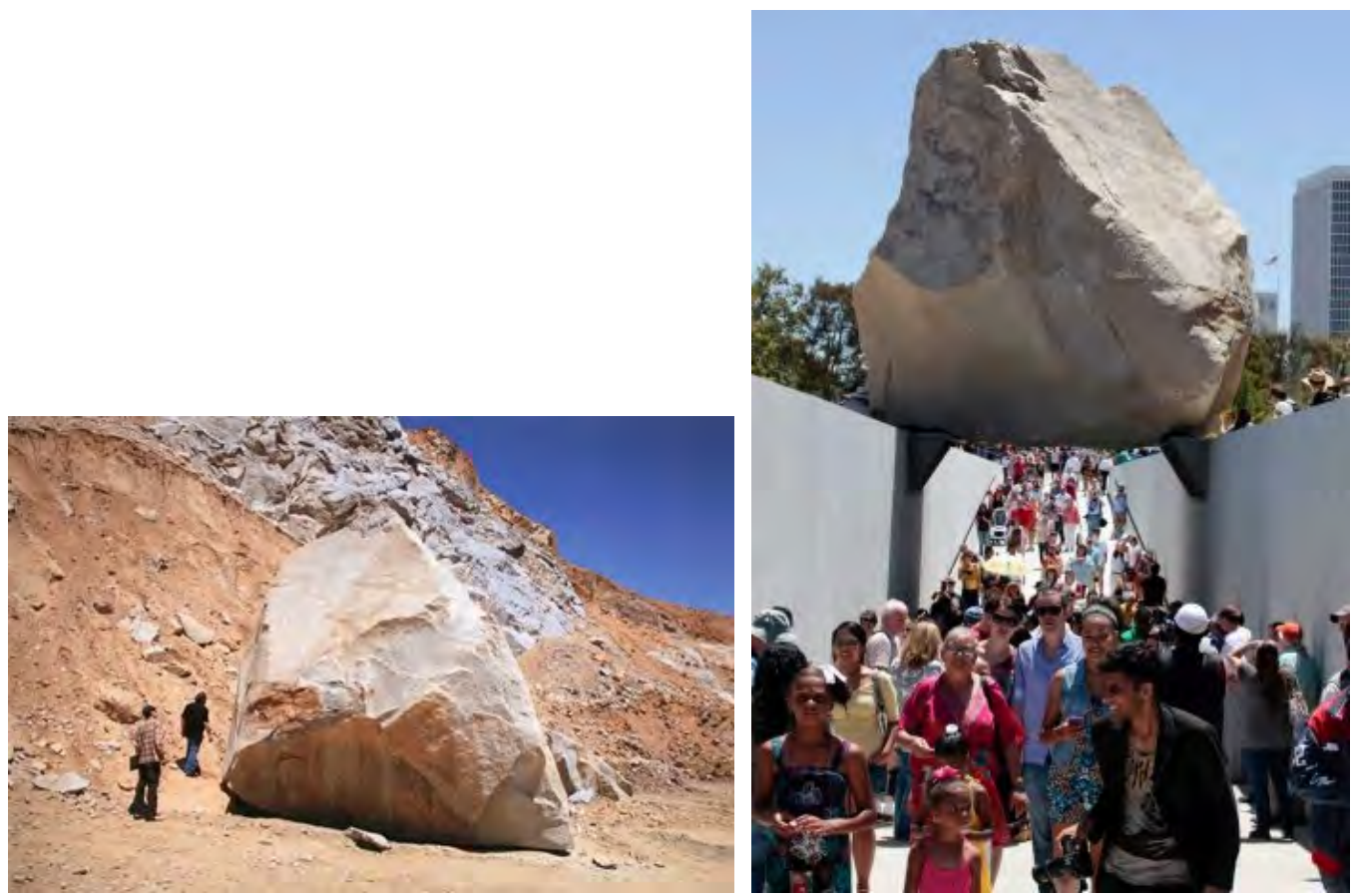

(25). Michael Heizer. Levitaded Mass. (1969-2012)

(Fonte Imagem:<http://www.lacma.org/art/exhibition/levitated-mass/)

Se, por um período, a arte exclui de suas considerações a apreciação estética, a natureza, ao contrário, quando bem moldada e enquadrada, sempre a acolheu. A arte da paisagem, que se desenvolve desde os anos 1960 em diferentes países, traz à tona a apreciação da natureza e da arte, ${ }^{103}$ simultaneamente, vistas como uma unidade ou em uma relação dialética. A apreciação deriva da percepção - processo mental, pelo qual estruturamos e organizamos nossa interface com a realidade e com o mundo, gerado também por interesses e necessidades - e nossas percepções estão em relação direta com tradições que se estabeleceram na relação com a paisagem.

Neste estudo, não há diferenciação entre arte da paisagem e arte ambiental, nem entre apreciação da paisagem e estética ambiental. Tanto a obra, como uma forma (composição) integrada à paisagem, quanto um projeto de revitalização de áreas degradadas, expandem a interação da arte com o meio, com a natureza em processo e com as questões sociais e culturais que interferem no meio, o que nos leva à paisagem. Na bibliografia atual, há ainda mais termos que se ramificam como "estética ecológica", que poderiam ser substituídos

\footnotetext{
103 É importante uma ressalva: nem todas as obras da arte da paisagem intentam a apreciação, algumas lidam francamente com lugares na "ideia do desprezível", como bem sintetizou Carlos Fajardo em entrevista. É o que se observa em obras como os projetos para áreas de refugo de Robert Smithson (Capítulo 02). No entanto, são igualmente atentas às transformações da natureza, do meio, que geram a paisagem.
} 
simplesmente por "arte e ciência" e nos indicam a falência das autonomias da arte, ciência e tecnologia $^{104}$ (BOBERG, 2004). A arte espelha desejos e ambições sociais, mas permanece ainda enraizada na relação humana com o meio e com o tempo, passível de ser traduzida em poesia, como a paisagem ainda pode ser.

Talvez seja pouco provável que consigamos refletir sobre meio ambiente e a apreciação estética da natureza e, ainda mais distante de nossa realidade, analisar a arte engajada em questões ambientais, sem antes estreitarmos laços com a natureza transformada das nossas paisagens; sem antes ancorarmos a arte nas nossas paisagens. Novamente cito Cosgrove, que aborda a paisagem como o contato primeiro do indivíduo com a natureza, com sua superfície.

Paisagem, ao contrário de lugar, nos coloca diante do esquema da natureza inserção na totalidade (...). Ao contrário de meio ambiente e espaço (abstrações), lembra-nos de que apenas com consciência e razão podemos conhecer este esquema e participar dele como seres humanos. (COSGROVE, 1989. In: CORREA; ROSENDAHL, 1998, p. 100)

104 BOBERG, Jochen. About the rebirth of a new world. In: STRELOW, Heike; DAVID, Vera (Org.). Ecological Aesthetics. Art in Environmental Design: Theory and Practic. Berlin, Basel:Birkhäuser, 2004, p. 07-09. 


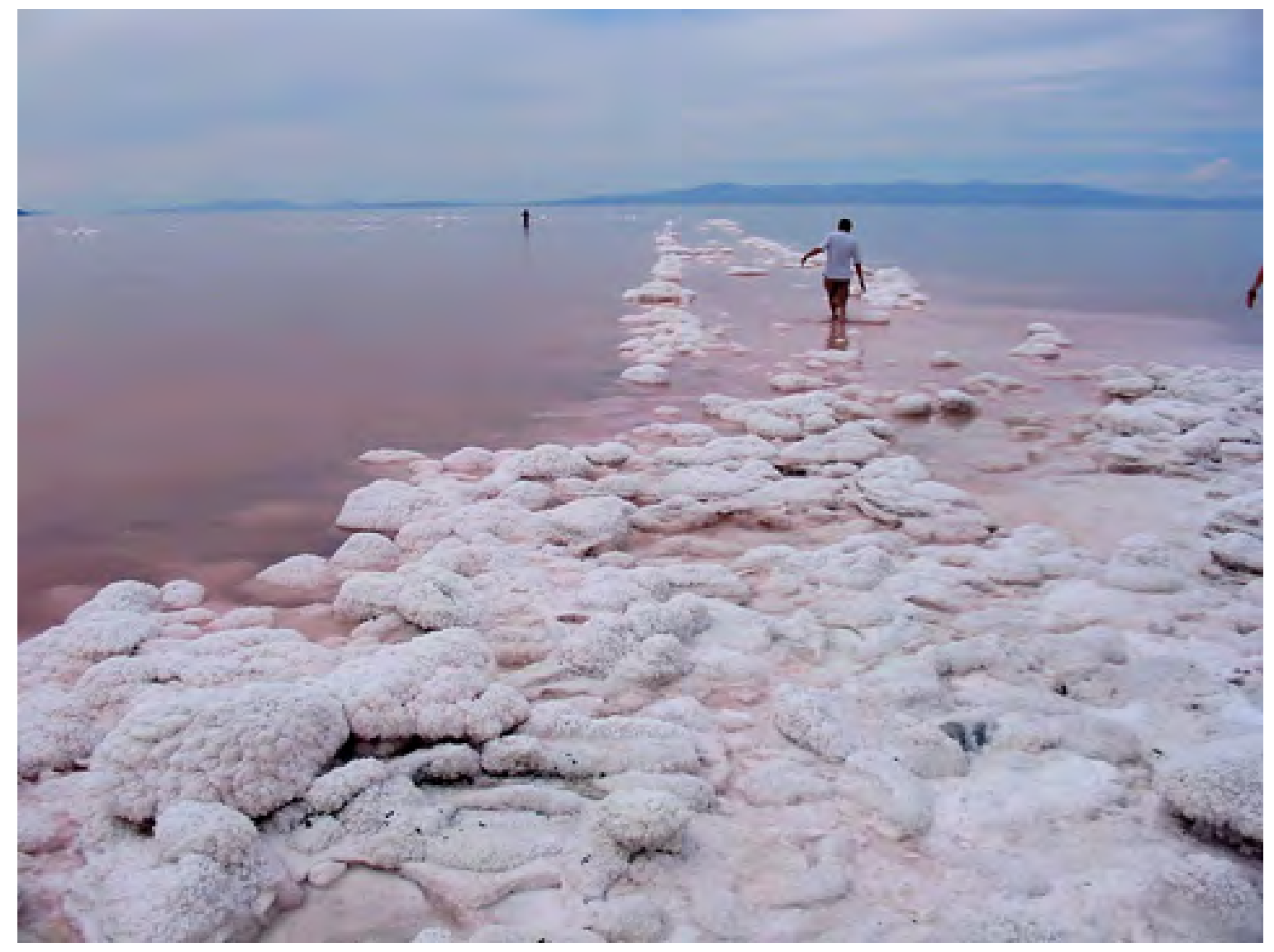

\section{CAPÍTULO 2}

A arte contemporânea da paisagem. 
26. Robert Smithson. Spiral Jetty. Great Salt Lake. Utah, EUA, 1970.

Pedras, terra, cristais de sal e água. Comprimento $1.450 \mathrm{~m}$ e diâmetro $45 \mathrm{~m}$.

(Fonte: <http://www.eveandersson.com/usa/ut/great-salt-lake:>) 
A partir dos anos 1960, artistas de diversas partes do mundo passam a trabalhar diretamente a paisagem. Suas obras ou ações são projetadas e construídas abarcando a paisagem em seus aspectos físicos ou humanos, naturais e culturais, assim como a experiência da paisagem. Esta torna-se parte, matéria-prima ou é ela mesma que constitui a própria obra.

Esta produção dá continuidade à crítica da mercantilização da arte, já presente na contracultura $^{1}$, questionando igualmente o valor do objeto cultural - obra de arte -, em contraponto ao objeto natural. A land $a r t^{2}$, que é essencialmente escultural, pode ser vista como um fenômeno uma vez que não existia, até então, no Ocidente uma tradição de escultura da paisagem ${ }^{3}$.

Tufnell (2006) indica o ano de 1968 como o início desta arte, não por ser uma espécie de marco zero, mas por ser o momento em que as ideias e os temas que norteariam uma arte ligada às questões da paisagem começaram a se caracterizar como tal em diferentes países. Duas exposições marcam este início: Earthworks, de outubro de 1968, realizada em Nova Iorque e Earth Art Exhibition ${ }^{4}$, de fevereiro de 1969, realizada em Itahca, EUA.

A land art não chega a ser um Movimento ${ }^{5}$, pois há divergências (que veremos adiante através de suas vertentes) entre as propostas e as opiniões dos artistas, cujos trabalhos são

1 A discussão sobre o valor do objeto artístico, elevando objetos cotidianos à categoria de Arte, e também o contrário, desestetizando a arte, ao trabalhar com elementos industriais sem valor per si, já estavam presentes na Pop Art e no Minimalismo - décadas de 1950 e 1960 - e, traçando uma genealogia, desde os ready-mades de Marcel Duchamp.

2 A palavra land, cujos significados, de acordo com o Oxford Dictionary of current English são: "parte da superfície da Terra não coberta por água, terreno, nação, região, terra, aterrissar, pousar, aterrar" não possui uma tradução direta para o português. Importante notarmos que a palavra é substantivo e verbo. Por isso, emprego a expressão "arte da paisagem" como análoga à land art.

Roger (1999) explica que a primeira ocorrência ocidental da palavra deu-se como "landschap", em holandês, na segunda metade do séc. XV. Besse, (2006, p. 20) aponta também que antes da significação estética (ligada à pintura) este termo "possui uma significação que se pode dizer territorial e geográfico", uma vez "que os valores paisagísticos são menos pitorescos que práticos". [grifo nosso]

3 Tufnell (2006, p. 16) também aponta como mudança fundamental na estrutura da arte o fato de estas obras tratarem do mundo real e seus artistas ficarem livres de produzir objetos.

4 Nesta exposição, o curador do Museu solicitou aos alunos que trabalhassem junto com os artistas e que também criassem suas esculturas ou escavações pelo campus. Ver CORNELL UNIVERSITY. Em 2008, a Cornell University, que sediou a exposição de 1969, promoveu uma exposição em homenagem aos 40 anos da land art: "From earth art to eco art" (Da arte da terra à arte ecológica). Pelo título, podemos perceber a abrangência de significados atrelados à paisagem ao longo do tempo. (Fonte: <http://www.news.cornell.edu/stories/Oct08/EarthArtEcoArt.da.html>)

5 Neste trabalho, considera-se "Movimento Artístico" um agrupamento de ideais e teorias filosóficas de seu tempo como premissas para a produção artística. Tais premissas com frequência precedem, condicionam e predefinem a natureza do próprio objeto de arte. Os conceitos, questionamentos e engajamento em determinadas teorias tornam-se, gradualmente, os principais componentes da atividade artística. STANGOS, Nikos. Título, 1991. In: Conceitos da Arte Moderna, 2000, p. 8. 
apresentados sob este título, e tampouco é um estilo. Podemos considerá-la uma manifestação da arte pública, que reflete em suas formas e conceitos as condições sociais e culturais de épocas e de países distintos, ao indicarem nossos modos de produzir e perceber a paisagem. Deste modo, associar land art com arte-protesto, com uma conscientização do meioambiente, como visto em leituras recentes, é generalizante, visto que nesta diversidade de obras existem as que se utilizam de um território ermo como "uma tela em branco"6 àquelas que se valem da simbologia de certas paisagens para performances e rituais.

Esta arte contemporânea da paisagem desenvolveu-se principalmente nos EUA, Inglaterra, Holanda e Alemanha. Destes países provém a vasta bibliografia que, nesta última década, contou com dezenas de novos títulos ${ }^{7}$, notando-se um ressurgimento do interesse por esta arte, que marcou principalmente as décadas de 1960 e 1970.

Ao compreendermos os conceitos desta arte - de sua origem aos dias atuais -, perceberemos que seu impulso transpassa fronteiras e o tempo, influenciando ainda hoje artistas e paisagistas em diferentes poéticas de trabalho.

\subsection{Land Art: arte da paisagem nos EUA e Europa.}

\section{Diferentes formas da arte da paisagem}

Rather than representing it in paint on canvas [...], a handful of artists chose to enter the landscape itself, to use its material and work with its salient features. They were not depicting the landscape, but engaging it... Their art was not simply of the landscape, but in it as well. (BEARDSLEY, John. 1998, p. 07)

\footnotetext{
${ }^{6}$ Michael Heizer usou a expressão blank canvas quando se deparou com a planície do deserto de Nevada, em 1968, da qual serviu-se para os seus primeiros trabalhos, como Depressions.

7 TUFNELL, Ben. Land Art. London: Tate Publishing, 2006. LAILACH, Michael. Land art: The earth as canvas. Taschen Basic Art Series, 2007. BEARDSLEY, John. Earthworks and Beyond. Michigan Univ: Abbeville Press, 2006. 4. ed. GOODING, Mel; FURLONG, William. Song of the earth: europpean artists and the landscape. Thames \& Hudson, 2002. KASTNER, Jeffrey; WALLIS, Brian. Land and Environmental Art. London: Phaidon Press, 1998. MALPAS, William. Land Art: a complete guide to landscape environmental, earthworks, nature sculpture and installation art. Crescent Moon Publisinhg, 2004. ELKINS, James; DELUE, Rachael. Landscape theory: The Art Seminar. New York: Routledge, 2008. ANDREWS, Malcon. Lanscape and Western Art. Oxford University Press, 1999. DEMPSEY, Amy. Destination Art. University of California Press, 2006. HOGAN, Erin. Spiral Jetta. Chicago: The University of Chicago Press, 2008
} 
John Beardsley (1989), em Earthworks and Beyond ${ }^{8}$, apresenta aquilo que une os trabalhos da Land Art e da Environmental Art: a ação na paisagem. A obra ocupa-a e circunscreve-a.

Nos EUA, é acentuada a busca pela paisagem fora do perímetro urbano, principalmente durante as décadas de 1960 e início da de 1970, assim como obras site-specific, enraizadas nas questões do lugar, de sua fisicalidade à história. Na Europa, também a partir dos anos 1960, os artistas passam a trabalhar diretamente em suas paisagens urbanas ou periféricas e atêm-se mais às questões da percepção da paisagem. Sobretudo, independente de a obra ou intervenção estar mais ou menos próxima à natureza, a Land e a Environmental Art têm como princípio a obra como parte do mundo, articulada a ele, e não mais uma adição à paisagem ${ }^{9}$.

Ferreira (1999), no colóquio ao tratar da Land Art, sugere que a paisagem para esta arte é um meio e "faz parte da experiência estética proposta por estes trabalhos, mas não é realmente tratada em si"10. Contudo, a Land Art tem suas vertentes, como a própria autora enumera, e abarca obras que envolvem "uma espécie de viagem de iniciação" até aquelas que tratam da recuperação de terrenos urbanos degradados. De um modo ou de outro, a tênue fronteira entre arte e meio natural ou urbano, que observamos em grande parte das obras da land art, torna latente a percepção da paisagem - com seus fatores culturais e naturais e sua problemática - -levando os artistas mais ligados às questões ambientais a tornarem-se ativistas para solucionar parte destes problemas, constituindo o grupo designado Environmental Art. A paisagem, nestes casos, deixa de ser um meio para ser uma causa.

Além de situarmos a Land e Environmental Art dentro da História da Arte, podemos compreender este retorno à paisagem e à natureza como uma tendência de reavivar as origens, presente em diversos processos culturais de emancipação da natureza. Jay Appleton apresenta esta necessidade ao discorrer sobre a experiência da paisagem:

\footnotetext{
8 "Earthworks and Beyond", título clássico sobre a Land Art e Environmental Art,cuja 1a edição fora publicada em 1984. A $4^{a}$ edição, que veio a lume em 2006, apresentou um novo capítulo sobre a produção mais atual dos artistas envolvidos em recuperação de terras e planejamento urbano (urban design).

${ }^{9}$ TUFNELL, 2006, p. 23.

${ }^{10}$ FERREIRA, Glória. Land art: paisagem como meio da obra de arte. In: SALGUEIRO, Heliana Angotti. Paisagem e Arte: a invenção da natureza, a evolução do olhar. São Paulo: CNPq/FAPESP/CBHA, 1999 2000.
} 
Just as the process by which man achieves his emancipation from nature through architectural, economic and urban advancement is periodically interrupted by the retracing of his steps in search of the natural habitat he is living behind, so the general twentieth-century trend towards the abstract in art has frequently been punctuated by reversals $[\ldots]^{11}$

Esta nostalgia das origens, que atua como uma compensação, é histórica no Ocidente: À medida que as cidades se tornaram cada vez maiores e mais congestionadas, a distância do campo e a nostalgia da natureza aumentaram, enquanto queixas contra a vida urbana especialmente a fumaça e o mau cheiro - se multiplicaram. Isso foi tão verdadeiro para a Roma do século I, como para Londres do século XVI e a Nova Iorque do século $X X^{12}$.

Esta mudança no foco de interesse da arte - que no Minimalismo recaía sobre os objetos industrialmente produzidos à paisagem e natureza abordadas na Land Art - é, possivelmente, um índice desta nostalgia da Natureza que nos é inerente e atribuiria à Land $A r t^{13}$ mais significados além daqueles do universo da arte. Contudo, esta nostalgia reside no desejo de uma totalidade na integração arte e natureza, e não através de uma natureza idealizada e contraposta à cidade, como expõe o artista norte-americano Robert Smithson ${ }^{14}$.

Embora haja o denominador comum - a ação direta na paisagem abarcando sua morfologia, aspectos culturais e imaginário -, o conjunto de trabalhos designados Land e Environmental Art manifesta uma vasta gama de diferenciação quanto à materialidade e à escala, assim como aos tipos de ação - da reverência à destruição, do efêmero ou ritualístico

\footnotetext{
${ }^{11}$ APPLETON, 1975, p. 176. O autor aponta que a experiência da paisagem vai além da apreciação e do prazer estético - igualmente contido ou atribuído à arte - suscitando uma atração ao meio ambiente natural que nos é inerente, assim como suscita as simbologias do abrigo [refuge] e a amplitude da perspectiva [prospect] e com isso sensações profundas de proteção, direção, domínio, liberdade, entre outras primordiais do Homem.

${ }^{12}$ SPIRN, Anne W. O Jardim de Granito. São Paulo: Edusp, 1995, p. 47.

O artista Robert Smithson também se refere a uma nostalgia: “Trata-se de uma arte da incerteza, porque a instabilidade de um modo geral se tornou muito importante. Então o retorno à Mãe Terra constitui um renascimento de um sentimento muito arcaico." Ver Discussões com Heizer, Oppenheim, Smithson (1970) In: FERREIRA, Glória; COTRIM, Cecília (orgs.). Escrito dos artistas: Anos 60/70. Rio de Janeiro: Editora Zahar, 2006, p. 283.

${ }^{13}$ A Land Art, temporalmente, situa-se em um período posterior ao Minimalismo e à Pop Art - Movimentos dos anos 1960 e 1950, respectivamente, que dialogavam com elementos industriais produzidos em repetição e progressão e com objetos de consumo de massa e suas imagens.

14 “[...] jardins tranquilos tidos como 'natureza ideal' - Édens insípidos que sugerem uma ideia de 'qualidade' banal - persistem nas revistas populares como House Beautiful e Better Homes and Gardens. Uma espécie de vitorianismo diluído, uma noção elegante de industrialismo na floresta [...]." Ver SMITHSON, Robert. Uma sedimentação da mente: projetos de terra, 1968. In: FERREIRA; COTRIM, 2006, p. 188.
} 
ao monumental - evidenciando, portanto, as divergências entre as propostas e as opiniões dos artistas quanto à apropriação da paisagem pela arte e suas possíveis consequências ambientais. Deste modo, através da arte contemporânea da paisagem, vê-se refletida as diferentes relações humanas com a paisagem e a natureza.

De início, a Land Art tendeu ao formalismo apresentando um cunho estético e experimental, desbravando novas fronteiras da arte ao ocupar outros territórios além das galerias e dos museus e, também, reforçando a crítica à mercantilização da arte. Posteriormente, a Land Art ou Environmental Art passa a se ocupar também de causas sociais e ecológicas e alguns trabalhos, visando mais qualidade paisagística e ambiental e, sobretudo, ampliando o significado da arte ao buscar respostas para desafios urbanos e ecológicos ou colocar em evidência sua problemática.

Uma nota importante: ao buscarmos exemplos da Land Art, precisamos atentar para artistas e obras que não necessariamente participaram das exposições nomeadas de Earth Art, earthworks, ou, posteriormente, Land Art (ou similares) ou ainda que foram catalogados como tal. Este é o caso do artista alemão Joseph Beuys (1921-1986), por exemplo. O que caracteriza uma obra como arte contemporânea da paisagem é sua inclinação a abordar modos de produção da paisagem, de trazer à tona seus elementos e sua dinâmica, intervindo diretamente nela, e não a representando. São estas as diretrizes que utilizaremos para analisar, em meio a outras denominações e interpretações, a arte contemporânea da paisagem no Brasil.

Beuys realizou uma das mais significativas obras da arte da paisagem, com 7000 Carvalhos $^{15}$ (citada no Capítulo 1), em Kassel, por ocasião da $7^{\text {a }}$ Documenta (1982), interrelacionando arte, paisagismo e mobilização social em relação às questões do lugar, da cidade. $\mathrm{O}$ artista plantou carvalhos ao lado de colunas de basalto nas ruas da cidade, enquanto dentro do museu funcionava um escritório que tratava da viabilização do plantio. Sua "inauguração", sob a forma de um ritual coletivo na abertura da exposição, ressalta a importância que nosso contato com a natureza ${ }^{16}$ e o lugar têm para o indivíduo.

$15 \mathrm{O}$ artista pensava em um projeto que acontecesse em diversas partes do mundo. O primeiro carvalho é plantado em 1982 e o último, após a morte do artista, por seu filho em 1986, na abertura da $8^{\text {a }}$ Documenta de Kassel. Nova lorque deu continuidade a este projeto, na década de 1990, através do Dia Foundation. Ver KASTNER; WALLIS, 1998, p. 165.

16 LEITE, 2006, p. 49. "O contato com a natureza é significativo e simbólico na vida das pessoas, e as diversas sociedades constróem, ao longo do tempo, um tipo de relação peculiar e específica com ela". 


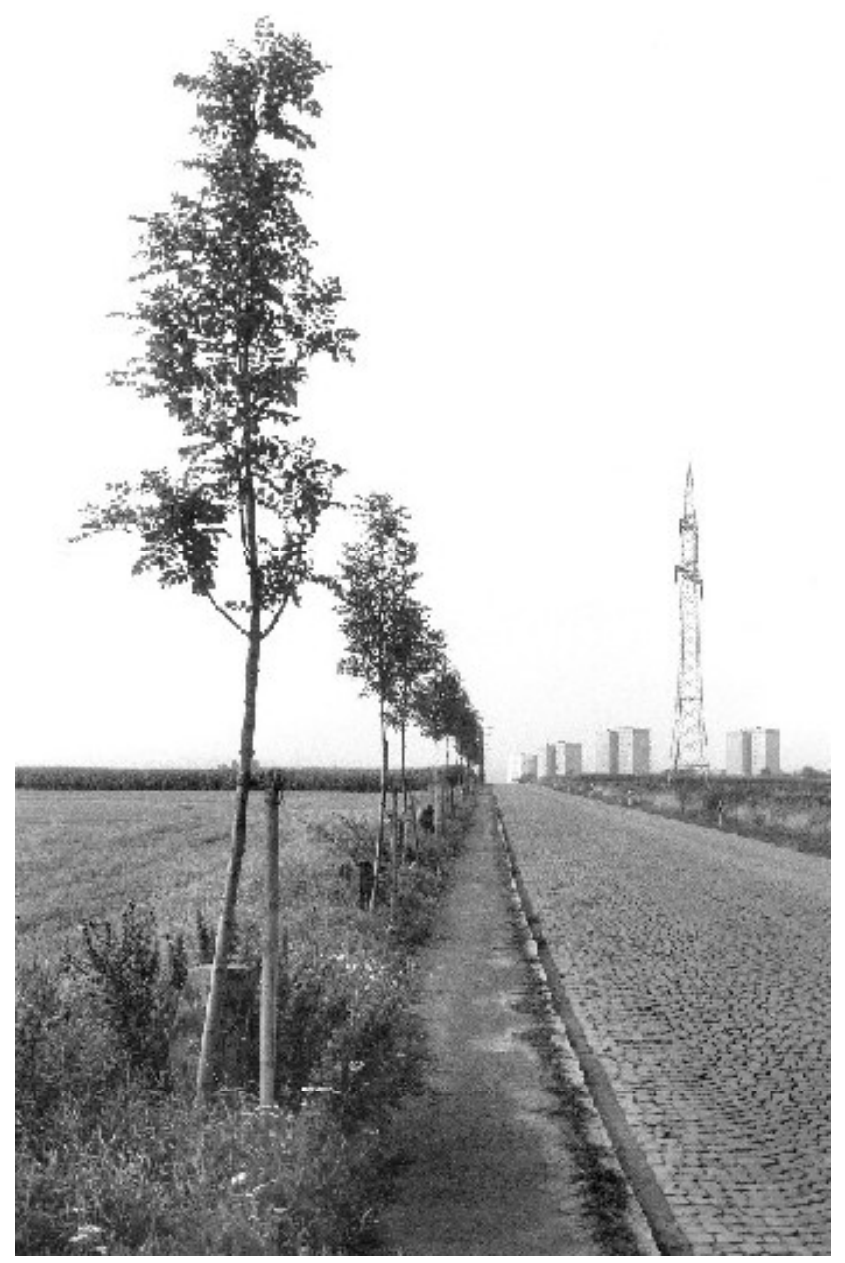

(07). Joseph Beuys. 7.000 Carvalhos, Kassel, Alemanha. Foto em 1986.

(Fonte: <http://www.artsandecology.org.uk/magazine/artworks/project-6>)

\subsubsection{Histórico.}

Land art reflected the socio-cultural conditions of its time. (TUFNELL, 2006, p. 13)

A Land Art que, no fim da década de 1960, já se apresentava como um grupo de obras com similaridades entre si - pela abordagem da natureza, paisagem ou ainda meio ambiente , pode ser considerada um desdobramento ${ }^{17}$ do Minimalismo. Mais especificamente, algumas

${ }^{17}$ BATCHELOR, David. Arte Minimalista. São Paulo: Cosac\&Naify, 1999, p. 25. Estas obras agrupadas sob o rótulo Minimalismo datam principalmente dos anos 1960 e apresentam "um solo comum": o uso de módulos ordenados no espaço, materiais e procedimentos industriais, composições geométricas, rearranjo de elementos existentes, e a eliminação da autoria (do traço do artista). Tais características grifadas continuam presentes nas obras da land art. [grifo nosso] 
de suas características já despontavam nos anos 1960 e 1950 com o Minimalismo e com a Pop Art, respectivamente, considerando as mudanças já ocorridas, desde então, na escultura e no posicionamento da arte contrário ao de mercadoria.

A arte já trilhava um caminho de anti-narrativa, de não ilusão. A Pop Art e o Minimalismo já se opunham ao modelo ilusionista da arte anulando metáforas ao empregarem elementos extraídos do cotidiano, do universo comercial além de questionarem o valor da obra e a mercantilização da arte. A Land Art, neste encadeamento, pode ser vista como o ápice da não-representação.

Se analisarmos a composição plástica ${ }^{18}$ das obras da Land Art, Pop Art e do Minimalismo, notamos semelhanças quanto ao uso e ao rearranjo de materiais: matériasprimas e objetos cotidianos e não específicos da práxis do artista ou clássicos do universo da arte. Portanto, tratar do mundo real utilizando o que nos circunda é característica comum a estas três manifestações artísticas. Enquanto a Pop Art comenta a cultura de massa e se vale de embalagens de mercadorias, de técnicas industriais de impressão ou de imagens extraídas de outras mídias; o Minimalismo emprega elementos industriais pré-fabricados e produzidos em série; a Land Art, por sua vez, constrói com topografia, água, vegetação, entulho de terrenos baldios ou equipamentos urbanos. Por esta razão, Tufnell considera a Pop e o Minimalismo como os "precursores (urbanos) diretos"19 da Land Art.

Tufnell adota o parênteses em "urbanos", uma vez que já se discutia, dentro da História da Arte que classifica e alinha uma sucessão de partidos estéticos e conceituais, se monumentos ao ar livre da Antiguidade já não seriam uma influência para certos trabalhos da Land Art, de Stonehenges às construções indo-americanas. Tecendo esta relação entre arte contemporânea e Pré-história, Lippard ${ }^{20}$ (1983) aproxima esteticamente alguns trabalhos da Land Art com monumentos de antigas civilizações, assim como com o processo de retorno à Terra - quer seja fisicamente ou simbolicamente - aproximando as visões contemporânea e antiga de integração entre arte, natureza e necessidades sociais.

18 Entende-se por plástica: “dar forma a, modelar, transformar"; e por composição: agrupamento, organização, produção, coordenação de partes. Portanto, composição plástica seria a organização (no caso da Pop Art e do Minimalismo, o rearranjo) das partes que constroem a forma.

${ }^{19}$ A Pop Art e o Minimalismo tratavam do mundo real, mas ainda mitificavam o objeto de arte, inserindo-o na galeria. "Land art is about the real world. This is a concern that has been attributed both to Pop and Minimalism - two of Land art's immediate (urban) precursors - but which, in retaining and respecting the sanctity of the art object and the gallery space, these earlier movements could only represent simbolically." TUFNELL, 2006, p. 16.

${ }^{20}$ LIPPARD, Lucy. Overlay contemporary art and the art of Pre-history. New York: Pantheon Books, 1983. 
Ainda tratando de composição, mas agora incluindo a disposição da obra no espaço, é com o Minimalismo que se matura o conceito de exterioridade da obra, ou seja, de inserir o ponto de vista e a experiência do percurso do observador como significantes e agentes da obra. Esta passa a ocorrer na relação observador-obra-espaço circundante, ativada pelo percurso. Esta exterioridade desenvolve-se ao longo dos anos 1960 e, para a Land Art, torna-se um ponto vital na construção e conceituação dos trabalhos. Mas há uma diferença: o Minimalismo relaciona obra e observador com o espaço do museu ou galeria, enquanto a Land Art abre-se para o exterior e busca paisagens significativas: do meio urbano aos desertos.

Encontra-se aqui o ponto que Tufnell considera como "revolução" ${ }^{21}$ da Land Art: as obras estão fora dos espaços convencionais - galerias e museus hibridando-se com a natureza ou com o desenho urbano. Ao se inserir na paisagem, a land art põe em xeque as distinções entre arte e não-arte e, sobretudo, entre cultura e natureza.

Rosalind Krauss, em Caminhos da Escultura Moderna ${ }^{22}$, analisa a mudança estrutural da escultura durante o século XX: a incorporação do tempo ao espaço da obra. Especialmente ao analisar a passagem do moderno para a produção minimalista - ou para o que se chamou posteriormente de Pós-moderna -, a autora toma como exemplos desde a escultura minimalista de Robert Morris (Vigas em "L", 1965) até as emblemáticas obras da Land Art, ou earthworks, de Michael Heizer (Double Negative, 1969) e Robert Smithson (Spiral Jetty, 196970). Destaca como estas duas últimas obras exploram o espaço circundante, a exterioridade, que passa a caracterizar e qualificar a obra, e como o percurso do observador pela obra ${ }^{23}$ e sua leitura tornam-se igualmente importantes. De fato, esta profunda mudança da escultura que se anula como objeto autônomo, pois se torna objeto espacial, marca o fim da produção moderna, sendo o grande denominador comum da escultura contemporânea.

Sobre Double Negative (1969), que consiste em duas fendas escavadas no topo de uma meseta, separadas por um desfiladeiro e simétricas a ele, Krauss (2007) comenta que sua composição, escala e lugar tiram-nos de nosso centro físico e psicológico. Isto porque o centro do trabalho está no desfiladeiro, cuja ocupação é impossível, induzindo a esta exterioridade de maneira radical. Já Spiral Jetty (1970) é destinada a ser adentrada, mas leva o observador para

\footnotetext{
${ }^{21}$ TUFNELL, 2006, p. 16.

22 KRAUSS, Rosalind E. Caminhos da escultura moderna. São Paulo: Martins Fontes, 2007, 2. ed. (Texto original, 1977.).

${ }^{23}$ Pela falta de terminologia para designar estas obras da Land Art, Rosalind Krauss refere-se a elas como "terraplanagens esculturais". Ibidem, p. 334. 
fora enquanto percorre-a em direção ao centro, através do movimento de ser "continuamente descentralizado em meio à vasta extensão de lago e céu". ${ }^{24}$

Todavia, se quisermos compreender estas obras além de uma análise formalista e, sim, por meio de uma análise que esteja afinada com os aspectos culturais da paisagem, é necessário compreender o que a paisagem do deserto norte-americano traz como símbolo, suas histórias, seus mitos. Yi-Fu Tuan ${ }^{25}$, ao descrever os significados do deserto - do antigo testamento ao norte-americano - daria à leitura de Krauss (2007) camadas de poesia que uma análise da forma - e sua apreciação estética - não dá conta em suscitar. O povoamento do deserto norte-americano como lugar da individualidade, da marginalidade, daqueles que "não pertenciam ao sistema econômico e cultural" (do litoral) um lugar "não humano e que desafia valores normais" nos faz aprofundar o que significou para Robert Smithson e Michael Heizer romperem com a arte de sua época exatamente intervindo no deserto, e não em uma praça pública.

$* * * * * * *$

Desconsiderar a paisagem - em qualquer país - em seus aspectos do simbólico ao econômico, para a análise da arte contemporânea da paisagem, é fazer uma leitura de obra como a fazemos em um museu, o que concorre para o "confinamento cultural" 26 , a que o artista Robert Smithson alertava caso a arte não se atrelasse às questões de sua época e lugar.

\footnotetext{
${ }^{24}$ KRAUSS, 2007, p. 336.

${ }^{25}$ TUAN, Yi-Fu. Desert and ice: ambivalent aesthetics. In: KEMAL, Salim; GASKELL, Ivan (org.). Landscape, natural beauty and the arts. Cambridge University Press, 1993.

26 SMITHSON, Robert. Cultural Confinement. Revista Artforum, 1972. Disponível em: < http://www.robertsmithson.com/essays/cultural.htm> Acesso em 15. jan. 2013
} 


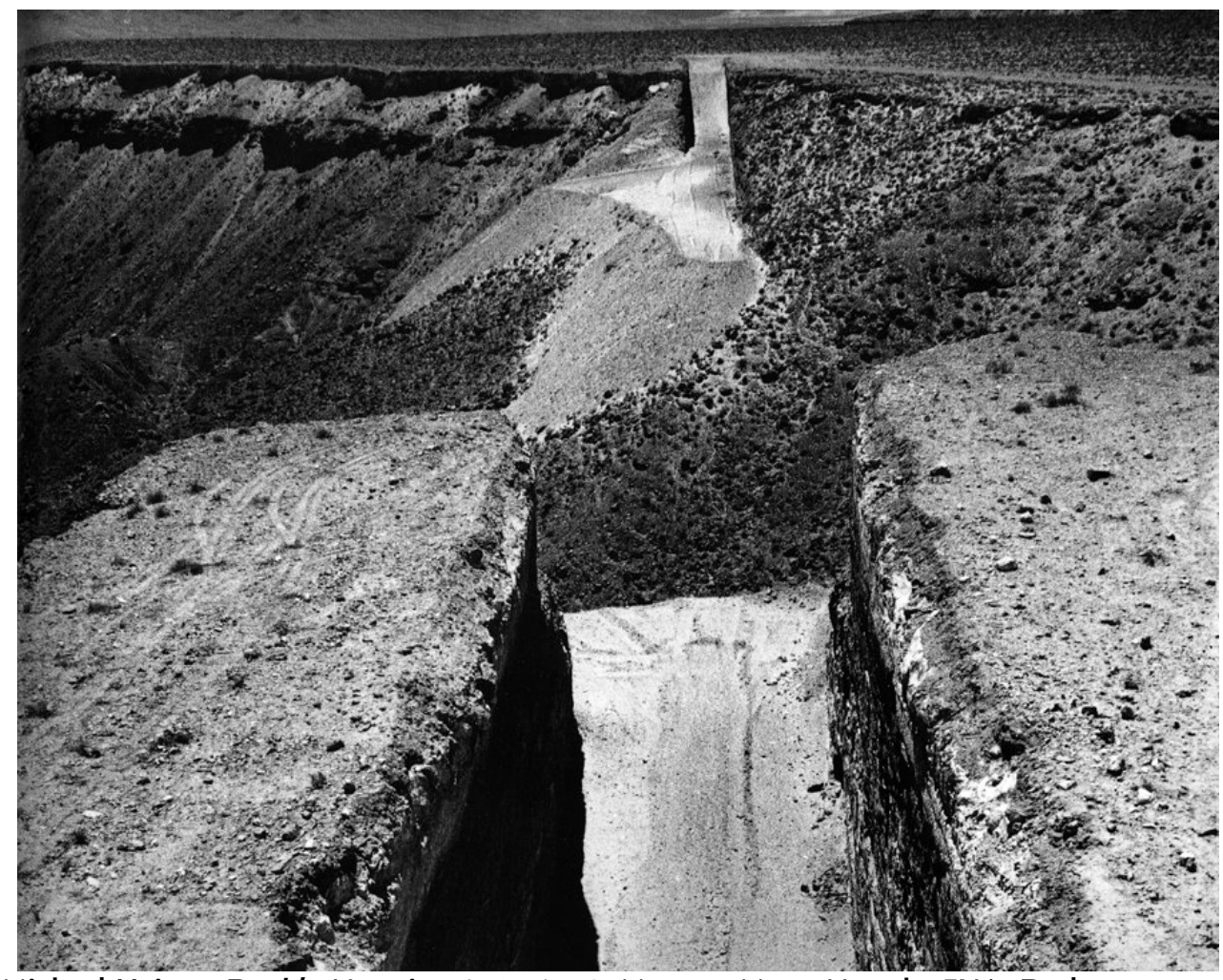

(02). Michael Heizer. Double Negative, 1969-1970. Mormon Mesa, Nevada, EUA. Deslocamento de 240 mil toneladas de terra e areia. $457 \times 15 \times 9$ metros.

(Fonte imagem: <http://www.portlandart.net/archives/2007/09/walking_the_pat.html>)

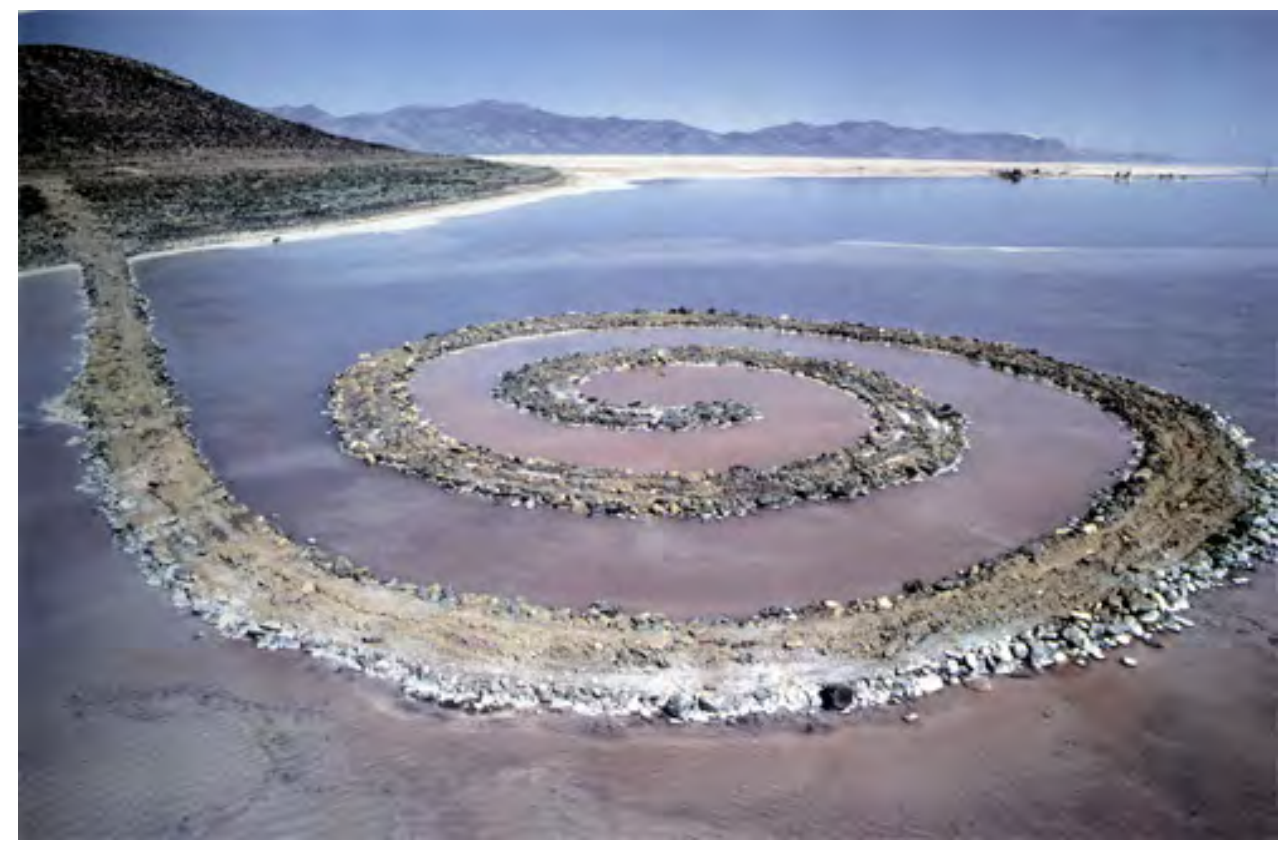

(26). Robert Smithson. Spiral Jetty, 1970. Great Salt Lake, Utah, EUA. Pedras, terra, cristais de sal, água. 1.450m e diâmetro 45m.

(Fonte: <http://atelier-hayat.com/2012/05/24/land-art/robert-smithson-spiral-jetty>)

Para a Land Art a obra e a paisagem são indissociáveis; a paisagem, com seus significados e narrativas, é incorporada à obra. Tal ampliação de possibilidades da arte, em 
específico da escultura, é também analisada por Rosalind Krauss no artigo "A escultura no campo ampliado" $(1984)^{27}$, como uma perda das fronteiras que delimitam ou definem uma obra de arte tridimensional, a partir do momento que esta solicita o percurso, a experiência espacial do observador e portanto, o tempo.

Nesse artigo, a autora começa por descrever uma obra da Land Art - a intervenção de Mary Miss (abaixo) -, já sugerindo toda a problemática e a extensão da "escultura" contemporânea, sua maleável categoria que abarcava já então "coisas realmente surpreendentes":

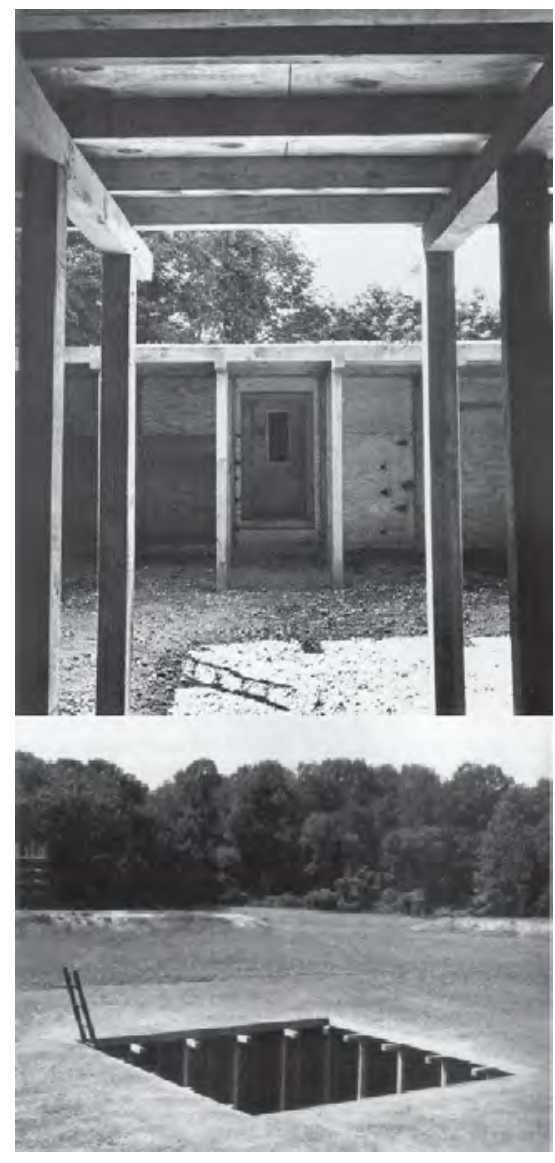

[...] A obra propriamente dita fica portanto abaixo do nível do solo: espécie de pátio, de túnel, fronteira entre interior e exterior, estrutura delicada de estaca e vigas. Perimeters/Pavillions/Decoys de Mary Miss (1978) é certamente uma escultura, ou mais precisamente, um trabalho telúrico.

(KRAUSS, Rosalind. A escultura no campo ampliado.1984)

27. Mary Miss. Perimeters/Pavillions/Decoys, 1978.

A problemática da arte pós-moderna abordada nesse artigo é o fato de o trabalho (ou a obra) estar em um campo "limítrofe à arquitetura e à paisagem", não sendo, contudo, nem

${ }^{27}$ KRAUSS, Rosalind. A Escultura no campo ampliado. Revista Gávea, Rio de Janeiro, n. 1, 1984, p. 87-93. Original: Sculpture in The Expanded Field. In: The Anti-Aesthetic - Essays on PostModern Culture, Washington, Bay Press, 1979. 
paisagem e nem arquitetura ${ }^{28}$. Em específico, ao adotar os agrupamentos paisagem e nãopaisagem e arquitetura e não-arquitetura, Krauss se refere às tangências e intersecções da arte "entre o construído e o não construído, o cultural e o natural" conceitos que nos são relevantes para a discussão da land art. Contudo, a autora separa arquitetura e paisagem, pensamento que é desconsiderado neste trabalho, que adota a paisagem como produto da interação entre a sociedade e a natureza, como marca e matriz, somatória de elementos naturais e culturais e suas dinâmicas.

Enquanto a obra minimalista é inserida no cubo branco - espaço moderno que propõe o padrão, o módulo abstrato -, a arte da paisagem ocupa lugares cujos conteúdos históricos e naturais despertam a priori nossa imaginação. Assim, um distante deserto, mesmo quando é apenas imaginado, contém por si só mensagens anteriores à arte que o ocupa e o transforma.

É por seus próprios significados que a paisagem é relevante na constituição da Land Art. Como vimos no Capítulo 1, ela corporifica valores identitários, estados de espírito ou ainda estruturas político-sociais.

$* * * * * * * *$

${ }^{28}$ Ibidem. O diagrama abaixo representa o campo ampliado, discutido por Rosalind Krauss, cuja lógica parte de um teorema matemático (grupo Klein), apesar de na década de 1970 já se discutir que a paisagem não se opõe à arquitetura, mas sim a abarca. Mesmo Krauss analisando-as como oposições, ela é aqui citada, pois apresenta um esforço em criar categorias da escultura contemporânea.

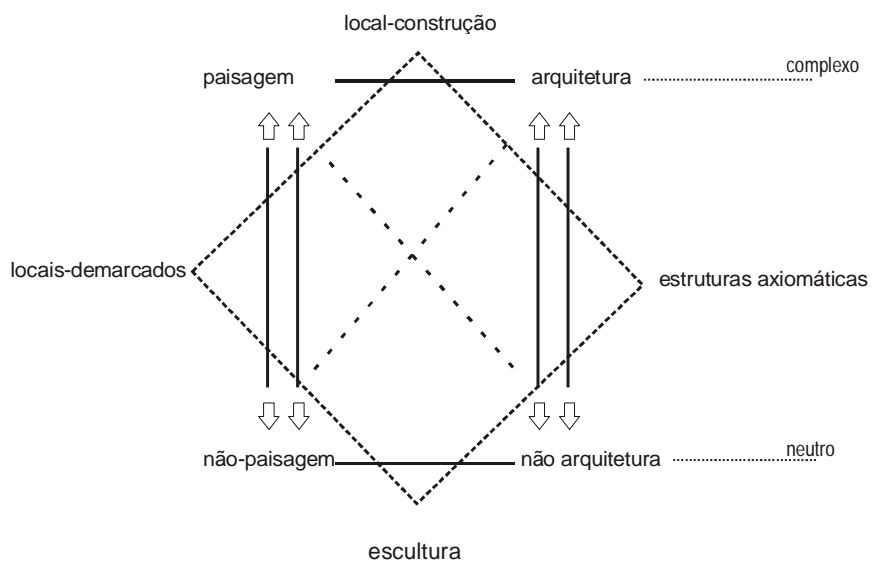

Esta pesquisa sobre a arte da paisagem não adota categorias formais - que se referem a tipos de construção -, mas, sim, analisa se a obra faz analogia a certos aspectos da paisagem ou se abarca-a em sua totalidade, além se seguir as vertentes de KASTNER; WALLIS, 1998, que consideram como a obra intervém na paisagem. 
Vamos analisar as diferentes vertentes da Land Art nos EUA e na Europa, atentando para os pontos de tangência entre elas. Como amostras das diferentes relações da arte com a paisagem, abordaremos algumas obras de Robert Smithson e de Richard Long, a fim de dar visualidade às vertentes que vão desde uma obra permanente para revitalização de terrenos até obras efêmeras que dizem mais sobre a percepção do indivíduo na paisagem. Poderemos compreender, ademais, a amplitude de modos como a arte contemporânea incorpora a paisagem na sua narrativa.

- Arte da paisagem nos EUA: os earthworks.

Desde a década de 1960 muitos artistas têm trabalhado com a terra. Porque a terra (land) tem um expressivo significado na América, trazendo o mito da fronteira e da terra prometida fecunda, não podemos evitar o debate do significado deste uso. (CARPENTER. 1983, p. 149) ${ }^{29}$

A Land Art norte-americana pode ser vista como o coroamento da busca por uma arte genuína, pois assume um caráter nacional identitário ao incorporar o imaginário do mito fundador da nação, além de refletir sobre suas paisagens e seu território. ${ }^{30}$ Por um conjunto de convergências que vão dos interesses próprios da arte deste período em expandir os limites da escultura, contestar o mercado de galeria, aos políticos (como o Governo que subsidia com verbas federais alguns trabalhos) ${ }^{31}$ a fim de, tanto construir, quanto divulgar a paisagem do país, o que nos permite interpretar que esta arte torna-se um Movimento nos EUA, o American Earthwork.

$* * * * * * * *$

No início de 1968, Michael Heizer viaja em direção ao sudoeste dos EUA, em busca de locais para um novo tipo de arte. No deserto de Mojave, em El Mirage, em um lago seco e absolutamente plano, a 250 milhas ao norte de Los Angeles, na planície de Nevada, ele encontra algo, a que se refere como sua tela em branco ou "blank canvas". Neste local, inicia uma série de trabalhos, que consistiam em estruturas de madeira inseridas no leito do lago,

29 CARPENTER, Jonathan. Alan Sonfist's Public Sculpture. In: SONFIST, Alan (org.). Art in the Land: A Critical Anthology of Environmental Art. New York: Dutton, 1983, p. 149.

${ }^{30}$ Durante o pós-guerra, as questões de território e paisagem ganham destaque nas disciplinas das Ciências Humanas. Como veremos no Capítulo 3.

${ }^{31}$ Grand Rapids Project (Michigan, 1974) de Robert Morris foi a primeira obra na paisagem a receber verba federal. Segundo Kastner, isto incentivou as instituições National Endowment for the Arts e organizações estaduais e municipais a se importarem com este tipo de arte, aumentando a interação de artistas com lugares de uso público. Ver KASTNER; WALLIS, 1998, p. 101. 
criando espaços "negativos" (vide pág.88). Foi um dos seus primeiros trabalhos feitos diretamente na paisagem e site-specific. Devido ao geometrismo e às relações indissociáveis entre objeto, observador e lugar/entorno, eles remetem ao Minimalismo. No entanto, o contexto das construções e sua localização distante do ambiente tradicional da escultura ocidental - galerias, museus ou espaços cívicos - difere radicalmente de qualquer outro movimento artístico.

Meses após, Heizer retorna a El Mirage com outro artista, Walter de Maria, que lá produz Two Parallel Lines, também conhecida por Mile Long Drawing: duas linhas riscadas de giz no solo com meia milha de comprimento cada. Esta obra só poderia ser apreendida por uma vista aérea. A obra ressalta a planície, a escala não-humana daquela paisagem, o deslocamento excessivo de um corpo para demarcá-la. As retas paralelas, proposição geométrica e abstrata de De Maria, em relação à vasta paisagem desabitada e indiferenciável, sugerem o infinito, uma paisagem suspensa no tempo ${ }^{32}$.

De Maria ao se fotografar em Mile Long Drawing (1968), perpendicular à linha de giz, parece sugerir a necessidade da experiência física e sensorial do artista e do observador na paisagem e com a obra.

Tanto De Maria quanto Heizer, além de interessados em arqueologia, buscavam através da arte alcançar certa experiência de religiosidade. De Maria ao aproximar o observador dos fenômenos naturais em obras cujos percursos requerem o silêncio, distanciamento (a passagem, o percurso) e tempo, como em Lightning Field (1977), vê esta reverência na Natureza: "Se todas as pessoas que vão ao museu pudessem sentir um tremor de terra" ${ }^{33}$; e Heizer, pela escala monumental das suas construções, que remetem aos monumentos pré-colombianos, mostra seu interesse em esculturas que suscitem o "sentimento de reverência [awe], um estado mental semelhante à experiência religiosa"34

Em setembro de 1968, Robert Smithson publica na revista Artforum um texto intitulado "A Sedimentation of the Mind: earth projects", no qual apresenta suas ideias de site, non-site e entropia, apontando que - naquele momento - seu trabalho tinha pouco a ver com

\footnotetext{
32 Richard Long realizou uma obra em contraposição a esta paisagem "suspensa" e "indefinida" em One Mile Walking, England, 1968. Long delimita em uma reta um percurso reconhecível, mensurável no tempo e no espaço; sua paisagem é específica.

33 FERREIRA, Glória. op. cit., p.186.

34 An interview with Julia Brown. In: BROWN, (ed.), Michael Heizer: Sculpture in Reverse. Los Angeles: Museum of Contemporary Art, 1984, p. $33 . \quad$ Disponível em: <http://www.diacenter.org/exhibitions/introduction/83>. Grifo nosso. 
uma visão Romântica da natureza mas, sim, com as questões de lugar e sítio, ideia compartilhada por Heizer. Além de seu trabalho plástico, o artista escrevia sobre paisagem e sobre uma arte ligada à paisagem (earthworks) e foi, de certo modo, um porta-voz do grupo norte-americano envolvido com esta arte.

As ferramentas da arte ficaram confinadas por tempo demais ao 'ateliế. A cidade dá a ilusão de que a terra não existe. Heizer chama os seus projetos de terra de "A alternativa ao sistema absoluto da cidade". (SMITHSON, 1968 In: FERREIRA; COTRIM, 2006, p.184)

Este ensaio de Smithson, além de apresentar algumas premissas dos trabalhos de terra, acabou por se tornar um manifesto para inaugurar a exposição Earthworks, em outubro de 1968 na Dwan Gallery, Nova Iorque, da qual participou junto com outros catorze artistas ${ }^{35}$. Nesta exposição, os trabalhos aconteciam ao ar livre, enquanto na galeria eram depositados os materiais do lugar da obra (um deslocamento do site, como sugere Smithson com a noção de non-site) ou representados por imagem. O crítico Craig Owens apontou ainda para outro deslocamento: o do ponto de vista, pois a experiência da observação pessoal, física estava mediada pela fotografia, texto ou filme ${ }^{36}$. A exposição opunha-se aos interesses do mercado da arte, pois os trabalhos eram muito grandes ou de difícil manuseio. Os artistas trataram das questões da terra e do território (land), com diferentes formas de abordagem e compreensão da paisagem e das relações humanas neste contexto ${ }^{37}$. Cabe lembrar que este momento é o ápice de ativismo contra a guerra no Vietnã, assim como o de organização social dos movimentos ecológicos ${ }^{38}$ nos EUA.

Em 1970, foi publicado o texto "Discussions with Heizer, Oppenheim, Smithson", que se tornaria emblemático da Land Art e que, segundo Ferreira ${ }^{39}$, evidenciava um novo tipo de

35 Com Michael Heizer (Dissipate, 1968), Dennis Oppenheim (anéis cortados em um trigal), Walter De Maria (linhas desenhadas no deserto), Robert Morris (earthwork, uma instalação de terra e lixo), Carl Andre (blocos de madeira alinhados sobre a topografia de um campo evidenciando o desenho do terreno) e Claes Oldenburg (escavação de um buraco no Central Park, seguido de seu preenchimento, com a ajuda de funcionários de cemitério (gravediggers). Ver KASTNER;WALLIS, 1998.

36 Ibidem, p. 24.

37 “ $[. .$.$] the various works included in the show all overturned stereotypical versions of landscape and its$ meaning; the contributing artists joined up, however awkwardly, with pioneering ecologists in turning attention to the land and people's relationship to it". Ibidem, p. 24.

${ }^{38}$ Foi ao final dos anos 1960 que surgiu em países como os Estados Unidos e Alemanha e, de forma geral, na Europa Ocidental, o "movimento ambientalista de massas, entre as classes populares e com base na opinião pública, (...) então se espalhou rapidamente para os quatro cantos do mundo" (CASTELLS, 1999:154 apud ROCHA). Em 1971 surgiram, nos EUA, o Greenpeace e o Friends of the Earth.

${ }^{39}$ FERREIRA; COTRIM, 2006, p. 276. 
atuação e reflexão dos artistas da época. Nesta entrevista destaca-se a frase de Michael Heizer que sintetiza um novo modus operandi da arte daquele período:

"O trabalho não é posto em um lugar, ele é esse lugar".

$* * * * * * * * *$

Compreender a magnitude que teve a American Earthwork requer, além da contextualização da arte, considerar também os significados da paisagem ao longo dos tempos. Taylor, em "A Land for Landscapes" norte-americana em relação à sua paisagem nos últimos dois séculos. O autor pontua, dentro desta história, os momentos que teriam influenciado a caracterização de um pensamento nacional sobre a paisagem.

Segundo o autor, o cerne deste pensamento está já na segunda metade do século XVIII, com a influência culta inglesa que preconizava uma "natureza como um bálsamo ou estimulante da mente humana" e, assim, os primeiros pintores de paisagem retratavam também os "valores espirituais da natureza". Os artistas desta época tinham como prática ir aos campos, montanhas e bosques do interior do país, em vez de irem estudar na Europa: o contato com a natureza e uma imersão em paisagens calmas eram de mais valia que o contato com mestres europeus. Paralelamente, conforme a urbanização avançava, a venda de pinturas de paisagem tornava-se mais lucrativa, como uma compensação das referências naturais que escasseavam nas cidades.

Tal tendência a relacionar paisagem, valorizando seus aspectos naturais, com estados de espírito ou humores (mood) permanece até mesmo com a chegada da influência do Impressionismo francês. No início do século XX, com a entrada das outras vanguardas, como o Cubismo e o Futurismo, Taylor ressalta que os artistas norte-americanos buscaram acompanhar estas propostas, valendo-se de paisagens imbuídas de significados. É o que se observa com Georgia O'Keefe, que traduz a vertente construtivista dos anos 1920 na paisagem árida e desértica (spare) da região do Novo México. Dessa forma, a paisagem na arte norteamericana teria significado liberdade e expansão ou, quando necessário, disciplina e concentração.

\footnotetext{
40 TAYLOR, Joshua. A Land for Landscapes. In: SONFIST, Alan (org.). Art in the Land: A Critical Anthology of Environmental Art. New York: Dutton, 1983, p. 1-7. 
Outro momento significativo da necessidade do resgate e da valorização de suas paisagens ocorre na década de 1930, com a Depressão pós-crise de 1929. Pinturas de campos férteis do centro-oeste americano (os artistas "descobrem" o interior, de Maine até Califórnia) dão ao público um "sentido de estabilidade, confiança e renovada sensação de lugar."

Taylor conclui que os jovens artistas da Land Art não contrariaram esta tradição de ter a paisagem como um motivo artístico: "The artist has used his sensitivity to the natural prospect as a way of adjusting and refining the response of man to his surrounding world".

\section{- Os primeiros trabalhos de Land Art europeus.}

A bibliografia sobre Land e Environmental Art na Europa apresenta, mais comumente, obras da Inglaterra, Holanda, Itália e Alemanha ${ }^{42}$. Enquanto nos EUA há uma forte presença da Pop Art e do Minimalismo como os precursores urbanos diretos da Land Art, na Europa esta presença é diluída e há, concomitante ao surgimento da Land Art, a Arte Povera ${ }^{43}$. Este movimento artístico dialoga com o momento sócio-político-cultural do pós-guerra europeu, mais especificamente da Itália, em uma crise de instabilidade política. Em vez de empregar os materiais clássicos da arte como o mármore, o bronze ou a tinta a óleo - sendo o Classicismo tão caro à Itália -, os artistas da Arte Povera utilizam materiais e elementos do cotidiano, abrindo a experiência da Arte para o processo. O processo passaria a ser mais importante que a obra (o objeto), e o tempo traduziria a poética da efemeridade.

\footnotetext{
${ }^{41}$ Ibidem, p. 7.

42 A Inglaterra é representada por um grupo grande de artistas, mas aqui cito Richard Long, Andy Goldsworthy, Antony Gormley e Hamish Fulton. Joseph Beuys e Hans Haacke são representantes da arte engajada em ecologia e política, da Alemanha. $O$ artista holandês Jan Dibbets aparece em catálogos, tanto da Land Art, quanto da arte conceitual. Giuseppe Penone, representante da arte na paisagem Italiana e integrante da Arte Povera. Movimento que teve as participações de Richard Long e Joseph Beuys, este que também fora chamado de "artista ecológico" (termo empregado em referência a ele por ocasião de sua participação, com a obra Idee di Pietra, na 13 ${ }^{\text {a }}$ Documenta de Kassel, Alemanha, em 2010). A fim de delimitar o escopo deste trabalho, serão apontadas apenas algumas obras americanas e europeias.

${ }^{43} \mathrm{O}$ momento mais marcante deste movimento deu-se entre os anos de 1967 e 1972 . Podemos entender Arte Povera como uma "variável das tendências contemporâneas, particularmente da Arte Conceitual e Minimalismo [...] Existem afinidades entre Arte Povera e os artistas da Land Art Robert Smithson, Robert Morris, Walter De Maria ...e com os brasileiros Helio Oiticica e Lygia Pape". Ver CHRISTOVBAKARGIEV, Carolyn. Arte Povera. London: Phaidon Press, 1999, p. 27.
} 


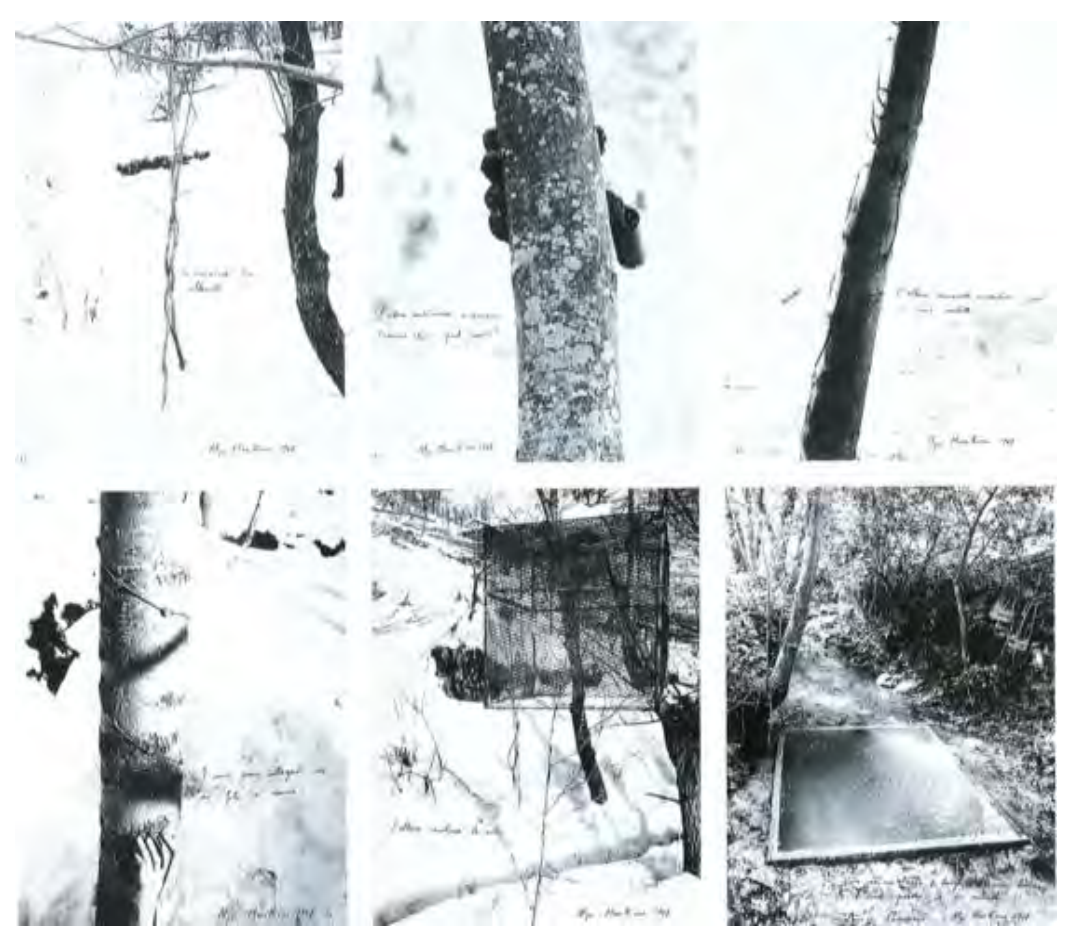

28. Giuseppe Penone. Alpi Marittime (Maritime Alps), 1968. Garessio, Itália.

(Fontehttp://www.stephengdewyer.com/Arte_Povera_and_Italian_Autonomia_Presenting_the_Laborer.html $>)$

Podemos dizer que na Europa há uma mútua alimentação de ideias e procedimentos entre Arte Povera e Land Art - como veremos com Penone e Richard Long -, uma vez que ambas tratam da síntese entre a vida e a natureza com a arte e questionam o seu valor (num período em que se buscava a reorganização e reconstrução de valores sociais). Desta troca resultará os primeiros trabalhos da Land Art europeia, nos quais prevalece a relação da paisagem na escala humana e o percurso em uma arte inserida nos processos do dia-a-dia. A ênfase nos elementos naturais, como vimos no Capítulo 1, parece indicar que também na Europa buscava-se por novos referenciais para a produção da paisagem.

É também 1968 o ano em que Giuseppe Penone realiza, em um bosque na cidade de Garessio, alguns experimentos de performance e poesia. Em Marittime Alps (1968-1978) ele segurou uma árvore marcando o ponto de contato e ali incrustou o molde de sua mão em bronze. Ao continuar a crescer, a árvore levaria esta marca e teria seu crescimento também alterado pela ação do artista. Seu trabalho trata do contato homem e natureza, por meio de identificação e ação.

No mesmo ano, o artista inglês Richard Long caminha dez milhas em linha reta na região de Exmoor, sudoeste da Inglaterra. Este caminhar ele designa como arte, e o nome do 
trabalho é A Ten Mile Walk (1968), Inglaterra. O artista, em uma de suas críticas à Land Artcomo "fenômeno" americano -, diz que se seu trabalho recebesse um rótulo, este deveria ser o de Arte Povera:

I see my work as having much to do with conceptual-art, de-materialization, or even Art Povera, closer in spirit. You can think of A Line Made by Walking as a classic Art Povera work, sort of simple and artless and made out of nothing. (LONG apud Tufnell 2006, p. 23)

My interest was in a more thoughtful view of art and nature, making art both visible and invisible, using ideas, walkings, stones, tracks, water, time, etc, in a flexible way... It was the antithesis of so-called American Land Art, where the artist needed money to be an artist, to buy real estate, to claim possession of the land and wield machinery. True capitalist art. (LONG, 1982 apud Tufnell, 2006, p. 15)

Se o Minimalismo e a Pop Art são precursores da arte contemporânea da paisagem norte-americana e a Arte Povera, da europeia, é necessário ressaltar que tais movimentos não estão circunscritos em fronteiras nacionais. Isto seria a antítese da arte que propõe o signo aberto. O Minimalismo e a Pop Art acontecem na Europa, assim como artistas americanos trabalham na poética da Arte Povera, como Alan Sonfist e Michael Singer, não sendo, no entanto, agrupados sob tal título por determinado curador ou evento.

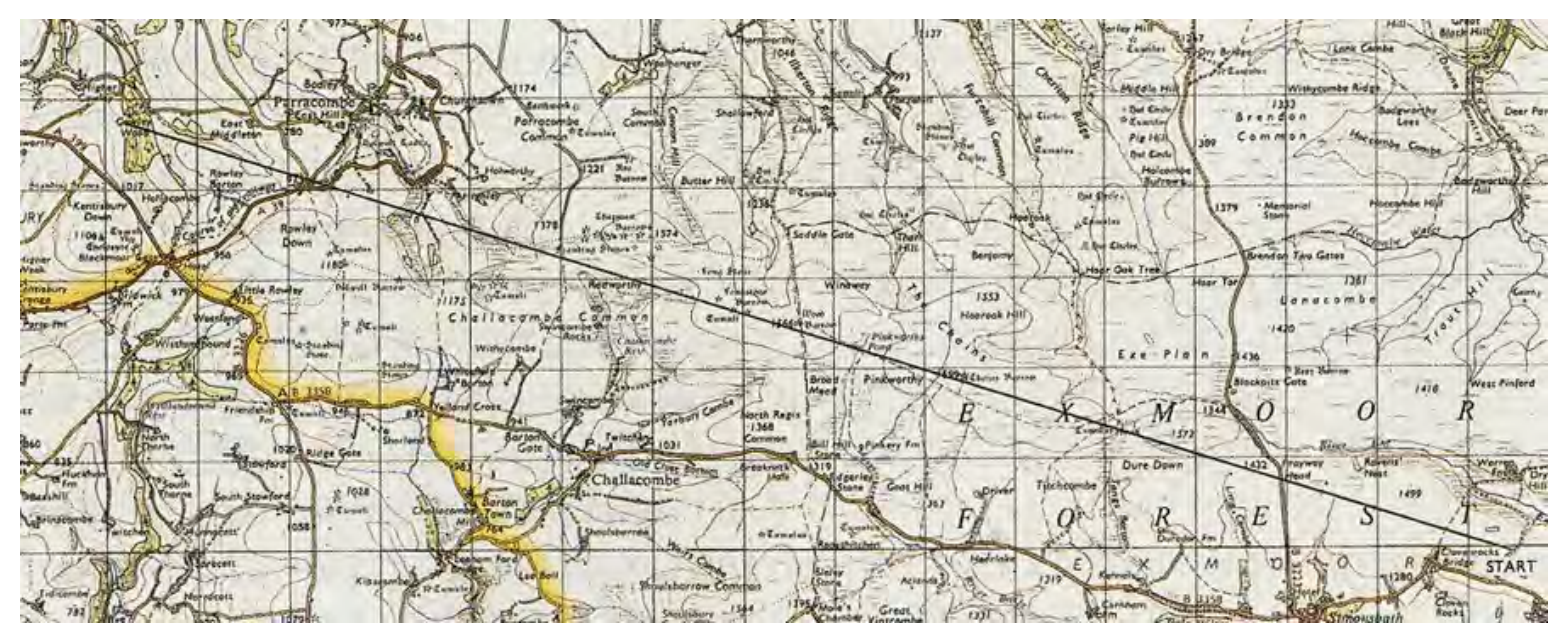

29. Richard Long. A Ten Mile Walk, England, 1968.

(Fonte imagem: http://www.tate.org.uk/research/publications/tate-papers/ten-miles-on-exmoor) 


\subsubsection{As Vertentes.}

Algumas obras priorizam os aspectos físicos da paisagem, suas matérias-primas, escala, proporção, composição; outras têm como foco a percepção, o envolvimento do indivíduo e a experiência da paisagem; outras, ainda, ressaltam e trazem à tona aspectos sócio-culturais da paisagem, investigam sua história e incitam problemáticas políticas. Dessa forma, a arte da paisagem - nos diferentes países e períodos - transitam da reverência à natureza em rituais efêmeros a construções monumentais permanentes.

Propondo leituras das obras da Land Art e Environmental Art que, afora tratarem da relação arte e paisagem ou homem e natureza, são capazes de diferirem quanto a escala, ocupação - urbana ou em paisagens ermas -, materialidade, permanência e intencionalidade, alguns autores agrupam as obras de acordo com o tipo de ação (a gestualidade do artista) ou de acordo com o resultado da obra em relação à paisagem (a composição de ambas). Tais agrupamentos por afinidades são as vertentes e, para este trabalho, tomarei como referência aquelas apontadas por Rosenthal ${ }^{44}$ e Kastner ${ }^{45}$.

Mark Rosenthal, em Some Attitudes of Earth Art (1983), estabelece cinco vertentes dentro da Land Art. Um primeiro grupo, chamado pelo autor de "gestos na paisagem", incluiria os norte-americanos mais conhecidos por seus "earthworks" como Walter De Maria, Michael Heizer, Dennis Oppenheim e Robert Smithson. A característica que os une é que suas obras são construídas na paisagem, por meio da tecnologia, utilizando recursos e aparatos das grandes obras de engenharia, realizando feitos prodigiosos, monumentos que, na maior parte das vezes, são vistos em totalidade somente por uma vista aérea. Esta produção mantém a tradição da História da Arte pela construção da forma e composição. Neste caso, são recorrentes as formas geométricas e por isso dá-se a influência do Minimalismo. Rosenthal sugere que esta vertente ainda possui algum resquício da visão modernista de artistas do século XX, que expressa a necessidade de autonomia da arte em relação ao meio.

As obras que são "quase-arquiteturas" e que o autor agrupa como "cercos (enclosures) na paisagem" formam o segundo grupo. Nele, estão obras que delimitam a paisagem e remetem a antigos monumentos ou construções. Exemplos são: Complex One /City (1972-76), de Michael Heizer; e Perimeters, Pavillons, Decoys (1978), de Mary Miss, obras que dão

\footnotetext{
${ }^{44}$ ROSENTHAL, Mark. Some Attitudes of Earth Art: from competition to adoration In: SONFIST, Alan. Art in the Land: a Critical Anthology of Environmental Art 1983, p. 60-72.

${ }^{45}$ KASTNER, Jeffrey; WALLIS,Brian. Land and Environmental Art, 1998, p. 17. 
margem à comparação com monumentos de antigas civilizações. $\mathrm{O}$ espaço criado pela obra não se integra ao entorno.

O terceiro grupo, segundo Rosenthal, que incluiria Richard Long e Michael Singer, trabalha com o "gesto sutil na paisagem", seja por seus percursos, seja reorganizando os materiais naturais encontrados em determinado local. Estas ações seriam uma atitude de reverência para com a paisagem, não inserindo-a na produção tecnológica. Seus gestos são modestos, por vezes passam desapercebidos. O foco reside na vivência do artista com a paisagem.

O quarto grupo deste autor é delimitado como "natureza ela mesma", no qual as obras tratam mais diretamente da natureza e seus processos. Aqui, os materiais são retirados diretamente do meio, com pouca interferência autoral. Tais elementos e processos são levados, se necessário, para o ambiente interno das galerias, e as qualidades estéticas da natureza substituem as da arte; por exemplo, enquanto o observador se depara com os processos naturais de crescimento e putrefação, em tempo real de transformação da matéria, ou com uma composição, cuja forma é natural e apenas rearranjada pela arte. São exemplos: Hans Haacke com Estação de tratamento de água do Reno (1972), Walter De Maria com Earth Room (1977) e os trabalhos de Robert Smithson non-sites (década de 1960).

A quinta vertente é chamada pelo autor de "paisagens idealizadas". Ela contém, em certa medida, um elemento romântico e abarca obras com visões pitorescas, nas quais o homem está ausente. Os artistas não tocam nem marcam presença na paisagem, não temos o seu gesto na obra ou na paisagem sendo, portanto, priorizados os valores e processos naturais. Rosenthal cita a produção de Alan Sonfist, com Time Landscape (1978), como um exemplo ápice desta linha de pensamento, assim como os percursos do artista Hamish Fulton, registrados em fotografias e textos, que são apenas indícios destas paisagens percorridas em diversos países.

Rosenthal, por sua vez, ressalta que as obras não estariam compartimentadas em um único grupo, sendo possível sobreposições de interpretação. A Spiral Jetty (1970), ícone de Robert Smithson, poderia ser lida como "natureza ela mesma", pois se desenvolve a partir dos fenômenos naturais locais, que independem do gesto do artista, assim como pela forma artificial que é implantada na paisagem sendo "gesto na paisagem".Vejamos também as vertentes de Kastner em Land e Environmental Art (1998), que se somam às leituras das vertentes já apontadas. Este autor, contudo, atem-se ao resultado, e não ao processo. Assim, mesmo uma obra gerada por tratores, caso sua forma resulte em continuidade com a 
paisagem, é agrupada na vertente integração. As outras vertentes deste autor são: interrupção, envolvimento, implementação (execução) e imaginação. De um modo geral, as obras da Land Art não estão necessariamente inseridas em uma única linha de pensamento ou vertente, isto é consenso entre os diversos autores.

$\mathrm{Na}$ vertente integração estão as obras dos artistas que manipulam a paisagem como uma matéria-prima, sendo as operações esculturais - corte, relocação, marcas, aglomeração realizadas diretamente no terreno. As características intrínsecas do lugar são consideradas fundamentais para a leitura e a experiência da obra. De modo geral, estas obras evidenciam a interveção humana na paisagem e há uma predileção pela paisagem natural, intocada. São exemplos os primeiros trabalhos norte-americanos Time Line (1968), de Dennis Oppenheim; Double Negative (1969) de Michael Heizer; Spiral Jetty (1970) ${ }^{46}$, de Robert Smithson e as obras dos europeus Andy Goldsworthy e Herbert Bayer.

O segundo grupo, interrupção, é diferenciado pela inserção de elementos industriais e sintéticos que, junto aos elementos naturais da paisagem, podem tanto coexistir harmonicamente, quanto causar estranhamento. As obras são mais transgressoras na ocupação da paisagem e em sua relação para com a mesma, e os artistas questionam a definição do que é natural. São exemplos as obras de Christo e Jeanne Claude ${ }^{47}$; Sun Tunnels (1973-1976), de Nancy Holt; Perimeters/Pavillions/Decoys (1978) de Mary Miss; The Lightning Field (1977) de Walter De Maria; e Complex City (1972-1976), de Michael Heizer. O autor também inclui neste grupo obras que são deslocamentos de elementos da paisagem para o interior da galeria, citando Richard Long e Robert Smithson (que veremos adiante).

O autor designa o terceiro grupo por envolvimento, já que trabalha a relação entre o corpo e o percurso ${ }^{48}$ com a paisagem, focando o indivíduo como quem a percebe e a constitui. As obras enfatizam a experiência subjetiva e remetem a uma ligação primordial com a Terra. São geralmente obras efêmeras, que se aproximam do ritual ou da performance. Os artistas usam estratégias da arte conceitual para fixarem suas relações com a paisagem através da fotografia, de mapas e da escrita. São exemplos as obras, de um modo geral, de Richard Long, Andy Goldsworthy e Hamish Fulton; Mile Long Drawing (1968) de Walter de Maria; a série de

\footnotetext{
46 Kastner (1998) analisa a composição da arte com a paisagem, portanto Spiral Jetty, entre outros "earthworks", estão em integração, mesmo que sua execução tenha requerido pesadas intervenções tecnológicas de transporte e sedimentação.

47 Pelo mesmo motivo, embora as obras de Christo e Jeanne Claude sejam efêmeras, estão em interrupção.

48 KASTNER; WALLIS, 1998, p. 235. Citando Henry David Thoreau, Walking (1861), sobre a arte de caminhar. 
silhuetas (1976-1982), de Ana Mendieta; Border Crossing (1993), de Christiam Müller; Mutações Geográficas (1969-1970), de Cildo Meireles, entre outros.

Em implementação, há uma mudança na prática artística, pois as obras passam a investigar questões ambientais, algumas atuando diretamente em causas ecológicas e urbanas. O processo e a ideia são concebidos como arte, mas a execução não difere, muitas vezes, da adotada pela ciência. Os aspectos formais estão em segundo plano, pois a relevância da obra está na ação sócio-política. A arte questiona os rumos do binário cidade e natureza e esta deixa de ser "uma tela em branco", fonte de recursos ou de apreciação estética apenas. As obras tratam do desperdício, desenvolvimento industrial, expansão urbana, intervenções científicas nos processos naturais, ligando-se a outras disciplinas envolvidas no estudo da produção da paisagem. Exemplos marcantes deste conteúdo são Wheatfield (1982) de Agnes Denes; Revival Fields (1992) de Mel Chin; Pool of Earth (1975) e Time Landscape (1965-1978), de Alan Sonfist; e 7000 Carvalhos (1984-1986), de Joseph Beuys .

Em imaginação, Kastner apresenta obras que têm a paisagem como uma construção ótica, um conceito ou uma elaboração linguística. A paisagem que interessa a estes artistas é menos física e mais metafórica, fornecendo um repertório de símbolos. Os artistas consideram o ambiente como uma narrativa histórica que fornece tal repertório de símbolos e estes podem ser utilizados para descrever a sociedade contemporânea. Algumas obras que elucidam esta vertente são: Little Sparta (1983), de Ian Hamilton Finlay; 12 hours tide objects with correction of perspective (1969), filme exibido na televisão, de Jan Dibbets e 42 Degree Parallel Piece (1968) de Douglas Huebler.

Serão adotadas estas vertentes de Kastner ${ }^{49}$, para analisarmos as obras de Fronteiras (1998-2001) e de Margem (2009-2010), mais adiante neste trabalho.

$* * * * * * *$

Há ainda outra maneira de agrupar e compreender as diversas formas que a relação arte e paisagem assume. Tufnell (2006) adota a cronológica. Segundo o autor, a primeira fase cobre aproximadamente os anos 1967 a 1977, um período de grande inovação, quando se abriram as fronteiras para a arte da paisagem e para a reflexão sobre modos de se pensar a

\footnotetext{
${ }^{49}$ Imagens de obras que ilustram estas vertentes podem ser encontradas nas páginas 72 a 83.
} 
paisagem e a natureza. Representam esta fase A Line by Walking (1967), de Richard Long a e The Lightening Field (1977), de Walter De Maria.

A segunda fase, do final dos anos 1970 incluindo a década de 1980, abrange obras ligadas a questões ambientais e urbanas, que também receberam a denominação de Environmental Art. Esta produção é menos formal, como era predominantemente a primeira fase. Questões conceituais da arte vão se alterando, ou desdobrando, em questões políticas e ecológicas. Tufnell sugere que são exemplos emblemáticos desta fase os trabalhos: 7000 Carvalhos (1982-1986), de Joseph Beuys; o "earthwork" de Robert Morris em King Country, pela causa de recuperação de terras (1979); e Wheatfield (1982) de Agnes Denes.

A terceira fase compreende os últimos quinze anos do século $\mathrm{XX}$ até a produção atual. Alguns dos artistas que a representam trabalham em diversas mídias, buscando referências nos trabalhos precursores da arte na paisagem e do contato arte e natureza, em continuidade à expansão de possibilidades e contextos. Tangenciando de âmbitos científicos, ecológicos a existenciais, são exemplos de obras desse momento: Tate Thames Dig (1999), de Mark Dion; Revival Fields (1992), de Mel Chin; Land Sea and Air II (1982), de Anthony Gormley; e Double Sunset (1999), de Olafur Eliasson.

As vertentes integração, interrupção, envolvimento, implementação e imaginação, que indicam áreas de interesse da arte pela paisagem ou pelas práticas sociais que se refletem nas artísticas, podem justapor-se às categorias "locais-demarcados" e "locais-construção", construídas por Rosalind Krauss ${ }^{50}$ e que se referem à espacialidade das obras. "Locaisdemarcados" seriam os trabalhos, cuja interferência na paisagem é sutil ou efêmera, aqueles que se fundem a ela. Estão representados, em sua maior parte, nos agrupamentos integração, envolvimento e imaginação. Já os "locais-construção" exigem a tecnologia da engenharia, são monumentos ou obras, cuja intenção é promover a igualdade entre arte e paisagem, e podemos encontrá-los nos exemplos de Kastner para interrupção.

Tanto como demarcações ou construções, há aquelas obras - apresentadas em implementação - que tangenciam ou invadem campos da ciência, do planejamento paisagístico ou da arqueologia urbana, entre outras disciplinas. Desta maneira, diluem-se os contornos da arte e, mais ainda, da composição escultural, tornando-se quase improvável agrupá-los de acordo com a espacialidade.

\footnotetext{
${ }^{50}$ Ver Diagrama de Rosalind Krauss, no artigo A Escultura no Campo Ampliado (1984) 


\section{integração}

a paisagem é manipulada c omo uma matéria-prima: cortada, realocada, marcada. Algumas obras com lirismo, outras com intenção política. ${ }^{51}$

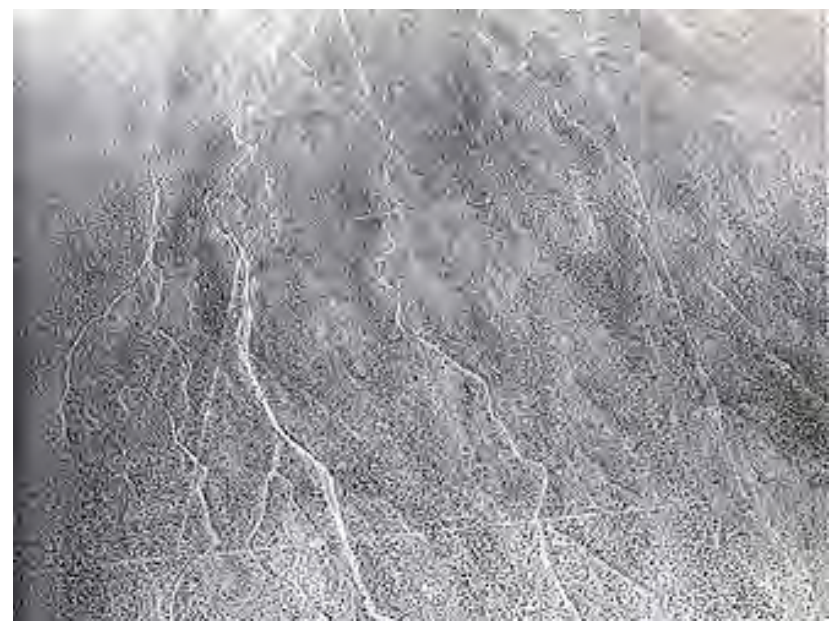

30. Walter de Maria. Las Vegas Piece, 1969. Cortes no terreno. Desert Valley, Nevada. Dois cortes de $844 \mathrm{~m} \times 244 \mathrm{~cm}$ e dois cortes de $1,6 \mathrm{~km} \times 244 \mathrm{~cm}$.

O trabalho intencionava explorar as ideias de medidas e de orientação do corpo na paisagem, além de comentar como o mapa se impõe sobre o meio.
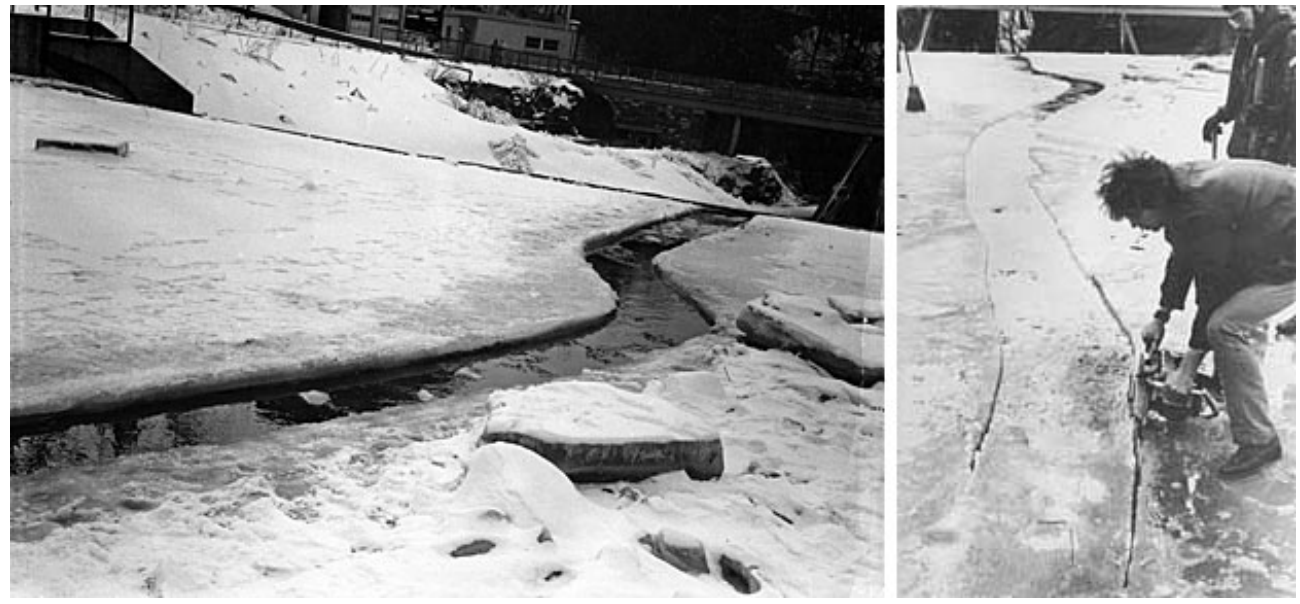

31. Dennis Oppenheim. Accumulation Cut, 1969. Bebe Lake, Ithaca, Nova lorque.

(Fonte: < http://www.dennis-oppenheim.com/works/142>)

Outras obras em Integração são:

de Robert Smithson: Spiral Jetty, 1970, Great Salt Lake, Utah; e Spiral Hill e Broken Circle, 1971. Emmen, Holanda. E de Michael Heizer: Double Negative, 1969-70. Nevada, EUA.

${ }^{51}$ KASTNER; WALLIS, 1998, p. 45. 


\section{integração}

a paisagem é manipulada como uma matéria-prima: cortada, realocada, marcada. Algumas obras com lirismo, outras com intenção política
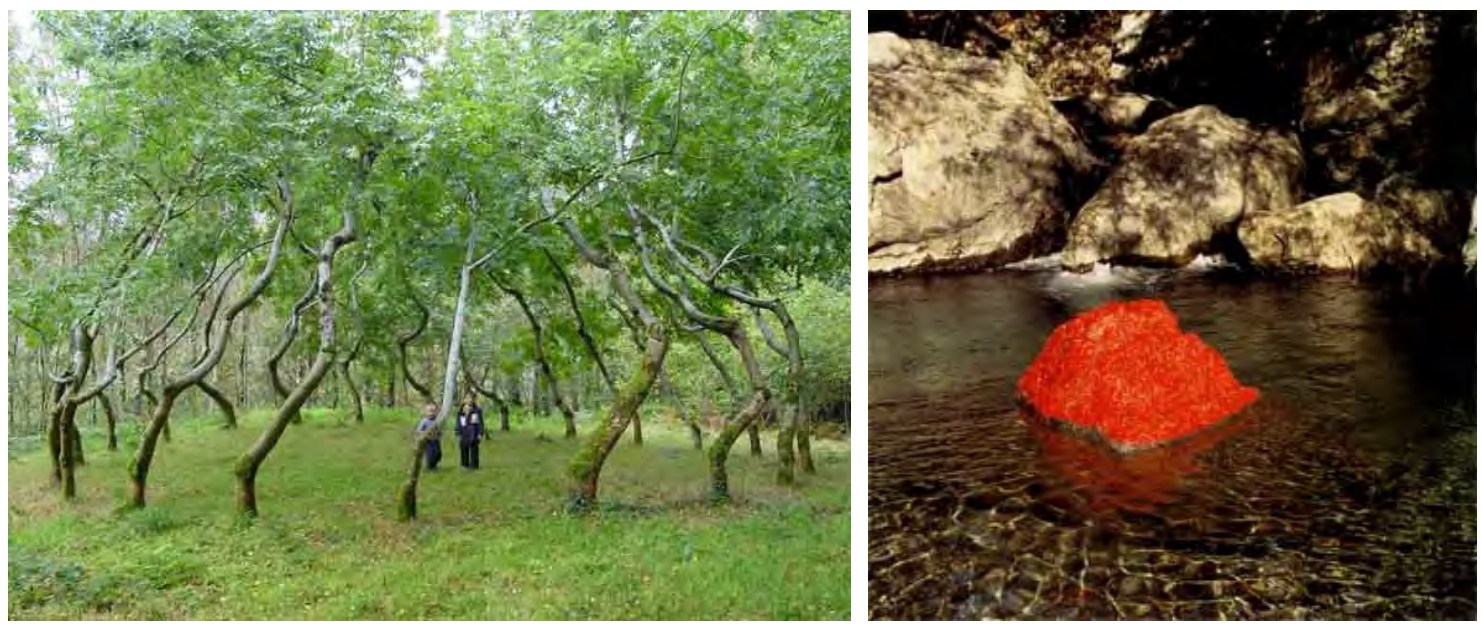

32. David Nash. Ash Dome, 1977-2006. País de Gales

e 33. Andy Goldsworthy. Maple leaves, 1991. Japão. (Fonte: http://coetirmynydd.co.uk/menulesspages/ashdome.html e http://www.art.pref.tochigi.Ig.jp /en/collection/collection05.html)

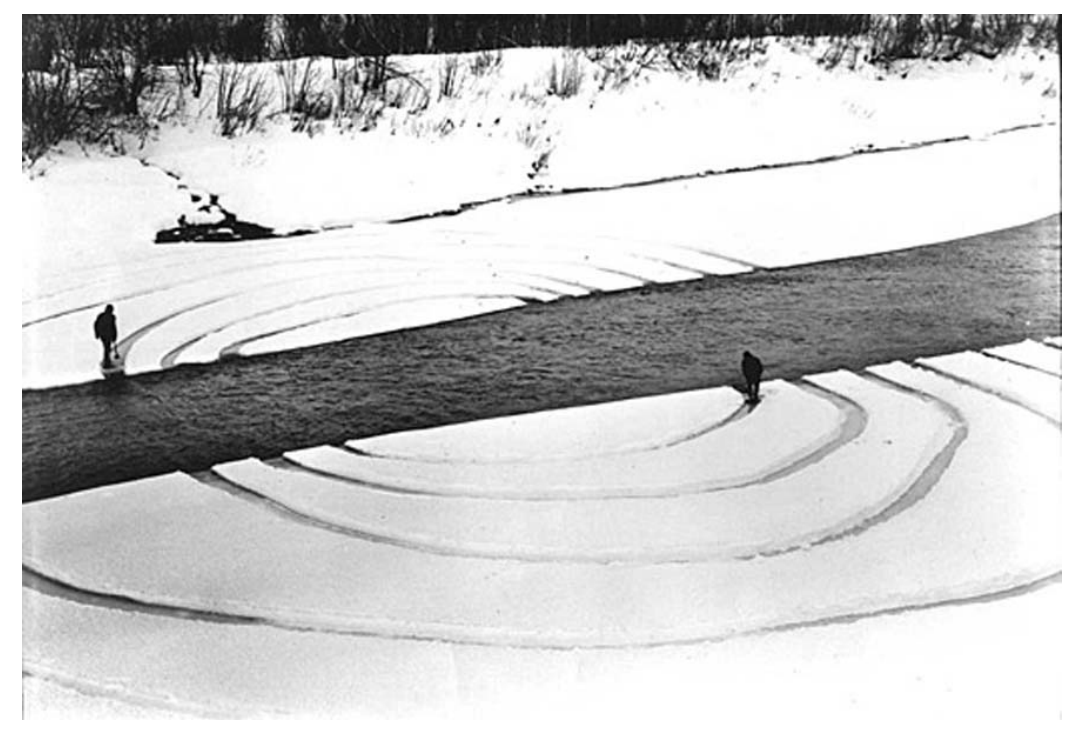

34. Dennis Oppenheim. Annual Rings, 1968. Fronteira EUA e Canadá.

(Fonte imagem: <http://dennisoppenheim.blogspot.com.br/>) 
interrupção

materiais e/ou técnicas estranhas à paisagem evidenciam o construído (man made). Algumas obras levam para galeria os elementos naturais encontrados na paisagem.

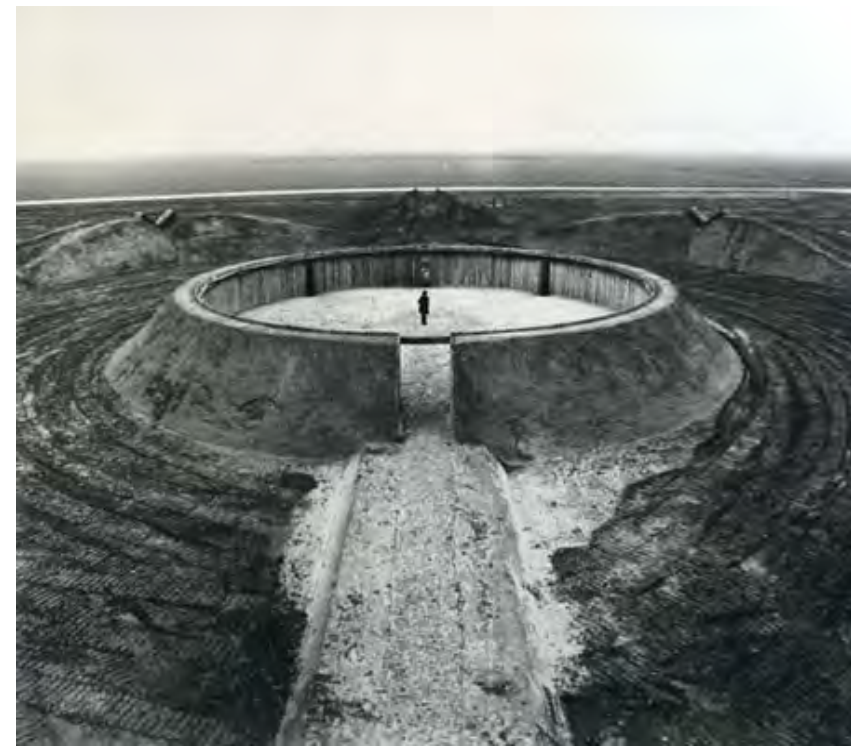

35. Robert Morris. Observatory, 1971. Ijmuiden, Holanda.

(Fonte: <http://www.architetturadipietra.it/wp/?p=2010>)

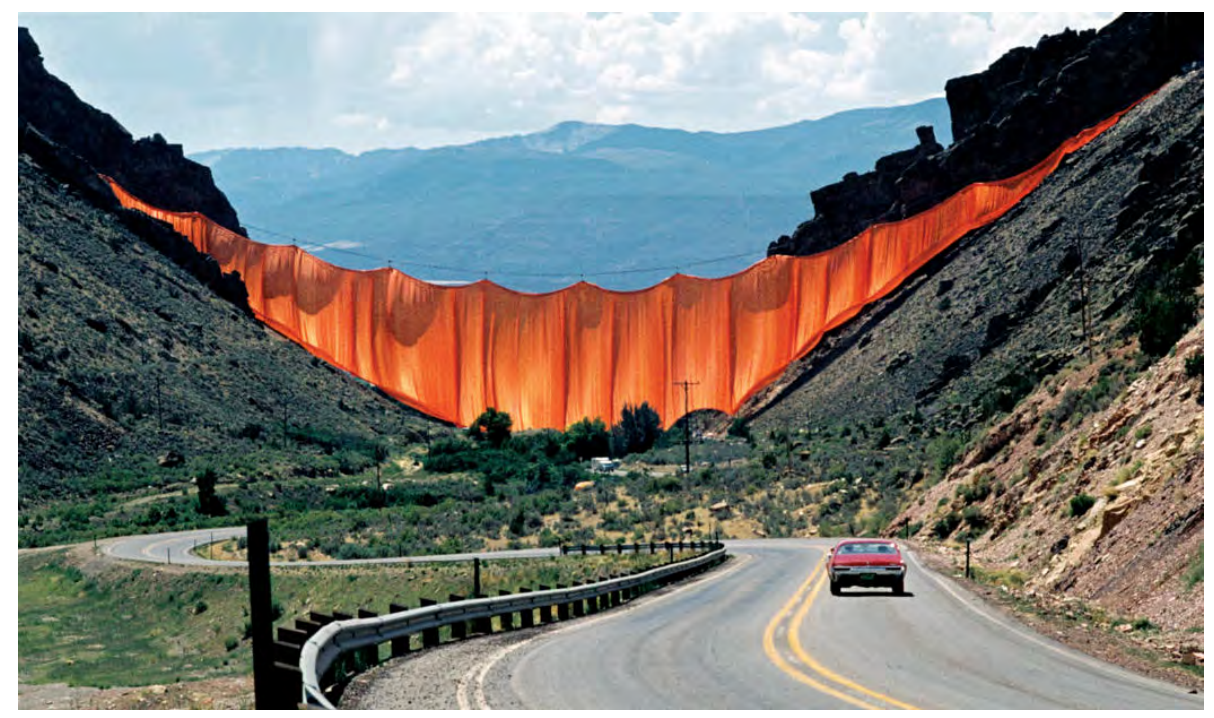

36. Christo e Jeanne -Claude. Valley Curtain, 1970-1972. Rifle, Colorado, EUA. Nylon e aço. (Fonte: < http://christojeanneclaude.net/projects/valley-curtain\#.USWOgPKRMsw>)

Vide também como Interrupção:

Sun Tunnels, 1973-6, de Nancy Holt; Running Fence, 1972-1976, de Christo e Jeanne-Claude;

Lightning Field, 1977, de Walter de Maria; Perimeters/ Pavilions/Decoys, 1977-1978, de Mary Miss, Nova Iorque. 


\section{interrupção}

materiais e/ou téc nic as estranhas à paisagem evidenciam o construído (man made). Algumas obras levam para galeria os elementos naturais encontrados na paisagem.

37. Michael Heizer. Dissipate, 1968. Black Rock deserto, Nevada . Estacas de madeira enterradas. (Fonte: <http://www.artperformance.org/article25911176.html>)
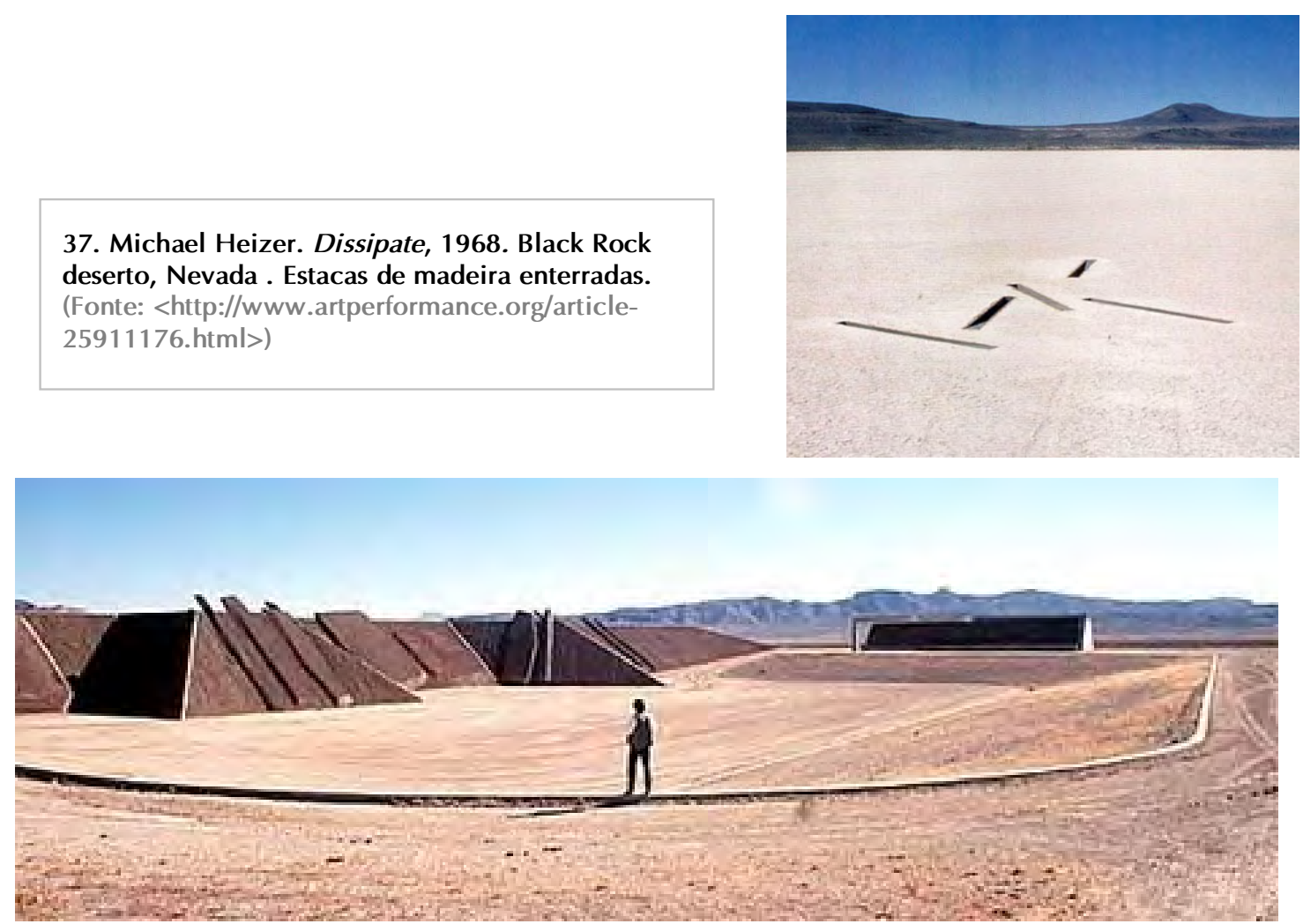

38. Michael Heizer. Complex One /City (1972-1976). Concreto, ferro, terra compactada. Nevada, EUA. (Fonte: <http://harry-clarke.com/hello-world-2/>)
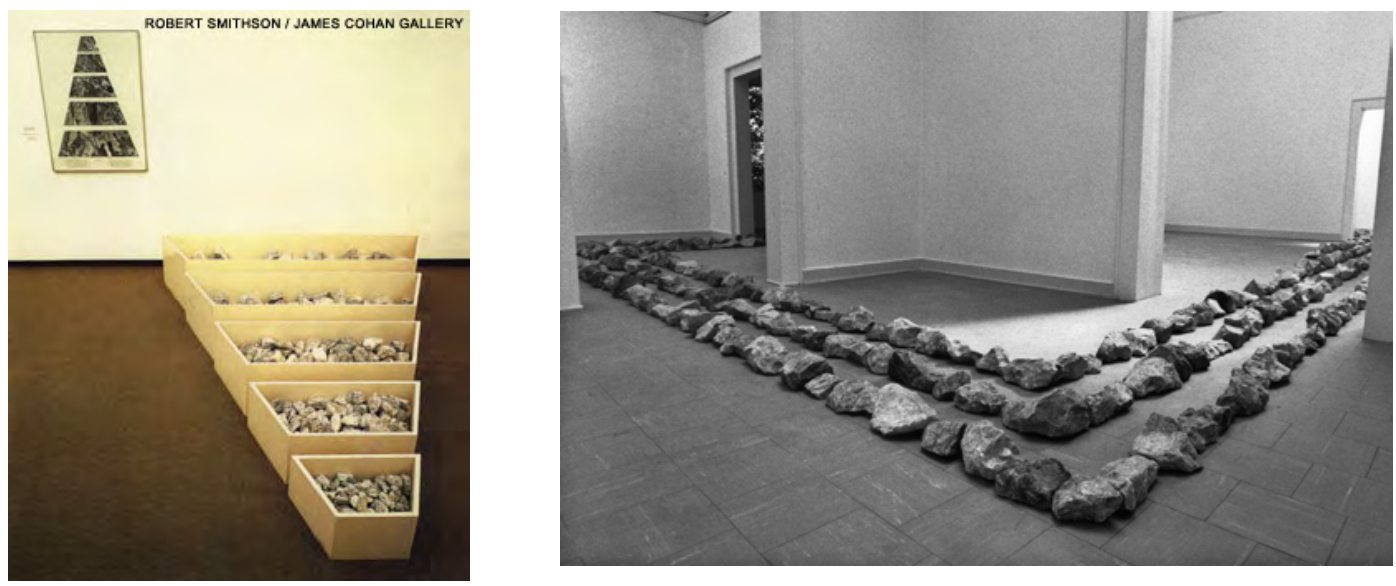

39. Robert Smithson. Non-site. (Franklin, New Jersey), 1968 e 40. Richard Long. A line of 682 stones, 1976.

(Fonte: <http://www.robertsmithson.com/sculpture/nonsite_franklin_280>.e $<w w w$.richardlong.org/Exhibitions/2011 exhibitions/six82stones.html>) 


\section{envolvimento}

é a ação humana que prevalece, como um ritual, uma ligação primordial e simbólica com a Terra „52

41. Richard Long. A Line in The Himalayas, 1975.

(Fonte:

http://www.tate.org.uk/art/art works/long-a-line-in-thehimalayas-t12035)
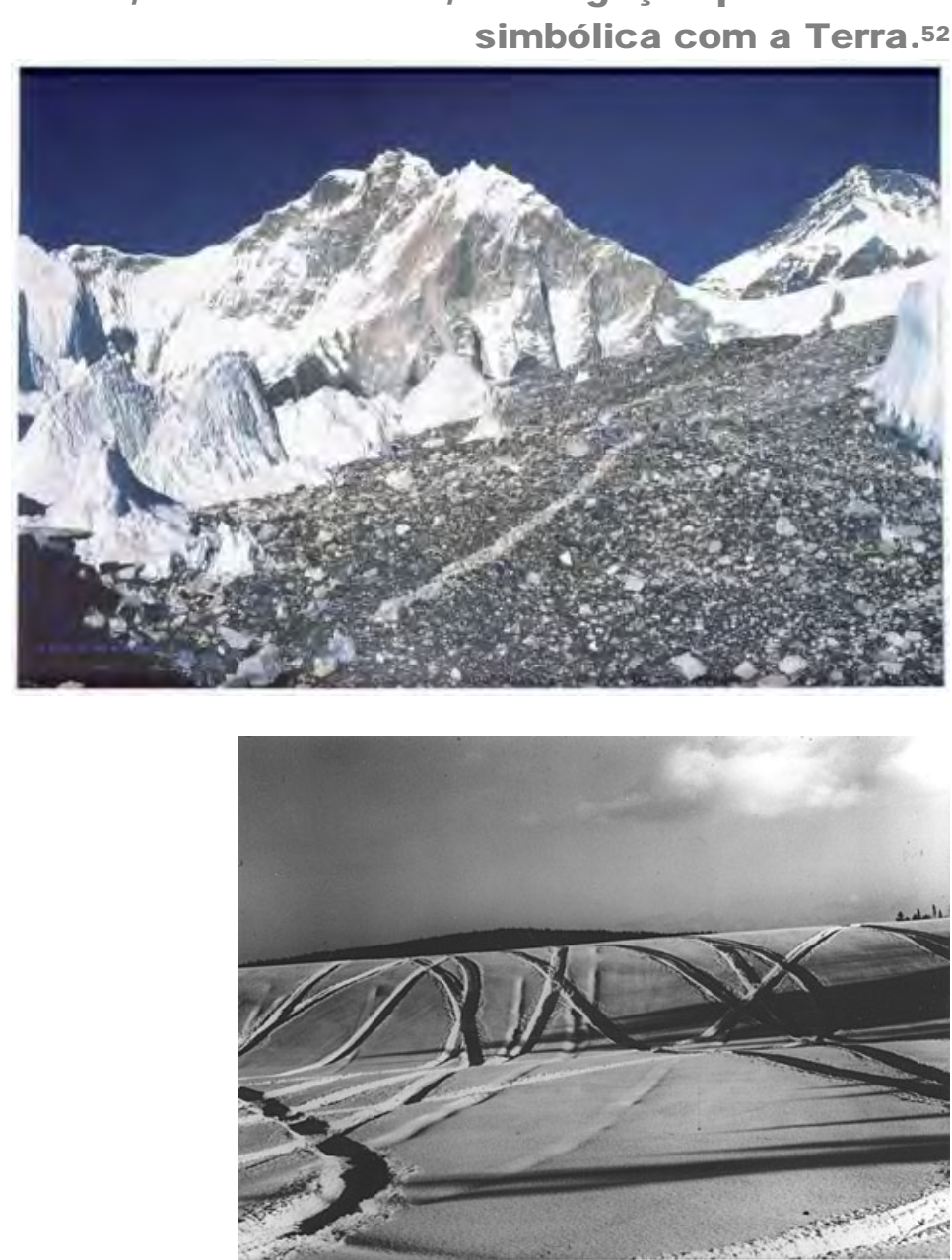

42. Dennis Oppenheim. One Hour Run, 1968. Seis milhas percorridas continuamente. Maine, EUA.

43. Walter De Maria. Mile Long Drawing (ou Two Parallel Lines), 1968.

El Mirage Desert, California, EUA.

(Fonte http://www.portlandart.net/archives/2009/03/

the_black_squar.html)

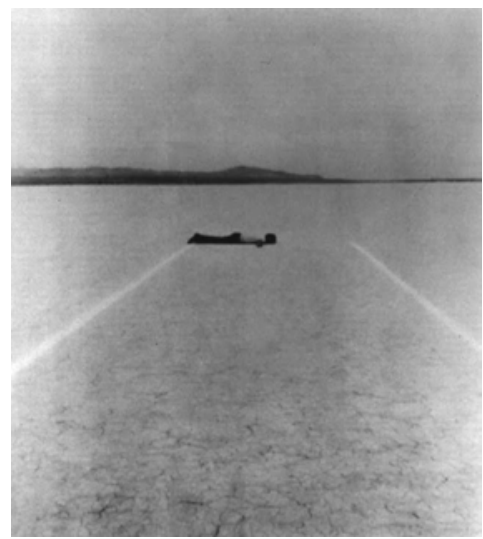

${ }^{52}$ KASTNER; WALLIS, 1998, p. 114. 


\section{envolvimento}

é a ação humana que prevalece, como um ritual, uma ligação primordial e simbólica com a Terra. ${ }^{53}$

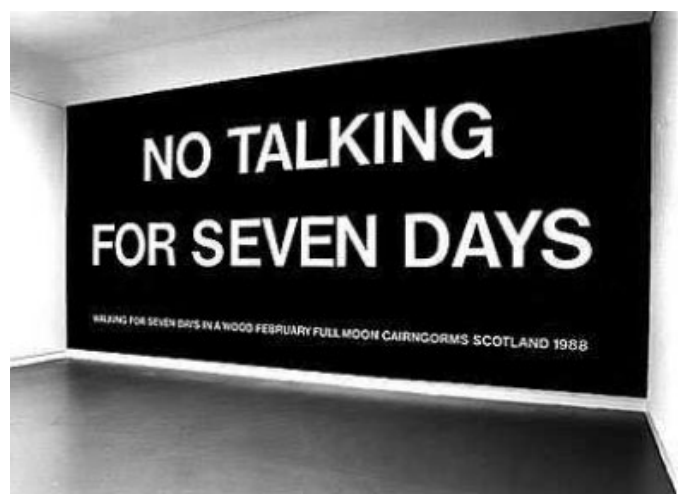

44. Hamish Fulton. No talking for seven days (walking for seven days in a wood Januart Full Moon Cairngorms, Scotland 1993). Texto pintado sobre parede.

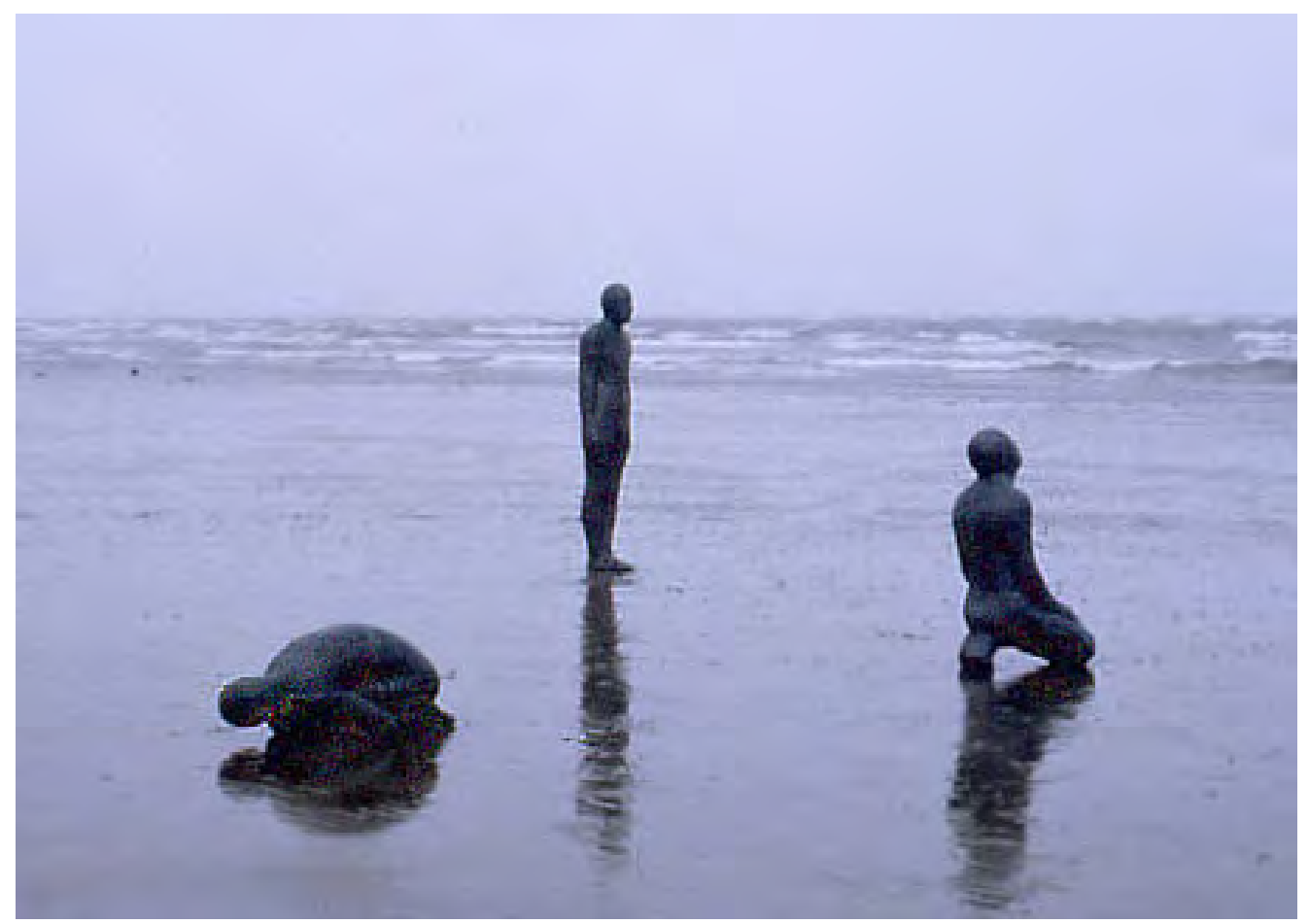

45. Anthony Gormley. Land, Sea and Air II, 1982. Inglaterra. Chumbo e fibra de vidro. (Fonte: < http://www.antonygormley.com/sculpture/item-view/id/249>)

Vide também como Envolvimento:

de Richard Long, A line by walking, 1967, Somerset, Inglaterra. Ver Capítulo 1.

${ }^{53}$ KASTNER; WALLIS, 1998, p. 114. 


\section{implementação}

a arte se engaja em investigação científica e em questões ambientais e

urbanas.

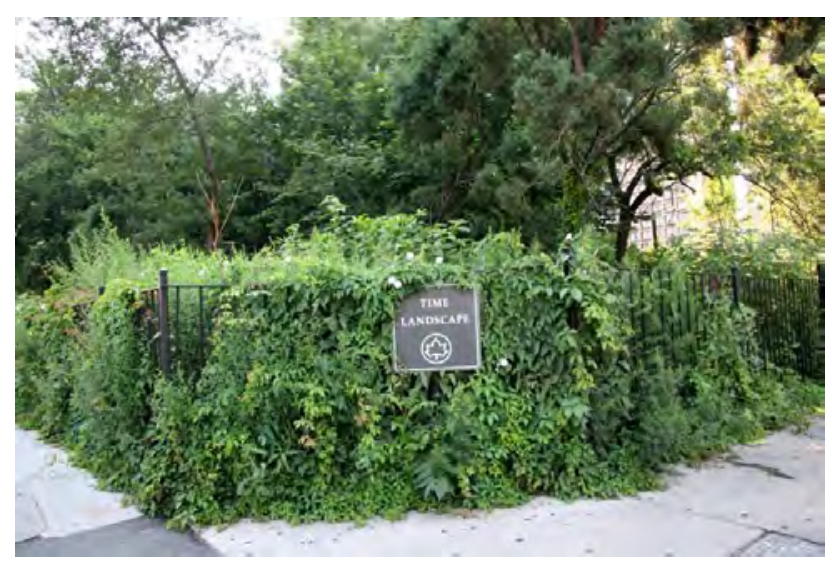

(Fonte: http://www.pbase.com/image/62793501)

\section{Alan Sonfist.} Time Landscape (196978).

La Guardia Place, Nova lorque. $9.000 \mathrm{~m}^{2} \mathrm{com}$ espécies vegetais, recriação de uma floresta pré-colonial.

(Fonte: http://avantguardians.com/sonfist1/as pop11.html

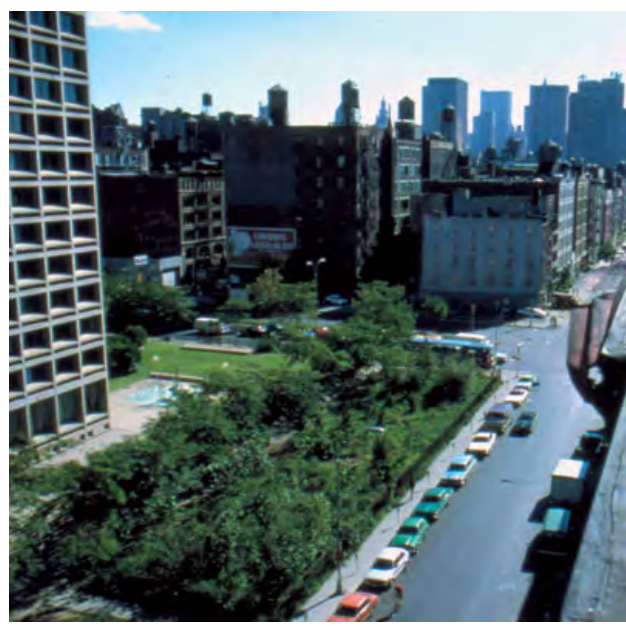

Em 1969, o artista iniciou a negociação para implantar a obra junto ao Metropolitan Museum of Art e órgãos do governo; a permissão e a abertura ao público ocorreu em $1978^{54}$. As dimensões da obra, sua complexidade, divergência de interesses quanto à ocupação do terreno são responsáveis pelo longo período do projeto à execução. É um exemplo respeitável de implantação da arte, no qual a administração pública e cultural atuam em parceria. A obra traz à tona preocupações com a paisagem, com o uso do terreno (land) urbano e prioridades do urbanismo ${ }^{55}$.

${ }^{54}$ HALL, Carol. Environmental Artists: Sources and directions. In: SONFIST (org.), 1983, p. 55.

${ }^{55} \mathrm{O}$ artista negociou até com a comunidade vizinha, tentando convencê-los de que o parque (ou viveiro) poderia "Ihes desenvolver uma consciência estética do meio ambiente". Ver ROSENBERG, Time and Space Concepts in Environmental Art. In: SONFIST, 1983, p. 210. 


\section{implementação}

a arte se engaja na investigação científica e em questões ambientais e urbanas.
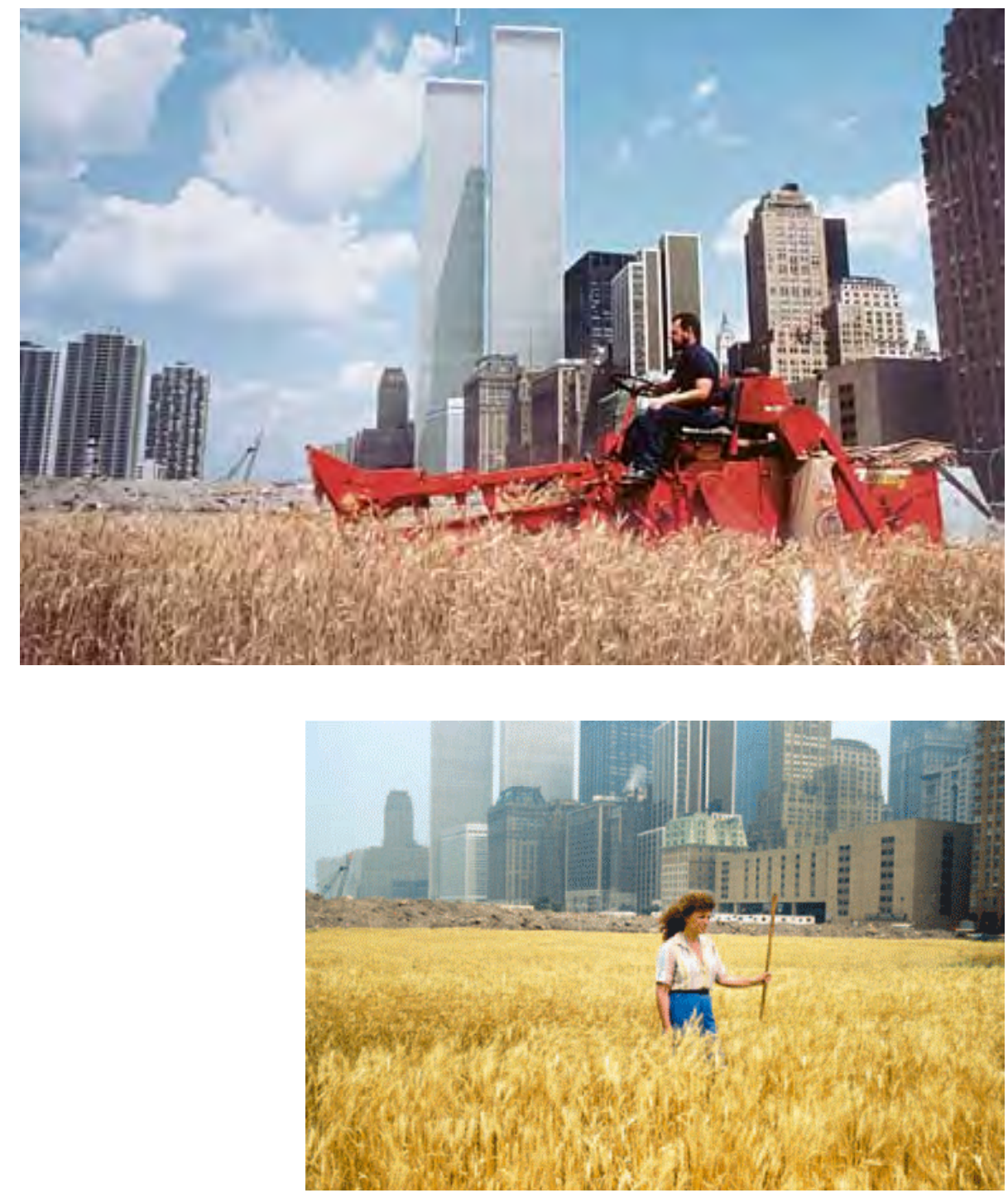

47. Agnes Denes. Wheatfield . Nova lorque. 1982.

(Fonte < http://weadartists.org/art-for-the-third-millennium>)

Denes expõe o "paradoxo de plantar trigo em uma área em que o terreno vale $\$ 4,5$ bilhões", chamando a atenção para valores sociais e para questões ecológicas. O trabalho participa da exposição "The International Art Show for the End of The World Hunger" organizada pelo Museu de Minnesota entre 1987-90. ${ }^{56}$

${ }^{56}$ KASTNER; WALLIS, 1998, p. 160. 
implementação

a arte se engaja na investigação científica e em questões ambientais e urbanas.
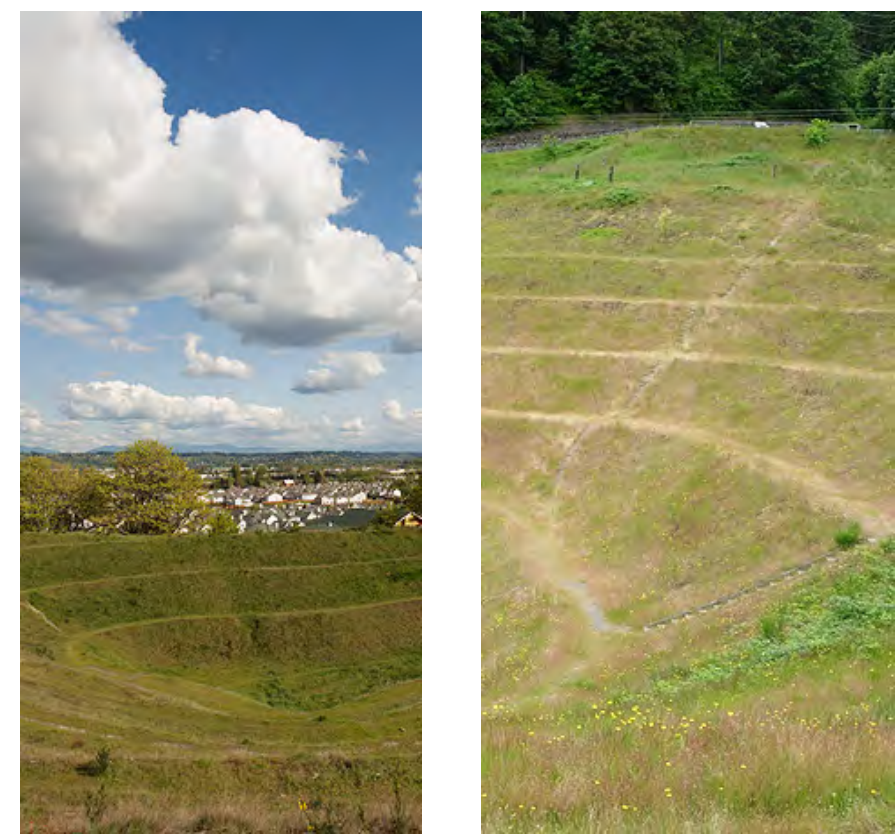

48. Robert Morris. Intervenção em King Country, recuperação de terras. 1979. A obra foi realizada junto com um simpósio apresentado pelo artista, "Earthworks: Land Reclamation as Sculpture".

(Fonte : <http://www.4culture.org/publicart/collection/profile.aspx?projectid=36\&cat1=Collection \&cat 2=Built\&cat3 $=$ Earthwork \&cat $3 \mathrm{~b}=4>$ )

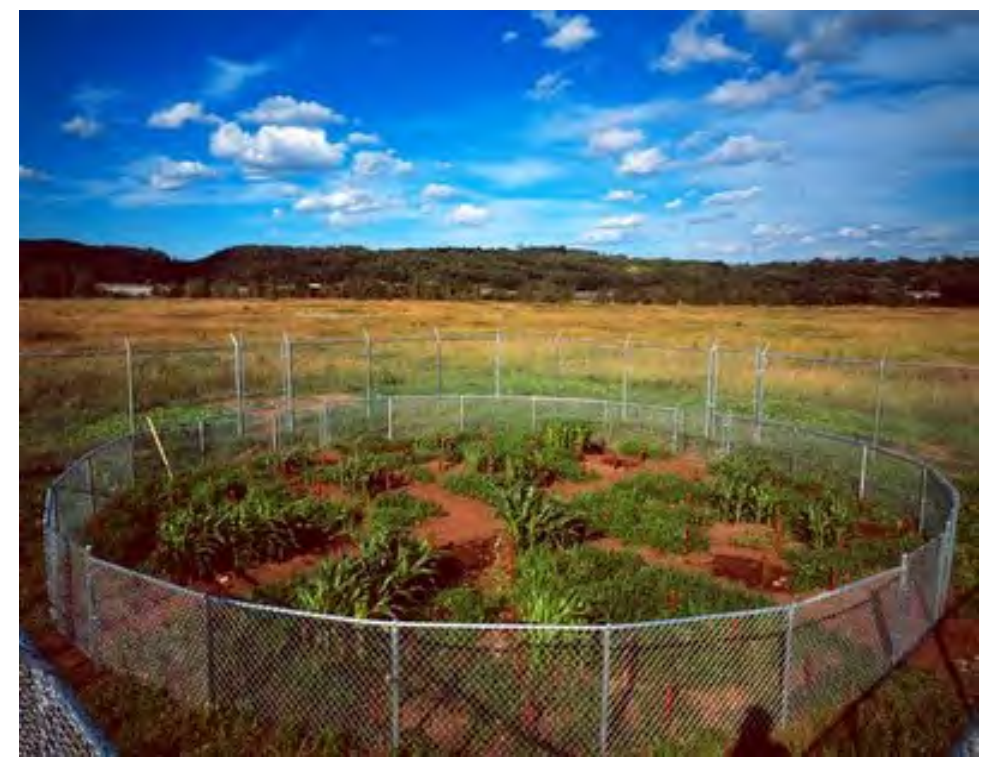

49. Mel Chin. Revival Fields. 1992-atual. St. Paul. Minnesota, EUA. Plantio para desintoxicar solo contaminado por metais. Início dos projetos em 1990, parceria com cientistas e suporte do National Endowment for the Arts.

(Fonte: <http://www.tumblr.com/tagged/mel\%20chin>) 


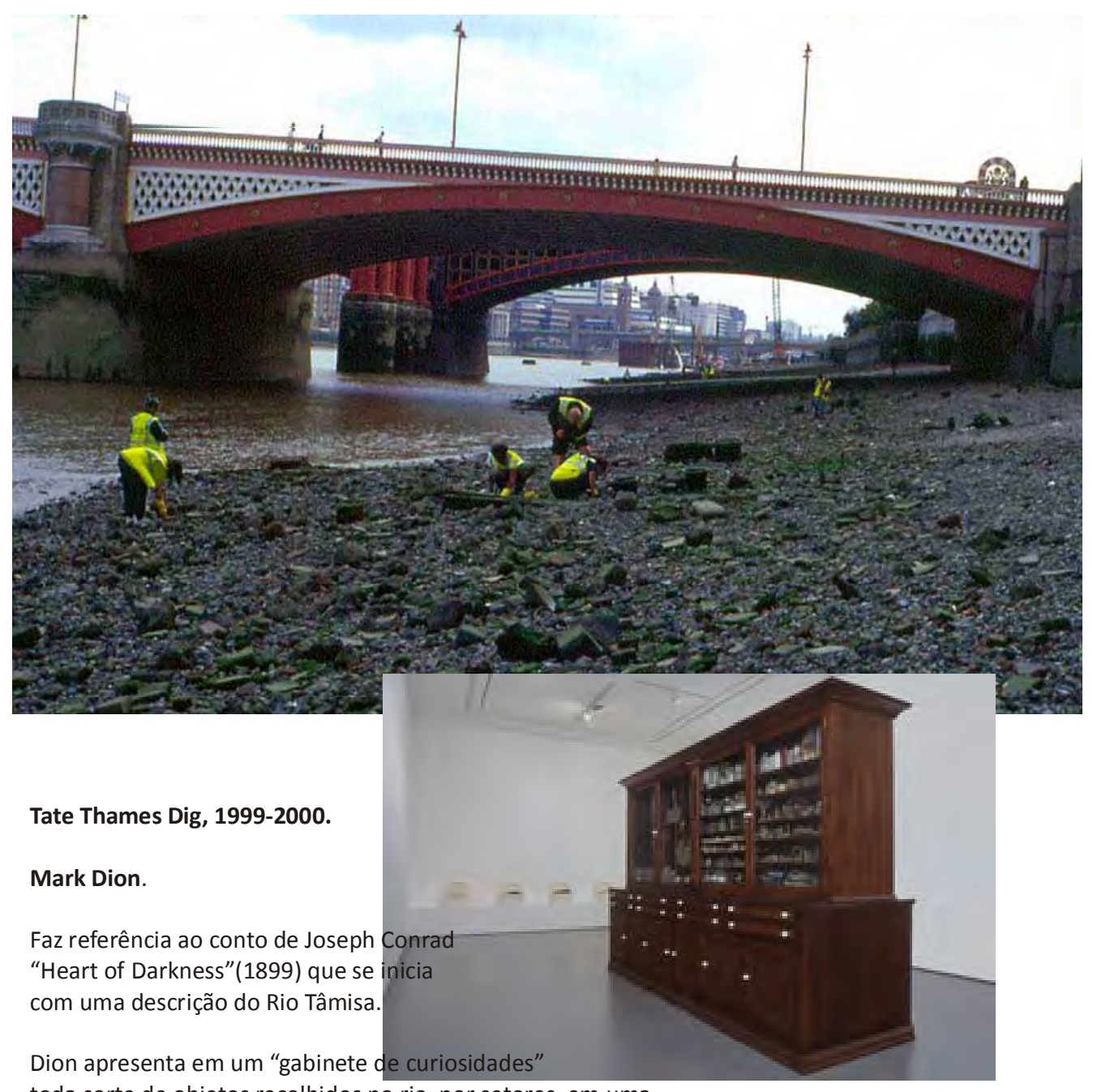

toda sorte de objetos recolhidos no rio, por setores, em uma arqueologia urbana.

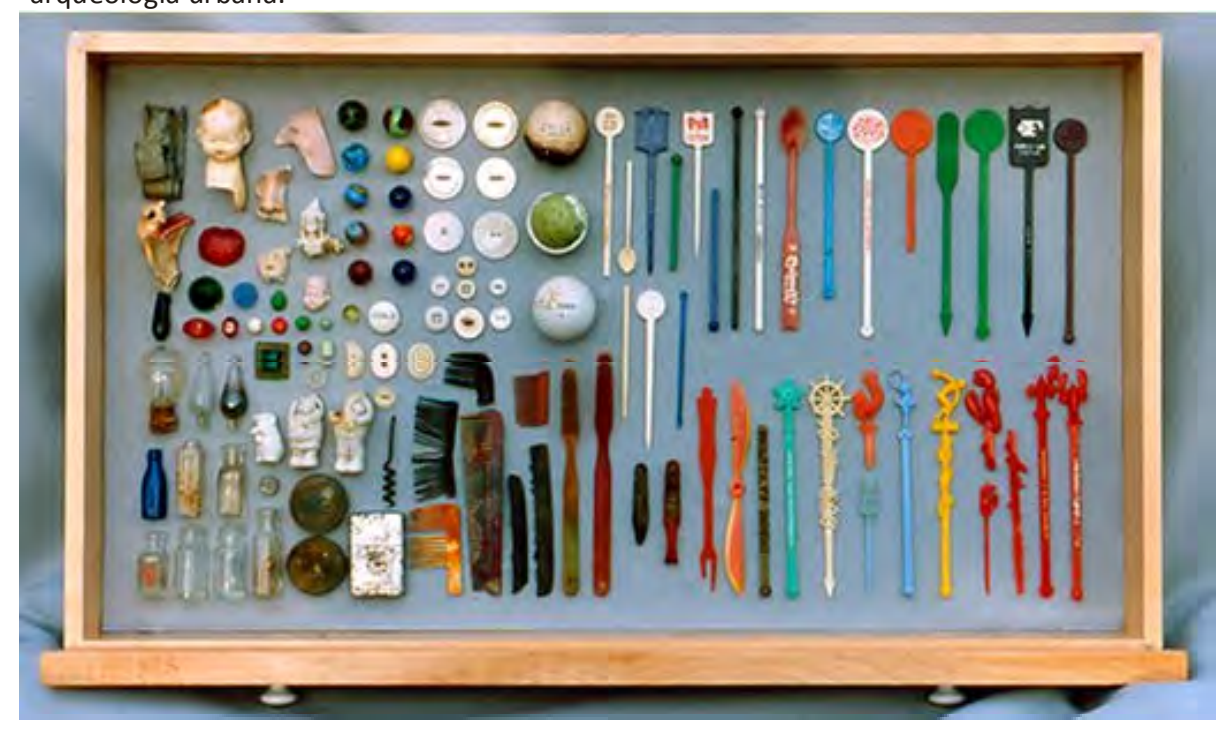

50. Mark Dion. Thames Dig, Londres. 1999-2000. 


\section{implementação}

a arte se engaja em investigação científica e em questões ambientais e urbanas.
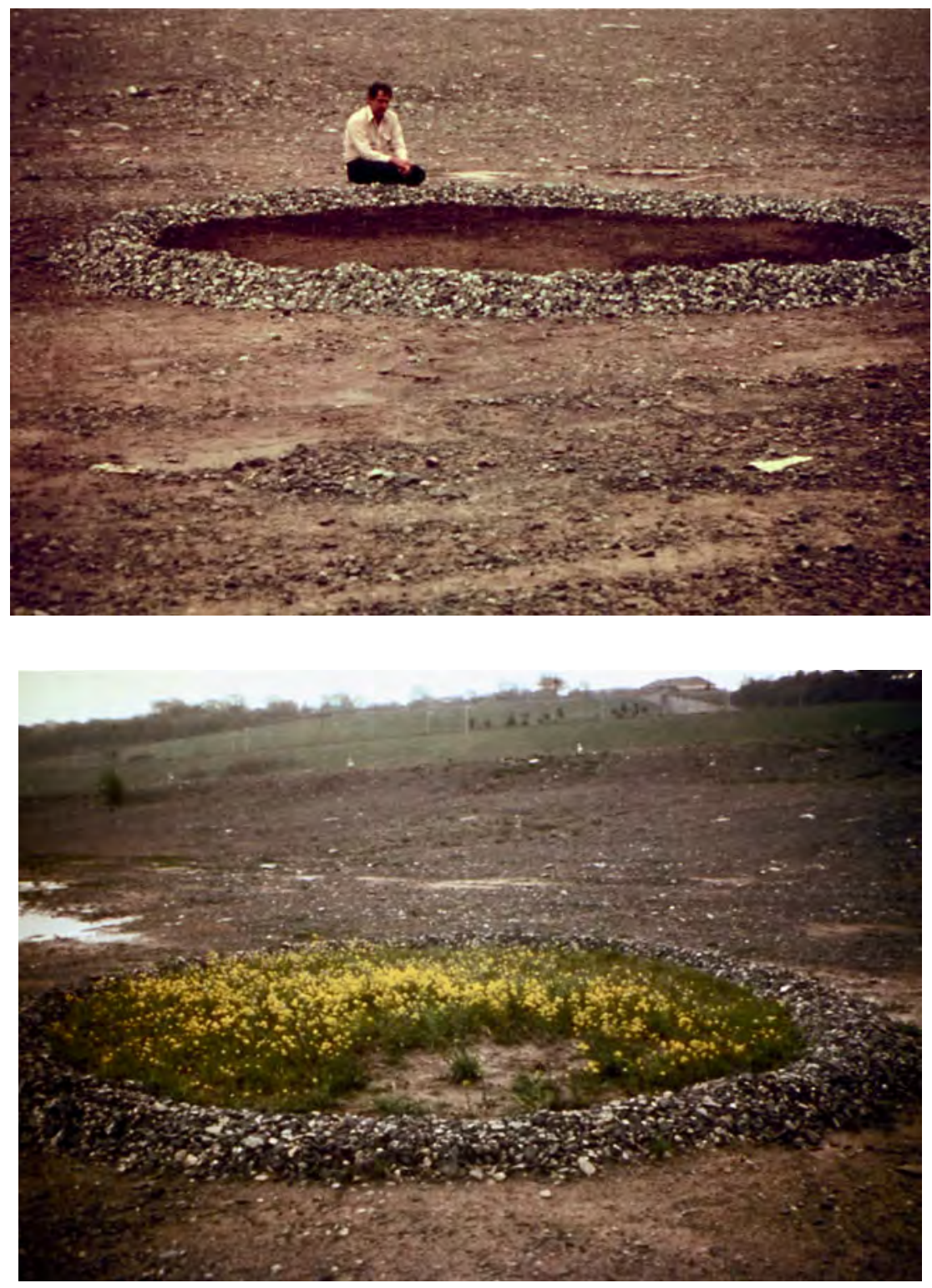

51. Alan Sonfist. Pool of Virgin Earth, 1975. Artpark, Lewiston, NY. (Fonte imagem: KASTNER; WALLIS, 1998)

Em um aterro químico, o artista delimita uma terra boa para o plantio e que recebe sementes vindas com o vento.

Vide como exemplos de Implementação:

Águas do Reno. Plantas de Purificação (1972), de Hans Haacke; Broken Circle e Spiral Hill (1971) de Robert Smithson. 


\section{imaginação}

A paisagem aparece mais em elaborações linguísticas, mentais ou numa construção ótica.

52. Jan Dibbets. Perspective Correction (Square with two diagonals), 1968.
53. Mark Dion. A metre of Jungle, 1992 (detalhe). Para a ECO 92, Rio de Janeiro.

Durante a ECO 92, RJ, Dion transporta um metro quadrado do solo da floresta amazônica, de Belém, PA, para a galeria no Rio de Janeiro.

(Fonte imagem: < http://www.genetologischonderzoek.nl/index.php/598/beeldend e-kunst/>)
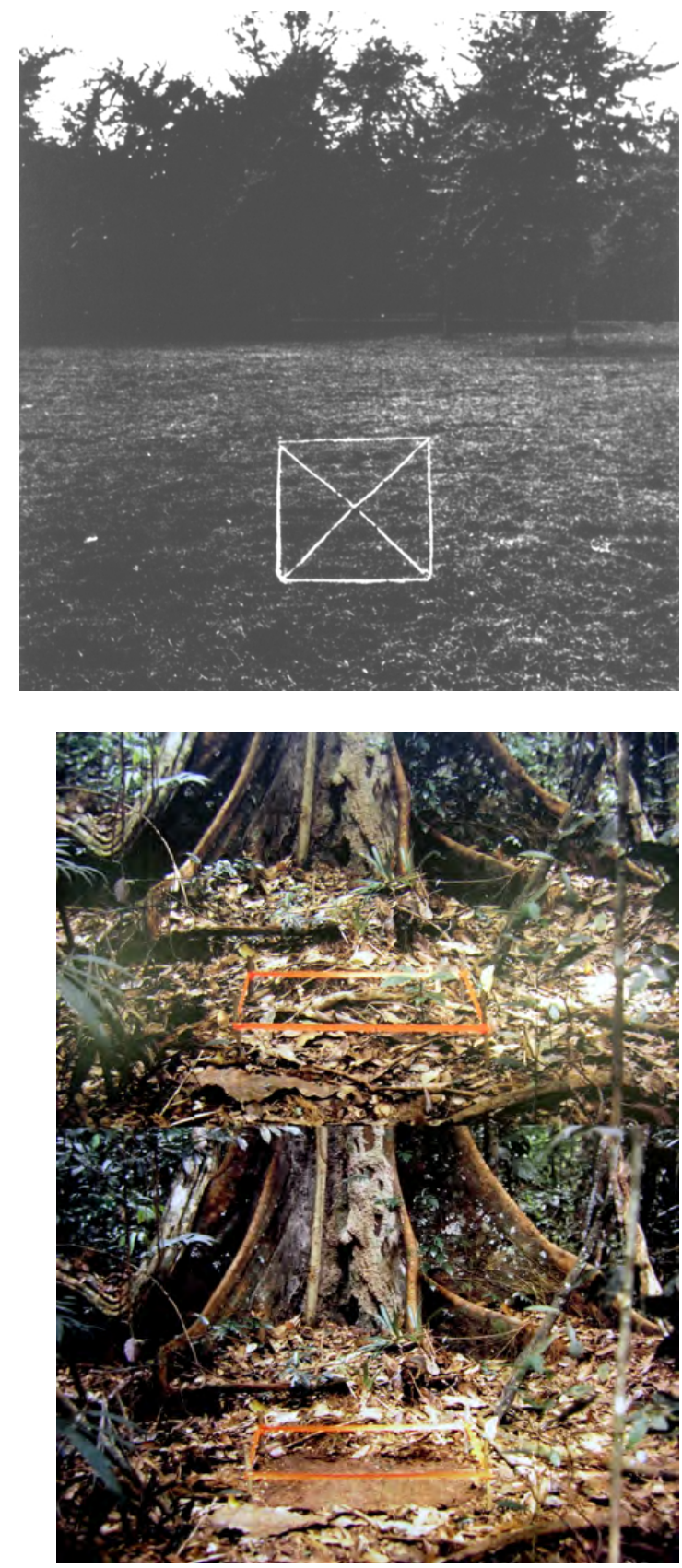

Utilizando métodos científicos, ele expõe a micro fauna e flora classificando-os, expondo o conhecimento humano sobre o meio. ${ }^{57}$

\footnotetext{
${ }^{57}$ KASTNER; WALLIS, 1998, p. 189.
} 


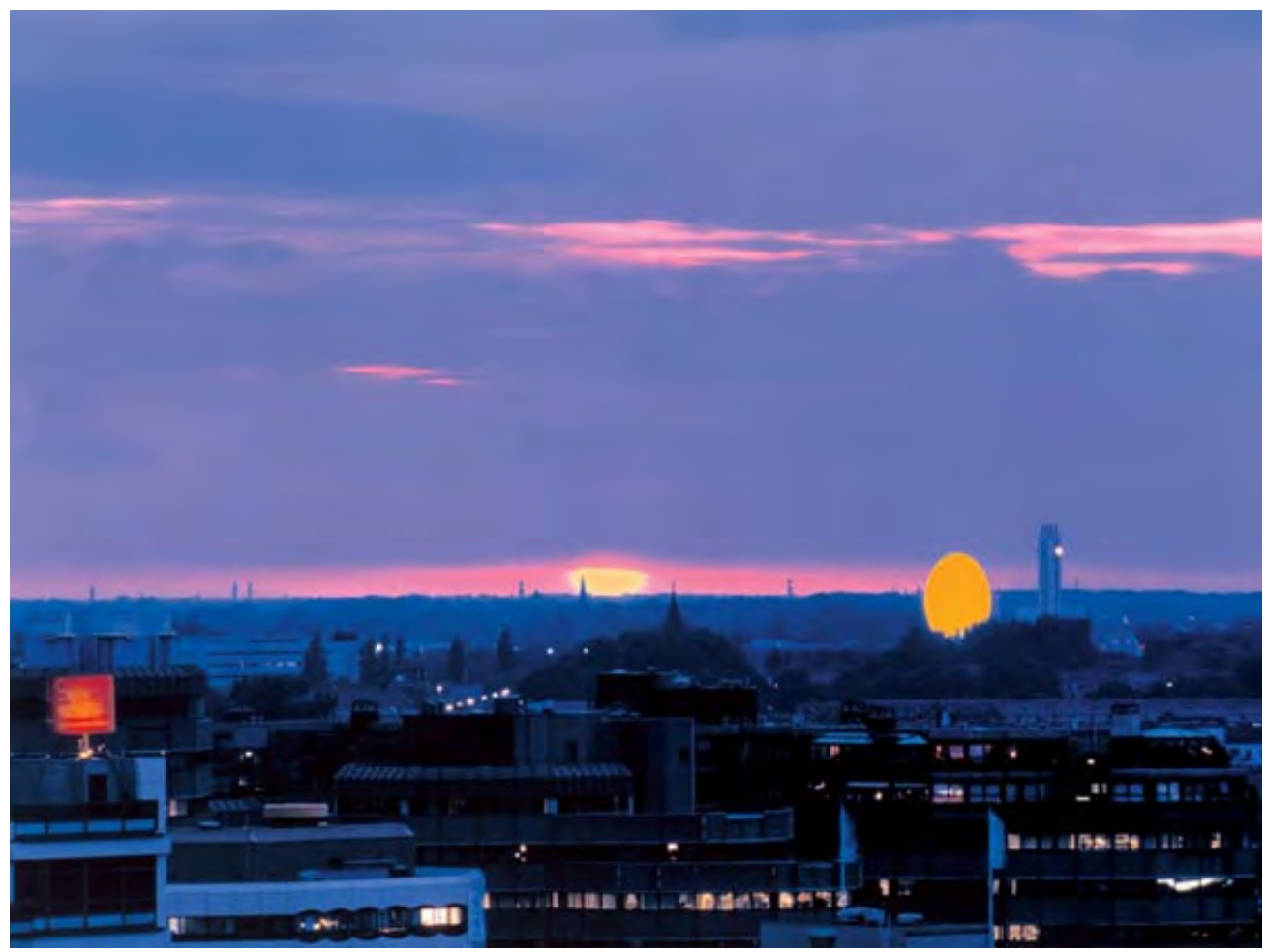

54. Olafur Eliasson, Double Sunset, 2000. Utrecht, Holanda.Aço, lâmpadas sobre andaimes.

(Fonte: <http://www.eikongraphia.com/?p=1311>)

Vimos um amplo arco de atuação da arte contemporânea da paisagem e os modos de compreendê-la, seja a partir da forma ou do resultado da interação, seja pelo processo ou pela gestualidade do artista. Dois artistas apresentam produções que ilustram bem este amplo leque de como a arte intervém, critica, transforma e incorpora a paisagem: Robert Smithson (1938-1973) e Richard Long (1945). Smithson trabalhou com paisagens degradadas e em transformação, paisagens ainda não artializadas -, assim como com aquelas simbólicas, de caráter identitário nacional. Richard Long, em contrapartida, trabalha com paisagens já sedimentadas no nosso imaginário, há muito artializadas in visu ou in situ. Vamos, então, observar algumas obras destes artistas, analisando as diferenças entre estas, que advêm das especificidades da produção da paisagem.

Sobre estas diferentes formas de as obras se relacionarem com a paisagem, Weilacher ${ }^{58}$, a partir da definição de Beardsley - de que a Land Art é a ação direta na

58 WEILACHER, Udo. Between Landscape Architecture and Land Art. Basel, Berlin, Boston: Birkhaüser, 1999, p. 23. 
paisagem - aponta a diferença de liberdade de ação entre artistas norte-americanos e europeus. Enquanto os pioneiros americanos da Land Art desbravam novos territórios e buscam o meio natural ainda intocado, os artistas da paisagem na Europa dialogam com suas "paisagens densamente povoadas e estruturadas culturalmente".

A fragmentação da paisagem, o caráter do ambiente culturalmente construído e a incorporação do paisagismo (landscape design) nos processos do dia-a-dia da sociedade produziram trabalhos em uma escala claramente menor e restringiram a liberdade de ação. (WEILACHER, 1999, p. 23).

Segundo Weilacher, tais paisagens, com seus conteúdos históricos, simbólicos e físicos, influenciam os processos de trabalho dos artistas e, por conseguinte, a realização das obras, resultando na heterogeneidade da arte contemporânea da paisagem. O que vemos em quaisquer destes contextos é, sobretudo, a interferência do artista na paisagem em uma ação intimamente ligada aos aspectos locais e aos processos de percepção da mesma.

A importância do conteúdo cultural e histórico da paisagem é evidenciada na declaração de Smithson que, participando da exposição Sonsbeek (1971), na Holanda, solicita um terreno não ocupado ou subaproveitado, pois, naquele país, "inserir um trabalho de arte em uma paisagem cultivada (desenvolvida) seria supérfluo" ${ }^{\text {"59. }}$.

Beardsley, investigando os antecedentes que fizeram florescer a Land Art nos EUA e na Inglaterra, encontra algumas explicações que vão além dos contornos da arte. O autor aponta, como influência direta dos artistas ingleses contemporâneos, a tradição de veneração à paisagem que se manifesta na pintura, literatura e jardinagem. Acrescenta ainda que o poeta William Wordsworthy ${ }^{60}$ seria o antecedente mais direto da sensibilidade contemporânea inglesa em relação à paisagem. Esta sensibilidade romântica também estaria presente nas obras americanas, contudo, os ingleses iriam manifestá-la de maneira menos "heroica" ou intervencionista.

Ligar-se à natureza sempre foi uma inclinação recorrente na arte, seja considerando-a fonte de inspiração e modelo para mimesis, seja buscando repetir na arte a experiência estética que se tem em sua apreciação. A partir da segunda metade do século XX, a natureza artificializada, degradada e menos idealizada continua a influenciar os artistas, mas,

\footnotetext{
59 "Feeling that the Dutch landscape was already very cultivated and that a work of art upon it would be superfluous, he asked to work at a disrupted site instead." Ver BEARDSLEY, 1998, p. 22.

${ }^{60}$ Beardsley cita o fato de o poeta romântico, que cantava a natureza e a paisagem, William Wordsworthy (1770-1850) vaguear pela paisagem de Lake District como forma de meditação e reflexão para compor. Ibidem, p. 41. 
sobretudo, impulsiona-os para novas atitudes, como a transformação em lugar da representação. Smithson não polariza natureza e cidade ${ }^{61}$, além de trazer para o campo das artes plásticas a paisagem pós-industrial. Para ele, a arte poderia incentivar a recuperação de terrenos degradados ou de áreas à margem da urbanização.

Smithson fala-nos de paisagens as quais habitamos mas também evitamos observar. Ele pensa o futuro das paisagens, projeta e constrói. Richard Long nos fala daquelas que, na maioria das vezes, não conhecemos, mas que "reconhecemos", pois habitam nosso imaginário de paisagens longínquas. $\mathrm{O}$ artista mostra-nos o quão potente são nosso olhar e memória na construção da paisagem.

\section{- Da reação crítica à aplicação funcionalista na arte da paisagem de Smithson.}

A arte de Robert Smithson inclui textos que refletem sobre sua obra, sobre a condição da arte de sua época, bem como sobre a paisagem. "Um passeio pelos Monumentos de Passaic" ${ }^{\text {62 }}$ é um destes textos, considerado um marco para o pensamento sobre a condição, ou a possibilidade, da arte em paisagens tecnocratas. Nele, Smithson descreve, de maneira crítica, uma sucessão de não-lugares, lugares insípidos ${ }^{63}$ e vazios de uma periferia de cidade industrial. A paisagem desta cidade apresenta, nas palavras do artista, "ruínas ao reverso [...] Isto é, o contrário da 'ruína romântica', porque os edifícios não caem em ruínas depois de haverem sido construídos, mas crescem até a ruína conforme são construídos”. (grifos do autor)

Passaic é, para Smithson, uma paisagem em transição e é com este trabalho que, pela primeira vez, uma paisagem não pitoresca e real é trazida para os campos da arte, sendo local para ação e reflexão.

\footnotetext{
${ }^{61}$ Smithson via as intervenções humanas na paisagem tão "naturais quanto um terremoto" e reconhecia nas atividades industriais uma necessidade de vida desenvolvida por nós mesmos. Ibidem, p. 23.

62 SMITHSON, Robert. A Tour of the Monuments of Passaic.Revista Artforum, dez. 1967. Ver FARIAS, Agnaldo. Apresentação, em Revista Espaço \& Debates, v. 23, p. 43-44 e 120-128, jan/dez. 2003.

63 LEITE, Maria Angela Faggin Pereira. As Tramas da Segregação: Privatização do Espaço Público. Tese de Livre-Docência FAU-USP, São Paulo, 1998, p. 56. "[...] são os lugares que qualificam a paisagem, isto é, que conferem por meio de processos simbólicos, um significado exclusivo aos elementos que as compõem". Passaic seria o avesso deste lugar significativo e, portanto, uma paisagem de exclusão, de não identidade ou reconhecimento.
} 

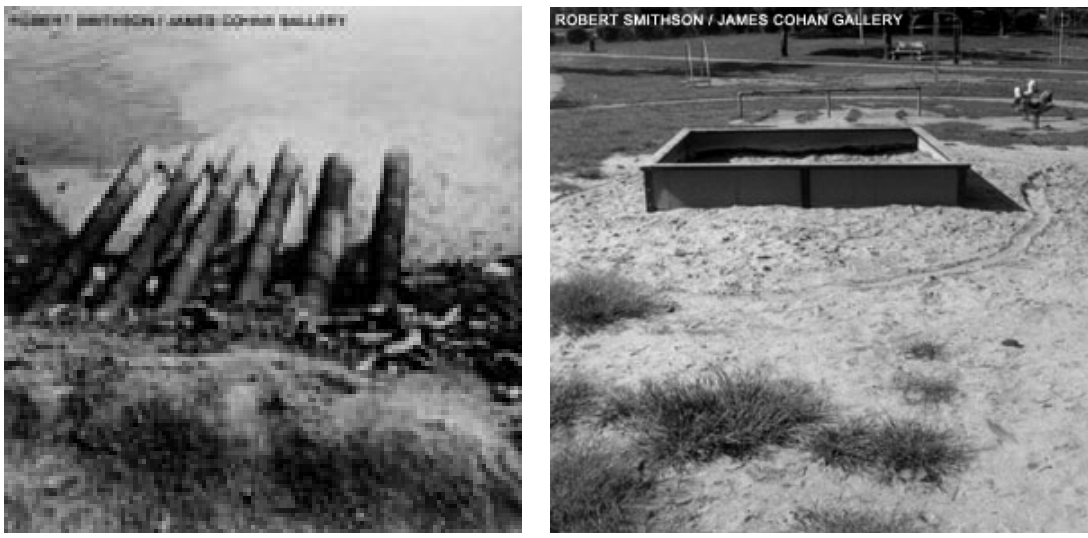

55. Robert Smithson, (acima) The fountain monument e The sand-box monument (também chamado de deserto)

(Fonte imagem: <Http//www.robertsmithson.com)
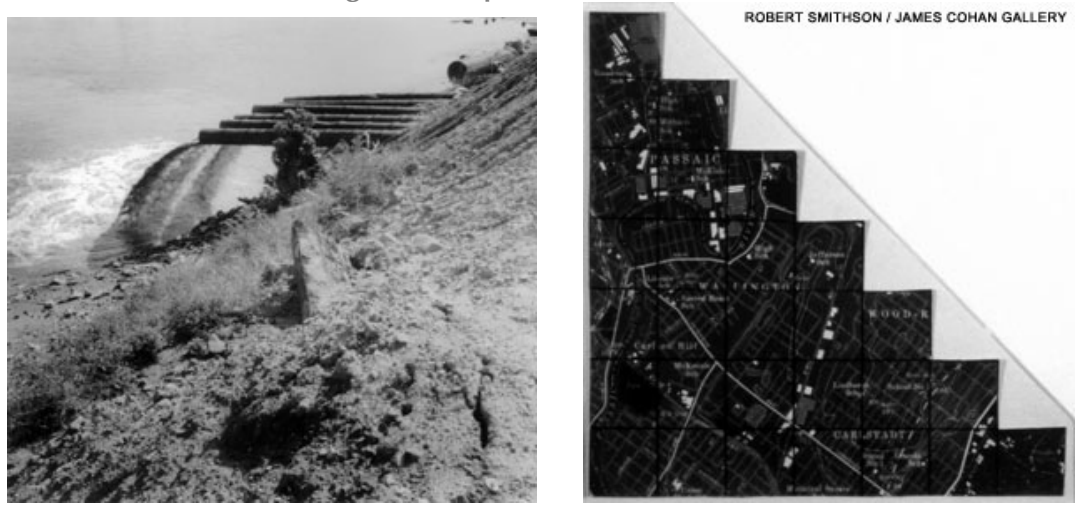

(55). Monumentos de Passaic, 1967.

New Jersey ${ }^{64}$ representa a paisagem pós-industrial, com sua beleza quase impossível e com a crueza de uma realidade sem História, "porque os subúrbios não têm História”. Em Um Passeio pelos Monumentos de Passaic, acompanhamos Smithson transitar por uma grande obra rodoviária ao longo do Rio Passaic, por terrenos baldios e arquiteturas desumanizadas, como extensos estacionamentos e conjuntos habitacionais. Ele diz: "este subúrbio sem imaginação, poderia haver sido uma eternidade desajeitada". Sob um sol ofuscante e diante de tratores e escavadeiras parados em dia de folga, ele desacredita o futuro e o progresso construídos daquela maneira. Expõe-nos ao absurdo da paisagem tecnocrata: quais seriam seus monumentos, o que imortalizaria esta cidade? Ele reflete, principalmente, como ou qual tipo de arte poderia ali se integrar.

\footnotetext{
${ }^{64}$ New Jersey, cidade natal de Robert Smithson foi um pólo de indústrias têxteis no século XX e, no século XIX, de indústrias de mineração. O boom do crescimento dos subúrbios ocorreu na década de 1950. Smithson refere-se, em "Um passeio pelos Monumentos de Passaic" (1967), às residências dos subúrbios e à falta de centros de um lugar à margem da História. Passaic é um dos principais rios que cortam a cidade e nomeia um bairro.
} 
O artista, no embate para ali reconhecer uma paisagem ${ }^{65}$, assume um olhar estrangeiro - como se fosse um turista - e descreve-a em um misto de desilusão e encantamento, como quem não compreende de fato, mas apenas vê. Faz lembrar Goethe que, em viagem, descreve as paisagens italianas "com um olhar intencional" ${ }^{66}$ de artista, sentindo-se "em casa" em uma paisagem estrangeira reconhecida através da pintura de Claude Lorrain. Smithson, no entanto, em profundo questionamento sobre o futuro da arte pública e daquela paisagem, descreve-a longe da esperança "de uma reconciliação com a natureza" 67 . Em um lugar onde não há pertencimento, o artista mostra-nos "os monumentos" de um pensamento tecnológico: canos de esgoto, guindastes, uma ponte ou o próprio canteiro de obras, expondo "a desagregação da cidade contemporânea, as chagas abertas por um crescimento descontrolado, feito à revelia da paisagem."

Em Passaic, como em outras paisagens do artista, o limite entre o natural e as áreas urbanizadas ou em processo de urbanização é dissolvido. A natureza está em contínuo processo de transformação pela industrialização e pela urbanização e também as inclui.

Temos que desenvolver um diferente senso de natureza; temos que desenvolver uma dialética de natureza que inclui o homem... Um tipo de beleza "virgem" foi estabelecido em um tempo remoto deste país e a maioria das pessoas que não olham com atenção tendem a enxergar o mundo através de cartões-postais e calendários o que afeta suas ideias de como a natureza deveria ser ao invés de como é. ${ }^{99}$

Acho que todos nós vemos a paisagem como sendo coexistente à galeria. Não acho que estamos lidando com o assunto em termos de um movimento de volta à natureza (back to nature movement). Para mim, o mundo é um museu. ${ }^{70}$

Segundo Flam (1996) ${ }^{71}$ é a partir das excursões por New Jersey e seus arredores que Smithson começou a fazer, por volta de 1966, que surge nele a consciência da paisagem pósindustrial. Daí emergiriam seus trabalhos de Nonsites, que consistem em estratos do solo,

${ }^{65}$ Veremos este mesmo embate, reflexão e esforço para delimitar e reconhecer a paisagem, em alguns dos artistas de Fronteiras e Margem.

${ }^{66}$ BESSE, 2006, p. 48.

67 Ibidem, p. 52.

${ }^{68}$ FARIAS, Agnaldo. Robert Smithson: o artista como viajante. Revista Espaço e Debates, São Paulo, v. 23, jan/dez, p 120-128, 2003.

${ }^{69}$ SMITHSON, Robert. 1972 apud FLAM, 1996, p. 298.

70 SMITHSON, Robert. Discussões com Heizer, Oppenheim, Smithson (1970). In: FERREIRA; COTRIM, 2006, p. 208.

${ }^{71}$ FLAM, Jack. Robert Smithson: The Collected Writtings. Univesity of California Press, 1996. 
minérios, coordenadas geográficas, fotografias do terreno, por vezes texto e referem-se a um lugar, site. Todavia, não dão conta de representá-lo e por isso Smithson trata-os como "lugares de uma ausência". $O$ artista trabalhou as ambiguidades entre interior e exterior, o natural e seu análogo ${ }^{72}$, o lugar e a ausência, equiparando estas dualidades de significante e significado.

Smithson estava convencido de que a arte não poderia mais estar contida nas categorias clássicas da arte - escultura, pintura e arquitetura -, assim como não se limitaria apenas ao interior do museu ou galeria, e, menos ainda, ao processo recluso de ateliê. A arte, ainda que fosse escultura, não deveria apenas se inserir na paisagem, mas pertencer à ela, seja fisicamente, seja em sua realidade social. "Os artistas mais convincentes hoje em dia se preocupam com 'lugar' [place] ou 'site': Smith, De Maria, Heizer, Oppenheim, Huebler - para citar alguns poucos." 73

Se o lugar é significativo para a arte da paisagem, assim também ele considera a matéria: ela é, antes de tudo, um indício de ideologia. Um artista, segundo Smithson, não deveria deixar-se seduzir por técnicas, materiais ou procedimentos que reforçam as ideologias tecnocratas. Tal pensamento já indicava a essência de sua pesquisa: o conceito entropia ${ }^{74}$ uma convergência de tempo e matéria -, que representa o avesso do pensamento tecnológico. Os processos entrópicos são agentes nas obras de Smithson, em específico em seus trabalhos de terra (earthworks). "Aço moldado e alumínio fundido são manufaturados a máquina, e o resultado é que carregam o selo da ideologia tecnológica. O aço é um material duro e inflexível, indicando a permanência dos valores tecnológicos". 75

\footnotetext{
56. Robert Smithson. Asphalt Rundown, 1969. Roma. Documentado em filme e croqui.

(Fonte imagem: < http://hettingern.peop le.cofc.edu/Aesthetic s_Fall_2010/Index.ht $\mathrm{m}>$ )
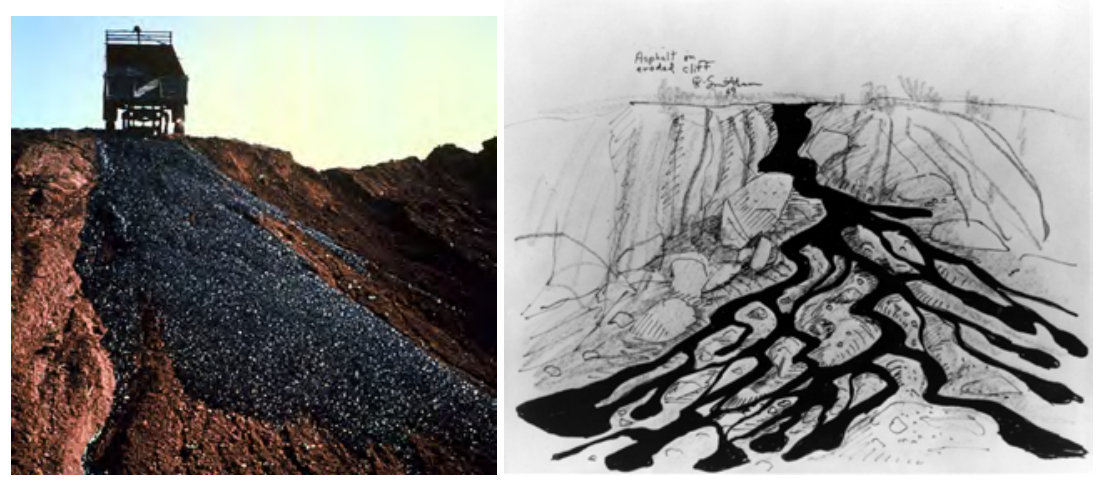

72 Ibidem, p. 129.

${ }^{73}$ SMITHSON, Robert. Uma sedimentação da mente: projetos de terra. 1968 In: FERREIRA; COTRIM, 2006, p. 187.

${ }^{74}$ A primeira vez que Smithson apresenta o conceito de entropia relacionado à arte e à arquitetura é com o texto Entropy and the new monuments (1966).

${ }^{75}$ SMITHSON, Robert. Uma sedimentação da mente: projetos de terra. 1968 In: FERREIRA; COTRIM, 2006, p. 187. 
(26). Robert Smithson. Spiral Jetty, 1970.

(Foto em 2003)

Depois das cheias do lago salino, os cristais de sal aderiram às rochas de basalto.

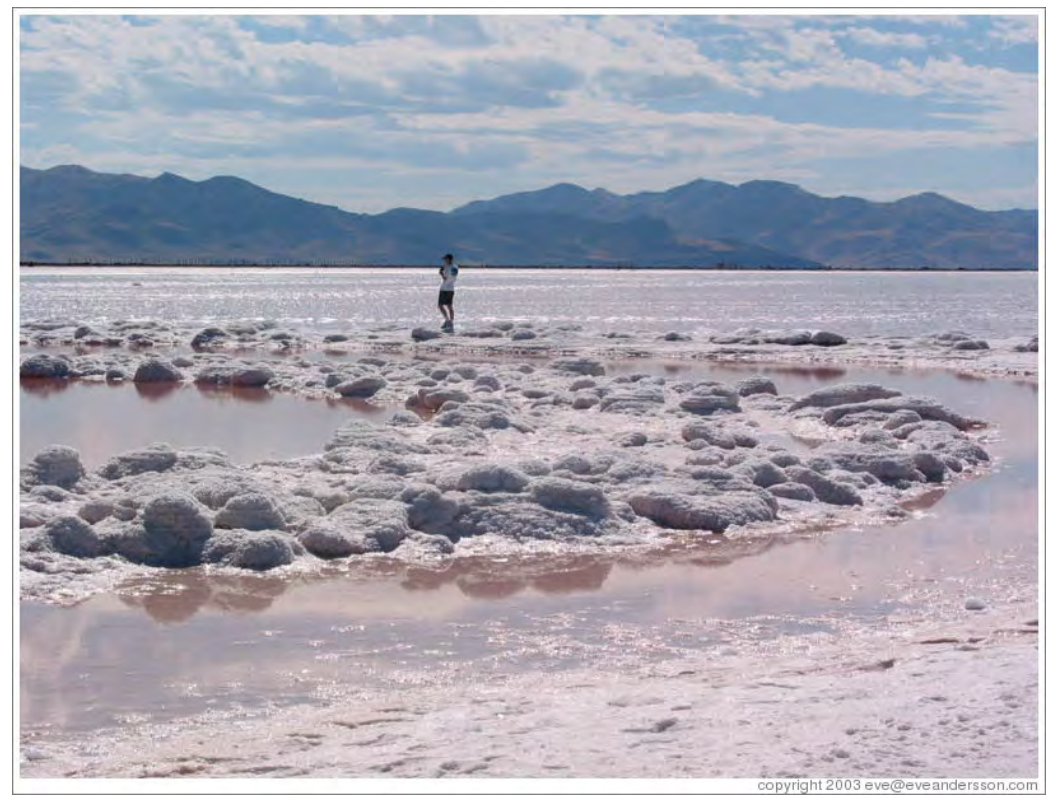

O trabalho foi modificando-se pelo ambiente, refletindo o interesse de Smithson pela entropia - a inevitável transformação pelas forças da natureza [...] é um profundo testemunho da dominação do homem na paisagem. (KASTNER; WALLIS, 1998, p. 58)

Em abril de 1970, Smithson inicia a construção da Spiral Jetty, que se tornaria um ícone da Land Art, em parte graças à fotografia de Gianfranco Gorgoni ${ }^{76}$. O artista buscava, a princípio, um lugar com águas vermelhas e, ao saber que o lago salino de Utah continha micro bactérias para a extração de sal que o coloriam de vermelho, decide conhecer o lugar ${ }^{77}$. Sem um projeto a priori, são as condicionantes físicas e históricas - o mito do lugar ${ }^{78}$ - que levaram o artista para a forma espiral.

Contemplando o local, ele reverbera para os horizontes sugerindo um ciclone imóvel, enquanto a luz bruxuleante fazia com que a paisagem inteira parecesse sacudir. Um terremoto dormente propagava-se por uma imensa circularidade. Desse espaço giratório surgiu a possibilidade do Quebra-mar espiral. ${ }^{79}$

${ }^{76}$ A obra esteve quase vinte anos submersa, além de ter um acesso difícil via estrada, o que Ihe confere ainda mais um espírito mítico.

77 TUFNELL, 2006, p. 41.

${ }^{78}$ Smithson “incorpora a existência do mito local na obra. Ao dizer 'ciclone imóvel' e 'espaço giratório', o artista referia-se à mitologia dos antigos colonos que acreditavam existir um canal subterrâneo ligando o lago salgado ao Oceano Pacífico e capaz de formar perigosos redemoinhos no centro do lago". Ver KRAUSS, 2007, p. 341.

${ }^{79}$ SMITHSON, Robert. “O quebra-mar espiral”, manuscrito não publicado apud KRAUSS, 2007, p. 336. 
Os earthworks Spiral Hill e Broken Circle (1971) foram construídos, a princípio, por tempo determinado, em uma pedreira de areia (sand quarry) desativada, na cidade de Emmen, Holanda, por ocasião de exposição internacional Sonsbeek Park ${ }^{80}$. Este díptico assinala o princípio de uma nova etapa de sua obra: projetos para terrenos urbanos subaproveitados, terrenos-depósito de refugos da mineração ou degradados pela industrialização, intentando unir a arte à indústria, a fim de reverter ou minimizar seus impactos. Estes projetos, Tailing Projects, são desenvolvidos pelo artista entre 1971 e 1973, período em que ele reconsidera o potencial social da Land Art ${ }^{81}$.

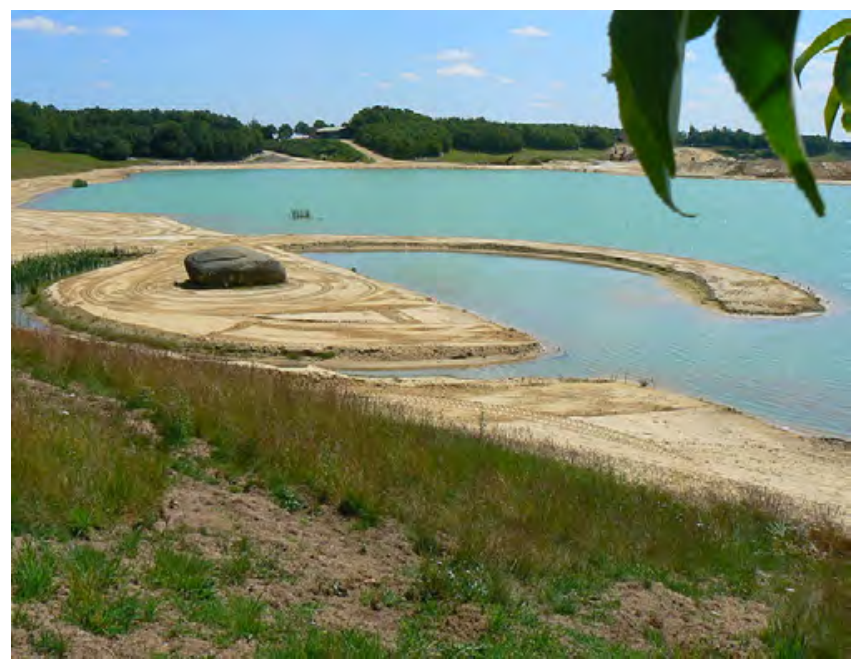

57. Robert Smithson. Broken Circle, 1971. Emmen, Holanda. Areia branca, amarela, argila, terra, água de coloração esverdeada existente do açude e um grande seixo encontrado durante a terraplenagem do trabalho.

(Fonte: < http://www.terminartors.com/artworkprofile/Smithson_Robert-Broken_Circle_and_Spiral_Hill>)

Beardsley (1998) aponta que a experiência na Holanda marca o empenho e a tentativa do artista em recuperar, através da arte, a paisagem devastada pela industrialização,sendo que estas propostas para revitalização de terrenos formam o seu legado mais importante, o qual inspirou e influenciou gerações posteriores de artistas.

\footnotetext{
${ }^{80}$ Sonsbeek Park 1971 foi uma exposição promovida pela Holanda que comissionou trabalhos site-specific a artistas americanos, europeus e japoneses, fomentando a arte ligada às questões da paisagem. Participaram dela Robert Morris, Richard Long, Jan Dibbets, Michael Heizer, Oppenheim, entre outros diretamente envolvidos com a Land Art. O terreno onde trabalhou Smithson estava destinado a uma área de recreação, mas a população pediu que as obras fossem mantidas, o que para o artista foi "gratificante". A partir disto, Smithson vislumbra a amplitude que a arte poderia assumir, ao se relacionar com a paisagem. $O$ que fundamenta uma obra esteticamente e conceitualmente poderia ser compatível com uma função social ou urbana. (Ver FLAM, 1996).
}

81 TUFNELL, 2006, p. 45. 

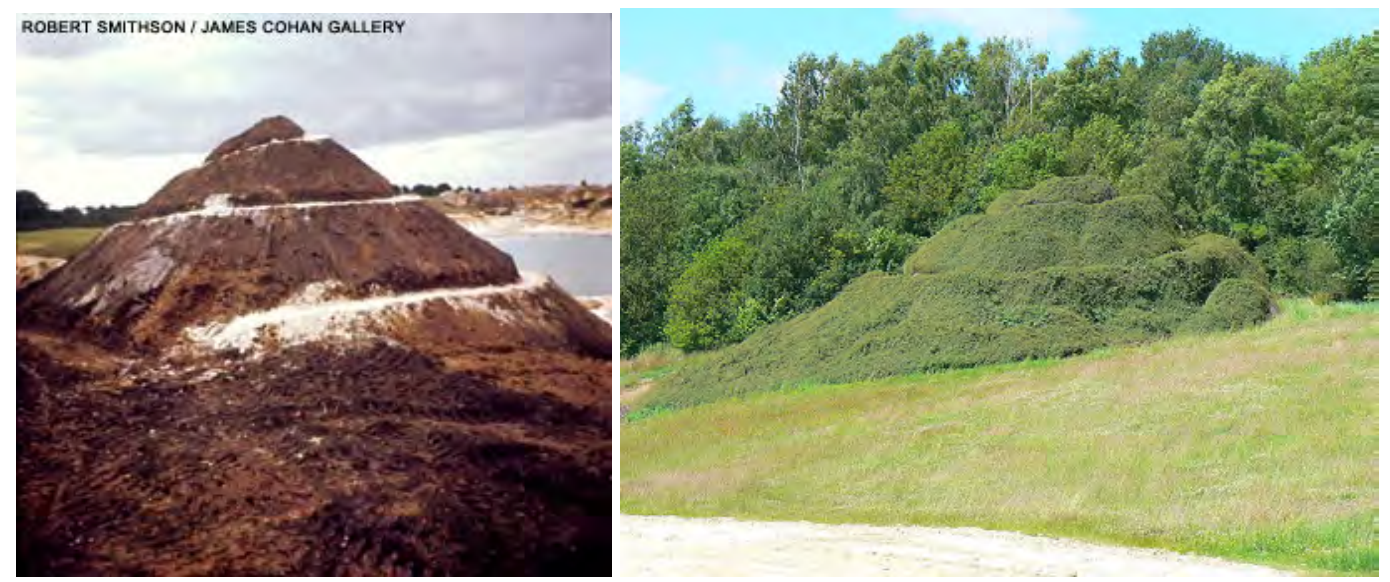

58. Robert Smithson. Spiral Hill em fotografia dos anos 1970 e em 2000.

59. O díptico Spiral Hill e Broken Circle, em projeto do artista.

(Fonte: http://www.robertsmithson.com

/drawings/spiral_hill_broken_circle_800.htm>)

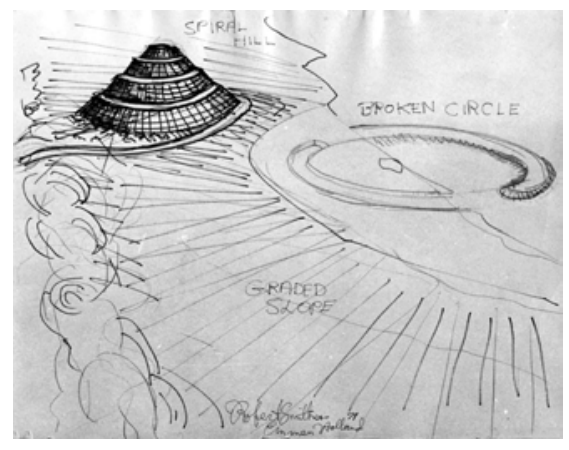

De 1970 a 1973, Smithson publicou artigos sobre Arte e Recuperação de Terras e apresenta seus projetos às Companhias de Mineração, oferecendo seu trabalho para "realçar visualmente as atividades de recuperação de terras da empresa" 82 ou "adicionar um foco visual ao lugar e chamar a atenção para o entorno em processo de recuperação (revitalização)" ${ }^{\text {" } 33}$. Chega a negociar com duas companhias, mas estas não dão continuidade ao processo, frustrando Smithson e levando-o a retornar às esculturas de terra em grande escala ao ar livre, aos earthworks. Sua obra seguinte, e última, foi Amarillo Ramp (1973), no leito seco do lago chamado Amarillo, em uma fazenda no Texas ${ }^{84}$.

82 Beardsley aponta que Smithson não tentou alterar as características industriais destes lugares, ao contrário, elas são brutalmente realistas e seriam como "testemunhos das rupturas na paisagem feitas pela industrialização", o que poderia alertar para uma política sobre recursos e paisagem. Ver BEARDSLEY, 1998, p. 23.

83 Ibidem, p. 23.

${ }^{84}$ A obra é finalizada pelos artistas Nancy Holt, sua esposa, e amigos Richard Serra e Tony Shafrazi, meses após a morte do artista em um acidente aéreo, junto ao piloto e fotógrafo, enquanto sobrevoavam o terreno para estudar a inserção deste earthwork. 


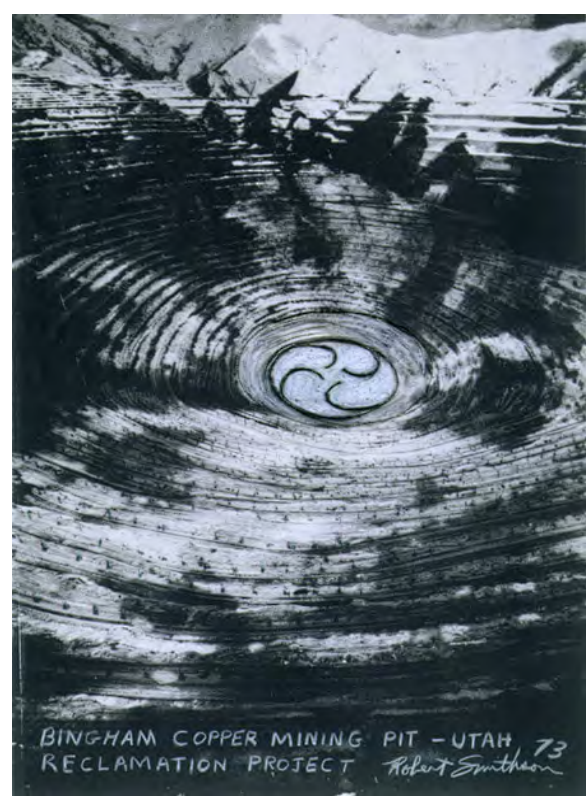

60. Robert Smithson, Bingham Copper Mining Pit_Utah / Reclamation Project, 1973. Foto em plástico e giz de cera $(47 \times 34.3 \mathrm{~cm})$

Across the country there are many mining areas, disused quarries and polluted lakes and rivers. One practical solution for the utilization of such devasted places should be land and water recycling in terms of "earth art".

A partir de seu legado, reforça-se a ideia de que a arte pode assumir diversas formas, ocupar toda a sorte de terrenos a serem transformados e utilizar-se de uma gama de matérias-primas que vai dos materiais naturais aos produtos industriais sub-aproveitados. $\mathrm{O}$ artista antevê um tempo em que indústria, arte e ecologia poderiam trabalhar em sinergia. Mesmo tendo uma breve trajetória, é uma fonte generosa em propósitos, que se tornam cada vez mais atuais, de Passaic à São Paulo.

Art can become a physical resource that mediates between the ecologist and the industrialist. Ecology and Industry are not one-way streets, rather they should be cross-roads. Art can help to provide the needed dialectic between them. ${ }^{86}$

\footnotetext{
${ }^{85}$ SMITHSON, Robert. Untitled. 1972. In: KASTNER; WALLIS, 1998, p. 251

${ }^{86}$ Ibidem, p.251. 

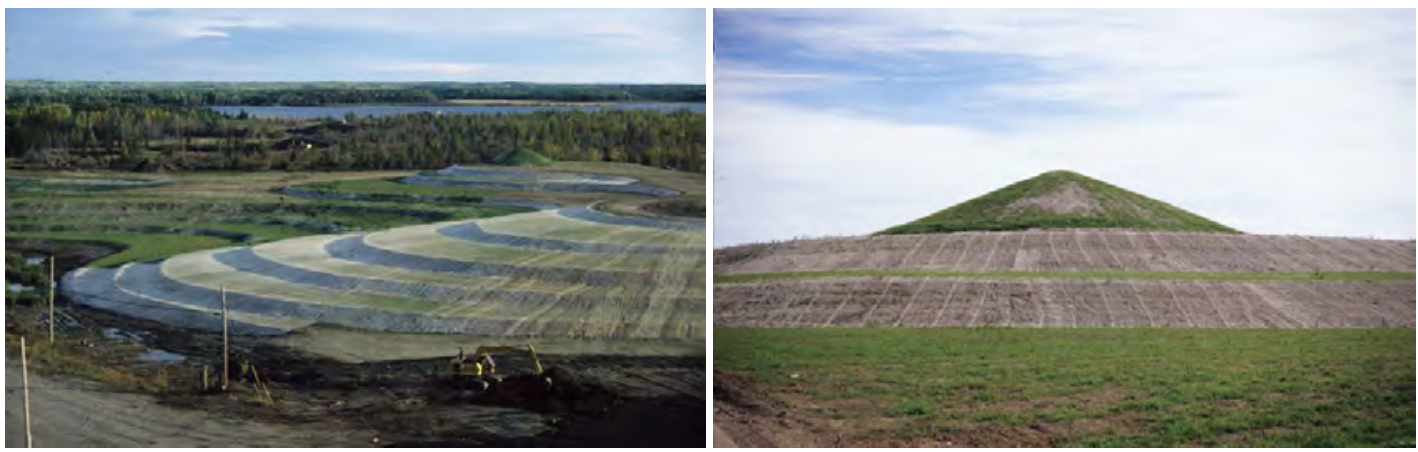

61. Smithson, como influência no paisagismo de Martha Schwartz (fotos acima) para recuperação de terras em área de mineração da empresa McLeod Tailings, Geraldton, Canadá.

(Fonte: http://www.marthaschwartz.com/projects/reclamation_tailings.php>)

- Os exemplos de Richard Long: paisagens desveladas e a experiência do gesto mínimo.

Para apresentar a arte de Robert Smithson (1938-1973), abordamos sua trajetória em etapas, a fim de melhor compreender o encadeamento e amadurecimento das preocupações paisagísticas em sua obra. Diferentemente, para apresentar um panorama das obras do artista inglês Richard Long (1945) não é necessário segmentar sua produção, uma vez que toda ela é homogênea, quanto ao tipo de ação e materialidade, e mantém-se fiel a alguns princípios, desde o fim dos anos 1960 aos dias atuais.

Um destes princípios é caminhar, uma ação central na arte de Long, que, na maioria das vezes, ocorre em lugares despovoados e inacessíveis. A obra consiste no percurso que é demarcado por seu rastro ou por materiais naturais rearranjados pelo artista no seu decorrer, e a representação desta experiência vivida na paisagem faz-se pela fotografia, textos ou, mais raramente, por mapas. A paisagem das obras de Long é traduzida em linguagem, e o que está em jogo é menos a sua fisicalidade ou realidade histórica, como na paisagem de Smithson, e mais as matrizes que norteiam a nossa percepção e o reconhecimento de que aqueles lugares ermos fotografados ou narrados são paisagens que parecem já termos visto.

Para Kastner, toda a produção de Richard Long, de um modo geral, enquadra-se na vertente envolvimento, pois sua obra nasce da experiência única do ser em meio à paisagem. Nela, o percurso adquire uma aura de ritual, "uma ação performática com o meio" ${ }^{\text {" }}$.

${ }^{87}$ KASTNER; WALLIS, 1998, p. 114. 
É característico das ações de Long estarem "em concordância com a paisagem, sujeitando-se a ela" ${ }^{88}$. Rosenthal inclui o trabalho de Long no grupo "gestos modestos", sutis, pois o artista toca a paisagem delicadamente. Suas marcas no terreno são geralmente formas geométricas em linhas e círculos constituídas dos elementos naturais presentes na própria paisagem - pedras, gravetos ou água -,apenas rearranjadas. Sobre os círculos e retas, sempre que indagado por que os repete, responde sucintamente: "eles já dão conta do recado" 89 . Sua obra não se constitui destas formas geométricas - dos indícios de que ele esteve lá -, e sim dos "lugares que eu escolho para colocá-los", somado ao seu próprio percurso e à experiência da paisagem.

A geometria, invenção humana, justaposta à composição caótica da natureza, é um recurso também utilizado nos earthworks americanos. Contudo, Richard Long dá primazia à paisagem - que já está posta, que construímos mentalmente -, pois suas intervenções, além de efêmeras, apresentam uma frágil construção. Não é a engenhosidade humana que se destaca no trabalho e tampouco na paisagem que contemplamos pela fotografia.

Mas que lugares são estes, cujas localizações só vislumbramos ao ler a legenda ou o texto que acompanha a obra? Geralmente despovoados, em raras exceções há neles animais ou pessoas, geralmente montanhosos e pedregosos, são paisagens que já habitam nosso imaginário. $\mathrm{O}$ artista reitera a tradição do olhar, enquadramentos e modelos de percepção que "já" reconhecemos como paisagem.

Em uma Inglaterra sobrecarregada pelo fardo do desenvolvimento industrial, cujo território é mais densamente povoado que o dos EUA, e cujos campos desde os séculos XVII e XVIII são redistribuídos para a produção estatal, o que gera a necessidade de um zoneamento rigoroso $^{90}$, a arte da paisagem inglesa parece somar seu histórico artístico à sua realidade política e geográfica agindo de modo sutil e desbravando outros territórios. Também parece influenciar o fato de os artistas ingleses trabalharem com a tradição do olhar que elege e compõe a paisagem.

\footnotetext{
${ }^{88}$ ROSENTHAL, Mark. Some attitudes of Earth Art: from Competition to Adoration. In: SONFIST, Alan (org.). Art in the Land: A Critical Anthology of Environmental Art. New York: Dutton, 1983, p. 66.

${ }^{89}$ TUFNELL, 2006, p. 27.

90 Ibidem, p.41 
Como vimos, Long, em 1982, criticou politicamente os earthworks como manifestação de uma arte capitalista ${ }^{91}$, dizendo que a sua arte é a antítese da americana, que se vale de possuir terras e maquinários.

Tufnell $^{92}$ apresenta a arte de Long como uma ruptura, uma nova e radical maneira de lidar com a paisagem, pois a obra se divide em ação direta na paisagem, no caminhar e rearranjar os materiais ao longo do percurso e da experiência vivida; não é mais uma adição, mas a obra integrada ao mundo. O escultor David Nash declarou sua admiração por Long, pois este "libertou uma geração de artistas de fazerem objetos", desde sua obra A Line Made by Walking (1967).

Mas um dos grandes méritos do artista reside no fato de que, apesar de a paisagem ser um tema caro à Inglaterra, quando Long, na década de 1960, inicia seus trabalhos, ela era considerada "fora de moda", um assunto a não ser abordado nas influentes Escolas de Arte. A despeito disso, o artista não desistiu do tema e, não por menos, suas primeiras exposições foram fora de seu país ${ }^{93}$. A Inglaterra de então estimulava a $P o p A r t$, elevada à categoria de vanguarda pelos norte-americanos. Posteriormente, Long não é só recebido na Inglaterra como praticamente forma uma escola inglesa da arte contemporânea da paisagem, tamanha sua influência. Obras de Andy Goldsworthy e Hamish Fulton compartilham raízes no pensamento de Long sobre a paisagem ${ }^{94}$.

A inserção comedida do código artístico abstrato junto à natureza parece apenas nos dizer que, para a paisagem ser arte basta ser ela própria, pouco necessitando de uma composição ou intervenção (uma adição). Assim, Long reduz as ações da arte ao mais simples e essencial possível, a fim de nos fazer pensá-las com maior profundidade.

My art is about working in the wide world, wherever on the surface of the earth. My art has the themes of materials, ideas, movement, time. The beauty of objects, thoughts, places and actions. ${ }^{95}$

\footnotetext{
${ }^{91}$ LONG, 1982 apud TUFNELL, 2006, p. 15.

92 TUFNELL, 2006, p. 23.

${ }^{93}$ Richard Long participou da Earth Art Exhibition, Ithaca, 1969, junto com Robert Smithson, e, no mesmo ano, também em Nova lorque ele participou da exposição Ecological Art.

${ }^{94}$ Estes artistas parecem trabalhar em paisagens já artializadas in visu e/ou in situ, evocando a memória e a tradição de um olhar que elabora e reconhece a composição da paisagem.

${ }^{95}$ LONG, 1982 apud TUFNELL, 2006, p. 20.
} 


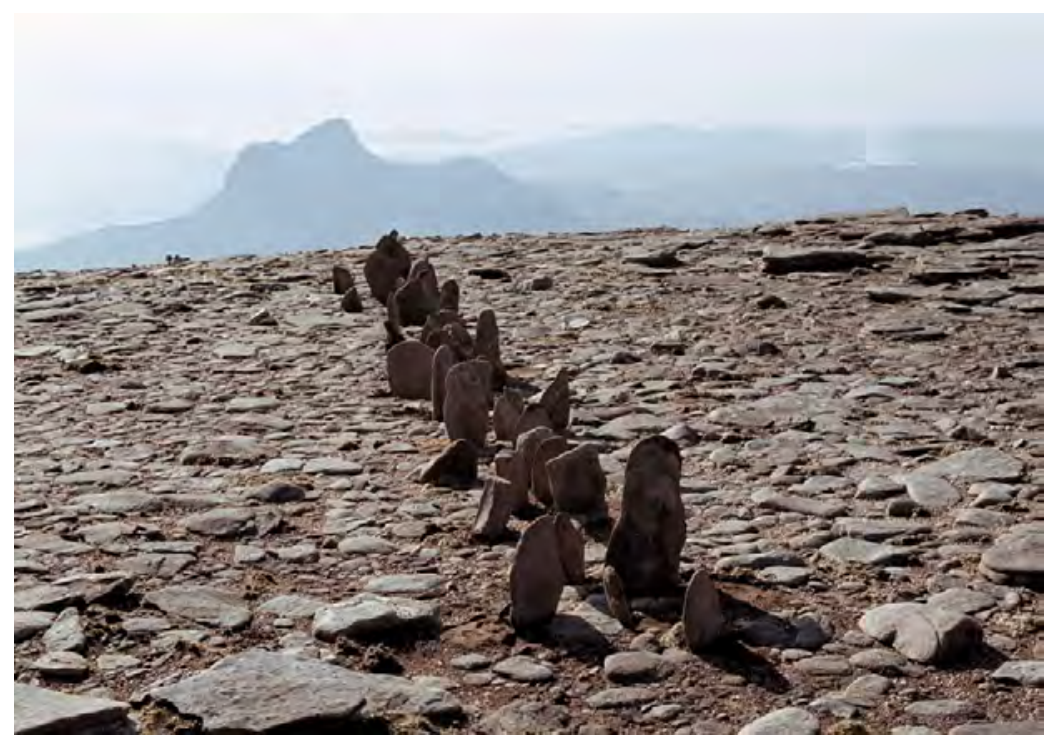

62. Richard Long. A Line in Scotland, Cul Mor, 1981. (Fonte imagem:< http://www.richardlong.org/Sculptures/2011sculptures/scotline.html>)

Retomando os termos de Roger, Long artializa $^{96}$ a paisagem in visu, ou seja, ele transforma-a através do olhar, ampliando o repertório e imaginário de paisagens na arte. Além disso, ele propõe enquadramentos, "esquemas de percepção e de deleite, modelos de visão" 97 . A maior parte das obras da land art transforma a paisagem in situ, ao "inscreverem diretamente o código artístico sobre o terreno" e ao requererem neste local o observador e a experiência da paisagem. Diferentemente disso, para Long, a paisagem dá-se na percepção e na elaboração mental.

O exemplo da montanha é particularmente instrutivo, porque ele nos confirma que a paisagem jamais é uma realidade natural, mas sempre uma criação cultural, e que ela nasce nas artes antes de fecundar nossos olhares. ${ }^{98}$

A arte de Richard Long sugere uma atitude de respeito, admiração e curiosidade em relação à paisagem e materializa-se na convergência entre rigor e franqueza. ${ }^{99}$

\footnotetext{
${ }^{96}$ ROGER, 1999.

${ }^{97}$ BERQUE In: CORRÊA, ROSENDAHL, 1998, p. 85.

${ }^{98}$ ROGER, 1999.

${ }^{99}$ TUFNELL, 2006, p.31. 


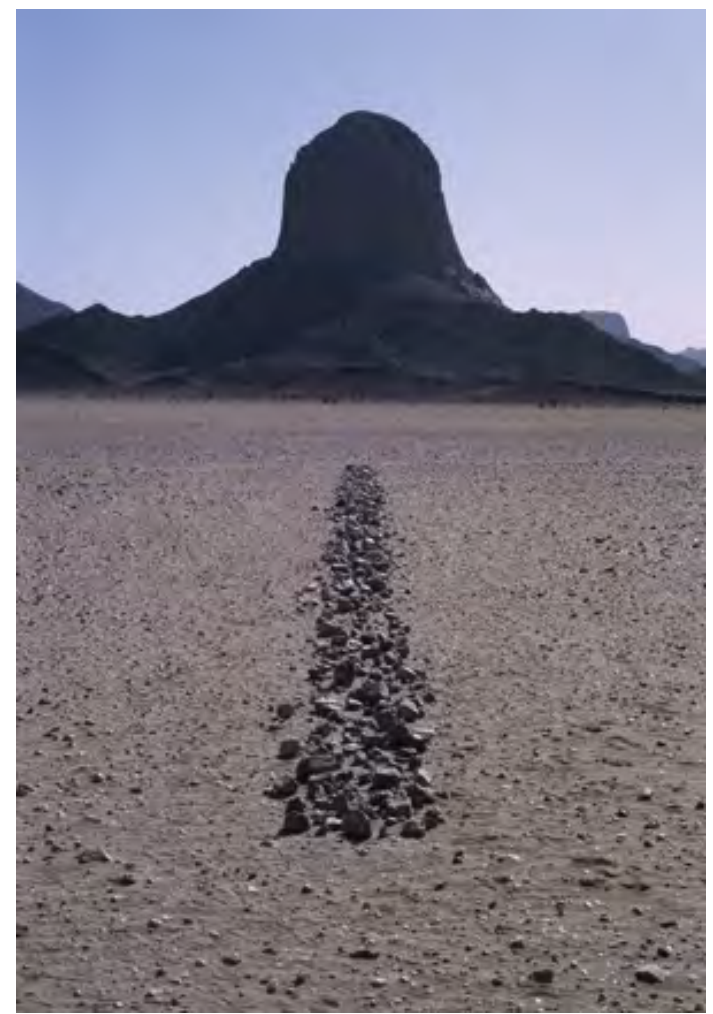

63. Richard Long. Sahara Line, 1988.

(Fonte: < http://paula-weetman.blogspot.com.br/2011_01_01_archive.html>)

\section{- Aproximações entre as obras de Richard Long e de Robert Smithson.}

Ao abordarmos as obras destes artistas, vislumbramos diferentes formas de como a arte se relaciona com a paisagem, de projetos para revitalização de terrenos a exemplos que trazem à tona a percepção e os processos históricos de artialização. Vimos os diferentes recursos que esta arte utiliza para abarcar a paisagem: a intervenção - ação site-specific -, a experiência da paisagem que é solicitada ao observador ou vivenciada pelo artista, a fotografia e a escrita. Cada recurso parece tocar em específicas questões da paisagem, que compõem uma totalidade complexa de interações entre o homem e a natureza.

Analisando como as obras de Long e Smithson lidam com a paisagem, também notamos que, talvez, o mais relevante não seja o fato de Smithson agir diretamente sobre a paisagem, utilizando recursos da tecnologia (como escavadeiras e tratores); enquanto Long age com seu campo físico, recolhendo manualmente pedras ou marcando o solo com suas pegadas. Esta distinção, geralmente na bibliografia, direciona-os a atitudes "invasivas" ou "respeitosas" em relação à paisagem. Talvez o mais relevante, de fato, sejam suas diferentes 
tendências em ver a paisagem como um campo para o projeto, materializando "visões do futuro" ou vê-la conforme a tradição de percepção da mesma, reiterando o quão sujeitos estamos às artializações.

Ademais, é fundamental notarmos que em suas obras parece haver uma preferência por lugares abandonados ou desabitados, ermos ou improdutivos, bem como um gosto pela desnaturalização. Suas paisagens não remetem ao pitoresco, parecem mais indicar lugares "à margem" 100 ou "sem fronteiras". Contudo, há diferenças significativas entre as suas obras, que residem nos processos culturais e nas posturas políticas que revestem ou impulsionam a arte da paisagem de seus países.

\section{- Considerações sobre a land art.}

A Land Art e Environmental Art estão, desde os anos 1960 até os dias atuais, em contínuo exercício. Elas modificam-se conforme mudamos os processos de transformação do meio, maravilhamo-nos e indignamo-nos com nossas paisagens. Elas encerram-se quando alienamo-nos dos processos naturais e da cultura que transformam nosso entorno.

Das sutis interferências na paisagem, que dialogam com a arte conceitual ou com a subjetividade de rituais, em obras cujos limites diluem-se na própria paisagem; àquelas, cujas execuções mobilizam profissionais da ciência, grandes equipamentos da engenharia e dialogam com o planejamento urbano e com a ecologia; foram apresentadas obras que refletem iniciativas pessoais e sociais empenhadas em valorizar, transformar e perpetuar paisagens e a nossa relação com o meio.

Tais iniciativas tornam-se mais facilmente obra quando o meio cultural, incluindo os interesses políticos e econômicos, está amadurecido quanto ao valor estético e cultural de suas paisagens.

Muitos artistas e trabalhos teriam que ser igualmente mencionados para uma justa apresentação das produções da arte da paisagem dos EUA e da Europa, que continuam a fomentar a Land Art em obras, em frequentes exposições e retrospectivas do tema e em novas produções bibliográficas.

100 As áreas de refugo de Smithson estão à margem de interesses sociais e políticos. Já as paisagens de Long parecem à margem da História. 


\subsection{Arte contemporânea da paisagem no Brasil: um breve histórico.}

Se a paisagem, principalmente em alguns países europeus e nos EUA, passa a ser fonte de reflexão e suporte para um determinado segmento da arte contemporânea, então surge a vontade de investigar analogias com a arte contemporânea nacional, a partir do mesmo período, de meados da década de 1960 aos dias atuais - quando tomam corpo obras pensadas para a paisagem e por ela influenciadas.

Desde então, como a paisagem tem participado dos projetos da arte no país? Como a produção contemporânea brasileira aborda a paisagem? Tal investigação tem como motivação um olhar crítico à escassez de propostas e de realizações observadas na arte neste campo. Entendendo a arte como "exercício experimental da liberdade"101 e, apesar de andar lado a lado com as utopias, ela parece manter-se afastada das questões da produção e da apreciação da paisagem.

É valioso traçarmos, mesmo que sucintamente, um histórico do moderno ao contemporâneo na arte brasileira para percebermos que, na passagem destes períodos, a paisagem, de certa maneira, perde seu espaço como tema ou como inspiração. Assim, buscaremos compreender como a arte, que abordava com significativa ênfase os temas natureza e paisagem durante o moderno, no contemporâneo passa a intervir timidamente na paisagem.

Entre nacionalismo e universalismo, a arte contemporânea no Brasil saltou sobre a discussão dos modos de produção da paisagem, passando diretamente da pintura de paisagem para as abordagens ecológicas ou ambientais. É por isso que nos últimos cinco anos tivemos importantes exposições que relacionam arte e natureza ${ }^{102}$, acompanhando uma tendência presente na Europa e nos EUA.

Assim também, antes de analisarmos as exposições e as obras de Fronteiras e Margem, é importante buscarmos como, de modo espontâneo, a paisagem foi incorporada na arte

${ }^{101}$ Definição da arte, segundo Mário Pedrosa, em artigo publicado no Jornal Correio da Manhã, 1968.

102 São elas: Arte Frágil, Resistências, MAC-USP, 2010, com curadoria de Lisbeth Resbollo e Jacques Leenhardt, com a temática da natureza em obras de artistas brasileiros e franceses; Krajcberg: Natura, MAM-SP, 2008; Ecológica, MAM-SP, 2008 (estas duas últimas com curadoria de Felipe Chaimovich); Poéticas da Natureza, MAC-USP, 2008, com curadoria de Kátia Canton. Morada Ecológica, MAM-SP, 2011; além dos projetos Fronteira e Margem (pelo Itaú Cultural), que inserem a arte ao ar livre na escala territorial e urbana, de maneira mais experimental, relacionando-a diretamente com a paisagem. 
contemporânea brasileira. Em outras palavras, o quanto ela é inspiração ou motivação crítica para a obra, e por isso vamos destacar alguns dos seus precursores.

Veremos que a arte contemporânea da paisagem no Brasil se distingue da definição de land art, de "interação direta na paisagem", empregada por Tufnell ${ }^{103}$, pois temos como exemplos obras que, depois de inseridas na paisagem, dialogam intensamente com ela; ou ainda, obras que se adequaram e se reformularam para determinada paisagem considerando suas condicionantes culturais, políticas e econômicas. Algumas obras ${ }^{104}$ de Fronteiras, por exemplo, foram produzidas primeiramente para um outro contexto e foram recolocadas em uma "paisagem de fronteira", onde ganharam significados diversos daqueles já experimentados em outras exposições.

Sobretudo, as obras serão consideradas ligadas às questões da paisagem quando a narrativa do artista se ater a ela. Quando os artistas descrevem os pontos de contato entre a paisagem e a obra, então estas passam a agregar a paisagem a si.

Beardsley ${ }^{105}$ analisa que a maioria das obras da land art" são estritamente vinculadas ao seu lugar, e grande parte de seu conteúdo reside na relação obra e características específicas do lugar e entorno". As obras brasileiras estariam nesta minoria na qual o autor deixa em aberto. Como analisa Salzstein, as obras de Fronteiras, aludem "a um outro lugar" "106 que não àquele da obra, pois não compartilham com as obras norte-americanas na ênfase sobre as questões do lugar, assim como não compartilham dos desdobramentos de artializações, explorados pelos artistas ingleses. Fronteiras foi um primeiro esforço em artializar paisagens da fronteira continental, através de intervenções e esculturas ambientais.

$\mathrm{O}$ artista Nelson Felix, em entrevista, explicou sobre a ênfase na fisicalidade das obras do Minimalismo e, por desdobramento, das obras norte-americanas ligadas à paisagem. Como vimos, a escultura minimalista foi uma influência direta para os earthworks e talvez daí tenha perdurado a relevância dada à materialidade do objeto, à disposição da obra no espaço e à relação com o percurso ou ponto de vista. Este comentário do artista auxiliou-nos a trilhar um caminho para a análise da arte da paisagem no Brasil. Isto porque nossa produção

\footnotetext{
103 TUFNELL, 2006, p. 15.

104 Pálio I e II, e Sem Título são exemplos de obras já expostas anteriormente e implantadas em Fronteiras (1998-2001).

105 BEARDSLEY, 1998, p. 7.

106 Referindo-se às obras de Fronteiras: “dão a impressão de que não pertencem completamente a seus lugares, de que apontam para 'um outro lugar', não deixa de sinalizar a fraca adesão da arte brasileira a uma noção de espaço público". Ver SALZSTEIN, 2005, p. 12.
} 
contemporânea assumiu, desde meados dos anos 1960 e nos anos 1970, os contornos da arte conceitual (que se espalhou simultaneamente pela América Latina, EUA e Europa) ${ }^{107}$ com envergadura política, em uma postura contestatória e em produções muitas vezes efêmeras.

Tais características de transitoriedade e sutil ocupação espacial, por consequência, aparecem em algumas obras da nossa arte contemporânea da paisagem. Estes aspectos concorrem para que a paisagem seja abordada, principalmente, em sua visualidade ou enquanto ideia, sugerindo certo distanciamento das ações sociais sobre ela, como a integração a projetos urbanos, por exemplo.

Não por menos, seguindo os agrupamento de Kastner, nossas obras pouco pertencem à vertente implementação, na qual os aspectos formais estão subordinados à ação social e engajada na produção de uma paisagem menos tecnocrata. Obras que, por exemplo, propõem revitalizar terrenos degradados, a despoluição de rios para lazer, entre outras questões urbanas e ambientais.

Como influência da arte contestatória das décadas anteriores, a arte contemporânea da paisagem no Brasil pouco se atém às questões identitárias nacionais. Ramirez ${ }^{108}$ aponta que a crise, a partir de meados dos anos 1960, fez que artistas e intelectuais se sentissem alienados, "periféricos não só dentro do próprio país - em relação à uma política interna ineficiente - mas em relação a uma política mundial que separava primeiro e terceiro mundo". Nesta situação, a identidade da paisagem deixa de ser uma questão emblemática, como fora no período de consolidação nacional, de desenvolvimentismo ou desarrollismo. ${ }^{109}$

\footnotetext{
107 Ramirez difere a arte conceitual norte-americana ou européia, que tem no objeto "desmaterializado" um enfrentamento ao capitalismo e um veículo para "examinar a transformação de objetos ou ideias em mercadorias". Ao invés disso, no Brasil, a arte conceitual se torna uma estratégia pra "expor os limites da arte e da vida sob condições de marginalização e, em alguns casos, de repressão". Ver RAMIREZ, Mari Carmen. Blueprint Circuits: Conceptual Art and Politics in Latin America. In: RAMUSSEN, Waldo; BRECHT, Fatima (eds.). Latin American Artists of the Twentieth Century. New York: Museum of Modern Art, 1993. p. 158.

108 Ibidem.

109 Helio Oiticica sintetiza bem esta questão quando declara, em 1970, na apresentação da exposição Information, Museu de Arte Moderna de Nova lorque: "Eu não estou representando o Brasil, nem nenhuma outra coisa. A ideia de representar e de representação já era".
} 


\subsubsection{A ideia de paisagem na arte moderna brasileira e a ida à paisagem} na arte contemporânea.

Observar como a paisagem era abordada no Modernismo Brasileiro, em especial na pintura, e qual influência exerceu nesta arte é diretamente significativo para compreendermos o esteio da nossa arte contemporânea ligada às questões da paisagem. Algumas características parecem ter perdurado, tais como a paisagem como espelho da alma - mais ligada a um universo íntimo - ou mais idealizada. Estas características veremos em algumas leituras das obras de Fronteiras.

Para alcançar este objetivo, faço um breve recuo até as pinturas de paisagem de Tarsila do Amaral e de Alberto da Veiga Guignard ${ }^{110}$ e, na passagem do moderno ao contemporâneo, é relevante citar também obras de Roberto Burle Marx. Trata-se de um recuo breve, uma vez que estudar o tema paisagem no período moderno geraria muitos desdobramentos, próprios para uma outra pesquisa. Apesar disso, é através de obras destes artistas que buscamos os indícios de como a paisagem passaria da representação para ser o suporte da obra.

O movimento moderno na pintura brasileira afastou-se do modelo acadêmico, cujos temas e técnicas eram internacionais, recorrendo ao regionalismo, a fim de eleger o que seria próprio do Brasil e lhe conferiria identidade. A paisagem é investigada Brasil adentro, por artistas e intelectuais, e representada com ênfase entre os gêneros da pintura, enquadrando-se novamente no anseio nacional do período.

O Movimento Moderno, a partir da Semana de Arte Moderna de $1922^{111}$, em tom revolucionário, almejou conquistar a autonomia da cultura brasileira, assim como de linguagens artísticas. Suas premissas são apresentadas no Manifesto Antropofágico ${ }^{112}$, de 1928, que é reinterpretado, no final da década de 1960, pelo Tropicalismo ${ }^{113}$.

110 Outros pintores modernos lançaram sobre a paisagem suas atenções. Contudo, para este trabalho, apenas buscamos apontar rastros de um pensamento sobre a paisagem - ora nacional, brasileira, ora interiorizada - que reaparece na arte contemporânea, como veremos em Fronteiras e Margem.

111 A semana de Arte Moderna de 1922 aconteceu como parte da comemoração do centenário da Independência e foi a primeira manifestação coletiva pública da cultura brasileira a favor de uma arte com linguagem própria, que buscava emancipação ao recusar as "importações" de modelos e temas. Os intelectuais e artistas apresentaram uma diversidade de influências do Futurismo ao Nativismo (retorno à cultura popular), mas o que se sobressaiu foi a proposta de repensar a dependência cultural do Brasil.

112 Ou Manifesto Antropófago, escrito por Oswald de Andrade e publicado na primeira edição da Revista de Antropofagia (1928), trazia a essência do Modernismo no Brasil preocupado em reformular a cultura brasileira. Propunha a ideia de antropofagia como metáfora de um processo crítico de formação da cultura brasileira, capaz de deglutir as formas importadas para produzir algo genuinamente nacional, sem cair na antiga 116 
Tarsila do Amaral (1886-1973) e Alberto da Veiga Guignard (1896-1962) são pintores que, em especial, cultivaram a paisagem, por vezes interpretada e difundida dentro de um projeto maior de construção de identidade nacional ${ }^{114}$. Ambos representam, grosso modo, duas etapas do modernismo brasileiro, que Mário de Andrade denominou como a de "espírito destruidor", inaugurada com a Semana de 1922 até a década de 1930; e, desta data em diante, uma fase "construidora", quando se deu a aceitação pública do "direito permanente à pesquisa estética, à atualização da inteligência artística brasileira; e à estabilização de uma consciência criadora nacional". ${ }^{115}$

Durante a primeira fase, a paisagem brasileira é principalmente adequada como tema, sob a influência das Vanguardas Modernistas internacionais. Com Tarsila do Amaral, as paisagens apresentam tanto a influência francesa do Cubismo e Surrealismo quanto uma vocação em revelar a brasilidade e superar modelos estrangeiros. Esta característica é resultado de sua formação artística em Paris e de suas excursões investigando, nas cidades históricas mineiras, ${ }^{116}$ os elementos da nossa paisagem, - da arquitetura, da natureza e dos tipos humanos.-A artista intentava formular através da pintura de paisagem uma imanente brasilidade. $^{117}$ Podemos dizer que muito de sua paisagem consiste na investigação das formas que traduzissem uma identidade brasileira.

relação model o/cópia, que dominou uma parcela da arte do período colonial e a arte brasileira acadêmica do século XIX e $\mathrm{XX}$.

${ }^{113}$ A obra de Helio Oiticica Tropicália (1967) cunha o nome do movimento artístico Tropicalismo, que inclui música, cinema, teatro, literatura e compartilha com o artista os ideais por uma arte experimental. Esta pretendia repensar o lugar dos símbolos da cultura brasileira, afinidades com "problemas universais da vanguarda, [...] radicalidade crítica e posição revolucionária no processo de revisão cultural e de renovação das artes no Brasil", mas "sem o objetivo de figurar uma realidade nacional, tarefa que mobilizou parte da tradição da arte Moderna". Ver FAVARETTO, Celso Fernando. A invenção de Helio Oiticica. São Paulo: Edusp/FAPESP, 1992, p. 146.

${ }^{114}$ Carlos Zílio discorda que a pintura de Guignard tenha afinidades com o nacionalismo, ao menos não dentro de um modelo heroico como o da pintura de Cândido Portinari, pois estabelece contato direto e intenso com o modelo, humano ou paisagem. Ver ZíLIO, Carlos. Catálogo A modernidade em Guignard. In: PAlHARES, Taisa. Modernidade, Tradição e Caráter Nacional na Obra de Alberto da Veiga Guignard. 2010, p. 18.

115 Mário de Andrade, em conferência em 1942 "O movimento modernista" refletindo sobre os 20 anos da Semana de 1922. Ver PALHARES, Taisa. Modernidade, Tradição e Caráter Nacional na Obra de Alberto da Veiga Guignard. 2010, p. 26.

116 Em 1924, em companhia de Oswald e Mário de Andrade e do poeta Blaise Cendrars, realizou uma importante viagem a algumas cidades históricas de Minas Gerais, determinantes para o conjunto de sua obra por colocaram-na em contato com formas e cores que imprimiriam seu estilo, nos termos de uma "vital brasilidade". Disponível em: <http://www.latinartmuseum.com/amaral.htm> Acesso em 05 dez. 2012)

117 “[...] demandas de um debate artístico brasileiro que vinham desde o séc. XIX. Entre elas estaria a ênfase em produções de caráter alegórico, comprometidas com temáticas que projetassem imagens ideais do Brasil ou de uma brasilidade "imanente'". Ver CHIARELLI, Tadeu. De Anita à academia: para repensar a história da arte no Brasil. Novos estudos Cebrap, São Paulo, n. 88, 2010. 

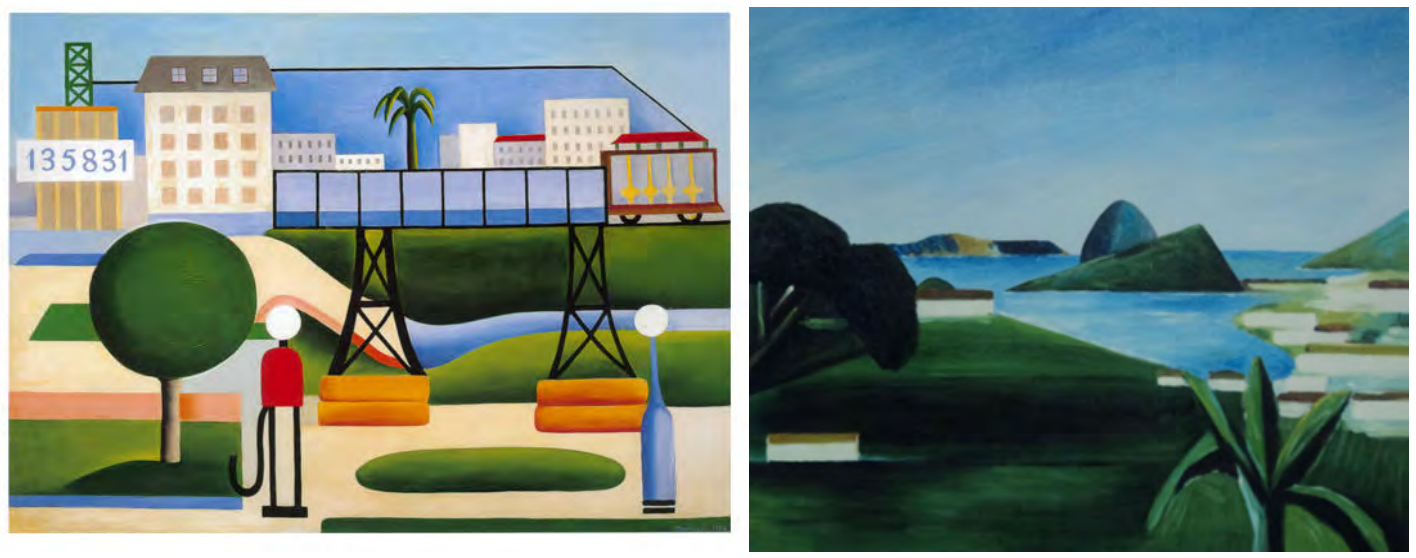

64. Tarsila do Amaral, São Paulo, 1924 65. Tarsila do Amaral, Rio de Janeiro, 1923.

(Fonte: <http://www.wikipaintings.org/en/tarsila-do-amaral/s-o-paulo-1> e

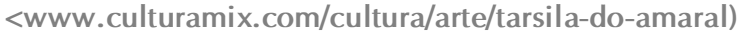

Tarsila codificava em chave cubista a nossa paisagem ambiental e humana, ao mesmo tempo que redescobria o Brasil nessa releitura que fazia, em modo seletivo e crítico (sem por isso deixar de ser amoroso e lírico), das estruturas essenciais de uma visualidade que rodeava desde a infância fazendeira. ${ }^{118}$

Em Guignard, o olhar volta-se em especial para a paisagem colonial mineira ou a paisagens idílicas. Este artista, o "pintor de paisagem do Brasil”, como o próprio se definia, elege a paisagem montanhosa de Minas Gerais, com a qual se identificava por sua atmosfera. Ele escreve ao amigo Portinari nos anos 1940: "eu sou montanhês" ${ }^{119}$.O artista é comumente identificado como representante do espírito regional da pintura brasileira, cujas paisagens e personagens possuem certa aura de ingenuidade e romantismo. Mas Guignard estava longe de ser um naïf, uma vez que sua formação na Academia de Artes de Munique propiciou-lhe o contato com antigos mestres, entre eles, "é possível identificar, em sinais que persistem posteriormente em sua própria obra [...] pequenas paisagens montanhosas de Jan Brueghel ou de Joos de Momper”" ${ }^{\text {"20 }}$, representantes da pintura de paisagem flamenga do século XVII. Podemos dizer que a paisagem de Guignard afina-se com a atmosfera dos lugares e com processos subjetivos de identificação e reflete-se como espelho da alma. "Guignard não é um analista, nem um construtor que traça o esboço da paisagem e a leva para arrumação posterior. Ele submete-se inteiramente à percepção, à natureza, à paisagem." ${ }^{121}$

\footnotetext{
${ }^{118}$ CAMPOS, Haroldo de. Tarsila, anos 20. 1997, p. 111. Disponível em: <http://www.macvirtual.usp.br/ mac/templates/projetos/roteiro/PDF/02.pdf>. Acesso em 05 dez. 2012.

${ }^{119}$ ANDRÉS, Maria Helena. Guignard, o mestre. 1996. Disponível em:<http://www.scielo.br/scielo.php? pid=S0103-40141996000300014\&script=sci_arttext>. Acesso em: 05 ago. 2012.

120 PALHARES, 2010, p. 73.

${ }^{121}$ PEDROSA, Mário. Textos escolhidos: Acadêmicos e Modernos. 2004 apud PALHARES, 2010, p. 33. 

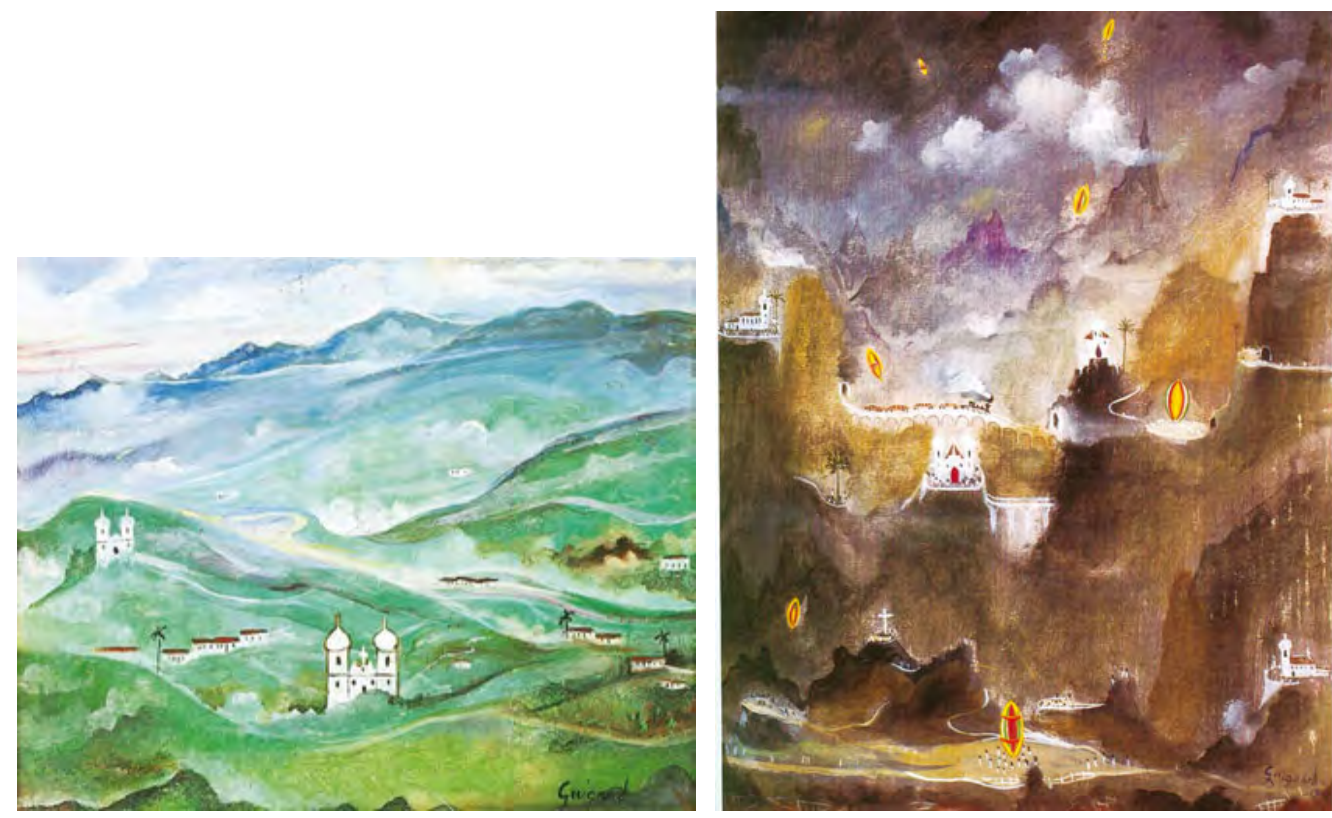

66 e 67. Alberto da Veiga Guignard Paisagem de Minas, década de 1940 e Noite de São João, 1961 (Fonte:<http://novalimaperfil.com.br/site_nlperfil/index.php?option=com_content\&view=article\&id=439:gu ignard-o-poeta-das-cores\&catid=14:arte-a-cultura\&ltemid=16>)

Nas décadas de 1950 e 1960, uma modernidade menos regional e mais abstrata e universal começou a se manifestar na pintura brasileira. Este é um período em que se intensificam a urbanização e industrialização, tranformando cidades em metrópoles e ocupando novas regiões, como com a construção de Brasília - o ápice deste movimento.

A obra de Burle Marx durante esse período é bastante relevante, no que se refere à convergência arte e paisagem, e eleva a paisagem e a natureza brasileiras à categoria de arte. Suas composições artísticas, utilizadas por ele na pintura, na tapeçaria e no desenho, são diretamente empregadas na paisagem, por meio de projetos paisagísticos integrados à nova arquitetura que fazia "as vezes" de escultura. Para Burle Marx, a paisagem é experiência sensível (artialização in situ) a se integrar no percurso do observador. 

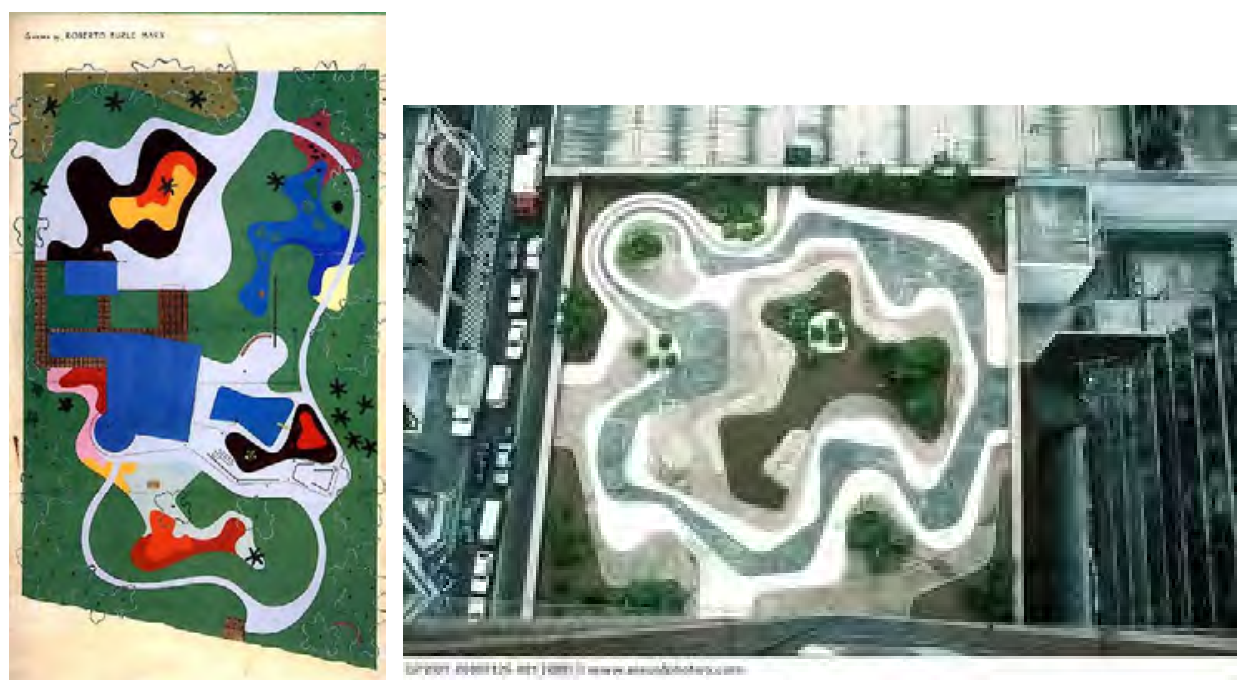

68 e 69. Burle Marx. Plano de jardim residencial, Sta. Bárbara, Califórnia, 1948 e Banco Safra, 1982

(Fonte:: http://www.moma.org/collection/object.php?object_id=78..>)

Além do projeto de "abrasileirar a cultura", compartilhado pelos modernistas nacionais, Burle Marx já apresentava afinidades com a arte minimalista e com a Land Art quanto aos interesses pelo lugar, pela estética dos materiais locais, assim como por estabelecer uma relação espacial entre obra, espectador e lugar. Segundo Leenhardt ${ }^{122}$, as novas possibilidades exploradas pelos artistas da Land Art, "em termos de local e experiência sensível do espaço", constituem "o cerne da pesquisa” de Burle Marx. O autor aponta que o paisagismo imbuído de arte de Burle Marx se apoiava no deslocamento do visitante pelo espaço e em sua percepção sensorial, ou seja, princípios da arte contemporânea da paisagem.

O horizonte artístico brasileiro da época é marcado por artistas "modernistas", muito diferentes uns dos outros, mas animados por uma mesma redescoberta do que seja propriamente brasileiro [...] a complexidade das influências que Burle Marx deixa trabalhar em si faz com que permaneça relativamente à parte, no que concerne aos excessos de formalismo engendrados pela onda modernista que rebenta sobre São Paulo graças à Semana de Arte Moderna, em $1922 .{ }^{123}$

No Brasil, a convergência entre arte e paisagem tem um momento ápice com a exposição do projeto de paisagismo de Burle Marx para o calçadão de Copacabana, na 35 Bienal de Veneza $(1970)^{124}$. Tal dissolução das fronteiras entre arte e paisagem tornar-se-ia

\footnotetext{
122 LEENHARDT, Jacques (org.). Nos Jardins de Burle Marx. São Paulo: Ed. Perspectiva, 1996, p. 24.

123 Ibidem, p. 10.

124 “a vida artística de Burle Marx culminou com a sala especial, onde se expôs sua pintura e seus jardins, inclusive o da Avenida Atlântica na sala individual do Brasil. Este foi o primeiro projeto paisagístico exposto em uma Bienal Internacional de Arte." Ver KATO, Gisele. Muito Além dos Jardins. dez. 2008. Disponível em: <http://bravonline.abril.com.br>. Acesso em abr.2011.
} 
cada vez mais presente na arte contemporânea da paisagem; e também chama-nos a atenção para o fato de que uma obra de arte, em determinado período, pode deixar de sê-la em um período sucessor, bem como aquilo que não pertencia ao domínio da arte é passível de pertencer posteriormente, pois esta categorização acompanha o movimento das construções culturais $^{125}$.

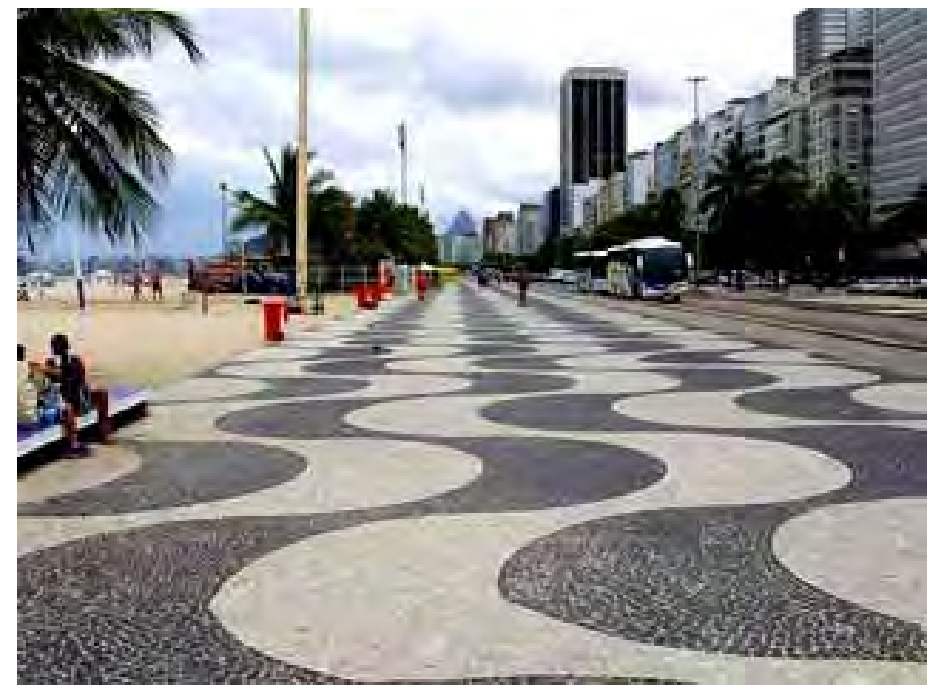

70. Desenho de Burle Marx para o Calçadão de Copacabana, Rio de Janeiro. 1970.

(Fonte: http://www.orquidariocuiaba.com.br/recomendo/comemorando-100-anos-de-burle-marx/>)

A necessidade de reconhecer os elementos da nossa paisagem e elegê-los como significativos e, ao mesmo tempo, acompanhar as premissas das artes estrangeiras, naturalmente trouxe em si contradições que seriam finalmente enfrentadas abertamente na arte contemporânea. É a partir dos anos 1960 que artistas como Frans Krajcberg (1912) e Hélio Oiticica (1937-1980) rompem com as categorias da arte e lançam seus olhares para além da paisagem tropical mitificada pelo Movimento Moderno, intervindo diretamente em paisagens, até então, à margem dos debates artísticos e que não eram estetizadas a priori.

$* * * * * * * * *$

A arte da paisagem no Brasil, até meados dos anos 1970, atém-se às questões da produção da paisagem urbana, talvez como parte de um programa maior de modernização, que significou, em termos rasos, na industrialização e urbanização. Este segmento da arte

125 "A definição do que é arte é sempre dada previamente pelo que ela foi outrora, mas é apenas legitimada por aquilo em que se tornou [...] Muitas obras, por exemplo, representações cultuais, metamorfoseiam-se em arte ao longo da história, quando o não tinham sido; e muitas obras de arte o deixam de ser." Ver ADORNO, Theodor W. Teoria Estética. Coimbra: Edições 70, 2008, p. 14. (original de 1970) 
empreende uma tentativa de reorganizar a produção cultural já existente e lidar com um fenômeno em expansão acelerada.

Nas décadas de 1960 e 1970, artistas brasileiros também buscam alternativas para o circuito de museus e galerias de arte, como o exemplo do graffiti e de outros modos de intervenção (ação site-specific) urbana. Estes precursores da formação de uma arte da paisagem, em iniciativas individuais ou coletivas, enfatizaram a transgressão da obra em ocupações efêmeras em continuidade com as características da arte conceitual brasileira de cunho político, indicando-nos que a arte contemporânea da paisagem no Brasil seria construída de modo similar.

Em São Paulo, os artistas Antonio Lizárraga e Gerty Saruê são pioneiros da arte contemporânea atenta às formas e aos usos que configuram a paisagem, que, na década de 1970, aproximavam a arte dos projetos urbanos.

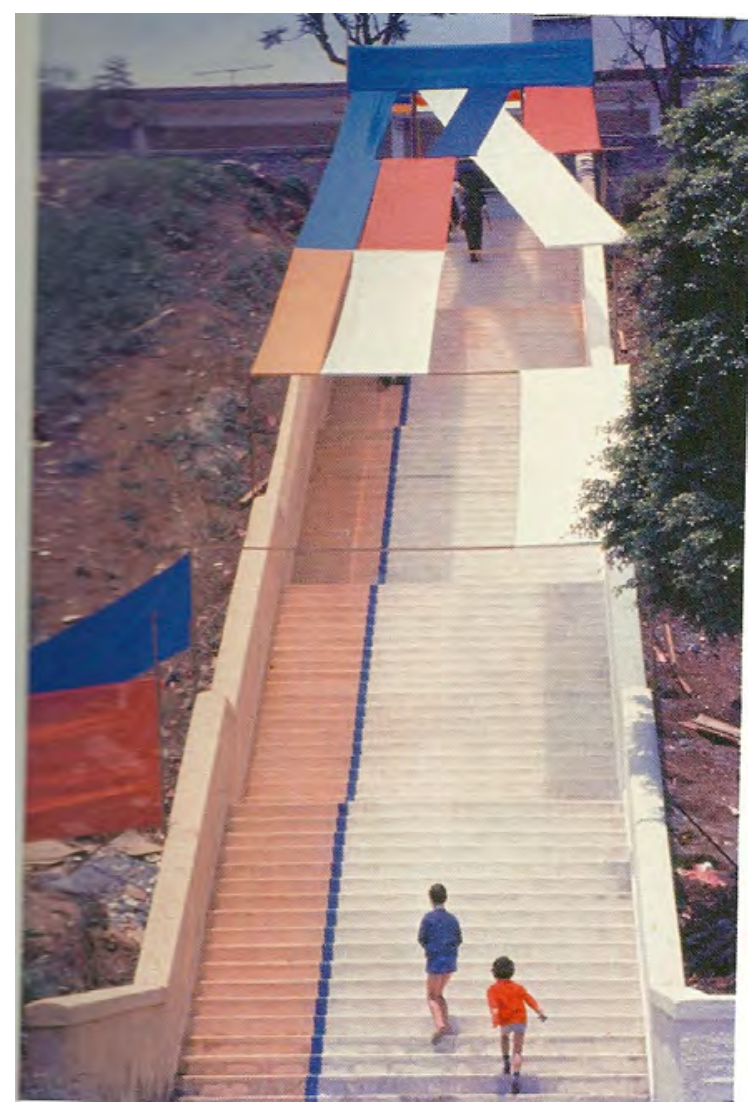

71. Antônio Lizárraga, colaboração de Gerty Saruê. Intervenção na Rua Gaspar Lourenço, Vila Mariana, São Paulo. 1972.

(Fonte: FABRIS, 2007) 
Fabris $^{126}$ descreve que o projeto acima suscitou reações adversas entre os vizinhos da intervenção. De reclamações daqueles que "ficaram de fora" e queriam o mesmo tipo de "requalificação" próxima às suas casas, até uma denúncia e a aplicação de uma multa ao grupo por “depredação dos bens públicos." 127

Freire $^{128}$ apresenta como um dos exemplos pioneiros da arte que se integra ao lugar, a intervenção do grupo 3Nós3. Esta, consistiu no ensacamento de bustos e monumentos em São Paulo, em 1978, contestando a ditadura e provocando nossa reflexão sobre quão simbólicas são as esculturas públicas comemorativas ou o quanto estas "dão voz" à nossa história. As ações do grupo, que atuou até 1982, são marcadamente transgressoras.

Freire ressalta o caráter efêmero da arte pública brasileira deste período, com a singular obra-performance Situação T. E. (1970), de Artur Barrio, na região metropolitana de Belo Horizonte. Barrio joga em um córrego - já transformado em esgoto - trouxas ensanguentadas (madeira e borracha enrolados em panos com sangue), causando medo, nojo e reações fotografadas pelo artista à paisana, acompanhando inclusive uma equipe de reportagem de TV que tenta desvendar o ocorrido. A “obra” é um acontecimento registrado pela mídia e no caderno-de-artista de Barrio e confunde-se com as práticas da ditadura. $\mathrm{O}$ artista, ao contestar, não por acaso escolhe um lugar comum na paisagem urbana brasileira: à margem da urbanização e do planejamento paisagístico, um lugar imerso no descaso.

Talvez a ênfase na crítica e reação ao regime militar - "enquanto na Europa e EUA, a contestação dizia respeito às limitações à liberdade impostas pelo capitalismo" ${ }^{129}$ - e os questionamentos quanto aos processos de urbanização desenfreados e precários ocuparam quase exclusivamente a nossa arte mais ligada às questões da paisagem ou que nela agia diretamente.

126 FABRIS, Annateresa. Antônio Lizárraga: uma poética da radicalidade. São Paulo: Edusp, 2000, p. 67.

$127 \mathrm{O}$ processo determinou a penhora dos bens do arquiteto e porta-voz do grupo Maurício Fridman, em 1976, e foi extinto por determinação do prefeito Olavo Setúbal.

128 FREIRE, Cristina. Espaço e Lugar: os registros da paisagem urbana na arte contemporânea, 1999 In: SAlGUEIRO, Heliana Angotti. Paisagem e Arte: A invenção da natureza, a evolução do olhar. São Paulo: CNPq/FAPESP/CBHA, 1999 - 2000. p. 357.

129 FREIRE, 1999, p. 360. 
72. Grupo 3Nós3. Ensacamento, 1979.

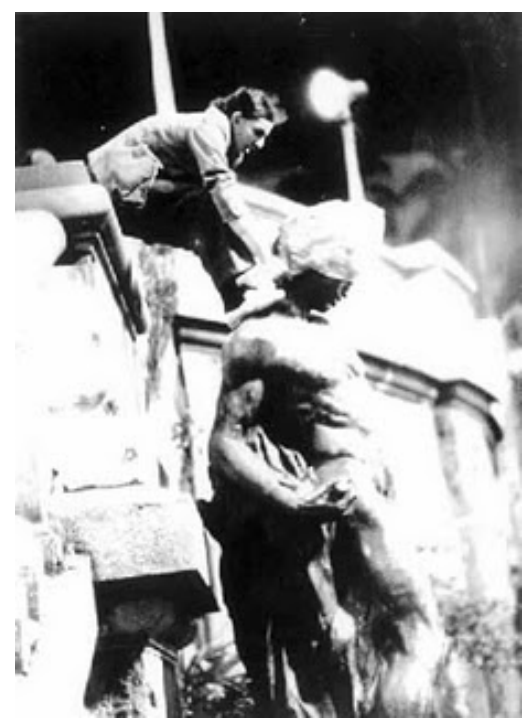

\section{Artur Barrio, Situação \\ T.E. - trouxas ensanguentadas. Belo Horizonte, 1970. \\ Registros em caderno-de- artista, fotografia e filme. Participação de 5 mil pessoas aproximadamente. \\ (Fonte: \\ http://www.muvi.advant.co m.br/artistas/a/artur_barrio/ artur barrio.htm. \\ Acesso em maio 2011)}

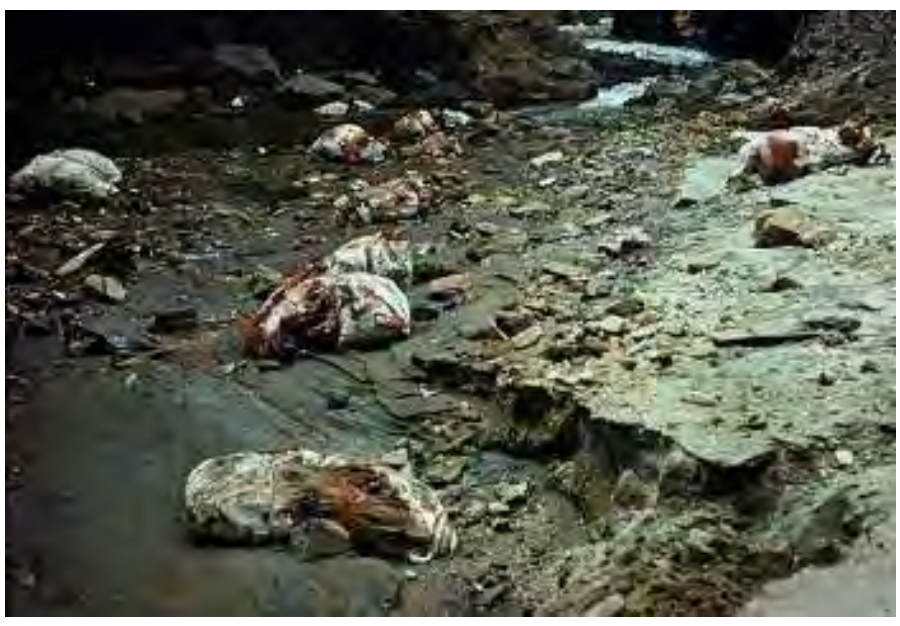

Diante deste panorama, surge uma inquietude em não compreender por que na passagem da escultura - obra tridimensional - da arte moderna brasileira para a obra sitespecifc ou intervenção (a escultura no campo ampliado, nos termos de Krauss), momento propício para a realização da arte através da paisagem, ela parece então se dispersar, sendo fracamente abordada nos eventos da arte contemporânea nacional.

Seriam nossas paisagens mais mitificadas e menos vivenciadas? Estão elas ainda contidas no imaginário explorado pela pintura de paisagem do século XIX e da primeira fase Modernista, que as coloriu como "tropical", "do futuro" ou "exuberante", representações confrontadas pela arte contemporânea? Ou elas apresentam-se diante de nós menos factuais e mais imaginárias, em universos íntimos, como na pintura de Guignard? 
Se, na década de 1970, a Geografia e o Urbanismo se debruçaram sobre as questões do lugar, ${ }^{130}$ valores locais versus globais, e estudavam as novas e grandes distâncias possíveis de serem compreendidas pela imagem do satélite, televisão e internet, assim também a arte brasileira atenta, a partir deste período, para as questões do lugar, focando o espaço público urbano.

É notável a similaridade das grandes dimensões territoriais entre Brasil e EUA, , a extensão territorial e a diversidade de paisagens - em transformação ou livres de ocupação -, contudo, não fomentaram a apropriação pela arte brasileira que permaneceu nos limites do urbano $^{131}$. Este é também um aspecto motivador desta pesquisa: por que, mesmo com a vastidão territorial e o histórico de enaltecimento da natureza nacional através da arte, esta - a partir de meados da década de 1960 -, ao se dirigir aos espaços comuns da sociedade, pouco se ocupa das questões de formação da própria paisagem e se constrói timidamente fora dos espaços institucionalizados pela arte?

A arte contemporânea da paisagem em diferentes países não pode ser comparada (como vimos com Smithson e Long), uma vez que, além dos aspectos naturais e físicos, ela é formada, principalmente, pela dinâmica social e cultural, com sua história e seus valores próprios em relação aos objetos e natureza. Devemos apenas atentar que esta arte requer uma sinergia de ações, política, social, artística e científica, para se manifestar, assim como vimos nos exemplos estrangeiros.

Uma primeira explicação quanto ao fato de a nossa arte se aderir à paisagem parcialmente seria a limitação econômica, mas acreditamos que ela não resume a questão. Decerto, não podemos comparar a infraestrutura administrativa, tecnológica, além da convergência de interesses públicos e particulares, presentes em obras de Christo e JeanneClaude, com os exemplos de Fronteiras ou Margem. Na Europa, contudo, , artistas voltavamse para a paisagem, de modo individual ou em coletivos, em diversas poéticas de trabalho

\footnotetext{
${ }^{130} \mathrm{Na}$ arquitetura, Aldo Rossi em $A$ arquitetura da Cidade (1966) acreditava na necessidade de se estudar e projetar de acordo com o locus, a singularidade, a situação; “dever-se-á analisar a relação entre locus e projeto. Somente à luz dessas pesquisas poder-se-á resolver o antagonismo aparentemente insanável entre o projeto como elemento racional e como imposição e a natureza do lugar que participa da obra." Ver ROSSI, Aldo. A arquitetura da cidade. São Paulo: Martins Fontes, 1995, p. 189. Já Norberg-Schulz pensa em uma arquitetura como atividade que produz o lugar, que traz à tona as características do genius loci, aflorando as "pré-existências ambientais". SCHULZ, Norberg Christian. The Phenomenon of Place, 1976. In: NESBITT, Kate (org.) Uma Nova Agenda para a Arquitetura. São Paulo: Cosac\&Naify, 2008, p. 459.

131 “Mas apesar das também generosas dimensões territoriais, as experiências em espaço aberto do Brasil concentram-se nos grandes centros urbanos e principalmente nas capitais São Paulo e Rio de Janeiro." FUREGATTI, Sylvia. Arte e Meio Urbano: Elementos de formação da estética extramuros no Brasil. Tese de Doutoramento, FAU-USP, São Paulo, 2007, p. 36.
} 
possíveis: do ritual subjetivo a temas ecológicos. Estes artistas compartilhavam alguns interesses: a paisagem, o lugar (de origem), a nação, a formação e a transformação das cidades e suas periferias, os modos de ocupação e fruição dos espaços públicos. As obras, imbuídas de crítica, também investigavam novas relações entre a sociedade e a natureza.

Furegatti ${ }^{132}$ aponta algumas possíveis respostas, no que concerne à diferença na formação da nossa arte da paisagem, em relação às obras da Land Art. A primeira diferenciação estaria em nosso momento histórico de formação das metrópoles, em processos de urbanização e industrialização acelerado, o que intensificaria um debate junto à arte sobre estas mesmas questões de urbanização, dos papéis sociais nesta nova rede, tendo-se em vista que a progressão do crescimento urbano era fenômeno recente. Outro fator que a diferenciaria das obras da Land Art aponta para os recursos tecnológicos. As obras de Christo, Robert Smithson e Heizer, por exemplo, mesmo em paisagens pouco construídas, requereram o uso da tecnologia e da engenharia, enquanto nosso momento histórico presenciava o início da industrialização.

Do ponto de vista cultural, "a reatividade dos artistas no espaço urbano internacional" encontraria como motivo propulsor a negação da tradição dos museus na Europa e, nos EUA, a necessidade crítica dos artistas em relação ao crescimento rápido do mercado de galerias, iniciado no período Pós-guerra. No Brasil, contudo, tanto os museus quanto as galerias eram pouco influentes, um "frágil comércio", não fomentando o distanciamento destas instituições rumo a novos territórios.

Não tratando diretamente desta comparação, Meneses ${ }^{133}$ diferencia o imaginário das paisagens na formação cultural americana e brasileira, o que pode ser um indício para compreensão do pouco envolvimento da arte contemporânea brasileira com a paisagem. Meneses faz a seguinte relação:

O sertão e a Amazônia, no imaginário brasileiro, também se revestem de potencial identitário. Mas, como detectou Janaína Amado, ao contrário do que ocorreu com a conquista do oeste norte-americano, que foi capaz de cimentar um mito integrador da identidade nacional - indutor de hegemonias de expressão interna e externa - no Brasil as paisagens simbólicas do sertão e da

\footnotetext{
132 FUREGATTI, 2007, p. 39.

133 MENESES Ulpiano Bezerra. A paisagem como fato cultural In: YÁZIGI, Eduardo (org.) Paisagem e Turismo. São Paulo: Contexto, 2002, p. 44
} 
Amazônia permanecem regionalmente circunscritas e não chegaram a "incluir a nação inteira em uma única narrativa.”

Outra questão é a busca de contato com a natureza, em áreas densamente urbanizadas, é uma tendência natural, uma reação contra a mecanização e a industrialização. Podemos, então, indagar o quanto esta tendência natural de compensação é capaz de influenciar nossas respostas ao ambiente urbano e, consequentemente, a relação da arte brasileira com a paisagem.

\subsubsection{Precursores da arte da paisagem no Brasil: Frans Krajcberg e Hélio}

\section{Oiticica.}

As obras de Frans Krajcberg (1921) e de Hélio Oiticica (1937-1980) abordam intensamente as transformações e apropriações da paisagem, trazendo à tona as heranças culturais que nelas agem. É diretamente da paisagem que eles extraem as matérias-primas e elementos de suas obras, que resultam da vivência na paisagem. Se o moderno intentou criar um caráter nacional ${ }^{134}$, as obras destes artistas mostram facetas de um Brasil, que permaneciam à margem ou aquém do moderno.

Krajcberg ${ }^{135}$ diz ter-se deparado de modo irreversível com a natureza brasileira no Paraná, em 1954, quando vê pela primeira vez uma queimada e declara: "as árvores eram como homens calcinados pela guerra. Não suportei. Troquei minha casa por uma passagem de avião para o Rio". 136

Antes de intervir diretamente na paisagem - colhendo dela suas matérias-primas - o artista realizava pinturas em ateliê. Com uma destas obras, "Samambaias", ganhou o prêmio de melhor pintor nacional na IV Bienal Internacional de Arte de São Paulo, de 1957. Viajou a

\footnotetext{
134 “[...] o caráter nacional, que a arte brasileira deveria assumir, pautou a produção artística e a crítica de arte modernista brasileiras, desvinculando-as, por um lado, de uma aproximação com as vanguardas européias mais radicais e, por outro, ligando-a a certas necessidades muito próximas daquelas percebidas pela arte e pela crítica de arte que antecederam o modernismo no Brasil." CHIARELLI, 2006 apud D`ANGELO, Martha. Educação estética e crítica de arte na obra de Mario Pedrosa. Rio de Janeiro: Editora NAU, 2011, p. 25.

135 Nasce em 1921, Kozienice, Polônia. Em 1947 migra para o Rio de Janeiro e, em 1948, para São Paulo, onde trabalha para Francisco Matarazzo no MAM e na $1^{\text {a }}$ Bienal Internacional de Arte de São Paulo (1951). Em 1957 ele se naturaliza brasileiro. (Disponível em: http://www.franskrajcberg.com/fkchronologieportugues.html. Acesso: 20 maio 2012)

136 KRAJCBERG, Frans. (Disponível em: <http://www.frans-krajcberg.com/fkchronologieportugues.html>. Acesso em: 20 maio 2012).
} 
Paris e lá se tornou amigo de Braque e Pierre Restany, com quem escreveria o Manifesto do Rio Negro, em 1978. Krajcberg viaja a Ibiza, onde de fato dá início a uma arte que interage diretamente com a natureza, não mais representando-a ${ }^{137}$. Neste período ele declara: "não há mais gestual pictórico. São impressões relevos: pedaços da natureza” e, com estes trabalhos, recebeu prêmio na Bienal de Veneza de 1964, quando então na Itália elaboravam-se os princípios da Arte Povera, que aproxima arte e vida, arte e natureza, em detrimento do industrializado.

Em 1964, já se fixa longe do eixo cultural das metrópoles do Rio de Janeiro e de São Paulo, viajando pela Amazônia e pelo Pantanal Mato-grossense, "fotografando e documentando os desmatamentos”. Também recolhe madeiras de troncos e raízes calcinados, transformando-os em escultura. Krajcberg critica o "vazio absoluto" em que se encontra o momento artístico, entregue à dominação do mercado desde o final do século XIX; segundo o artista, se no início daquele século a arte estava atrelada à política e "abria portas para as mudanças", hoje ela parece não ter mais voz. Para ele, apenas a fotografia, à qual tem-se dedicado nas últimas décadas, serve de denúncia contra a barbárie que destrói a natureza.

O Manifesto do Naturalismo Integral ou Manifesto do Rio Negro, concebido pelo artista junto a Pierre Restany e Sepp Baendereck, foi relido em ocasião da recente exposição no MAM-SP 60 anos Frans Krajcberg: Natura, em 2008 ${ }^{138}$. O Manifesto começa por explicar que "naturalismo" é a oposição ao realismo que a arte perpetuou, através dos tempos, sendo apenas uma metáfora das formas do poder; do Renascimento, como metáfora do poder religioso e econômico, até o poder da sociedade de consumo, na Pop art.

Após séculos de tirania do objeto, que culminou na apoteose da aventura do objeto como linguagem sintética da sociedade de consumo, a arte duvida da sua justificação material e se desmaterializa, se conceitualiza. Os procedimentos conceituais da arte contemporânea só têm sentido se elas forem examinadas por uma ótica autocrítica. A própria arte se coloca em posição crítica. Ela se questiona sobre sua imanência, sua necessidade, sua função. (Krajcberg, Restany e Baendereck, Manifesto do Naturalismo Integral, 1978)

Krajcberg duvidou da necessidade da arte como adição ou artifício e entrelaçou sua vida a uma arte que olha para fora, mas muito além do entorno próximo ou das questões sitespecific ou site-oriented (nos termos da arte estrangeira institucionalizada) que permeiam a

\footnotetext{
${ }^{137}$ Suas obras deste período são impressões de rochas e de relevos, quadros de pedras e de terra.

138 A Exposição Frans Krajcberg: Natura faz parte de um conjunto de exposições do MAM-SP que visou discutir arte e ecologia. Outras exposições foram: Ecológica (2010), Festival de Jardins e Morada Ecológica (2011).
} 
arte pública contemporânea, inclusive no Brasil. Com uma visão de sobrevôo, o artista mostra um panorama do Brasil, evidenciando e denunciando, através de suas esculturas, fotografias e depoimentos, a histórica violação da paisagem brasileira e dos recursos naturais. A obra de Krajcberg não poderia estar ausente em um trabalho que trata da arte ligada às questões da paisagem. O lugar trabalhado pelo artista é o Brasil - em um tempo expandido -, que abarca o histórico da nossa colonização.

Questionado sobre o significado de sua arte, responde:

Na Amazônia, vi três montanhas de lixo esperando para serem queimadas e vi centenas de índios mortos pendurados em árvores, que arte eu devo fazer? Eu gostaria de pegar aquelas três montanhas e mostrar que a minha revolta é enorme. ${ }^{139}$

Durante a $1^{\text {a }}$ Conferência Mundial das Nações Unidas sobre Meio Ambiente e Desenvolvimento, a ECO 92, no Rio de Janeiro, Krajcberg expõe no MAM-RJ Imagens do Fogo. Esta exposição é apresentada por Kastner (1998), como vimos, como um ponto de inflexão nos modos de a arte abordar a paisagem: a partir de então, tornaram-se mais frequentes obras engajadas em questões ambientais, dentro ou fora dos limites do urbano.

Comumente nos depararmos com interpretações de sua obra reduzida a metáforas da natureza, assim como "das florestas" 140 ou "do verde", que procuram alienar o discurso do artista, que expõe o processo de devastação da natureza, tanto quanto um histórico de políticas nacionais de apropriação como recurso econômico. A questão ecológica, como bem elucida o curador Felipe Chaimovich, por ocasião da exposição Ecológica, 2010, MAM-SP ${ }^{141}$, é essencialmente urbana e ligada ao desenvolvimento capitalista e do consumo.

\footnotetext{
${ }^{139}$ NETO, Ernane Guimarães. Vanguarda de Raiz. Folha de S. Paulo, São Paulo, 30 nov. 2008. Caderno Mais. Entrevista com o artista Frans Krajcberg. Disponível em: <http://www1.folha.uol.com.br/fsp/mais/fs3011200806.htm>. Acesso: 20 maio 2011.

140 De julho a novembro de 2011 no Museu Afro Brasileiro em São Paulo, a exposição Krajcberg, o Homem e a Natureza no Ano Internacional das Florestas, data criada pela ONU, que promoveu, em diversos países, encontros e exposições e premiou iniciativas, a fim de "conscientizar quanto a conservação das florestas e sobre o desenvolvimento sustentável" (Disponível em: $<$ g/en/events/iyof2011/index.shtm>)

${ }^{141}$ Esta exposição sucedeu a de Krajcberg, dentro de uma série de exposições e eventos que pautaram o tema arte, ecologia e meio ambiente. Ver $\mathrm{CHAIMOVICH}$, Felipe. ECO lógica, Catálogo, São Paulo: MAM-SP, 2010.
} 

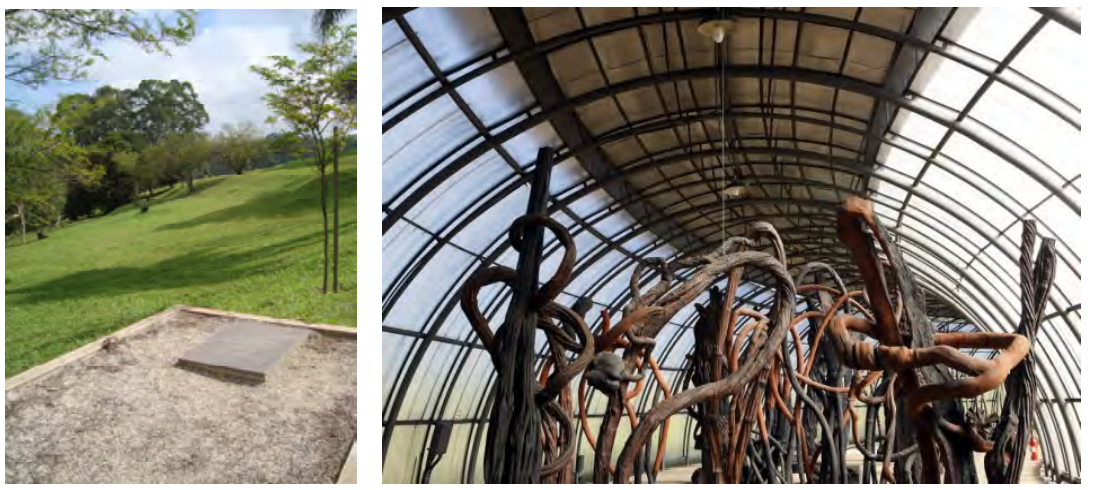

74 e 75. À esquerda, a pedra fundamental lançada em 2009 para a construção do Pavilhão Krajcberg ${ }^{142}$ no Parque do Carmo, São Paulo. Esta obra não foi iniciada e contaria com uma valiosa doação de esculturas do artista. (Fonte: arquivo pessoal, 2010). À direita, Instituto Frans Krajcberg de Arte e Meio Ambiente, inaugurado em Curitiba, 2003, com uma exposição permanente do artista com 107 esculturas. Mas em 2006, o artista processou a Fundação por descaso com suas obras ${ }^{143}$.
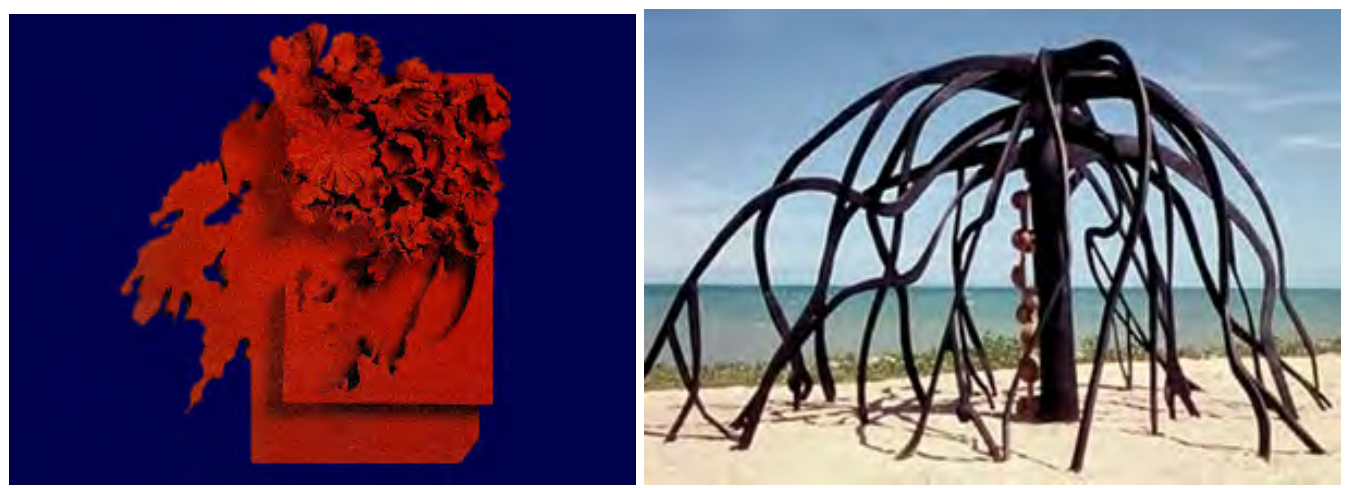

76 e 77. Frans Krajcberg. Floração, 1968 e Flor do Mangue, década de 1970.

(Fonte: www.itaucultural.org.br)

Krajcberg produz testemunhos de um histórico de devastação da paisagem, longe de tornar suas obras objetos para contemplação e simples apreciação. Na contramão da maior parte das obras da Land Art, que deixam suas marcas na paisagem, ele, ao contrário, recolhe marcas do extrativismo e da exploração ilegais, marcas recorrentes na produção da paisagem nacional desde o período colonial, e também fotografa-as ${ }^{144}$. As paisagens do artista são

${ }^{142}$ O Pavilhão que abrigaria quarenta esculturas doadas pelo artista à Prefeitura do Município de São Paulo, inicialmente, seria no Parque do Ibirapuera. Mas, posteriormente, foi instalado no Parque do Carmo, onde também ocorreu a cerimônia oficial para sua implantação em agosto de 2009. (Fonte: Revista Projeto Design, jul. 2009).

${ }^{143}$ Ver MATEVSKI, Nikola. Krajcberg-versus-Curitiba. Gazeta Do Povo, Curitiba, 2 set. 2006. Caderno G. Disponível em: <http://www.gazetadopovo.com.br/cadernog/conteudo.phtml?id=595705\&tit=Krajcbergversus-Curitiba>. Acesso 12 out. 2012.

144 De certo modo, esta forma de agir do artista faz lembrar as pedras recolhidas por Smithson nos arredores de Nova Jérsei, que eram levadas à galeria formando os non-sites (não lugares), como "indoor earthworks": um lugar que remete ao outro. Também se assemelha com as vivências na paisagem de Richard Long. Contudo, enquanto as paisagens já artializadas de Long são registradas perpetuando uma tradição do olhar e do imaginário, as paisagens não artializadas de Krajcberg são destruídas antes de alimentarem, de fato, nosso imaginário. 
distantes da maior parte da população brasileira, urbana, e silenciada por políticas públicas e até mesmo pelos meios de comunicação.
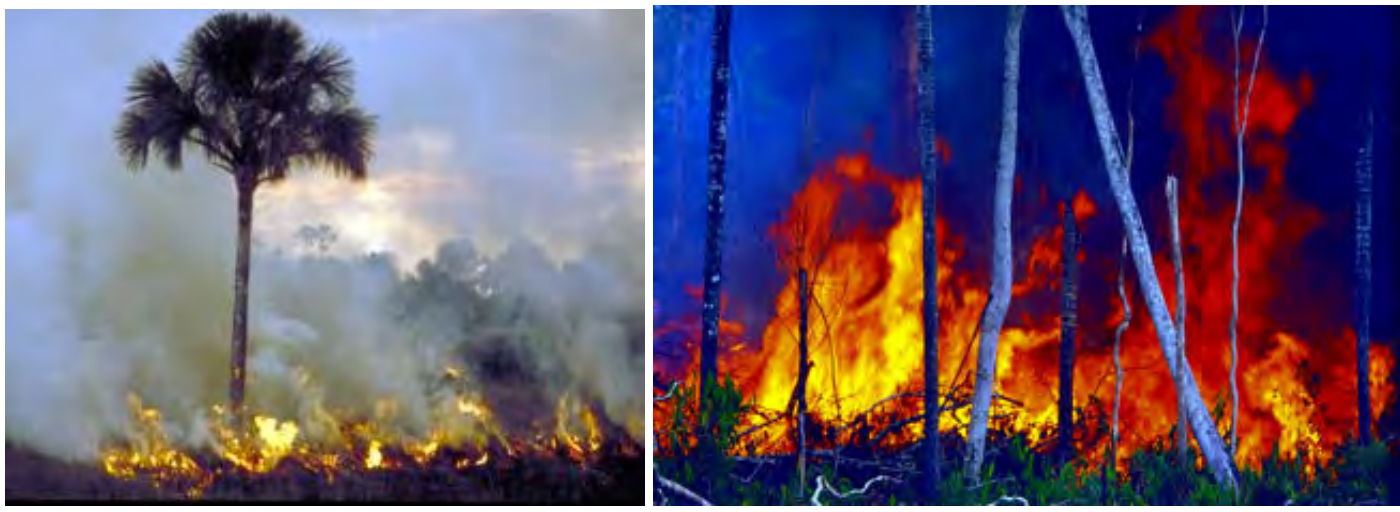

78. Fotografias de queimadas ilegais, em Frans Krajcberg: Natura, MAM-SP, Pavilhão da Oca, 2008.

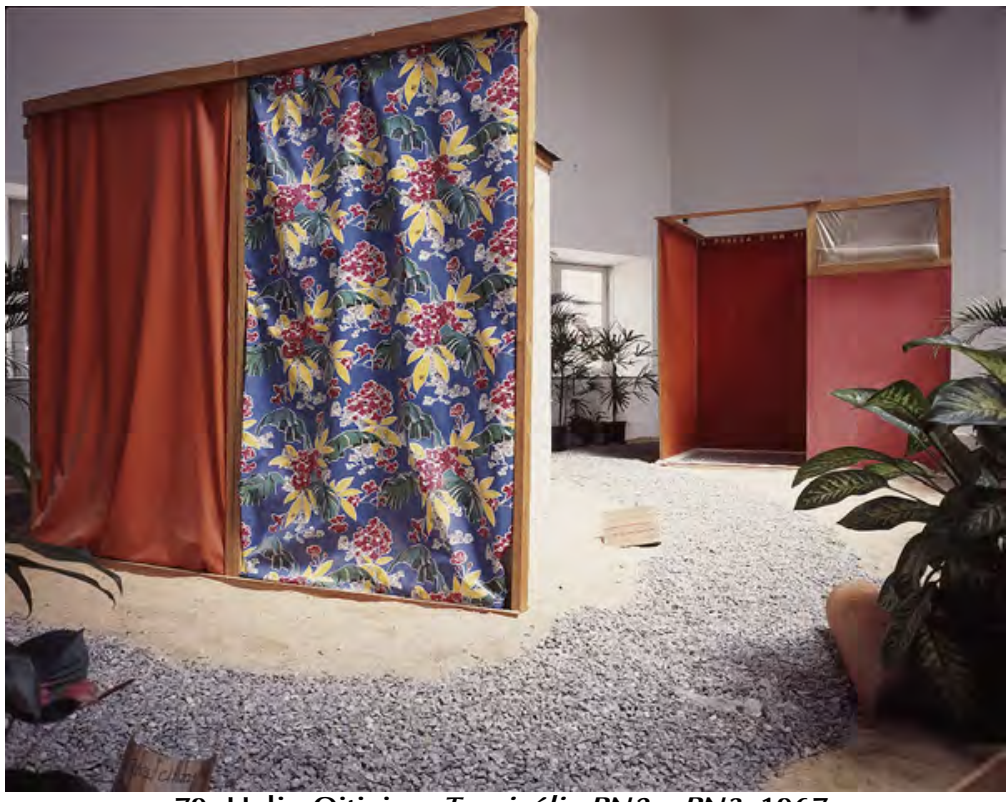

79. Helio Oiticica. Tropicália PN2 e PN3, 1967.

(Fonte: http://bravonline.abril.com.br/blogs/arteria/2010/03/24/tres-motivos-para-prestar-atencao-em-heliooiticica/. Acesso em: 20 dez. 2012)

A arte de Hélio Oiticica, que a partir de meados dos anos 1960, interage principalmente com as matrizes culturais da paisagem, é também denominada arte ambiental $^{145}$ e traduz "o campo ampliado" da escultura contemporânea (nos termos de Krauss), na arte brasileira.

${ }^{145}$ Arte ambiental é um termo batizado por Mário Pedrosa para os trabalhos de Helio Oiticica que podiam ser vivenciados, percorridos. "Arte Ambiental é como Oiticica chamou a sua arte. Não é, com efeito, outra coisa. Nela nada é isolado. Não há uma obra que se aprecie em si mesma, como um quadro. O conjurto sensorial domina. Nesse conjunto, criou o artista uma 'hierarquia de ordens' - Relevos, Núcleos, Bólides (caixas) e capas, estandartes, tendas (Parangolés) - todas dirigidas para a criação de um mundo ambiental." Ver PEDROSA, Mário. Arte ambiental, arte pós-moderna, Helio Oiticica, 1966 In: OITICICA, Hélio. Aspiro ao grande labirinto. Rio de Janeiro: Ed. Rocco, 1986. São exemplos os "Penetráveis", obras que estão para o percurso e para o uso, tanto quanto 
Oiticica vale-se das construções culturais que caracterizam a paisagem - em especial das favelas cariocas da Mangueira ${ }^{146}$ - e as reelabora como experiência estética e sensorial, dentro da galeria ou museu, onde o observador, ou vivenciador (nos termos do artista), percorre os ambientes e traça analogias entre a arte e o mundo que conhece lá fora. Os elementos da paisagem são rearranjados - prática comum na Land Art - sem serem representados.

Da paisagem das favelas, Oiticica abarca as características de suas construções, da ocupação territorial, assim como a dinâmica que as produz e, por isso, informalidade e coletividade são processos e resultados formais em suas obras. Assim como Krajcberg, Oiticica vivenciou a paisagem e não a abordou como objeto para contemplação, mas como objeto de investigação e apropriação.

Ao se apropriar do modo de construção, dos materiais e da dinâmica social das favelas cariocas, o artista aborda uma paisagem local e ao mesmo tempo reconhecível como brasileira, que se estende a todo país. Esta é uma característica fundamental da arte contemporânea da paisagem no Brasil: ao mesmo tempo que aborda um lugar em específico, também remete a uma ideia de lugar generalizante, se adequando a outras situações espaço-temporais. Não delimitamos um lugar específico para as queimadas ou as favelas.

Jacques $^{147}$, sobre Tropicália (1967) e Éden (1969), que visitara em uma exposição em Paris, descreve-nos a experiência que teve de "um sentimento de lugar familiar" e acrescenta: "era como se a galeria tivesse se transformado, subitamente, em um pedaço do Rio". Segundo a autora, as obras evocam comunidades alternativas - próprias do período destas obras -, utópicas, assim como as marginalizadas dentro do projeto de desenvolvimento nacional, como as indígenas ${ }^{148}$. Podemos considerar que Oiticica não propôs estetizar a favela, mas entrelaçar a cultura popular com a erudita em seu programa de democratização das artes.

para o olhar. Helio Oiticica denomina-as aludindo às ruas, labirintos e aos barracões de carnaval, algumas chamam-se inclusive Barracão, Ninho.

${ }^{146}$ Em 1964, o artista vai morar na favela da Mangueira e sua ligação com a escola de samba homônima passa a ser uma influência direta em sua arte.

147 JACQUES, Paola Berenstein. Estética da ginga: A arquitetura das favelas através da estética de Hélio Oiticica. 2a ed. Rio de Janeiro: Casa da Palavra, 2003, p.10.

148 Isto é compreendido a partir do catálogo da exposição em Londres, produzido pelo artista, no qual aparecem de imagens de rodas de samba da Mangueira a ocas e um funeral indígena. Éden (1969) traz consigo um pouco de taba e de reminiscências de um longo processo histórico brasileiro de construção de sua paisagem. 
Talvez por conta deste "reconhecível", que é específico e ao mesmo tempo abarca um vasto Brasil (até então com pouca visibilidade nas artes), Guy Brett, escreve que Oiticica passa "de maneira muito sutil da metáfora da dança/música/corpo à da arquitetura/urbanismo e, depois, à da paisagem/território." 149
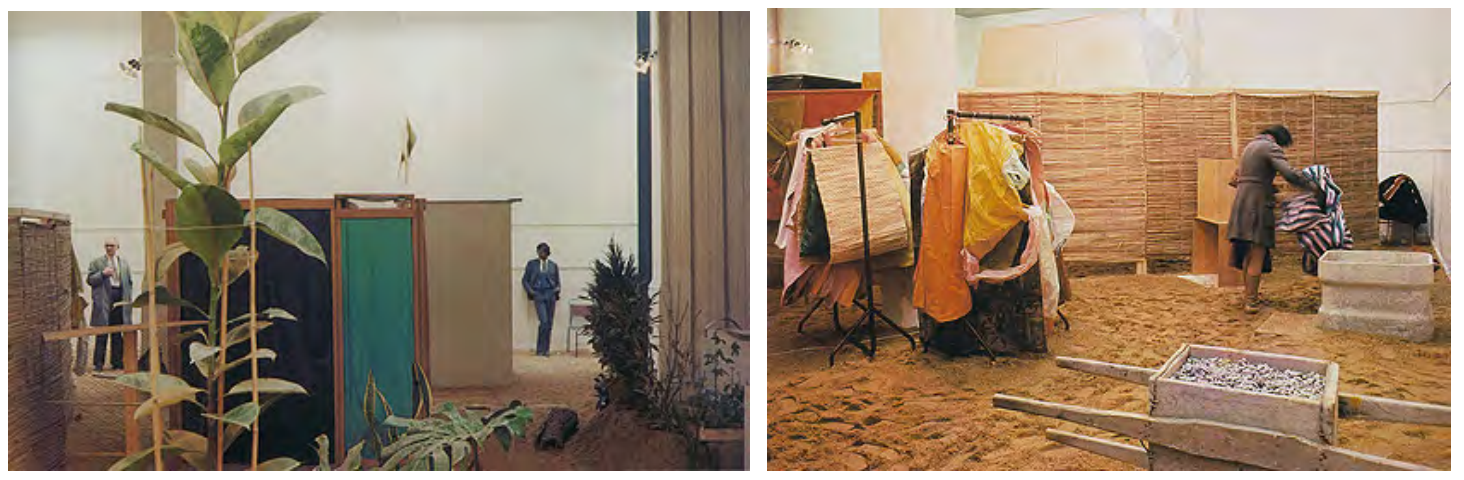

80 e 81. Hélio Oiticica, Tropicália, 1969, plantas, areia, pedras, araras, aparelho de televisão, tecido e madeira e Éden, 1969, em exposição na galeria Whitechapel, Londres.

(Fonte imagens:: <http://www.itaucultural.org.br> Acesso em: maio/2001)

Em entrevista ${ }^{150}$ a Aracy Amaral, em 1977, Oiticica comenta sobre a distância dos seus trabalhos com os de artistas representativos da Land Art, e refere-se em particulara obras de Christo e Jeanne Claude:

Eu não quero mais fazer coisas que as pessoas vejam como se fosse uma exposição, mesmo que seja do lado de fora. Eu acho que os americanos fizeram muito isso, aquelas cortinas de Christo, não sei o quê, você vai para a natureza para ver uma exposição. ${ }^{151}$

Em suas obras ambientais, Tropicália (1967) e Éden (1969), a arte da paisagem brasileira retoma o debate das questões identitárias, contudo, o artista opunha-se à ideia de uma "realidade brasileira" ou de uma "linguagem universal" e conjuga uma linguagem entre o nacional e o internacional. Oiticica expôs o precário e o incerto de nossas paisagens, a rapidez de suas mutações, na coexistência de araras - como amuletos que possam garantir a fartura da terra - e de uma televisão transmitindo notícias de um mundo que homogeneíza-se.

\footnotetext{
${ }^{149}$ Brett foi o curador da exposição na Whitechapel Gallery, Londres, 1969. Ver JACQUES, 2003, p. 122. Oiticica trata no texto "Mundo-Abrigo" do encadeamento das escalas do corpo à da cidade, interpretação que aparece nas ideias de "aldeia global" de McLuhan, por quem o artista declara ser influenciado, citando em especial o livro Understanding Media (1964).

150 OITICICA, Hélio. Hélio Oiticica: tentativa de um diálogo, 1977. In: AMARAL, Aracy. Textos dos Trópicos de Capricórnio: artigos e ensaios (1980-2005), v. 3. São Paulo:Editora 34, 2006.

${ }^{151} \mathrm{O}$ interesse maior de Oiticica estava em aproximar arte e cotidiano, portanto critica obras em espaço urbano que se tornam "show-espaço urbano", em seus termos. Ibidem.
} 
Os elementos naturais - representados por plantas, araras (em algumas montagens não há pássaros), com a terra ou areia - têm o propósito de "provocar a explosão do óbvio"152. A obra "devora a própria imagem do Brasil e da tropicalidade" 153.

o ambiente criado era obviamente tropical, como num fundo de chácara, e, o mais importante, havia a sensação de que se estaria de novo pisando a terra. Esta sensação, sentia eu anteriormente ao caminhar pelos morros, pela favela, e o mesmo percurso de entrar, sair, dobrar "pelas quebrada" $[\ldots]{ }^{154}$

O próprio termo "Tropicália" era para definitivamente colocar de maneira óbvia o problema da imagem [...] Todas estas coisas de imagem óbvia de tropicalidade, que tinham araras, plantas, areia, não eram para ser tomadas como uma escola [...] Tropicália era exatamente para acabar com isso [...]. ${ }^{155}$ [grifo nosso]

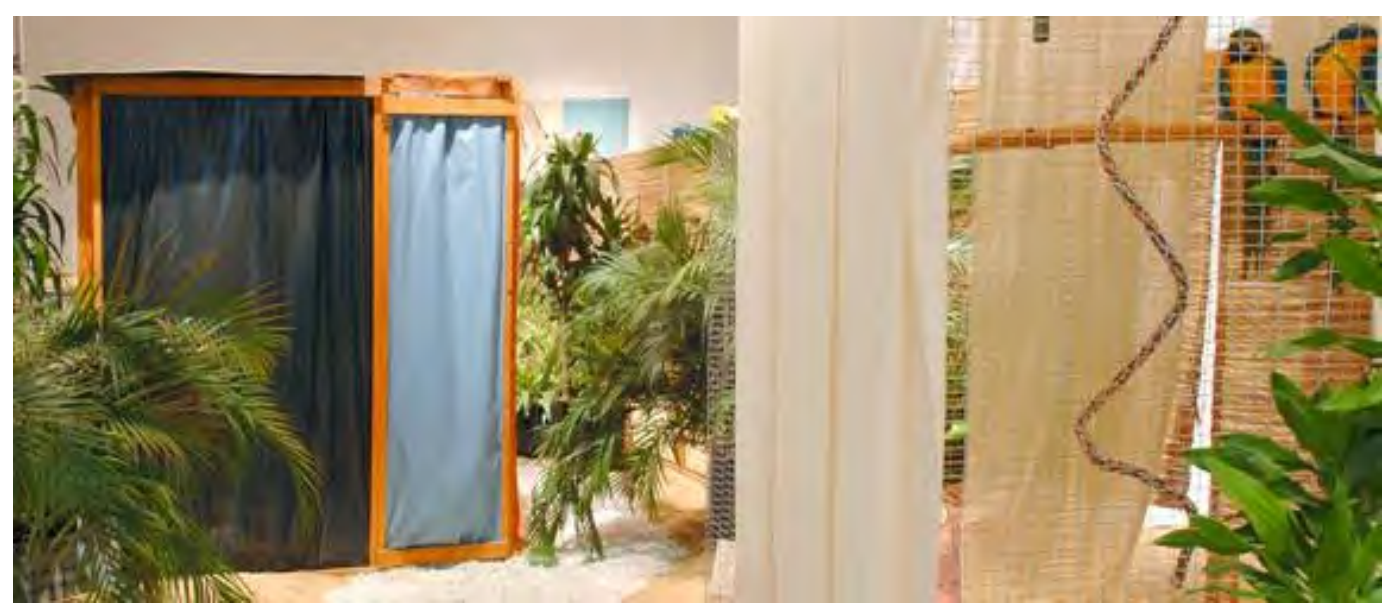

82. Hélio Oiticica, Tropicália, 1967. (montagem no MCA Chicago, EUA). A obra consiste em dois Penetráveis PN2 (1966) - Pureza é um mito - e PN3 (1966-67) Imagético, mais plantas, araras, areia, poemas-objeto, parangolés e um aparelho de televisão. Esta obra-labirinto, sua arte ambiental, foi exposta na Mostra Nova Objetividade Brasileira no MAM-RJ, em 1967)

Tropicália parece ficar no limiar do que é representativo do Brasil, do Rio de Janeiro ou das favelas.

\footnotetext{
152 FAVARETTO, Celso. 1992, p. 139.

153 JACQUES, 2003, p. 81. A autora cita Hélio Oiticica que referia-se à Tropicália "como a obra mais antropofágica da arte brasileira."

${ }^{154}$ OITICICA apud FAVARETTO, 1996, p.138.

155 Ibidem, p.139.
} 

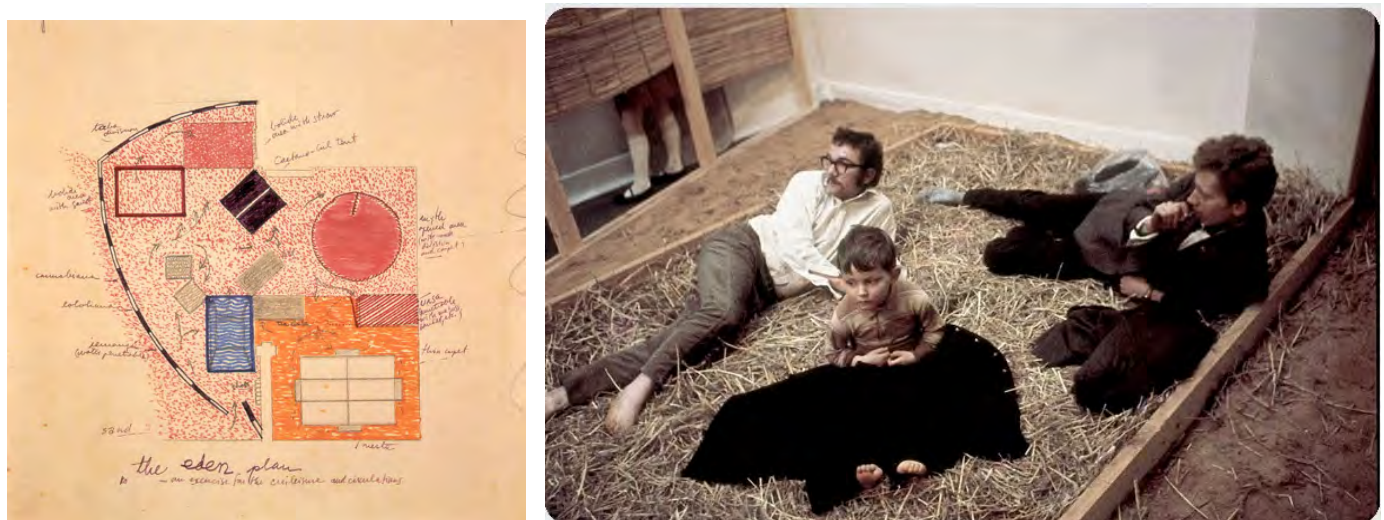

83. Hélio Oiticica, Éden, 1969 (projeto) e Éden, 1969. Galeria Whitechapel Gallery, Londres.

É também com Magic Square que podemos tecer reflexões sobre como a arte contemporânea brasileira foi gradualmente referindo-se à paisagem, dos aspectos estéticos até sua produção, e chegando a incluir a experiência da paisagem. Relevante sobre esta obra é que a "praça mágica" também não seria elaborada para lugares específicos (não é uma obra site-specific), pois o artista projetava-a em maquete para depois adequá-la aos lugares. Neles, a paisagem circundante, a luz, o uso público dos espaços urbanos seriam incorporados posteriormente à obra.

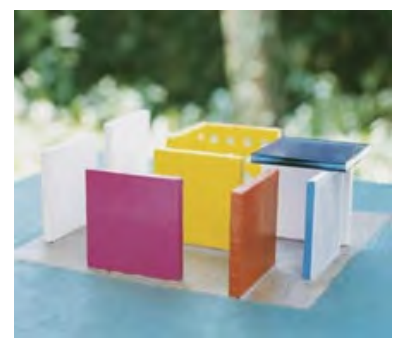

84. Hélio Oiticica, Maquete Magic Square, 1978.

85. Helio Oiticica. Magic Square \# 5, DeLuxe, 1977. Inhotim.

Brumadinho, MG.

(Fotos: arquivo pessoal, 2011).

11 placas de $5 \mathrm{~m} \times 5 \mathrm{~m}$ de cores primárias e branco.

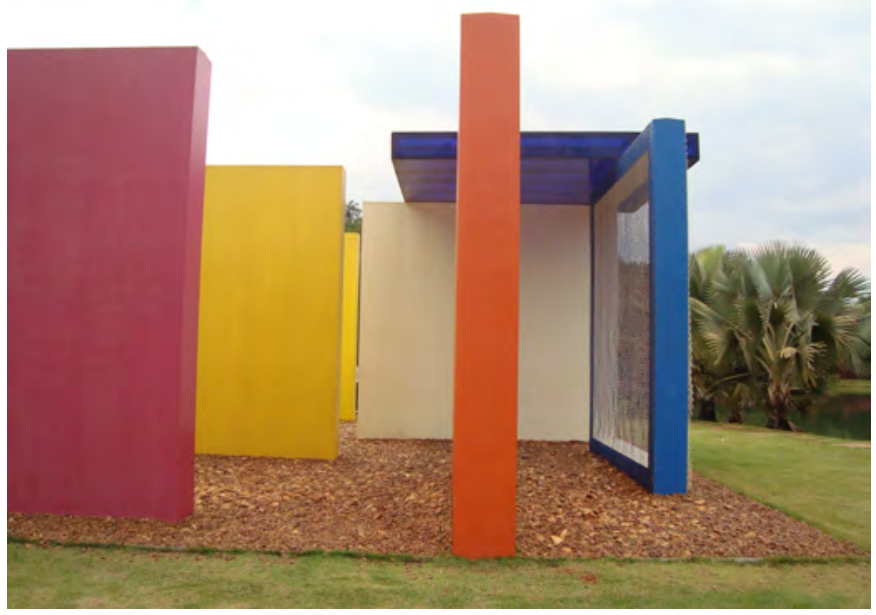



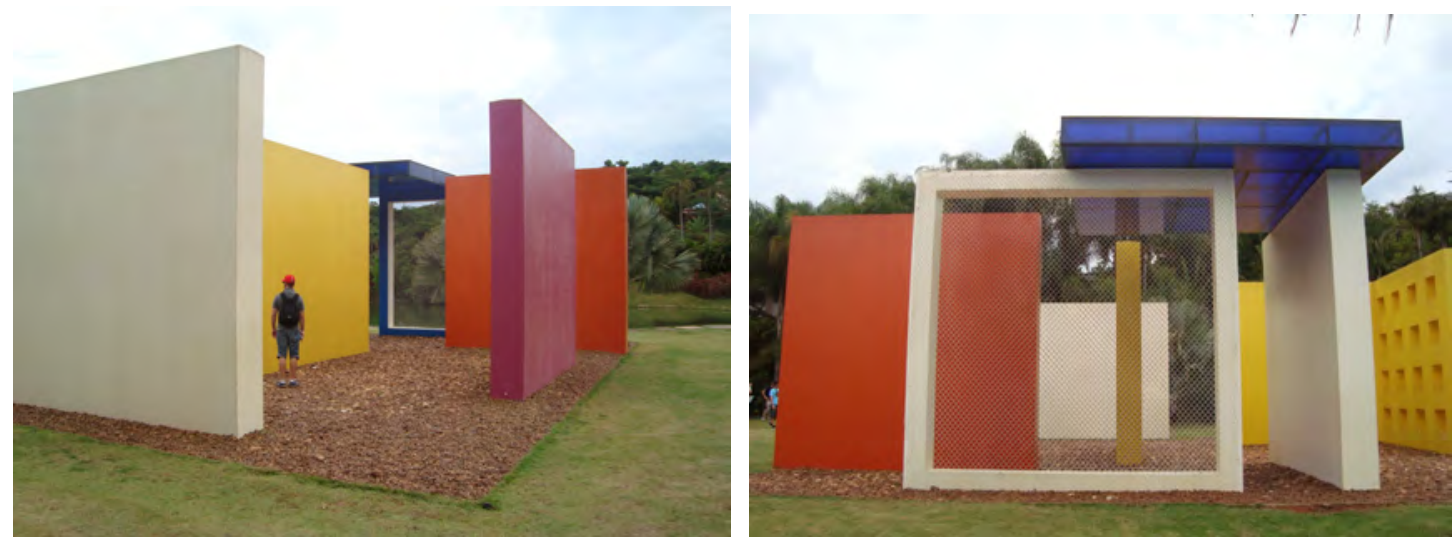

(85). Helio Oiticica. Magic Square \# 5, De Luxe, 1977. Inhotim. Brumadinho, MG.

(Fotos: arquivo pessoal).

Krajcberg e Oiticica são, provavelmente, os artistas contemporâneos que mais questionaram os modos de produção e as heranças de nossas paisagens. Ambos corajosamente avançaram paisagens a dentro. Em contrapartida, veremos que as obras mais recentes - como alguns exemplos de Fronteiras e Margem - parecem recuar em relação à paisagem, abarcando-a com ressalvas e ambiguidades. Por último, ao aproximarmos as obras dos dois artistas, é importante não reduzirmos a paisagem de Krajcberg a "natural" e a de Oiticica a "urbana". Vivemos num período em que "a natureza não está mais além dos muros da cidade" ${ }^{156}$. Estas se expandem e se interceptam, o não-urbano é também construído em campos industrializados e em rodovias, seus elementos naturais também estão presentes nas cidades, mesmo que ocultos.

\subsubsection{Iniciativas no Brasil: Fronteiras, Bienal do Mercosul, Quase Líquido}

\section{e Margem.}

Uma arte ligada às questões da paisagem no Brasil vai-se tornando mais nítida, a partir dos anos 1990, abordando, desde então, a qualidade urbana e ambiental. Por esta arte situar-se nos limites do urbano, ela vai ao encontro de uma outra questão: a dos espaços públicos.

\footnotetext{
156 “[...] as cidades não tem mais muros, estendem-se em desesperadores labirintos de cimento, desfiam-se nas sórdidas periferias de barracos e, para lá da cidade, ainda é cidade, a cidade das auto-estradas e dos distribuidores automáticos, dos campos cultivados industrialmente. E mesmo que algum pedaço de natureza sobrevivesse, escapando da especulação imobiliária ou da indústria turística, não o veríamos, porque o atravessaríamos a 200 quilômetros por hora de automóvel, ou o sobrevoaríamos a jato" (ARGAN, Giulio C., História da Arte como História da Cidade. São Paulo: Martins Fontes, 1993, p. 222)
} 
Por isso, Salzstein ${ }^{157}$ ao apresentar o projeto Fronteiras, começa traçando a condição frágil da arte brasileira em espaços públicos urbanos, analisa a restrita e tímida produção da arte pública no Brasil, que advém do histórico de formação destes espaços. A autora explica que, já na década de 1950, esta arte se caracterizava "com certa dose de reserva e ambiguidade", refletindo uma resistência ao "entorno mordente e degradado da metrópole contemporânea" e atrela tal questão a uma cultura de público ainda em desenvolvimento.

Tal processo atribulado [da implantação das obras de Fronteiras], além de compor um percurso de reflexões e práticas que permitem afinar a compreensão dos trabalhos, decerto remete, em alguma medida ao histórico alheamento de nossas cidades em relação à presença da arte e, em última instância, à tímida cultura "pública" do meio artístico brasileiro. ${ }^{158}$

A arte contemporânea da paisagem é também pública por ocupar “o espaço da vida" ${ }^{159}$. Pallamin ${ }^{160},(1994)$ ao analisar a arte pública contemporânea, comenta que esta filiase historicamente à escultura ambiental da Land Art, não devendo, contudo, ser confundida com ela. Apesar das tangências entre ambas as categorias da arte, esta dissertação não adentra na especificidade da Arte Pública contemporânea, e tampouco na ampla discussão levantada pelos significados de espaços público urbanos. ${ }^{161}$ Contudo, é importante situarmos que a nossa arte ligada às questões da paisagem lida com as mesmas limitações e condicionantes que produzem nossos espaços públicos urbanos.

Leite (1998), traçando um histórico do espaço público nas cidades brasileiras, expõe como este foi sendo minado em sua potencialidade de lugar significativo do cotidiano e de convívio (e, por conseguinte, para uma arte ligada à paisagem).

Pressionado [o espaço público] ora por um, ora por outro grupo social e deixado à sua própria sorte pelo poder público, que dele não se ocupa a não ser para intervir, em geral pesadamente, quando os conflitos sociais se tornam agudos, esse espaço de domínio coletivo perde completamente sua função de apontar alternativas para o futuro. Não sendo a ele atribuída nenhuma outra função que não a de passagem, de trânsito entre lugares da cidade, retira-se dele qualquer

\footnotetext{
${ }^{157}$ SALZSTEIN, 2005, p. 25.

158 Ibidem, p. 16.

159 Ibidem, p. 24."[...] a arte no 'espaço da vida' que não outro senão a superfície da cidade[...]".

160 PALlamiN, Vera M. Arte Urbana: Aspectos Contemporâneos. Revista Sinopses, São Paulo, n. 22, p. 2432, dez. 1994.

161 As obras de Carmela Gross, Waltércio Caldas e Nuno Ramos questionaram mais diretamente a necessidade de estarem em espaço público (premissa do Itaú Cultural para Fronteiras) e o significado desta premissa em municípios ou regiões de fronteira ou de usos esparsos e pouco vivenciados, como áreas de aglutinação.
} 
possibilidade de deflagrar processos de contestação do estabelecido, indispensáveis para o trabalho do imaginário no projeto. ${ }^{162}$

Se os espaços públicos ajardinados de nossas cidades começaram a ser gradeados na década de 1970 - período em que a arte, em diversos países, ganha as ruas nas chamadas intervenções urbanas, período em que floresce a Land Art -, então nossa arte contemporânea da paisagem nasce a partir de contradições, no enfrentamento da indiferença que habita tais espaços.

“A urbanização e a presença da obra escultórica em nossa capital é um fenômeno bastante recente, mesmo comparando com outras cidades do chamado Novo Mundo."163 É neste contexto que a arte contemporânea brasileira da paisagem tem se desenvolvido de modo esparso, com raro apoio de instituições em conjunto com órgãos públicos que, pouco entrosados, não levam adiante projetos em escala urbana ou ambiental, e em algumas iniciativas individuais. Questões da administração pública constituem também a arte contemporânea da paisagem, pois esta ocupa ruas, praças até áreas ermas da fronteira continental. Em suma, a obra contemporânea ligada diretamente à paisagem constrói-se onde há brechas, em meio ao adensamento urbano, ou onde há possibilidade de ocupação do solo. E frente à impossibilidade destas brechas, ela constrói-se efêmera.

Duas exposições são também relevantes na investigação deste trabalho e contrastam quanto às "brechas" encontradas em suas paisagens: Quase Líquido (2008), às margens do Tietê, em São Paulo, cujas obras - em sua maioria - se realizaram dentro da galeria; e a $\mathbf{5}^{\boldsymbol{a}}$ Bienal do Mercosul (2005), cujas obras implantadas na margem do Guaíba constituem um acervo permanente de arte pública.

Antes de Margem (2009-2010), a exposição Quase Líquido - também parte de um evento multidisciplinar promovido pelo Itaú Cultural - propôs aproximar a arte dos rios urbanos, em específico o Rio Tietê, no trecho central da cidade de São Paulo, entre março e maio de 2008. Paralelamente às obras, foi promovido um debate sobre meio ambiente e vida urbana, a partir da ideia de modernidade líquida, de Zygmunt Bauman.

$\mathrm{Na}$ apresentação da exposição, fez-se uma analogia entre a indefinição do estado físico da água do Tietê - gelatinoso, quase sólido - com a indefinição que "simboliza também a condição da contemporaneidade, marcada pela fluidez sempre a ponto de se modificar".

\footnotetext{
162 LEITE, 1998, p. 84.

163 AMARAL, 1998, p. 47. 
Ainda segundo o curador, "o Tietê é um símbolo do nosso estágio de modernização"164. Nossa modernidade não seria propriamente "líquida", mas quase, pois lidamos com as intensas contradições como um dos piores trânsitos viários do mundo e um dos mais intensos tráfegos de helicópteros. Contradições que advém de nosso processo particular de modernização.

Dos catorze artistas participantes desta exposição, dois intervieram diretamente no rio. Pets, de Eduardo Srur - vinte garrafas PET de 3 metros de diâmetro e 10 metros de comprimento dispostas em uma extensão de 1,5 quilômetros - podia ser também visitada por barco. Posteriormente, as Pets recicláveis se transformaram em mochilas escolares, demonstrando uma convergência de ações da arte com outros setores da cultura. Segundo Srur, "instalar garrafas gigantes em um dos rios mais poluídos do mundo é uma forma de convocar todos para o problema e nos tirar da posição de irresponsabilidade. É uma provocação política"165.


86. Eduardo Srur. Pets. Margem Rio Tietê, São Paulo. Março a maio de 2008. (Fonte: < http://eduardosrur.tumblr.com/post/807140939/pets. Acesso em: 05/12/2012)

O grafiteiro Zezão apresentou para Quase Líquido o vídeo Suco Gástrico, mostrando como realiza seus graffiti de "ondas" azuis, presentes em canais de escoamento de águas pluviais, esgotos e bueiros da capital paulista. Para ele: "a cidade é como um corpo humano gigante e doente". Em relação à paisagem, sua produção é singular, pois foca naquilo que é quase invisível: os fluxos subterrâneos. Pelo mesmo desenho que emerge de tempos em tempos dos dutos e galerias, lemos como uma charada (traçando uma linha imaginária) o seu percurso.

\footnotetext{
164 ALVES, Cauê curador da exposição Quase Líquido. Itaú Cultural, 2009. (Disponível em: $<$ http://www.itaucultural.org.br/index.cfm?cd_pagina=2716\&cd_noticia=6223>. Acesso em 05 dez. 2012).

${ }^{165}$ Idem.
} 

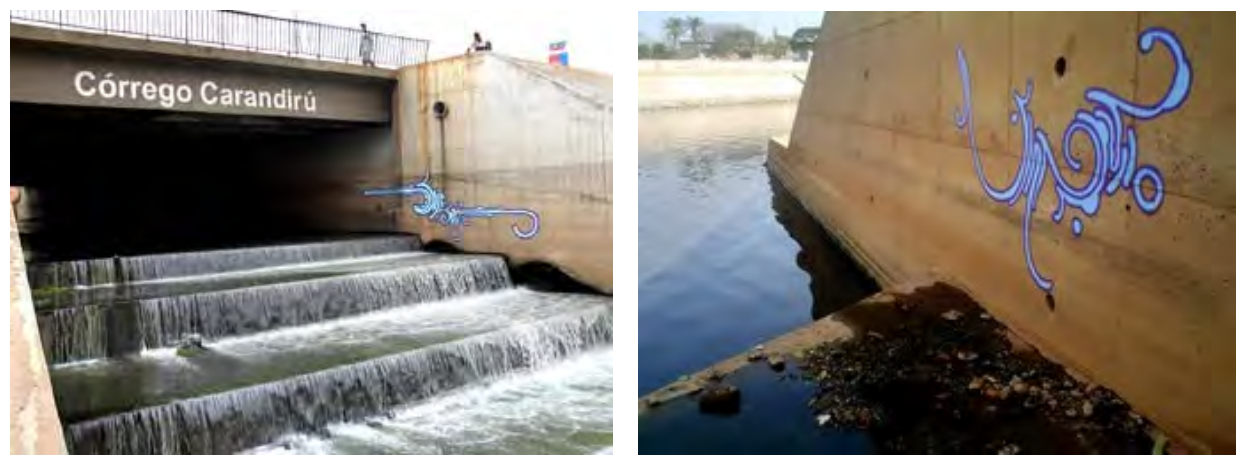

87. Zezão, Suco Gástrico, 2008.

(Fonte: http://artescienciastecnologias.wordpress.com/category/invencao/ Acesso em 09 dez. 2012 e http://www.cremesp.org.br/?siteAcao=Revista\&id=366)

Exemplo bastante significativo da arte contemporânea da paisagem no Brasil, ligada aos aspectos formais e à dinâmica cultural do seu lugar e entorno, foi a $5^{\boldsymbol{a}}$ Bienal do $\mathbf{M e r c o s u l}$, em Porto Alegre, 2005. O vetor Transformações do Espaço Público ${ }^{166}$ propôs doar à cidade um acervo permanente de obras na orla do Lago Guaíba, o que foi possível devido à convergência entre os interesses político-econômicos e os da arte. As obras situam-se em uma paisagem fortemente simbólica, o que as enraíza no lugar ou simplesmente torna sua relação com a paisagem mais vivenciada. Assim também, ao se inserirem em uma paisagem de identificação afetiva, as obras tornam-se simbólicas.

Totalmente voltado no sentido Oeste Sudoeste, o local tem como característica marcante o fato de ser privilegiado palco da efeméride que consagra a cidade: $\mathrm{o}$ pôr-do-sol do Guaíba. Essa talvez tenha sido uma das características mais relevantes do local que chamou a atenção dos artistas do vetor. ${ }^{167}$
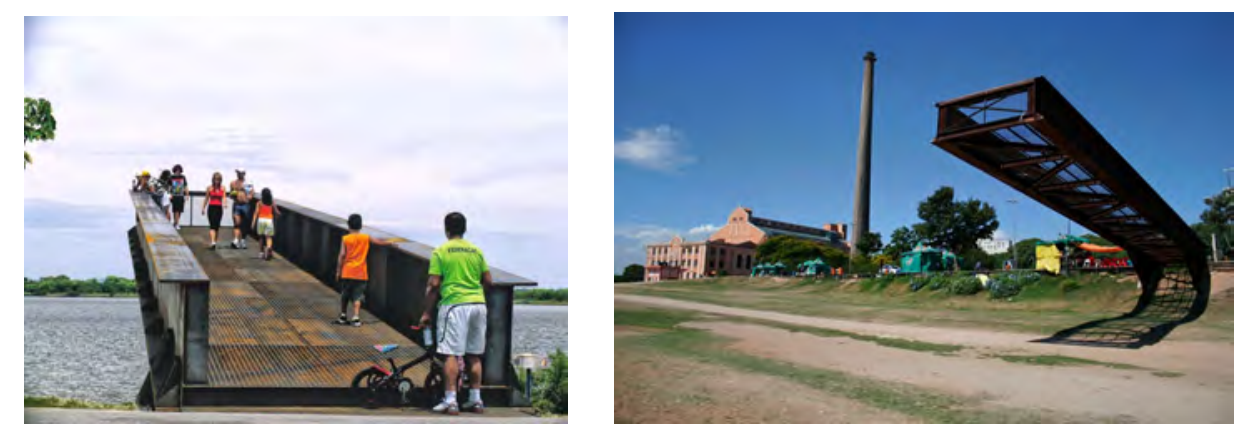

88. José Resende. Olhos Atentos. 5 $5^{\underline{a}}$ Bienal do Mercosul. Orla do Guaíba, Porto Alegre, 2005

\footnotetext{
${ }^{166}$ ALVES, José Francisco. Histórias da Arte e do Espaço: Transformações do espaço público.: Catálogo, Porto Alegre, Fundação Bienal de Artes Visuais do Mercosul, 2006. Catálogo integrante da 5a Bienal do Mercosul, apresentou quatro vetores discutindo a relação entre arte e espaço: Da escultura à instalação; Transformações do espaço público; Direções no novo espaço; A persistência da pintura; e o vetor especial Amílcar de Castro.
}

167 Ibidem. 


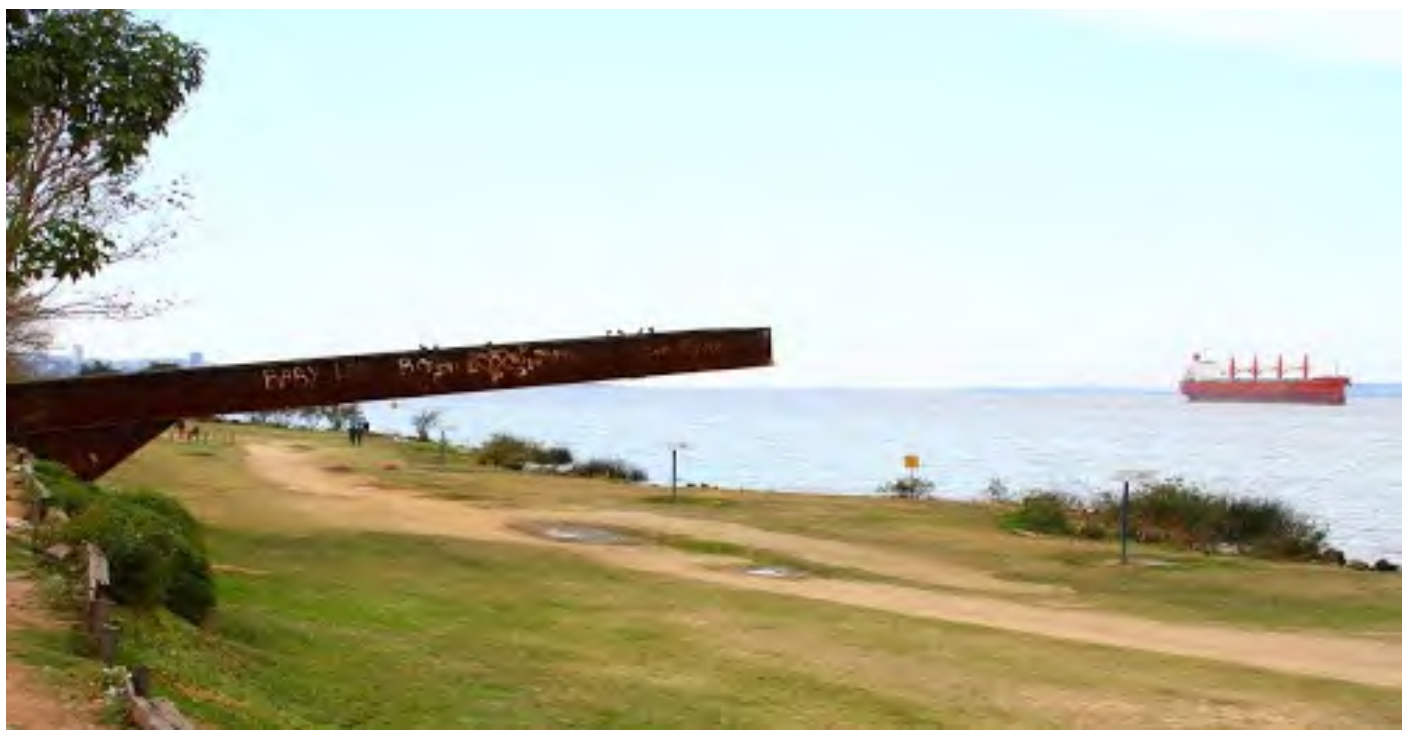

(88). José Resende. Olhos Atentos. 5ª Bienal do Mercosul. Orla do Guaíba, Porto Alegre, 2005. Aço corten.

(Fonte imagem acima e pág. anterior: José Francisco Alves. A especificidade da Arte Pública da 5aㅗ Bienal do Mercosul - Porto Alegre, 2011)

89. Após ser interditada, a população solicitou a restauração da obra. Este é um forte indício da arte em uma paisagem cujos usos $e$ significados estão vivos, possibilitando o desenvolvimento da arte da paisagem que ultrapassa a condição de "objeto inserido" na mesma.

(Fonte:

http://www.public.art.br/wordp ress/wp-

content/uploads/Prefeito-

Fortunati-ZH-22-12-2011.jpg)

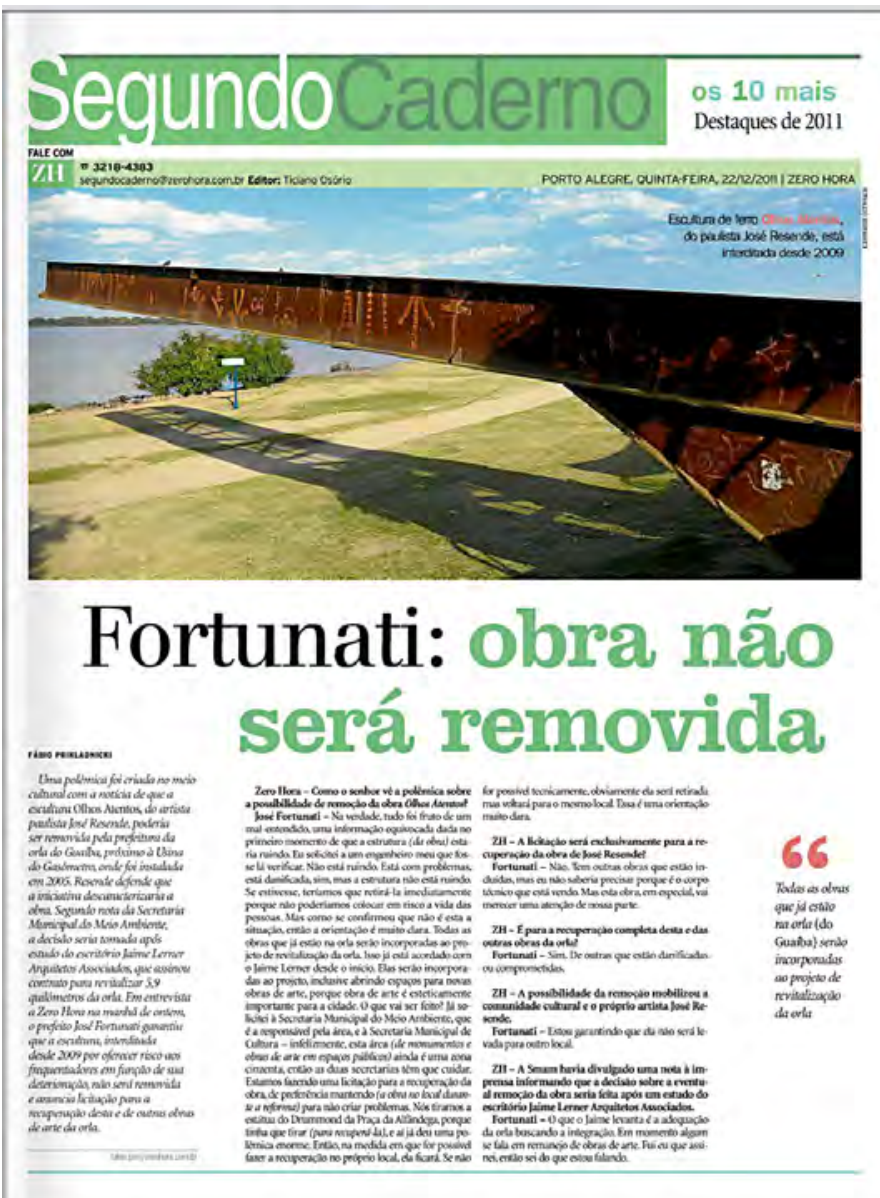


Segundo Alves $(2006)^{168}$, é na relação entre o olhar, a paisagem e a obra que resulta no fenômeno artístico de Espelho Rápido, de Waltércio Caldas, que pode ser vista da avenida, em um plano superior com seus movimentos rápidos. Sobre Paisagem, de Mauro Fuke, o curador observa que a obra dá vazão a usos lúdicos em um lugar "bucólico" da orla, chamado prainha, onde se ouve o som das pequenas ondas.

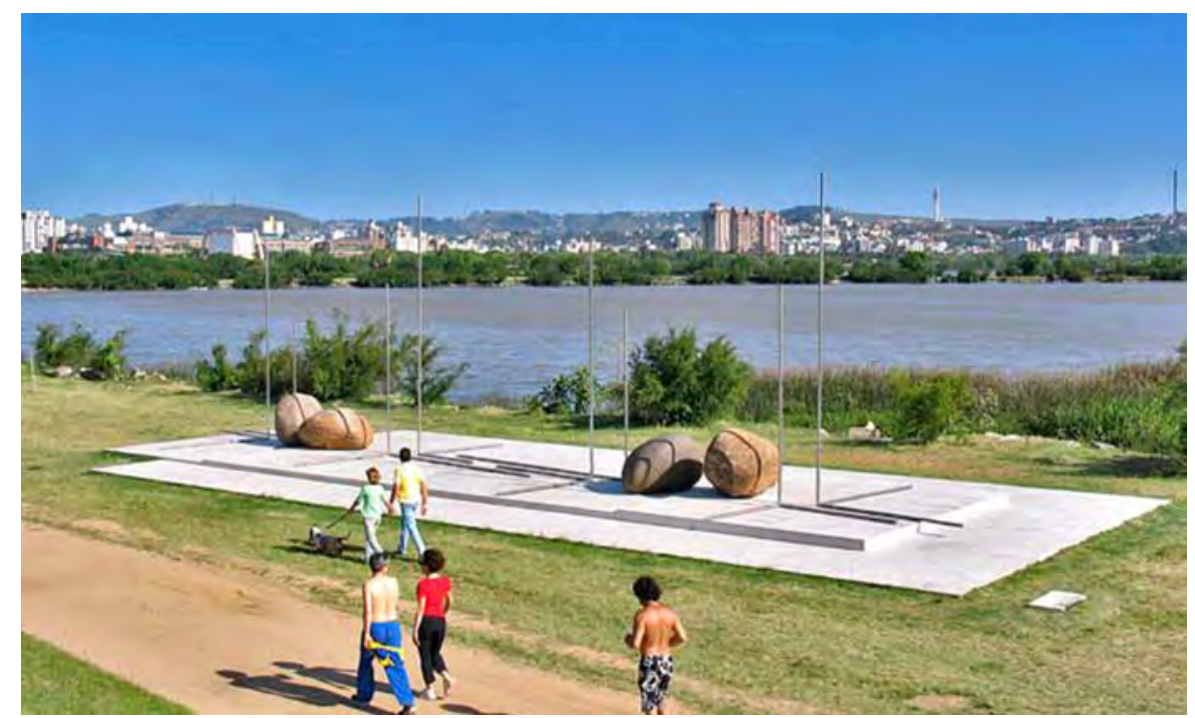

90. Waltércio Caldas. Espelho Rápido, 2005. Plataforma de granito, aço inoxidável, matacões de granito. (Fonte: José Francisco Alves de Almeida. A especificidade da Arte Pública da $5^{2}$ Bienal do Mercosul Porto Alegre, 2011)

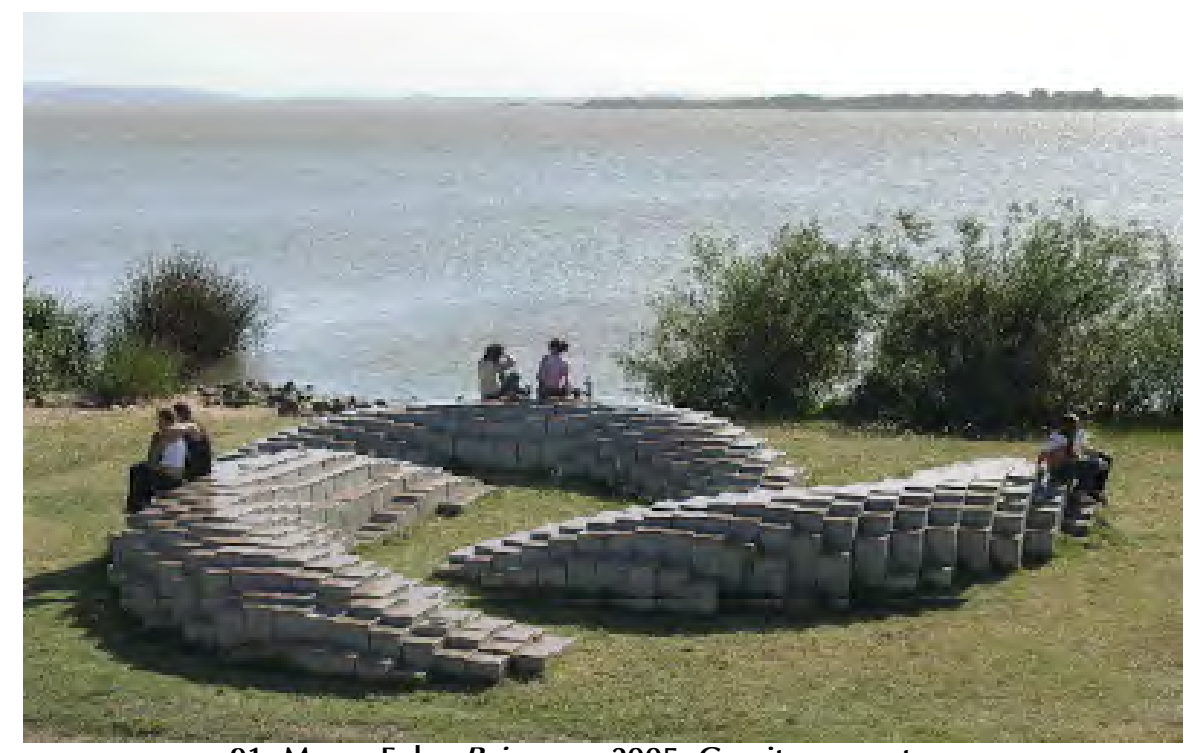

91. Mauro Fuke. Paisagem, 2005. Granito rosa, aterro.

(Fonte: < http://mauro-fuke.blogspot.com.br/2007_10_01_archive.html>) 
O artista gaúcho Mauro Fuke sintetiza que esta obra "trata da ação humana na paisagem". Ele recriou uma topografia de morros em uma área de aterro e inseriu blocos de granito que constituem um equipamento urbano para que as pessoas tenham contato "com a paisagem urbana e com a paisagem para além do Guaíba" ${ }^{\text {169 }}$, um pretexto a mais para se aproximarem do rio.

Com a mesma proposta de uma obra como objeto urbano que adquire usos e, com isso, significados, Carmela Gross criou Cascata. Como veremos em Fronteiras (1998-2001), a artista tem como princípio a arte atrelada aos usos sociais e aos espaços públicos que qualificam a paisagem. Segundo Alves ${ }^{170}$ (2006), os degraus que compõem uma "escadaria de ritmo desconcertante", logo, serviram de assento para as pessoas tomarem chimarrão, e contemplarem o pôr-do-sol do Guaíba.

92. Carmela Gross. Cascata, 2005 Concreto e Ferro. Aproximadamente $1.600 \mathrm{~m}^{2}$.

(Fonte: www. carmelagross.com.br. Acesso em dez. 2012)
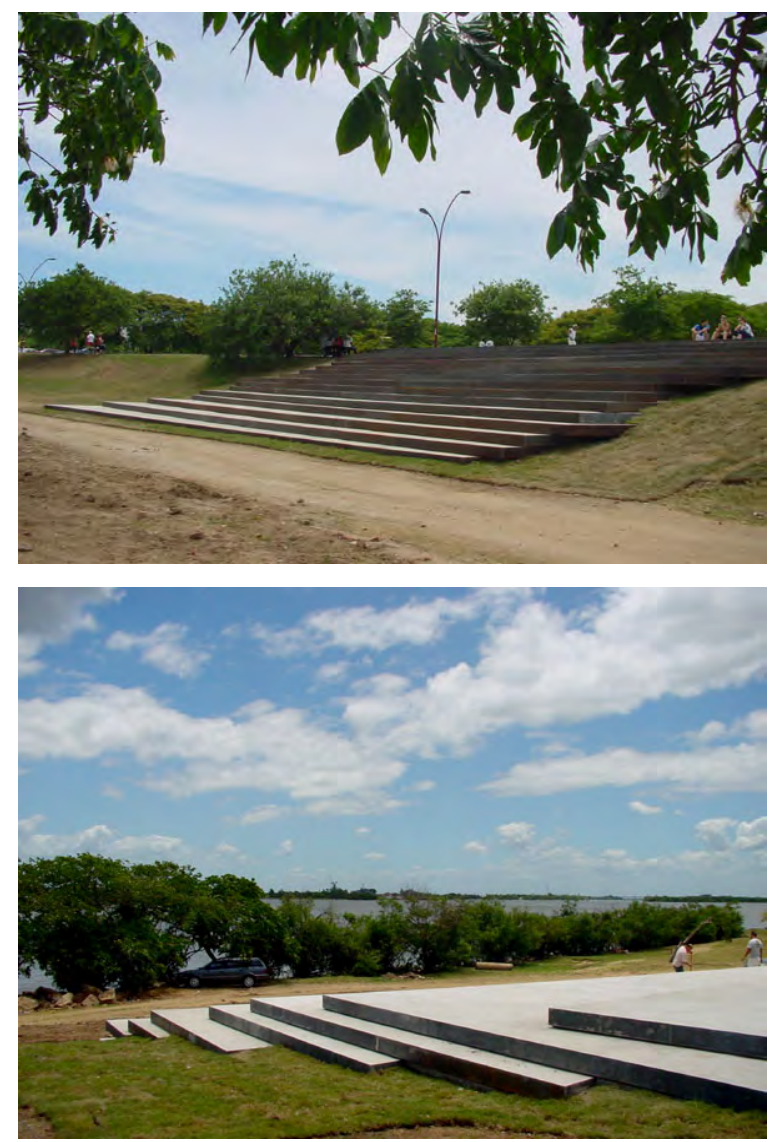

169 ALVES, José Francisco. A especificidade da Arte Pública na 5a Bienal do Mercosul. Tese de Doutoramento, Instituto de Artes, Porto Alegre: UFRGS, 2011, p. 110.

170 ALVES, José Francisco. Histórias da Arte e do Espaço: Transformações do espaço público: Catálogo, Porto Alegre, Fundação Bienal de Artes Visuais do Mercosul, 2006, p. 46. (Catálogo integrante da $5^{a}$ Bienal do Mercosul, Porto Alegre, 2005) 
A paisagem está em constantes transformações e as obras da arte da paisagem, caso sejam permanentes, atravessam intempéries, vandalismo, a passagem do tempo e recebem os interesses sociais que lhes atribuem ou retiram significados e usos. A obra que se liga à paisagem adequa-se às suas características (à sua natureza) e pode indicar-nos novos olhares e novas perspectivas sobre ela.

Alguns artistas, em atividades isoladas, relacionam sua produção e reflexão com a paisagem, refletindo a estrutura social e seus valores. A arte da paisagem é múltipla em formas e enraíza-se nos lugares onde tanto a arte quanto a paisagem são significativas para a sociedade.

A paisagem, reflexo da relação circunstancial entre o homem e a natureza, pode ser vista como a tentativa de ordenar o entorno com base em uma imagem ideal. A forma pela qual a paisagem é projetada e construída reflete uma elaboração filosófica e cultural que resulta tanto da observação objetiva do ambiente, quanto da experiência individual ou coletiva com relação a ele. ${ }^{171}$

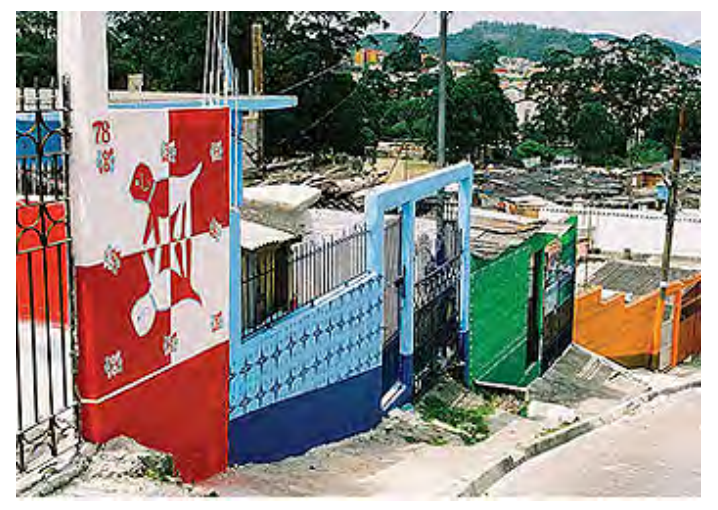

93. Mônica Nador. Projeto Paredes Pintura, em Bairro Jardim Santo André, 2009.

(Fonte:

http://www.flickr.com/photos/monicanador. Acessado em abr. 2011)

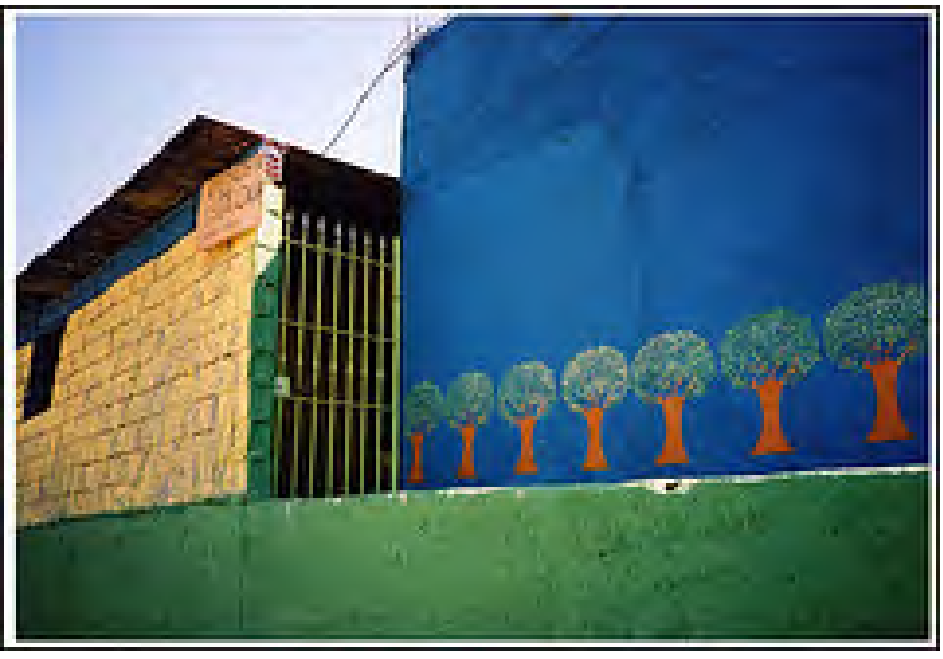

94. Mônica Nador. Jardim Miriam, São Paulo, 2002.

(Fonte:

http://www.flickr.com/phot os/monicanador. Acessado em abr. 2011)

\footnotetext{
${ }^{171}$ LEITE, 2006, p. 47.
} 


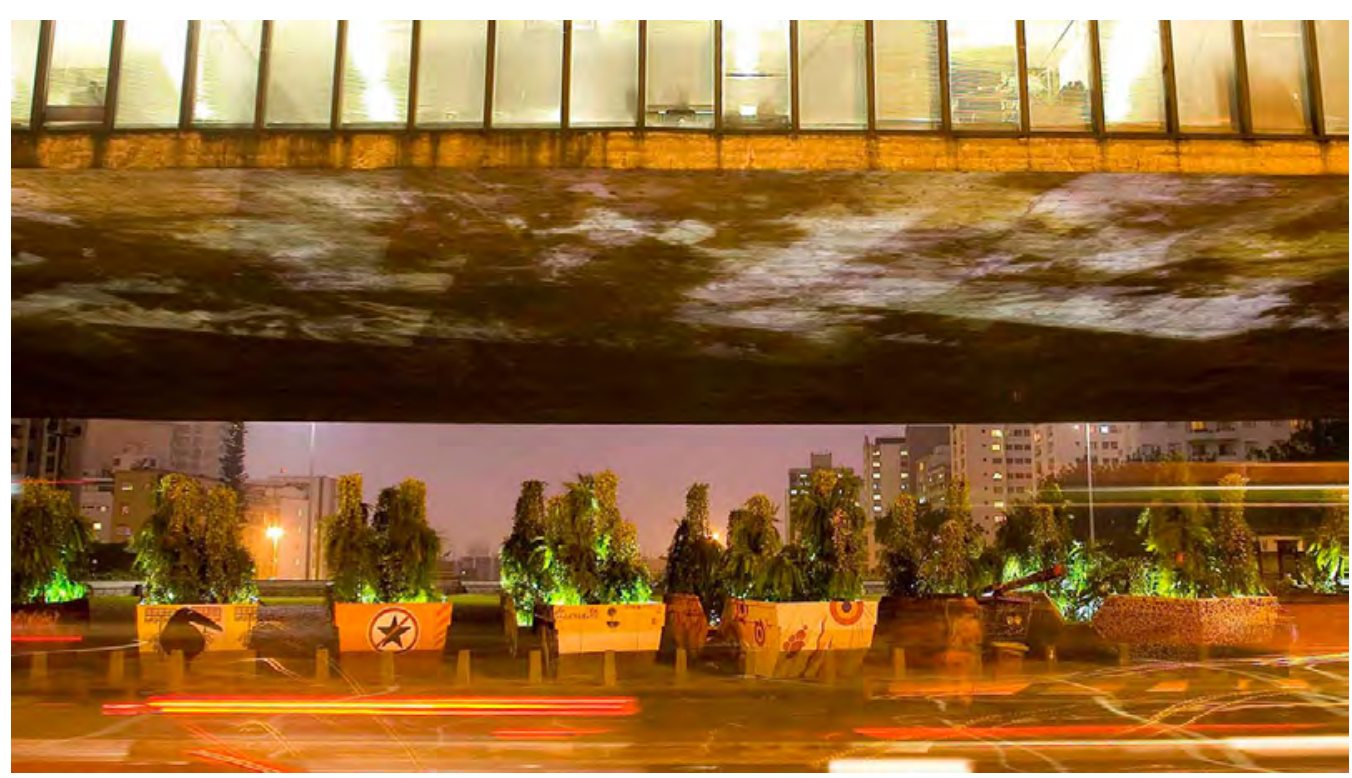

95. Bijari. Natureza Urbana \#2. Caçambas Verdes. Vão do MASP, 2008.

96. Marcos Chaves.

Eu só vendo a vista. Intervenção em relógios da cidade do Rio de Janeiro 1997.

(Fonte:

http://www.marcoschaves. net/instalacoes/avista/interv encao_pt.htm)
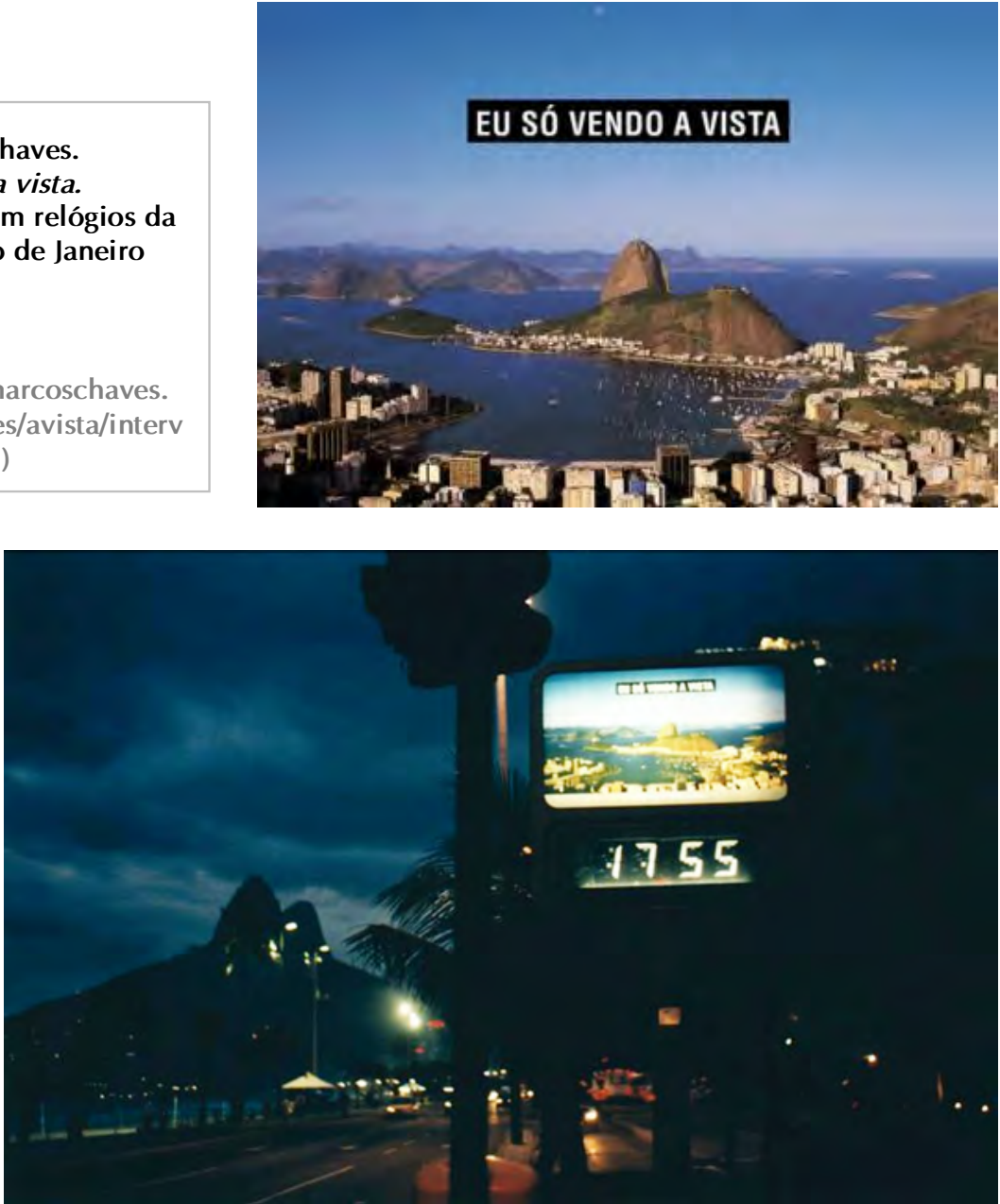

Avenida Paulista e Baía de Guanabara, paisagens simbólicas das cidades de São Paulo e Rio de Janeiro. 
Arte e paisagem. Estudo de obras contemporâneas brasileiras 

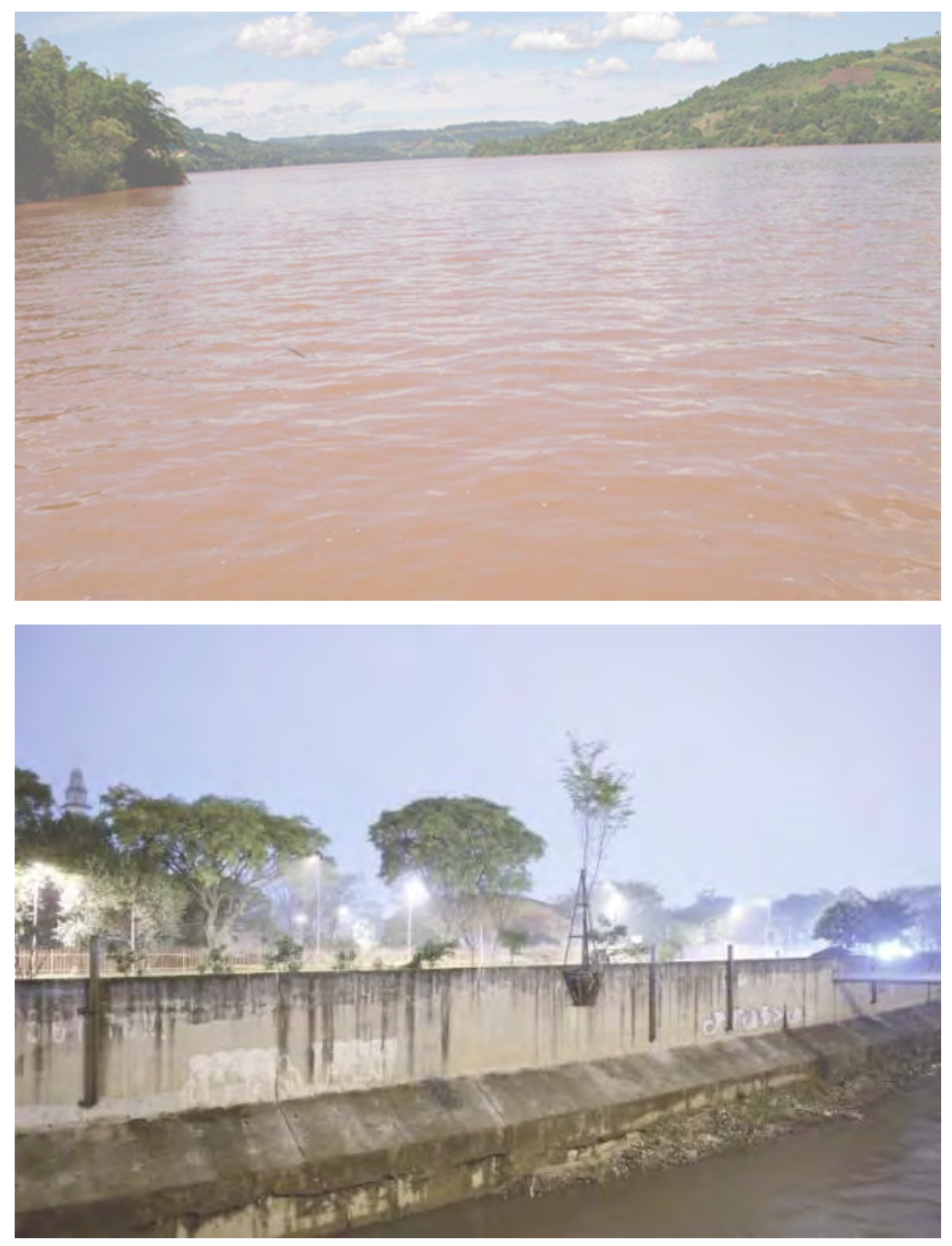

CAPÍTULO 03

Projetos Fronteiras (1998-2001) e Margem (2009-2010): lugares de transição. 
97. Página anterior: Imagem Goog/e Earth / Panoramio. Rio Uruguai, em Itapiranga, SC. Cidade próxima à obra Momento de Fronteira (2000), projeto Fronteiras (1998-2001)

abaixo

98. Hector Zamora, Errante (2010), Rio Tamanduateí, São Paulo. Obra implantada pelo projeto Margem (2009-2010). 
As exposições dos projetos Fronteiras (1998-2001) e Margem (2009-2010) envolveram a arte brasileira contemporânea diretamente com as questões da paisagem e se propuseram, a princípio, a atuar em escala nacional. A primeira teve como premissa "implantar, em espaços públicos e comunidades afastadas dos grandes polos culturais, ${ }^{276}$ obras que dialogariam com as referências geográficas da paisagem. Já a segunda relaciona a arte com os rios urbanos, tendo proposto intervir em rios de cinco bacias hidrográficas que influenciaram a formação e organização das grandes cidades brasileiras. Assim, a paisagem nesta exposição discute referências urbanas.

Pelos temas destas exposições, a paisagem se faz ver através do projeto de ocupação territorial e da interação entre sociedade e natureza, mais especificamente, de como a cidade se apropria de seus rios. ${ }^{277}$ Contudo, estes dois eixos não dão conta de abarcar a paisagem, cuja formação, além de incorporar diretrizes econômicas e políticas, também inclui as necessidades culturais e estéticas. ${ }^{278}$ São as obras que passam a evidenciar os aspectos estéticos (ou sua carência) e culturais da produção de nossas paisagens, cujo modelo reflete nossa interação com a natureza, interpretada como vastidão irrecorrível ou apropriada como recurso.

Independente de serem distantes ou centrais, as paisagens de Fronteiras e de Margem foram, na maior parte das vezes, tecnicamente produzidas: ${ }^{279}$ cumprem o papel de delimitação de território ou a necessidade de transporte, escoamento ou produção de energia. Uma vez que tais funções são remodeladas ao longo do tempo, adequando-se às novas necessidades, tais paisagens podem, então, se tornar obsoletas e ruírem diante de nossos olhos. A arte da paisagem, mesmo neste contexto, nos desperta para valores sociais, estéticos e simbólicos, que a mantém vívida.

276 ITAÚ CULTURAL. Texto de apresentação: Fronteiras. São Paulo, Rio de Janeiro: Itaú Cultural / Contracapa, 2005.

277 No release da obra Errante, de Margem (2010), o Itaú Cultural apresenta o debate "acerca da sustentabilidade, tanto em relação à água como recurso natural, quanto ao transporte fluvial como instrumento de integração e soberania nacional."

${ }^{278}$ LEITE, 2006, p. 81.

279 Ibidem, p.18. "Projetos que acompanham os ritmos natural e cultural de um lugar, que os ecoam, clarificam ou estendem, contribuem para o enraizamento social no tempo e no espaço, marcando a diferença entre a paisagem socialmente produzida e a paisagem tecnicamente produzida". Podemos entender que a land art trabalhou, na maior parte das vezes, com paisagens socialmente produzidas e, por isso, teve mais facilidade em integrar-se a elas. 
Fronteiras (1998-2001), para as artes plásticas, teve por fim a área de atuação reduzida à Região Sul. Margem (2009-10), após a implantação da primeira obra na cidade de São Paulo e da realização de palestras abertas ao público sobre a arte em relação aos rios urbanos, foi cancelada.

Considerando os títulos das exposições, os termos "fronteiras" e "margem" abordam o distante, o limítrofe (que pode pertencer a dois conjuntos e, neste sentido, é também ambíguo), assim como o que é deixado à deriva, aquilo que não pertence e está fora do conjunto. Indicam linhas ou, no mais, faixas territoriais ao longo de, e a linha nos leva ao desenho - que é mais pensamento, projeto, intenção e menos o espaço experimentado. Analogamente, algumas das obras destas exposições abordam a paisagem mais como uma ideia, imagem, ou em suas narrativas, e menos como espaço produzido, vivo. Através das obras de ambas as exposições, podemos nos aprofundar nos significados das nossas paisagens, que ficaram, de certo modo, à deriva da pauta artística; assim como nos significados desta arte pensada para o lado de fora dos museus e galerias." 280

As paisagens onde se inseriram as obras de Fronteiras pouco haviam sido, até então, elaboradas ou abordadas pela arte (artializadas). Já a paisagem da São Paulo de Margem, embora tenha recebido olhares da arte - da pintura, da fotografia, da poesia, entre outros -, parece ser tão opaca e compacta, que pouco permite que a arte adentre: a obra parece não artializar in visu ou in situ; ${ }^{281}$ é a paisagem de São Paulo que se infiltra na obra.

A partir das obras de Fronteiras e da obra implantada por Margem, podemos nos perguntar se estamos diante de paisagens em formação ou em desenvolvimento, ou ainda se estamos em paisagens já irreversíveis ou obsoletas. O projeto - seja da paisagem, seja da arte ou da arquitetura - que considera os aspectos estéticos e simbólicos do lugar e do entorno, mesmo quando suas diretrizes continuam sendo as de interesses econômicos rápidos, é um meio possível de transformação (mesmo que breve ou sutil) como a lançada por estas obras.

\footnotetext{
280 SALZSTEIN, 2005, p. 24.

${ }^{281}$ ROGER, 1999.
} 


\subsection{Fronteiras nas Artes Plásticas (1998-2001): seu contexto no projeto homônimo multidisciplinar.}

É importante compreender primeiramente o eixo curatorial do projeto multidisciplinar Fronteiras que, além das artes plásticas, incluiu um Núcleo de Pesquisas sobre $o$ Território Brasileiro ${ }^{282}$ e exposições nas linguagens fotográfica e audiovisual. O projeto, como um todo, se propôs a "desvendar as cicatrizes geográficas, os limites histórico-culturais, revelados através do imaginário e do registro documental das regiões fronteiriças do país."283 Nele, a exposição Fronteiras (1998-2001) reuniu esculturas e intervenções de nove artistas plásticos, em cidades da fronteira entre Brasil e os países do Mercosul - Argentina, Paraguai e Uruguai.

De acordo com a apresentação na publicação Fronteiras (2005), a proposta para as artes plásticas contemplava a implantação de "obras da arte contemporânea em espaços públicos e comunidades afastadas dos grandes polos culturais", pretendendo-se evitar "a concentração excessiva de obras em uma ou outra região." Deste modo, propunha-se à ocupação da maior área possível, nesta faixa de fronteira, com obras que, compondo um acervo permanente, garantiriam "a visitação irrestrita do público". Mas a vastidão da fronteira, entre outras questões, já é apresentada como um fator impeditivo para tal visualização, que se faz possível, graças à publicação deste catálogo. Nele são apresentados o processo de criação e implantação das obras e entrevistas com os artistas. Tais premissas direcionaram estes artistas a trabalharem com a "escala ambiental,"284 o que, em um primeiro momento, aproxima as obras de Fronteiras com as da land art.

Como vimos no capítulo anterior, as paisagens das metrópoles brasileiras, desde meados dos anos 1960, servem de suporte para artistas que nelas têm atuado diretamente, e não por representação, incorporando seus elementos e dinâmica e refletindo sobre a sua formação. Mas podemos dizer que é com Fronteiras (1998-2001) que se exercita, pela primeira vez no país, a arte em estrita relação com paisagens além dos limites do urbano.

As metrópoles que compõem o circuito da arte são as mesmas que compõem os polos econômicos do país. Fronteiras é uma exposição pioneira por não se realizar nestes polos,

\footnotetext{
282 Ver o histórico da divisão territorial brasileira apresentada pelo núcleo em http://www.itaucultural.org.br/fronteiras/projeto/territorio/Divisao.htm.

283 RIBENBOIM, Ricardo. In: ITAÚ CULTURAL. Eixo Curatorial 98. São Paulo, Itaú Cultural, 1998.

284 SALZSTEIN, 2005, p. II
} 
evidenciando fragilidades e ambiguidades na ocupação de espaços públicos - por vezes nem tão urbanos e nem tão públicos - e na implantação de projetos em grande escala.

É pelo distanciamento do urbano que a natureza ganha relevo na apreciação e no discurso das primeiras obras da land art, por vezes como um retorno intencional a referenciais mais primordiais, ou, mais recentemente, acompanhada de questões ambientais. Do mesmo modo, em Fronteiras (1998-2001), vemos que os elementos naturais da paisagem assumem destaque, seja na concepção das obras, seja nas falas dos artistas, seja como elementos com os quais as obras dialogam mais intensamente. E a natureza, esteticamente se mostrando a um ser que a contempla provando sentimentos, é a paisagem, como expõe Ritter $(1963){ }^{285}$

Se por um lado autores como Argan (1993) contextualizam a arte como fenômeno urbano (pensamento compartilhado pela artista Carmela Gross ao explicar sua obra em Fronteiras), outros autores ${ }^{286}$ enxergam na arte da paisagem, a partir das primeiras obras da land art, afinidades e complementaridades entre arte e natureza, considerando que a obra, inserida no meio natural, a ele se integra em harmonia; como se arte e paisagem, ou certos elementos da natureza, estivessem em um continuum; ou arte e paisagem resultassem em um par dialético, em que a alteridade entre elas se mantém, e desta tensão de forças se formasse a obra.

Vimos que as interpretações e apropriações da natureza pela arte são amplamente discutidas na land art e na environmental art. Mesmo não podendo delimitar as obras de Fronteiras (1998-2001) ou mesmo de Margem (2009/2010) como land art, tampouco como exemplos de uma arte que levanta questões ambientais, podemos dizer que elas são indícios dos modos como a arte contemporânea nacional incorpora a natureza em seu discurso e sua experiência.

Algumas obras de Fronteiras não estão nesse continuum com os elementos da paisagem e, talvez por isso, parecem não pertencer àquelas paisagens. Como "corpos

\footnotetext{
285 RITTER, Joachim. Paisagem: função estética na sociedade moderna. Tradução francês-português: Vladimir Bartalini. Texto para o uso exclusivo na disciplina da pós-graduação da FAU AUP 5882 Paisagem e Arte - Intervenções contemporâneas (original em alemão de 1963, tradução para o francês em 1997).

286 BERLEANT, Arnold e CRAWFORD, Donald W. Vide Capítulo 1. 
estranhos, ${ }^{1287}$ ao invés de integrarem-se à paisagem as obras parecem descolar-se dela, ou até mesmo opor-se ao lugar e ao entorno.

Tal descolamento não implica numa maior evidência da obra, pois também pode concorrer para sua dissipação, ou seja, sua diluição no meio, quando então a obra parece perder seus nexos com "o lado de fora”. O fator que contribui ou não para esta adesão da obra $^{288}$ à paisagem é a dimensão cultural desta, que não é autoevidente, pois é formada por suas matrizes culturais. Deste modo, é buscando compreender esta dimensão que entenderemos melhor por que algumas obras de Fronteiras parecem ganhar força ou dissiparse na paisagem.

Ponto importante para este debate é considerar que o fato de a obra ser permanente não implica necessariamente sua adesão à paisagem - seus elementos, história e dinâmica. Mesmo obras efêmeras ${ }^{289}$ podem integrar-se e refletir efetivamente sobre as questões da produção da paisagem.

Em Fronteiras, analisaremos como as obras abordam, ressaltam, ou projetam os aspectos naturais e culturais da paisagem, sem, no entanto, tê-las como objetos autônomos: esta dimensão cultural torna-se parte integrante, seja no processo, seja no corpo das obras.

Vamos, então, inserir a exposição na proposta global do evento multidisciplinar homônimo para compreendermos as premissas com que lidaram as artes plásticas.

Em 1998, o Itaú Cultural organizou sua programação a partir de um eixo curatorial, cujo tema era territórios. O interesse estaria em "descobrir, conhecer, reconhecer e tomar posse de territórios geográficos, culturais e artísticos brasileiros." ${ }^{290}$ A partir deste tema, quatro

\footnotetext{
287 Três livros e meio, de Artur Barrio, Mesa de Nelson Félix, Minuano de Nuno Ramos e Momento de fronteira de Waltércio Caldas apresentam-se mais como "corpos estranhos" na paisagem. Suas materialidades, formas e/ou disposição no espaço não são aquelas já presentes na paisagem, causando estranhamento em relação ao lugar e entorno. Algumas das obras da land art que se integram à paisagem não adicionam materiais ou uma organização estranha à ela. Ver KASTNER; WALLIS, 1998, p. 45.
}

288 Exemplos de obras que são como "corpos estranhos" e, mesmo sendo efêmeras, adquirem força devido à dimensão cultural da paisagem presente na obra, em seu processo e discurso: Valley Curtain (197072), Running Fence (1972-76), dos artistas Christo e Jeanne-Claude.

289 Aproveitando os exemplos dos artistas acima citados, Valley Curtain, como uma obra efêmera, interveio na paisagem de rodovias da Califórnia, EUA, com o mesmo peso e medida das intervenções da engenharia que a modelaram. A obra dialoga diretamente com a paisagem dessas rodovias, que recortam colinas, assim como sua dimensão e recursos empregados são compatíveis com a escala da paisagem e com o seu processo de produção.

290 RIBENBOIM, Ricardo. In: ITAÚ CULTURAL, 1998. 
eventos (ou projetos) compostos por exposições, palestras e encontros foram organizados, a partir de assuntos correlatos: Viagens, Amazônicas, Fluxos Urbanos e, por último, Fronteiras.

Viagens, o primeiro destes eventos, abordou as expedições científicas e artísticas que até hoje perduram, "fascinadas pela imensidão e riquezas do país", com a proposta de "evidenciar a diversidade da cultura brasileira." Amazônicas pretendeu debater questões ambientais e culturais da região, como suas fronteiras e sua biodiversidade, considerando "o equilíbrio da paisagem humana e natural." Fluxos Urbanos focou a paisagem urbana, tendo como determinantes da sua formação os deslocamentos e fixações.

Por fim, a quarta ação cultural foi o evento multidisciplinar Fronteiras, que envolveu fotografia, vídeo, artes plásticas e a ação educativa com o núcleo de pesquisa em Formação do Território Brasileiro: Divisão Territorial do Brasil e Constituição das fronteiras externas do Brasil. ${ }^{291}$ Fronteiras, através das diferentes linguagens artísticas, propôs direcionar nosso olhar sobre os lugares de fronteira, a fim de conhecer suas identidades e contribuir para "o conhecimento do Brasil".

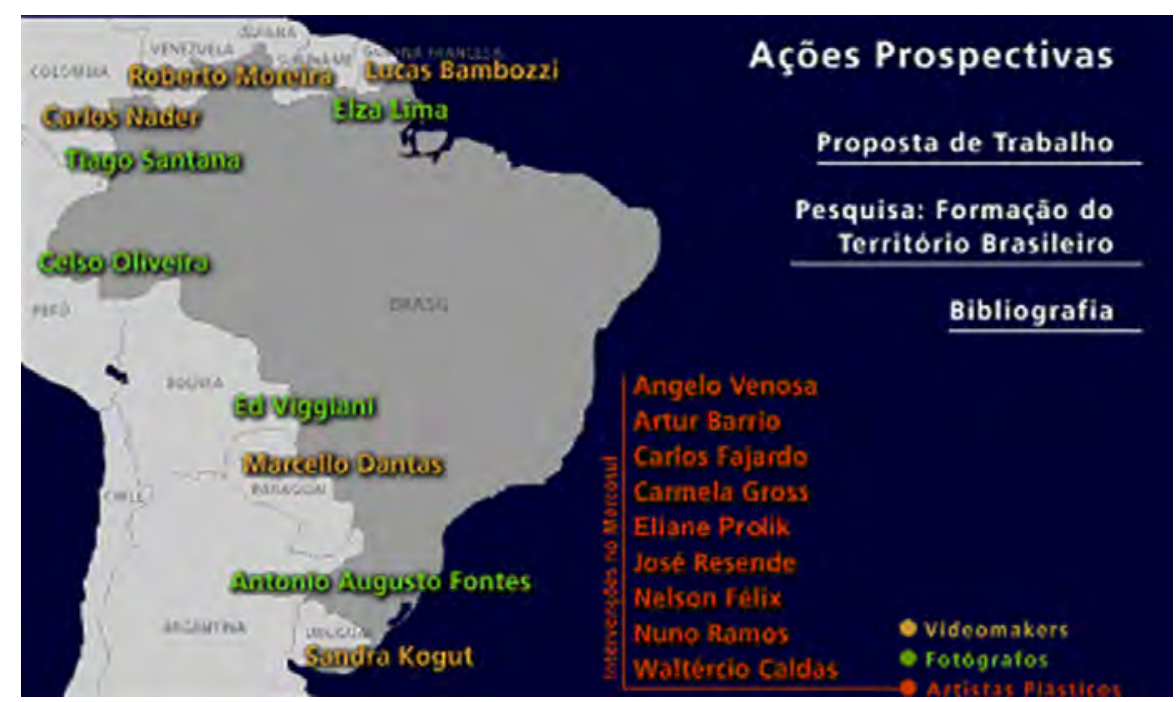

99. Apresentação do projeto multidisciplinar Fronteiras em sítio eletrônico do Itaú Cultural.

(Disponível em:<http://www.itaucultural.org.br/fronteiras/projeto/ proposta.htm> Acesso em: 20/05/2011)

291 "O Itaú Cultural afirma sua vocação institucional empenhada na contribuição para o conhecimento do Brasil, para a problematização de imagens de identidade nacional e para a abertura de possibilidades de elaboração dos valores culturais. [...] Para o evento Fronteiras, o Itaú Cultural mobilizou um grupo de fotógrafos e videomakers que viajaram pelas fronteiras do Brasil. Esses artistas registraram, construíram narrativas, interpretaram fatos e experiências. Integrando o projeto Fronteiras, durante o ano de 1999, nove artistas plásticos estarão executando obras em diferentes lugares das fronteiras do Brasil com os países do Mercosul." (RIBENBOIM, Ricardo. Projeto Fronteiras. Proposta de Trabalho. Disponível em:<http://www.itaucultural.org.br/fronteiras/projeto/proposta.htm> Acesso em: 20/05/2012, grifo nosso. 
A proposta de trabalho para vídeo, Viagens na Fronteira, registrou os percursos realizados por cinco videomakers em diferentes pontos da fronteira continental brasileira. Sem a pretensão de descrever as regiões visitadas, estes trabalhos oscilam entre o documentário e o poético e revelam "imagens de um Brasil pouco conhecido como também registram o impacto dessa descoberta na subjetividade dos realizadores. ${ }^{292}$ Foram trabalhadas as fronteiras com a Guiana, Guiana Francesa, Uruguai, Venezuela-Colômbia, Argentina e Paraguai.

Já em Fotografias Nas Fronteiras (1998), cinco fotógrafos registraram localidades da fronteira continental "em busca da vida nas fronteiras continentais e encontram - no sentido vernacular - um Brasil extremado onde culturas confinam e se amalgamam. ${ }^{293}$ Identificamos nas fotografias - que retratam cenas urbanas, ribeirinhas, rurais - o gênero da paisagem, já sedimentado pela pintura e recorrente na fotografia, desde meados do século XIX, quando era realizada especialmente por artistas estrangeiros "desbravadores". ${ }^{294}$ As fronteiras fotografadas são Rio Grande do Sul / Argentina / Uruguai, Paraná / Argentina / Paraguai, Acre / Peru / Bolívia, Rondônia / Bolívia e Amapá / Guiana Francesa.

Enquanto Amazônicas e Fluxos Urbanos abordam a paisagem natural, a humana e a urbana, o programa proposto para Fronteiras não faz uso do termo "paisagem" e aborda os espaços geográficos sistematizados: território e fronteira, enfatizando a ação de ocupação. ${ }^{295}$ Propunha-se que as obras se fixassem "como novos marcos geográficos" em "ações demarcatórias." 296 Mas foi através do trabalho dos nove artistas plásticos, que lidaram diretamente com os lugares e as condicionantes econômicas e culturais das localidades de

292 Ver em: <http://www.itaucultural.org.br/fronteiras/projeto/proposta.htm>.

293 Ibidem.

294 Podemos dizer que há uma tradição da paisagem na linguagem fotográfica no Brasil, a partir de meados do século XIX, quando se registram novas fronteiras - descobertas sociais e científicas - através das paisagens. Destacam-se os fotógrafos: Victor Frond, August Stahl, August Riedl, Albert Frisch, Marc Ferrez. No século XX, dão continuidade à fotografia de paisagens e tipos sociais, sedimentando um reconhecimento do que é brasileiro: Claude Lévi-Strauss (São Paulo, paisagens), Pierre Verger, Jean Manzon (índígenas), entre outros. Ver MIGLIACCIO, Luciano. In: FUNDAÇÃO BIENAL. Arte do Século XIX. Mostra do Redescobrimento. Brasil +500: Catálogo, São Paulo: Fundação Bienal, 2000, p. 48.

295 Ocupação é um tema recorrente no catálogo Eixo Curatorial 98. Em Amazônicas, estuda-se a ocupação dos grandes espaços ainda vazios e desafiadores da Região Norte do país e "a interferência que esse processo tem na imaginação, na cultura e no meio ambiente". Trazendo o olhar para o espaço urbano - em Fluxos - vemos o mesmo movimento de ocupação só que de forma acelerada: "casas são demolidas em um dia; no outro, os terrenos são ocupados por sem-teto; os muros remanescentes abrigam camadas superpostas de anúncios, de pichações. Tudo isso denota o incessante fluxo de ocupação."(grifo nosso)

296 ITAÚ CULTURAL. Texto de apresentação: Fronteiras. São Paulo, Rio de Janeiro: Itaú Cultural / Contra Capa, 2005. 
fronteira, que a paisagem - em suas diferentes acepções - seria elaborada e tornar-se-ia visível. A arte contemporânea da paisagem é menos um marco ou monumento e mais uma continuidade ou um diálogo com os elementos da paisagem, sejam eles visíveis ou invisíveis.

O termo "paisagem" só seria mencionado a partir da publicação do catálogo homônimo em 2005. Isto parece indicar uma necessidade da arte - das esculturas ou intervenções in loco de Fronteiras - de tê-la como um referencial.

Cinco anos após a implantação de obras de arte contemporânea em regiões de divisa brasileira com a Argentina, o Paraguai e o Uruguai, o projeto Fronteiras, promovido pelo Itaú Cultural, ganha uma publicação homônima para levar ao público fotos da arte registrada nos limites do país. Com textos ensaísticos e documentais assinados pela crítica de arte e curadora Sônia Salzstein, e fotos e registros do desenvolvimento de cada trabalho artístico, sua instalação e presença na paisagem. ${ }^{297}$

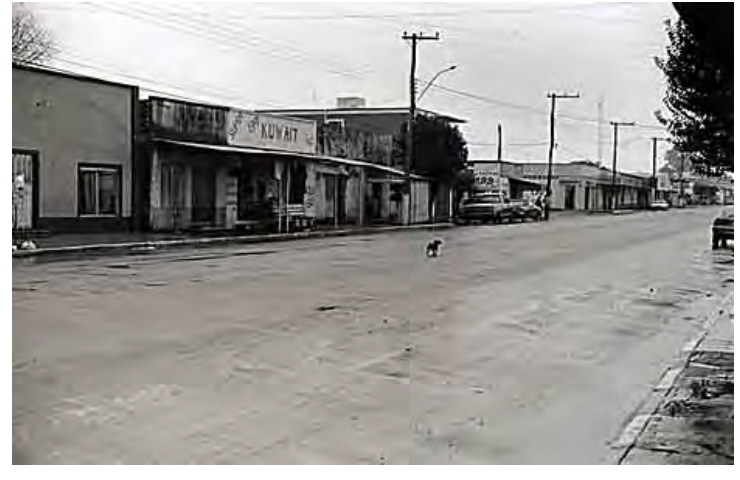

100. Fotografias: Antônio Augusto Fontes. Barra do Quaraí. RS, 1998.

In: Fotografias Nas Fronteiras. projeto Fronteiras, 1998.

É em Barra do Quaraí, em uma estância a $20 \mathrm{~km}$ do município, que Nuno Ramos trabalhou Minuano (2000).
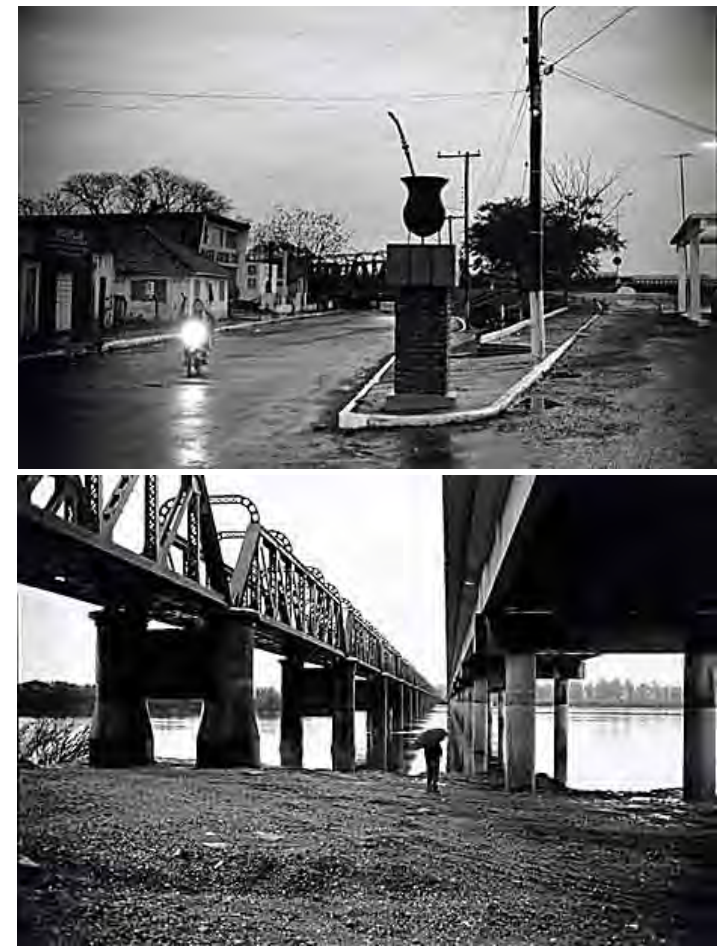

Refletir sobre a proposta temática composta pelos quatro eventos, com seus mitos que reforçam imagens de grandeza - como vastidão territorial, riquezas e diversidade cultural -,

297 ITAÚ CULTURAL. Artes Visuais: Projeto Fronteiras é finalizado com livro. Disponível em: <http://www.itaucultural.org.br/index.cfm?cd_pagina=2716\&cd_noticia=5741>. Acesso em: 19/05/2012, grifo nosso destacando a primeira vez que aparece o termo paisagem em relação ao projeto Fronteiras. 
nos remeteria à elaboração de uma paisagem nacional no imaginário popular. ${ }^{298}$ Algumas obras de Fronteiras, por exemplo, reforçam, através do discurso dos artistas, a ideia de lugares de caráter "rarefeito", "vazio" ou "apenas o horizonte." ${ }^{299}$ Estas ausências e vazios parecem ir ao encontro do mito da vastidão territorial, de um Brasil a perder de vista, um país ainda a ser desbravado. Talvez não seja tão simples desvencilhar-se de antigas representações da paisagem. Segundo Schama, ${ }^{300}$ nem as fronteiras entre o selvagem e o cultivado e nem aquelas entre passado e presente são facilmente delimitadas.

Mas esta dissertação tem seu foco nas artes plásticas: de que maneira estas obras como indícios - se relacionam diretamente com a paisagem? Considerando a paisagem como uma maneira de ver, cuja gênese está na intenção estética, assim como a interação entre sociedade e natureza, que produz, além de objetos estéticos, relações político-econômicas e culturais. Este olhar, encarnado no mundo, ${ }^{301}$ evidencia-nos tais relações, das quais a arte não se desvencilha; pelo contrário: dialoga, incorpora ou se opõe, como marcas e matrizes da paisagem. Veremos que muitas obras de Fronteiras contornaram ou assumiram limitações dadas pelas premissas políticas, econômicas e culturais.

Mesmo que inicialmente direcionadas para os conceitos "território" e "fronteira", as obras transformaram o foco da ocupação territorial (objeto de interesse administrativo) em paisagem ou no uso social do espaço. Apesar de a ideia de fronteira não ter sido oferecida como um tema, mas, sim, como forma de se pensar relações espaciais e sociais, sua acepção estritamente geográfica não suscitou o interesse dos artistas plásticos. Estes foram, em sua

\footnotetext{
298 "[...]a ideia de país vazio persiste por muito (até hoje percebemos seus laivos) em um discurso que chegou a incitar políticas de aumento demográfico para preencher áreas anecúmenas, assim como se dão incentivos para que isso ocorra, que permitem até legalmente, o desmatamento [...]". FREDERICO, Maria Elvira B. Guarapiranga - paisagem e natureza filtradas pela cultura ou Arte e Meio Ambiente como expressão cultural, educacional, comunicacional e ecológica. Tese de Doutoramento, FAU-USP, São Paulo, 1998, p. 83.

299 Sem título de Carlos Fajardo e Minuano de Nuno Ramos reforçam em seus discursos o "vazio" da paisagem . Momento de fronteira, de Waltércio Caldas, buscou intencionalmente um lugar pouco habitado. Talvez a única obra que intencionalmente buscou o adensamento e usos diversificados tenha sido Pálio de Eliane Prolik.

300 SCHAMA, 1996.

301 Besse apresenta uma definição de paisagem que cabe bem a esta situação de ir a um lugar desconhecido que tateamos por meio de mapas - como as localidades de Fronteiras - mas que, para se captar sua essência - suas características físicas naturais, culturais e sua história -, é necessário adentrar: "Não há paisagem de sobrevôo, para retomar a imagem frequentemente usada por MerleauPonty, o que quer dizer que a paisagem exige, para ser, um corpo de carne, um olhar encarnado, um olhar vivo, em outras palavras, um ímpeto, uma intencionalidade presente e que atravessa o espaço que se abre para o aqui e o distante. Em suma, não há paisagem sem profundidade, uma profundidade que se dá a ver sob a forma de uma presença nos longes, de um ser na distância que significa o espaço da vida. A profundidade da paisagem é a da existência." BESSE, 2006, p. 92.
} 
maioria, críticos a esta premissa conceitual que alimentou os debates do evento multidisciplinar, uma vez que ela não indica o espaço relacional ou vivencial onde a arte se desenvolve.

Outra discordância entre os artistas e a premissa da instituição se deu quanto à ocupação do "espaço público" com obras permanentes e a incoerência entre a logística oferecida e a sugestão de que as obras fossem em escala geográfica, indicando que Fronteiras teve um caráter experimental. A exposição levantou mais questões sobre como uma arte da paisagem pôde se desenvolver no Brasil e inaugurou olhares sobre paisagens, até então, pouco artializadas, cujas características vamos descobrindo conforme acompanhamos os processos, da concepção à implantação das obras.

As obras, além de suas poéticas, também revelam-nos a fragilidade de estarem distantes dos polos econômicos e à mercê de uma política cultural que compartimenta projeto, implantação, divulgação (as obras exigiriam deslocamento para a apreciação) e manutenção. Tais ações, que são estruturais para a arte contemporânea da paisagem, requerem uma política cultural integrada. ${ }^{302}$ Sem a sinergia de ações culturais, o intencionado "acervo permanente" em "escala ambiental" ou geográfica, conforme apresentado pela instituição, se encerra no próprio discurso. É certo que não podemos concluir, a partir disso, que nos polos econômicos e culturais a arte brasileira não esteja também em descaso, à mercê do vandalismo ou dando apenas corpo e status a alguma transação política.

Analisar como a paisagem é parte da obra implica em perceber como a natureza é abordada pela nossa arte contemporânea. O que nos leva à questão: a apropriação da natureza atendeu às necessidades técnicas, econômicas e culturais e os referenciais naturais são significativos, simbólicos? De que maneira a natureza é uma referência na identidade destas paisagens de fronteiras? A natureza, através das obras, aparecerá ora na escala do Cosmo, em uma aproximação conceitual, na qual seus elementos são simbólicos; ${ }^{303}$ ora algumas obras a verão como "pitoresca" - ou paisagem pitoresca -, evitando-a.

\footnotetext{
302 Salzstein comenta a necessidade de um projeto deste porte estar vinculado a instâncias culturais regionais, estaduais, criando uma rede de preparação para a arte, assim como para sua divulgação. (Entrevista à autora, maio de 2012).

303 As obras $O$ aleph, de Angelo Venosa, e Minuano, de Nuno Ramos, remontam à ordem do Cosmo, a uma natureza anterior e maior que aquela vivenciada pela obra no lugar. A primeira remete aos megalitos que se alinhavam com as estrelas e Minuano transmite o circuito da luz solar. Momento de Fronteira, de Waltércio Caldas, também se refere aos símbolos da natureza, em uma tríade: mata, rio, 158
} 
Nuno Ramos, em entrevista, nos fala de algo muito precioso para compreendermos essa interação com a natureza: "a natureza continua resistindo firmemente". Dessa maneira, procura explicar porque as obras, que parecem timidamente tocar a paisagem, não dão conta da sua escala (aqui também poderíamos pensar o quanto elas se integram à sua história, à sua realidade). Ramos fala de um sentimento de natureza como o de Euclides da Cunha. Então, buscamos nas escritas euclidianas - no intervalo de um século - pistas sobre essa "natureza brasileira" que se impõe hostil ou indiferente, como a do sertão; ou, que não é facilmente recebida, como a paisagem amazônica. Esta última ele compara com "um enorme quadro cuja moldura quebrara-se," ${ }^{1304}$ pois não se adequava às paisagens até então sedimentadas no imaginário, artializadas pela arte ou literatura, além de se opor ao sentido de ordem ou composição.

Há paisagens cultas que vemos por vezes, subjetivamente, como um reflexo subconsciente de velhas contemplações ancestrais. Os cerros ondulantes, os vales, os litorais que se recortam em angras, e os próprios desertos requestados, afeiçoam-se-nos às vistas por maneira a admitirmos de um modo qualquer de reminiscência atávica. Vendo-os pela primeira vez temos o encanto de equipararmos o que imaginávamos com o que nos antolha, numa exteriorização tangível de contornos anteriormente idealizados. ${ }^{305}$

céu. Elementos da natureza que podemos sintetizar como simbólicos - terra, água, ar - e que são anteriores à experiência da paisagem.

304 Euclides da Cunha narra a natureza Amazônica tendo como referencial o significado das paisagens como "formas culturais por excelência no estabelecimento de parâmetros de observação, percepção e de compreensão do mundo." Ver MURARI, Luciana. Natureza e Cultura, 2002, p. 220.

305 CUNHA, Euclides da. Contrastes e Confrontos, 1919 apud MURARI, Luciana. Natureza e Cultura, 2002, p. 224. 


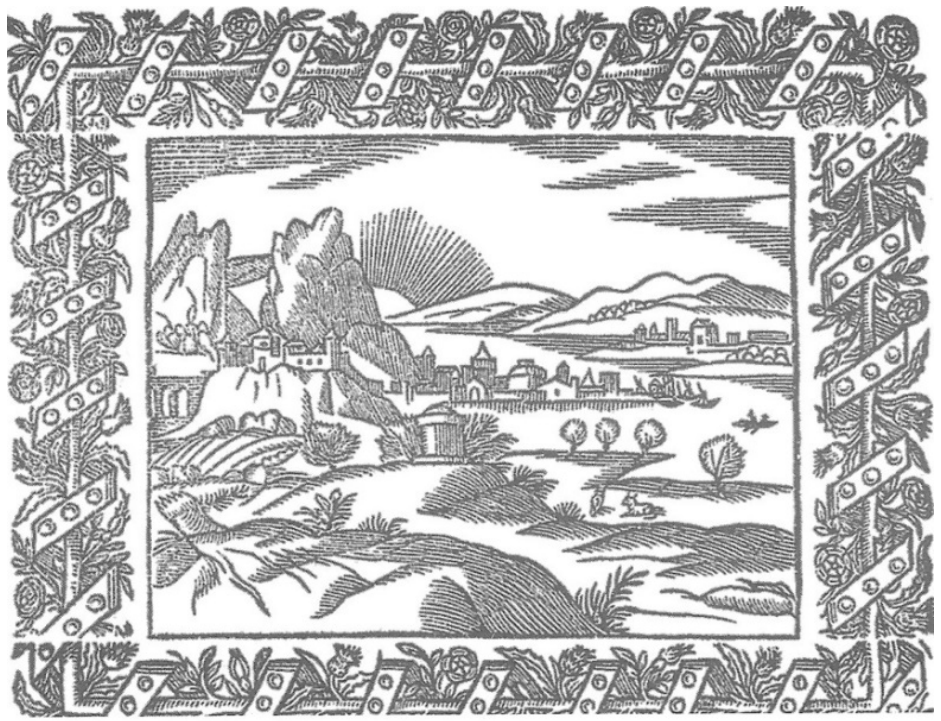

101. Henry Peachmam, Rura mihi et silentium, no livro de emblemas Minerva Britannia, 1612.306

(Fonte: Paisagem e Memória. Simom Schama. São Paulo: Companhia das Letras, 1996, p. 20)

Isto ajuda a explicar a diferença da paisagem na fotografia e nas artes plásticas (na escultura ambiental) do projeto Fronteiras. A exposição Fotografias Nas Fronteiras (1998), de certo modo, no Brasil, deu continuidade a uma tradição de fotógrafos viajantes que retratavam preferencialmente os elementos naturais e os tipos humanos. Já as esculturas ou intervenções in loco não têm referenciais no imaginário nacional e na representação da nossa paisagem. Elas estão agudamente na paisagem mas dificilmente se enraízam nela. Mais ainda, têm como referência, dentro da sua categoria de arte pública ambiental, a land art, mesmo que indiretamente, como apresenta Salzstein. ${ }^{307}$

Considerando que há diferenças entre o histórico de ocupação territorial brasileiro, em relação ao dos países que promovem a land art e, por conseguinte, diferenças no modo de aproximação e apropriação da natureza pela cultura, podemos dizer que as obras reportam a essa arte da paisagem no que tange a três aspectos: primeiramente, a escala; em segundo, o fato de não se realizarem apenas nos centros urbanos, ocupando áreas de transição, inclusive as pouco habitadas; e também, em maior ou menor grau, por considerarem como parte constituinte das obras os elementos naturais da paisagem.

\footnotetext{
306 Paisagem prototípica presente "em incontáveis quadros, gravuras, cartões-postais, fotografias de trens e cartazes de guerra, que bastava reproduzir para suscitar lealdade à abençoada ilha de clima ameno", que se perpetuou (SCHAMA, 1996, p. 22). O autor se refere à imagem ensinada em manuais de como elaborar a "landskip", cujo modelo trazido das paisagens holandesas fazia escola na Inglaterra.

307 "Não há um único trabalho que possa ser definido rigorosamente como 'instalação' ou que assinale experiências puras em site-specificity ou land art." Ver SALZSTEIN, 2005, p. 15.
} 
A fotografia é o meio artístico que desbravou as fronteiras territoriais e culturais e é fonte importante para trilharmos a elaboração da paisagem no imaginário do país.

102. Fotografia de Albert

Frisch ${ }^{308}$. Índios Tapuias, na periferia de Manaus, c.

1865. Instituto Moreira

Salles, RJ.

(Fonte: Olhar Distante, Mostra do

Redescobrimento, 2000.
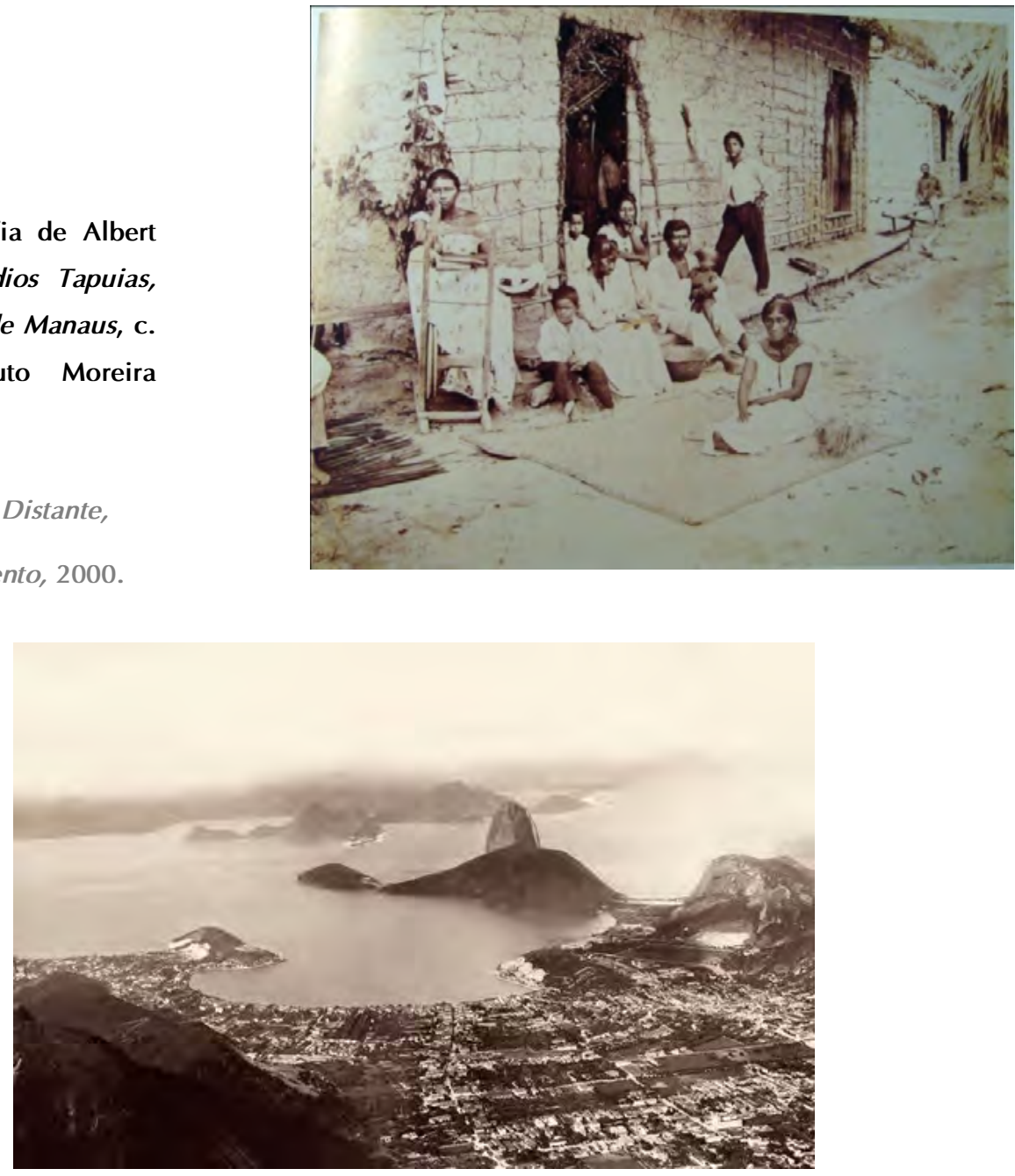

103. Fotografia de Marc Ferrez. ${ }^{309}$ Uso de câmera panorâmica para captar a Enseada de Botafogo, Rio de Janeiro, 1885. (Fonte: http://veja.abril.com.br/221106/p_104.html).

308 Frisch foi provavelmente o primeiro fotógrafo dos índios da Amazônia. A foto nos surpreende pelo "duplo desbravamento de fronteiras" ao registrar os índios Tapuias e o início do desenvolvimento das periferias urbanas. Suas fotografias dos índios e da Amazônia na década de 1870 eram identificadas como "fotografia a partir da natureza de A. Frisch". Ver LAGO, Pedro Corrêa do. In: FUNDAÇÃO BIENAL. Olhar Distante. Mostra do Redescobrimento. Brasil +500: Catálogo, São Paulo: Fundação Bienal, 2000. p. 257.

309 Marc Ferrez (1843-1923) é o mais famoso dos fotógrafos do século XIX no Brasil. Na década de 1860, anuncia sua especialidade como "vistas do Brasil." Como os demais fotógrafos deste período, ajuda a formar no imaginário popular a natureza, a urbanização, os tipos humanos brasileiros. Em 1874, integra a expedição Geológica de C.F. Hartt, para a qual tirou mais de duzentas fotografias para "reconhecimento do Brasil." Ver LAGO, Pedro Corrêa do. Título. In: FUNDAÇÃO BIENAL. OIhar Distante. Mostra do Redescobrimento. Brasil +500: Catálogo, São Paulo: Fundação Bienal, 2000. p. 258. 
Abaixo Fotografias Nas Fronteiras, $1998 .^{310}$ (exposição integrante do projeto multidisciplinar Fronteiras).

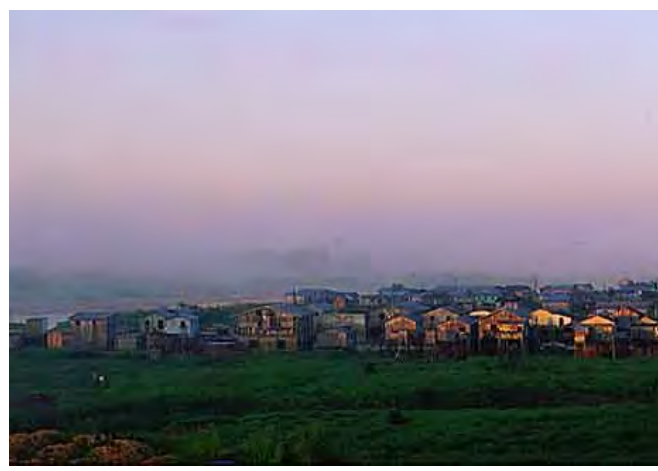

104. Celso Oliveira. Cruzeiro do Sul, AC.

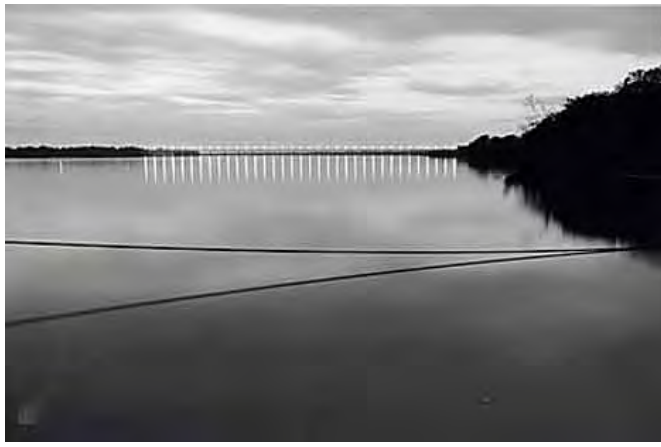

105. Antônio Augusto Fontes. São Borja, RS.
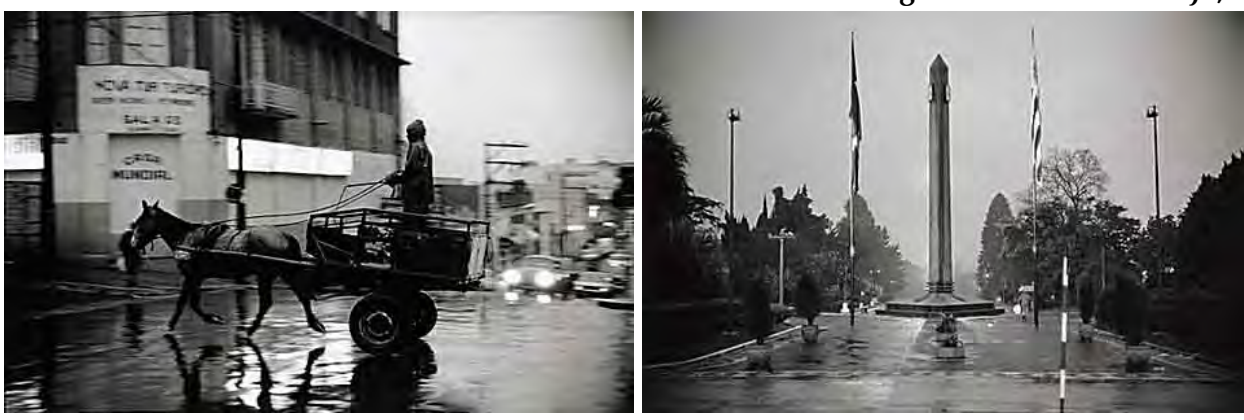

106. Antônio Augusto Fontes. Santana do Livramento, RS

(Fonte: www.itaucultural/proposta/fronteiras)

Em Santana do Livramento (RS), no Parque Municipal do Batuva, Angelo Venosa trabalhou $O$ Aleph (1999).

Um dos pontos essenciais para compreendermos a relação da arte contemporânea com a paisagem brasileira através de Fronteiras (1998-2001) está na implantação de obras públicas fora do circuito das metrópoles que detêm culturalmente as atividades das artes. À medida que nos afastamos dos polos econômicos e culturais, rumo aos municípios ou áreas de

310 Em 2001, os cinco fotógrafos de Fotografias Nas Fronteiras (1998), projeto vinculado ao Itaú Cultural, lançaram um catálogo independente: BOJUNGA, Claudio. Brasil sem Fronteiras. Catálogo: São Paulo: Editora Tempo D’Imagem, 2001. 
transição do rural ao urbano, é inevitável pensarmos sobre o processo de desenvolvimento nacional, seu modelo de ocupação e, consequentemente, o imaginário de paisagens - como reservas em potencial - gerado por tal modelo.

\subsubsection{Descolando espaços: território e paisagem; geografia e paisagem.}

O território começa a ser paisagem quando começa a ser pensado. (RAFFESTIN, 2005, p. 55 apud SAQUET, 2007, p. 143) $)^{311}$

Território pode ser definido como área de um país, Estado, província ou cidade. É a base geográfica sobre a qual se institui o poder em seus mais diversos níveis de soberania e que abrange tanto o solo como os rios, lagos e mares. Circunscrever os limites dessas áreas em um mapa é fácil, bem como o é determiná-los com precisão, com os instrumentos de agrimensor. Mais difícil, porém, é delimitá-los do ponto de vista cultural. Especificamente nas regiões de fronteira, onde essa identificação é mais complexa, pois as culturas vizinhas se misturam, sobrepõem-se, diluindo supostos laços nacionais. (ITAÚ CULTURAL. Eixo Curatorial 98. Catálogo São Paulo, Itaú Cultural, 1998)

Se analisarmos o projeto multidisciplinar Fronteiras - incluindo as exposições de fotografia, vídeo, artes plásticas e o Núcleo de Pesquisa Sobre Território Brasileiro -, veremos que foram ressaltadas questões que vão desde o território ao meio ambiente. Portanto, questões econômicas, políticas, sociais, ambientais, todas elas formadoras da paisagem, no entanto, esta permanece ainda nos interstícios destes debates. Talvez pelo pouco peso que o país tem dado às questões culturais que valorizam seus lugares e como os tem elaborado, por meio de projetos.

Vemos, desde a apresentação do projeto até a publicação do catálogo de artes plásticas, um cruzamento de conceitos que apresentam bases comuns, mas que divergem quanto às suas essências: território e paisagem ou geografia e paisagem. É necessário descolar tais conceitos para finalmente chegarmos à paisagem, quando, de fato, os artistas veem esse território, suas regiões e lidam com o conteúdo simbólico e estético dos lugares e da arte.

Leite $^{312}$ expõe que "região", categoria espacial que confere determinado valor ao território, tem em comum com a paisagem o fato de depender "da história econômica, cultural

\footnotetext{
311 RAFFESTIN, Claude. Dalla nostalgia del territorio al desiderio di paesaggio. Elementi per una teoria del paesaggio. Firenze: Alinea, 2005, p.55 apud SAQUET, Marcos Aurélio. Abordagens e Concepções de Território. São Paulo: Editora Expressão popular, 2007.
} 
e ideológica de cada sociedade". Ambas são delimitadas por relações econômicas, culturais, espaciais e naturais, conferindo ao espaço "significados ideológicos ou finalidades sociais." A região, contudo, é formada por critérios funcionais (sendo a divisão social do trabalho a organizadora desse espaço), enquanto a paisagem é subjetiva, ligada fortemente aos valores culturais de uma sociedade, além dos valores estéticos.

A autora ainda expande esta diferenciação do modo como determinada sociedade se relaciona com seu espaço/natureza, ao apontar região e paisagem como símbolo e signo, ${ }^{313}$ respectivamente. Esta abordagem símbolo-signo, que trata do todo com suas partes e significados, é um caminho para compreendermos se, ou quando, os elementos da paisagem da fronteira entre Brasil e países do Mercosul foram significantes para a arte, e de que maneira esta atribui novas camadas de significados aos lugares onde se inseriu.

Perceberemos que alguns desses elementos das paisagens que seriam significantes, como o fato de um terreno onde se instala a obra ser de uso agrícola ou pecuário ou com rarefeita urbanização circundante, passam desapercebidos e os espaços são narrados por vezes como indefinidos em uma amplitude (inespecificidade) que reforça a distância. O que explica essa adjetivação é a compreensão das sensações (além da visualidade) de experiência limite, experiência de trabalhar a arte onde não se estabelecem contatos de apoio, ${ }^{314}$ o que ressalta o isolamento.

Besse (2006) também propõe a ideia de paisagem como signo ou um conjunto de signos, e que, por isso, pode ser lida, sendo mais do que uma vista ou representação. Segundo o autor, a paisagem também é o lugar do indivíduo perante uma profundidade do tempo e do espaço - então é uma experiência - em que ele toca a natureza e tange o infinito. Ler a paisagem é perceber "formas de organização do espaço, extrair estruturas, formas, fluxos, tensões, direções, limites, centralidades, periferias".

Não se trata portanto de negar o visível, mas de lhe atribuir, além da experiência sensível que dele se pode fazer, um outro estatuto, uma outra função: o visível

\footnotetext{
312 LEITE, 2006, p. 80.

313 Ibidem, p.81.

${ }^{314}$ Sônia Salzstein, em entrevista para esta dissertação, destacou essa "experiência de limite", de fazer arte sem estrutura, sem se saber quem é o público de tal arte, reforçando a sensação de vazio, que é recorrentemente citada pelos artistas.
} 
revela algo. Ele exprime. $\mathrm{O}$ que quer dizer que ele não é unicamente uma representação. ${ }^{315}$

A respeito de território, Saquet ${ }^{316}$ aponta que, para compreendermos seu conceito, devemos remontar às lições de Humboldt e Ritter de que o conhecimento científico do mundo é acompanhado pelo caráter subjetivo e pelo projeto moral e civil implícito nas suas representações. Este autor cita ainda Raffestin ${ }^{317}$, cujas abordagens de território vão ao encontro deste estudo, uma vez que se justapõem à reflexão sobre a paisagem. Ambos, território e paisagem, apresentam uma essência em comum - o próprio território -, podendo assumir diferentes contornos, quando a paisagem passaria a ser a aparência, o projeto ou a imaginação desta essência: "Os homens, cotidianamente, não constroem a paisagem, mas o território que poderá, talvez, ser transformado em paisagem." ${ }^{318}$

Seguindo o pensamento de Raffestin, o território não necessariamente apresenta uma paisagem e, de fato, acompanharemos, no processo de elaboração e de implantação das obras de Fronteiras, um embate entre ocupar territórios, fronteiras e buscar para a obra a paisagem como referência - formal e conceitual. Também, foi pela leitura da paisagem que os artistas buscaram compreender o lugar onde as obras se inseririam.

Mas, ainda segundo este autor, o contrário também pode existir: a partir de uma paisagem - que além de representação da realidade, é também compreendida como intenção, projeto e a elaboração sobre o real, capaz de transformá-lo - pode-se formar um território. Assim, ele explica que não se trata de princípio e resultado: "Hoje o território é projetado, desenhado e planificado. Isto significa que antes de ser construído e produzido, já é imagem." ${ }^{319}$

Saquet, ao discorrer sobre as abordagens de território, pontua que sua acepção como processo de relações sociais surge a partir da reelaboração da geografia nos anos 1950-60 e, principalmente, com as novas perspectivas adotadas nos anos $1970 .{ }^{320}$ Neste período, a

\footnotetext{
${ }^{315}$ BESSE, 2006, p. 64.

${ }^{316}$ SAQUET, 2007.

317 RAFFESTIN, 2005 apud SAQUET, 2007..

${ }^{318}$ RAFFESTIN, 2005, p. 33 apud SAQUET, 2007, grifo do autor.

319 Ibidem, p. 58.
}

320 Considerando as realidades sócioeconômicas de cada país, este debate parte de estímulos diferentes. $\mathrm{Na}$ Itália, ele desenvolve-se pela luta dos trabalhadores no chamado triângulo industrial, especialmente em Turim, 1968. "A redescoberta deste conceito a partir de um processo socioespacial se dá em meio ao 
geografia envolve-se com outras ciências sociais e com a filosofia, e ganham destaque quatro tendências ou perspectivas de território, que se sucedem e coexistem em algumas situações. A primeira é eminentemente econômica, o território é entendido a partir das relações de produção e das forças produtivas; a segunda é pautada pela dimensão geopolítica; a terceira, centrada na fenomenologia, enfatiza as dinâmicas política e cultural, simbólico-identitárias, tratando de representações sociais. Por fim, a quarta, principalmente a partir dos anos 1990, foca as questões de sustentabilidade ambiental e desenvolvimento local.

Tais tendências direcionam uma abordagem de território que vai além daquela descritiva, classificatória e acrítica que predominava até os anos 1950-60, ou seja, vai além de sua redução como produto de centralidades e autoridades, sem sujeitos sociais, sem as interações no e com o lugar.

Territórios e territorialidade são vividos, percebidos, substantivados por relações de integração ou conflito, localização ou movimento, línguas, identidades, religiões, mercadorias, instituições, natureza exterior ao homem; por diversidade e unidade; imaterialidade. ${ }^{321}$

Estão implícitas na compreensão de território - além das questões econômicas, políticas e culturais - a relação do homem em sociedade com a natureza, a construção histórica, identitária, e as redes de circulação e comunicação. É igualmente no período de renovação da geografia, no pós 1960-70, quando se retoma a discussão sobre território, que se apresentam novas compreensões da paisagem também reconhecendo nela os aspectos das relações sociais, do processo histórico, da percepção dos sujeitos, da representação e dos símbolos da vida cotidiana.

Há, a partir de então, uma interação entre os debates sobre território, paisagem e espaço geográfico que, no projeto Fronteiras, são alinhavados através da arte elaborada para alcançar a escala geográfica.

Para Leite, ${ }^{322}$ território e região "são espaços teóricos, abstratos e consequentemente não podem ser percebidos." É apenas quando o espaço se torna lugar, quando se distingue ao ser vivenciado, percebido e apropriado, que nos defrontamos com a paisagem.

conflito social". Ver SAQUET, 2007, p.40. Em outros países como EUA e França, a retomada pelo estudo do território se dá no âmbito das mudanças sócioespaciais efetivadas no pós-Segunda Guerra Mundial.

321 SAQUET, 2007, p. 25.

322 LEITE, 1990, p. 26. 
O território nacional é desdobramento direto do modelo de ocupação espacial, que, do período colonial à República, com a economia latifundiária da monocultura, gerou "uma rede urbana pobre, centrada em grandes e poucas cidades, sedes do controle administrativo do capital comercial; ${ }^{1323}$ este modelo fora reproduzido até o período da industrialização brasileira e da expansão das fronteiras agrícolas. Neste sentido, o território nacional não motivou os artistas como "um tema", mas, de certo modo, influenciou no processo de implantação das obras. Elas foram doadas a municípios que, em alguns casos, pouco se interessaram por elas, e com esta ação deu-se por encerrada a política cultural de implantação das obras.

O espaço do território, organizado pela divisão do trabalho e pela política nacional e internacional, e representado através da técnica da cartografia, não oferece a profundidade da paisagem. Se considerássemos as premissas do projeto, poderíamos pensar que o conteúdo político ganharia espessura nas ações dos artistas. Veremos, no entanto, que a maioria não se guiou pelo viés político do tema fronteira - o ponto de partida conceitual -, nem do território - premissa do eixo curatorial -, e sim se pautou por questões de tempo e espaço: o ilimitado, indeterminado, as justaposições dos tempos da Terra e da experiência de fronteira como experiência de limite.

Outro termo que precisamos descolar da paisagem e que é recorrente nas falas, desde a apresentação do projeto pela Instituição Cultural até a publicação do catálogo Fronteiras (2005), é o termo "geográfico" e aqueles que remetem à geografia. Sônia Salzstein e o artista Waltércio Caldas empregam, em diferentes momentos, o termo "situação geográfica." Também na apresentação do evento encontramos a ação demarcatória e os novos marcos geográficos. A paisagem, através da narrativa do projeto Fronteiras, facilmente desvia-se pelo território e pela geografia.

Creio ser igualmente importante distinguir o pensamento que adota a geografia e prefere lidar com os espaços sistematizados, relacionando-os com a arte, daquele que aborda a paisagem na arte. Para tanto, recorremos a Jean-Marc Besse (2006), em busca das das gêneses de paisagem e geografia e das diferenças, esmiuçadas por ele, que há entre elas.

Para Besse, a paisagem seria a geografia sensível, que requer, além do saber ver - os objetos, fatos e ações -, o ir ver, ${ }^{324}$ a intencionalidade que abarca desejos de ordem e

\footnotetext{
${ }^{323}$ Idem, 2006, p. 120.

${ }^{324}$ BESSE, 2006, p. 76.
} 
composição, nossa essência estética. Mais ainda, citando Merleau-Ponty, "não há paisagem de sobrevoo" ${ }^{1325}$ e vamos percebendo que, embora haja uma essência de visibilidade, ela necessita um "olhar encarnado", um estar ali, tal e qual se propuseram os artistas em suas aproximações com a fronteira, buscando nela se adentrar e descobrir suas paisagens.

Quando Fronteiras propõe que as obras sejam como novos marcos geográficos, parece haver a intenção de inaugurar referenciais simbólicos, pois a ideia de "marco" pode remeter a "monumento." ${ }^{1326}$ Mas há o hiato de mais de um século ${ }^{327}$ entre monumento e obra contemporânea; tempo em que houve a descentralização dos espaços públicos e centros cívicos, a incorporação do tempo no percurso do observador e no tempo e processo da obra, a mobilidade e imaterialidade de tecnologias, que, entre outros fatores, põem-se na contramão do momentum-monere, da permanência da memória, que caracterizam o monumento. As obras de Fronteiras, diante de fronteiras às vezes pouco vivenciadas, se afastam da postura de monumento.

Percebemos, então, que território, situação geográfica ou fronteira, ou seja, a geografia física que sistematizou o espaço, ${ }^{328}$ estão apenas na superfície das questões estabelecidas pelas obras de Fronteiras. Os artistas adentraram esse espaço normativo, desejando compreender nas cidades e nos pequenos municípios suas histórias, dinâmica, seus aspectos estéticos e ausências. Para buscar a paisagem é necessário assumir um ponto de vista extremamente

${ }^{325}$ MERLAU-PONTY. Phénoménologie de la perception, 1945, apud BESSE, Jean- Marc. Ver a Terra: Seis ensaios sobre a geografia e a paisagem.São Paulo: Perspectiva, 2006. Tal pensamento é útil para melhor analisar as obras de Fronteiras que primeiramente foram concebidas pela Instituição Cultural como inserções em uma mapa, predominando a visão de paisagem como representação cartográfica. Com a concepção e implantação das obras pelos artistas, passa-se a considerar a presença no lugar.

326 Monumento: "símbolo coletivo, de presença marcante e fundamental para caracterizar o lugar e transmitir suas convicções..." referência ao outro, fato, período histórico ou lugar, pelo qual lemos uma narrativa, vinculando passado e futuro.

GIEDION, Siegfried; SERT, Jose Luis; LÉGER, Fernand. Nove Pontos sobre a Monumentalidade: Uma Necessidade Humana, 1943.Texto apresentado na disciplina Modos de Produção do Espaço na Arte Contemporânea, 2008, pós-graduação FAU-USP.

${ }^{327}$ KRAUSS, 2007, p. 37-40. A autora cita "A porta do inferno" (1880-1917) e "Balzac" (1897) de Auguste Rodin como obras que se revelam pelo processo, pelo "ato que deu forma à figura ao longo do tempo", referindo-se a "um momento anterior da cadeia narrativa". A mudança de foco da narrativa para a própria obra e dela - de sua forma, construção ou composição - para o lugar e o entorno - como meio físico ou de vida - é o que caracteriza a passagem da escultura moderna para a contemporânea.

${ }^{328}$ STRAUS, Erwin. Du sens des sens, apud BESSE, Jean- Marc. Ver a Terra: Seis ensaios sobre a geografia e a paisagem.São Paulo: Perspectiva, 2006, p. 80. 
humano, como o da arte, ponto de vista cheio de "ímpeto, uma intencionalidade presente e que atravessa o espaço que se abre entre o aqui e o distante," 329 que se posiciona diante do mundo e delimita o infinito.

Veremos nas falas dos artistas que o desejo de ver a paisagem é intenso. Contudo, pela falta de referenciais físicos, históricos ou simbólicos - indícios capazes de demarcar uma composição, de remeter a uma ideia - a paisagem é vista em sua característica de rarefação e de vazio, é "mais um horizonte que um lugar". Alguns artistas recorrem além do visível e buscam nas macroescalas da Terra e do Cosmo a ordem e a composição, inerentes à paisagem. Leremos descrições da paisagem como "monótona" e "antipaisagem," demonstrando o embate entre delimitá-la, compreendê-la e abarcá-la através da obra. Contudo, está sempre presente a intenção ou a necessidade de configurá-la (essa estetização da natureza que, se nos escapa às mãos ou à vista, poderia, então, ainda ser elaborada recorrendo-se a seus símbolos).

Reconhecemos a paisagem-natureza e também a paisagem urbana, onde a arte já habita, tal como o claro e o escuro lidos por contraste. Mas e os meios-tons? Esses são difíceis de serem artisticamente moldados em paisagem como, por exemplo, a área rural de uma estância que não é "nem natureza nem pasto. ${ }^{1331}$. Estas áreas de meios-tons, fadadas - na fala de alguns artistas - à monotonia não são nem representativas de forças da natureza, nem artefatos de uma cultura apreciável: a paisagem parece, então, ficar encoberta.

De um modo geral, os artistas de Fronteiras relatam duas posturas diante daquele mundo de fronteira: a intencionalidade de instaurar uma paisagem; e a impossibilidade de reconhecê-la, compreendendo a paisagem como uma composição já sedimentada culturalmente, capaz de influenciar nossa percepção. Sobre estas posturas, transcrevo Humboldt, que, mesmo diante de paisagens monótonas, reconhece nelas a potência da Natureza e vê-se maravilhado. Independente da composição da paisagem, reconhece nelas o

329 BESSE, 2006, p. 92. Besse expõe a simultaneidade da paisagem que além da ordem de simples visibilidade é também um lugar onde quem vê, ao se situar nela, "descobre as dimensões do seu ser".

330 Nuno Ramos, para Minuano, se refere aos pampas gaúchos como "tudo muito monótono" e "massacrante", mais um horizonte que um lugar. O artista também cita uma proximidade com certo trabalho de Michael Heizer, mas "a relação com a natureza é muito mais forte no trabalho do Heizer." Ver RAMOS, Nuno. In: Fronteiras, 2005 p. 198. Fajardo propusera, para seus primeiros trabalhos, paisagens intensas - Iguaçu, Itaipu -, depois trabalhou, em Laguna, uma paisagem rarefeita, quase uma "antipaisagem." Cf. Fronteiras, 2005, p. 89.

331 Como Nuno Ramos se refere à estância onde instalou Minuano, em Barra do Quaraí, RS. RAMOS, Nuno. Ensaio Geral. 2007 p. 222. 
infinito que transborda o visível e, talvez, esteja na presença transbordante do infinito no finito a força mais íntima da experiência paisagística. ${ }^{332}$

Seja numa planície monótona de amplo horizonte, onde plantas de uma mesma espécie (urzes, cistáceas, gramíneas) cobrem o solo, seja onde as ondas do mar banham a costa e fazem reconhecer seus traços pelas estrias verdejantes de ulvas e de conjuntos de algas flutuantes, o sentimento da natureza, grande e livre, arrebata nossa alma e nos revela, como por uma misteriosa inspiração, que existem leis que regulam as forças do universo. [...] O que essas impressões [...] têm de grave e solene, [...] elas o apreendem do contraste que oferecem os limites estreitos do nosso ser com essa imagem de infinito que se revela em toda a parte, na abóbada estrelada do céu, numa planície que se estende a perder de vista, no horizonte brumoso do oceano. ${ }^{333}$

É também interessante retomarmos Cosgrove, já citado no Capítulo 01, quando ele ressalta que composição, harmonia, e simbologia são necessárias para que possamos compreender e ter acesso mental e visual à paisagem. ${ }^{334}$

O ver paisagem pressupõe que há referenciais simbólicos para o indivíduo ou sociedade que podem nela intervir, pois têm um imaginário com padrões estéticos e culturais; ${ }^{335}$ ou seja, com a paisagem evocamos a história, que a simples ocupação do território, produção econômica, interesses políticos ou geografia física, não revelam.

O referencial simbólico, seja marco geográfico ou monumento, não se constrói ao ser apontado em um mapa, em um "aqui está" sem perspectiva, tampouco por sua simples construção na paisagem. O que contém o simbólico requer o espaço da vida, da existência através da história. Não se refaz a paisagem de Veneza, mesmo com a reprodução fiel de suas construções em um parque temático, porque ali não adentramos nas camadas de sua história e de seus ideais.

Tanto na paisagem como na arte, esse tempo, a história e os ideais que são suas motivações, sedimentam-se e tornam-se perceptíveis, sensíveis, como em uma pintura onde

\footnotetext{
332 BESSE, Jean-Marc. 2006: VIII. Ver a Terra: seis ensaios sobre a paisagem e a geografia. Tradução Vladimir Bartalini.

333 HUMBOLDT, Alexander Von. Cosmos. Essai d'une description physique du monde, 1846 apud BESSE, Jean- Marc. Ver a Terra: seis ensaios sobre a geografia e a paisagem. São Paulo: Perspectiva, 2006, p. IX.

334 COSGROVE, 1989 in CORREA; ROSENDAHL, 1998, p. 99

${ }^{335}$ LEITE, 2006, p. 48. 
velaturas de tinta, entre transparências e opacidades, resultam, ao final de um dado tempo, no tom de cor "certo."

\subsection{Projeto Margem: seu contexto no projeto multidisciplinar.}

A cidade brasileira construiu, assim, lentamente, a negação da paisagem local como ideário de civilização: a expressão perfeita da vida urbana prescinde de campos, matas, roças, enterra cursos de água ou os transforma em megareceptores de dejetos, confina o ar e a luz do sol a pontos privilegiados e, por isso, supervalorizados, reduz, enfim, o natural ao urbano pela insistência em qualificá-lo como infraestrutura a serviço do progresso ou do lucro. ${ }^{336}$

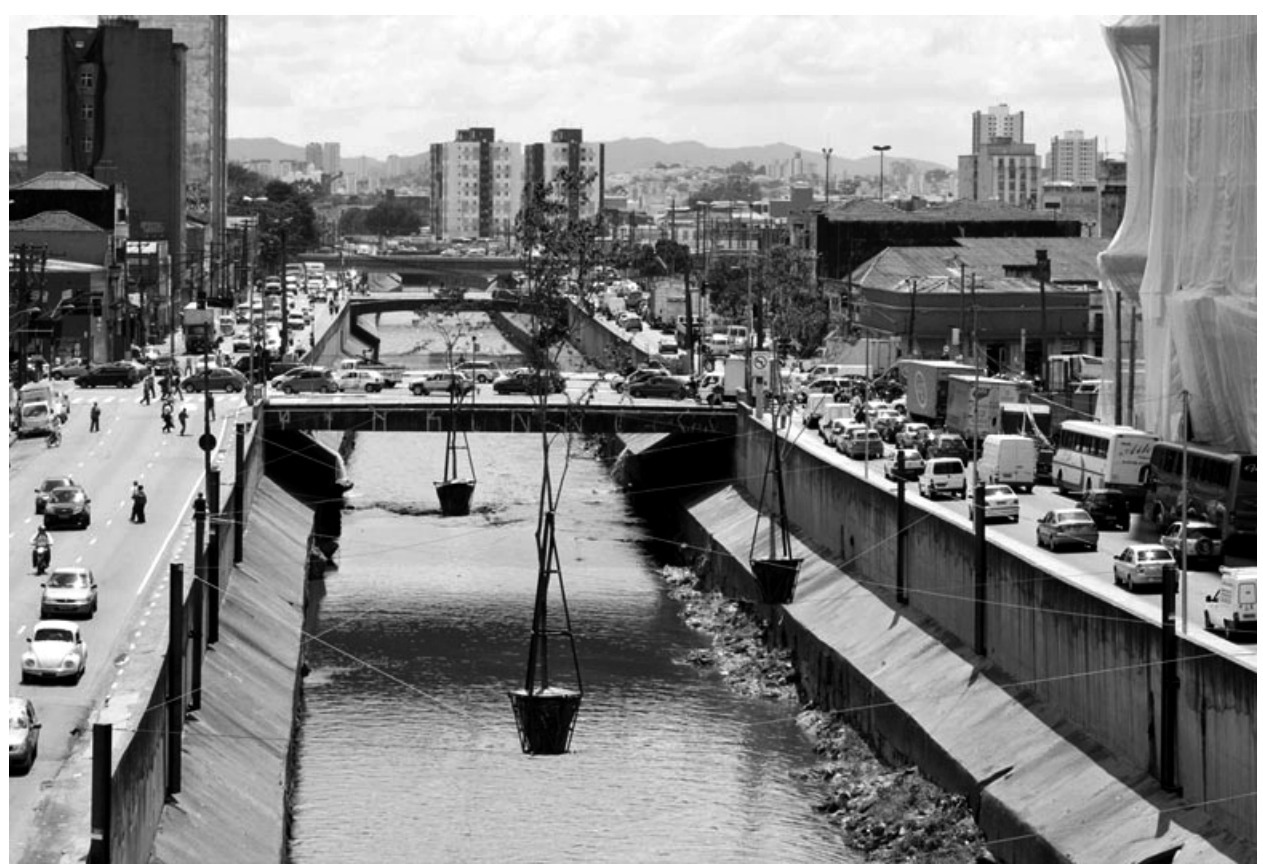

(98). Hector Zamora. Errante, 2010 . Projeto Margem, Rio Tamanduateí - São Paulo, SP.

Margem (2009-2010) foi o primeiro projeto de arte pública urbana em escala nacional, de cunho site-specific, promovendo uma reflexão sobre os rios urbanos. O curador Guilherme Wisnik buscou alinhavar a vastidão territorial, abordando os rios como elementos de força motriz na formação e desenvolvimento das cidades, como "modo de dar um eixo, um

${ }^{336}$ LEITE, Maria Angela Faggin Pereira. As Tramas da Segregação: Privatização do Espaço Público. Tese de Livre-Docência, FAU-USP, São Paulo, 1998, p. 50. 
sistema interligado que formou e articula as cidades. ${ }^{1337}$ A instituição que promoveu o projeto descreve a proposta:

Os rios possuem funções vitais na formação e na organização das cidades, e compõem um elo territorial que integra esses espaços urbanos em um sistema unitário, de pontos estáveis e de fluxos. Trazem consigo a questão acerca da sustentabilidade, tanto em relação à água como recurso natural, quanto ao transporte fluvial como um instrumento de integração e soberania nacional. ${ }^{338}$

O nome "margem" sugere ambiguidade de interpretações, o que seria positivo, para alargar as discussões, segundo o curador. As intervenções artísticas rumariam Brasil adentro, nos fazendo atentar para o interior de um vasto país, cuja ocupação fora majoritariamente costeira. De modo simbólico, repetiriam os trajetos de exploração colonial brasileira, onde os rios foram meio de transporte, assim como remeteriam às expedições de caráter científico. Margem, além das beiras dos rios, refere-se ao que ficou de lado no progresso, à margem do desenvolvimento, voltado ao exterior e concentrado no litoral e, ainda, como projeto para dar margem a novas discussões. ${ }^{339}$.

O projeto foi lançado inicialmente ao público através do Seminário Internacional de Arte Pública As cidades e suas margens, ${ }^{340}$ em que palestraram profissionais e pesquisadores nas áreas da arquitetura e urbanismo, antropologia, literatura, história, além dos artistas até então convidados. Embora não tenha havido menção à paisagem, seja em sua dimensão histórica ou de projeto, de cidades que se desenharam a partir dos rios ou que impuseram a eles seus desígnios; e, ainda que nas palestras não tenha havido, em específico, uma reflexão sobre como a sociedade tem se apropriado da natureza e como tem espelhado seus desejos de redenção da mesma (o que nos levaria a debater diretamente sobre a produção da paisagem);

337 ITAÚ CULTURAL. Seminário Internacional de Arte Pública: As cidades e suas margens._DVD IC EVE FV485 pt.1, 16/09/09. Acervo Midiateca Itaú Cultural.

338 ITAÚ CULTURAL. Margem. Hector Zamora - Errante: Folder, São Paulo: Itaú Cultural, 2010.

339 Guimarães Rosa, com o conto A Terceira Margem do Rio (em Primeiras Estórias, 1962), e Euclides da Cunha, com À Margem da História (1909), reforçam com suas "margens" a potência de significados, como citado no seminário que apresenta o projeto. $O$ historiador palestrante Francisco Hardman sugere um horizonte para o projeto Margem no qual se uniriam ciência e arte "em uma perspectiva humanista". Ele traça analogias entre o projeto e as viagens e escritas de Euclides da Cunha e cita: "O mundo futuro terá que ter um outro tipo de representação, uma união entre arte e ciência". CUNHA, Euclides da. Prefácio. In: RANGEL, Alberto. Inferno Verde. 1907.

${ }^{340}$ Foram três dias de palestras e debates no Itaú Cultural, em São Paulo, SP, em setembro de 2009, quando, até então, só haviam sido envolvidos no projeto artístico Nuno Ramos, Ana Maria Tavares e Hector Zamora, que conferenciaram no segundo dia do Seminário, com a pauta "Práticas de arte pública site-specific". 
podemos dizer que a paisagem está em todo o lugar nos debates do projeto de arte pública em escala nacional Margem (2009-2010).

Na abertura do seminário, Wisnik compara os projetos das artes plásticas Margem (2009-2010) e Fronteiras (1998-2001), diferenciando as propostas, mas entendendo-as como um passo seguido adiante, dentro de um projeto maior da Instituição, que "há mais ou menos dez anos iniciou trabalhos de arte pública. ${ }^{341}$ Ao mesmo tempo, ele aponta que, por trás dos debates sobre navegabilidade e desenvolvimento econômico através dos rios - pautados por Margem -, "pulsa um discurso de território", tema já trabalhado em Fronteiras.

Com o projeto Fronteiras abriu-se caminhos para trabalhos de land art, obra em espaço aberto, em regiões longínquas, remotas da fronteira mas não em contexto urbano, salvo raras exceções. Agora é arte urbana de fato. Margem é uma fronteira interna, é uma dobra, dobra interna das nossas cidades. ${ }^{342}$

Para expor o projeto Margem (2009-10) para as artes plásticas, diferentemente de Fronteiras (1998-2001), conto com os seminários e os folders de apresentação do projeto e menos com as obras e entrevistas dos artistas. Tal ênfase no discurso não promove a mesma visualização sobre arte e paisagem, possível quando podemos contar com as obras de fato implantadas. Mas Margem não poderia estar fora desta pesquisa por sua proposta generosa de, em escala nacional, focar objetos incômodos da paisagem urbana brasileira que, ao mesmo tempo, estruturam sua produção. Sua proposta trouxe à tona questões sobre a apreciação, as transformações e possíveis projetos para a paisagem, por meio da arte, assim como nos faz pensar na dependência que se estabelece entre a arte da paisagem e políticas culturais coesas. $^{343}$

As obras deste projeto dialogariam com rios importantes de três bacias hidrográficas nacionais: a Amazônica, nas cidades de Manaus, Rio Branco, Porto Velho, Belém, Palmas; a do São Francisco, em Juazeiro/Petrolina, Belo Horizonte, incluindo Recife, em uma "licença

\footnotetext{
${ }^{341}$ A Instituição Itaú Cultural iniciou a promoção da arte em espaços públicos urbanos e também em áreas ermas de ocupação com as exposições Diversidade da Escultura Contemporânea Brasileira (1997), na Averida Paulista, e Fronteiras (1998-2001).

342 ITAÚ CULTURAL. Seminário Internacional de Arte Pública: A cidade e suas Margens. Abertura de Guilherme Wisnik. 17/09/2009. DVD IC EVE FV 485. Acervo Midiateca Itaú Cultural.

343 O projeto foi lançado por uma Instituição Cultural que já promovera a arte contemporânea em lugares mais longínquos do território brasileiro (Fronteiras) e que já promovera, em 2008, exposições e debates sobre os rios urbanos (Quase Líquido), além de ter tido parceria com o Governo nas três instâncias: Prefeitura de São Paulo - Coordenação das Subprefeituras e Secretaria do Verde e Meio Ambiente -, do Governo do Estado de São Paulo e Ministério da Cultura.
} 
poética"(uma vez que não pertence à referida bacia), devido à importância do Capibaribe e dos manguezais na cidade; e a do Paraná-Prata, com São Paulo, Goiânia, Corumbá e, também em licença poética, Porto Alegre, onde o Guaíba é forte referência. Nestas cidades, se propunha a intervenção artística em um rio urbano. Com ressalvas para Recife e Porto Alegre, é uma característica comum nestas cidades a presença quase oculta de rios reduzidos à condição de fonte de recursos e destinação de esgotos, que cumprem funções técnicas de escoamento ou transporte e que se perderam como lugares de usufruto.

A relação da paisagem urbana com seus rios é mais positiva em Porto Alegre, onde o Rio Guaíba participa das atividades urbanas sendo um "respiro" para a cidade, com parques em suas margens; e em Recife onde também o pedestre pode se aproximar do rio Capibaribe, o que indica uma escala mais humana do desenho urbano nas proximidades dos rios: a apreciação da paisagem urbana nestas cidades incorpora o rio. Em contrapartida, rios são de extremo incômodo, por exemplo, em Manaus, que murou o Rio Negro, construindo-se de costas para ele, e em São Paulo, cuja urbanização e industrialização aceleradas, somadas à falta de planejamneto e de conservação de bens naturais como os rios, transformou o Tietê, seu afluente Tamanduateí e o Pinheiros em eixos de autopistas.

No seminário que apresentou o projeto, Wisnik traçou um panorama do papel dos rios nas cidades do Novo Mundo que se "civilizaram' dentro de um regime colonial" 344 e "se desenvolveram em um batalha contra o meio natural. ${ }^{1345}$ Estas cidades, em sua maioria, cresceram dando as costas para seus rios, como se fossem fundos de quintal. Devemos remontar ao desenvolvimento urbano-industrial do século XX, para compreendermos melhor o processo acelerado de degradação dos rios urbanos das cidades brasileiras, cujas áreas alagadiças de várzea tornar-se-iam mais baratas, sendo então absorvidas pelos projetos de macrotransporte urbano e pela habitação das classes de baixa renda. Este processo, segundo o curador, tem sua gênese na exploração colonial, cuja ocupação urbana se caracterizava como "refúgio", com a intenção de se proteger da natureza.

Contudo, segundo ele, há aproximadamente dez anos configura-se uma mudança de paradigma, e estas áreas de várzea, comumente as mais baratas das cidades, estão paulatinamente tornando-se espaços para a reconfiguração urbana, uma vez que são brechas em meio ao intenso adensamento. Os terrenos de várzea passaram a ser disputados em Belém,

\footnotetext{
344 ITAÚ CULTURAL. Folder: Apresentação do projeto Margem e do Seminário As Cidades e Suas Margens. Acervo Gráfico Itaú Cultural, 2009.

345 Idem, 2009. 
Rio Branco e em São Paulo - nas margens do Pinheiros - onde se encontram investimentos para instalações turísticas ou comerciais e a expulsão de moradias de baixa renda.

As paisagens tecnocratas onde Margem e Fronteiras se inserem foram produzidas por este mesmo modelo de desenvolvimento urbano que relegou rios a canais de escoamento; que preteriu seus espaços públicos urbanos, que se apresentam indeterminados - seja pelo uso ou pela forma, como "lugares que não se constituem." ${ }^{346} \mathrm{O}$ curador, em concordância com Salzstein (2005), sobre a condição da arte pública em lugares pouco simbólicos ou apropriados, ${ }^{347}$ conclui: "Vem daí um certo caráter vacilante ou tímido da arte. Como ela pode criar esse embate? As margens dos rios replicam esses problemas". A arte nestes espaços caracterizar-se-ia, então, similarmente à natureza dos espaços ocupados.

Assim como alguns artistas de Fronteiras referem-se aos lugares de suas obras como "não-lugares," 348 as margens dos rios também apresentam esta característica, emanando uma atmosfera de impermanência, própria dos lugares de passagem ou daqueles pouco receptivos à escala ou usufruto humanos; ou ainda daqueles cujo histórico se perdeu em sucessivas e descontinuadas camadas - de modo que também se perderam nossos referenciais de memória e de afetividade.

Os rios urbanos são, nesse sentido, típicos "não-lugares". Isto é, locais margeados por pistas de tráfego expresso e/ou espaços residuais, estéreis e impessoais. Mas, por isso mesmo, suas orlas são enormes reservatórios de urbanidade no coração dessas mesmas cidades, sobretudo se tomarmos como referência as orlas marítimas. Haveria exemplo mais emblemático de um espaço público vital, no Brasil, do que o calçadão de Copacabana? ${ }^{349}$

Embora o curador mencione como referencial uma obra em que convergem a arte e o paisagismo (forma e função), ele ressalta que as obras de Margem estão liberadas de "qualquer

\footnotetext{
346 Idem, 2009.

347 Ibidem. Esta qualificação da arte reitera a análise de Sônia Sazstein (2005) sobre como as obras de Fronteiras se relacionam com o lugar e com o entorno: voltam-se interiorizadas criando um espaço mais íntimo do que objetivo. Importante notar que a natureza dos espaços ocupados pela arte em ambas exposições difere quanto à urbanização, mas se assemelham quanto à natureza dos espaços públicos urbanos - espaços ambíguos, não apropriados - e quanto à carência ou necessidade de se formar uma paisagem, de instaurar um olhar estético.

348 AUGÉ, Marc. Não Lugares: Introdução a uma antropologia da supermodernidade. Campinas: Papirus, 2007.

349 ITAÚ CULTURAL. Folder: Apresentação do projeto Margem e do Seminário As Cidades e Suas Margens. Acervo Gráfico Itaú Cultural, 2009.
} 
compromisso restaurador ou edificante. ${ }^{350}$ Também, ele declara que o projeto não toma os rios e suas margens como "metáforas nostálgicas de uma urbanidade perdida." ${ }^{351}$ No entanto, no folder da exposição, acima da imagem da obra Errante (2010), aparece uma fotografia da Várzea do Carmo de $1890 .^{352}$ Talvez a arte não tenha como se aproximar da paisagem se não visar a algum tipo de intervenção, ou composição harmônica, ou de investigação que, no fim, retorne mais rica de referenciais que a própria realidade. Carentes destas intervenções lembramo-nos do calçadão carioca ou da paisagem paulistana em fotos antigas.

Margem, como projeto de arte pública, mostrou-nos tais características, justificadas pela natureza do espaço. Mas a arte tende a se assemelhar à paisagem? (englobando, no conceito de paisagem, o espaço público urbano). Estão na forma e no modo de produção da paisagem o repertório, as forças ou condicionantes que moldam e contaminam a arte contemporânea da paisagem? Simplesmente concordar que a arte reage à paisagem, ao espaço urbano (ou em vias de) e dele incorpora certas características comprometeria uma característica essencial da arte: sua autonomia. ${ }^{353}$

Com a proposta de Margem, podemos refletir sobre os rios como elementos vitais da paisagem, que são determinantes nos processos de suporte - geológico, climático - e utilizados como recursos nos processos sociais e culturais formadores da mesma. ${ }^{354}$ Assim também, uma vez que os rios são tocados pela arte da paisagem, podemos refletir sobre a visibilidade que eles alcançam, suas histórias e o imaginário que evocam.

Para ampliar este debate, antes de focar os exemplos brasileiros, apresentaremos, em um discurso de imagens, algumas obras contemporâneas estrangeiras que incorporam, em seu

350 ITAÚ CULTURAL. Folder : Margem: Errante.09 out. a 28.nov. Itaú Cultural, 2010.

351 Ibidem.

352 Ver imagem 156.

353 Bürger apresenta que a autonomia da arte resulta da separação entre a arte e a práxis vital, ocorrendo em três ordens: na finalidade (não mais subordinada ao culto ou à representação), na produção (o artista produz como indivíduo, domina o processo de produção) e na recepção (a fruição estética é individual e não mais coletiva como no culto ou na sociabilidade da corte). Embora este estudo não adentre o extenso debate da Teoria da Arte, refletir o quão autônoma pode ser uma arte que se relaciona diretamente com a paisagem pode aclarar nossa compreensão do quanto a arte da paisagem se afasta da tradição burguesa. Ver BÜRGUER, Peter. Teoria da Vanguarda. Lisboa: Veja, 1993.

354 ALEX, Sun. Água e paisagem: questões de paisagismo em torno de um reservatório de abastecimento na grande São Paulo. Dissertação Mestrado, FAU-USP, 1985, p. 8. 
conceito ou fisicalidade, os rios urbanos e, por decorrência, lançam luz ao debate da paisagem por eles qualificada. Propomos refletir, com estas obras, sobre os modos pelos quais a arte contemporânea da paisagem abarca a produção da paisagem.

Devemos somar a este repertório, as obras brasileiras apresentadas no Capítulo 02, que integraram as exposições Quase Líquido (2008) e as que compõem o acervo de arte pública permanente da $5^{a}$ Bienal do Mercosul (2005), pois antes de serem exemplos da nossa arte da paisagem, elas tiveram os rios como ponto de partida ou como elemento significativo. Esta é a maneira que encontramos para dar eco, através da arte, à proposta de Margem que, além da obra Errante, de Hector Zamora, apresentou o projeto Cabaré Chinelo, de Nuno Ramos, para Manaus, mas que não foi implantado.

Também apresentarei exemplos que abordaram in loco, ou como ideia, as fronteiras geográficas e políticas e os territórios, para pensarmos as nuances de significados que estes "temas" podem ter de acordo com a paisagem.

Este breve repertório de imagens, longe de ser um memorial de obras ${ }^{355}$ sobre os temas de Fronteiras (1998-2001) e de Margem (2009-2010), tem a intenção de somar mais camadas de interpretação às obras destes projetos.

\subsection{Fronteiras e territórios na arte contemporânea da paisagem.}

Artistas contemporâneos brasileiros e estrangeiros já haviam discutido e trabalhado a ideia de fronteira, e os lugares de fronteira, em suas implicações políticas, como reflexão sobre o desenho (demarcação, designação) e a representação, tendo nos mapas objetos simbólicos da representação espaço-tempo.

A partir de meados da década de 1960, a arte contemporânea no Brasil assume contornos mais políticos, uma vez que reagia à ditadura e à escassez de espaços para se desenvolver. Neste período, meios de comunicação - tais como cartas, postais e inclusive o

\footnotetext{
355 Obras que artializam in situ rios urbanos e fronteiras desenvolvem-se desde a segunda metade do século XX. Fortes, em Poéticas Liquidas: a água na arte contemporânea, aborda especificamente as aproximações desta arte com a água. No Capítulo 3, o autor faz um panorama de obras que abordam os rios como tema ou como meio. Ver FORTES, Hugo. Poéticas Líquidas: a água na arte contemporânea. Tese de Doutoramento, ECA-USP, São Paulo, 2006, p. 52-91.
} 
mapa - são empregados pela arte para driblar essas barreiras. Prevalece o tempo do efêmero materializado em formas sutis ou fugidias.

O mapa, como representação do território, do poder, agregava discursos políticos e foi objeto de interesse e assunto da arte contemporânea - no Brasil e exterior -, a partir dos anos 1960 e, principalmente, durante os 1970. É herança do Minimalismo o interesse pelos números, medições e pelo tempo e, para a arte que se relaciona diretamente com a paisagem, vemos que o mapa se torna "um veículo" entre os artistas. Isto porque ele registra eventos de obras impalpáveis ou retratos de jornadas, sobretudo por indicar os binários tempo e lugar, representação e experiência.

Segundo Lippard:

O mais comum dos mapas tem sua beleza formal inata como desenho e satisfaz uma natural necessidade pela ordem através de uma sintaxe, uma linguagem para se apreciar - sem representar - a paisagem. É um modo de modernizar toda a noção que a arte tem sobre o espaço. ${ }^{356}$
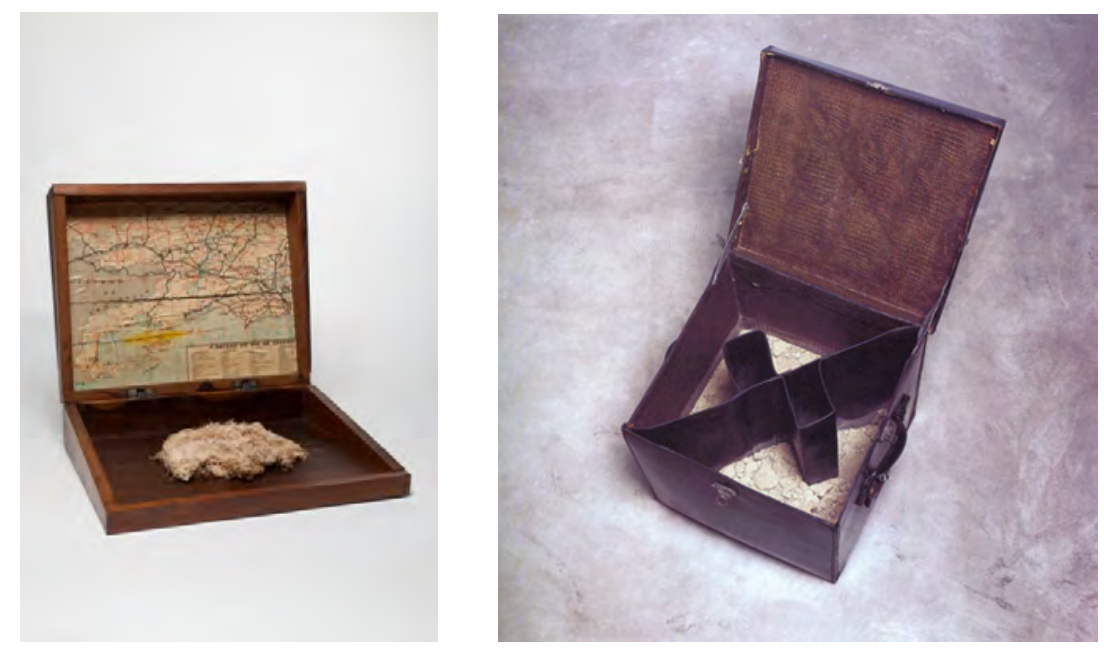

107 e 108. Cildo Meireles. Cordões 30Km, 1969 e Mutações Geográficas: fronteira Rio-São Paulo, 1969.

(Fonte: <http://tcmagazine.wordpress.com/2011/10/24/panorama-da-arte-brasileira-2011-coloca-em-

debate-o-tema-itinerarios-itinerancias/>, Acessado em: 05/12/12 e

$<\mathrm{http}$ //www.itaucultural.org.br/aplicexternas/enciclopedia_IC/

Enc_Obras/dsp_dados_obra.cfm?cd_obra=6323\&cd_idioma $=28555 \& c d$ verbete=581\&num_obra=8>, Acessado em: 05/12/12)

\footnotetext{
356 "The most ordinary map has an inherent formal beauty as a drawing and it satisfies a basic longing for order by offering a syntax, a language through wich to appreciate, without depicting, landscape. It is a way of modernizing the whole notion of art about space." (tradução nossa).Ver LIPPARD, Lucy. Overlay contemporary art and the art of Pre-history. New York : Pantheon Books, 1983, p. 121-122.
} 
O único artista brasileiro apresentado por Kastner (1998) é Cildo Meireles com as obras Mutações Geográficas: fronteira Rio-São Paulo (1969) e Condensados II (1970), dentro da vertente envolvimento. ${ }^{357}$ Estas obras evocam a fronteira - linha imaginária - em sua materialidade, assim como o mistério de se passar através dela ou o que está além do seu contorno ou delimitação. Na primeira obra, Meireles escavou um buraco de cada lado da fronteira entre São Paulo e Rio de Janeiro, e neles transferiu terra, plantas e escombros. Parte destas escavações foi posta em uma caixa de couro que reproduz internamente, com uma divisão, a delimitação da fronteira. Em Condensados (versões em miniatura de suas obras), a terra, junto a um diagrama que relata o processo e construção da obra, são inseridos dentro de um anel de prata, ametista e ônix.

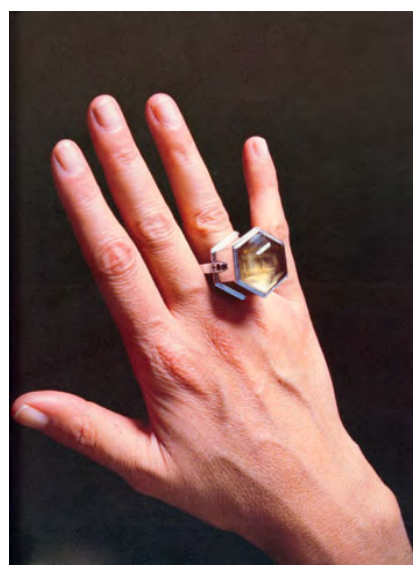

"Condensados (1970) demonstra que a potência do trabalho de arte não é restringida pelo tamanho, enquanto Mutações Geográficas: fronteira Rio-São Paulo (1969) reflete sobre distância e fronteiras em relação à vastidão territorial do Brasil".

(KASTNER; WALLIS, 1998, p. 134-135)

109. Cildo Meireles. Condensados II - Mutações Geográficas: Rio-São Paulo, 1970.

Fronteiras territoriais e mapas são recorrentes na arte conceitual ${ }^{358}$ e na land art, não só como objeto, mas também como tema em diversos países, incluindo o Brasil. Podemos dizer até que estas categorias da arte, que apresentam contornos distintos, têm em comum a alusão à fronteira e ao mapa. Há obras que, por contestação política, agem sobre esta linha, muitas vezes tensionada. Também há obras que, através de mapas, investigam de que modo dimensões de tempo e espaço existem no intervalo entre a representação e a existência.

A fronteira territorial pode ser mais uma relação política e cultural do que um fato ou objeto - como um acidente geográfico, por exemplo. É também uma relação entre tempos e

357 KASTNER; WALLIS, 1998, p. 17. Como vimos no Capítulo 02, estes autores agrupam as obras da land art por áreas de interesse ou tipos de prática. Aqui, designa-as por envolvimento pois nelas predomina a escala humana, a ação - o efêmero de uma performance ou de um ritual - além de revelar "a paisagem como uma zona de invasão ou exclusão, dividida pela invisível e complexa rede política."

358 Mapas e fronteiras são objetos e temas caros à arte conceitual, que "desmaterializa" a obra e foca o discurso, valorizando as ideias sobre o objeto de arte, assim como o corpo em ação e os meios de comunicação que propagam e registram tais ideias: cartas, postais, vídeo, xerox, fotografias, mapas. 
espaços. Para a arte contemporânea da paisagem, ela parece indicar o limiar entre a realidade sensível e o artifício da cultura arbitrariamente sobreposto a tal experiência ou, como uma metáfora, suscita uma situação limite em relação à percepção. Vejamos algumas abordagens de fronteiras e territórios na arte contemporânea da paisagem.

- Fronteira sóciopolítica de grande tensionamento: Tijuana (México) e San Diego (EUA). Arte da paisagem como ação em conjunto.

A Bienal Insite Art Practices in the Public Domain, que promove "ações públicas" da arte na região de fronteira entre San Diego (EUA) e Tijuana (México), implantou obras como o Dirty Water Iniciative - que intensamente se relacionam com essa paisagem fronteiriça. Seus curadores, como Osvaldo Sanchez, ${ }^{359}$ adotaram a premissa de que a arte deve estabelecer relações entre grupos sociais das duas cidades e, para tanto, a Bienal oferece residência artística de dois anos. Assim, a arte que intervém diretamente na paisagem, é pensada como fruto da vivência na paisagem, de modo a ser amadurecida durante o tempo entre pesquisa de elaboração e implantação, a fim de criar nexos com o lugar, com as pessoas e com o entorno.
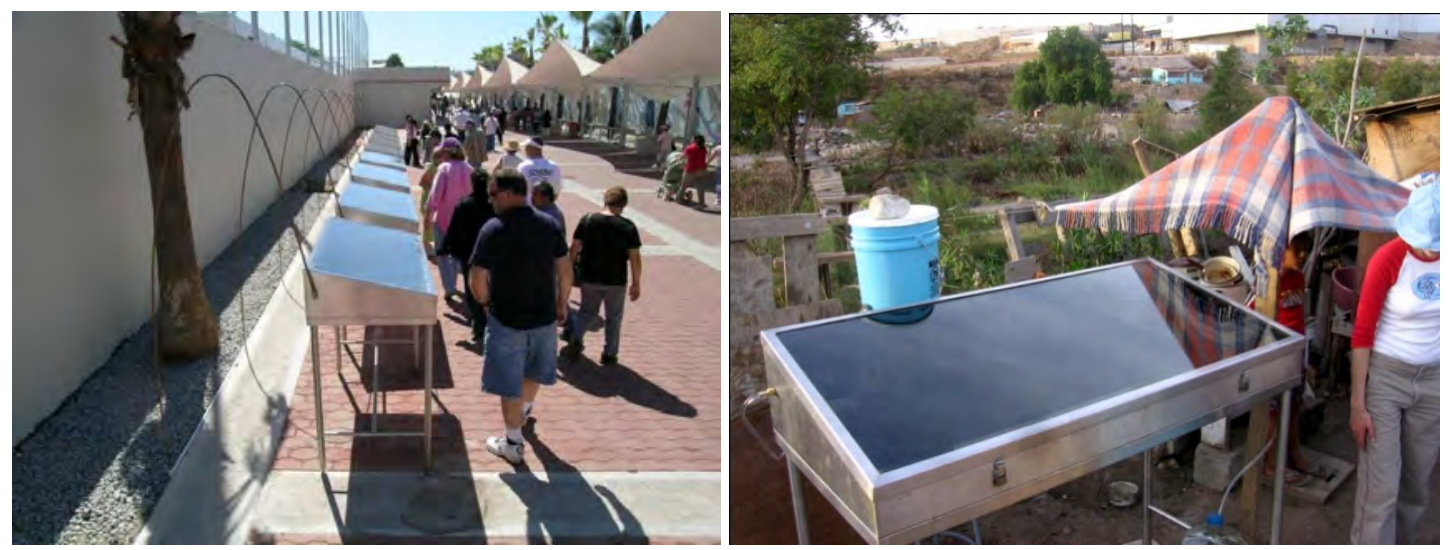

110. Intervenção Dirty Water Initiative. Coletivo Simparch, 2005. Trinta minidestiladores de água movidos a energia solar em via de pedestres na divisa entre EUA e México.

(Fonte: < http://www.simparch.org/dwi.html>)

\footnotetext{
359 Sanchez, diretor artístico da Bienal de 2005 foi palestrante no projeto Margem em 18/09/2009 (Fonte: < DVD ICEVE FV 487 pt.2). Em entrevista para esta dissertação, Nuno Ramos chamou a atenção para a diferença entre discutir a fronteira onde ela é vívida - como em Tijuana/San Diego - e a falta de nexo em abordar, através da arte, este tema no Brasil, "cujos limites geográficos não são tensionados."
} 
Neste contexto, tal proposta promove o desenvolvimento de uma arte da paisagem significativa, que não resulte em simples adição de um objeto na mesma. A obra se afasta do monumento ou do objeto em linguagem autônoma.

A obra do Coletivo Simparch abordou a disparidade na oferta de água pura entre as cidades vizinhas norte-americana e mexicana. Margeando a calçada norte-americana alinham-se os purificadores de água, como fontes públicas, que após a exposição da bienal, foram levados para áreas carentes de água potável no lado mexicano.

- Fronteira como experiência do tempo e espaço percorridos: arte da paisagem como ação.

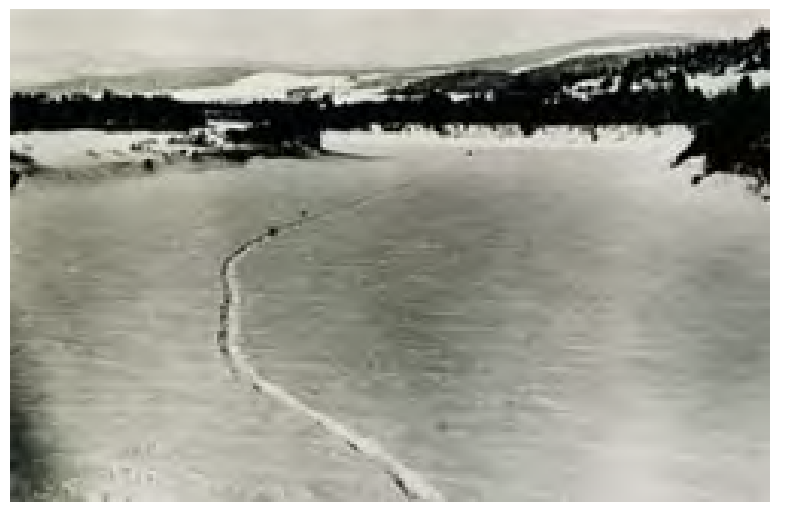

111. Dennis Oppenheim. Time Line, 1968. Neve e veículo sobre neve. Duas linhas, $30 \times 91 \mathrm{~cm} \times$ 4.827 Km, sobre o rio congelado St. John. Fronteira entre EUA (Fort Kent, Maine) e Canadá (Clair, New Brunswick).

(Fonte: < http://www.radicalart.info)

Oppenheim, por sua vez, levou dez minutos em um veículo sobre neve à velocidade de trinta e cinco quilômetros por hora para sulcar duas linhas paralelas no gelo. Segundo Kastner:

O artista explora a relação entre tempo e espaço: o tempo é simultaneamente o mesmo e diferente de cada lado da fronteira. Isto evidencia o contraste de tempo como um conceito abstrato e como uma experiência de movimento através do espaço. $^{360}$

Parece que, para estar a par com a natureza (neste caso com o Rio St. John, que demarca essa fronteira), o artista lança mão da tecnologia, de uma máquina-veículo que corta

${ }^{360}$ KASTNER; WALLIS, 1998, p. 50. 
o gelo, com a qual consegue marcar a superfície com um desenho humano. Oppenheim desenha junto com o rio, seguindo sua velocidade e seu contorno, em um registro efêmero.

- A aparente zona neutra da fronteira: arte da paisagem como performance e provocação.

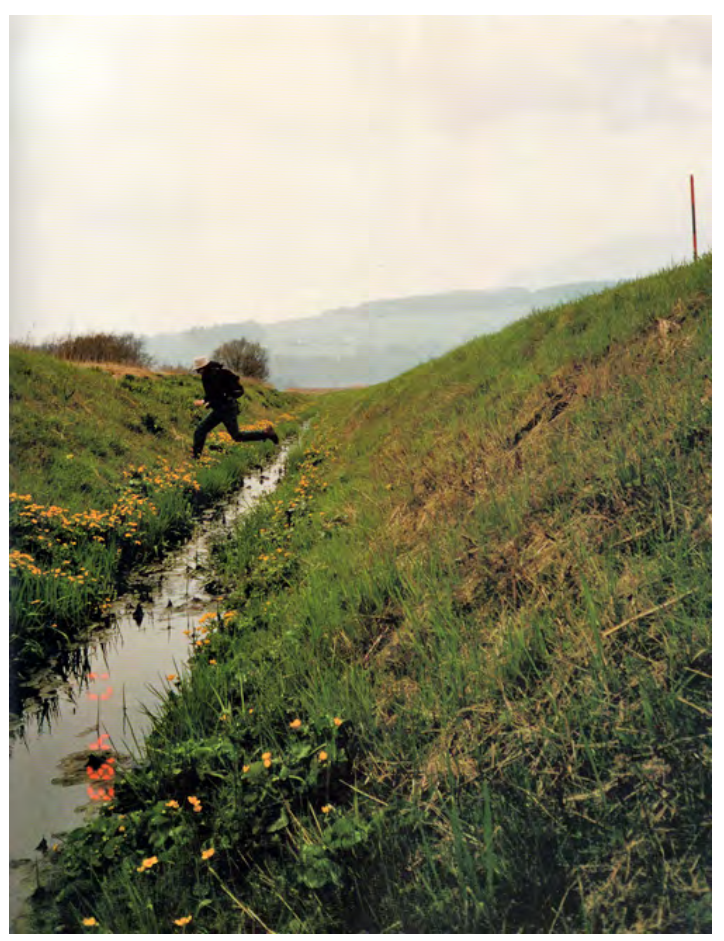

112. Christian Phillip Müller. Illegal Border Crossing Between Austria and the Principality of Liechtenstein. Performance, 1993. (uma de oito travessias)

Em Illegal Border é novamente o rio que aparece como elemento natural de fronteira. Se ele está oculto pela neve na obra de Oppenheim, que refaz seu desenho, na foto de Müller, este se encontra em primeiro plano: delicadamente o curso d'água com margem florida representa este pequeno obstáculo natural que é saltado pelo artista. Mas a imagem em tons suaves que alude a uma paisagem pastoral não indica a rede complexa que ali se estrutura, além dos elementos da natureza enquadrados..

Müller cruza a fronteira entre a Áustria e seus oito países vizinhos, descrevendo-nos seu itinerário e meios de transporte. Na fronteira com a República Tcheca, ele foi preso e 
proibido de voltar ao país por três anos. Ele registra que, apenas ao ver pintado o chão com as cores azul e vermelho (cores da bandeira tcheca), sabia que não estava mais na Áustria.361

A provocação política é evidente: o fato de ressaltar que "apenas ao ver as cores da bandeira" ele sabia que estava em outro território é um forte índicio de um espaço construído, representado e sedimentado culturalmente. O livre passear em um campo (a que a imagem pode remeter), o lirismo de evidenciar os elementos naturais como o riacho e a grama em primeiro plano podem sugerir uma paisagem - como visualidade - que não se relaciona com a dinâmica do lugar e os elementos de controle agregados àquela natureza.

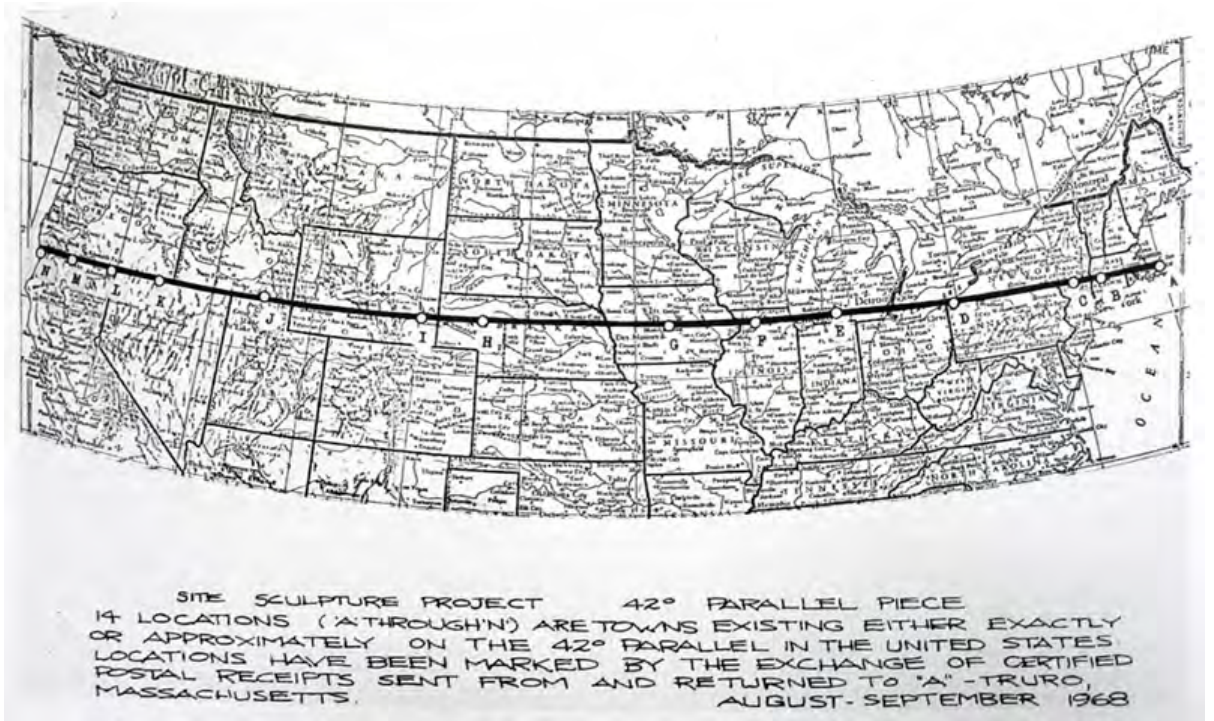

113. Douglas Huebler. Left and opposite, 1968.- Mapa e recibos postais documentados. Performance. (Fonte: KASTNER; WALLIS, Land and Environmental Art, 1998, p.176-177.)
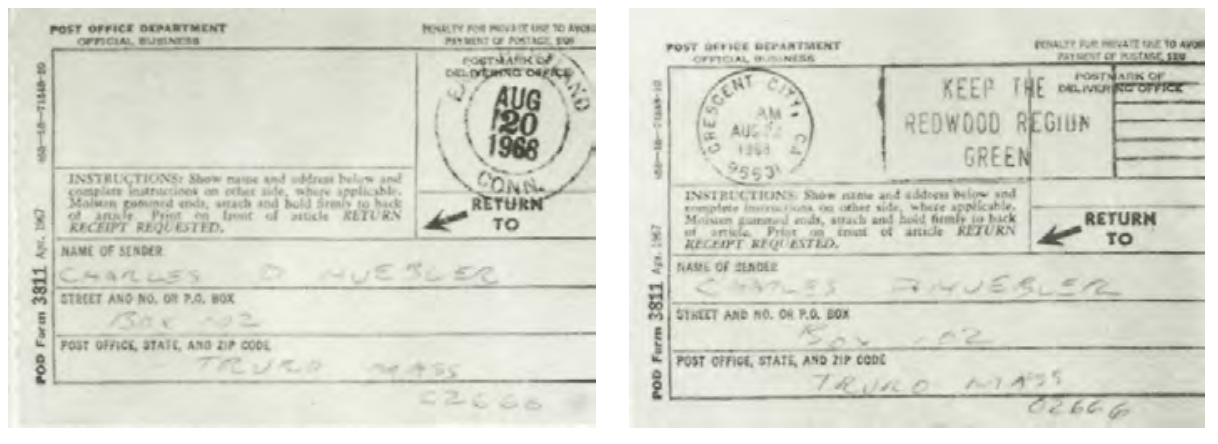

Huebler elege o paralelo $42^{\circ}$ e nele marca catorze cidades e municípios que estão exatamente ou aproximadamente nesta linha. O artista envia cartas a estas cidades, sem uma

${ }^{361}$ KASTNER; WALLIS, 1998, p. 133. 
destinação específica, elas vão e voltam para o endereço do artista. Os canhotos datados de recebimento e devolução pelo Correio são expostos com o mapa. É interessante pensar sobre o recebimento e a devolução da correspondência em um intervalo de dias, o que nos diz sobre distâncias e tempo. Também nos diz muito sobre uma organização espacial e social estruturada a partir de dados objetivos e funcionais. Simples objetos banais, como os canhotos postais, ganham uma densidade histórica, relacional e este é um intento comum à arte conceitual: atribuir alguma poesia, uma história a mais a um objeto da existência comum.

\subsection{Rios na arte contemporânea da paisagem.}

A vida essencialmente urbana que se instala definitivamente a partir do início do século XX, muda a relação do homem com a natureza e suas matérias. A água canalizada na cidade, não é mais a mesma que se vê nos rios renascentistas, nos mares holandeses e venezianos e nas cachoeiras e geleiras românticas. A água vista pela arte começa a ganhar uma autonomia baseada na significação de seus processos e sensações, e não é mais tão importante se ela provém dos rios ou dos mares. (FORTES, 2006, p. 47)

O interesse pela paisagem vem crescendo e são muitos os fatores que o justificam. Alguns deles são a demanda por qualidade ambiental, a necessidade estética que não se produz apenas no âmbito das artes ou ainda a necessidade de referenciais sociais e individuais, uma vez que a paisagem, como uma compreensão holística do meio, é contraponto ao modelo de urbanização tecnocêntrico.

Dentre as paisagens de maior interesse estético e ambiental estão aquelas com água. A presença da água na paisagem é constatada por diversos autores como um fator altamente atrativo, talvez pelo seu reconhecimento como elemento indispensável à vida, meio de circulação, marco territorial que estrutura o desenho da cidade ou ainda como escoamento ou elemento simbólico. Quase de modo universal, os sentidos se aprazem com a água e atribuem valores estéticos e simbólicos às suas diversas ocorrências. As águas em movimento, por exemplo, são preferidas às águas paradas, geralmente associadas a pântanos. Em 1968, nos EUA, implantou-se uma política nacional de proteção de certos rios, "Wild and Scenic Rivers $A c t$ ", visando a valorização dos mesmos, de acordo com suas características naturais e culturais. Para tanto, desenvolveram-se métodos de pesquisa para classificar as preferências 
paisagísticas relativas aos rios, a fim de contruir uma base de dados para o projeto e planejamento da paisagem. ${ }^{362}$

Estamos nos referindo a uma época e país em que o estudo da paisagem estava em alta, motivado por "objetivos pragmáticos de planejamento, ordenamento, projeto e/ou gestão."363 Pensando em intervenções na paisagem, duas vertentes distintas têm sido encontradas: uma que considera a paisagem essencialmente do ponto de vista estético e artístico, apontando suas qualidades formais e cênicas; e outra, no campo da ecologia, que "associa aos ecossistemas naturais e não modificados o valor estético mais elevado." ${ }^{364}$

Conforme veremos nos exemplos a seguir, também a arte contemporânea da paisagem apresenta dois modos de aproximar-se ou abordar os rios e suas paisagens de margem. Um ressalta os aspectos estéticos e simbólicos da paisagem fluvial, da água; enquanto o outro reforça o contexto político e econômico da paisagem, pelo qual o rio é recurso a ser preservado ou elemento formador da cidade, mesmo que tenha sido subjugado a interesses tecnocratas. Tais aproximações, no entanto, apresentam permeabilidade. Dificilmente poderemos enquadrar a obra de arte da paisagem, estritamente, em um ou outro modo.

Se, há aproximadamente cinco décadas, a paisagem e a natureza (re)despertaram o interesse da arte, há pelo menos duas décadas esta arte, em diversos países, trata dos rios urbanos em escala social, com o desejo de revitalizá-los como elementos simbólicos e formadores da paisagem. Valores estéticos e ecológicos estimulam discussões, também compartilhadas pela arte, sobre a recuperação de rios e a revitalização ambiental.

No Brasil, a arte contemporânea vem recentemente se ocupando dos rios - das suas margens - e pouquíssimos projetos os abordam de modo mais estruturado, ou seja, não contando apenas com a ação individual de artistas isolados. Histórias de rios como o de Coketown ${ }^{365}$ se repetiram e ainda se repetem em muitos lugares.

\footnotetext{
362 SARAIVA, Maria da Graça Amaral Neto. O Rio como Paisagem: Gestão de corredores fluviais no quadro do ordenamento do território. Lisboa: Fundação Calouste Gulbenkian, 1999, p. 243. (Coleção Textos Universitários de Ciências Sociais e Humanas). Sobre a preferência de paisagens com água pelos fatores significado e envolvimento.

363 Ibidem, p. 231.

364 Ibidem, p. 232

365 Charles Dickens denunciou as condições insalubres do novo ambiente urbano, retratadas na cidade de Coketown, em seu romance Hard Times (1854). Na cidade, ele descreve, "havia um canal escuro e um rio de cor roxa com manchas mal cheirosas, e uma série de edifícios cheios de janelas que sacolejavam e tremiam o dia inteiro, e onde o pistão da máquina a vapor monotonamente trabalhava para cima e para baixo como a cabeça de um elefante num estado de melancolia insana. Possuía várias ruas largas
} 
Vejamos algumas obras:

* (Vide imagem 50: Mark Dion. Tate Thames Dig, Londres. 1999/2000. No CAP.2, pág.94 )

O artista, junto a profissionais e voluntários, coleta objetos encontrados em um trajeto do Rio Tâmisa. Como uma arqueologia urbana, estes itens são expostos em uma espécie de gabinete de curiosidades, em procedimentos quase científicos e significados artístico, simbólico e cultural.

(Fonte: <http://www.tate.org.uk/art/artworks/dion-tate-thames-dig-t07669>. Acessado em:

$15 / 12 / 12)$

Com Tate Thames Dig (1999-2000), dissecamos objetos encontrados no rio e seus tempos, mergulhando na história do Tâmisa. ${ }^{366}$ Para tanto, é necessário tempo de implantação da obra; tempo para a participação dos voluntários, que junto à equipe técnica procuraram nas margens por materiais que contassem "histórias individuais e efêmeras;" ${ }^{367}$ tempo para a exposição da obra junto a debates, convergindo em um tempo para a reflexão. Podemos ainda dizer que a obra trabalha a ideia de tempo que um rio suscita, mesmo que longe da sua condição natural.

Enfatizando os processos de transformação do rio e da paisagem, Dion transcreve um trecho de "Heart of Darkness" (1899), de Joseph Conrad, que inicia com uma descrição do rio Tâmisa como o "rio da escuridão". O público relaciona artializações da literatura da própria paisagem e pode tecer um imaginário através de memórias e dos objetos identificados (mas não classificados historicamente). Tate Thames Dig se refere à paisagem em seus aspectos naturais e culturais, abarcando a história das pessoas em relação ao rio. A obra, lindamente, aproxima os conteúdos científico e artístico da paisagem.

Outro exemplo para a reflexão da paisagem através dos rios, mas efêmero, é a obra Green River Project (1998 a 2001), do artista dinamarquês Olafur Eliasson. Rios urbanos de grandes cidades foram pigmentados de verde, em uma provocação para chamar a atenção das pessoas para eles. O pigmento verde é o mesmo usado por cientistas para detectar correntes marítimas, mas sua intensidade em meio à paisagem urbana tanto nos desperta para uma beleza "natural", quanto nos causa estranhamento. Green River aborda o limiar entre nossa

todas parecidas, e muitas ruas pequenas mais parecidas ainda, habitadas por pessoas igualmente parecidas, entrando e saíndo nos mesmos horários, com o mesmo som sobre os mesmos pisos, para fazer o mesmo trabalho e para quem cada novo dia era igual ao de ontem e de amanhã [...]." Ver DICKENS, Charles. Hard Times. apud LIMA, Catharina P. C. dos Santos. Natureza e cultura: o conflito de Gilgamesh. Revista Paisagem e Ambiente, São Paulo, FAU-USP, n.18, 2004.

366 O rio é considerado responsável pela localização, crescimento e desenvolvimento da cidade de Londres. (FISKE; BOTINELLI, 2002. Disponível em: < http://www.tateorg.uk/art/artworks/dion-tate-thames-digt07669/text-summary. $>$ )

367 Ibidem. 
ideia de natureza e os artefatos da paisagem. A arte da paisagem no contemporâneo, longe de ser aquela pictórica que teve sua primazia até o século XIX, retorna, neste caso, a ter a cor como qualidade essencial.
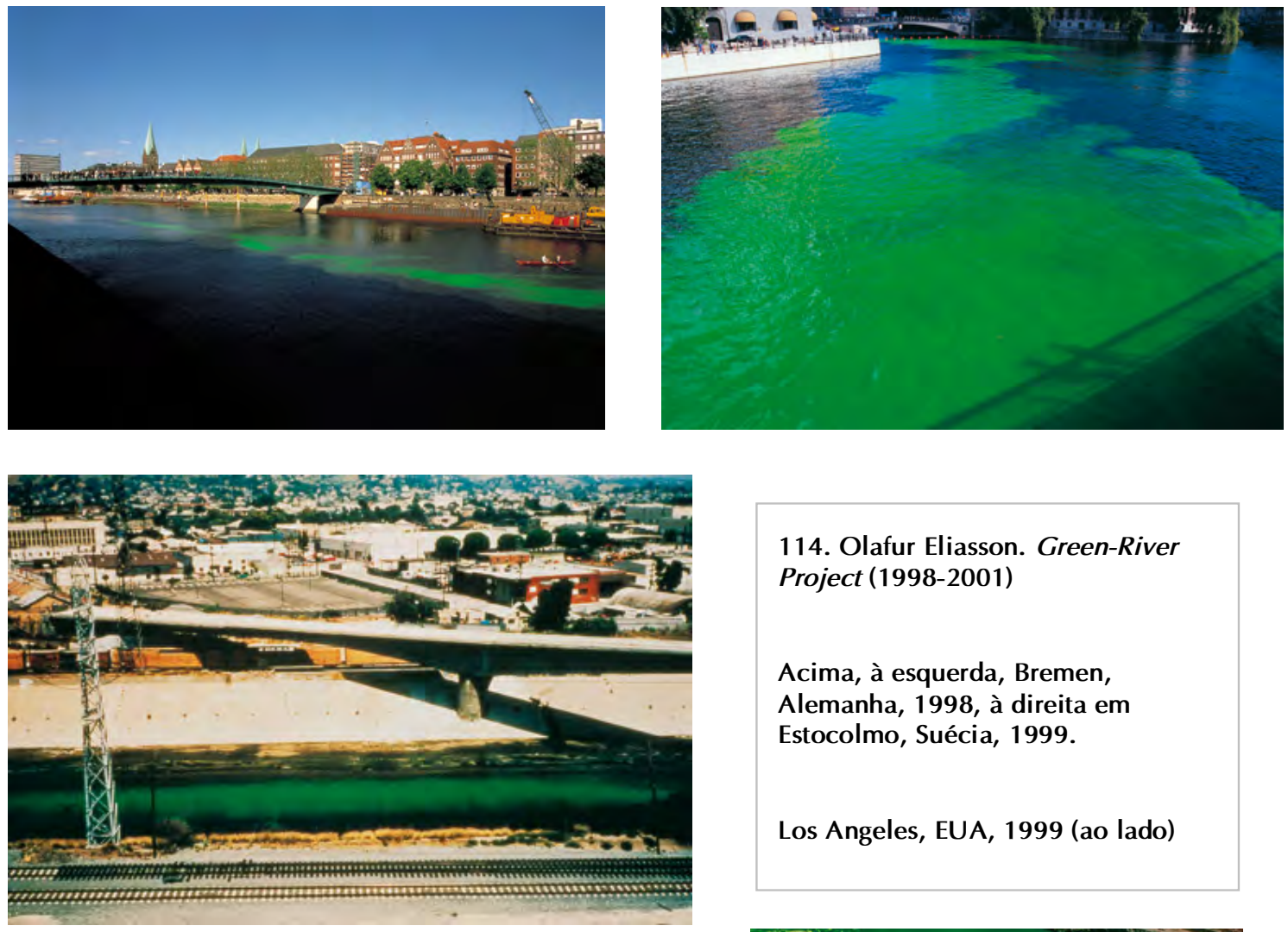

114. Olafur Eliasson. Green-River Project (1998-2001)

Acima, à esquerda, Bremen, Alemanha, 1998, à direita em Estocolmo, Suécia, 1999.

Los Angeles, EUA, 1999 (ao lado)

(114). Abaixo, à esquerda, Tókio, 2001; e à direita em Moss, Noruega, 1998.

(Fonte:<http://www.olafureliasson.net/works/green_ri ver_4.html>. Acessado em: 15/12/12)
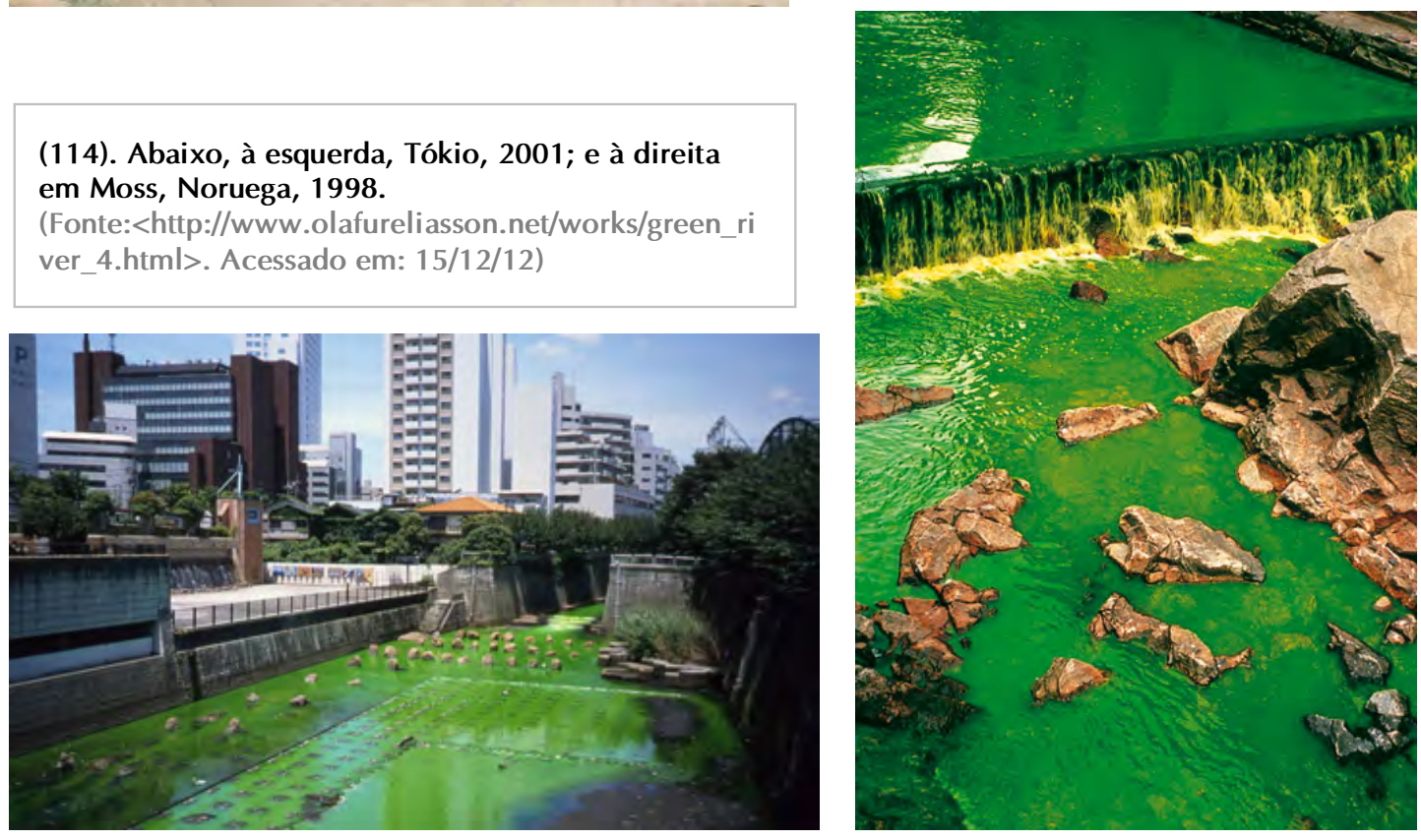
É também de Eliasson o conjunto de intervenções Waterfall Project (1998-2011), igualmente para diversas metrópoles, e que incluiu São Paulo. Aqui, a "cascata" foi exposta em Seu Corpo da Obra (2011), no Sesc Pompeia, onde, em uma palestra, o artista falou sobre sua dificuldade em encontrar um espaço público para a obra, assim como ressaltou a permeabilidade entre os espaços público e o privado, característica da cidade, que muito nos revela sobre nossa paisagem. A "cascata" se transformou em um elemento de lazer no deck do SESC Pompeia, indicando a possibilidade da arte existir como equipamento de lazer e, ao mesmo tempo, de contemplação. Onde quer que intervenha, Waterfall Project sensibiliza-nos sobre nossa relação com os elementos da natureza e como tais elementos estão presentes ocultados, transformados - em nossas paisagens.

Segundo Fortes, ${ }^{368} \mathrm{o}$ artista trabalha, através da água e da tecnologia, as aproximações entre a arte, o sublime e a natureza. Em "cascata" e em outras de suas obras a natureza é "recriada através de um aparato tecnológico artificial, que é muitas vezes incorporado à apresentação visual da obra..

115. Olafur Eliasson. Waterfalls Project,

Nova lorque, EUA, 2008. (à direita)

(Fonte:<http://www.olafureliasson. net/works/waterfall_3.html>. Acesso em: 05/12/2012)

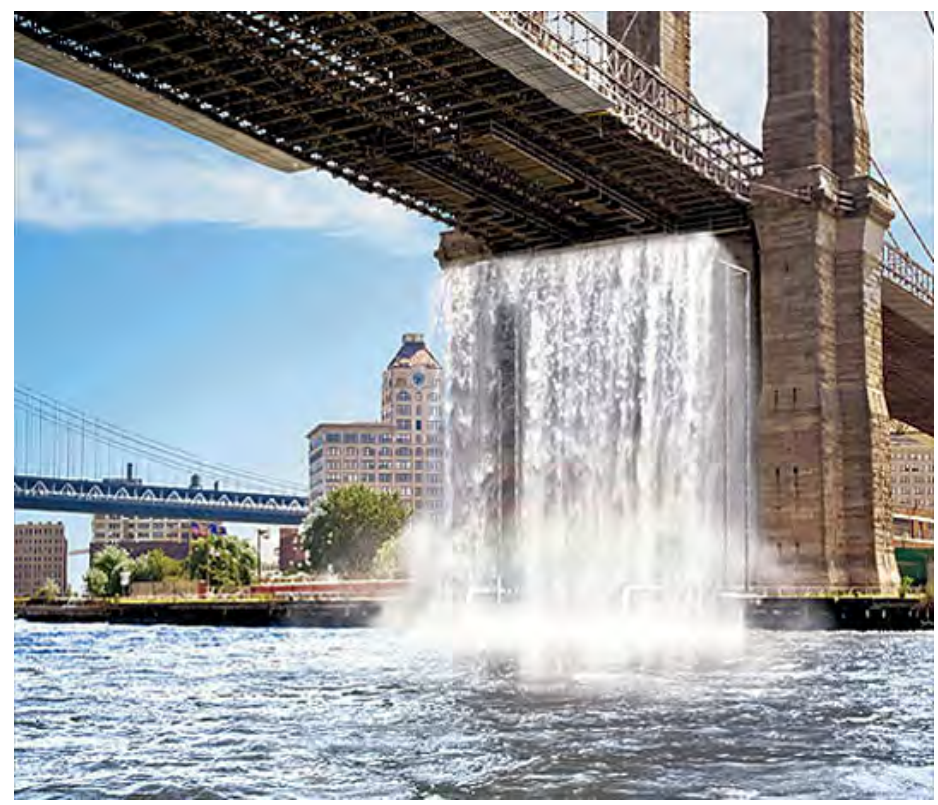



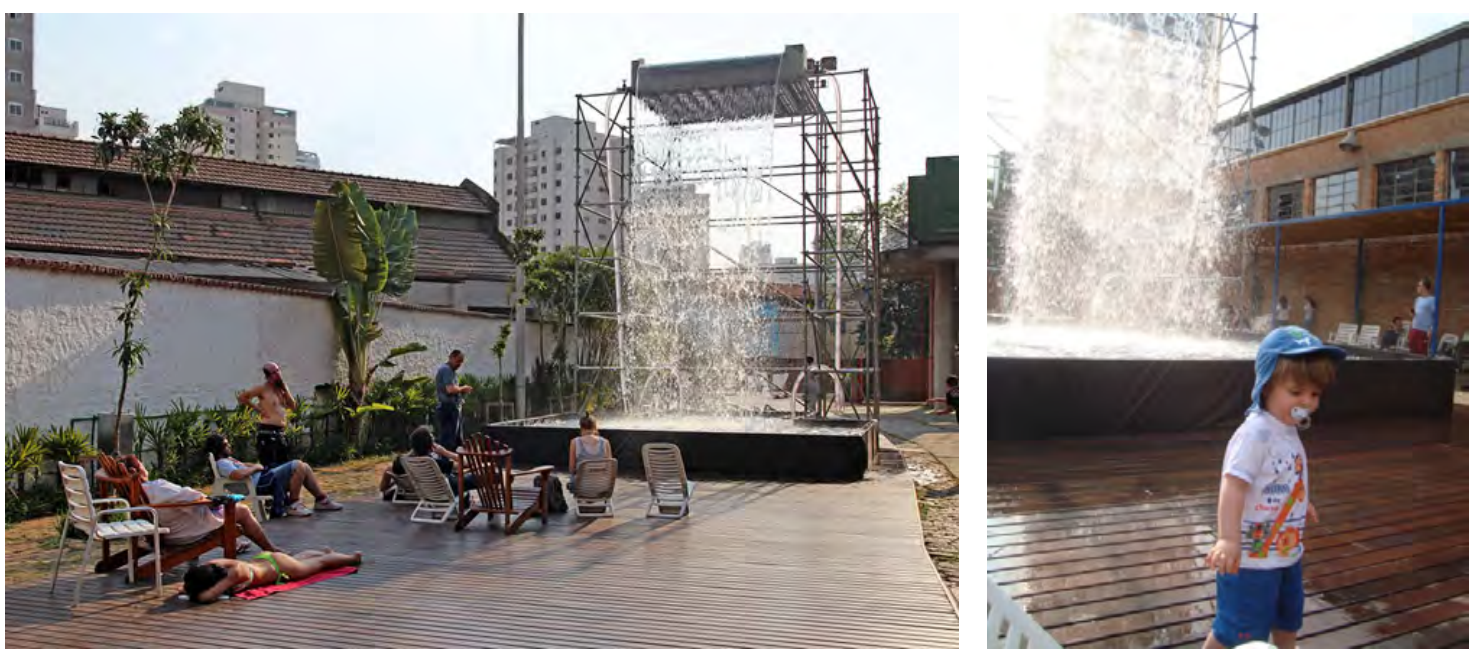

115. Olafur Eliasson. Waterfalls Project, São Paulo, SESC Pompeia, 2011. Parte da exposição Seu corpo da obra. (Obs.: Foi ao saber que abaixo do deck passa um córrego que Eliasson escolheu aquele como o lugar para sua obra). (Fonte: arquivo pessoal)
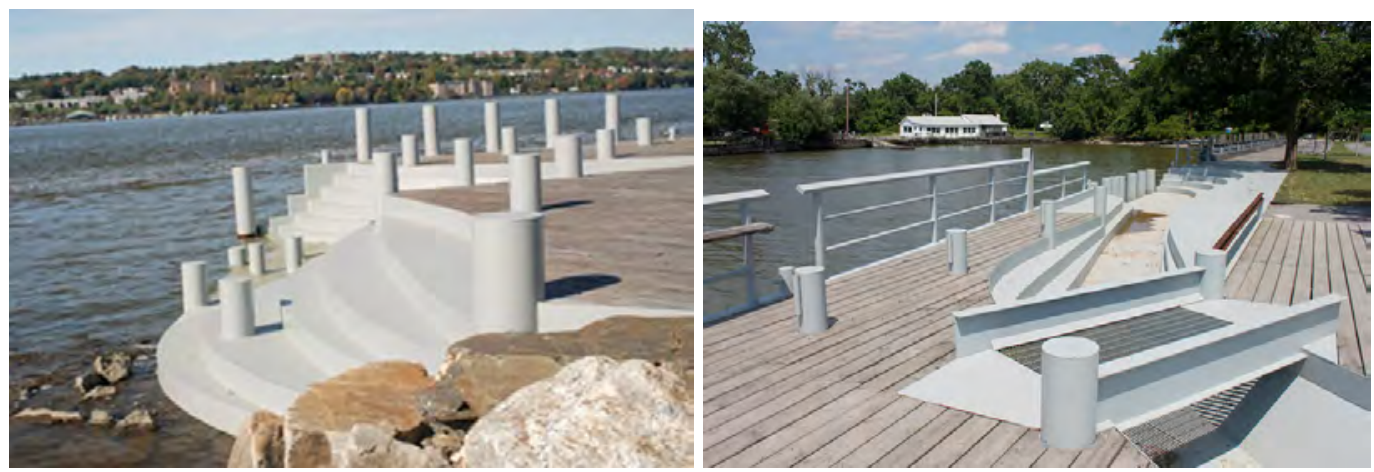

116. George Trakas. Beacon Point, 1999-2007.

(Fonte:<http://www.diaart.org/sites/page/60/1385> Acesso em: 05/12/12)

Um exemplo da arte contemporânea da paisagem a favor dos rios e que se hibrida com o paisagismo do lugar é a escultura de George Trakas, uma obra site-specific ou "esculturapier", como também é chamada. A obra, Situada em Beacon Point, NY, nas margens do rio Hudson, é formada por um terraço em ângulos, um passeio público na margem e de parte da costa natural preservada. Ela é apresentada como uma conexão entre as pessoas e o rio ${ }^{369} \mathrm{e}$ integra um projeto maior, o Scenic Hudson, que trata do paisagismo nas margens e proximidades do rio e previa, paralelamente à execução da escultura, um parque local.

369 Scenic Hudson foi criado para revitalizar uma área industrial em desuso. Junto com a obra do artista, desde 1999, deu-se início ao paisagismo nas margens com novas espécies vegetais e o projeto de um parque para se integrar ao pier. (Disponível em:

<http://www.scenichudson.org/whatwedo/ourtowns/beacon/trakas.> Acesso em: 05/12/2012) 
Fortes $^{370}$ apresenta outras obras contemporâneas que têm na água, incluindo os rios, sua poética. Em todas podemos pensar a água como fonte da vida, matéria-prima simbólica, como meio direto para atrelar a arte a políticas ambientais. Também podemos pensar em incorporá-la ao ambiente simplesmente pelo encanto de seu tempo e forma fugidios. Água e rios nunca deixaram de ser representados e de estarem presentes na arte.

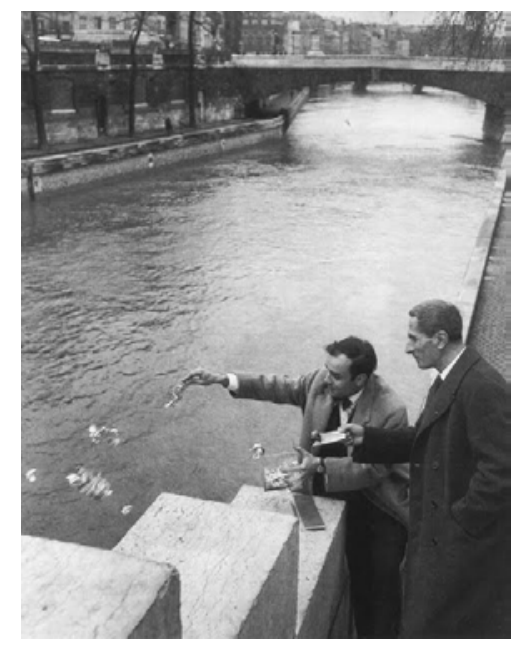

117. Yves Klein. Ritual de Entrega de uma Zona de Sensibilidade Imaterial (26/01/1962).

Klein lança folhas de ouro sobre o Sena. "O trabalho se dá por uma ação produzida pelo próprio ambiente em que se realiza, sendo o artista apenas um facilitador para que a ação aconteça. A fluidez da água do rio assinala a efemeridade da arte e da vida" (FORTES, 2006, p. 55)

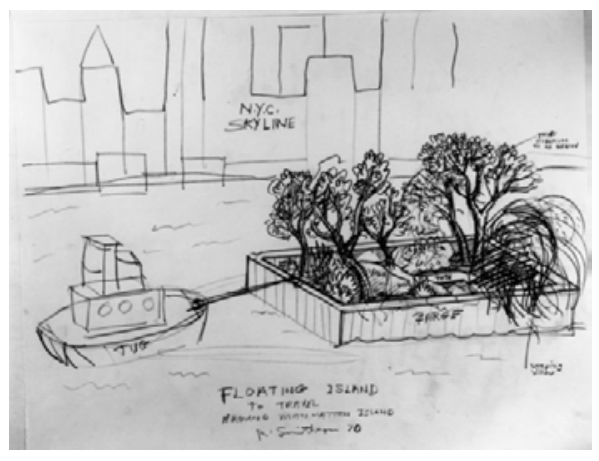

118. Robert Smithson. Floating Island to Travel Around Manhattan Island, 1970 / 17 a 25, set. 2005

A partir de um esboço de Smithson, em 1970, a escultura - como é denominada no site oficial do artista - é construída pela data de sua retrospectiva em 2005, quando esteve uma semana em navegação.

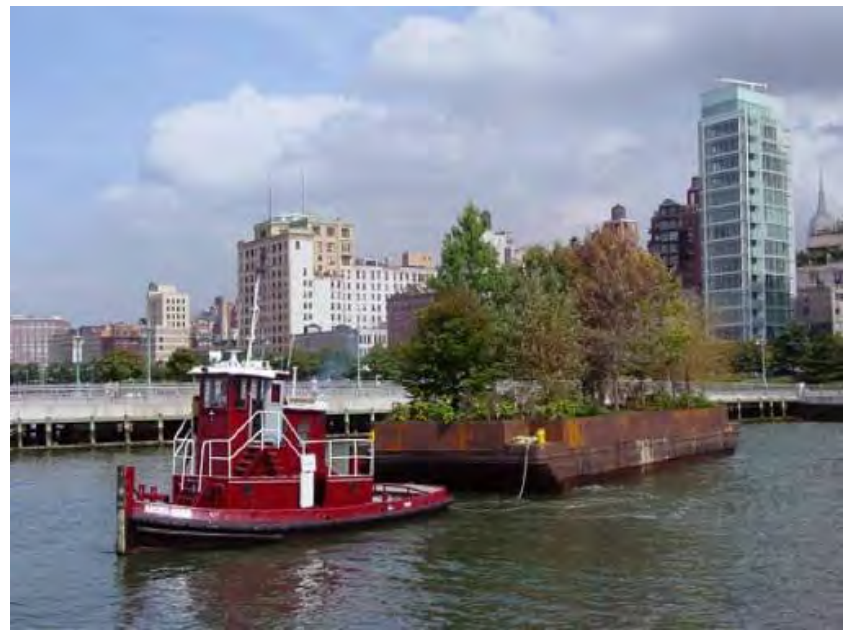

${ }^{370}$ FORTES, 2006. 


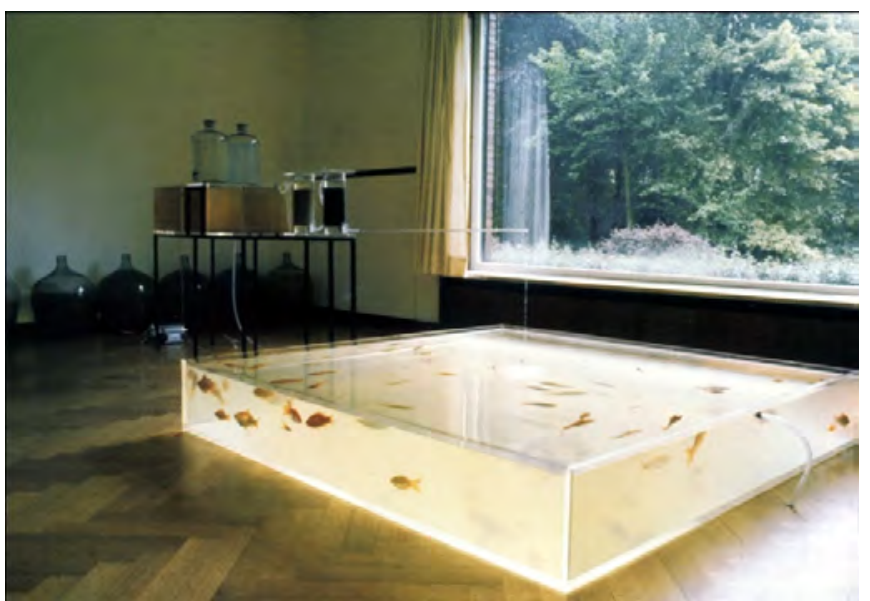

(Fonte: http://www.tumblr.com/tagged/hans\%20haacke)
119. Hans Haacke. Estação de tratamento de água do Reno (1972)

"...não se pode deixar de notar a qualidade estética atingida ao confrontar os diferentes graus de transparência da água, ou mesmo a beleza poética da inserção dos peixes que nadam neste grande aquário"

(FORTES, 2006, p. 66)

A obra acima destaca a água como fonte de vida e prenuncia uma arte ecológica, cujo propósito é menos a forma e mais o despertar para assuntos de interesse social e ambiental. Também podemos dizer que compartilha com a arte conceitual o interesse pela ideia e pelo processo, sendo a forma o resultado. $\mathrm{O}$ aquário, frente à janela por onde vemos o jardim do museu, indica uma perspectiva, um modo de olhar integrado, que remete à ideia de paisagem harmônica. Outro aspecto igualmente relevante que observamos com relação à obra de Hans Haacke é que a arte da paisagem pode estar dentro do museu, ou galeria, pois o que a caracteriza são seus vínculos com as questões da paisagem e como nos influencia a olhá-la mais profundamente.

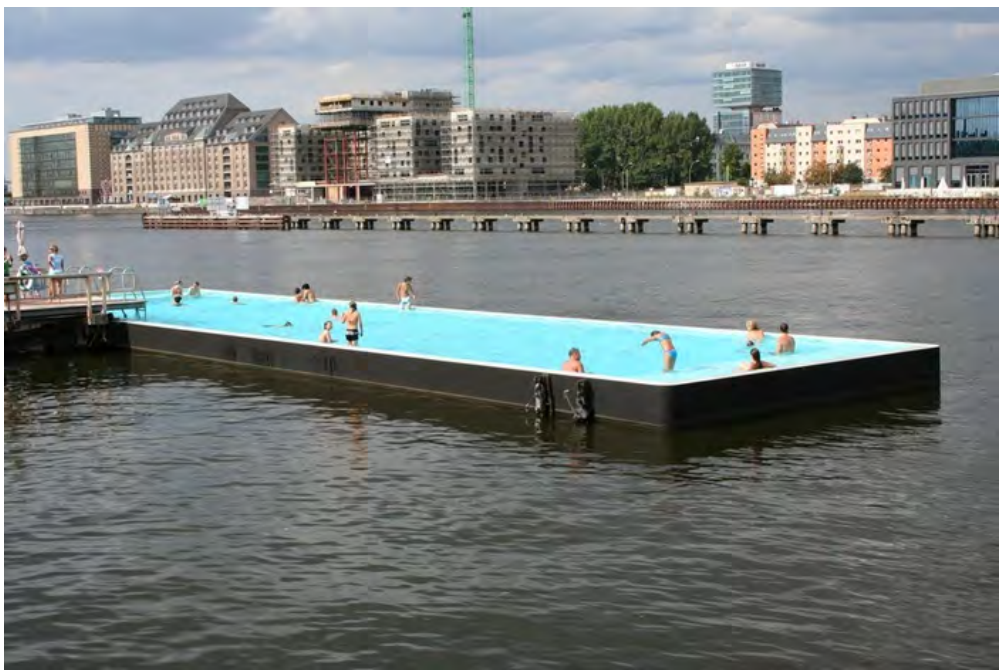

120. Susanne Lorenz. Badeschiff ("navio-piscina"). Rio Spree, Berlin, 2004-atual. Dimensões: 8x34m (Fonte: http://www.amusingplanet.com/2010/11/badeschiff-floating-swimming-pool-in.html)

A artista Susanne Lorenz e um grupo de arquitetos conceberam a piscina flutuante Badeschiff sobre o rio Spree, que é impróprio para banho, para o projeto municipal de incentivo à arte "City Art Project Society of Berlin". A obra, a princípio temporária, acabou 
permanecendo e se tornando ponto turístico e de referência na paisagem. Aqui, a obra assume diretamente uma função de equipamento de lazer, talvez porque a memória do rio como espaço de recreação e contemplação ainda esteja vívida nas pessoas.

Notamos que os rios, mesmo que sem o apelo do sublime que o curso natural da água evocaria, pela sua força ou pela associação ao imaterial e espiritual, continuam sendo para $a$ arte representativos da natureza, pois a água, perdura como símbolo.

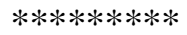

Antes de Margem (2009-2010), artistas brasileiros atuaram diretamente nos rios urbanos em intervenções efêmeras. Tais obras, mesmo que esparsas no tempo e em nossa extensão territorial, dizem-nos muito a respeito de nossas paisagens, pois evidenciam os rios como elementos quase ocultos nas mesmas e de difícil acesso, em sua maioria, avessos ao propósito de apreciação estética e desfrute.

Ao investigar obras contemporâneas, brasileiras e estrangeiras, que abordam rios urbanos, nota-se que entre as estrangeiras parece haver a convergência entre propostas paisagísticas e artísticas. As obras podem ser, ao mesmo tempo, equipamentos de lazer e objetos de contemplação, além de debaterem questões ambientais e valores sociais. As questões ambientais tornaram-se a pauta da nossa arte relacionada aos rios a partir da década de 1990. Assim, vemos que a "qualidade ambiental" forma o centro do debate na exposição Quase Líquido (2008) - que vimos no Capítulo 02 -, uma das primeiras exposições coletivas a promover a reflexão sobre os rios urbanos no Brasil. Esta questão somada à da "sustentabilidade" reaparece no discurso de Margem (2009-2010). 


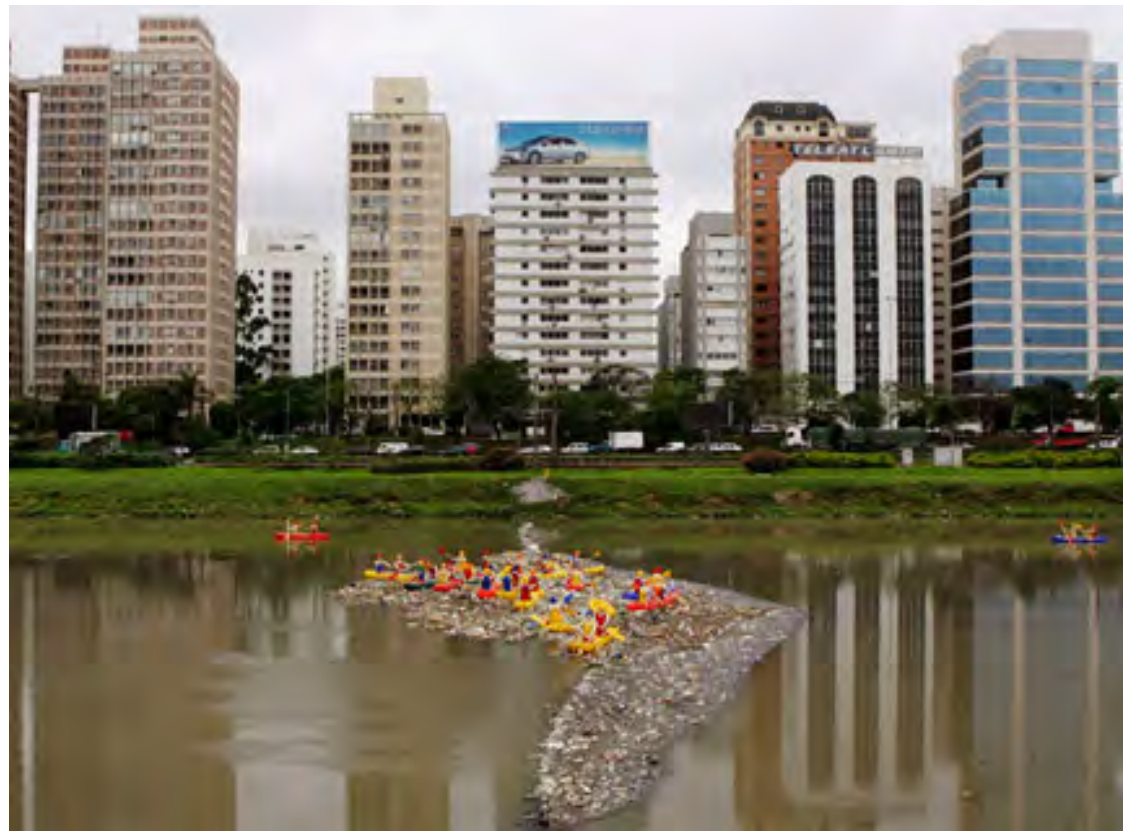

121. Eduardo Srur. Caiaques, Rio Pinheiros, São Paulo, outubro de 2006.
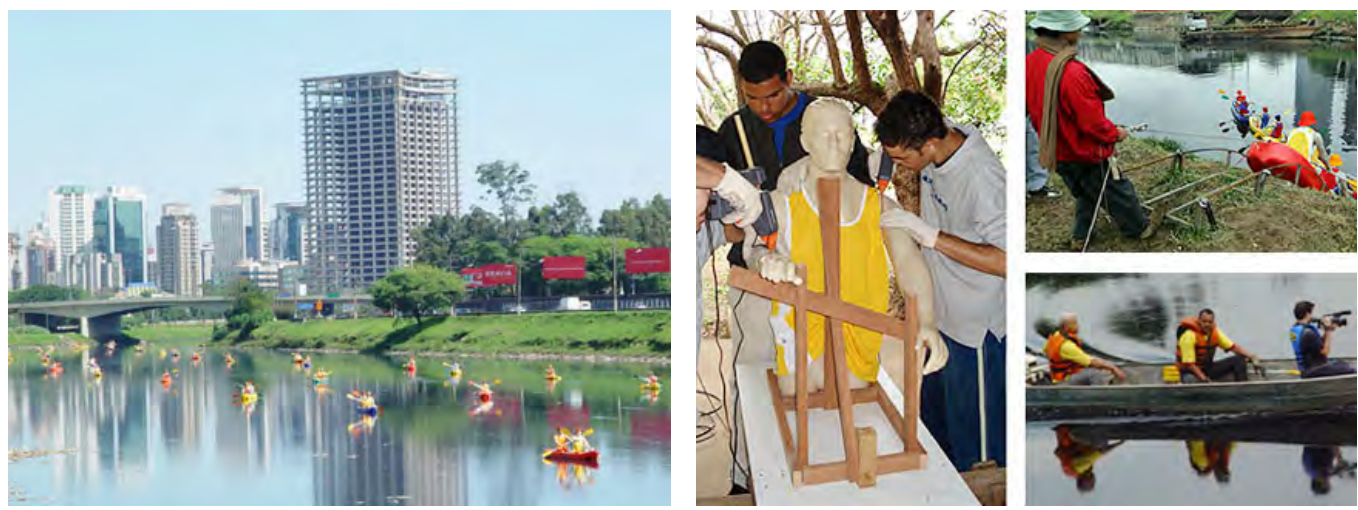

(Fonte:<http://planetasustentavel.abril.com.br/album/caiaques-230143.shtml?foto=7>Acessado em: 05/12/12)

Antes de Pets (2008), que integrou a exposição Quase Líquido, Eduardo Srur ocupou o Rio Pinheiros com a intervenção Caiaques (2006), que aparece no limiar entre a crítica e o humor. Cem caiaques e cento e cinquenta manequins permaneceram por sessenta dias no Rio Pinheiros. Ao final, o lixo sólido se acumulou, formando uma "ilha" e alterando a configuração inicial da intervenção. ${ }^{371}$ Novamente, a ideia está em dar visibilidade ao rio, reavivar uma memória coletiva e despertar o imaginário. Tendo em vista a dificuldade de o nosso olhar abarcar as paisagens de rio da cidade - pelo seu isolamento como eixo entre autopistas de velocidade; pelo seu rebaixamento e pelo entorno de pouco ou nenhum tratamento paisagístico - para que uma obra ligada à paisagem alcance visibilidade, é

${ }^{371}$ Disponível em: <http://eduardosrur.tumblr.com/post/806940635/caiaques. Acesso em: 05/12/12. 
necessário um grande esforço, tanto na implantação da obra, quanto na sua divulgação. Para esta, resta a incumbência de (re)despertar nosso olhar e reflexão para a paisagem. Caiaques se destacou como assunto e curiosidade além da crítica especializada em arte, fato que corrobora sua aderência na paisagem.

As intervenções efêmeras em rios das cidades de Belém e Belo Horizonte, de Lúcia Gomes e Artur Barrio, respectivamente, talvez não tenham como foco o processo de transformação dos rios ou, menos ainda, abarquem a produção da paisagem através deles. Apenas, por intermédio dos rios e pelo ambiente ao redor deles, os artistas realizam suas poéticas. A obra da artista tem um caráter de performance, pois nela prevalece a ação. Já na de Artur Barrio é latente a crítica política. A paisagem periférica de um córrego-esgoto foi o cenário perfeito para tratar de ações ocultadas pelo governo da época. A movimentação do público em torno das trouxas ensanguentadas foi registrada pelo artista e pela televisão, em ação investigativa sobre um suposto crime.

122. Lúcia Gomes. MMMM7, 2006.

Belém, PA.

Fonte: Catálogo Ecológica. MAM-SP, 2010.
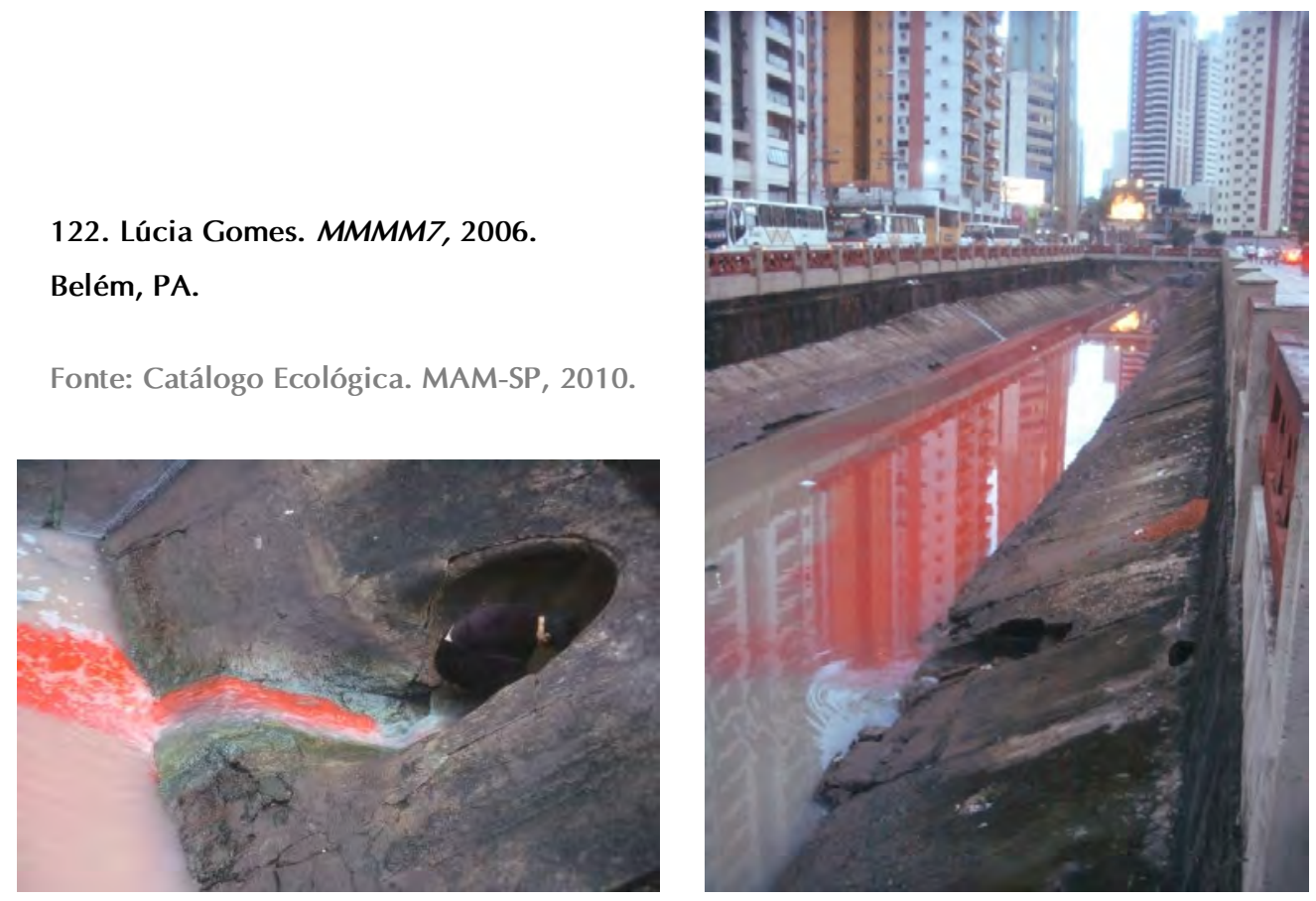


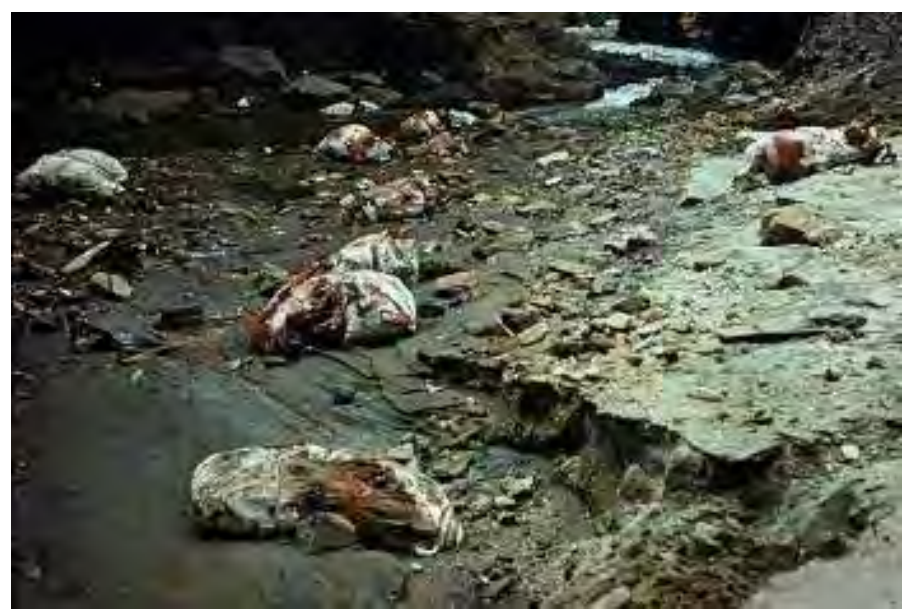

(73). Artur Barrio. Situação T.E. - trouxas ensanguentadas. Belo Horizonte, 1970.

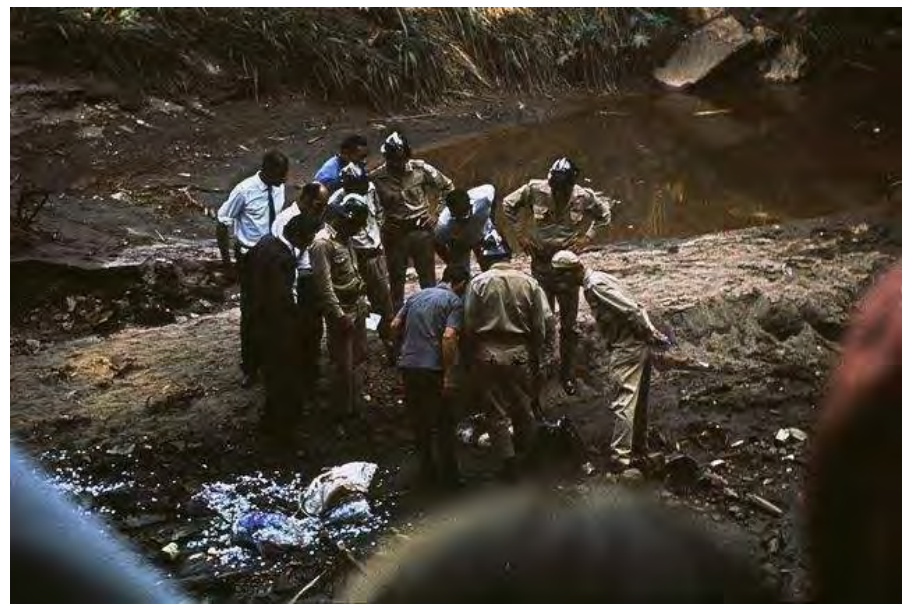

(73). Artur Barrio. Situação T.E. - trouxas ensanguentadas. Belo Horizonte, 1970.

Registros em caderno-de-artista, fotografia e filme. Participação de 5.000 pessoas aproximadamente. (Fonte: http://www.muvi.advant.com.br/artistas/a/artur_barrio/artur_barrio.htm. Acesso em: 10/07/2011)

\subsection{Acepções da paisagem.}

A transformação axial na visão do mundo, de cosmo para a paisagem pode ser rastreada na mudança do significado das palavras "natureza", "paisagem" e "cenário". No uso moderno, as três palavras compartilham de um núcleo comum de significado: cenário e paisagem são muitas vezes usados como sinônimos e ambos implicam natureza. No entanto, a união não foi sem sacrifício. A palavra natureza aparece junto com cenário e paisagem porque perdeu muito do seu domínio semântico e as palavras cenário e paisagem são 
quase sinônimas devido à perda de precisão em seus significados. (TUAN, 1980, p. 152$)^{372}$

Ater-se, logo de início, às diferentes acepções do termo polissêmico paisagem é frequente nas diversas pesquisas que a tematizam. Busca-se seus significados usando desde a etimologia, a partir de landschap, ${ }^{373}$ e pays sage, até as definições segundo as correntes da geografia ou do paisagismo mais atuais, de modo a inserir a paisagem em determinada abordagem das correntes do pensamento. Preferimos, contudo, apresentar primeiramente as definições da matriz da arte contemporânea da paisagem - da land art -, traçando seu histórico e seus paralelos com a produção brasileira, para então contextualizar os projetos Fronteiras e Margem, cujas obras (e seus discursos) nos revelarão sobre nossas paisagens.

Veremos, no Capítulo 04, que cada artista se referiu à paisagem com pesos e sentidos diversos, considerações estas que são preciosas para compreendermos suas obras em relação à paisagem. Fronteiras (1998-2001) teve como tônica um viés político e econômico do espaço, de modo que os lampejos de paisagem no discurso dos artistas ocorrem porque há a convergência entre a arte e essa geografia sensível, nos termos de Besse. ${ }^{374}$

Se eles referem-se à paisagem em visões singulares, há também semelhanças entre as narrativas das "paisagens de fronteira", percebidas como "não-lugares," ${ }^{375}$ e as paisagens que apresentam referenciais predominantemente móveis, impalpáveis e incertos, tais como água, dunas, linha do horizonte, o vazio, o vento e a rala ou dispersa urbanização. Paisagens estas que, de um modo geral, indicam algo instável. Essa atmosfera de contatos sutis, do imaterial e do disforme e a fisionomia da paisagem acabam por se refletir nas obras, que "parecem apontar para um outro lugar." ${ }^{376}$

372 TUAN, Yi-fu. Topofilia: um estudo da percepção, atitudes e valores do meio ambiente. São Paulo: Difel, 1980, p. 152.

373 Como vimos no Capítulo 01, os termos landschap e landschaft (neerlandês e alemão), já empregados no século XVI, ou paese (italiano) designam porções de território com suas vizinhanças humanas e naturais (e que podiam ser cartografadas), "são de uma materialidade tangível e só de modo secundário pertencem a esfera da estética". Ver BESSE, 2006, p. 20. Roger, ao abordar a primeira paisagem que influenciou nosso imaginário, o campo, refere-se a ele em sua etimologia "pays sage" (país tranquilo). Ver ROGER, 1999, p. 3.

374 BESSE, 2006, p. 64.

375 É como Fajardo referiu-se à cidade de Laguna (SC), cujos espaços públicos são pouco habitados; a economia sazonal e a urbanização rarefeita parecem não ancorar sua vida urbana. Além de que as dunas e o mar compõem uma paisagem sempre móvel (em entrevista, junho/2012).

376 SALZSTEIN, 2005, p. 12. 
É importante considerarmos que, mesmo adotando acepções de paisagem que norteiam esta pesquisa, estas não são condições a priori para a arte, uma vez que a obra pode interferir, abarcar ou comentar a paisagem, sem ter tais questões como sua motivação essencial. Por outro lado, devemos atentar para o fato de que as acepções da paisagem influenciam a cultura - nos esquemas de percepção e de ação, nos termos de Berque. ${ }^{377}$ Por isso, o termo "paisagístico", na língua portuguesa (sobretudo no contexto brasileiro), "tem uma aproximação com o pensamento sobre a paisagem, em sua intervenção, como por exemplo: projeto paisagístico,"378 e menos com a produção dela. Paisagem, para alguns artistas, remete à pintura de natureza, fato que a "distancia" da intervenção no lugar.

Vamos nos deter em algumas acepções de paisagem, desde as formuladas por paisagistas, até aquelas presentes em dicionários, para mais adiante relacioná-las com os significados atribuídos pelos artistas. Estes, de um modo geral, delimitam-na pela ênfase na visibilidade ou pelo sentido de natureza.

Macedo, ${ }^{379}$ ao definir paisagem, apresenta primeiramente que sua escala e os interesses multidisciplinares que nela incidem, delimitam as acepções. $\mathrm{O}$ autor aponta que discorrer sobre a paisagem é "tratar sobre o meio ambiente humano, e este permeia todos os momentos da vida: estamos inseridos na paisagem." 380

Tal interpretação é generosa ao ver a paisagem possivelmente em todos os lugares de existência. Mas também “a expressão física por ele [homem] codificada visualmente pode ser denominada paisagem" e, nesse sentido, paisagem implica em percepção, assim como em ação humana, como o autor nos explica em seguida: "O homem altera o ambiente e este altera ou limita o seu comportamento e este é um processo contínuo no tempo." O autor aproxima definições de outros autores que se complementam, introduzindo-nos no campo polissêmico da paisagem. "A paisagem é o reflexo da dinâmica dos sistemas naturais e sociais."”381

\footnotetext{
377 BERQUE, 1984. In: CORRÊA; ROSENDAHL, 1998, p. 84.

378 MARIA, 2010, p. 20. A autora também aponta que o termo "paisagístico" remete à profissão do paisagista e ao paisagismo. Por isso ela se atém ao termo de Berque que, referente à paisagem, emprega "paysagère" um pensamento paysagère - e não paisagístico - pois no termo original remete a um pensamento influenciado pela paisagem, pela sensibilidade da paisagem, tomando-a em seu aspecto mais amplo, de totalidade de ações, objetos e sentidos.

${ }^{379}$ MACEDO, Silvio S. São Paulo, paisagem e habitação verticalizada: os espaços livres como elementos de desenho urbano. Tese de Doutoramento FAU-USP, São Paulo, 1988.

${ }^{380}$ Ibidem, p. 5.

${ }^{381}$ LAURIE, Michael. An Introduction to Landscape Architecture, p.1 apud MACEDO, 1988, p. 5.
} 
Tudo isto são paisagens [refere-se o autor a diferentes situações, como um campo de maçãs ou uma cidade europeia...], formas mais ou menos duráveis. $\mathrm{O}$ seu traço comum é ser a combinação de objetos naturais e fabricados, isto é, objetos e ser o resultado da acumulação das atividades de muitas gerações. (SANTOS, Milton. Da sociedade à paisagem. O significado do espaço humano. Apud MACEDO, 1988, p. 5)

Todas as forças da coletividade, num processo dinâmico de tempo e espaço, formam uma completa relação em constante mutação de que resulta a paisagem. (MAGNOLI, Miranda Martinelli. Espaços livres e urbanização: uma introdução a aspectos da paisagem metropolitana, 1982 apud MACEDO, 1988).

Macedo elege definições de paisagem que reforçam os processos culturais que a produzem e, por último, cita mais um sentido que abre a perspectiva de significados: "Toda paisagem é um espaço, um campo de atuação." 382

Podemos compreender que a paisagem para o autor está na convergência entre o meio ambiente humano (seus elementos físicos); as ações humanas, que transformam esse meio em "campo de atuação"; e o tempo. Pensando na arte contemporânea da paisagem como uma ação (uma intervenção ou ação direta na paisagem), é interessante a reflexão do autor sobre as ações do homem como agentes de "um desequilíbrio ou um reequilíbrio e a cada uma delas uma configuração da paisagem se altera, se modifica de formas diversas, de acordo com a dimensão do projeto." 383

Pensar nas obras de Fronteiras e de Margem nestes termos, como ações pontuais ou sutis que equilibram, ${ }^{384}$ ou não, a configuração da paisagem, é um caminho para analisarmos como a arte e a paisagem estabelecem ligações.

A paisagem pressupõe um observador e um fruidor com sua bagagem cultural, portanto é também uma construção cultural, uma relação desta natureza com o lugar e o entorno e menos uma forma a ser quantificada. Esta abordagem, com ênfase nos aspectos culturais - na dinâmica política, econômica e social que a produz e que influencia nos modos de vê-la - é apresentada por Leite, ${ }^{385}$ como vimos no Capítulo 01.

\footnotetext{
${ }^{382}$ ALEX, Sun. Documento para Disciplina AUP 222 - Paisagismo: Introdução, FAU-USP, 1983.

383 MACEDO, 1988, p. 5.

${ }^{384}$ Como equilíbrio tanto visual como físico se entende: "um estado de distribuição no qual toda a ação chega a uma pausa [...] o todo assume o caráter de 'necessidade' de todas as partes", ou seja, as necessidades são contrabalançadas. (GOMES FILHO, 2006, p. 57-59)

${ }^{385}$ LEITE, 2006, p. 82. 
No plano do projeto e da intervenção na paisagem, as questões mais relevantes não se referem, portanto, apenas à leitura, identificação e atribuição de valores aos elementos naturais ou construídos que lhe conferem forma e caráter. É necessário buscar nos processos econômicos, políticos e culturais da sociedade, os fatos que explicam e justificam essa forma e esse caráter.

A dimensão cultural da paisagem, contudo, não se desvela simplesmente no olhar. Ela é tecida, na medida em que a sociedade se apropria de seus lugares de vida e com eles estabelece uma identificação, criando elos além do uso. A autora aponta que são três os aspectos que qualificam as categorias do espaço, lugar, paisagem e território: a atribuição de significado, a identificação e a apropriação.

A apropriação dos lugares é que permitiria à paisagem manifestar sua dimensão cultural. $^{386}$

Mas se são os lugares que qualificam a paisagem, isto é, que conferem, por meio de processos simbólicos, um significado exclusivo aos elementos que a compõem, é a reunião dos lugares que nos dá o sentido de territorialidade, de pertencer àquilo que nos pertence, sentimento simbólico de exclusividade e limite, que não se confunde com delimitação político-administrativa. Um território é uma extensão apropriada e usada e, por isso, contém, fortemente, o sentido de espaço e tempo. ${ }^{387}$

Esta abordagem é valiosa para compreendermos as lacunas nas aproximações da arte, em Fronteiras e Margem, com a paisagem, pois alguns artistas narram a ausência de referenciais simbólicos e de elos de identificação com as cidades e divisas onde intervieram. Assim, o lugar se mostrou, para algumas obras, como uma abstração (ou geometrização) em vez de ancorar a arte; enquanto a paisagem tornou-se mais etérea, mais uma elaboração intelectual.

Ainda segundo Leite, ${ }^{388}$ "a paisagem é uma mistura entre arte e ciência [...] Para que o contato com a paisagem se dê simultaneamente por meio do conhecimento e da experiência, é necessária uma aproximação maior entre seus lados artístico e científico." Esta consideração vai ao encontro de muitas das obras da land art que nos confundem com feitos da ciência ou da técnica usados para também interferir na paisagem. ${ }^{389} \mathrm{Da}$ mesma forma, outras obras

\footnotetext{
386 Idem, 1998, p. 5.

387 Ibidem, p. 56.

388 Idem, 2006, p. 48.

389 O obra de Christo, Valley Curtain (1970-72), leva-nos a pensar sobre uma paisagem de rodovias, construída pela técnica, na qual uma obra demonstra - mesmo que efemeramente - a equivalência entre
} 
abordam paisagens já tão artializadas, que as olhamos como grandes produtos artísticos, pouco atentando para a técnica que, paulatinamente no decorrer de longos anos, as produziu.

Leite também define a paisagem como representação da interação entre sociedade e natureza, o que exige que sejam consideradas a percepção, a realidade sensível, e a elaboração cultural, além da realidade factual. Inclui também pensar a paisagem como resultado de intervenções mais ou menos permanentes.

A paisagem é uma representação dessa realidade e dos elementos que a compõem. O que está representado na paisagem é decorrência da interação entre a sociedade e a natureza e da interpretação, individual ou coletiva, dos processos de estruturação do território. ${ }^{390}$

A paisagem tem, naturalmente, diferentes acepções, de acordo com o campo do conhecimento:

Para História, a paisagem é a estratificação do trabalho social que se sucede sobre o território. Para Psicologia é a impressão, a emoção despertada no homem pelo conjunto das condições sensíveis de seu ambiente de vida. Para Antropologia Cultural é a manifestação exterior da atividade social, ligada às características dos instrumentos culturais que as sociedades possuem. ${ }^{391}$

Lima $^{392}$ ressalta a ambiguidade na definição da paisagem e de seus conceitos correlatos - meio ambiente, entorno, natureza, suporte físico ou suporte ecológico. Esta imprecisão concorre para reforçar as interpretações nas quais, não raro, paisagem e tais conceitos aparecem como sinônimos.

Paisagem é um termo impreciso - toda a palavra que vem à literatura através da linguagem popular, termina por ser imprecisa. A imprecisão vem do fato de que além de palavra popular, a expressão é descoberta pelos artistas antes de sê-lo pelos que teorizam. Entrou no vocabulário popular muito antes de entrar em vocabulário específico. Também toda palavra traduzida de uma língua para outra induz frequentemente a equívocos interpretativos. A palavra tem

ciência e arte naquele momento histórico e lugar. As obras de Andy Goldsworthy simplesmente evidenciam as paisagens campestres inglesas mostrando-as como arte e nelas o sentimento de encontro com a natureza é tão premente, que "esquecemos" os séculos de transformação do meio natural. A paisagem é, para os artistas ingleses, a própria obra.

390 LEITE, 2006, p. 82.

391 Ibidem, p. 80.

392 LIMA, Catharina P. C. dos Santos. Paisagem em metamorfose: a cidade de Natal. FAU-USP, Dissertação de Mestrado, FAU-USP, 1987. 
significação ambígua no alemão; traduzida para o inglês acresceu essa ambiguidade. Em alemão significa de um lado aparência de terra (paisagem) e de outro, porção limitada de terra (área, região). (anotações de aulas de Milton Santos e Miranda M. Magnoli, de 1985, FAU-USP. In: LIMA, 1987, p. 2)

A autora também trata dos termos correlatos de paisagem, apontando que meio ambiente humano é o resultado das interações das sociedades humanas com o suporte, a base física e biológica que as envolve. Daí, podemos definir ambiente "como a interação da sociedade com o suporte físico", quer este apresente características naturais, quer construídas. Por fim, a interação social com o suporte "pelas adaptações, transformações, readaptações e novas transformações" - se há intencionalidade no arranjo dos elementos - cria, então, a paisagem. Em suma, "a essas conFORMAções, conFIGURAções, carregadas de interação social com o suporte, temos denominado PAISAGENS." (MAGNOLI, Miranda Martinelli, anotações em aula, 1985. In: LIMA, 1987, p.2)

Além disso, Lima também ${ }^{393}$ chama a atenção para o fato de que a natureza é uma construção da cultura e que sua percepção na história "sofre contínuas reavaliações, o que ocorre também em função das perdas materiais e espirituais decorrentes das cisões entre natureza e cultura". Compreendendo Natureza como "força criadora invisível" (natura naturans) e também como o mundo físico e visível (natura naturata), é pelo processo de manipulação de seus dados que a paisagem, enquanto expressão formal, "fornece um poderoso referencial sobre o desenvolvimento da cultura."

Podemos dizer que a arte contemporânea da paisagem nos fala sobre os valores culturais que constroem nossas paisagens ou que projetam ideais e formas, buscando transformá-las.

Há ainda acepções recorrentemente empregadas como as noções de paisagem como sinônimo de panorama, vista, ou ainda como gênero da pintura, conforme podemos conferir nos dicionários.

Paisagem s.f. Extensão de território que a vista pode abranger numa visão pintura, gravura ou desenho cujo tema principal é a representação de um local

393 LIMA, Catharina P.C. dos Santos. Natureza e cultura: o conflito de Gilgamesh. Disponível em: Revista Paisagem e Ambiente n.18. FAU-USP, São Paulo, 2004. 
natural ou urbano. (V. ENCICL.) // Lit. gênero literário que descreve cenas campestres e a vida nos campos." ${ }^{394}$

f. Trecho da Superfície da Terra que se oferece à vista em dado momento; panorama, vista. Ext. Tudo o que o olhar abrange em dado momento. Liter. Descrição de aspectos da natureza. Geogr. Expressão usada pela geografia humana em duplo sentido: paisagem natural, i.e., o meio geográfico propriamente dito, (relevo, vegetação, hidrografia, clima); paisagem cultural, quando o meio geográfico já se viu transformado pelo homem graças às suas atividades econômicas, habitações, vias de comunicação, etc." ${ }^{\text {395 }}$

Apenas para considerarmos o contexto cultural que interpreta a paisagem, incluo a definição italiana, onde a cena já tem sentido histórico. Paisagem (como pintura) não seria "natureza", pois era inventada. Também por ser "trecho de um país", a paisagem, nesta definição, abarca implicações políticas, econômicas e culturais do mesmo, pois apenas é uma parte do que podemos ver e está distante do sentido de uma natureza pintada: "Paesaggio. Tratto di paese (V.) Che se offre alla vista, e La Pittura (V.) Che lo ritrae; - P. storico, Pittura di $P$, non copiata dalla Natura, ma inventata, com antiche monumenti ed uma scena storica."396

$* * * * * * * * *$

No Capítulo 04, veremos que a paisagem, para os artistas de Fronteiras, raras vezes, inclui a dinâmica político-econômica e as condicionantes sociais. Contudo, a ideia de uma paisagem vivenciada, humana, e que vai além de seus aspectos geomorfológicos, é recorrente entre eles e ponto de partida para pensarmos as aproximações entre arte e paisagem.

\footnotetext{
394 ENCICLOPÉDIA DELTA LAROUSSE, p. 5034. In: FREDERICO, 1998, p.18.

395 DICIONÁRIO ENCICLOPÉDICO BRASILEIRO. Magalhães: 1953, p. 12-13 e 23.

396 DIZIONARIO DI CULTURA UNIVERSALE E DELLA LINGUA PARLATA., 1907, p. 446. In: FREDERICO, 1998, p. 23.
} 


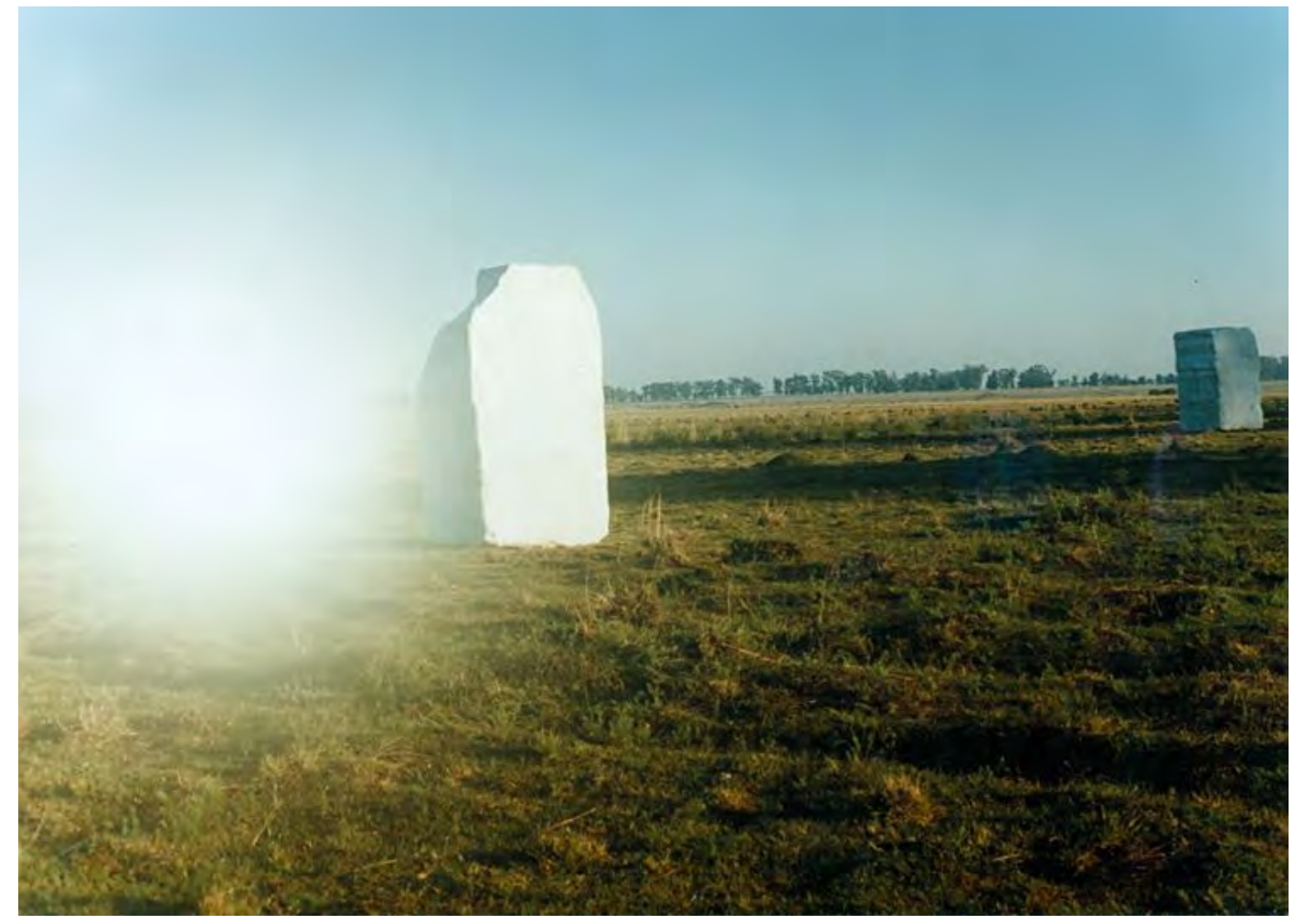

CAPÍTULO 4

As obras de Fronteiras (1998-2001) e de Margem (2009- 2010) 
123. Nuno Ramos. Minuano, 2000. Barra do Quaraí. RS.

Fonte imagem: $<$ http://www.nunoramos.com.br/portu/comercio.asp?flg_Lingua=1 \&cod_Artista=100\&cod_Serie $=49>$ ) 
Para as nove obras de Fronteiras, nossa fronteira continental sugeriu, de um modo geral, paisagens ermas, pouco adentráveis, lugares de pouca apropriação ou de passagem, nãolugares. Três das obras situaram-se em espaços públicos urbanos, tensionando limites dos significados destes espaços. Destas, uma foi implantada em uma vívida zona fronteiriça, abordando os limites sociais de uma possível área integradora, de encontro e trocas comerciais.

As obras, em sua maioria, traçaram analogias entre os conceitos de limite e fronteira ${ }^{398}$, e os artistas investigaram conotações e implicações de limite como, por exemplo, o limite de uma experiência - a possibilidade de transpassar de uma situação para outra, acarretando uma transformação; limite que aponta para o que está além - almejando o impalpávele a obra, então, ao invés de tratar do que pode ser visto, aborda o que podemos vislumbrar. Também foi abordada a possibilidade de justapor diferentes tempos e lugares, situação que é sensível na travessia de fronteiras geográficas. Talvez, as obras Evanescente, de José Resende, e Pálio I e II, de Eliane Prolik sejam as que mais coloquem em questão um viés político de fronteira.

Embora tenha sido uma premissa da Instituição que as obras interviessem em espaços públicos $^{399}$, algumas são reticentes ao fazê-lo, questionando a dimensão pública do espaço público urbano e da própria arte.

Independente da abordagem de fronteira, a partir do momento em que as obras interferem in loco e são projetadas a partir dos lugares - em sua maioria desconhecidos, mas cujos elementos e história foram investigados para serem compreendidos e abarcados por elas - estas buscam ancorar-se na paisagem como experiência visual e espacial. É a paisagem que os artistas revelam-nos e descrevem-nos junto às obras e que, muitas vezes, empresta suas características e atmosfera para a arte.

\footnotetext{
398 “Um dos caminhos mais recorrentes nos estudos sobre fronteira é iniciá-lo tratando logo de estabelecer as profundas inter-relações entre fronteira e limite. [...] Toda propriedade ou apropriação é marcada por limites visíveis ou não, assinalados no próprio território ou numa representação do território: plano cadastral ou planta cartográfica. Ainda o autor expõe o significado existencial de limite, que vai além da ideia de traço, representação ou barreira física." RAFFESTIN, Claude. Por uma geografia do poder. 1993apud FURQUIM JR., LAÉRCIO;.Fronteiras terrestres e marítimas do Brasil: um contorno dinâmico. Dissertação FFLCH - USP, São Paulo. 2007, p.4.

399 ITAÚ CULTURAL. Texto de Apresentação. Fronteiras, 2005. "O interesse do Itaú Cultural foi implantar, entre 1999 e 2001, obras de arte contemporânea em espaços públicos e comunidades afastadas dos grandes pólos culturais."
} 
Em contrapartida, a obra Errante e o projeto Cabaré Chinelo, de Margem, lidaram com um elemento da paisagem que é simbólico e continuamente apropriado pela sociedade. "O rio constitui uma paisagem natural e cultural que tem servido de referência para o homem ao longo de toda a sua existência" ${ }^{400}$. Como fonte de água, elemento vital, como marco territorial que percorre e estrutura o espaço, como meio de transporte ou circulação, sua presença fez-se constante na arte e na poesia. Na arte contemporânea da paisagem eles são, além de tema para reflexão e contemplação, o próprio suporte da intervenção. Elemento natural ou apenas seu resquício, encobertos pelas camadas da cultura que os transformaram, os rios têm sido redescobertos pela arte, assim como revestidos de novos interesses sociais e políticos tais como os da ecologia, da sustentabilidade ou dos espaços públicos de lazer.

A arte, vista desde inscrições murais da Antiguidade, passando pelas pinturas de paisagem e chegando aos exemplos da land art, mostra-nos, de modos bem distintos, fases da interação entre a sociedade e a natureza ao longo dos tempos, que vemos refletidas nos rios. Saraiva (1999) define estas fases de desenvolvimento das sociedades, vistas através da apropriação dos rios como: aquela de harmonia e ajustamento, de controle e domínio, de degradação e sujeição e a atual ${ }^{401}$, para alguns países, de recuperação. As obras do projeto Margem refletem sobre a degradação das paisagens de rios, enquanto os debates apresentados no seminário abordaram a etapa de recuperação.

Neste capítulo serão analisadas, caso a caso, as obras dos projetos Fronteiras (19982001) e Margem (2009-2010), incluindo projetos de obras que não foram implantadas ${ }^{402}$. Será investigado de que modo as obras abarcam a paisagem, de acordo com as vertentes propostas por Kastner (1998) assim como serão explicitadas as descrições e referências à paisagem, traçadas pelos artistas. Como vimos, na arte contemporânea da paisagem não há como isolar a obra dos aspectos naturais e/ou culturais da mesma, assim também, não há como separá-la da narrativa sobre a paisagem ${ }^{403}$ elaborada pelos artistas. Algumas das interpretações sobre o

400 SARAIVA, 1999, p.1.

401 “Em alguns países, têm sido implantadas propostas para a recuperação e inclusive restauro de rios degradados [...] Na Alemanha, Estados Unidos e Reino Unido, entre outros, estão em curso programas de recuperação e restauro de rios, margens e leitos de cheia.". AMARAL, Maria da Graça Amaral Neto Saraiva. O Rio como paisagem, 1999, p.79. Podemos dizer que estas políticas públicas refletem-se também em propostas artísticas.

402 No decorrer deste trabalho, passei a considerar, além da obras implantadas e seu processo, os projetos de obras não implantados, uma vez que estes apresentaram, às vezes, relações mais ricas e elaboradas com a paisagem, pois buscavam se enraizar e interferir nos lugares de acordo com significados.

403 Independente da acepção de paisagem empregada pelos artistas, as obras, de um modo geral, unem a experiência da paisagem com a experiência estética da arte. A visualidade da paisagem, o tempo - do percurso, do ol har -, a necessidade de adentrar a paisagem descobrindo suas matérias-primas, história e aspectos sensíveis (como o som, a luz, a direção e o movimento) são geralmente trazidos à tona e ressaltados através das obras. 
lugar e o entorno entrelaçam-se às características das obras, desde aquelas referentes à construção àquelas próprias da leitura da obra.

Veremos que as obras destes projetos abarcam a paisagem de acordo com as vertentes integração, interrupção, envolvimento e imaginação. Contudo, não temos exemplos que se afinem com a vertente implementação ${ }^{404}$. Ao circunscrever as obras nestes agrupamentos, não buscamos delimitá-las em uma categoria, mas analisá-las quanto aos modos de abordar ou incorporar a paisagem, sendo que algumas delas apresentarão uma leitura bastante ambígua.

De maneira geral, também podemos pensar em dois modos (que podem até se sobrepor) de a paisagem ser incorporada pela arte. No primeiro, a paisagem é parte constitutiva da obra, ou seja, através de sua unidade visual e por sua experiência sensível, ela integra-se fisicamente à obra ou está presente em sua concepção. Há convergência entre a experiência da paisagem e a experiência estética da obra ${ }^{405}$. As características conferem certa atmosfera à paisagem parecem infiltrar-se na obra, que lhe é uma continuidade.

No segundo modo, a obra tece conexões com determinados elementos da paisagem, dialogando com ela por meio de metáforas e analogias em relação a seus objetos, elementos naturais ou ao seu processo de produção. A paisagem empresta à obra alguns de seus elementos - naturais ou construídos ou mesmo sua dinâmica -, que são tratados como assuntos pontuais ${ }^{406}$. A arte aqui, não evoca o envolvimento do indivíduo com a paisagem através da apreciação estética e do sentimento de pertencimento.

Ao estudar as obras concluídas e os projetos, vamos costurando sentidos, percebendo onde se encontram as lacunas entre a arte contemporânea brasileira e a paisagem, compreendendo as sutis interferências das obras nela e a vontade de trazer para o repertório da arte paisagens ainda pouco artializadas e com grande potencial de transformação.

Como vimos no Capítulo 02, a arte contemporânea da paisagem no Brasil já se aproximava - desde meados da década de 1960 - dos espaços públicos urbanos como certa

404 Vertentes da arte contemporânea da paisagem. Ver Cap. 02 e KASTNER; WALLIS, 1998, p. 17.

405 São exemplos O Aleph, Momento de Fronteira, Sem Título . Como veremos, Fronteira, Fonte, Foz, apesar de se propor como "continuidade da paisagem", enfatiza o estranhamento, no embate da relação entre obra e paisagem. Errante, longe de se afinar como a paisagem que é objeto de contemplação, também poderia ser incluída neste grupo, uma vez que a paisagem infiltra-se e domina a obra, que lhe é continuidade.

406 São exemplos Pálio I e II, Fronteira, Fonte, Foz, Minuano,. Estas obras também nos levam em direção à paisagem, à sua apreciação e, principalmente como característica da arte contemporânea, a uma visão crítica sobre seu modo de produção; contudo, inserem-se nela mantendo maior alteridade. 
reserva e ambiguidade ${ }^{407}$. Fronteiras e Margem foram oportunidades de se pensar e implantar a arte em escala ambiental e em relação direta com a paisagem, não só nos limites do urbano. No entanto, tais características de reserva e ambiguidade permanecerão, como veremos mais adiante, $\mathrm{m}$ algumas destas obras.

\subsection{As obras do projeto Fronteiras (1998-2001) e como os artistas abordam a paisagem.}

Fronteiras, conforme apresentação do catálogo, surgiu em 1998 através de um convite do Itaú Cultural a um grupo de nove artistas propondo obras na escala ambiental e tomando a ideia de "fronteira" como ponto de partida para a elaboração das obras, não como um tema a ser representado, mas para ser refletido. De 1998 a 2001, deu-se o período de concepção à implantação das obras, passando, como veremos em cada caso, por adaptações e mediações. São elas: Pálio I e II (1996/99), de Eliane Prolik - obra já existente e adaptada para a cidade de Ponta Porã, MS; o Aleph (1999), de Angelo Venosa, em Santana do Livramento, RS; Mesa (1999), de Nelson Félix, em Uruguaiana, RS; Momento de Fronteira, de Waltércio Caldas, uma obra "contígua" composta por um livro (1999) e uma escultura (2000) em Itapiranga, SC; Minuano (2000), de Nuno Ramos, em Barra do Quaraí, RS; Fronteira, Fonte Foz (2001), de Carmela Gross, e Sem Título, de Carlos Fajardo, ambas em Laguna, SC; Três livros e meio (2000), de Artur Barrio, em Chuí e Santa Vitória do Palmar, RS; e, Evanescente (2001), de José Resende, única obra que não ocupou fisicamente um lugar e consistiu na ação de pôr em circulação sete mil moedas de bronze, em uma das faces o título do trabalho, na outra um trecho da linha de fronteira continental do Brasil e um polígono unindo as capitais do Mercosul: Montevidéu, Assunção, Buenos Aires e Brasília.

Considerando-se os encurtamentos de projetos e subsídios para vencerem as distâncias espaciais e culturais, os nove artistas lograram intervir e elaborar suas obras (êxito que não se repetiria com o projeto Margem). Como vimos no Capítulo 2, as obras da arte contemporânea da paisagem, principalmente as situadas em lugares ermos, contaram geralmente com a divulgação e documentação, viabilizando perpetuar o imaginário criado por ela. Neste caso, a simples ocupação territorial, onde as obras assumiriam a característica de "marco geográfico", já se inclinava a lançá-las ao acaso e ao isolamento.

407 SALZSTEIN, 2005, p. 24. 
Mesmo Pálio I e II - em Ponta Porã, de Eliane Prolik - e Sem Título - de Carlos Fajardo, em Laguna -, que já haviam sido expostas, são repensadas para o novo contexto, levando-se em conta as paisagens de fronteiras, de modo a criarem novos nexos. Fajardo, por exemplo, analisa a praça pouco habitada e a urbanização rarefeita de Laguna, em contraponto ao cubo "lançado ao vazio da paisagem". Também em relação à paisagem, o artista diz que pelas frestas do cubo vê-se "um pequeno farol que sinaliza o ponto onde começa a laguna". Este sinal, essencial na organização da paisagem, pois é referência para a pesca - atividade produtiva vital da cidade -, é então incorporado à obra. No exemplo de Prolik, a artista propôs que seus "pálios" pudessem ser tocados pelas pessoas, emitindo, o som metálico das pás do ferro. Por isso, situou-os em um lugar de convergência (na conurbação das cidades de Ponta Porã e Pedro Juan Caballero), abordando uma paisagem vivenciada. Esta ênfase nas trocas humanas reanima o referencial social da obra, uma vez que a artista relaciona as formas das pás com os instrumentos agrícolas.

As paisagens das obras de Fronteiras pouco foram "artializadas" in situ ou in visu, de modo que a narrativa dos artistas sobre a obra, seus processos de criação, assim como sobre a paisagem, representam um norte para analisarmos os modos como as obras abarcam a paisagem ou nela intervêm.

Tais paisagens, conforme veremos nas descrições dos artistas, apresentam-se, de modo recorrente, como "rarefeita", "vazia", com um quê de dispersão e um alheamento em relação ao lugar e entorno, mostrando-se contornos tênues e pouco fixos. Salzstein interpreta que as obras "tematizam um estranhamento [de estarem] na amplitude [...] são como um recuo" ${ }^{408}$. Tal "recuo" não é apenas em relação à paisagem, mas também por indeterminações culturais que vão desde os artistas não terem contato com o público das obras à pouca mediação da Instituição para implantá-las -, enfim, por estarem em uma situação extrema e desconhecida para a arte brasileira. Assim, as obras revelam um forte "espaço interiorizado"409, uma poética que fala mais ao indivíduo. Tal característica é vital para compreendermos as obras em relação à paisagem.

Pode-se dizer, de modo geral, que em todos os trabalhos a fronteira foi percebida como experiência do ilimitado, da indeterminação e da relativização da noção de lugar. Tal sentido vago e às vezes negativo atribuído a essa noção, assim como a atitude reflexiva e, digamos, natureza "interiorizada" que marca tantos

408 Em entrevista para esta dissertação, realizada em maio de 2012.

409 Ver em Salzstein, 2005, pág. 24. Veremos nas considerações sobre as obras de Fronteiras que o espaço interiorizado é, recorrentemente, destacado nestas obras. 
trabalhos decerto estão associados à percepção das regiões distantes das capitais, das áreas rurais mais extremas do país, como um grande e imperscrutável "vazio", uma natureza que parece resistir àquele tipo de intervenção ou dissolvê-la em sua própria textura. (Salzstein, 2005:12) [grifo nosso].

Se as obras não "pertencem completamente a seus lugares", isto poderia justificar-se pelo parco exercício da arte brasileira no espaço público e por uma cultura de público pouco desenvolvida, segundo Salzstein. Talvez esse não pertencimento ao lugar também nos revele que estas obras sejam um exercício inicial de instaurar naqueles municípios, áreas rurais e cidades médias - distantes da prática artística institucionalizada - suas paisagens como composição simbólica e identitária.

O ponto de ancoragem das obras de Fronteiras com o mundo é menos a fisionomia, a matéria que constrói a paisagem (uma vez que algumas inseriram-se em descampados, em áreas sem "composição" e de indeterminada fisionomia), e mais o impalpável sentimento despertado pela paisagem, sua atmosfera. ${ }^{410}$ Por isso, veremos que as interpretações e descrições da paisagem, de um modo geral, atentam para essa essência que a singulariza e a delimita em meio ao mundo.

\subsubsection{Angelo Venosa. O aleph, 1999}

Pedra grês rosa assentada com junta seca, $1.200 \mathrm{~m}^{2}$. Santana do Livramento, RS. Parque Municipal do Batuva. (Fronteira Argentina / Uruguai).

\footnotetext{
"Na coxilha ou na planura do pampa, deixar uma marca, cicatriz, um desenho de pedra. Um anel, labirinto, um lugar inútil, passagem de um lugar para ele mesmo" (VENOSA, Angelo In: Ações Prospectivas. Itaú Cultural, 2000)
}

410 A stimmung ou atmosfera da paisagem que "reside no reflexo afetivo do espectador e não nas coisas exteriores [...]". SIMMMEL, 1913. 

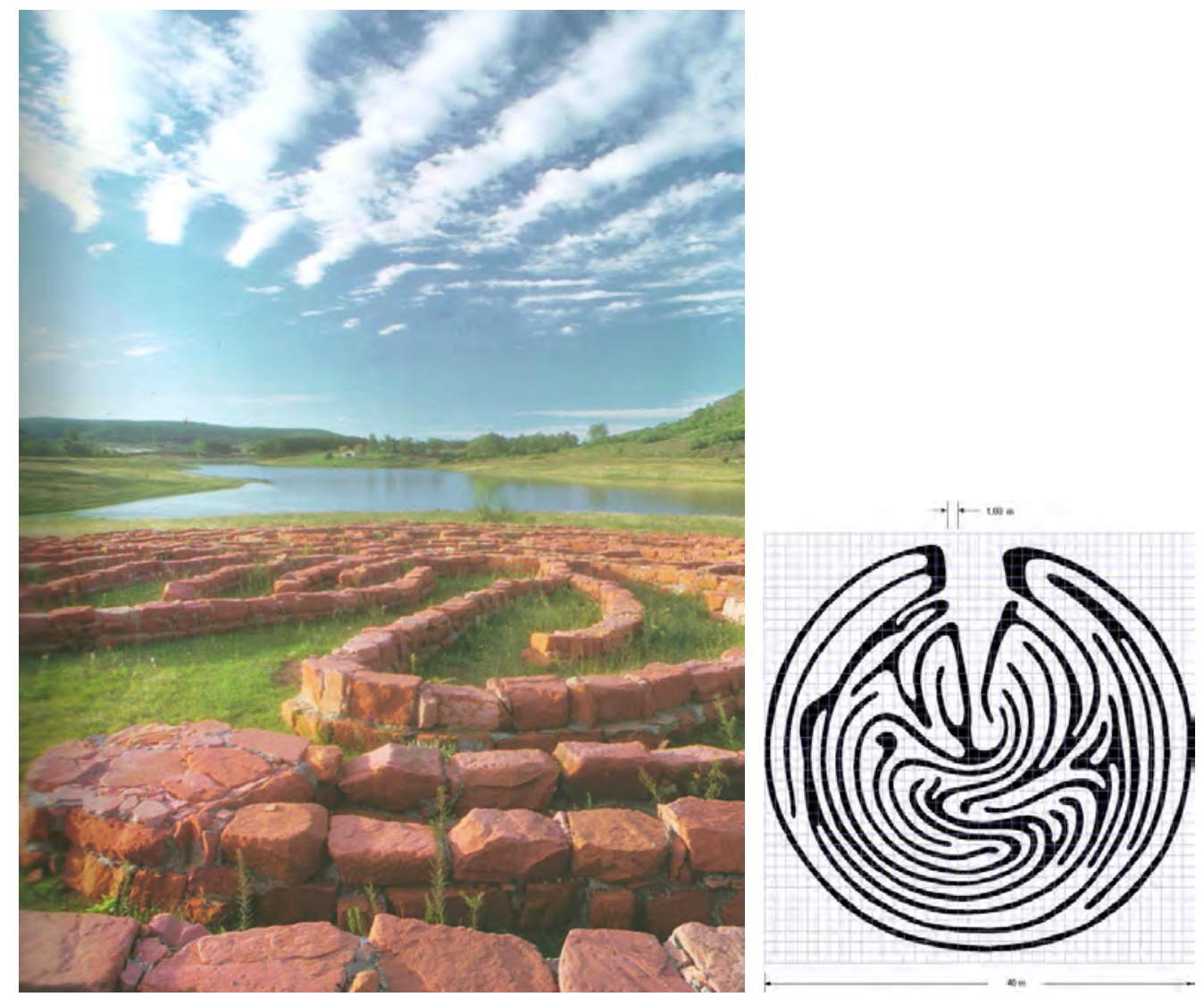

124. Angelo Venosa. $O$ Aleph, 1999. Santana do Livramento. RS.

(Fonte imagens: Fronteiras, 2005, p. 39 e http://www.angelovenosa.com/images/98/im9803.html. Data: 26/04/12.)

A ideia inicial do artista Angelo Venosa era filmar uma determinada região da fronteira entre Brasil e Uruguai e transmitir as imagens em video-wall, em algum grande aeroporto do país. As câmeras transmitiriam continuamente os "acontecimentos em seu curso": do gado pastando à movimentação das nuvens. $\mathrm{O}$ artista interviria na velocidade e na luz das imagens exibidas.

Este projeto traria à tona questões referentes ao lugar, à passagem, ao tempo e à representação da paisagem. Principalmente, abordaria características destes não-lugares, lugares de passagem, como a própria fronteira ou os saguões de um aeroporto, que o artista considera um "marco de fronteira", pois "de certa forma se apresenta como a soma de muitos lugares sem definir lugar algum"411. Podemos ainda traçar analogias entre o vídeo em tempo real como tecnologia à serviço da segurança de "territórios". Seria, então, atribuído àquela fronteira "neutra" um controle latente.

411 VENOSA, 2005, p. 37. 
Outras propostas antecederam $\boldsymbol{O}$ aleph. Venosa quis intervir em uma vila rural e em uma região que estaria em processo de desertificação ${ }^{412}$. Esta, em especial, despertou-lhe interesse "pela neutralidade e rigor da paisagem". Percebemos que o artista norteou-se pela atmosfera da paisagem, tanto para compreender o lugar que receberia sua obra, quanto para transmitir as experiências sensíveis através da obra.

Quando visitei essas cidades, tive uma sensação muito estranha, como se já as conhecesse - porque de algum modo era um "lugar" na minha memória. Acho que fui chegando a Livramento aos poucos, por meio de uma afetividade geográfica. (VENOSA, Angelo. Fronteiras, 2005, pág. 36)

Por fim, O aleph (1999) foi trabalhado no Parque Municipal do Batuva, a partir de um antigo interesse do artista por "desenhos enigmáticos em escala geográfica", realizados por povos antigos ${ }^{413}$. Por estar em um parque, o artista preferiu isolar a obra da área que concentra a infraestrutura de lazer, deixando o entorno livre, a visão ampla "de um terreno ondulado, de vales e colinas baixas".

Embora esse lago seja artificial e se situe em uma área de recreação, integra-se perfeitamente à paisagem, sem muito "desenho" ou intervenção de objetos construídos. A vista no parque é ampla, há vales e colinas, e não destoa da fisionomia da região, que é toda de pequenos açudes que irrigam as plantações de arroz e servem às criações de gado. (Ibidem, p.36)

Salzstein comenta que o trabalho incita um duplo movimento de rotação: somos levados a um espaço para dentro do labirinto (que analogamente é uma digital), sugerindo o espaço da individuação, enquanto apreendemos a totalidade daquela paisagem, pois a obra está em um lugar privilegiado, de onde se tem o panorama do alto de uma colina. Também a autora interpreta que a obra remete a um "lugar mais mental e mais enigmático". $\boldsymbol{O}$ aleph, assim como outras obras de Fronteiras, segundo ela, induz a um lugar intimista. ${ }^{414}$

Explorar o lugar intimista é, de certa maneira, comum à arte contemporânea da paisagem, e tal qualificação do espaço pode coexistir com sua dimensão oposta, a pública, e mais ainda com aquela da escala geográfica ou de tempos geológicos. Como exemplo desta

$412 \mathrm{O}$ artista comenta obre uma vila rural que pertence a Santana do Livramento, mas reivindicada pelo Uruguai e, sua outra escolha, a região entre Alegrete e Santana do Livramento, que estaria se desertificando, mas esta região era um pouco distante da fronteira. (Ibidem, p. 45).

413 O artista cita os geoglifos latino-americanos do Deserto do Atacama e, no decorrer da entrevista, relembra sua visita aos menires de Évora (Portugal) e relaciona-os com as Stonehenges.

414 "[...] o trabalho de Angelo Venosa reagiu à solicitação da escala geográfica como uma espécie de monumentalidade às avessas, segundo a qual o trabalho rumaria e se expandiria incessantemente 'para dentro'[...]." Ver SALZSTEIN, 2005, p. 35. 
coexistência de escalas, poderíamos pensar na Spiral Jetty (1970) de Robert Smithson. No entanto, como vimos no Capítulo 2, se tal característica de explorar mais o espaço interiorizado e a escala humana é recorrente na arte brasileira que se liga à paisagem, isto é devido ao histórico do desenvolvimento de nossa arte pública contemporânea.

Sobre o labirinto e a digital, imagens evocadas pela obra, e que podemos compreender como contrapontos em meio à vastidão ambiental, àquela "escala geográfica", Venosa comenta: "[...] percebo que as poucas experiências que tive com trabalhos de grande escala sempre acabam privilegiando a escala humana no confronto com o desmesurado." 415

A obra explora a justaposição de tempos: o presente intensificado, com a experiência do percurso interiorizado, e o tempo remoto, aludido pela "ruína" e pelos monumentos neolíticos.

Com todas essas ruínas e menires no pensamento, acabei desenhando uma linha espiralada de pedras, semelhante a um "labirinto". Por que labirinto? Quis marcar essa ideia de espaço que se realiza para dentro; a ideia de que fronteira não indica apenas uma experiência quantitativa do espaço, mas um horizonte móvel, interno, subjetivo [...] (Venosa, 2005, pág. 41)

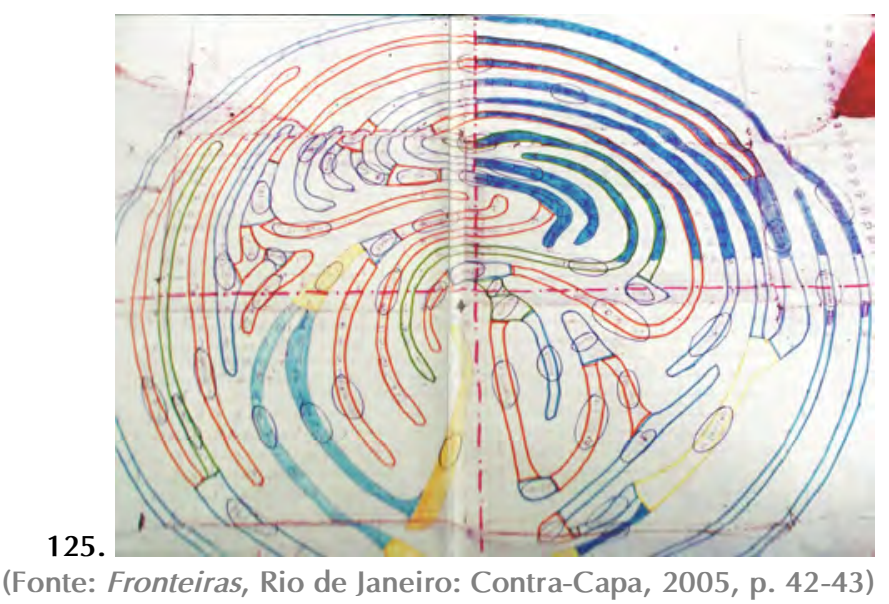

É por esta referência à arte do Neolítico - os megalitos - que a obra apresenta "um

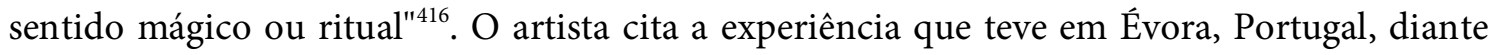
dos cromelechs, cujo alinhamento das pedras obedece ao das constelações. Uma arte de cunho sagrado, ritualístico e que se direciona para a abstração ou geometria, materializa reflexões

415 VENOSA, 2005, p. 40.

416 Ibidem, p. 40 
menos individuais ou sociais e coloca-nos na escala do incomensurável, aproximando-nos da cosmogonia e da paisagem como natureza.

Importante notarmos que muitas obras da arte contemporânea da paisagem evocam as esculturas ou monumentos pré-históricos com a intenção de re-ligar o observador com o lugar, com a natureza e, por requererem o percurso, com a experiência da paisagem, assemelhando-se a rituais. Analisando similaridades formais e processuais entre as obras da land art e monumentos do Neolítico, Lippard (1983), aborda o retorno às paisagens pouco habitadas, distanciando-se das tecnologias, da indústria e do consumo - já então incorporados pela arte -, como esvaziamento de signos e reaproximação com a natureza, da arte com a vida $^{417}$.

O interesse em retornar a um tempo arcaico, religar-se à Terra, é vastamente compartilhado por artistas da paisagem de outros países. Smithson e Heizer, por exemplo, têm como inspiração o Serpent Mound ${ }^{418}$ e citam os monumentos pré-colombianos como referências estéticas para a arte norte-americana de sua época. Carl André expressa a influência das Stonehenges e, de modo geral, da arte do Neolítico sobre os erthworks e land art dos anos 1960, como se a mudança da figuração para a abstração - que também se deu do Paleolítico para o Neolítico - estivesse acontecendo similarmente naquele período; como se a necessidade de se esvaziar de símbolos e signos acontecesse toda vez que as sociedades precisassem se readequar-se e repensar suas técnicas, quando nos deparamos com uma profunda mudança tecnológica na organização da sociedade.

[...] abstraction arose in Neolithic times, after Paleolithic representation, for the same reason that we are doing it now. The culture requires significant blankness because the emblems, symbols and signs which were adequate for the former method of organizing production are no longer efficient in carrying out the cultural roles that we asign to them [...]. (ANDRE, CARL apud LIPPARD, 1983, p. 125)

Poderíamos incluir $\boldsymbol{O}$ aleph nos exemplos de Lippard. Mesmo não estando no período da contracultura - quando as obras iniciais da land art voltavam-se para o interior de seus

417 LIPPARD, Lucy. Overlay contemporary art and the art of Pre-history. New York : Pantheon Books, 1983, p. 10 "[...] modern art primal art are ideologically opposed. Primal art is integrated with daily life and modern art is set totally outside daily life - either above it all, as the producof some mysterious superior activity, or below it at all, as "useless".

418 Serpent Mound, em Ohio, EUA, é um trabalho de terra (earthwork) que pode datar dos anos 10001500. Em forma de serpente, seu relevo tem a extensão de mais de 400m. (Disponível em: .In: http://www.ohiohistory.org/museums-and-historic-sites/) 
territórios, seja por questões políticas ou existenciais -, a obra de Angelo Venosa reafirma o distanciamento com a eloquência do contemporâneo.

Um tempo remoto é apresentado na forma do labirinto-ruína, construído com um arenito rosa da região e com o modo de assentamento de muros utilizado pelos escravos, sem o uso de argamassa. A cor vermelha da pedra contrasta com o verde, mas, com o tempo, o artista imagina que "o labirinto criará algum limo, o mato tomará conta da região". A obra já é pensada considerando sua dissolução na paisagem. Também pela obra se integrar ao entorno "pouco desenhado", podemos considerá-la como um anti-monumento do contemporâneo, no limiar entre pertencer e diluir-se.

$\boldsymbol{O}$ aleph evoca a experiência da paisagem, que se funde à do percurso da obra e à experiência estética da obra ${ }^{419}$. Por meio deste percurso, centramo-nos em nossa escala, em um movimento de introspecção; mas direcionamo-nos, simultaneamente, à expansão que a paisagem, no seu desmesurado, nos impele através da visualidade que "tudo abarca". Venosa explica que $\boldsymbol{o}$ Aleph é essencialmente ligado ao lugar, que foi escolhido a partir de um ponto mais alto da colina, tirando partido da visualidade da paisagem e de sua contemplação.
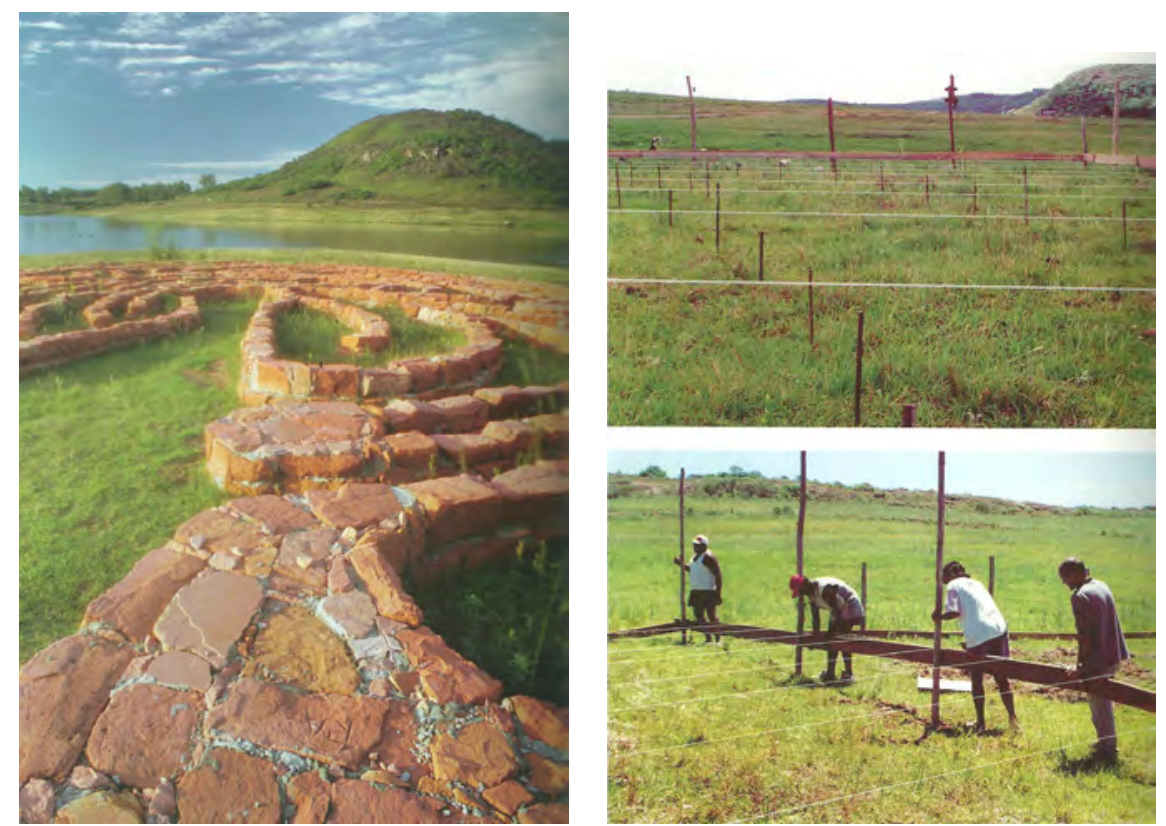

126. Angelo Venosa. $O$ Aleph, 1999. Santana do Livramento. RS e execução da obra.

(Fonte: Fronteiras, Rio de Janeiro: Contra-Capa, 2005, p. 34 e 44)

419 Vide entrevista com o artista. Anexo I.

NOTA: As falas dos artistas que datam de 2012 correspondem às entrevistas para esta dissertação, e estão documentadas no Anexo I desta. 
Segundo as categorias de Kastner, podemos incluir $\boldsymbol{O}$ aleph em envolvimento e integração ${ }^{420}$. No primeiro grupo porque há o predomínio da escala humana na obra e da ação do indivíduo diretamente na paisagem, assim como menção a um simbolismo primordial de re-ligação com a Terra, comum às obras deste grupo, mas que são, geralmente, efêmeras. E, no segundo grupo, porque a obra trabalha a paisagem e seus elementos como matérias-primas, rearranjando-as. Assim como as características do lugar - topografia, materiais e sua história - formam o repertório da obra que não lhe adiciona componentes alheios.

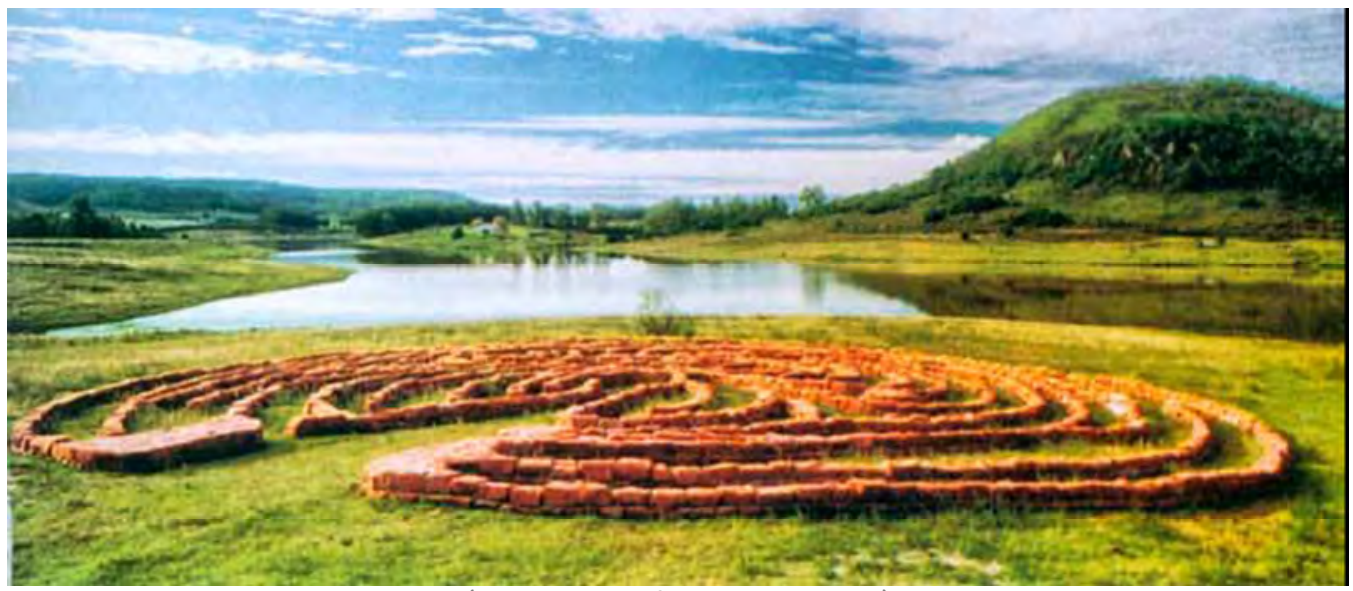

(Fonte: Fronteiras, 2005, p. 38)

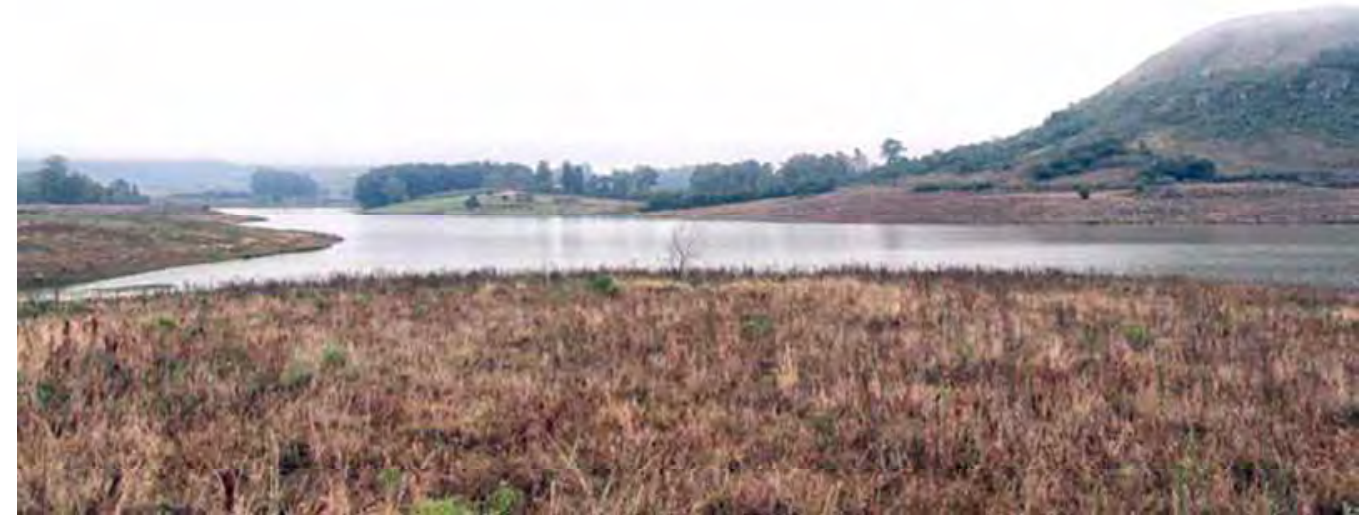

127. Acima, foto de Francisco Alves, 2010: obra retirada do Parque do Batuva.

(Fonte: ALVES, José F. A especificidade da Arte Pública na 5.a Bienal do Mercosul - Porto Alegre)

420 KASTNER, WALLIS, 1998. O autor agrupa as obras da land e environmental art de acordo com seus modos de abordar ou incorporar a paisagem: integração, envolvimento, interrupção, implementação e imaginação In: Land e Environmental Art. (Ver em Capítulo 02). 
Foto aérea de 13/07/2003.

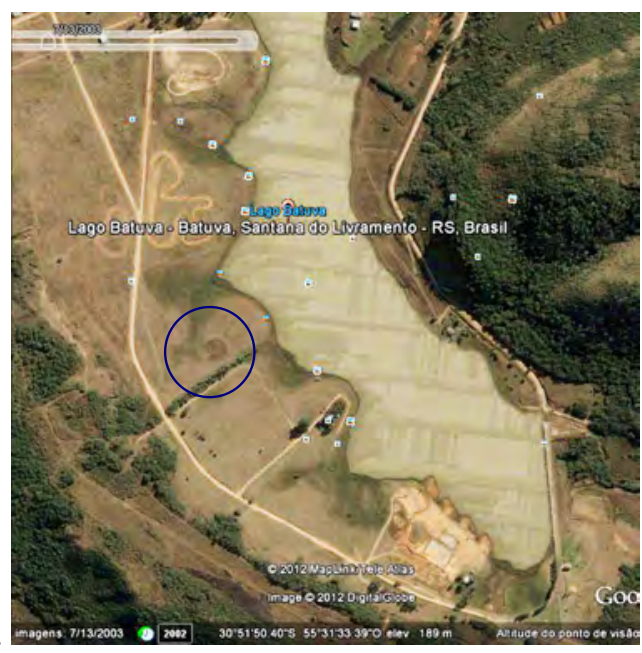

128. Situação da obra em vista aérea do Parque Municipal do Batuva, Santana do Livramento, RS

$\mathrm{Na}$ narrativa sobre a paisagem de Fronteiras, Angelo Venosa atenta para a morfologia da paisagem "de terreno ondulado, de vales e colinas baixas" e ressalta seus elementos naturais: o arenito, o relevo, o limo, o corpo e seu percurso. Em entrevista para esta dissertação, ele também aponta os elementos culturais que diferenciam a paisagem da fronteira entre Brasil e Uruguai, "a natureza é a mesma, mas é como água e óleo" ${ }^{\$ 21}$. A obra o Aleph propõe uma abordagem singular da paisagem, ao ressaltar o tempo e a memória como formadores e mediadores de nossa percepção e vivência na paisagem e na obra nela inserida.

[o trabalho] integra-se perfeitamente à paisagem, sem muito "desenho" ou intervenção de objetos construídos. A vista do parque é ampla, há vales e colinas e não destoa da fisionomia da região [...] (Venosa, 2005, p.36)

Angelo Venosa tem importantes obras em espaços públicos urbanos, que se relacionam com a paisagem, como Baleia (1990), a princípio instalada na praia de Copacabana. Mas, uma de suas obras que talvez mais se relacione com a paisagem foi exposta dentro do ambiente de galeria, por ocasião da $45^{\mathrm{a}}$ Bienal de Veneza, no pavilhão brasileiro. Era uma escultura de ossos que aludia laconicamente à paisagem sofrida do sertão. Dentro de uma sala fria e branca de exposição, do artifício do cubo branco construído para não interferir na obra, a ossada de boi disposta delicadamente sobre o piso, compondo uma absurda simetria, conseguia evocar, com tamanha força, essa paisagem muito brasileira.

421 Em entrevista. Anexo I, 


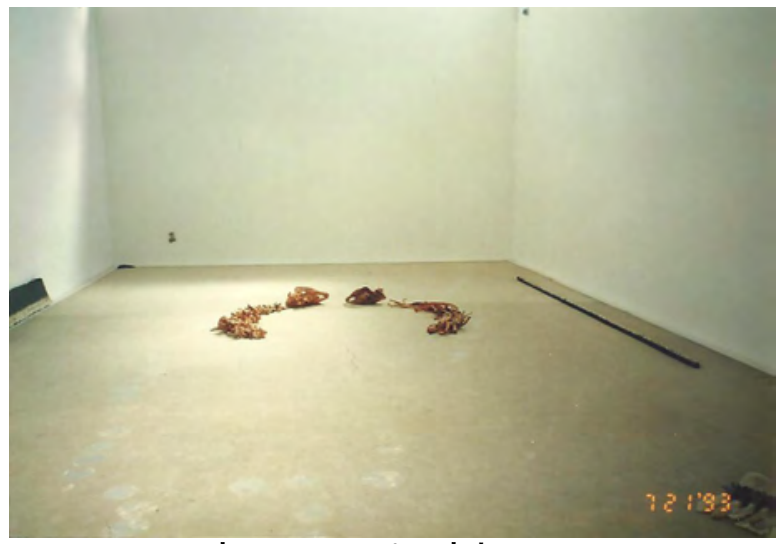

129. Angelo Venosa. Bienal de Veneza, 1993.

(Fonte: arquivo pessoal)

Principalmente pela exposição se organizar por representações nacionais, a paisagem seca e de morte do nordeste constrangeu-me. Talvez para quem desconheça essa paisagem, ou suas imagens, a escultura abordasse forma, matéria ou corpo.

A obra, embora não diretamente na paisagem aborda suas questões e vale para nos lembrar que não é pelo fato de estar "do lado de fora" que a arte nos sensibiliza para as questões formadoras da paisagem, para seus elementos ou história.

\subsubsection{Nelson Félix. Mesa, 1999}

Aço corten, troncos de eucalipto e 22 mudas de figueira-do-mato. $50 \mathrm{~m}$ chapas de aço, aproximadamente $183 \mathrm{~m}^{2}$. Uruguaiana, RS

(Fronteira Brasil / Argentina / Uruguai)

Mesa (1999), diferente das outras obras de Fronteiras, não faz o percurso - a percepção do lugar e do tempo através da obra - convergir com a experiência da paisagem. A obra, que requer o crescimento de vinte e duas mudas de figueira para erguerem, no decorrer de aproximadamente duzentos anos, uma extensa chapa de aço, desenvolver-se-á de acordo com as forças da natureza, desenhando-se mais no espaço mental. Para Salzstein, o artista trabalha com uma percepção do tempo e do espaço que vai "além das estruturas históricas, sociais e institucionais, e não coincide com a percepção de uma consciência individual." 422

422 SALZSTEIN, 2005, p. 165. 
O extenso plano em chapa de aço, primeiramente sustentado por mourões, será "mordido" pelos troncos, conforme cresçam, e erguido até a altura da linha do horizonte. Esta horizontalidade presente na obra é o ponto de relação com a paisagem. Contudo, o trabalho do artista não busca referenciais na paisagem, mas na "construção do pensamento plástico" ${ }^{423}$, como ele próprio enfatiza.

O lugar de Mesa foi escolhido a partir de coordenadas geográficas - Félix elegeu o paralelo $30^{\circ 424}$ - estabelecendo como única relação uma outra obra sua: O grande Budha (1985-2000). Mesa e o grande Budha relacionam-se com outras duas - Vazio Coração (deserto) e Vazio Coração (litoral) -, formando uma obra-totalidade: Cruz na América ${ }^{425}$. Ao término das quatro obras que formam Cruz na América, quatro paisagens emblemáticas são reveladas como espaço da existência humana: floresta, campo (pampa), deserto e praia. Embora o artista tenha abstraído a paisagem, ela acaba por retornar em seu trabalho, não como uma intenção primeira, mas talvez pelo fato de a nossa relação com a natureza ser filtrada por camadas de história - nossas matrizes culturais -, pelo nosso olhar estetizante do mundo. Cruz na América parece reiterar nossa aproximação estética com o mundo, ao mapeá-lo, organizá-lo e ao lhe atribuir valores.

Se a arte e a paisagem operam segundo um certo grau de composição, é exatamente esta que o artista tenta evitar, buscando romper com o repertório de imagens e memórias que nos direcionam, quase que invariavelmente, à composição. Nelson Félix, contudo, reconhece que para a arte "cortar todo o vínculo com a composição seria o mesmo que uma morte" ${ }^{426}$.

É no embate com a composição e, ao final, reconhecendo-a sob a forma de paisagens simbólicas - como se elas estivessem apenas esperando pelo nosso olhar -, que resulta uma das belezas de sua obra. Ao descobrir que esse processo de escolha resulta nas quatro paisagens, o artista se diz muito orgulhoso por esse acaso.

\footnotetext{
423 Em entrevista, Anexo I

424 No princípio, quando o projeto incluía toda a fronteira continental do país, o artista elegeu o paralelo $10^{\circ}$ "seja lá onde isso for". Ver SALZSTEIN, 2005, p. 169. Ao limitarem Fronteiras para a divisa entre Brasil e países do Mercosul, Félix acaba por eleger o paralelo $30^{\circ}$, no alinhamento de $O$ grande Budha.

$425 \mathrm{Na}$ entrevista para esta dissertação (Anexo I), o artista explica que trabalha com obras dentro de outras, e que é necessário traçar as relações entre elas. Cruz na América também está inserida dentro de outro pensamento maior, que é o Concerto para encanto e anel.
}

426 FÉLIX, 2005, p. 167. 
Nelson Félix escolheu o paralelo $10^{\circ} 70^{\prime}$ para a intervenção de $O$ grande Budha, na floresta Amazônica, incidindo no Acre. Esta obra é o ponto de partida para as demais. Mesa, em Uruguaiana, RS, (ponto 2), Vazio Coração / deserto (Atacama, Chile), ponto 3 e Vazio Coração / litoral (Ceará), ponto 4. Pela mediatriz do eixo de $O$ grande Budha e Mesa e do prolongamento da longitude do ponto, encontrou as coordenadas no deserto e de lá, em linha reta até interceptar o mar, no litoral cearense.

As quatro obras formam o trabalho Cruz na América (1986-2003).

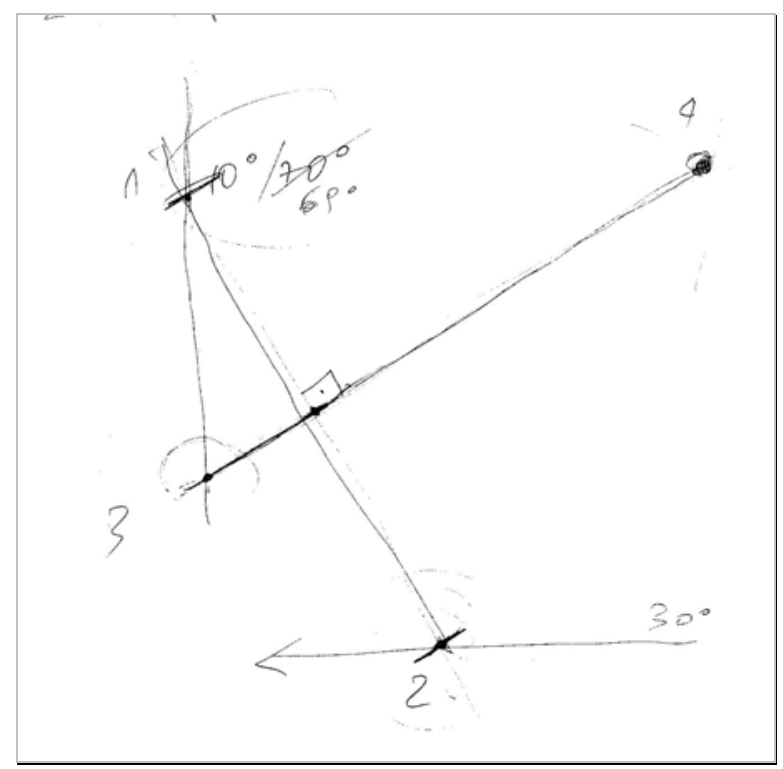

130. Nelson Félix. Croqui do artista, em 28/06/2012.

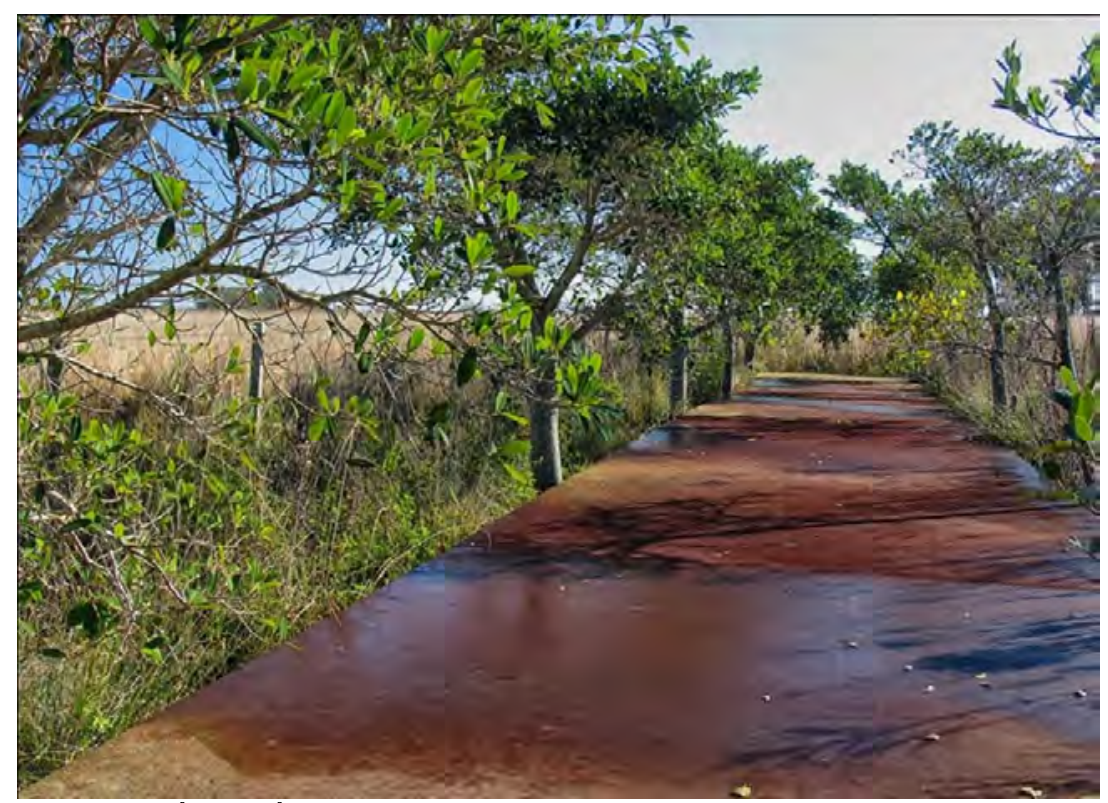

131. Nelson Félix. Mesa, 1999. Uruguaiana, RS. Foto em 2010.

(Fotografia de José Francisco Alves

In: No Limite: Obras Públicas na Fronteira do Rio Grande do Sul, 2010).

Salzstein ${ }^{427}$ relaciona o espaço geográfico - representado pelas coordenadas que o artista emprega como ancoragens das obras no mundo - com o espaço mental. Mas a tradução do espaço geográfico por meio de mapas também implica no espaço geométrico, que é utilizado esquematicamente pelo artista, a fim de indicar o lugar de suas intervenções

427 SALZSTEIN, 2005, p. 165. 
sobre o globo terrestre. É como se, primeiro, o artista trabalhasse em uma antecâmara, livre das singularidades do espaço geográfico, recorrendo livremente à abstração da geometria, capaz de manipular a Terra como um objeto; para depois se lançar no espaço geográfico de fato, espaço este que nos termos de Dardel (1952) não é abstrato, mas praticado, vivido. Félix confronta abstração e realidade, vivenciando-a através de suas intervenções e viagens paisagens adentro.

O espaço geométrico é homogêneo, uniforme, neutro. Planície ou montanha, oceano ou selva equatorial, o espaço geográfico é feito de espaços diferenciados [...] A geometria opera sobre um espaço abstrato, vazio de todo o conteúdo, disponível para todas as combinações. O espaço geográfico tem um horizonte, um modelo, cor, densidade. Ele é sólido, líquido ou gasoso, largo ou estreito: ele limita e ele resiste. (DARDEL, Eric. L'Homme et la Terre, 1952 apud BESSE, 2006, p. 86)

Gênese de uma forma [...] A decisão arbitrária é o único modo de evitar esse mau passo. $\mathrm{O}$ mesmo vale para a paisagem. Quando é que ela surgiu como noção, como conjunto estruturado, dotado de regras próprias de composição, como esquema simbólico de nosso contato próximo com a natureza? ${ }^{428}$

(131). Nelson Félix, Mesa, fotografia em 1999. (Fonte: Fronteiras, 2005, p.171)

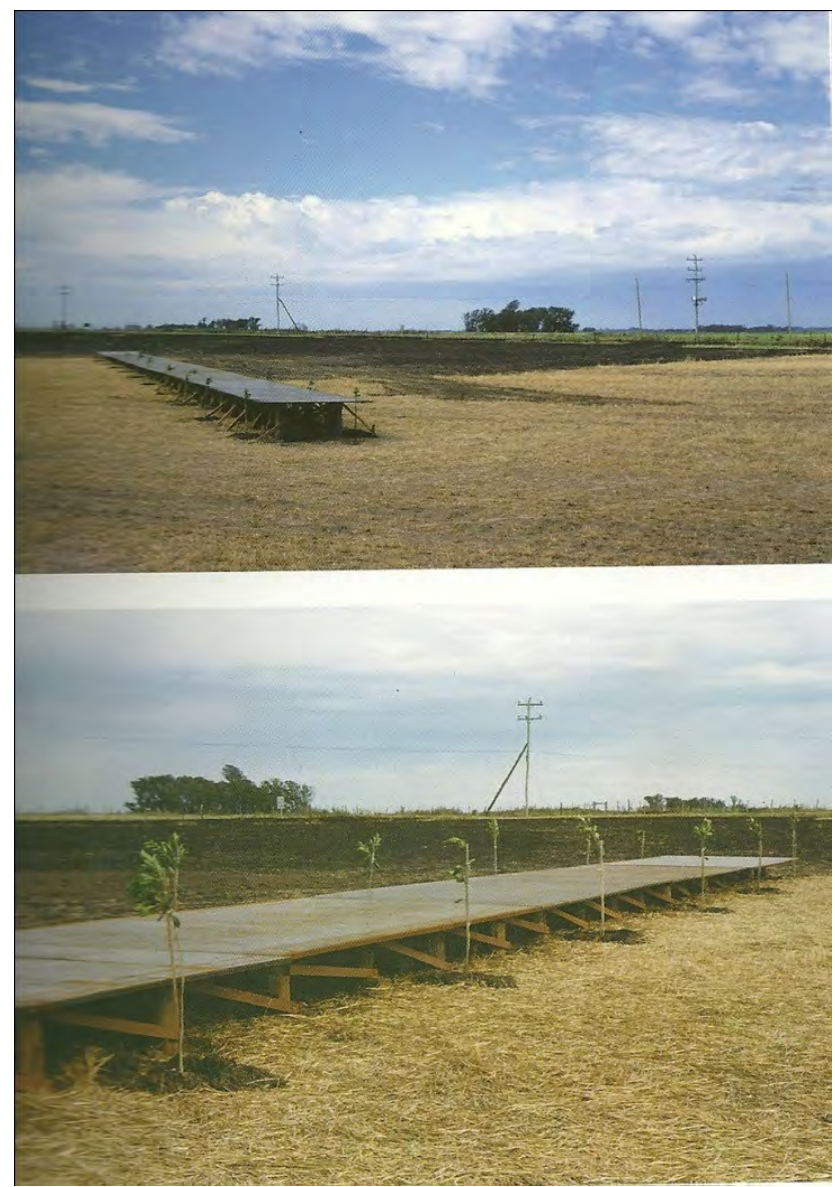

428 CAUQUELIN, 2007, p. 35. 


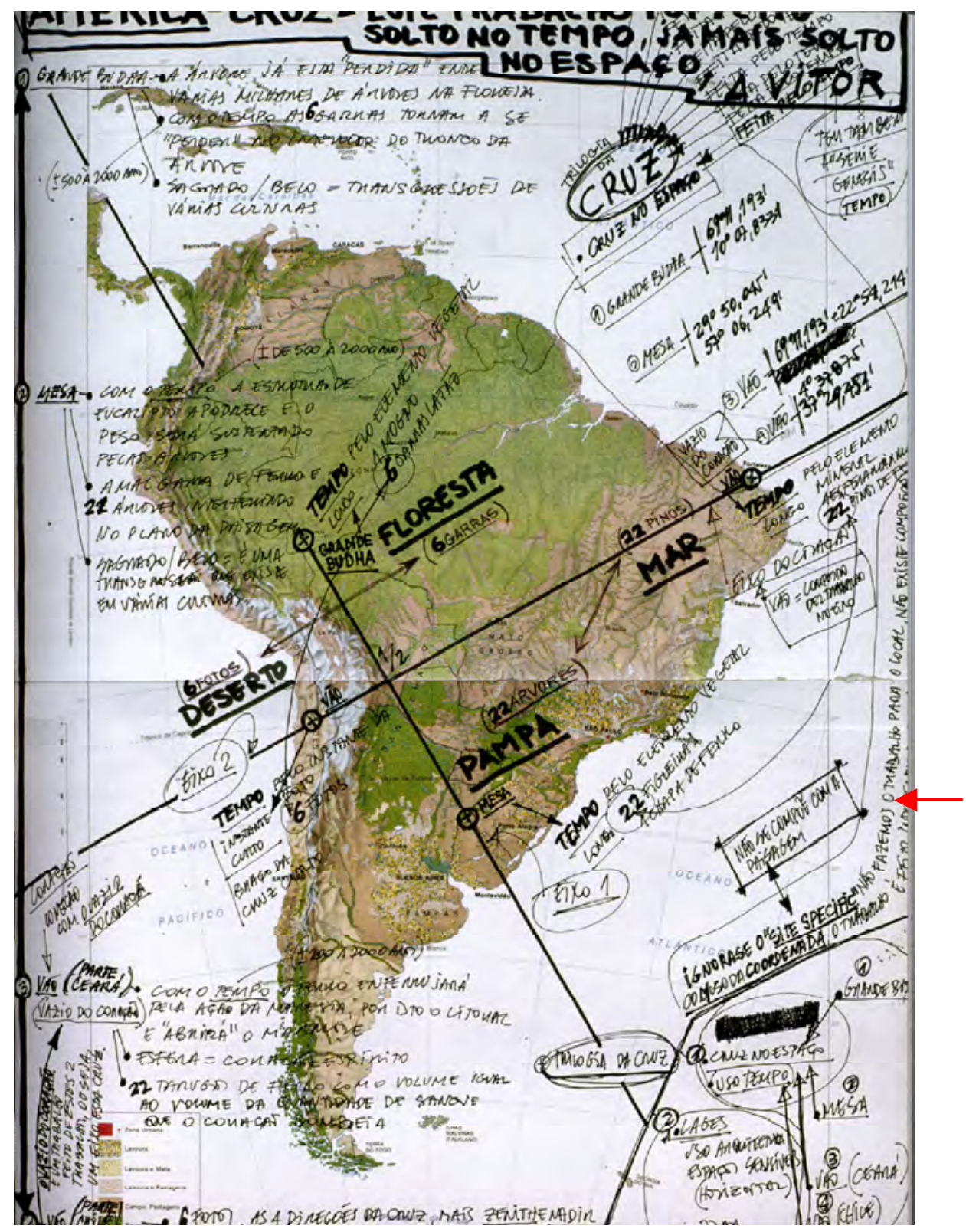

132. Nelson Félix. Cruz na América."Quatro paisagens onde o artista interveio entre 1986 e 2003 , relacionando-as" (Fonte: Concerto para encanto e anel, 2011, 125)

(Fonte: http://www2.dbd.pucrio.br/pergamum/tesesabertas/0510851_08_cap_01.pdf. Data: 28/06/12)

É importante compreendermos que a paisagem acaba por influenciar na nossa leitura da obra, mas não é ponto de partida na concepção da mesma. Félix escreve em seu desenho, em Cruz na América : "não compõe com a paisagem" ${ }^{429}$. As coordenadas geográficas, pontos de ancoragem das obras no mundo, são traduzidas em paisagens através da linguagem da arte.

429 BRITO, Ronaldo; FÉLIX, Nelson; FLORIDO, Marisa. Concerto para encanto e anel. Rio de Janeiro: Susy Produções, 2011. 


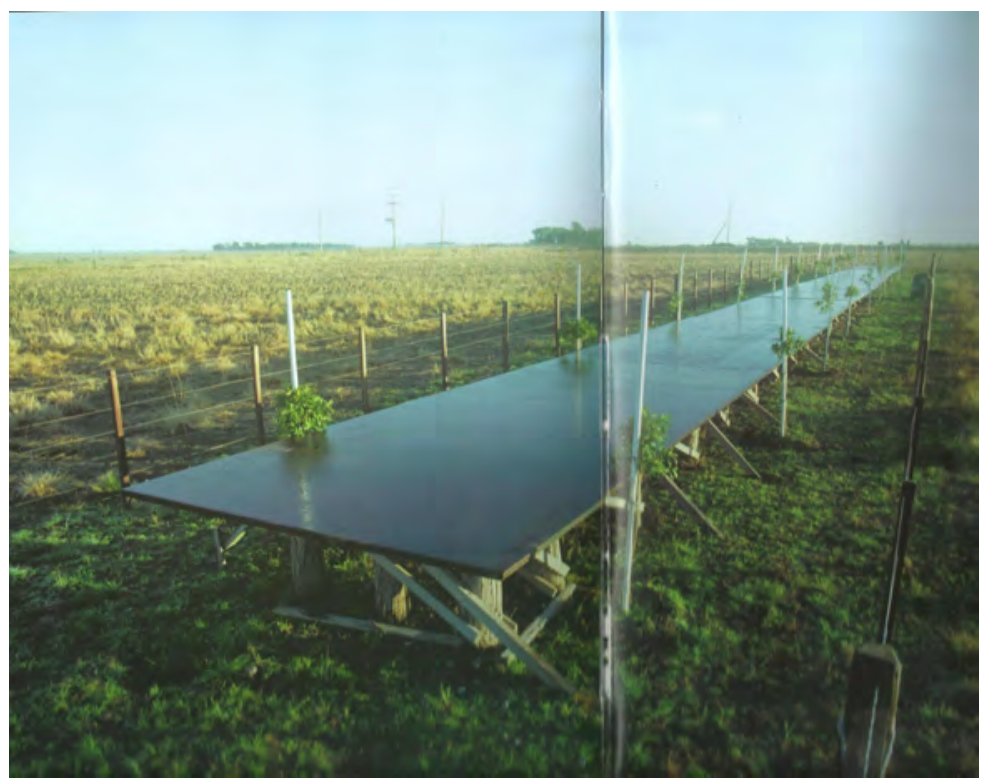

(131). Nelson Félix. Mesa, fotografia em 1999. (Fonte: Fronteiras, 2005, p.174-175)

$51 \mathrm{~m}$ de comprimento aço corten sobre toras de eucalipto, 22 mudas de figueiras, 11 de cada lado.Os troncos das figueiras vão "morder" a chapa e levantá-la, podendo levar dois séculos para que a chapa seja erguida até a linha do horizonte.

As outras três obras que formam Cruz na América ${ }^{430}$ :

133. Nelson Félix. O Grande Budha (19852000).

Árvore Mogno e Latão (Fonte imagem: http://monolitho. labin.pro.br/? p=563. Data: 28/06/12)

Assim como em Mesa (1999), Nelson Félix teve que recuar quilômetros do paralelo $1070^{\prime}$, uma vez que nesta área havia confrontos de grupos indígenas e posseiros. A Funai mediou a ação do artista que migra, então, para o paralelo $1069^{\prime}$.

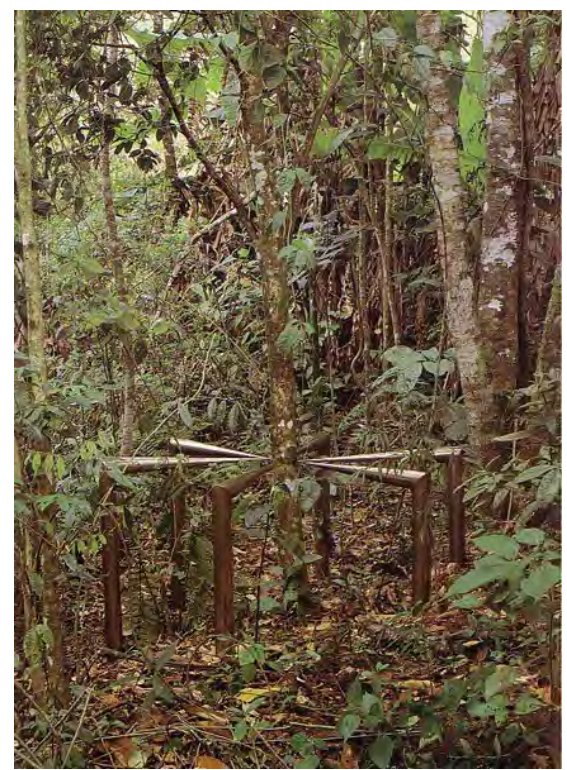

(Fonte: http://www.itaucultural.org.br/aplicExternas/ enciclopedia_IC/iData: 28/06/12)

430 É necessário fazermos um parênteses na análise de Mesa (1999), pois para contextualizá-la precisamos inserí-la no trabalho Cruz na América. No Anexo I, em entrevista, Nelson Félix expõe a interdependência de suas obras. 
134. Nelson Félix. Vazio Coração, deserto do Atacama, Chile (1999-

2003).

No Atacama, o artista fotografa em direção à Mesa e ao grande Budha. Os registros saem superexpostos devido ao tempo de abertura do diafragma da máquina - que deveria acompanhar o ritmo dos batimentos do coração do artista. O trabalho idealizado a priori, desaparece naquela situação.
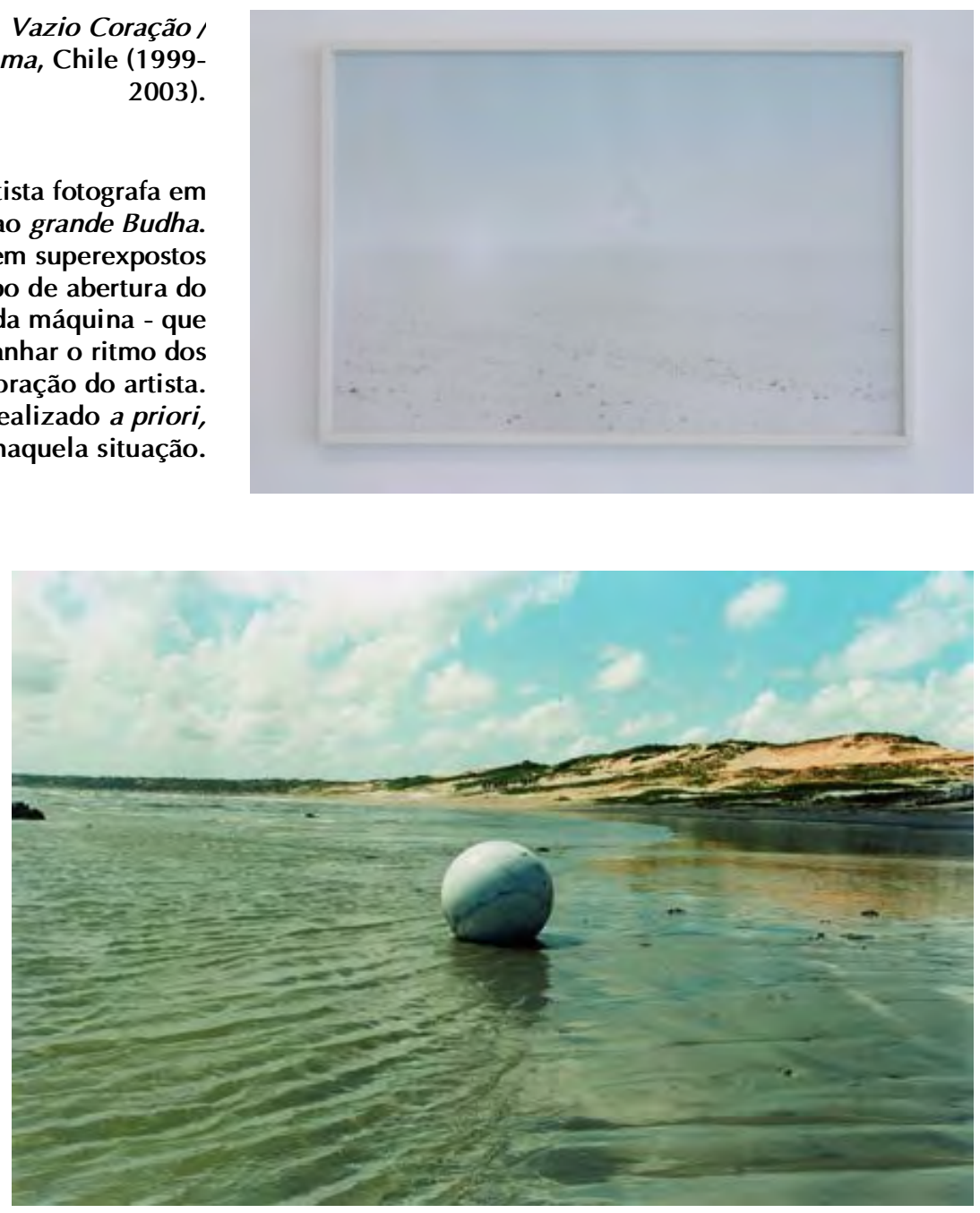

135. Nelson Félix. Vazio Coração / litoral. (1999-2004). Praia Redonda com Ponta Grossa, Ceará.

Esfera de mármore, 22 pinos de ferro que, ao oxidarem, exercerão pressão e estourararão o mármore. (Fonte://www.bienaldecuritiba.com.br/2011/home/?secao=3\&artista=73. Em 28/06/12)

Nas quatro obras de Cruz na América, o tempo é um elemento estruturador, que se faz sensível em O grande Budha e em Mesa, por intermédio do elemento vegetal - o mogno e as figueiras. Em Vazio Coração / deserto o tempo dos batimentos cardíacos determinaria o instante da foto. E em Vazio Coração / litoral, o tempo de oxidação do ferro - elemento mineral - determinaria a existência da obra (ou seu fim, fazendo-a estourar). Félix trabalha com uma "escala amorfa", que abarca o segundo da batida do coração até séculos de crescimento de uma árvore. 
Conceber a obra a partir do lugar como um dado a priori implicaria na composição. Para o artista, a composição não se refere apenas àquela plástica ou formal, mas inclui também esquemas de pensamento e desenvolvimento da arte. Assim, ele recusa a composição implícita na premissa da Instituição por obras "site-specific", pois este direcionamento poderia "moldar" processos e resultados na arte. Questões pertinentes à especificidade do lugar são fortemente questionadas por Nelson Félix através de Mesa.

Para mim, isso soou, de imediato, como exigência de uma certa composição, isto é, eu teria de "compor" algo para aquele local. [...] Por outro lado, convenhamos: é difícil não compor; todo trabalho se afirma por meio de certa dose de convenção e reiteração [...] (FELIX, 2005, p. 167)

$\mathrm{O}$ artista em entrevista para esta dissertação, explicou que a paisagem, para cada uma das quatro obras de Cruz na América - e portanto para Mesa - não é uma referência, mas que em Cruz na América ela é como uma matéria-prima a ser manipulada.:

Trato neste trabalho [Cruz na América] a paisagem quase como matéria, como um material. Utilizo as 4 diferentes formas de paisagem, nesta escala, como um escultor utiliza os diferentes materiais, ferro, cobre, mármore, etc. No fundo neste olhar maior da Cruz, ela (a paisagem) é um material, no olhar mais específico de cada trabalho em si, como Grande Budha, Mesa, etc., não. Ela é ela mesma. (FELIX, Nelson, 06/12/2012)

Sobre as condicionantes da paisagem, Mesa situa-se no paralelo $29^{\circ} 58^{\prime}$, em uma propriedade da Pontifícia Universidade Católica (PUC), no campus de Zootecnia, em terreno de uso pecuário e agrícola, por isso a obra é cercada para se isolar do pasto. O proprietário que "contém" o paralelo $30^{\circ}$ da fronteira não aceitou a obra em seu terreno e, embora Félix imaginasse uma outra situação, mais erma, aceita tais elementos físicos e culturais da paisagem.

No fim das contas recaímos em um terreno da Pontifícia Universidade Católica (PUC), com algumas zonas de pasto e agricultura; fiquei meio chateado que não fosse um terreno mais ermo, mas pensei: o acaso também faz parte do trabalho! (FELIX, 2005, p.169)

Mesa, apesar de lidar com a vastidão territorial e com a escala geográfica - e abarcar processos naturais que transformam ou desenvolvem a obra - difere de muitas das obras da arte contemporânea da paisagem pois não intensifica a percepção do lugar no tempo de apreensão da obra, assim como não abarca a fisicalidade do lugar. Félix explica sobre estas diferenças: 
De fato, se compararmos a atitude presente nesse trabalho (Mesa) com grande parte do que se fez na land art, veremos que é radicalmente diferente, que é o inverso da confiança minimalista na fisicalidade dos processos [...] (FELIX, Nelson, 2005, p.167)

Do ponto de vista do trabalho, essa relação tópica com o lugar sempre solicita uma atitude compositiva. Por que não brigar com isso? (Ibidem, p. 169)

Mesa aprofunda a investigação sobre os sentidos da paisagem e sobre a condição pública da arte. Por isso, ele não trabalha com uma premissa site-specific que poderia resultar em arbitrariedade naquela situação de fronteira e que, ainda, atrela-se fortemente a uma produção de meados dos anos 1960 e 1970, da arte minimalista e da land art.

Segundo Ferreira (2009) $)^{431}$, as obras O grande Budha e Mesa dialogam "com a expansão do espaço artístico conquistado a partir dos anos 60, particularmente com a Land $A r t^{\prime \prime}$ quando a partir de então a obra incorpora o meio, seu contexto é ampliado, e tornam-se imprecisos os limites entre lugar e obra, "esta revelando-se apenas de maneira fragmentada". Mas, se boa parte da land art está circunscrita pela ideia de Michael Heizer - "Não se coloca uma obra em um lugar. Ela é esse lugar" ${ }^{1432}$-, Ferreira ressalta, em contrapartida, que as obras de Félix "pontuam espaços e supõem processos em dimensões temporais de centenas de anos, aos quais nós, seus contemporâneos, não teremos acesso".

Considerando os agrupamentos de Kastner, Mesa estaria tanto em interrupção, ao inserir materiais e técnicas estranhos ao lugar, cuja presença marcante sobressai-se no entorno; assim como em imaginação ${ }^{433}$, pois Nelson Félix abstrai-se da paisagem para testá-la: vê-la surgir ou desvanecer. Ele desenha sobre o globo unindo o espaço geométrico ao geográfico, mas insere-se neles como espaço da existência. As obras desta vertente elaboram a relação com o mundo exterior a partir do espaço, tempo, distância, geografia, astronomia, migração e dão continuidade à tradição conceitual que originou a Land Art.

Em relação a suas impressões sobre a paisagem, o artista refere-se a ela como "violenta", por isso propôs um trabalho que "submergisse nela, mas que, ao mesmo tempo,

431 FERREIRA, Glória. A coisa é ar. In: BRISSAC, Nelson; FERREIRA, Glória;SALZSTEIN, Sônia. Nelson Félix. Rio de Janeiro: Casa da Palavra, 2001.

432 Ver em FERREIRA, 2006, p. 275. Discussões com Heizer, Dennis Oppenheim, Robert Smithson (1970)

433 Em imaginação, a terra ou a paisagem (land) não é tomada fisicamente mas como uma metáfora, um significante. Como um conceito ou uma construção linguística, os artistas trabalham com mapas, construções teóricas, com arbitrariedade e acasos. $\mathrm{O}$ ambiente é visto como uma narrativa histórica, nele há símbolos que podem ser organizados para descrever a sociedade contemporânea.Ver KASTNER; WALLIS, 1998, p. 174. 
marcasse uma diferença". Se projetarmos Mesa mentalmente e imaginarmos seu desenvolvimento (as quarenta e uma toneladas de aço erguidas pelos troncos das árvores), a obra é monumental, impactante, contudo, a obra se mescla a uma das características mais marcantes daquela paisagem: a horizontalidade. Podemos dizer que a obra oscila entre uma imposição e aquilo que se infiltra ou se desenvolve naturalmente, ou quase, imerso na paisagem.

O fato de a obra se configurar como uma imensa superfície disposta sobre a linha do horizonte se deve, evidentemente, à marcada condição de horizontalidade que encontrei no local, mas não é que a obra reaja a ela, antes adere a essa horizontalidade para se confundir com ela. (FELIX, 2005:170)

As questões da paisagem em Mesa, e nas obras Cruz na América e Concerto para encanto $\boldsymbol{e}$ anel, que ela integra, levam-nos a refletir sobre a tradição do olhar, filtrado pela cultura que, talvez, naturalmente conforma paisagens.

Mesa é fortemente uma obra conceitual e, principalmente, se analisada no conjunto de Cruz na América, evoca a experiência da paisagem, que é apreendida em sua totalidade. Esta obra, aliás, é feita de paisagem ${ }^{434}$ (como declarou o artista), esta que assume a característica de entidade simbólica e, sobretudo, como experiência da mente humana questionadora de nossa posição no mundo.

\footnotetext{
434 "Mas para que nasça a paisagem é sem dúvida necessário que a pulsação da vida, na percepção e no sentimento, seja arrancada da homogeneidade da natureza [...]"SIMMEL, Georg.Filosofia da paisagem. 1913.
} 


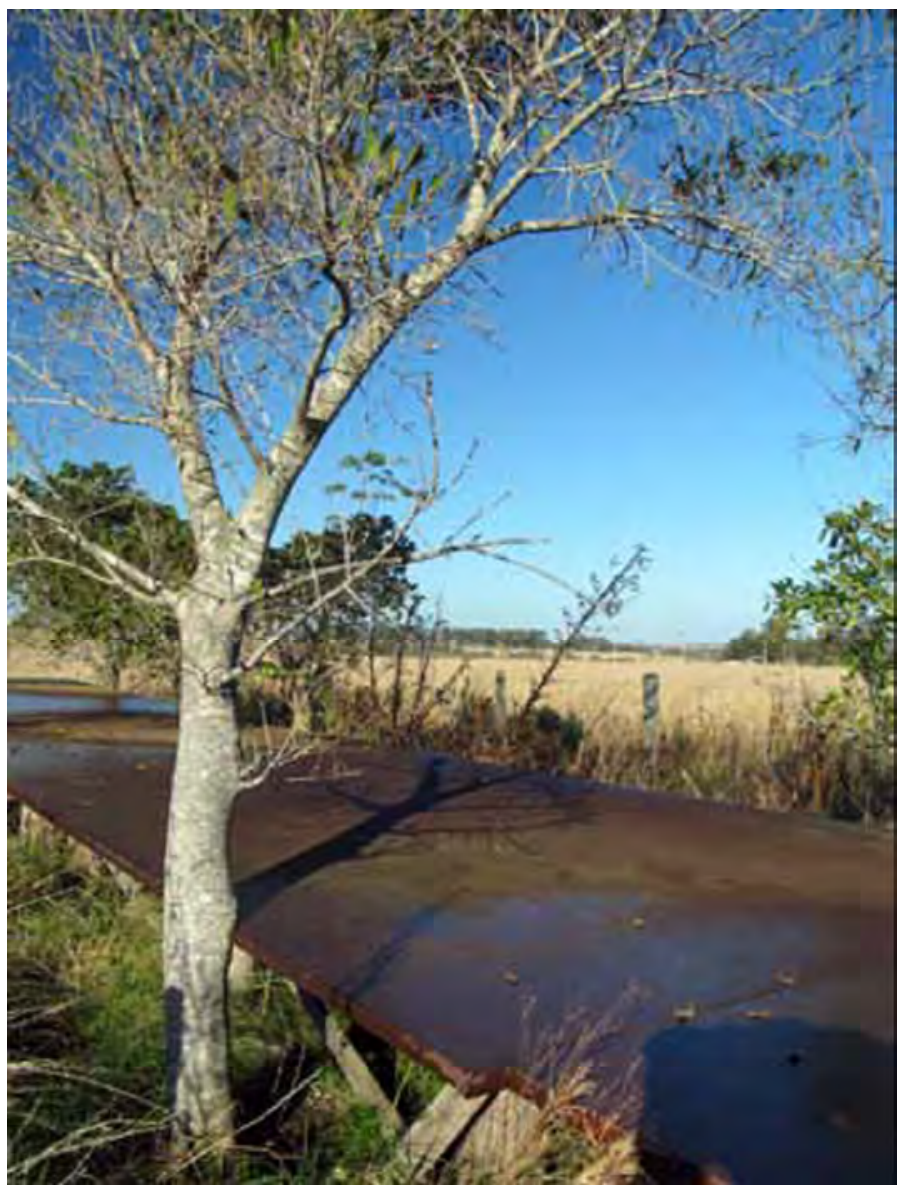

(130). Nelson Félix. Mesa, 1999. Fotografia tirada em 2010. (Fonte imagem: José Francisco Alves In:

No Limite: Obras Públicas na Fronteira do Rio Grande do Sul, 2010).

\subsubsection{Carlos Fajardo. Sem título, 1993/2001}

13 mil tijolos de barro cozido. $340 \times 280 \times 280 \mathrm{~cm}$. Laguna, SC.

Instalado em uma praça à beira mar.

PHOTETO MONREIZAS

3 to

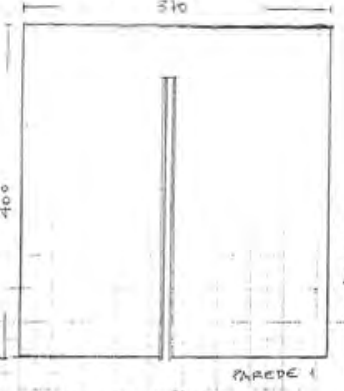

CARIOS PATARDO OA

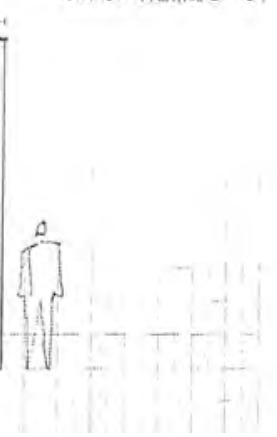

136. Dados do Projeto:

O projeto é construído por quatro colunas de secção quadrada compostas de fileiras de tijolos colocados de pé, com a medida de 190 centímetros de lado (cada coluna). A distância entre as colunas é de $10 \mathrm{~cm}$ (meio tijolo), formando um grande cubo de 36.000 tijolos.

(Carlos Fajardo. In: Ações Prospectivas. Itaú Cultural. 2000) 


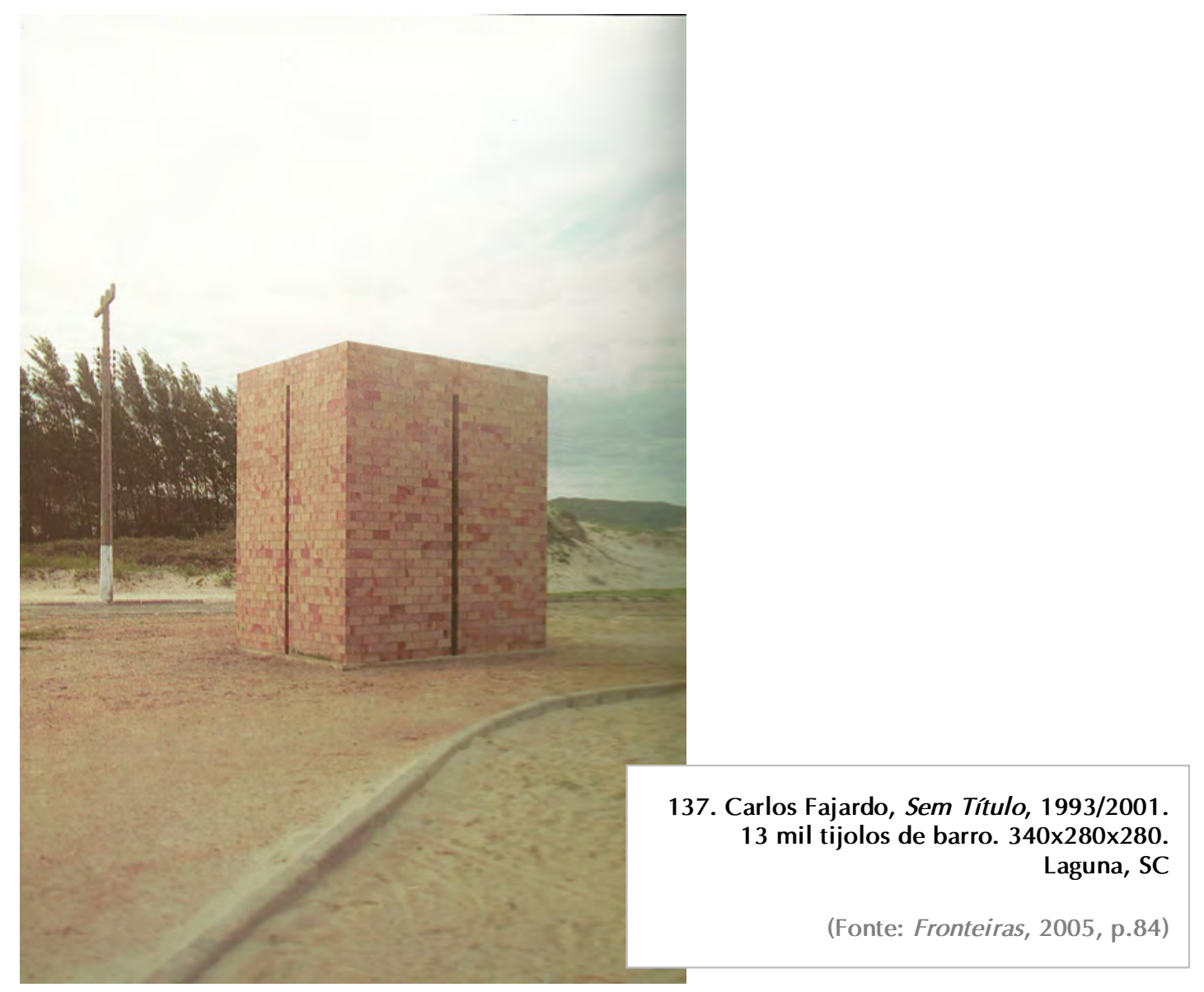

A escultura Sem título já havia sido construída para outras ocasiões, em locais abertos e fechados, com algumas variações em relação à dimensão e ao material empregado, "mas sempre preservando a característica essencial, que é a de relacionar-se intensamente com o entorno" $^{435}$. Em Fronteiras, a obra abarcou e comentou intensamente a paisagem sem contornos específicos da beira mar de Laguna, SC, estabelecendo com ela conexões tanto formais quanto conceituais. Fajardo comenta que suas esculturas de tijolos empilhados têm a ver com "jogos entre cheio e vazio, entre interior e exterior" ${ }^{436}$. Em específico, em uma praça pouco povoada na extremidade de uma larga avenida à beira-mar, a escultura - por seu isolamento - "apenas expande a escala daquela praça, de modo a relacioná-la com a vastidão do $\operatorname{mar}^{\prime 437}$. Percebemos como o artista tece conexões entre a forma e materialidade da escultura com as características formais e culturais da paisagem e, sobretudo, com sua atmosfera, através de oposições e complementaridades:

435 SALZSTEIN, 2005, p. 79.

436 FAJARDO, 2005, p. 80.

437 Ibidem, p. 93. 
Ele [o trabalho] não acrescenta àquele lugar como uma escultura propriamente, como um valor dado a priori, como um corpo adicionado. Ele apenas expande a escala daquela praça, de modo a relacioná-la com a vastidão do mar, com um entorno que passa a ser percebido em toda a sua rarefação, como um lugar introspectivo que ultrapassa todo limite geográfico. (FAJARDO, 2005, p. 93)[grifo nosso].

Carlos Fajardo, em Fronteiras (2005) e em entrevista para este trabalho, referiu-se com frequência à paisagem, pois é ela o objeto da experiência artística em seus dois primeiros projetos e é ela que, junto à obra implantada em Laguna, incita a leitura ora em continuidade, ora em paradoxo com a escultura. Perceberemos que mesmo sendo uma escultura projetada $a$ priori da paisagem, esta envolve Sem Título (1993/2001) em sua experiência sensível e leitura.

Fato muito significativo é Fajardo ter escolhido, em seus dois primeiros projetos, paisagens ruidosas, o que já as colocaria em contraponto com a arte, com o "silêncio em que vejo mergulhado o trabalho de $\operatorname{arte}^{\prime 438}$. Devemos considerar estes projetos antes de atentarmos para a obra construída em Laguna, pois eles mostram-nos um encadeamento de intenções da arte em relação à paisagem e efeitos desta sobre a obra.

O primeiro projeto de Carlos Fajardo para Fronteiras foi uma caixa de vidro com isolamento acústico sobre a queda d'água das Cataratas do Iguaçu (PR). Nela, o observador poderia entrar e ver "girando o panorama das águas de todos os ângulos possíveis", completamente isolado dos ruídos do lugar. A paisagem, neste projeto de Fajardo, poderia ser traduzida como uma superfície, uma visualidade destituída de movimento: "uma dimensão de superfície tão potente que silencia toda aquela 'mecânica' da natureza"439. Contudo, ao visitar o local e descobrir que o barulho das águas "não se destacava como um elemento pleno", e ao deparar-se com impedimentos ambientais e outros, o artista muda o projeto de lugar.

Como era imprescindível achar um ponto de fronteira em que a intensidade do ruído fosse tanta e tão envolvente que se igualasse ao silêncio em que vejo mergulhado o trabalho de arte, não foi difícil chegar a hidrelétrica de Itaipu. (FAJARDO in Fronteiras, 2005:81)

\footnotetext{
438 Ibidem, p. 81.

439 Ibidem, p. 80.
} 
Se antes a visibilidade impactante da paisagem pertencia mais à natureza, no segundo projeto, na hidrelétrica de Itaipu, a "superfície de paisagem" ${ }^{440}$ é resultado das excessivas transformações do meio, "no cerne de uma monumental produção tecnológica". A caixa de vidro acústica estaria sobre o vertedouro da hidrelétrica. Ao propor intensificar a experiência visual, em ambos projetos, o artista suscitaria uma "experiência de nascimento da visibilidade", gerada pelo estado limite das sensações.

Mas a ideia continuava funcionando por contraste: produzir o plano silencioso da arte, aquela superfície redobrada sobre si mesma, não em meio ao entorno esmagador e indiferente da natureza, mas no cerne de uma monumental produção tecnológica. (Fajardo, 2005, p.81) [grifo nosso]

É bastante significativo que o cubo de vidro, tanto inserido na paisagem de exuberância natural quanto em uma monumental paisagem industrial, poderia despertar-nos, através da visão aguçada e intensificada, uma maior consciência a respeito de nós mesmos, silenciados em meio à paisagem; ou, nos termos de Fajardo, poderia incitar-nos a relacionar algo de nossa existência mais íntima com a força esmagadora do cenário natural ou dessa "superfície opaca das coisas". ${ }^{441}$ Ou seja, não reside apenas no caráter das paisagens o "funcionamento" da obra mas, principalmente, no aguçamento resultante de nossa percepção do meio, isolado de seus sons.

138. Carlos Fajardo, Sem título (maquete), 1999

aço corten, vidro e alumínio

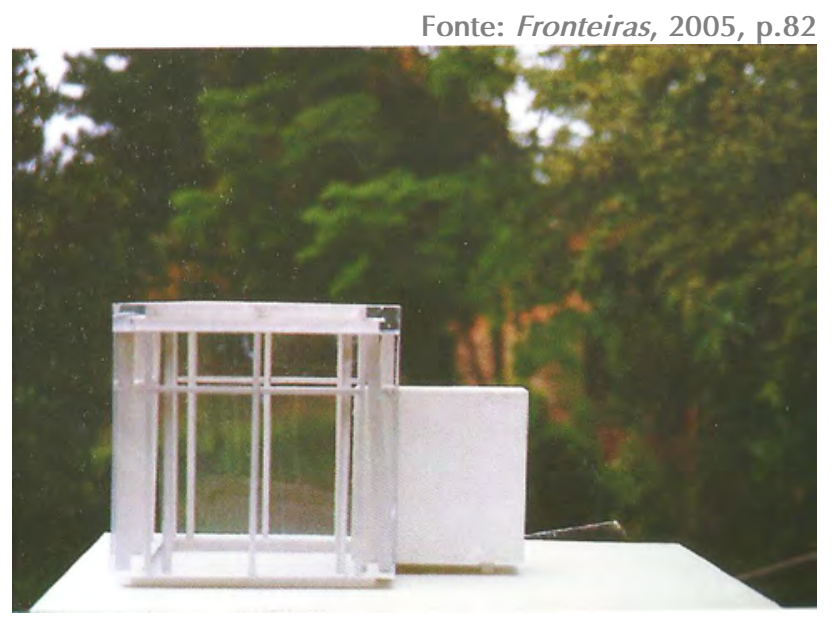

Fajardo preferiu Itaipu às Cataratas do Iguaçu, pois buscava o lado "não eloquente da natureza", assim como declarou que não lhe interessava o "lado pitoresco da natureza". Como

440 "Queria, portanto, tomar a paisagem em sua dimensão estrita de superfície, eliminando o movimento, ou ao menos chegar a uma noção mais 'interior'". Ibidem, p. 80.

441 Ibidem, p. 86. 
vimos no Capítulo 1, algumas obras de Fronteiras referem-se à natureza na tradição de sua representação na pintura pitoresca ${ }^{442}$ da paisagem. Tal referência ao "pitoresco" é muito relevante para pensarmos sobre uma arte contemporânea brasileira ligada às questões da paisagem, que busca desvencilhar-se da herança da pintura brasileira de paisagem, como beleza "acrítica" ou como uma imagem de cartão-postal.

O projeto da caixa de vidro pretendia dissecar a paisagem, como em uma experiência de laboratório. Seriam isoladas e então intensificadas a visualidade, a experiência da paisagem (experiência sensorial) e o tempo.

Ao ter que desistir do projeto da caixa de vidro, Fajardo (2006:86) expõe: "a questão do lugar voltou a estaca zero [...] porque ali, evidentemente, o lugar e o trabalho são uma coisa só". Assim, percebemos que neste projeto, arte e paisagem formam uma unidade. Se nestes projetos o artista havia escolhido paisagens impactantes e de visualidade monumental; para Sem título, ele acabaria por intervir em uma paisagem de vazios, "quase uma antipaisagem" ${ }^{443}$.

Primeiramente, o artista descreve a paisagem à beira-mar de Laguna ${ }^{444}$ como: $^{4}$

A paisagem lá é belíssima, com um farol sinalizando aos navegantes que se aproximam da costa o limite entre as águas do mar e a laguna propriamente dita. Achei muito sugestivo aquele horizonte aberto, com uma orla pouco povoada hoje, a cidade vive principalmente da pesca do camarão e de um turismo sazonal, permanecendo imersa em um certo silêncio durante a maior parte do ano. (FAJARDO, 2005, p. 87)

442 O termo apresenta diversas acepções. Do italiano, pittoresco provém de próprio para ser pintado. Sendo então derivado da pintura, ele também adentra o Brasil pelo paisagismo de influência inglesa, em parques públicos, no fim do século XIX, e daí a ligar-se à graciosidade ou a amenidades. Para John Ruskin, Philosophical Enquiry (1849), o pitoresco vislumbra-se por ruínas, pelo aspecto antigo, e através do sublime. Ele seria "uma sublimidade parasitária [...] que depende de fatores acidentais ou de caracteres menos essenciais dos objetos aos quais pertence". Por isso, para a arquitetura moderna brasileira, o pitoresco adquire coloração de artificialidade, ornamentação e afetação, e tal acepção talvez tenha perdurado para a arte moderna e contemporânea. (Podemos estender este significado para além da arquitetura moderna). Ver PINHEIRO,Maria Lucia B.; D'AGOSTINO,Mário Henrique S.. A noção do pitoresco no debate cultural das primeiras décadas do séc. XX no Brasil. Rio de Janeiro: CBHA/UERJ/UFRJ. 2004, p. 339-351.

443 FAJARDO, 2005, p. 89.

444 Laguna vem como proposta da Instituição, por ser a cidade onde passa a linha imaginária de Tordesilhas, tratado entre as metrópoles Portugal e Espanha, de 1494, que divide as terras da colônia americana. É também o local da batalha por independência de Giuseppe Garibaldi. 
Contudo, ao relacioná-la com a obra, a paisagem revelou-se, sobretudo, "imersa em certo silêncio", "um ambiente ralo", ressaltando a "noção do vazio" e "uma atmosfera de rarefação". Inserido neste meio, a escultura contou com poucos referenciais para se relacionar.

Naquela situação, ele [o trabalho] ficou, de modo mais claro efetivamente lançado ao vazio da paisagem, paisagem que é, de fato, quase uma antipaisagem, porque ali não tem nada, são só as dunas, uma linha do horizonte com o mar aberto e algumas construções esparsas, aqui e ali. (Ibidem, p.89) [grifo nosso]

Se para o projeto da caixa de vidro Fajardo partiu de paisagens em que "a visibilidade fosse um dado impositivo e decisivo"445, para a escultura em Laguna, a paisagem e seus elementos não são ponto de partida e, sim, pontos de ancoragem: a obra busca referências no lugar e entorno para adquirir sentidos.

Pensei em localizar o cubo de tal maneira que um observador posicionado diante do trabalho pudesse ver, através da fenda que divide o bloco em quatro partes simétricas, um pequeno farol que sinaliza o ponto onde começa a laguna; esse farol informa às embarcações que a laguna está à direita e que o mar está à esquerda, e esse é um dado crucial para a vida da cidade, pois ela tem na pesca uma importante atividade produtiva. Do ponto de vista formal, considero o cubo uma anti-arquitetura, que anula todo o ambiente construído a sua volta, que reduz a paisagem e o espaço construído a graus diversos da matéria, de cheios, vazios [...]. (Ibidem, 89)

Sem título é um anti-monumento, pois não tem narrativa, além de estar em um lugar "sem afetividade" ${ }^{146}$, um "não-lugar". Fajardo parece, de alguma maneira, aproximar as ideias de paisagem e monumento. No projeto da caixa de vidro, a obra seria simples veículo para os sentidos: um lugar transparente para receber o observador. Em contrapartida, a escultura em Laguna mesmo maciça incorporou o caráter rarefeito da paisagem, a que ele se refere como anti-paisagem. Fajardo explica que emprega este termo seguindo o pensamento de Rosalind Krauss, quando a autora analisa o desenvolvimento da escultura na passagem do moderno ao pós-moderno, tecendo exclusões e intersecções entre os campos: arquitetura, escultura, nãoescultura (objeto) e paisagem.

445 Ibidem, p.80, grifo nosso.

446 Entrevista em Anexo I. 


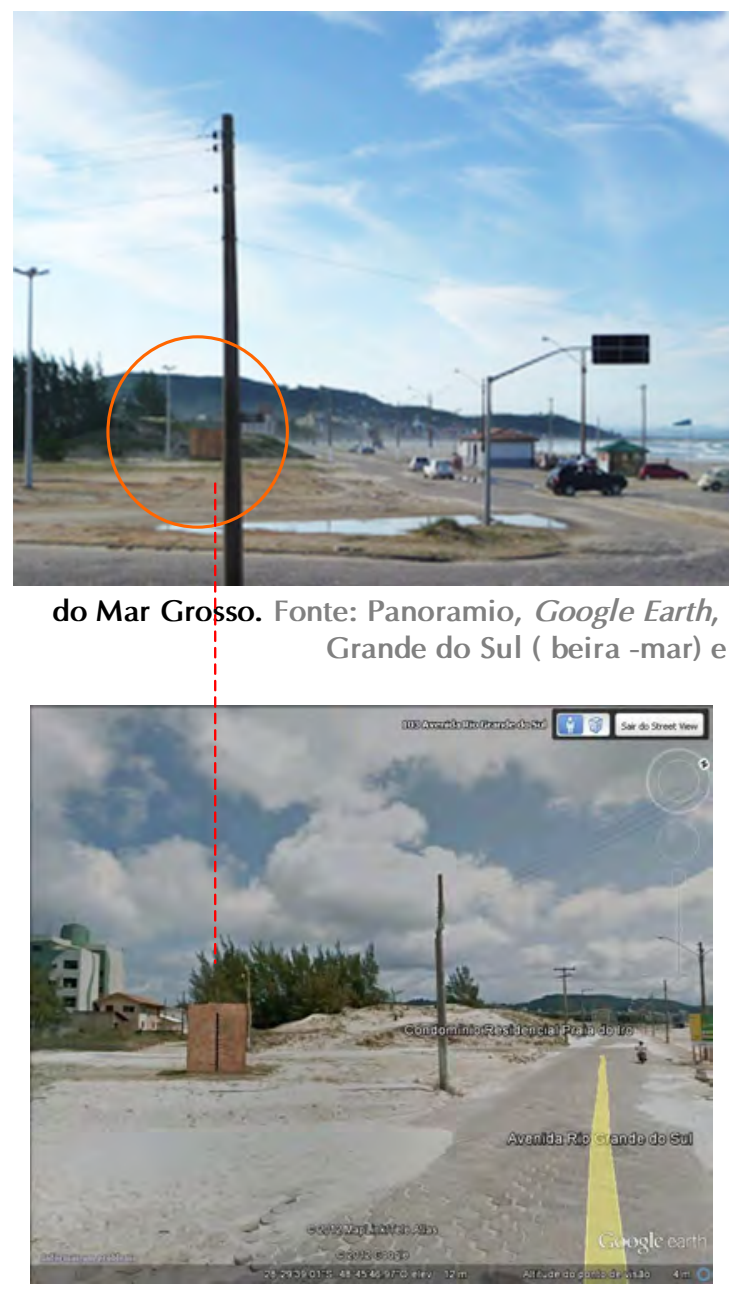

139. Carlos Fajardo, Sem título está na praia

do Mar Grosso. Fonte: Panoramio, Google Earth, de 2009. Abaixo em Goog/e Earth, vista da Av. Rio Grande do Sul ( beira -mar) e Vista Aérea, data: 30/01/2012.

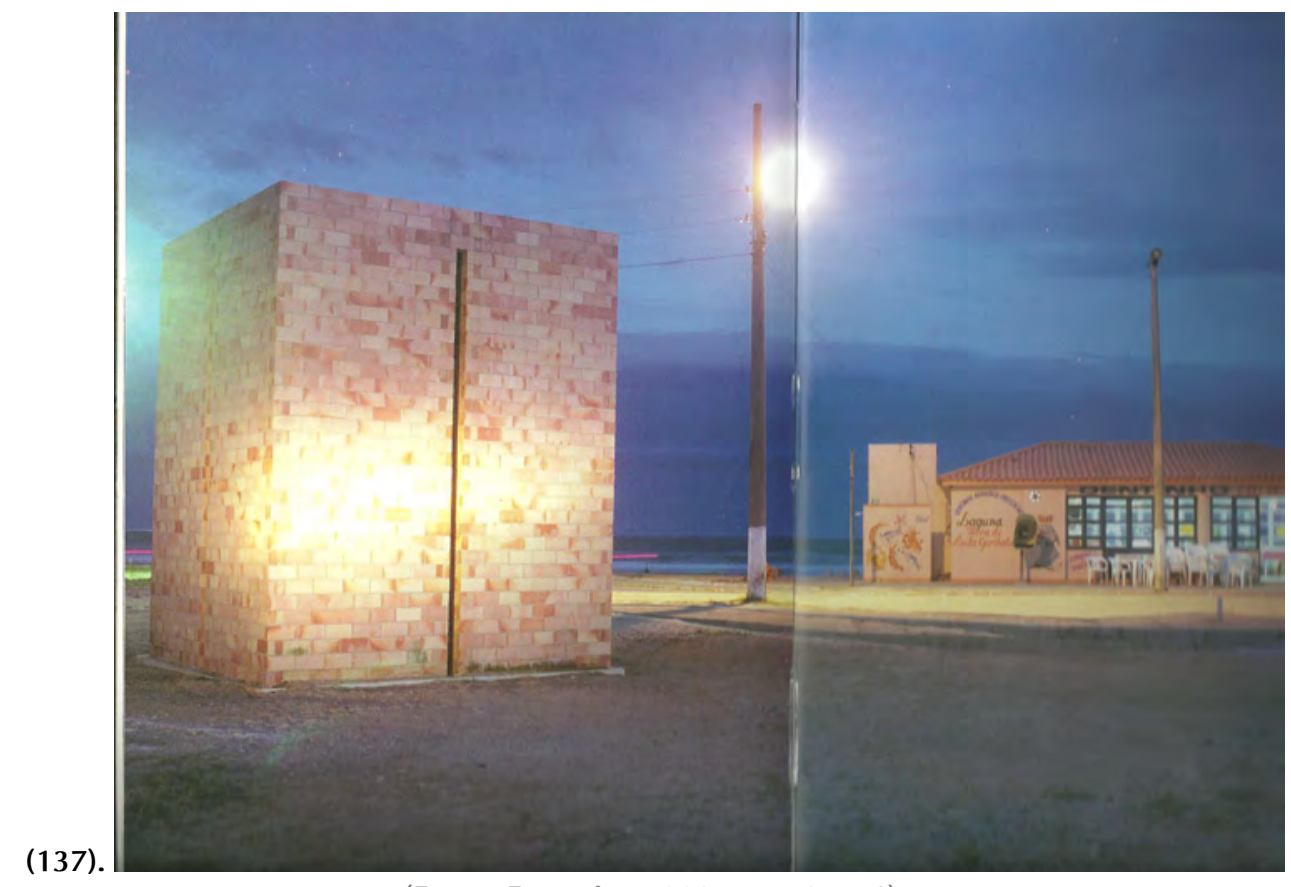

(Fonte: Fronteiras, 2005, p. 90 e 91). 
À primeira vista, Sem Título parecia ser alheia à paisagem. No entanto, quanto mais analisamos sua relação com a mesma, mais percebemos que ela se integra ao lugar e ao entorno. Estranhamente, a obra fica no limiar da vertente integração ${ }^{447}$, de Kastner, por remeter a uma construção similar a outras que, naquela paisagem, também emergem desconexas e isoladas; ou, porque a paisagem silenciosa naturalmente acolhe a obra, que não foi inserida para se "acrescentar àquele lugar como uma escultura, como um dado a priori[.... $]^{1448}$

Por se basear na repetição e ser muito simples do ponto de vista construtivo, esse trabalho é, para mim, uma espécie de avesso da arquitetura; por isso, achei que ele dialogaria bem com aquele ambiente ralo, em que predominam a distância e o vazio do horizonte. (FAJARDO, 2005, pág. 87)

Esse diluir-se na paisagem tem a ver com sua situação deslocada neste "não-lugar", onde a paisagem não se define como composição. Este não-lugar afina-se com uma característica própria dos nossos processos de ocupação urbana, que modelam tais "ambientes ralos" com elementos dispersos, em paisagens não coesas, onde a unidade visual da paisagem parece afirmar-se pela ausência de estrutura ou de significativas relações formais ou afetivas.

Sem título teria ganhado uma feição mais escultórica exatamente pelas características da paisagem local, por estar inserida na "solidão da paisagem" ${ }^{449}$, o que acabou por trazer à tona sua forma e construção, ali isoladas em uma praça pouco frequentada. Por contraste, esse entorno torna-se mais consciente de seu pouco adensamento, "como um lugar introspectivo que ultrapassa todo limite geográfico". ${ }^{450}$

A paisagem à beira-mar de Laguna é ricamente narrada pelo artista, que a descreve belíssima (em uma visão poética de sua chegada à cidade, que percorreu por três dias para escolher o lugar da obra), assim como ressalta seu aspecto vazio, sua praça pouco frequentada, como um lugar introspectivo. Vimos em suas descrições que tanto a composição - as formas visíveis - como a atmosfera e os aspectos sociais e econômicos, que igualmente "moldam" aquela a realidade, traçam relações com a obra.

\footnotetext{
447 KASTNER; WALLIS, 1998, p. 72.

448 FAJARDO, 2005, p. 93.

449 Ibidem, p.89.

450 Ibidem, p. 93.
} 
Nos projetos de cubos de vidro com isolamento acústico, podemos dizer que a paisagem em sua totalidade está na obra, ou melhor, o próprio artista diz que, nesses projetos, a obra é o lugar, havendo completa integração entre arte e paisagem.

Nessa caixa de vidro, teríamos o exercício da visão em estado máximo, emancipado das tagarelices da ação, do movimento - daí, portanto, a ideia do silêncio ... [...] Por isso, e voltando ao comentário inicial, a natureza só me interessa como um estado de coisas que já se encontra dentro do trabalho, não como lugar mítico, originário, externo ou transcendente ao trabalho... Ao contrário do que faz a arquitetura, meu trabalho não cria uma ruptura com o espaço natural [...].(FAJARDO, 2005, p.83) [grifo nosso]

$\mathrm{Na}$ obra em Laguna, a integração com a paisagem não é tão óbvia, devido às imprecisões de uma composição rarefeita e dos contrastes desta com a obra. Mas é também a totalidade da paisagem, delimitada por sua atmosfera, experiência sensível, que atribui peso e valor à escultura.

Carlos Fajardo apresenta uma abordagem sui generis em relação à paisagem, ao atentar para seus ruídos como elemento a se relacionar com a obra. Ao buscar silenciar a paisagem, ele também se refere aos repertórios de informação e de imagem que nos influenciam: às matrizes formadoras da paisagem e da nossa percepção.

Através do exemplo de Sem título, é interessante refletirmos como, e quando, as características da paisagem podem contaminar a obra - e vice-versa - em uma espécie de projeção de características do lugar e do entorno na obra. 


\subsubsection{Nuno Ramos. Minuano, 2000.}

Cinco blocos de mármore $300 \times 150 \times 150 \mathrm{~cm}$ e espelhos incrustados. Aproximadamente $5.000 \mathrm{~m}^{2}$. Barra do Quaraí, a $22 \mathrm{~km}$ de Uruguaiana, RS.

(Fronteira Brasil / Argentina / Uruguai)

No que diz respeito à questão proposta pelo C.C. Itaú, o trabalho estará de certo modo fazendo fronteira com o sol (e com as estrelas e a lua), já que deve ajustarse ao seu movimento para que a sequência de reflexos dê certo. (RAMOS, Nuno. In: Ações Prospectivas, Itaú Cultural, 2000)

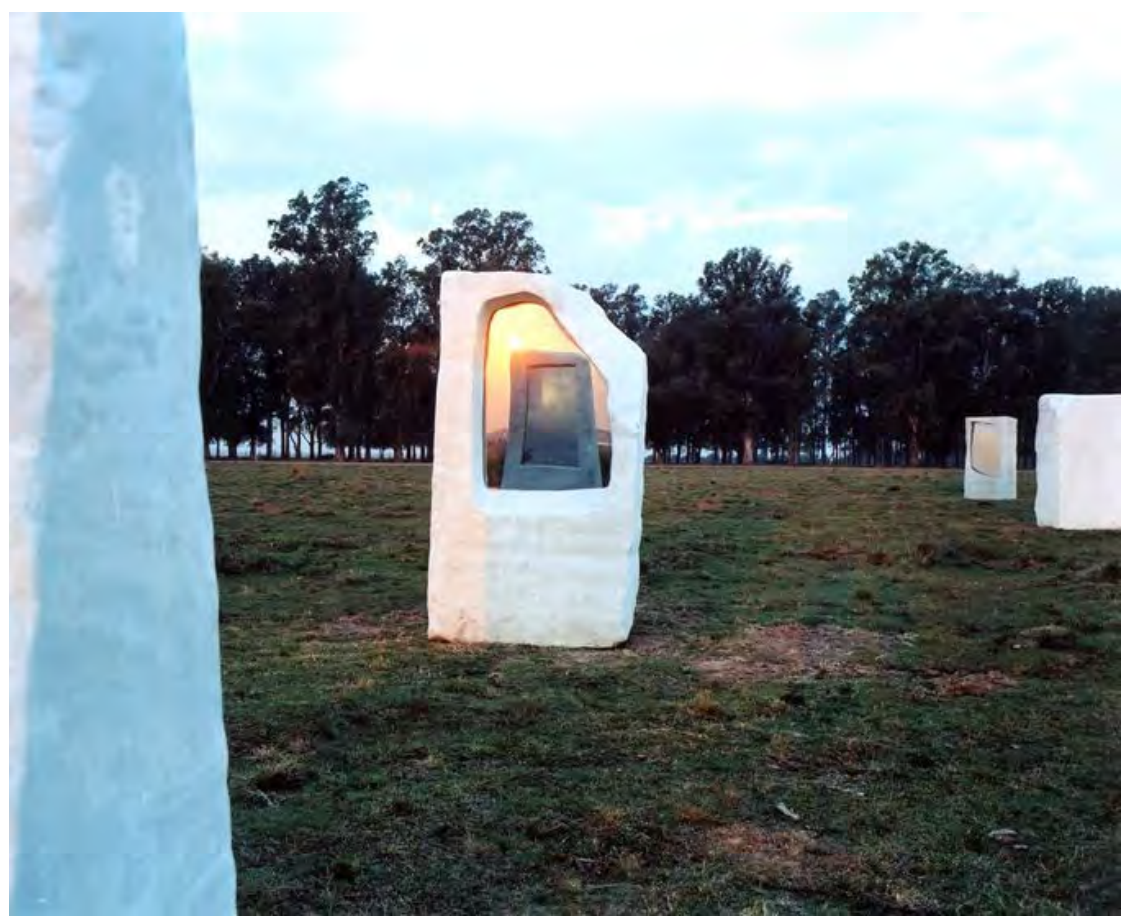

(123). Nuno Ramos. Minuano, 2000.

(Fonte: http://nunoramos.com.br/portu/comercio.asp?flg_Lingua=1\&cod_Artista=100\&cod_Serie=49).

Similarmente à obra O aleph (1999), Minuano ${ }^{451}$ (2000) remete, de certo modo, a um tempo pré-histórico ao sugerir megalitos. Estas esculturas refletem o percurso do sol e funcionam como "faróis" nas palavras do artista, que faz analogia com os espelhos usados por índios norte-americanos em filmes de bangue-bangue para trocarem sinais, que atravessavam longas distâncias.

451 Minuano é o nome popular de um vento constante nas planícies dos Pampas que sibila aos ouvidos. 
A ideia é que uma pedra lance luz sobre a outra, reflita o céu, o chão, como megalitos, monumentos mortuários pré-históricos que colhem luz e apontam para o chão, para as nuvens [...] Talvez o mais próximo do tema "fronteiras" seja essa troca de sinais entre coisas inertes e distantes. ${ }^{452}$

Como também acontece com outras obras de Fronteiras inseridas na vastidão ${ }^{453}$ de paisagens ermas, "a perder de vista", a obra tende à dualidade entre dialogar com a escala ambiental e com a escala e percepção humanas. Entre comunicar algo em uma dimensão subjetiva, envolvendo o observador em um "ambiente 'interior", assim como lançar-se em um espaço "que assoma como distância, como exterioridade irrecorrível que só se pode oferecer sob a forma de horizontes vazios e resistentes à escala humana." 454

Ao remontar a tempos pré-históricos e, por sua disposição a partir da incidência solar, a obra evidencia-nos as macroescalas da Terra e do Cosmo. Ela consegue, ao mesmo tempo, alinhar estas macroescalas com a do indivíduo em seu percurso, no qual poderia ver os reflexos, conforme sua posição diante da obra e o tempo transcorridos por seus passos. "Espero também que o trabalho consiga de alguma forma captar o circuito do sol, pois depende de sua posição para que funcione." ${ }^{455}$

A obra - assim como Mesa - está na área rural gaúcha e ocupa uma fazenda de plantação de arroz. Mas Nuno Ramos não se opôs a esta localização, ao contrário, até preferiu um terreno com estas características, uma vez que o desabitado e ermo terreno imaginado não caberia em uma "ambientação urbana", mesmo que fosse escassa, como a de Barra do Quaraí, RS. É bastante significativa tal "escolha" do artista, que claramente se opôs e questionou o sentido de ocupar o espaço público urbano - que era uma das premissas da Instituição -, nestes termos e localidades de fronteiras. "O trabalho não vai ficar num lugar público. Não há lugar público em Quaraí, só uma rua asfaltada, cheia de lojas mal-iluminadas, e duas paralelas de terra, o esgoto aberto à frente das casas [...]". ${ }^{456}$

\footnotetext{
452 RAMOS, 2005, p. 192.

453 Salzstein reporta-se à dimensão "[...] impessoal do ambiente geográfico " para descrever o pampa gaúcho, em que se insere Minuano. Há um reforço de linguagem, pois o geográfico tende ao impessoal. É interessante atentar que, não havendo a identificação de quem vê, não se emprega o termo paisagem. São recorrentes as denominações que incluem o "geográfico", parecendo indicar algo mais conceitual. Ver SALZSTEIN, 2005, p. 191

454 Ibidem.

455 RAMOS, 2005, p. 192.

456 Idem, 2007, p. 223. 
Sobre a paisagem de Barra do Quaraí, o artista descreve em Ensaio Geral (2007), ao fazer um diário da obra, o ralo desenvolvimento (ou adensamento) do município, como um lugar adormecido, disperso. Minuano, analogamente, apresenta uma dispersa composição. Os blocos de mármore com espelhos incrustados em uma das faces não criam uma forma reconhecível, como um círculo, por exemplo, parecendo dispostos sobre o terreno de maneira aleatória.

Já acerca da paisagem dos pampas, o artista frisa características como a lonjura, o "a perder de vista", o "massacrante" da planície que desperta um sentimento "modorrento" e a horizontalidade. "A paisagem aí não tem muita diferenciação, é tudo muito monótono. Era isso o que eu queria, mais um horizonte que um lugar." ${ }^{457}$

Analogamente a este horizonte, que não adentramos e que resiste como uma superfície - um plano sem profundidade ou perspectiva -, Minuano é feita de dois materiais, mármore e espelho, cuja força reside na superfície: o espelho plano que reflete superfícies e a pedra maciça, cujo interior é o mesmo da superfície. Não adentramos a paisagem onde se instalou Minuano, ela sempre se mostra plana e homogênea. Os referenciais de profundidades e volumes que habitam o imaginário de paisagem, com o equilíbrio entre refúgios e amplitudes, que lhe atribuem o repouso da visão, praticamente inexistem ali. Assim também, não "adentramos" Minuano, ao contrário, a obra rebate-nos cada vez mais para o exterior, uma pedra lançando luz sobre outra, refletindo o sol, "expandindo a paisagem" ${ }^{458}$.

Por estar em uma paisagem de composição formal monótona, de extrema horizontalidade, Ramos busca aqueles referenciais de paisagem que eram utilizados pela pintura de paisagem como primeiro ou segundo planos. Estes referenciais de planos e volumes, luz e cor, amparam nosso sentido de direção, criam profundidade e, assim, ajudam a mediar nosso contato com a natureza. "Tentarei colocar as pedras perto de algum acidente natural, um lago, um conjunto de árvores, algo que possa 'circunscrever' um pouco o trabalho, porque tudo ali é vasto demais." 459

Isto também nos fala sobre composição, implícita tanto na arte quanto na paisagem. A monotonia desta, que o artista descreve-nos, resulta da escassez de tais referenciais, ou seja,

457 RAMOS, 2005, p. 193.

458 SALZSTEIN, 2005, p. 190.

459 RAMOS, 2005, p. 192. 
podemos dizer que a escassez de elementos significativos - formais e culturais - limita a aproximação da arte com a paisagem.

Vamos percebendo que a organização dos elementos da paisagem que resulta em um projeto estético, a composição, é essencial para se "ver" uma paisagem. Este segmento da arte contemporânea - com seus elementos, materiais, formas, posicionamento - parece dar continuidade à composição da paisagem ou então tenta imprimir nela uma composição.

Retomando a questão do embate entre a escala ambiental e a humana, o artista vê Minuano em uma "escala tímida"460, em relação à paisagem vasta dos pampas gaúchos. Faz lembrar Venosa, ao comentar que mesmo suas obras de grande escala parecem "privilegiar a escala humana”. Ramos, compreendendo que esta situação é compartilhada por outras obras de Fronteiras, busca compreendê-la. "O projeto inteiro segue a escala da land art, mas pensando bem - e parece também que este é o caso de quase todos os outros -, a natureza continua resistindo firmemente." ${ }^{\$ 61}$

Imaginamos o impacto que o incomensurável da natureza, em uma "região de ostensiva indefinição formal"462, teve para o artista e teria em nós. Ramos, ao referir-se à natureza, como vimos no Capítulo 01, afina-se com a ideia de Euclides da Cunha ${ }^{463}$ de uma natureza que resiste e se impõe hostil. ${ }^{464}$

Observando as vertentes de $\operatorname{Kastner}^{465}$, esta obra estaria em interrupção, pois insere materiais e técnicas que não pertencem ao lugar. Ela também se relaciona com a paisagem por analogias: onde tudo é extenso como uma grande superfície, o mármore e os espelhos materiais que trabalham na superfície pela opacidade e pelo reflexo - reforçam a homogeneidade característica da paisagem.

460 RAMOS, 2005, p. 193.

461 Ibidem, p. 193.

462 SALZSTEIN, 2005, p. 190. Modo como autora se refere à paisagem dos pampas para explicar que a obra lidaria, "sem soluções de continuidade, com escalas e temporalidades incomensuráveis[...]".

463 É também afinado com o pensamento euclidiano, presente em À Margem da História (1909), que o artista abordará as ruínas da paisagem de Manaus para o projeto Margem (2009-2010), descrevendo-nos um lugar onde "tudo facilmente se recobre de limo", como veremos adiante.

464 É importante atentarmos que a dimensão cultural da paisagem e a divulgação da arte da paisagem, por textos críticos e imagens, são fatores essenciais que amalgamam essa natureza, que se impõe e resiste a qualquer intervenção. Algumas obras sobreviveram décadas pelas imagens difundidas e pelo simples interesse pela arte e pela paisagem.

465 KASTNER; WALLIS, 1998. 
Fato relevante, como vimos no Capítulo 1, é o referencial natural da paisagem (o circuito do sol, essencial para a obra) que o artista elege como elo entre as esculturas e a paisagem, evocando a contemplação em um tempo e espaço na escala da Terra.

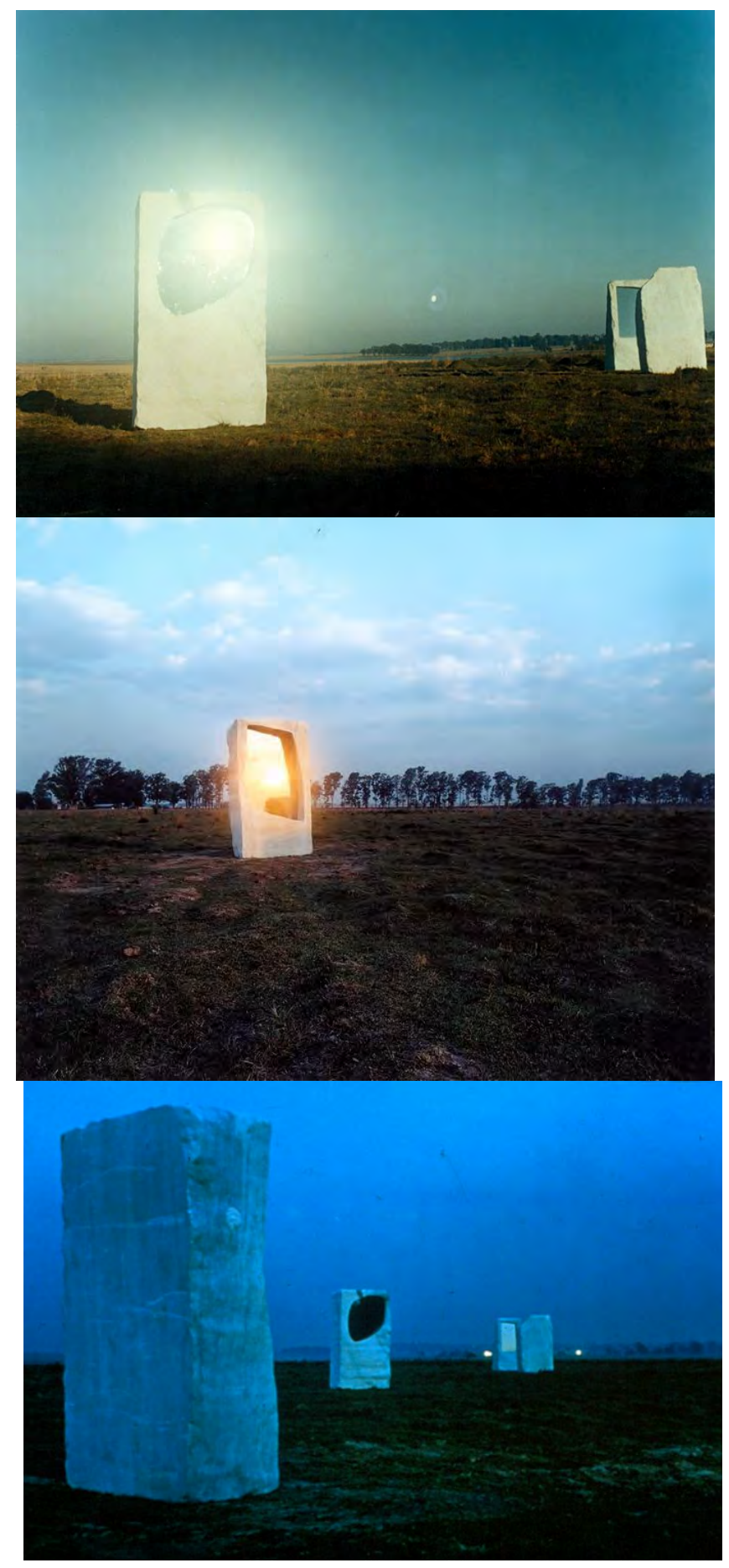

(140). Nuno Ramos. Minuano, 2000. Cinco Blocos de Mármore e espelhos, Ocupa uma área aproximada $5.000 \mathrm{~m}^{2}$. Barra do Quaraí. RS (Fonte: http://nunoramos.com.br/portu/comercio.asp?flg_Lingua=1\&cod_Artista=100\&cod_Serie=49) 
Os "faróis" de mármore no descampado formam uma imagem muito forte, que se multiplica pelos rebatimentos. Neste jogo de reflexos que cegam e atordoam em uma profundidade ilusória, pode ser observada uma alusão ao som do vento minuano que sibila e mareia os sentidos, como se em alto mar a obra buscasse a segurança da terra e da pedra.

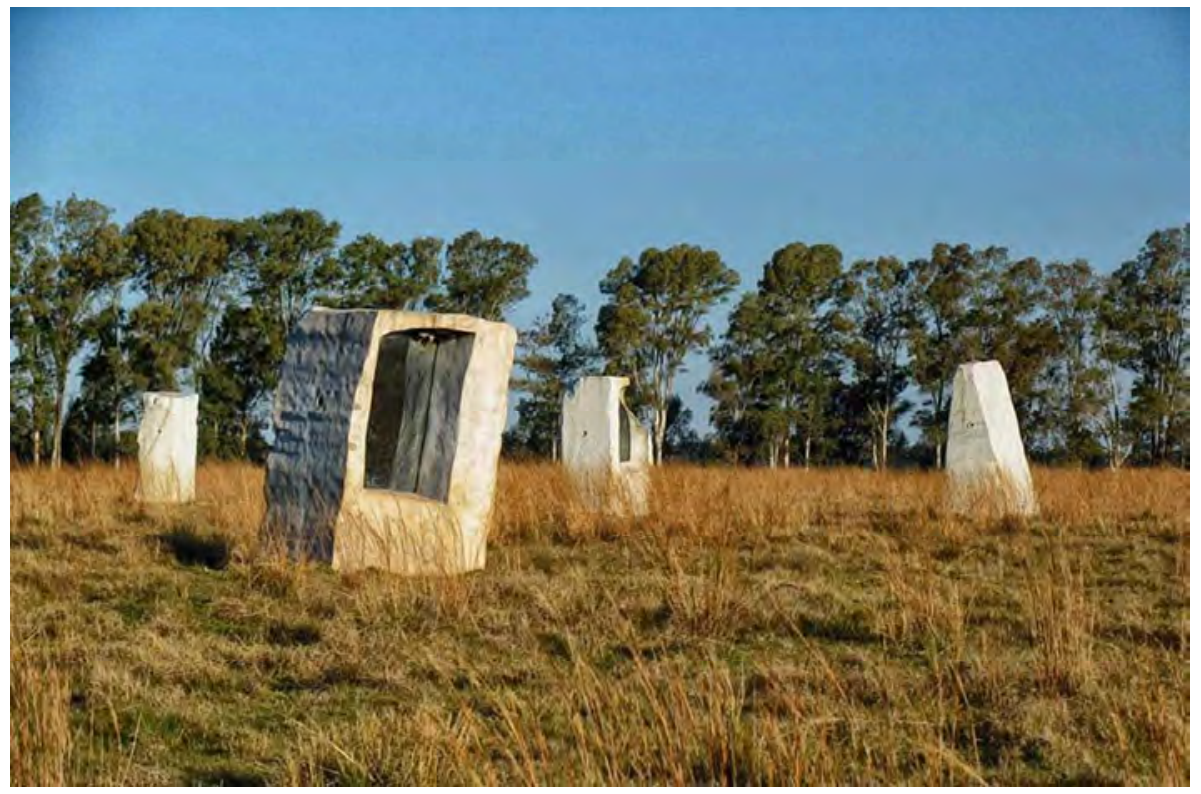

(140). Nuno Ramos, Minuano em Fotografia de José Francisco Alves, em 2010. Em levantamento in loco, ALVES (2012), No Limite: Obras Públicas na Fronteira do Rio Grande do Sul, descreve que pelas intempéries um dos blocos tombou, os outros quatro estão intactos.

Sobre sua narrativa acerca da paisagem, Nuno Ramos cita primeiramente os aspectos físicos e formais, sua composição ou sua fisionomia. No caso de Minuano, esta composição parece não apresentar coesão entre seus elementos, o que se percebe quando o artista descreve-nos: "Era isso o que eu queria: mais um horizonte que um lugar" e também quando diz que procurou por um maciço de árvores para "circunscrever" a obra no descampado, para dar-lhe referenciais de composição.

É em contraponto a esta paisagem de unidade monótona que ele busca um norte e encontra-o na ordem o no ritmo preciso do movimento solar. Também o artista explora a atmosfera da paisagem.

Não é natureza, não é pampa. É apenas um pasto. Cercas, porteiras, vacas, alamedas artificiosas de eucaliptos, barragens, sulcos encharcados por onde brota o arroz tornam aquilo um lugar, imensidão domesticada, infiltram finalidade na paisagem. Por outro lado, o sol oblíquo, a lonjura plana (o céu mais 
curvo, por contraste), algumas estranhas formações de nuvens e, principalmente, uma desproporção entre perto e longe quando algo passa por você, além do silvo constante do vento (Minuano ou Sul) e a possibilidade de ver, simultaneamente no horizonte, à esquerda o Uruguai e à direita a Argentina, tornam o pasto novamente natureza. (RAMOS, Nuno. Ensaio Geral, 2007:222)

\subsubsection{Waltércio Caldas. Momento de fronteira, 2000.}

\section{Aço inoxidável, 450x400x700cm (2000) e livro (1999) oitocentas páginas, oito exemplares.}

Itapiranga, SC. (Fronteira Brasil / Argentina)
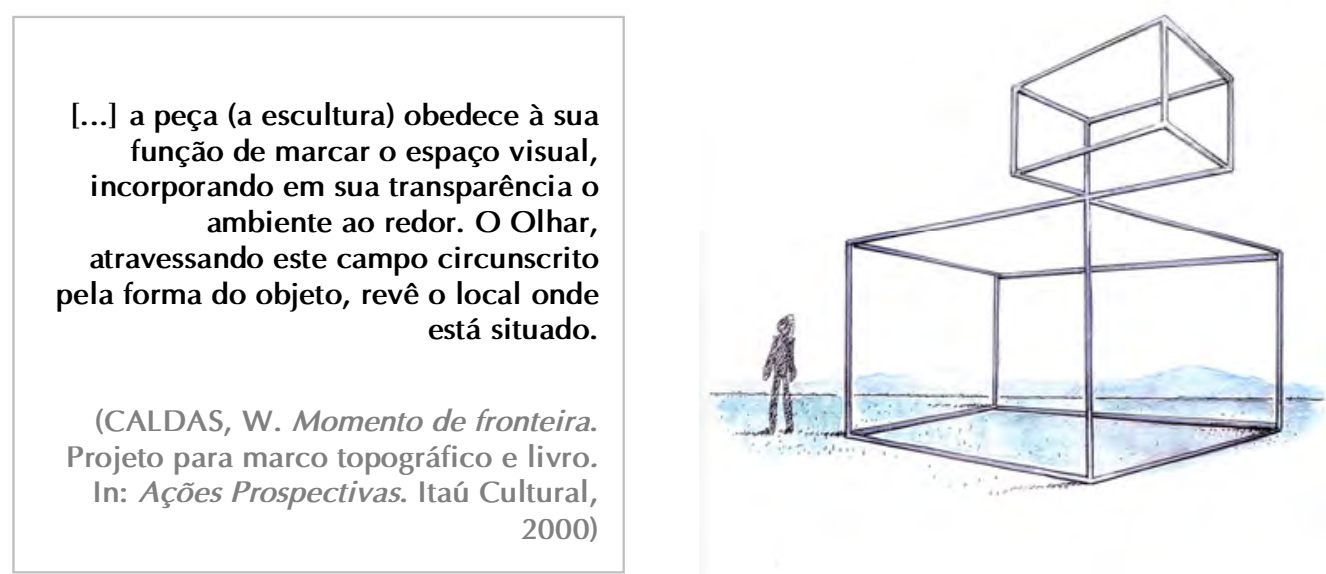

141.

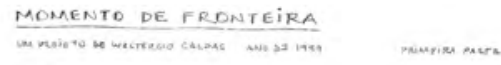

Waltércio Caldas pensou a fronteira como experiência do limite, uma relação entre tempo e espaço. Considerando que a fronteira continental brasileira é praticamente inacessível e mais conhecida "por meio de Atlas do que por experiências físicas", o artista assume esta questão para a obra, inserindo-a longe do espaço urbano.

Sobretudo, propõe uma obra que é mais uma relação entre escultura, a ideia do lugar e a representação gráfica do lugar, que um objeto em si. O artista desmaterializa a obra como objeto, tal como a "fronteira" pertence mais a um espaço mental, político, relacional. 
A escultura de cubos vazados em Itapiranga, SC, está em contiguidade ${ }^{466} \mathrm{com}$ o livro, cujos volumes recortados na espessura das páginas quadriculadas remetem ao volume cúbico da escultura. Segundo Salzstein ${ }^{467}$, há "um espelhamento imaginário de lugares". A escultura de tubos de aço lida com a imaterialidade da fronteira no espaço físico, enquanto o livro apresenta a exatidão, "a densidade corpórea" apresentada em um mapa.

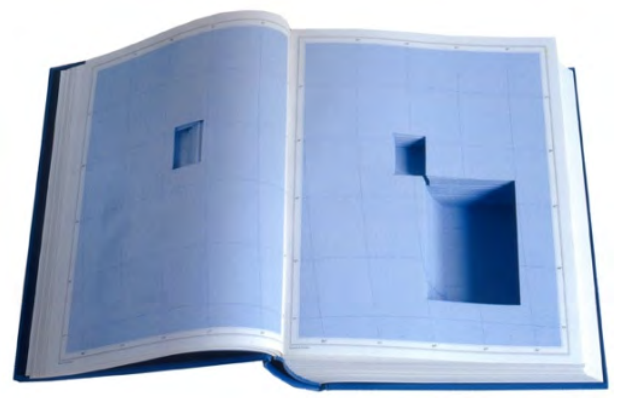

142. Livro-objeto Momento de fronteira, 1999. papel cuchê e off-set, capa couro.

Oitocentas páginas, oito exemplares. 24,5×31 cm (fechado).

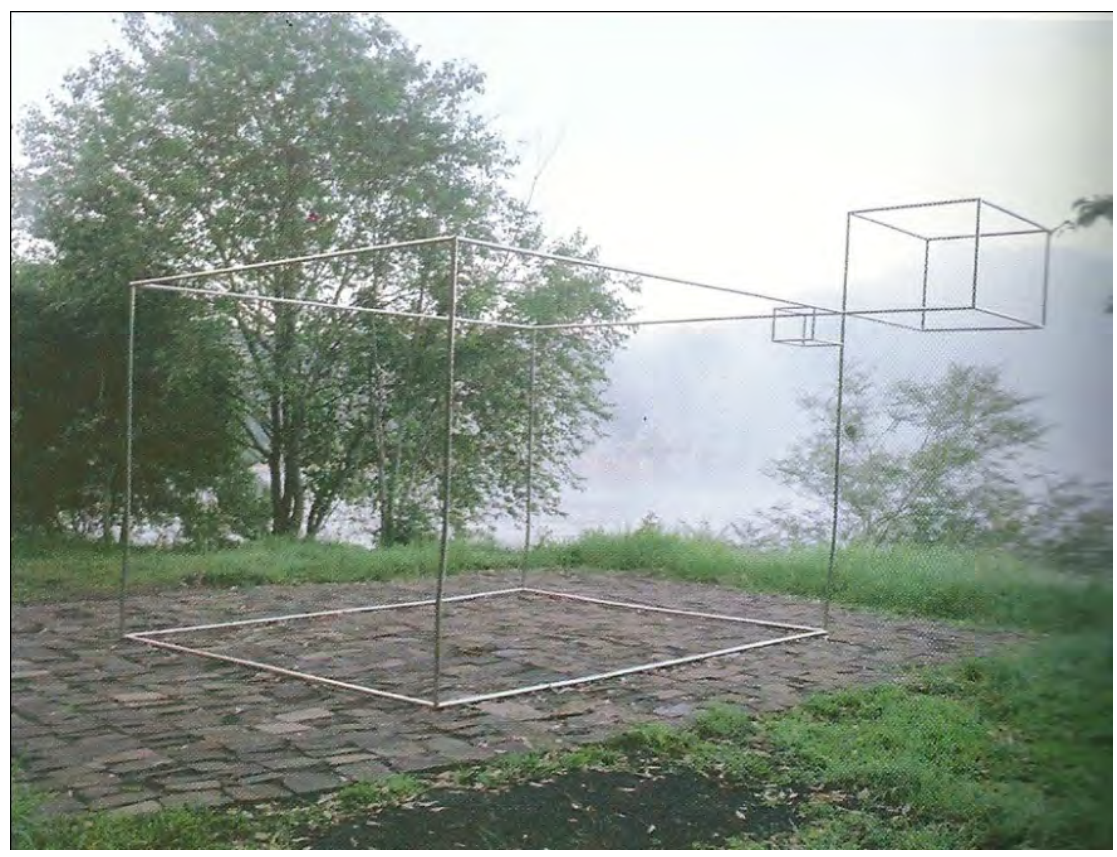

143. Waltércio Caldas. Momento de fronteira, 2000 aço inoxidável, 450×400×700cm. Itapiranga, SC.

466 Contiguidade é um termo empregado pelo artista que sintetiza a relação entre escultura e livro. "A definição de contíguo é muito bonita: quando duas fronteiras compartilham seus limites". Ver CALDAS, 2005, p. 215.

467 SALZSTEIN, 2005, p. 213. 
É necessário ter "vontade" de contemplação para contemplar. A contemplação é nesse caso, uma "atividade física" pela qual o trabalho tem alto apreço (CALDAS, Waltércio. Fronteiras, 2005, p. 222)

A obra está na fronteira com a Argentina delimitada pelo Rio Uruguai e intencionalmente dista cerca de dez quilômetros da área urbana de Itapiranga para que, segundo o artista, "os moradores não tenham de conviver diariamente com a escultura, devendo, se quiserem vê-la, tomar a atitude de se deslocar ${ }^{1468}$. Momento de fronteira está mais próxima da ideia de um objeto, pois não sugere um espaço - compreendendo-o em sua"determinação quantitativa"469, que confina, estrutura ou organiza, ao contrário, é mais a espacialidade "projetual, transitiva".

As massas sugeridas passam, então, a ser mais importantes que as linhas, a matéria transparente é mais evidente que a periferia demarcada por linhas. $\mathrm{O}$ objeto justifica a presença que ele emana. Começa a ser percebido como dotado de uma fisicalidade de outra ordem que não a do espaço positivo que preenche, mas de uma cascata de transparências. (CALDAS, 2005, p.217)

O ponto de partida para o artista era não inserir um objeto na paisagem. Pelos desdobramentos da ideia de fronteira, o fator relacional da obra ganha potência, não apenas na relação entre escultura e lugar, mas também na contiguidade entre a escultura e o livroobjeto que se elabora no espaço do pensamento, fazendo convergir o espaço físico e o cartográfico.

Assim como Nelson Félix, Waltércio Caldas alude ao espaço mental, onde projetamos e relacionamos objetos e significados. Ambos também não se referem a um "lugar", mas sim a "local"470.

Contudo, apesar de a obra desenvolver-se neste espaço abstrato relacional - entre livro e escultura -, Waltércio Caldas atenta à paisagem em sua visualidade e experiência sensível: ambas integram a obra.

O artista descreve ricamente a paisagem à beira do Rio Uruguai, ressaltando a importância do som da água que a vivifica e a força dos seus elementos naturais. A paisagem

468 CALDAS, 2005, p. 215.

469 SALZSTEIN comenta sobre o espaço ter uma positividade, que confina, separa, uma determinação quantitativa que o lugar não tem. O lugar seria projetual, transitivo. (2005, p. 216)

470 "A escultura nem sequer tem massa, ou melhor, a massa sugerida é a do local, a "quantidade de local" que ela consegue concentrar [...]." Ibidem, p. 216. 
do artista nos leva à contemplação, e equilibradamente evidencia as diferentes forças e elementos da natureza.

Chegando a uma fronteira você a contempla. É um lugar onde o olho pode darse o prazer da deriva. A fronteira, enfim, é algo como uma medida de distância para o olhar: até onde o olhar é capaz da espacialização, como na célebre fórmula "até onde a vista alcança. (CALDAS, 2005, p. 217)

O som da água que corre no local é um elemento extraordinário que se agrega a ele, sendo também paisagem. Além disso, todos os elementos dessa paisagem pulsam de maneira muito definida, e com força equivalente: o rio, o céu, a mata, todos esses elementos têm o mesmo valor. (Ibidem, p. 219)

Assim como Caldas descreve poeticamente a reverberação do visível em três elementos da paisagem - rio, céu e mata -, há na escultura três cubos que, como os elementos naturais, tangenciam-se e inscrevem-se. Diz ele: “As melhores paisagens são as paisagens recíprocas. $\mathrm{O}$ céu se ampliando com o ruído do rio, o ruído do rio se ampliando com a mata, e assim por diante; essas relações se acumulam e ampliam o panorama." ${ }^{471}$

Em meio a essas reverberações e transparências entre os elementos da paisagem que compõem-se como unidade, inserir uma escultura torna-se um desafio. Caldas não quis, portanto, a escultura como "um objeto a mais", e sim dar continuidade a essa teia de relações que já existem no local. Uma obra deveria, segundo o artista, "pertencer a esse sistema $^{4772}$ [grifo nosso] e trabalhar em conjunto com as transparências sem, contudo, representá-las.

$\mathrm{O}$ artista trabalha com a paisagem como experiência sensível. Além da visualidade que se desdobra em reflexos, ele nos diz sobre sentir a amplitude, o som, as relações entre os elementos, atribuindo à paisagem a profundidade de um espaço inatingível, como o do céu azul.

Estar "dentro" da escultura é tecer relações com o lugar e entorno, com a paisagem e sua experiência: "O trabalho quer confundir-se com o espaço que ocupa"473.

\footnotetext{
471 Ibidem, p. 219.

472 Ibidem, p. 219.

473Ibidem, p. 222. 
Waltércio Caldas elege uma paisagem plena de visibilidade e pouco vivenciada. Tratase de uma paisagem que não abarca as questões do espaço público urbano, da apropriação de usos ou questões políticas próprias de uma fronteira; mas sim, mais afinada às questões da percepção, da filosofia da paisagem e da proximidade entre paisagem e natureza.

Pelas formas de agrupamento de Kastner ${ }^{474}$, a obra estaria em interrupção, que, como vimos no Capítulo 2, não implica em oposição às características da paisagem. Ao contrário, algumas obras ressaltam, "emolduram" seus elementos naturais ou seus objetos através da inserção do artifício e de processos e materiais alheios ao lugar. No entanto, por se aproximar de uma obra conceitual - onde formulamos o sentido de fronteira e imaginamos a beleza dessa paisagem recíproca nos espaços entre livro-lugar-escultura -, ela também tem traços do grupo imaginação.

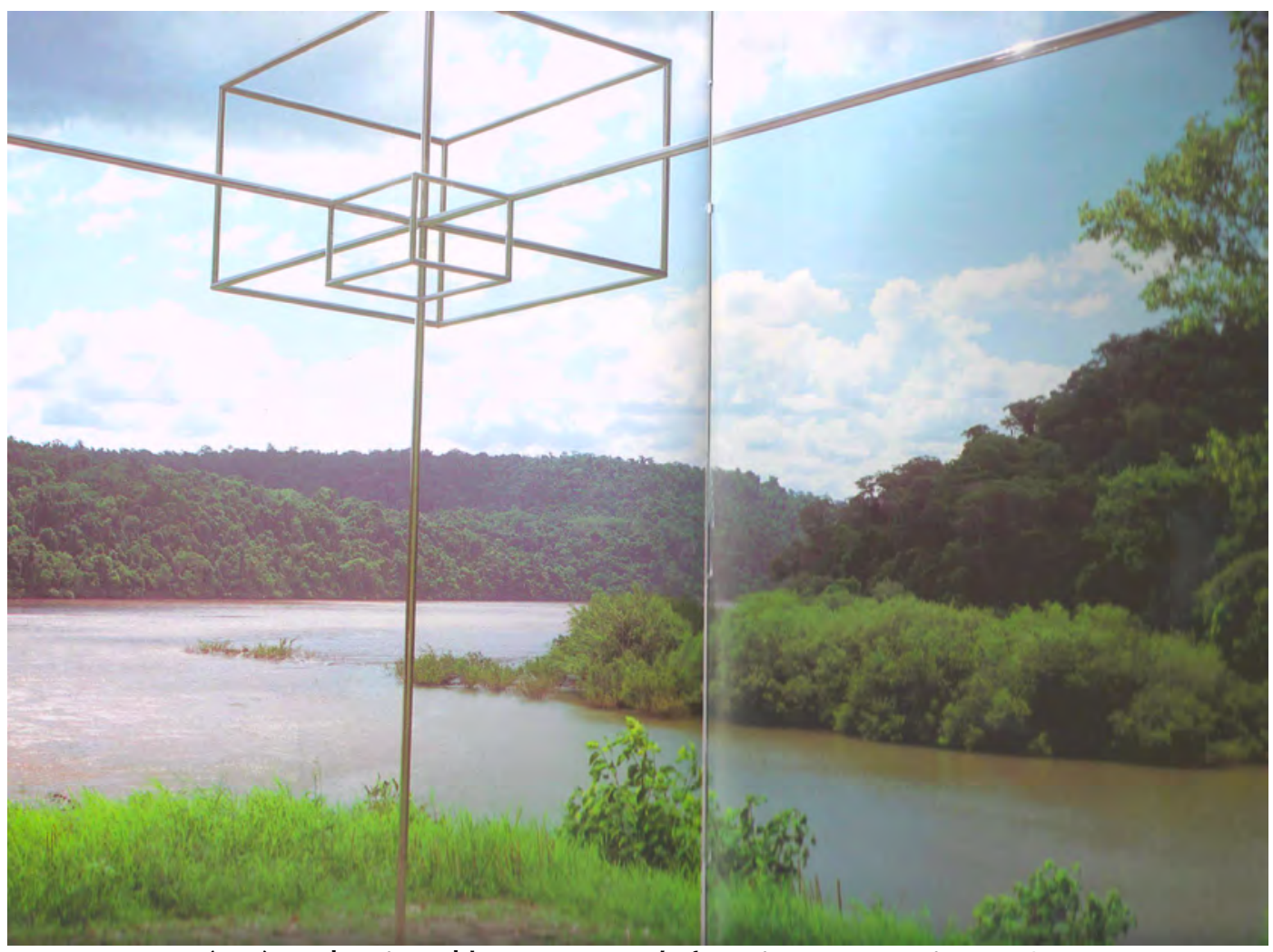

(143). Waltércio Caldas. Momento de fronteira, 2000. Itapiranga, SC.

(Fonte: Fronteiras, 2005, p. 220)

474 KASTNER; WALLIS, 1998. 
A paisagem na narrativa de Waltércio Caldas, é compreendida como totalidade, pois é incorporada pela obra, que não poderia interromper sua dinâmica, mas apenas reverberar relações já existentes. Por isso, declara ser "um desafio insinuar uma escultura nessa situação, para que ela, ao adentrar essas relações, passe a pertencer ao sistema"475.

De forma similar a Carlos Fajardo, Waltércio Caldas refere-se fortemente à paisagem fronteiriça com a Argentina demarcada pelo rio Uruguai. Ele ressalta os elementos naturais e o som que preenche aquela paisagem. Esta, que é tratada por "ambiente ao redor" ou "situação geográfica" ${ }^{476}$, é o corpo da obra, cuja apreciação estética passa pela contemplação da paisagem.

Um dado que diferencia Momento de fronteira das demais obras da exposição é que ela parece ter sido mais afortunada na escolha do lugar e entorno, resultando conforme o artista esperava.

A esse respeito a situação geográfica em Itapiranga é muito favorável. Tive a sorte de encontrar um marco de fronteira que é uma ponta de terra circundada por um rio. O trabalho está como que debruçado sobre essa ponta, e o som de água que corre no local é um elemento extraordinário que se agrega a ele, sendo também paisagem. (CALDAS, 2005, p. 217)

$\mathrm{Eu}$ quis essa fronteira bem marcada por água, e que trouxesse, de maneira evidente, a noção de passagem. É claramente uma margem. (Ibidem, p.224)

A paisagem na obra de Waltércio Caldas é predominantemente sensorial. Os elementos culturais perpassam nossos padrões de ver, enquadrar, "circunscrever o campo" de elementos naturais da paisagem que lhe atribuem poesia. Esta obra remete à transparência do cubo de vidro de Carlos Fajardo, no qual a experiência estética da obra se funde à experiência estética da paisagem.

\footnotetext{
475 CALDAS, 2005:219.
}

$476 \mathrm{O}$ primeiro termo está na documentação dos projetos dos artistas arquivados em Ações Prospectivas. Itaú Cultural; o segundo está em Fronteiras, 2005. Este último também é empregado por Sônia Salzstein, em outros momentos da entrevista. "Situação geográfica" confere um caráter de dados físicos e naturais do local, não trazendo para o mesmo sua história, seu imaginário, sua poesia, que iriam além de uma situação que é pontual. 


\title{
4.1.6 Eliane Prolik. Pálio / e II, 1996/1999.
}

\author{
Ferro e seixo branco. Aproximadamente $120 \mathrm{~m}^{2}$ e $4 \mathrm{~m}$ altura \\ Ponta Porã, MS. (Fronteira Brasil / Paraguai)
}

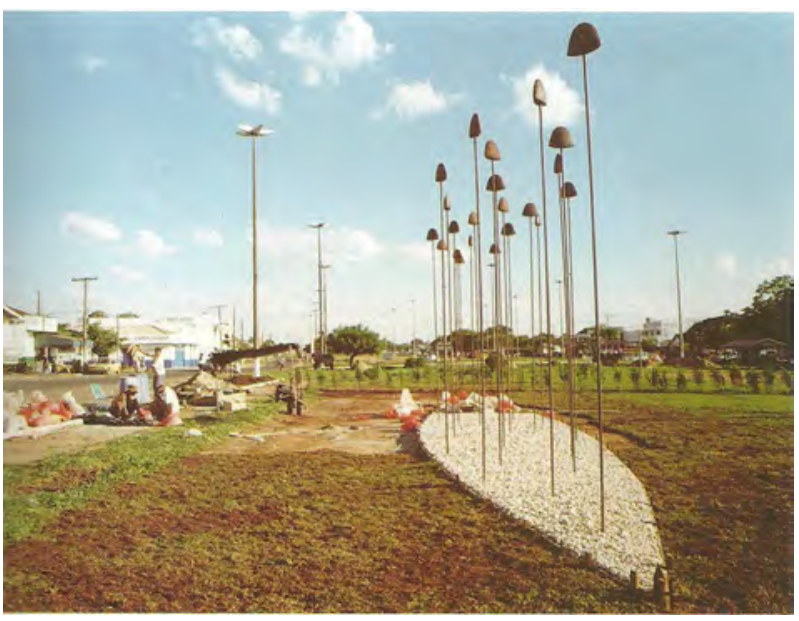

" Pálio é uma escultura pública que se divide em vários elementos executados em ferro. Ocupa área que o visitante pode entrar e percorrer a seu modo. São 60 peças de $400 \mathrm{~cm}$ de altura [...] O título da obra é uma referência a instrumentos ou ferramentas que empunhamos, como pás, e também aos vegetais que se voltam para cima em busca de energia e alimento".

144. Eliane Prolik. Pálio I, 1996-1999.

(Fonte: Fronteiras, 2005, p.137)

Pálio I e II foram instaladas no canteiro que separa as cidades de Pedro Juan Cabellero, Paraguai, e Ponta Porã, Mato Grosso do Sul, e que acompanha em extensão as avenidas Dr. Francia, do lado paraguaio, e Rua Paraguai, no lado brasileiro. As esculturas estão na parte central deste canteiro, lugar onde existem pequenos comércios, alguns usos de lazer, mas que, de um modo geral, apresenta certa informalidade nas relações e ocupações, características que instigaram a artista a desenvolver lá o seu trabalho.

A obra consiste em hastes de ferro que terminam em forma de pá e remetem ao "pálio", objeto utilizado em procissões e cortejos. Também Prolik explicou, em entrevista para esta dissertação, que as formas aludem às ferramentas agrícolas erguidas por trabalhadores do MST em uma manifestação que, em certa época, tornou-se uma imagem emblemática, difundida em jornais.

Dentre as obras de Fronteiras, é a que de fato se lançou em uma fronteira política, "viva, não rígida"477, como apresenta a artista. Prolik quis inserir sua obra no perímetro urbano, e daí a escolha pela localidade, que está na conurbação entre a cidade brasileira e a paraguaia. Em Pálio, temos a fronteira vivenciada, negociada ${ }^{478}$ - de modo subversivo até. O

477 A fronteira de o Evanescente é enfaticamente política, mas não ocupa um espaço público urbano.

478 Eliane Prolik, em entrevista para esta dissertação, dá o exemplo do cimento que, sendo mais barato no lado paraguaio, não era vendido no lado brasileiro. Como outros produtos que passavam por essa dupla 
canteiro, uma demarcação que indicaria separação, "é curiosamente vivido como uma espécie de centro pulsante, ainda que configure uma área neutra e de remanso." ${ }^{\text {479 }}$

Neste canteiro, que é mais uma zona de fronteira, Pálio adquire a latência de questões da arte no espaço público urbano e, por conseguinte, da arte da paisagem. Isto porque traz questões políticas, sociais, culturais, uma vez que se insere onde há moradores, fluxo de passantes e usos. A obra, diferentemente das outras de Fronteiras, pôs-se à prova, ao se relacionar com os aspectos culturais da paisagem.

As paisagens ao longo do rio Uruguai, à beira-mar de Laguna ou dos pampas gaúchos contam com o apelo dos elementos naturais, que são fortes o bastante para não darem a devida evidência à obra como um monumento ou como um objeto autônomo inserido. $\mathrm{Ou}$ também, a paisagem pode ser por demais vasta e "rarefeita", quanto à sua composição e a obra não transpõe a barreira de se relacionar com tamanha amplitude que aponta para o infinito da natureza.

Pálio, em contrapartida, inseriu-se em um lugar árido e tenso e, ainda, menos estético. Seu resultado também não é essencialmente estético. A escultura toca em uma paisagem desconfortável, de grandes vias de circulação, concretagens extensas, construções desalinhadas, cujas superfícies são quase sempre inacabadas - seja pela velocidade das transformações, seja pelo desnecessário acabamento. As hastes cruas de ferro parecem repetir o "desnecessário acabamento" das paisagens com fisionomias desoladas ${ }^{480}$, como bem sintetiza Salzstein.

Há um mimetismo da obra em relação àquele ambiente urbano, com os postes de iluminação, com ferros de construção civil - obras em processo -, com um ambiente aparentemente em contínua construção e esparsa ocupação; ou ainda com as "barras de ferro que suspendem painéis de propaganda"481. As hastes e suas pás, comenta a artista, mimetizavam mais a natureza, quando a obra fora exibida em São Paulo, e mais os elementos

avaliação, que "de certo modo eram corrompidos (carros, artigos importados, gasolina, produtos agrícolas e industriais, gado, etc.). Passar para o outro país significava apenas uma quadra de distância, o outro lado desse canteiro".

479 PROLIK, 2005, p.122.

480 Salzstein tece uma profunda crítica ao modelo de desenvolvimento urbano que, principalmente, a partir dos anos 1970, é acelerado pela industrialização, rodoviarismo e desmatamentos, somados à nossa pouca cultura de urbanização. Aponta que este conjunto de aspectos formam paisagens com fisionomias desoladas, descuidadas, mal planejadas. Ver SALZSTEIN, 2005, p. 126.

481 SALZSTEIN, 2005, p. 128. 
urbanos em Ponta Porã. Este é um grande indicativo da influência da paisagem sobre a leitura da obra.

Talvez este mimetismo funcione devido à transparência da obra: por entre as hastes vê-se a cidade. Esta escultura vazada, cujos intervalos são maiores que os cheios, faz relações com o entorno, criando um espaço para se adentrar; impõem-se com menos presença no lugar. Salzstein vê em Pálio, assim como em outras obras de Fronteiras, a ocupação do espaço com certa 'ambiguidade" ${ }^{482}$, assim como igualmente aponta nesta obra "um forte caráter introspectivo". E além disso, insere esta obra na mesma condição de outras esculturas em espaços públicos de cidades brasileiras: "a escultura adquire um estatuto indefinido" ${ }^{1483}$.

A escultura, então, adquire um estatuto indefinido, parece não aderir plenamente ao lugar, o que talvez seja típico das esculturas nas cidades brasileiras em geral, mas especialmente em cidades mais afastadas dos centros metropolitanos e cujo passado histórico não é significativo. (SALZSTEIN, 2005: 126)

Mas esta não é uma qualidade específica de Pálio (1996/1999), que talvez ocupe mais um espaço entre autopistas, e menos aquele que solicita o percurso em um tempo para apreciação e participação. Sem título (1993/2001) e Fronteira, Fonte, Foz (2001) também não estão em praças - compreendidas como espaços de uso social diversificado, aglutinadores, ativos -, situam-se assim como Pálio $^{484}$ em espaços públicos que são recortes do sistema viário.

A artista comenta que, ao verem a execução da obra, moradores locais, disseram: "Isso não vai durar nenhum dia" e "Isso vai estragar da noite para o dia". Demonstrando, além de um sentimento de serem "reconhecidos" por ganharem uma escultura, sobretudo descrédito na organização ou manutenção de seus espaço públicos. Eliane Prolik é, talvez, a artista que mais analisa a aproximação das pessoas com a obra em Fronteiras (2005).

482 Ibidem, pág. 133.

483 Salzstein explica que este fato pertence a uma problemática mais ampla e que perpassa outras esculturas feitas para locais públicos no Brasil, o que "decerto tem a ver com o fato de nós brasileiros não termos uma tradição constituída dessa relação com o espaço público". (Ibidem, pág. 126)

484 Existe uma falta na documentação fotográfica de Pálio / e // para o catálogo Fronteiras (2005) que trai a intenção da obra. A escultura aparece sempre ocupando quase que todo o campo de imagem e não a vemos na paisagem, de modo que se pudesse perceber como se dão tais relações da obra com o lugar espaço público ou não - a possibilidade de passantes em relação à obra, sua escala, o quanto a obra se híbrida com os elementos da cidade, ou se dilui ou causa estranhamento. 
Tal como Caldas e Fajardo, Prolik atenta para o som, como elemento da paisagem. As duas pás nas pontas da hastes formam um oco que produz som quando as hastes são movimentadas. A obra solicita a participação das pessoas. Parece que o som nas obras destes artistas, seja da torrente de águas do Rio Uruguai - cujo som profundo é experiência única -, seja o som dos ferros tilintando, seja o som das quedas d'água de Foz do Iguaçu ou de Itaipu; este parece preencher os vazios, os grandes intervalos e distâncias na paisagem.

Assim como outros artistas de Fronteiras, Eliane Prolik propôs primeiramente uma intervenção na cidade de Guaíra, PR (local que sofreu mudanças intensas com o desaparecimento do Salto das Sete Quedas, alagada pela hidrelétrica de Itaipu) onde abordaria a história de transformação daquela paisagem e a desertificação de uma cidade inteira, em suma, um projeto cuja preocupação paisagística era acentuada. Contudo, a Instituição sugeriu que se deslocasse Pálio, já exposta no Itaú Cultural em São Paulo, 1996, para esta exposição. Assim como Fajardo, Prolik adequa uma obra existente ao contexto do projeto Fronteiras.

Pálio, de maneira semelhante à obra $\boldsymbol{O}$ Aleph, pode ser adentrada: "A ideia dessa escultura é que as pessoas possam estar dentro dela, possam percorrê-la" ${ }^{145}$ e também, neste sentido, aproxima-se de Fronteira, Fonte, Foz, um trabalho "para ser pisado", para ser utilizado, incorporado aos caminhos e usos da cidade.

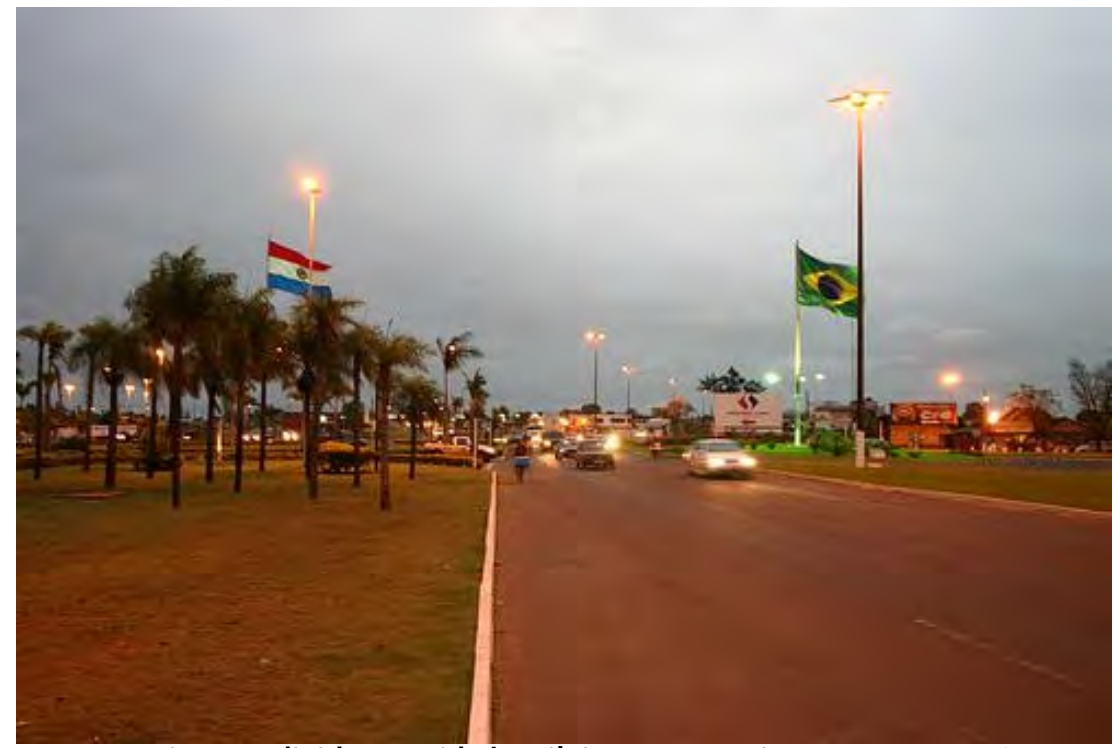

145. Canteiro que divide Avenida brasileira e paraguaia. Ponta Porã, MS, 2012. (Fonte: http://mochileiro.tur.br/ponta-pora.htm. Data 05/05/2012).

485 Prolik, 2005, p. 121 


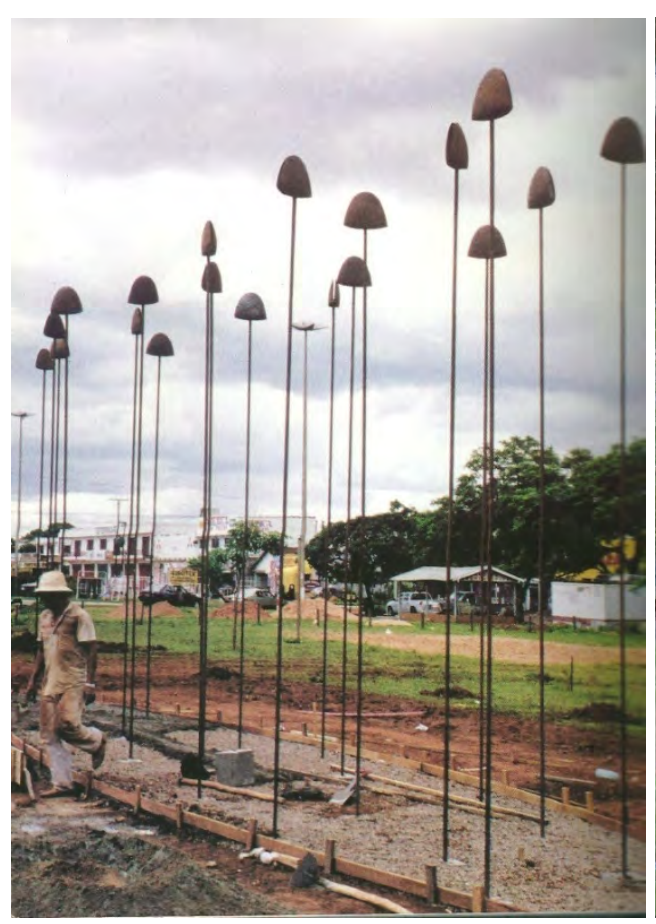

146 e 147. Eliane Prolik. Pálio I, 1996/1999

Ferro e seixo branco, $60 \mathrm{~m} 2$

(Fonte: Fronteiras, 2005, p. 132 e 129)

Achei interessante abordar a questão de fronteira em que os limites de marcos são rompidos o tempo todo. (PROLIK, in Fronteiras, 2005, p. 121)

Seguindo os agrupamentos de Kastner ${ }^{486}$ - que se diferenciam pelo modo como a obra abarca a paisagem - podemos dizer que Pálio está na vertente integração. A obra vale-se dos materiais, objetos e ações da paisagem. Embora nesta vertente o autor refira-se à obras que manipulam os elementos naturais da paisagem, para o estudo das obras brasileiras, incluo também aquelas que manipulam, rearranjam e agem sobre os objetos - de quaisquer natureza - existentes na paisagem. ${ }^{487}$

Pálio difere radicalmente de outras obras de Prolik em espaços públicos urbanos, como Cantos, que são "esculturas-receptáculos", que agem como interrupções na paisagem e fazem as vezes de refúgios, de delimitações na amplitude da paisagem. Dentro de Cantos que veremos adiante -, o observador volta-se para sua própria escala, para uma pausa. Pálio, ao contrário, é continuidade, é passagem em meio à paisagem de fronteira de Ponta-Porã.

486 KASTNER; WALLIS, 1998.

487 Uma vez a paisagem na arte contemporânea brasileira está recorrentemente dentro dos limites do urbano. 
Podemos analisá-la tecendo analogias com os usos sociais e urbanos daquela paisagem, como as hastes se mimetizando com as armações de ferro de construções, como ferramentas ou elemento específico de manifestação religiosa. A obra não pretende evocar no indivíduo a contemplação da paisagem, como a maioria das obras de Fronteiras. Ela se insere refletindo e investigando sobre as possibilidades do lugar.

"Continuo acreditando que a escultura contemporânea tem de inventar o seu lugar. Essa experiência que tivemos no projeto Fronteiras incita uma constelação de problemas para os quais nosso meio ainda precisa amadurecer". ${ }^{488}$

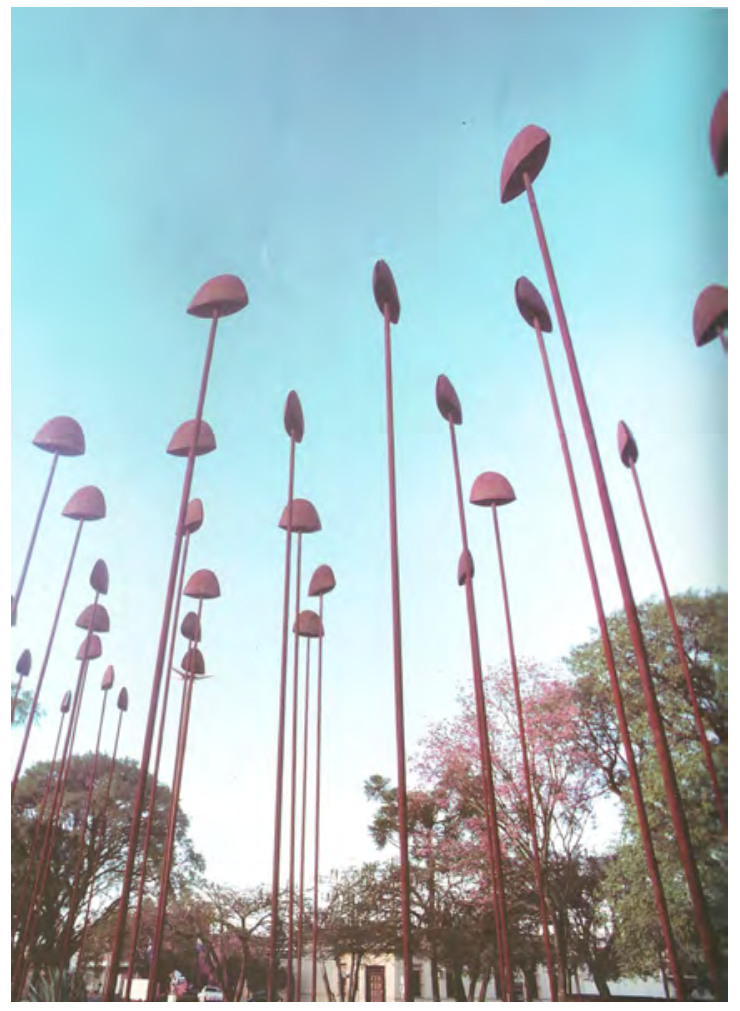

(147). Eliane Prolik. Pálio II.

(Fonte: Fronteiras, 2005, p. 120)

A paisagem na narrativa de Eliane Prolik aparece como cenário, ou natureza: " $O$ trabalho se chama Pálio e um de seus traços fortes é a demanda constante de convivência humana; ele não se contenta em relacionar-se apenas com a paisagem [...]."489

Mas, de fato, a escultura abarca o lugar e o entorno além da condição de cenário, pois a artista ateve-se aos aspectos culturais da paisagem, uma vez que elegeu uma paisagem vivenciada para investigar de que maneiras a área de remanso era utilizada, quais eram suas trocas e os percursos ali possíveis.

488 PROLIK, 2005, p. 138.

489 Ibidem, p. 122. 
Ao buscar lugares em Ponta Porã para implantar Pálio, a artista negou uma pracinha junto à Biblioteca Municipal (sugerida pela Prefeitura), interessando-se por um canteiro em uma área exatamente na fronteira entre Brasil e Paraguai. Lá existem pequenos comércios, áreas para prática de esportes e, ao mesmo tempo, é depósito de lixo e apresenta um descuidado paisagismo. Tais usos informais e a dinâmica social da paisagem chamaram a atenção da artista pois concorreram para desfazer a "ideia fixa e formal de fronteira".

Prolik não comenta sobre a atmosfera da paisagem, como essa totalidade de essência estética. Também não descreve poeticamente seus elementos naturais ou seus objetos. Talvez como exceção, a obra atentou mais para a paisagem factual, na busca por vestígios de práticas sociais que sucessivamente, ocupam e transformam a paisagem, e menos na apreensão subjetiva que esta nos causa.

\subsubsection{Carmela Gross. Fronteira, Fonte, Foz, 2001.}

Aproximadamente $1.600 \mathrm{~m}^{2}$, mosaico português.

Laguna SC.

148. Desenho de Carmela Gross

(In: Ações

Prospectivas. Projeto

Fronteiras. Itaú

Cultural, 2000).
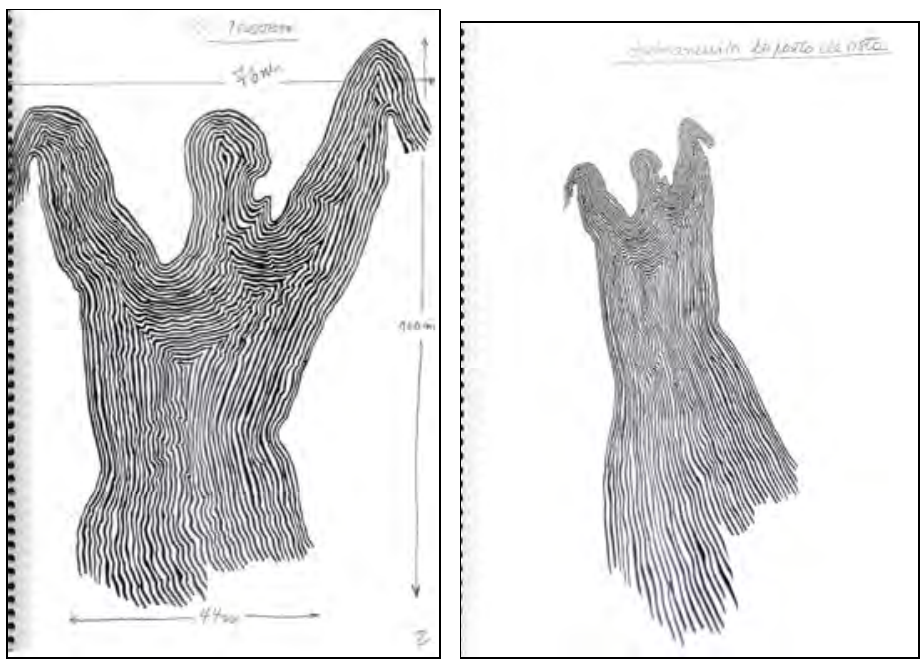
Os desenhos para o Projeto Fronteiras são possíveis configurações para uma grande praça a ser construída em uma área urbana na fronteira do Brasil com Paraguai, Uruguai ou Argentina [...] Como o terreno não foi ainda determinado, poderão ocorrer modificações quanto à escala e à topografia: a forma básica poderá ser alongada ou estreitada [...] as linhas do desenho poderão ser vistas, em certas áreas, como degraus. (GROSS, Carmela. Dados do Projeto. In: Ações Prospectivas, Itaú Cultural, 2000)

Fronteira, Fonte, Foz (2001) é uma praça de calçamento em mosaico português branco e preto, formando linhas orgânicas, em uma avenida à beira-mar em Laguna. Carmela Gross tinha primeiramente como intenção um desenho no piso, que não se sobrepusesse à paisagem da cidade, a princípio percebida como "uma paisagem estrangeira", com a qual ela não tinha familiaridade. Depois, o trabalho encaminhou-se para a ideia de praça.

Sobre esta paisagem, a artista chama a atenção para os elementos físicos e naturais, como a presença imperativa do mar e da linha do horizonte, o encontro entre a laguna e o mar; assim como para a atmosfera indicada pela indeterminação, vastidão, o caráter pouco denso e a situação de passagem. "[...] sua paisagem é dominada pela água, pela relação com esse horizonte impalpável que marca o encontro do mar com a laguna propriamente dita."490

Duas considerações da artista indicam que a obra atenta para as características formais e culturais da paisagem. A primeira está no fato do desenho no piso ter sido proposto como "um risco humano, estendendo-se em uma linha de continuidade com a paisagem ${ }^{491 ", ~ p a r a ~ s e ~}$ integrar e não se impor a ela como"um anteparo". A segunda na explicação de que a obra "seria um lugar de pisar, de andar, no qual poderiam acontecer coisas ligadas às pessoas da cidade. ${ }^{492}$

Se podemos traçar analogias entre as linhas tênues e amorfas desta paisagem e sua horizontalidade com o desenho e o plano de Fronteira, Fonte, Foz, devemos também ressaltar que o interesse de Carmela Gross não reside na paisagem ${ }^{493}$, mas nos espaços públicos e no uso social do espaço - em específico, da praça. No entanto, ao compreendermos a natureza destes espaços - como são apropriados -, nos é revelado sobre a produção da paisagem, que

\footnotetext{
490 GROSS, 2005, p. 111.

491 Ibidem, p. 102, grifo nosso.

492 Ibidem, p. 102.

493 Veremos no Anexo I (entrevistas) que Carmela Gross relaciona a arte com o fenômeno urbano. Para ela, assim como para outros artistas contemporâneos, a "paisagem" parece vir revestida de seu histórico de pintura da natureza, que encobria discursos exploratórios ou ainda aludindo a uma dádiva, um souvenir, nos termos da artista. Também já vimos tal idéia exposta no Cap. 01, pág. 39.
} 
se constitui de lugares e seus significados; de dinâmicas sociais que constroem e transformam o espaço, além da natureza que em conjunto qualifica tais lugares.
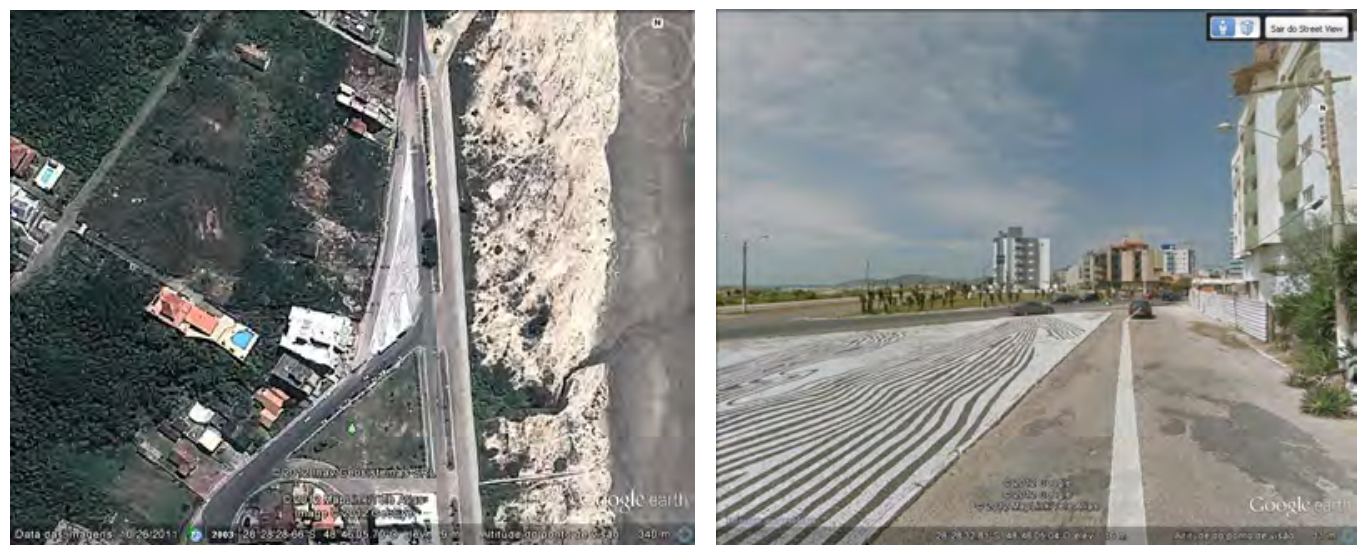

149. Vista aérea, em 2009, e situação da obra no lugar, em 30/01/2012. Goog/e Earth. (Acesso em: 20/12/12).

150. Carmela Gross. Fronteira, Fonte, Foz. 2001. Laguna SC.

Aproximadamente 1.600 $\mathrm{m}^{2}$, mosaico português.

(Fonte imagem: Fronteiras, 2005, p. 98)

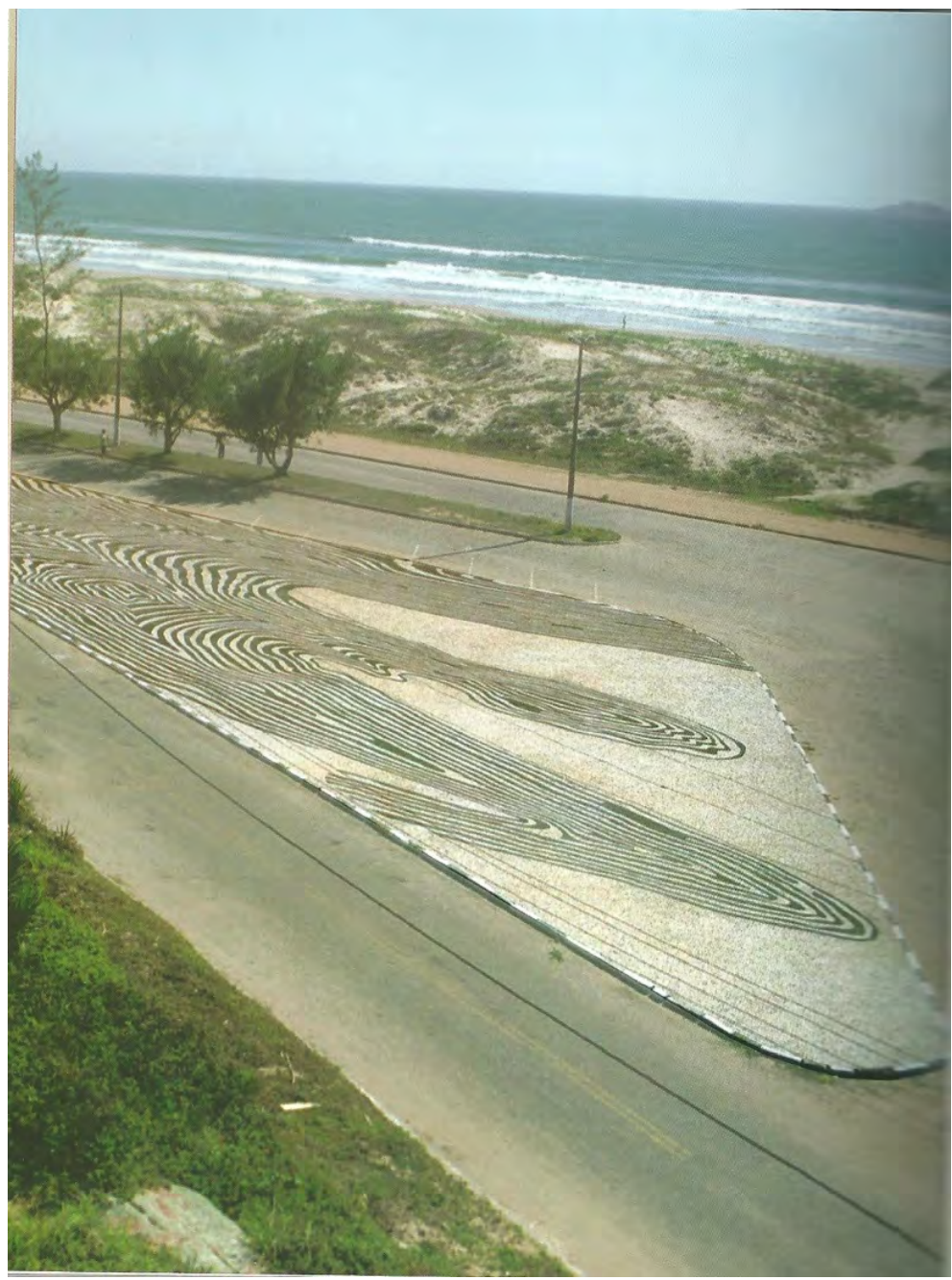


Fator determinante é que não lhe interessava trabalhar fora do contexto urbano. Primeiramente, a artista estudou intervir no município de Dionísio Cerqueira, SC, fronteira com a Argentina, em uma praça "localizada numa situação meio indefinida, deslocada do contexto da cidade. Não se situava no centro, não acolhia uma igreja, não era enfim, um ponto de adensamento e irradiação do ambiente urbano, mas, sobretudo um lugar de passagem." ${ }^{494}$ Nesta praça, viriam à tona questões sobre a passagem, a distância, a extensão, com as quais a artista queria trabalhar. Por impedimentos operacionais, foi-lhe sugerido intervir em Laguna onde, então, escolheu um lugar cujas características da paisagem adequaram-se às questões conceituais de sua investigação artística.

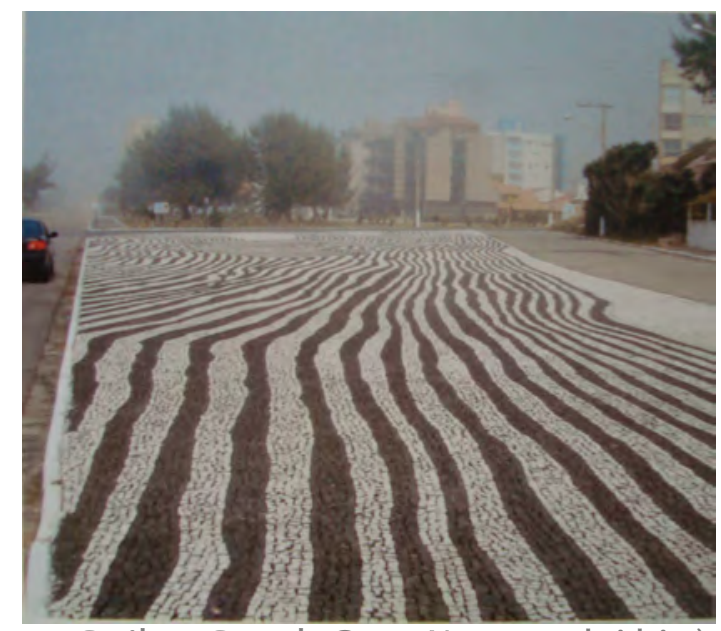

(150). (Fonte: Catálogo Carmela Gross. Um corpo de ideias).

Se por um lado Fronteira, Fonte, Foz parece configurar-se a partir de características do entorno - como a linha tênue do horizonte entre céu e mar, a linha cambiante das dunas e das ondas do mar, ou da areia que avança continuamente sobre o calçamento -, ao mesmo tempo, a obra independente do entorno desta "praça", permanece coesa com a poética de outras de suas obras. Em entrevista para esta dissertação, ela explica que não foram estes elementos físicos e naturais da paisagem que inspiraram o desenho. Seu ponto de partida está no próprio desenho, em suas representações e na possibilidade de se hibridar ao uso urbano, sendo a intenção da obra ser apropriada pelas pessoas. A figura que aparece no piso é a distorção de uma imagem da pintura renascentista de Piero della Francesca (1415-1492), enquanto a obra, como uma praça, pondera sobre os percursos, encontros e usos do espaço urbano:

494 Ibidem, p. 107. 
Sabemos que no Renascimento o traçado das praças surgia de uma medida precisa, baseada no caminhar das pessoas; era o caminhar das pessoas que determinava a escala das praças renascentistas. Eu pensei muito nisso, e nesse trabalho quis interrogar o tipo de caminhar que, contemporaneamente, é possível em uma praça. (Carmela Gross, 2005:107) [grifo nosso]

Sobre esta praça na paisagem à beira-mar de Laguna, observa:

O que poderia ser uma praça nessa situação que induz à experiência da distância, o olhar de longe? Que espaço vazio é esse? É possível nele o encontro? Não sei. Cheguei a um caminhar redobrado sobre si mesmo, sem fixidez, sem culminações. ${ }^{495}$ (Ibidem)

Coexistem fortemente em Fronteira, Fonte, Foz a potência do desenho que se impõe como um ponto focal na paisagem à beira-mar, onde predominam as distâncias, a linha do horizonte e o mar, assim como uma abertura ou não delimitação da obra que é transpassada pela paisagem, traçando analogias a ela. Esta ambiguidade entre ser continuidade na paisagem e seu não enraizamento na mesma apontam para o fato de que a "praça" é tanto lugar de passagem e dispersão, quanto convergência do nosso olhar e estranhamento.

Por esta característica dual, Salzsteinobserva que a obra parece lançar o observador a um "cíclico ir-e-vir" alternadamente "ao campo mental do desenho e à percepção da fenomenologia da paisagem." 496

Salzstein também chama a atenção para certas características do trabalho de Carmela Gross. Uma delas é "intervir em uma dimensão linguística"497 e, portanto, conceitual. Já o título da obra revela sentidos para a leitura do desenho, remete à água que brota da terra: " [...]é um híbrido entre água e terra, entre fixidez e mobilidade, entre paisagem e desenho." ${ }^{498}$ O desenho, por sinal, é descrito por Carmela Gross como "um acontecimento físico". Outra característica marcante nas obras públicas da artista é destas poderem ser utilizadas como equipamentos urbanos. ${ }^{499}$ Gross apresenta a essência de Fronteira, Fonte, Foz:

\footnotetext{
495 Ibidem.

496 SALZSTEIN, 2005, p. 100.

497 Ibidem, p. 99.

498 GROSS, 2005, p. 102, grifo nosso.

499 Exemplos de obras como equipamentos urbanos ou projetos paisagísticos são: Cascata (2005), apresentada no Capítulo 2, um misto de escultura e arquibancada em área de lazer; BleuJauneRougeRouge (2004), projeto de intervenção em uma escola com pinturas no piso e módulos coloridos na fachada; Carne (2006), na qual um ônibus-instalação, todo vermelho, circulava com as pessoas. Sobre esta obra, assim como as demais da categoria pública, serve o que a artista explica: "Não quero em nenhum momento fazer uma obra que exija do público uma posição contemplativa". Ver
} 
"O trabalho teria de participar de algum modo da vida das pessoas da cidade, diluindo-se nela." ${ }^{500}$

A artista comenta que seu interesse em participar do projeto Fronteiras estava em poder trabalhar com o uso social do espaço, especificamente com uma praça (proposta sua mesmo antes de definir o lugar da obra). Então ela encaminha uma carta à Instituição ${ }^{501}$ apresentando suas expectativas e críticas ao projeto Fronteiras, e explicando que seu modo de pensar a arte pouco tem a ver com uma obra como "marco da praça pública" ou simples objeto inserido, alheio ao contexto. Seu trabalho deveria relacionar-se com as características físicas, sociais e culturais do lugar, fazer sentido, divergindo de um projeto que mapeia o território e aborda a "ocupação". A artista critica a ênfase no espaço geográfico presente na abordagem do projeto e afina-se com questões do lugar, acabando por aproximar sua arte com a paisagem ao investigar um lugar significativo.

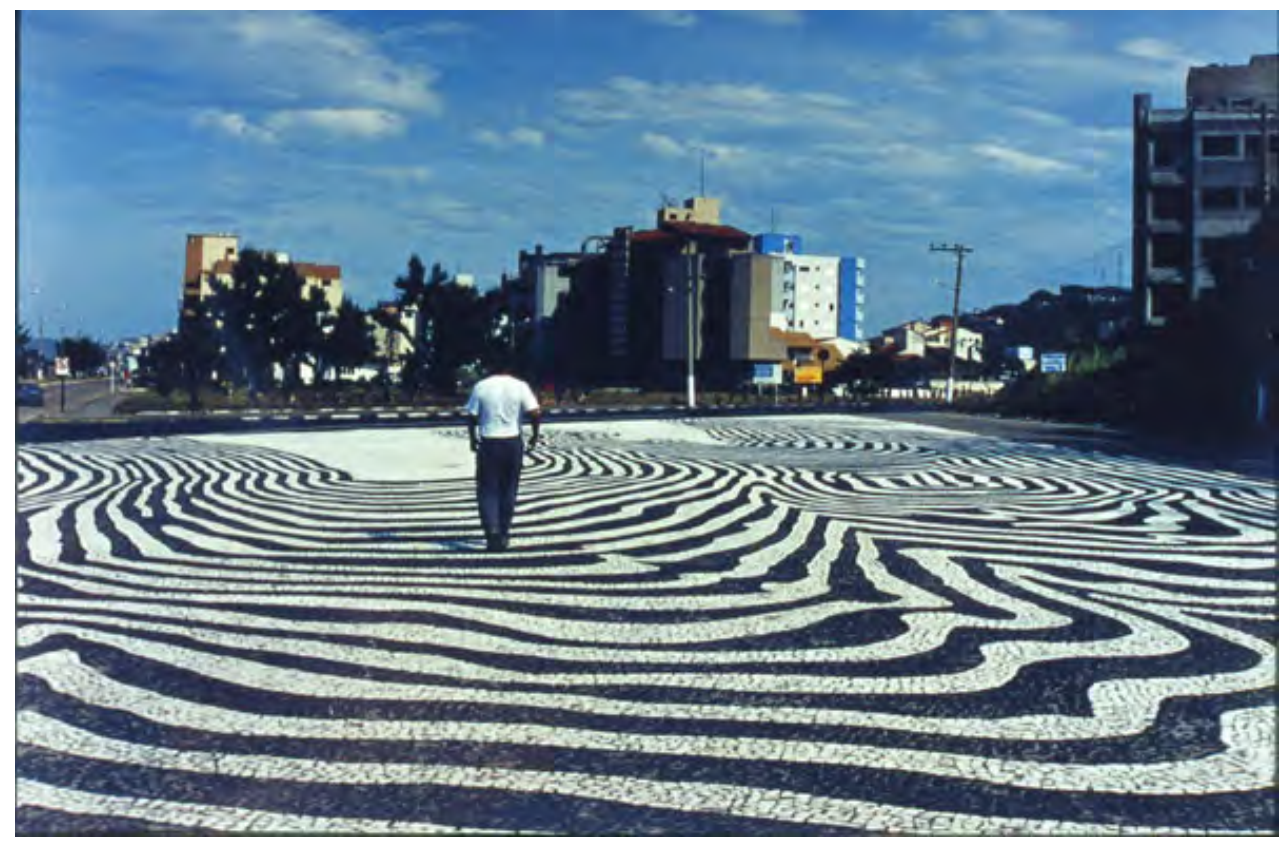

(150). Carmela Gross. Fronteira, Fonte, Foz, 2001. Laguna. SC

(Fonte: www.carmelagross.com.br)

Não nos passa despercebida a escolha do mosaico português que, em avenidas à beiramar remete ao paisagismo de áreas públicas, das praças secas ao calçadão de Copacabana de

LONGMAN, Gabriela. Carmela Gross prepara obra que "pede passagem". Folha de São Paulo, São Paulo, 23 fev. 2006. Caderno Ilustrada. Entrevista com a artista Carmela Gross. Disponível em: <http://www1.folha.uol.com.br/fsp/ilustrad/fq2302200626.htm>. Acesso em: 15/01/2013

500 GROSS, 2005, p. 102, grifo nosso.

501 A carta é apresentada na entrevista. Ver Anexo I. 
Burle Marx. Contudo, segundo a artista, a escolha deste revestimento deu-se principalmente por questões técnicas do assentamento e não por referências simbólicas.

Carmela Gross afirmou em entrevista que a paisagem não lhe referência, e frisou que a arte é essencialmente urbana ${ }^{502}$. No entanto, são muito significativos seus dizeres na apresentação do seu projeto para Fronteiras, propondo uma obra que se caracterizasse:

por uma interferência na paisagem urbana, passa pela ideia de hibridação entre homem, o animal, o relevo da terra, o fluxo das águas, ao mesmo tempo fonte e foz. O material escolhido - a pedra justaposta como mosaico - reconstitui o trabalho sistemático e repetitivo que está na origem remota do traço do homem na natureza. (GROSS, Carmela. In: Ações Prospectivas, Itaú Cultural, 2000.)

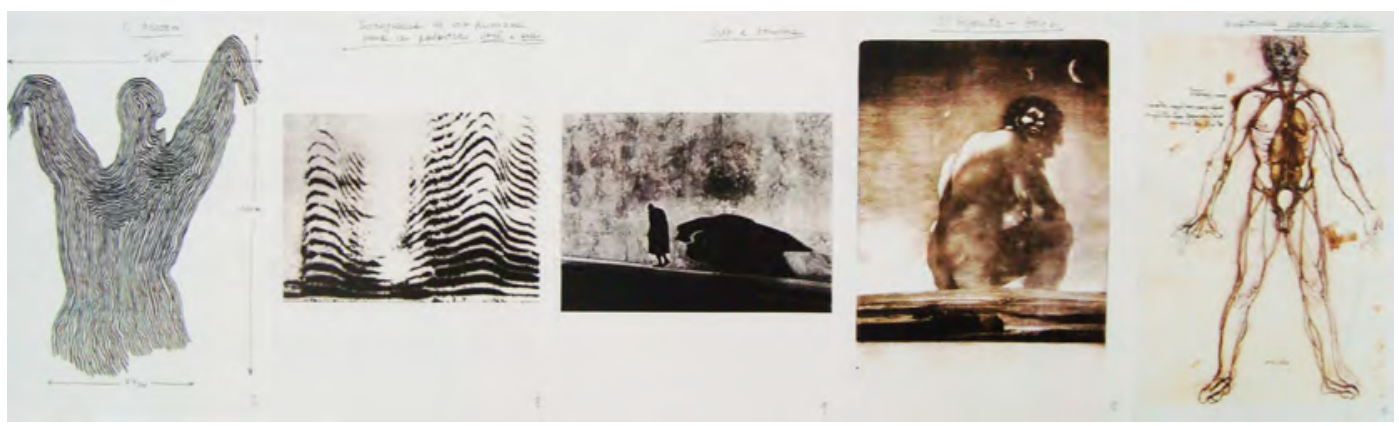

151. Carmela Gross, Estudos para Fronteira, Fonte, Foz

(Fonte: Catálogo Carmela Gross. Um corpo de ideias. Projeto. Sonograma da voz humana para as palavras você e sim. Luz e sombra. O Gigante - Goya. Anatomia Leonardo da Vinci).

Igualmente relevante é o fato de Carmela Gross ter escrito à Instituição que "precisava respirar a 'paisagem' pelo lado de dentro, possuí-la e deixar-se possuir por ela" ${ }^{2503}$. Além de afirmar que a arte deveria relacionar-se com o lugar, entorno e entrelaçar-se aos sentidos humanos e usos sociais: "a escala, o lugar, sua materialidade e resoluções técnicas formam um único bloco poético". Para a artista, não há como pensar arte sem atrelá-la às "trocas pessoais, sentidos e sentimentos humanos", "suas vizinhanças, entornos e sombras, que serão componentes indissociáveis dela".

Neste contexto, por abarcar a totalidade da paisagem sem interferir em seus fluxos, Fronteira, Fonte, Foz estaria em integração pois dialoga com os vazios e com o movimento cambiante da natureza de Laguna. Em contrapartida, por questionar a impermanência e

502 Como já vimos na pág. 261.

503 A carta é apresentada na entrevista. Ver Anexo I. 
indefinição dos espaços públicos urbanos, estabelecendo analogias com alguns dos elementos da paisagem; e por apresentar-se como uma composição contrastante em relação ao entorno de rarefeita presença, a obra estaria também na vertente interrupção. Salzstein analisa o "descolamento" da obra em relação à paisagem como "uma espécie de recesso espaciotemporal"504, enfatizado pelo nosso estranhamento em relação ao desenho no piso, o que concorre para interpretar a obra em interrupção com a paisagem.

Como os contrastes entre figuras em branco e preto, para análise de figura e fundo ${ }^{505}$, se analisarmos a relação da obra com a paisagem a partir do entorno, em direção à obra, esta parece integrar-se à paisagem. Mas, se a imaginarmos a partir de um percurso na obra, seu peso visual e sensível - dado pelo contraste das linhas e movimento - reverberam mais alto que os elementos e características do lugar e entorno.

Assim como Mesa, Fronteira, Fonte, Foz parece convergir para a paisagem "sem querer", talvez pela fusão da arte como lugar, considerando-o em seus usos simbólicos, e em sua apropriação

\subsubsection{José Resende. O Evanescente, 200}

\subsection{0 moedas de bronze.}

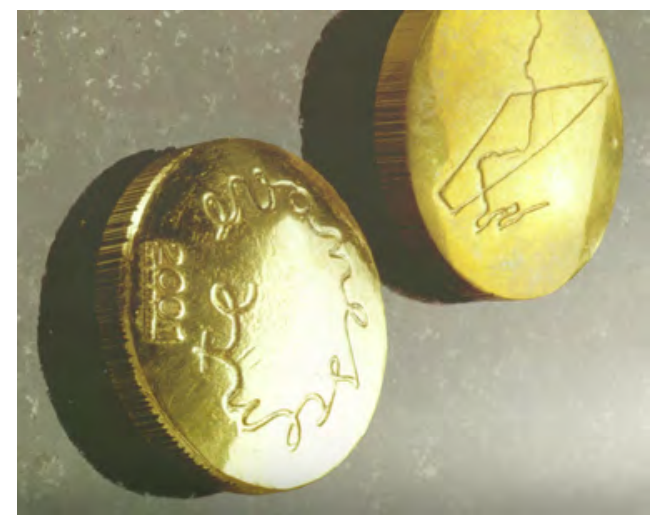

152. José Resende, $O$ Evanescente, 2001. Sete mil moedas cunhadas em bronze. De uma lado a escrita manual "evanescente", do outro um polígono indica em seus vértices as quatro capitais do Mercosul.

(Fonte: Fronteiras, 2005, p. 156)

\footnotetext{
504 SALZSTEIN, 2005, p. 100.
}

505 Esquemas de figura-fundo são utilizados nos estudos da percepção espacial. "[...] não há algo como uma imagem bidimensional verdadeiramente plana". Ver ARNHEIM, 1991, p. 217. 
O Evanescente foi a quarta proposta do artista José Resende apresentada ao Itaú Cultural para Fronteiras. As propostas anteriores abarcaram desde a intervenção no curso de um rio a fontes em lagos como Itaipu e o de Laguna. José Resende é, entre os artistas do projeto, provavelmente o mais ligado à tradição da escultura ${ }^{506}$, cuja produção inclui obras públicas em grande escala.

O artista teve como partido seguir a lógica do projeto Fronteiras e, por isso, propôs intervir em escala ambiental - ou como é também apresentada, escala geográfica - assim como, manteve-se fiel à sua poética caracterizada por "eleger um material e, por meio da ação, transformá-lo, criando uma situação nova para os elementos que são manipulados"507. Daí a proposta de redesenhar o curso de um rio e projetar grandes fontes, transpondo seu processo de trabalho para a escala geográfica. Contudo, já neste princípio surgiram incongruências, uma vez que a magnitude destas intervenções requereriam maiores investimentos e planejamento.

As fontes de José Resende têm como referência a obra "O observatório dos amantes" 508 , do artista ícone do surrealismo Man Ray, em específico, a figura da "boca" pintada sobre uma paisagem de céu e floresta. $\mathrm{O}$ rio seria dividido e depois reunificado seguindo o contorno desta figura. Mas limitações operacionais e orçamentárias inviabilizaram este projeto.

$\mathrm{Na}$ segunda proposta, seriam então tubos figurando uma boca, que flutuaria e circularia por várias cidades na beira do lago de Itaipu, dando a impressão de movimento e de fala para quem olhasse da margem. Para o artista, apenas uma vista aérea possibilitaria a apreensão das intervenções nos rios, nessa escala ambiental proposta pela Instituição.

506 SALZSTEIN, 2005, p. 145.

507 RESENDE, 2005, p. 147.

508 Man Ray, A I'heure de I'observatoire, les Amoureux (1932-34). Óleo s/ tela. 
Ao conhecer Itaipu, me veio imediatamente a imagem daqueles enormes lábios da obra de Ray flutuando, de forma que a paisagem desenhasse as linhas da boca. Por estar flutuando, o constante movimento da água causaria no público a impressão de que os lábios estariam se articulando na tentativa de estabelecer algum diálogo. ${ }^{509}$
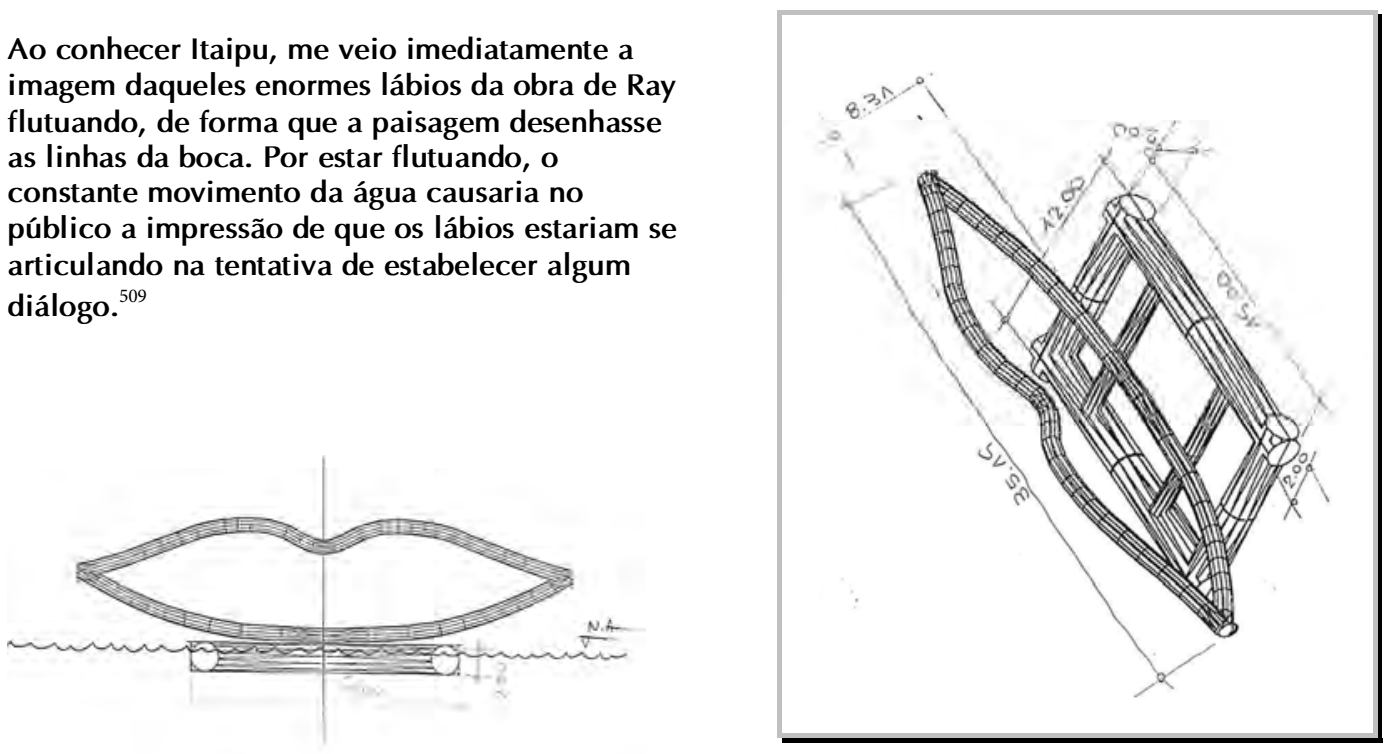

153. Projetos de José Resende. Sem título, 2000. tubos de aço calandrado, dimensões a definir. In: Ações Prospectivas, Itaú Cultural, 2000.

Por fim, em um terceiro projeto, Resende propôs um enorme chafariz na laguna da cidade homônima, que poderia ser visto da autopista que leva ao Rio Grande do Sul. Os jatos d'água desenhariam no ar a "boca".

O artista, assim como Carmela Gross, chama a atenção para a incongruência da proposta de Fronteiras, que solicitava uma arte em escala ambiental, mas que para tanto, seria necessário, segundo o artista, "trabalhar em ações do tamanho de Itaipu, possibilidade que evidentemente não existe ${ }^{\prime \prime 10}$. Também ponderou sobre a compatibilidade entre matéria e técnica nesta escala, além dos meios para se efetivar tal projeto.

Sobre a referência que faz ao trabalho de Man Ray, explica:

Ocorreu-me utilizar uma componente figurativa emprestada do trabalho de Man Ray, a imagem dos lábios pintados pelo artista sobre um horizonte, no céu de uma paisagem, de tal modo que ela só aparecesse muito sutilmente, como um elemento inusitado, mas que tivesse brotado da própria "ação sobre o material"[...] A inserção dessa referência figurativa em uma escala geográfica seria um desafio e tanto. (Resende, 2005, p. 147) ( ${ }^{*}$ grifo nosso)

509 RESENDE, José. Dados do projeto. In: ITAÚ CULTURAL, 2000.

510 Idem, 2005, pág. 147 
Outro dado importante ponderado pelo artista é que ao considerar a amplitude da paisagem, uma obra nesta escala não encerraria em si um "significado":

\begin{abstract}
Nessa escala, haveria um certo descontrole meu sobre a ação em jogo, como, aliás, habitualmente ocorre; deste modo, a referência absurda a um "significado" - no caso a figura do trabalho de Man Ray - em um trabalho que lida com a paisagem desfaz a noção de controle como intenção, embora realize, mesmo assim, em outro nível...(Ibidem, pág.149)
\end{abstract}

O Evanescente, por sua vez, consiste em sete mil moedas de bronze, que seriam trocadas na "abertura" da exposição e que, a partir de então, circulariam livremente. Neste raio de ação da moeda em trânsito criou-se um espaço público - como o criado pela comunicação. Como vimos, os artistas questionaram a premissa da Instituição de a obra estar em "espaços públicos $^{1511}$.

A obra teria a intenção de diluir a ideia de fronteira, de ser uma moeda comum e de tocar em outros espaços públicos que não o urbano. Mas a Instituição julgou-a com tom de sarcasmo, uma vez que, naquela época, o país havia desvalorizado o real, o que havia causado certa inquietação entre os países do Mercosul $^{512}$. Também fora negado, a princípio, pois se distanciava da proposta para o projeto de ocupar fisicamente um espaço público urbano. Por fim, o artista realiza o Evanescente (2001) contudo, não houve a troca inter-países desta moeda. Quando o catálogo Fronteiras (2005) foi publicado, quase cinco anos após a implantação das obras, as moedas foram inseridas na capa.

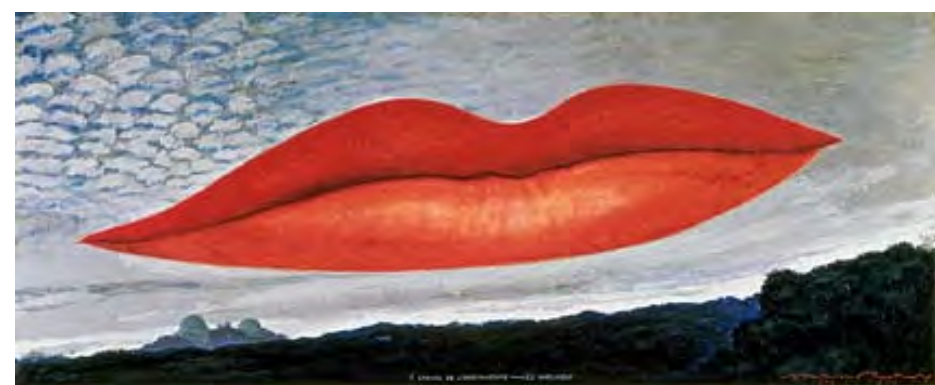

154. Man Ray.A L'Heure de L'Observatoire Les Amoureux, 1933.

(Fonte: http://fineartprintsandframes.com/lovers-by-man-ray/ Acesso: 20/12/12).

[...] Aqui natureza e paisagem ainda estão mais para Macunaíma. Dorival Caymmi fala, mas só do mar ou de uma Copacabana que já não existe mais. E, como o pais é muito desigual, a paisagem que é urbana, talvez esteja mais para Blade Runner. (José Resende, entrevista em 22/09/2012).

511 ITAU CULTURAL. Apresentação In: Fronteiras, 2005.

512 José Resende In: Fronteiras, 2005, p. 152. 


\subsubsection{Artur Barrio. Três livros e meio, 2000.}

Cinco blocos de granito em formatos e dimensões variadas. Entre as cidades de Chuí e Santa Vitória do Palmar, RS. (Fronteira Brasil / Uruguai)

A obra consiste em cinco blocos de pedra (granito, basalto, mármore e ardósia), em localidades entre as cidades de Chuí e Santa Vitória do Palmar, RS, escolhidas casualmente, de modo que além das marcações do artista que, aparentemente, registrou seus posicionamentos em latitude e longitude, não conseguimos através de referenciais concretos da paisagem alcançar esses lugares.

Como é prática de Artur Barrio, anotações em caderno de artista traduzem algumas ideias como a da existência daquilo que apenas se vislumbra ou se ouve falar - e que remete à ideia de fronteira - "algo que nunca existiu, que passa a existir, e que nunca mais existirá", como o bloco lançado ao mar. É uma biblioteca de pedra que "conta a história do Planeta Terra [...] em meio a um descampado, perto de um bosque". ${ }^{513}$

Alguns referenciais da paisagem estão presentes nestas anotações: como a intensidade do sol, o descampado, o bosque. São visões e sensações, mas não chegam a insinuar uma atmosfera ou fisionomia da paisagem, tampouco de que modo estas interferiam na inserção das obras ou se há relação com as mesmas. Barrio apresenta, frequentemente, uma forte ligação com a escrita - cadernos ou livros de artista e anotações diversas.

Estas esculturas estão arraigadas na trajetória do artista, em seu modo de realizar ou pensar sua arte e, podemos compreendê-las como intervenções e registros que pouco se relacionam diretamente com a paisagem, pois não buscam referenciais objetivos no meio. ${ }^{514}$

513 Anotações do artista. Ver SALZSTEIN, 2005, p.70 e 71.

514 Como não há entrevista de Barrio sobre estas obras, podemos traçar algumas relações delas com a paisagem, com seus aspectos físicos e naturais. Contudo, por e-mail Barrio respondeu-me que não se interessava pela abordagem desta pesquisa, pelo "tema" paisagem. 


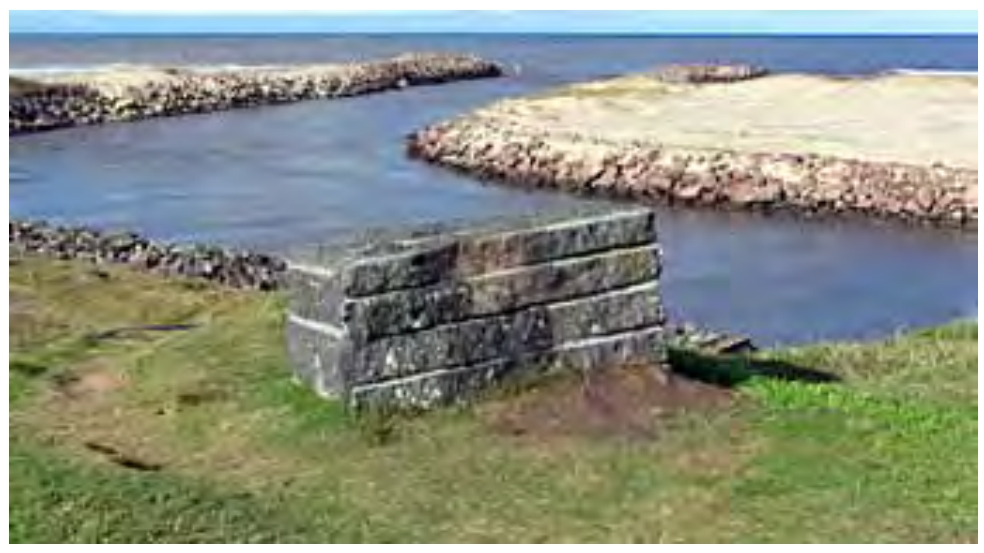

155. Artur Barrio. Três Livros e meio, 2000. Barra do Chuí-RS. (Foto: Franscisco Alves de Almeida, 2010).

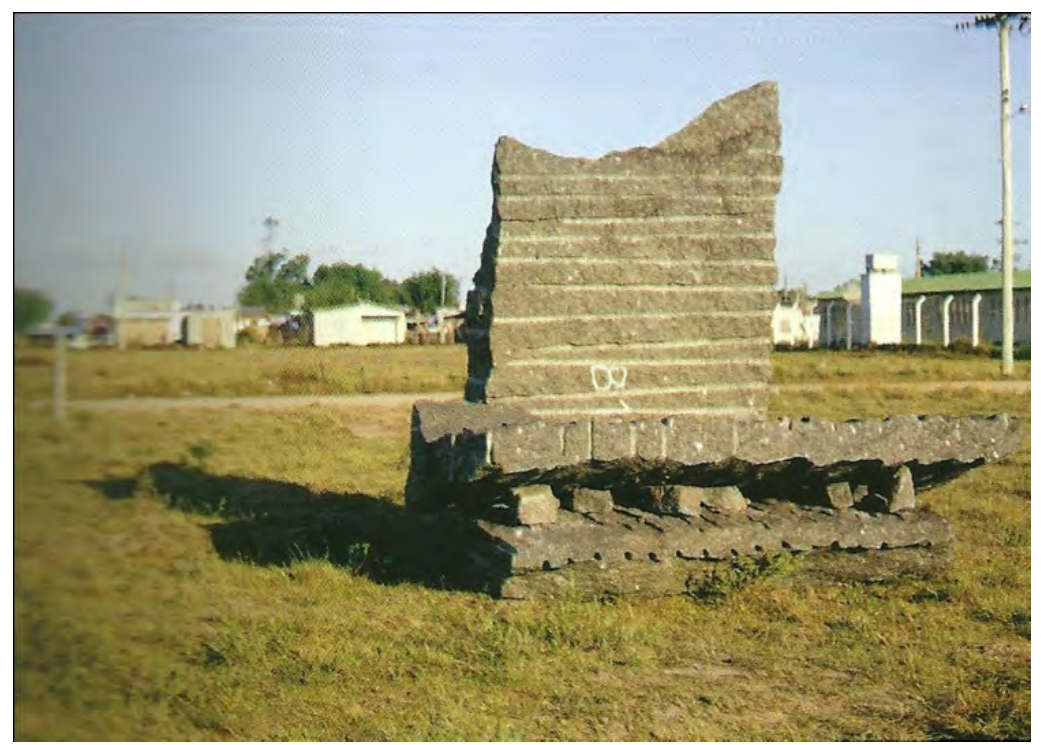

(155). Artur Barrio. Três livros e meio, 2000. Chuí e Santa Vitória do Palmar, RS.

Cinco blocos de granito de "grandes dimensões" espalhados entre as cidades de Chuí e Sta. Vitória do Palmar, RS, um jogado ao mar.

Salzstein vê oscilar na obra de Barrio o intimismo de um caderno-de-artista até a "monumentalidade de um earthwork" ${ }^{1515}$. Contudo, é interessante vermos que muitos earthworks não são monumentais, são estritamente "trabalhos de terra" como o termo designa. É o caso dos primeiros de Michael Heizer (estacas de madeira e trincheiras escavadas formando desenhos geométricos) e mesmo a Spiral Jetty, 1970, de Robert Smithson, que embora tenha grandes dimensões, nem de longe se aproxima das dimensões do lago Utah, pois é na combinação entre a escala da paisagem e do observador que a obra realiza-se. Também este termo é usado para os trabalhos de recuperação de terras (land reclamation)

515 SALZSTEIN, 2005, p. 56. "[...] intervenção que oscila entre a monumentalidade de um earthwork e o intimismo de um caderno depositário de toda a potência da imaginação pessoal[...]" 
degradadas pelo uso industrial, como os de Robert Morris e Heizer, nos quais o trabalho é revitalizar a terra, e não criar um marco geográfico.

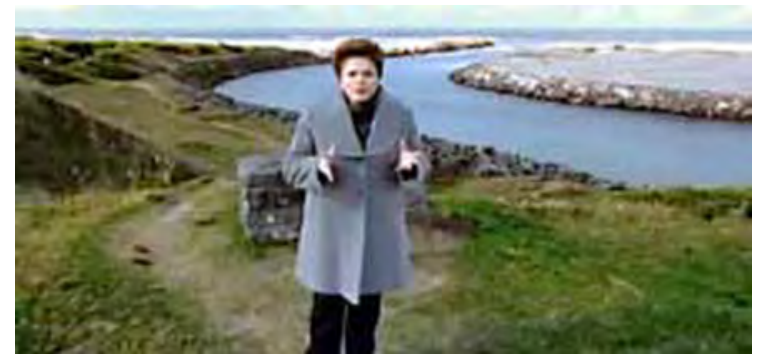

(155). Artur Barrio. Três Livros e meio, 2000. Barra do Chuí-RS.

Dilma Rousseff, em sua campanha à presidência (imagem de TV). (Foto: Franscisco Alves, 2010).

- Considerações sobre as obras do projeto Fronteiras (1998-2001): prevalência de uma "espacialidade interna" em "não-lugares".

Algumas das obras de Fronteiras suscitam uma experiência espacial ambígua, pois, mesmo inseridas na escala geográfica, acabam por privilegiar a escala humana, ou o lugar do indivíduo, sublinhando "uma forte espacialidade interna"516. A coexistência das espacialidades externa e interna que se referem à escala da paisagem (com sua totalidade diante do indivíduo) e àquela do observador, é explorada por muitas das obras da land art.

A ênfase na espacialidade interna destas obras talvez se justifique por elas depararemse com uma vastidão e "uma exterioridade irrecorrível"517, que transpassa o espaço físico. Resultam da ausência de pontos de ancoragem - simbólicos, históricos - das obras, que se inseriram em "não-lugares", lugares de passagem, além das indeterminações dentro do próprio projeto, o que concorre para o isolamento destas em relação ao meio, dando a "impressão de que não pertencem completamente a seus lugares, de que apontam para um outro lugar." 518

A maior parte das obras de Fronteiras, então, incide em um espaço interiorizado, ou um espaço mental, como reação ao desmesurado de lugares que são só um horizonte a perder

\footnotetext{
516 São exceções Mesa e Três Livros e Meio, que não têm como premissa a escala e a percepção humanas. Sônia Salzstein refere-se à obra Mesa, mas também trata das outras obras "produzidas no âmbito desse Projeto". Esta sugere uma certa interioridade pois, no embate com a da escala geográfica, "[...] se desvanece em um espaço e tempo imponderáveis". Ver SALZSTEIN, 2005, p. 167.

517 Ibidem, p. 191.

518 Ibidem, p. 12 
de vista ou ainda lugares onde atuam as potentes forças da natureza que, como sintetizou Nuno Ramos, "continua resistindo firmemente."

$\boldsymbol{O}$ Aleph combina a experiência do percurso introspectivo em direção ao centro do labirinto (ou do corpo) com a experiência de apreender toda a paisagem circundante. Mas como declara o artista, seus trabalhos de grande escala "sempre acabam privilegiando a escala humana no confronto com o desmesurado." ${ }^{519}$

A paisagem imaginada, elaborada no espaço mental por relações entre objetos, foi trabalhada em Momento de fronteira (2000), de Waltércio Caldas; em Mesa (1999), de Nelson Félix, e em Três livros e meio (2000), de Artur Barrio. Estas fazem referência ao "local", e não ao lugar, e guiaram-se por abstrações ou coordenadas geográficas.

Minuano (2000) trabalha desde a escala da Terra, ao abarcar os corpos celestes, como na escala do sujeito ${ }^{520}$, que acompanha os reflexos da luz solar. Contudo, o artista vê o conjunto de esculturas em uma "escala meio tímida"521. Também em Pálio I e II, destaca-se a ambiguidade na apropriação do espaço, este mais problematizado, por se tratar de um espaço público urbano. A obra, inserida em uma área de passagem, cria seu próprio espaço interno que pode ser percorrido pelo observador. Tal contexto é compartilhado pelas obras Sem Título de Fajardo, e Fronteira, Fonte, Foz,de Carmela Gross, ambas em praças pouco transitadas.

Segundo Salzstein, as frestas do cubo de tijolos de Sem Título sugeririam uma interioridade $e^{522}$. Esse espaço interiorizado era premente no projeto de cubo de vidro do artista sobre as Cataratas de Iguaçu ou sobre um vertedouro na hidrelétrica de Itaipu. Em Fronteira, Fonte, Foz a ambiguidade não se dá exatamente pelo confronto entre a amplitude amorfa da paisagem beira-mar com a escala do observador-passante, mas por lidar com um espaço aglutinador - a praça -, que é enfatizado quanto à sua condição de passagem e impermanência.

\footnotetext{
519 VENOSA, 2005, p. 40.

520 RAMOS, 2005, p. 191.

521 Ibidem, p. 193.

522 SALZSTEIN, 2005, p. 89. Carlos Fajardo não concorda com esta "interioridade", pois ele vê sua obra como superfície, como relação com o entorno.
} 
A espacialidade das obras que, no embate com a totalidade da paisagem, se volta para seu interior e suas aderências frágeis em relação aos lugares, criam tensão pelo rebatimento de opostos: pertencimento e estranhamento.

Talvez ainda, este espaço interiorizado que as obras elaboraram diante da paisagem resulte da pouca transformação ou reflexão de nossas artializações; daí ficarmos no limiar entre abarcar a escala da Natureza - ou do incomensurável - e ater-nos ao espaço reconhecível, dado pela escala humana ou no espaço mental. Novamente podemos citar Roger,(1999) quando aponta a importância das elaborações da arte para formarmos as imagens de um país ${ }^{523}$.

Consideração importante para esta pesquisa, descoberta através de duas obras e seus relatos, é que devemos fazer uma ressalva quanto a uma das definições de Tufnell ${ }^{524}$ para a land art - de arte diretamente ligada ao lugar -, adequando-a aos exemplos brasileiros que não apresentam tal inclinação às questões do lugar. São elas Sem título, de Carlos Fajardo, e Mesa, de Nelson Félix: obras concebidas a priori da paisagem e que, contudo, abarcaram-na sensivelmente.

Estas obras independem das características do lugar, físicas ou históricas. Mais ainda, não reconhecem nos espaços onde se inseriram um lugar. Embora elas se aproximem de esculturas inseridas na paisagem uma vez inseridas, atentam aos elementos e aspectos simbólicos da paisagem, devolvendo-nos não apenas um discurso sobre a obra, mas sobre a própria paisagem, sobre a inserção e relações da obra com o lugar e o entorno.

Deste modo, se a arte da paisagem - principalmente as obras norte-americanas das décadas de 1960 e 1970 - eram principalmente site-specific ${ }^{525}$ (termo que depois se tornaria uma espécie de "categoria" da arte, ou até mesmo modismo), no Brasil, tal aderência ao lugar é

523 “Um país não é, de entrada, uma paisagem, é que entre um e outro se encontra toda uma elaboração da arte, essa mediação que se chama artialização." ROGER, 1999, conforme citado no Cap. 1.

524 Segundo a definição de land art de Tufnell, as obras não são inseridas na paisagem, mas dela participam diretamente, em ações diretas. "Não é simplesmente a escultura posta na paisagem, mas abarca uma atitude em relação ao lugar e experiência que vai além do objeto, enfatizando a paisagem em que está inserido [...]. " TUFNELL, 2006, p. 16, grifo nosso.

525 A obra encontrava no lugar as condicionantes para sua composição, empregando suas matérias-primas, objetos, práticas; ou ele se tornava uma causa (como as obras de revitalização de terrenos ou land reclamation). 
pouco recorrente. Mesmo o projeto Margem, que se apresentou como "exposição de arte pública site-specific" acaba por ter como obra construída Errante que, como bem elucida o artista mexicano Hector Zamora, "vale para o Brasil, para o México, para o mundo".

\title{
4.2 As obras do projeto Margem (2009-2010) e como os artistas abordam a paisagem.
}

\begin{abstract}
Tampouco tivemos, ao longo desta segunda metade do século, a beleza das intervenções de Isamu Noguchi, artista extremamente sensível ao urbano e ao urbano articulado com a natureza [...] E jamais experimentamos a abundância de propostas com água, a devolver ao concreto e à terra um pouco da magia e da dinâmica da natureza. (AMARAL, Aracy. Arte Pública em São Paulo. in Arte Pública, SESC, 1998, p. 52)
\end{abstract}

Como apresentado no Capítulo 3, Errante (2010), do artista mexicano Hector Zamora, foi a única obra implantada pelo projeto Margem, sobre o leito do Rio Tamanduateí, em frente ao Mercado Municipal, na região central de São Paulo. A obra esteve em visitação no período de 09/10/2010 a 28/11/2010 e sua proposta foi esboçada no Seminário As cidades e suas margens (setembro de 2009).

Outros dois projetos foram também apresentados neste seminário, quando, então, estavam em processo de criação. Hector Zamora, Nuno Ramos e Ana Maria Tavares expuseram suas observações sobre as paisagens em que interviriam, e, em específico, abordaram a relação das cidades com seus rios, a partir de suas pesquisas in loco para desenvolverem as obras. Apresentaremos o projeto de Nuno Ramos, que, se não chegou à implantação, devido ao término de Margem, já estava na etapa de projeto executivo e seria implantado em Manaus, próximo ao Rio Negro. Com a artista Ana Maria Tavares a arte seria levada à Porto Alegre, na orla do Guaíba. 


\subsubsection{Hector Zamora. Errante, 2010.}

Rio Tamanduateí, Várzea do Carmo, São Paulo, SP.

(98). Hector Zamorra.

Errante, 2010.

Conjunto de árvores suspensas sobre o leito do Rio Tamanduateí (entre o mercado Municipal e a Passarela do Parque Dom Pedro II), centro de São Paulo.

* Relação das espécies: Canafístula, Copaíba, IpêRosa, Jequitibá, Magnólia, Mirindiba e Sapucaia.

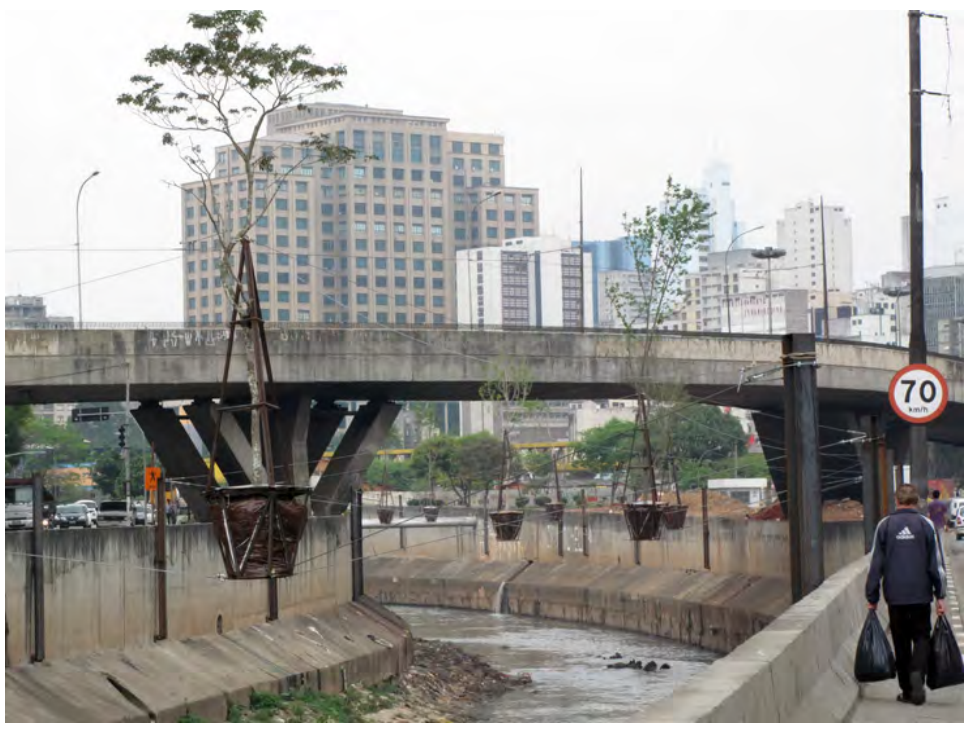

(Fonte: Folder Margem - ERRANTE, 2010. Itaú Cultural. Fotografia: Guilherme Wisnik

Errante critica explicitamente uma "São Paulo que não pára", criando ainda mais tensão na paisagem, ao inserir árvores suspensas - suportadas por cabos de aço, quase transparentes - sobre o rio Tamanduateí. As árvores ocuparam o trecho do rio próximo ao Edifício São Vito, na época em vias de implosão, e em frente ao Mercado Municipal, em meio a um entorno conflituoso ${ }^{526}$. É uma obra essencialmente de engenharia - aquela que configura nossas cidades. Podemos dizer que Errante estabelece analogias com os modos de produção da paisagem.

Em uma área central de suma importância no desenvolvimento da cidade, que sofreu transformações da paisagem de maneira acelerada e nos modelos tecnocratas, Errante talvez suscite a reflexão de que tais modelos de produção da paisagem tornam-se tão rapidamente obsoletos que a área, que seria irradiadora para a cidade, transformou-se em uma periferia

526 "o Tamanduateí está em uma região popular, conflituosa e rica de informação, marcada pelo comércio informal, pelos moradores de rua, pela perda de moradias históricas. Procuramos abordar essas relações", comenta o curador Guilherme Wisnik. ITAÚ CULTURAL. Projeto Margem. Disponível em: $<w w w$.itaucultural.org/margem>. Acesso em: 20/09/2012. 
central. Sem a sedimentação de lugares simbólicos que possam ser usados ou contemplados pela sociedade, a paisagem torna-se um ideal ou retorna a sua condição bidimensional.

A obra, enredada em tal complexidade de elementos formadores e influenciadores da paisagem, poderia ter permanecido por mais tempo no lugar - ou em "exposição" -, a fim de repercutir e criar uma rede de diálogos entre a arte e demais setores culturais. Além do tempo, a Instituição Cultural que promoveu o projeto, caso visasse fomentar o debate sobre os rios urbanos e dar-lhes visibilidade, poderia ter ampliado as possibilidades da obra - ou de obras -, em termos de escala. Estando inserida nas margens do Tamanduateí, zona fronteiriça entre a cidade e sua sombra, em uma paisagem tecnocrata, a obra requereria uma dimensão que lhe fizesse afronta. Tais possibilidades de tempo, de ocupação e escala, e de debates sobre a relação obra e lugar, não se vislumbram apenas na obra, como se esta fosse um objeto "mágico" ou redentor, mas estão contidas também nas premissas e na política do projeto.

Segundo o artista Hector Zamora, a arte tem sua "própria linguagem" e defende esta postura ao afirmar que ela não precisa assumir funções sociais ou urbanas, mas, sim, suscitar reflexões acerca de determinada situação, lançando luz sobre aquela problemática.

No entanto, parece haver uma certa incongruência em se ater à ideia de autonomia da $\operatorname{arte}^{527}$ e ter como fato observado que a arte contemporânea da paisagem adquire as características dos espaços que ocupa, dos lugares e seus entornos, ou simplesmente reage à falta de clareza destes espaços. Este desencontro parece indicar o calcanhar de Aquiles da arte contemporânea da paisagem no Brasil e nos dá pistas do porquê algumas obras são mais efetivas em alcançar a escala da paisagem, em abarcar seus elementos e, com isso, ter seu campo expandido.

O artista acredita que a obra pode trazer à tona discussões sobre problemáticas econômicas, culturais, sociais, mas não tem como função, ou "dever", solucionar tais problemas. Tal visão é compartilhada pela Instituição Itaú Cultural e apresentada no folder da exposição:

[...] a arte contemporânea conquistou um território antes restrito à arquitetura e ao urbanismo - tanto em temática quanto em escala - misturando-se a ele. Liberada, porém, de qualquer compromisso restaurador ou edificante, e podendo assumir, ao contrário, um ângulo essencialmente crítico e negativo. Assim os rios e suas margens não são, para este projeto, metáforas nostálgicas de

527 Refiro-me à arte em espaço público urbano e, por conseguinte, à arte da paisagem. Aquela que ocupa os lugares da vida. 
uma urbanidade perdida.(ITAÚ CULTURAL. Folder: Margem .Hector Zamora. Errante, 2010)

Errante grita-nos a hostilidade daquela paisagem central paulistana, que prescindiu dos elementos naturais, reduzidos a fonte de lucro e de função. Sem lugares que acolham e sem as referências naturais, a paisagem míngua à condição de imagem, "transforma-se em um cartão postal, um lugar sem pessoas e sem uso, imagem que sob a luz dos refletores revela a face final da segregação: a intolerância e a violência." ${ }^{528}$

\section{6.}

Hector Zamora, Errante. Itaú Cultural. 9/10 a 28/11/2010.

Imagens Fonte: folder MARGEM.

acima: autor desconhecido. Acervo Iconográfico do Museu da Cidade de São Paulo. Várzea do Carmo, 1890

abaixo: foto Hector Zamora

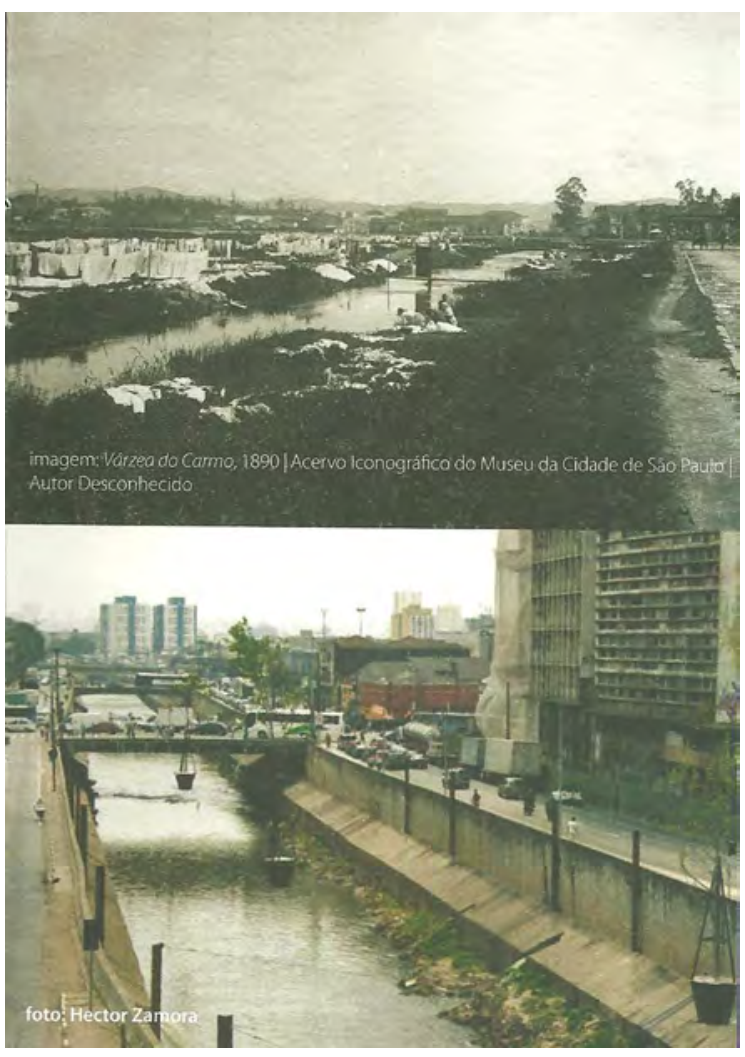

Primeiramente, o artista interessou-se em trabalhar no conjunto habitacional localizado na antiga Favela do Gato, pois estas moradias estão em uma situação única na cidade: na margem do Rio Tietê, tendo uma faixa verde de contato com sua margem. Depois lhe interessou o edifício São Vito ${ }^{529}$, propondo um restaurante de luxo na cobertura, onde só se teria acesso pelo tráfego aéreo: uma ironia à incapacidade de a cidade lidar com seus problemas de transporte, saltando para "soluções" cada vez mais além do sustentável. Zamora

528 LEITE, 1998, p. 79.

529 Edifício para moradias populares projetado em 1954, desocupado em 2004 e demolido em 2010. 
acabou por escolher o Tamanduateí (observou o quanto a escala humana é remota nas margens do Tietê), pois seu projeto requeria "percorrer as margens à pé ".

O Tamanduatei ${ }^{530}$, no centro de São Paulo representa menos um "rio" na paisagem e mais uma retificação, um escoamento. A paisagem da região central, onde se implantou a obra, fala-nos diretamente sobre uma história de políticas públicas de expansão, ocupação e progresso sem planejamento paisagístico. O lugar em que Errante se inseriu evidencia ideais obsoletos de progresso através da industrialização e do rodoviarismo, culminando na falência do seu entorno em termos de adensamento e usos. Mas, em outros tempos, a região da Várzea do Carmo, já recebera atenção pela sua importância paisagística, sendo objeto da legislação para salvaguardar seu conjunto, uma vez que era a "porta de entrada" dos viajantes que chegavam do Rio de Janeiro. ${ }^{531}$

Já no início do século XIX, as inundações eram frequentes na várzea do Tamanduateí. Data da década de 1820 a início da à retificação do rio, que terminaria em 1916 e, em 1854, a navegação no rio Tamanduateí foi suspensa, em virtude destas obras ${ }^{532}$. Portanto, as queixas contra o rio alagadiço atravessaram quase dois séculos. Contudo, a retificação e a ocupação industrial de suas margens não promoveram melhorias na qualidade urbana e ambiental. A arte que escolhesse o rio Tamanduateí, e, em específico, a região central da cidade, escolheria interferir em um lugar, cujo histórico em relação a um rio-estorvo é traumático. Desta relação adveio outra mais ampla, a do urbano com o meio ambiente, que se estabelecia com animosidade desde início do século XIX.

Como a arte, em meio a esta paisagem, poderia nos sensibilizar e despertar discussões sobre os símbolos, valores culturais, o histórico da produção e rumos desta paisagem?

As obras de canalização do rio seguiram adiante estendendo-se aos bairros e municípios vizinhos, alinhadas com o progresso trazido pelo café, pela industrialização e ferrovias, assim como com a urbanização rodoviarista que em São Paulo faz-se notar já a

\footnotetext{
530 Tamanduateí significa na língua tupi "rio de muitas voltas". Nasce na Serra do Mar, passa pelas cidades de Santo André, São Caetano e São Paulo e deságua no Rio Tietê, com o mesmo índice de oxigênio de um esgoto.

531 TOLEDO, Benedito Lima de, 2004 apud CACCIA-GOUVEIA, Isabel C. M. Da originalidade do sítio urbano de São Paulo às formas antrópicas. Tese de Doutoramento FFLCH-USP, São Paulo, 2010, p. 150. "[...] O Código de Posturas da Câmara Municipal da Imperial Cidade de São Paulo, em 1875, exigia que se mantivessem apresentáveis, pintadas e caiadas as [...] frentes e outões [...] bem como os fundos [das casas] que deitarem para [...] a Várzea do Carmo".
}

532 Ibidem, p. 164 
partir da década de 1930. Além da retificação, vieram ainda os tamponamentos do rio para alargamento das avenidas para automóveis como a Avenida do Estado.

Mais recentemente, intervenções na paisagem às custas de maus tratos à natureza despertam nosso mea culpa, evocado principalmente em um período em que as preocupações são "ambientais" e acerca da "sustentabilidade", questões-chave abordadas na apresentação ${ }^{533}$ do projeto Margem.

A paisagem da obra é radicalmente oposta às paisagens de vazios de Fronteiras. Nos termos de Carlos Fajardo, é uma paisagem "eloquente", e, sobretudo, carente de intervenções paisagísticas e artísticas compatíveis com a importância de seu raio de influência.

A obra aponta para uma característica muito presente na arte contemporânea brasileira que ocupa os espaços da vida, quando não efêmera por vocação: ainda tem algo de transitório, impreciso quanto à ocupação espacial, errante. Seriam, também, estas características que conformam nossas paisagens?

A paisagem do Tamanduateí, central na narrativa do artista, aparece como "uma parte muito estéril da cidade" ${ }^{1534}$. Zamora conta que foi se aproximando da paisagem paulistana como um turista, observando o rio pela janela do ônibus, do trem, em um esforço para se aproximar de suas margens. Ele seguiu o Tamanduateí até sua nascente em Mauá, assim como, em sua pesquisa para conceber a obra, seguiu os cursos dos rios Tietê e Pinheiros. O incômodo da sociedade em relação a seus rios foi um fato que lhe chamou a atenção e causou-lhe estranhamento as concretagens para contenção e tamponamento dos rios.

Hector Zamora, diferente dos artistas de Fronteiras, por estar em uma paisagem tecnicamente produzida, atém-se à crítica quanto ao modo de produção da paisagem, e menos à sua atmosfera. Embora faça uso dos elementos naturais - de árvores -, que são, talvez, o foco de atenção na obra e criam tensão ao estarem suspensas sobre o leito do rio, a ênfase está nos

533 No folder de apresentação Margem. Hector Zamora-ERRANTE sábado 9 de outubro a 28 novembro 2010. Itaú Cultural, 2010. Onde lê-se "Os rios possuem funções múltiplas [...] Trazem consigo a discussão acerca da sustentabilidade, tanto em relação à água como recurso nacional, quanto ao transporte fluvial como instrumento de soberania nacional". O tema também este presente no Seminário de Apresentação do Projeto e Arte Pública Internacional em 16/09/2009.

534 Fala no Seminário Internacional As cidades e suas margens (2009), Itaú Cultural, set. 2009 
processos de produção da paisagem, sua dinâmica, suas técnicas. Sobre as árvore, ele relembra as que viu serem transplantadas para a ampliação das Vias Marginais.

Em São Paulo, poucas vezes houve espaço para projetos de arquitetura ou de arte que pensassem a paisagem a partir dos rios urbanos. Outra tentativa, além de Quase Líquido (2008), de abordar e intervir diretamente nos rios e margens através da arte não tiveram êxito. Foi o caso da exposição Olha o Tietê $(2005)^{535}$, que seria realizada em onze pontes do rio Tietê. Os rios, talvez pela suas proximidades com as vias arteriais da cidade, cujo intenso fluxo é salvaguardado como visceral para o "funcionamento" da cidade; ou talvez por terem-se transformado em sombras de um progresso, elementos quase ocultos, ainda representam para a nossa arte da paisagem um árido caminho a adentrar.

Talvez a arte contemporânea da paisagem desenvolva-se em outros países, cujos rios também estão poluídos e retificados, porque mesmo longe da condição ideal - ou natural -, eles perpetuam-se como forte referência simbólica na paisagem, guardando a possibilidade de aproximação com a sociedade.

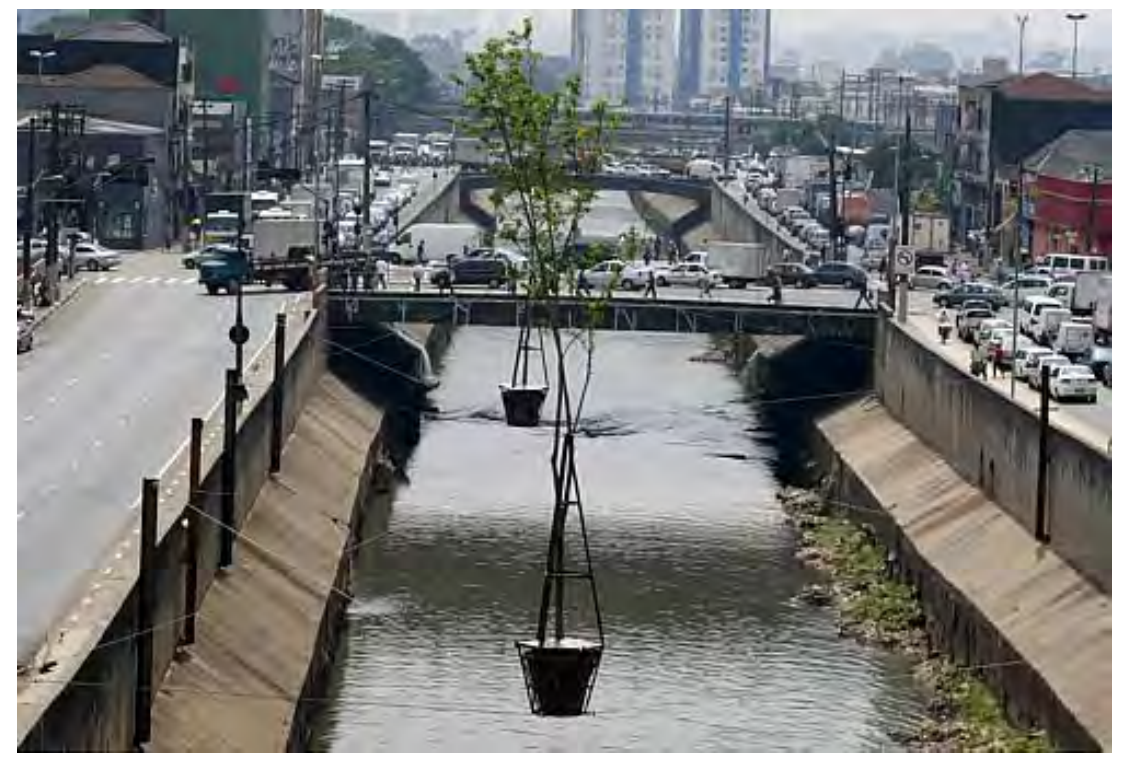

(98.) Hector Zamora. Errante, 2011. Várzea do Carmo, Rio Tamanduateí. São Paulo.

("Instalação "Errante", que suspende nove árvores sobre o rio Tamanduateí (SP), é uma crítica ao desenvolvimento urbano não planejado e remete ao debate sobre arte e ecologia." Disponível em: <http://entretenimento.uol.com.br/album/errante_sp_2010_album.htm\#fotoNav=8>) [grifo nosso]

535 Idealizada por de Cacilda Teixeira da Costa e Tadeu Jungle junto a Pinacoteca do Estado de São Paulo Para a crítica de arte Cacilda Teixeira da Costa, "após a canalização, o rio [Tietê] tornou-se muito mais algo que se pensa do que uma paisagem para observar. A velocidade dos carros nas marginais determina isso". Em 2005, ela idealizou o projeto Olhe o Tietê, convidando cerca de 20 artistas visuais e poetas a criar obras para a calha de concreto. "É depressivo viver numa cidade cujo rio é um esgoto. As obras recuperariam a auto-estima dos paulistanos, pena que não conseguimos financiamento." (Fonte: http://www.itaucultural.org.br/index.cfm?cd_pagina=2720\&cd_materia=405) 


\subsubsection{Nuno Ramos. Cabaré Chinelo, 2009.}

No segundo dia do Seminário As cidades e suas margens (2009) Nuno Ramos apresentou sua reflexão sobre o projeto Margem e propostas de trabalhos para Manaus, para o Rio Negro, que não estavam até então definidas. Em entrevista para esta dissertação o artista apresentou o projeto da obra Cabaré Chinelo (2008) que relacionaria construções em ruína do Período da Borracha com o Rio Negro. Este projeto chegou às vias de detalhamento executivo e propunha-se a durar até a Copa de 2014, mas não fora iniciado.

De início, Ramos ressaltou que à arte caberia o discurso plástico, perceptível, sensível, chamando a atenção para os riscos de um debate que antecede a realização da obra: "é um projeto ambicioso há de se esperar a resposta que só a arte dá, a arte supera o que era esperado dela".

Das suas observações sobre a paisagem de Manaus, duas são marcantes (e seriam ressaltadas e incorporadas em Cabaré Chinelo). Uma é sobre a atmosfera de ruína que parece envolver tudo na cidade, "há limo até nos outdoors" e as coisas ficam na "eminência da ruína". Ramos ilustra tal "atmosfera" com um trecho da música de Caetano Veloso "Aqui tudo parece que é ainda construção e já é ruína".

Outra característica da formação daquela paisagem é uma certa animosidade da sociedade em relação ao rio ou, como refere-se o artista ao que está do lado de fora, "a cidade é um enorme dentro", e fecha-se em muralha, contra o rio. $\mathrm{O}$ artista conta que queria ter uma vista do rio e, só o via por brechas por janelas dos fundos das casas.

A primeira proposta do artista foi implodir algumas construções, limpar o entulho e deixar um "lugar vacante". Também, ele contou que viu uma barca ancorada no meio do Rio Negro, uma fábrica de gelo desativada, e pensou em fazer "esculturas" de gelo gigantes para enviar a praças de vários lugares do país. Haveria uma carta no gelo, Carta do Negro, que derreteria, deixando as praças molhadas pelo rio.

Mas também chamou a sua atenção os casarões do período áureo do Ciclo da Borracha (de 1879-1912) (536 $^{5}$ com seu urbanismo parisiense, que pareciam "hiatos no tempo [...] um fora no tempo e em outro lugar". Viu nas suas fachadas fantasmagóricos rostos que o artista

536 Ver PORTAL 200 ANOS MINISTÉRIO DA FAZENDA. Ciclo da borracha. Disponível em: <http://200anos.fazenda.gov.br/linha-do-tempo/1800-1899/1882-ciclo-da-borracha>. Acesso em:20/08/2012) 
relaciona com "os rostos de Goeldi"537. Então, cogita inundar um casarão, criar uma espécie de fonte, o que viria a ser o projeto de Cabaré Chinelo. Nuno Ramos finaliza dizendo que Manaus lembra São Paulo, pois, além desta animosidade da cidade em relação a seus rios, existe "um agora constante, uma sucessão de coisas indistintas". No entanto, ele frisa que há uma diferença: ao adentrar o Rio Negro, Manaus adquire outra escala, "é a cidade que pertence ao rio, o rio domina a cidade" ${ }^{n 38}$.

Cabaré Chinelo (2009) mostra-nos uma aproximação da arte contemporânea brasileira em relação à paisagem extremamente sensível à problemática de como estas são produzidas, de como se realizam as interpretações e apropriações dos elementos naturais. $\mathrm{O}$ projeto evidencia as marcas da paisagem, nos termos de Berque ${ }^{539}$, enquanto comenta, severa e delicadamente suas matrizes. A obra critica o quanto a natureza brasileira foi velozmente transformada de fonte de lucro a refugo industrial e cultural.

Ramos, pelo viés histórico da paisagem, comenta suas transformações, sobretudo como as pessoas se relacionam com o rio, o que diretamente se faz visível nas construções e ruínas da cidade. O enfoque histórico da produção da paisagem através dos rios urbanos é um viés a mais que o artista oferece às temáticas do projeto multidisciplinar Margem apresentadas pela Instituição - como, por exemplo, a sustentabilidade.

O artista propôs ocupar um casarão do século XIX, no centro da cidade, que no curto período áureo do Ciclo da Borracha abrigou um hotel de luxo e que, com o fim da extração no período de decadência -, transformou-se em prostíbulo. As ruínas de Cabaré Chinelo teriam a água do rio Negro chegando pelo telhado em dutos visíveis aos passantes das ruas, dutos de borracha, que desaguando pelo teto, deixariam-se escorrer pelas paredes, como se fossem lágrimas "em um choro contínuo", nos termos do artista. Os visitantes entrariam no antigo casarão, podendo percorrer seu interior sobre um piso flutuante.

O fluxo das águas dentro dos dutos de borracha, sustentados pelos postes da rede elétrica - como "ramificações parasitárias" - tornar-se-ia visível. A obra revelaria os

\footnotetext{
537 Nas xilogravuras de Oswald Goeldi os contrastes de claro e escuro são dramáticos, as figuras soturnas, sinistras, emergem de sombras. A noite representada em suas paisagens e a "noite da alma" são muito marcantes na obra de Goeldi. É muito relevante que Nuno Ramos, ao ver a paisagem de Manaus - do Rio Negro -, relaciona-a com a arte e assim ela torna-se simbólica, revestindo-se com sensações e imaginação, para além do factual.

$538 \mathrm{O}$ artista considerou muito marcante o fato de Manaus ter-se erguido de costas para o rio Negro, sendo ele uma presença tão forte, mas ao mesmo tempo oculto.
}

539 BERQUE, In CORRÊA; ROSENDAHL, 1998, p. 84. 
elementos que a paisagem oculta. A recusa a não refletir sobre os processos de produção da paisagem, em não ver o rio e a dinâmica que se constrói no seu entorno e que é repetida ciclo após ciclo mal findado, seriam trazidas à tona.

Cabaré Chinelo constrói ricas conexões entre os elementos naturais e culturais da paisagem, que lhe são a base de seu desenvolvimento. Ramos diz que buscou aproximar dois tipos de ruína: a natural e a cultural. O casarão que abrigou diversos tipos de exploração, ao esvaziar-se e lavar-se de negro propõe relações poéticas entre os elementos da paisagem, que oscilam entre uma triste realidade e uma potencialidade simbólica.

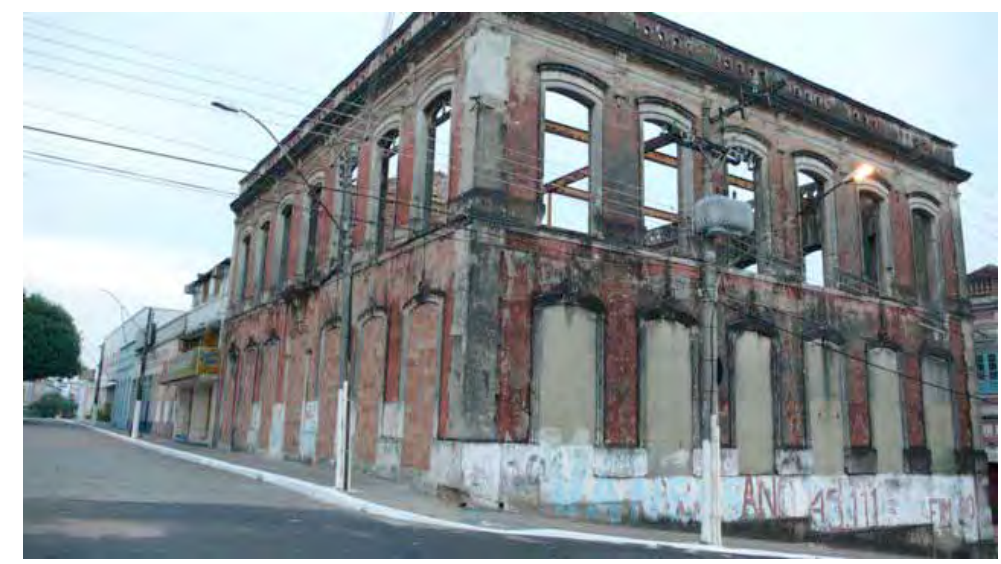

157. Margem urbanizada do rio Negro e Casarão Manaus, 2009. fotos Nuno Ramos

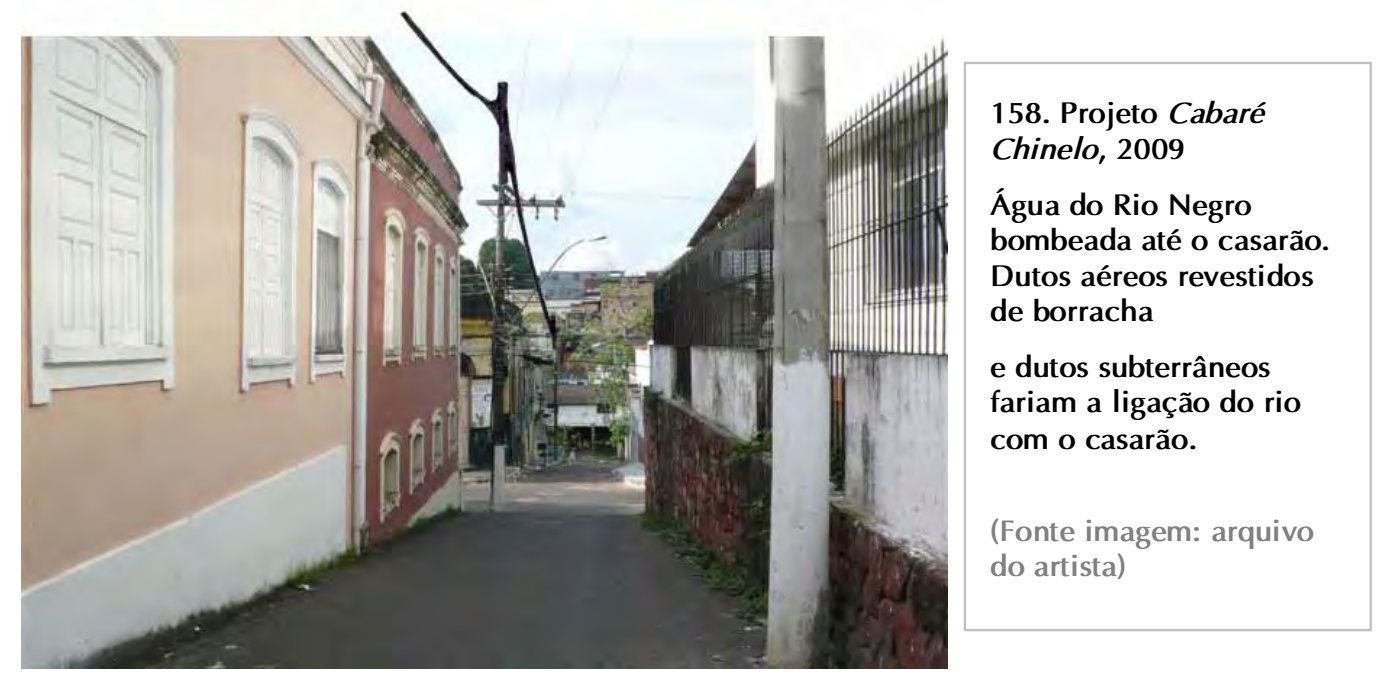

Cabaré Chinelo era prevista para abrir ao público antes da Copa do Mundo de 2014, quando Manaus será uma das cidades a sediar o evento, e esperava-se que permanecesse dois anos em visitação. 

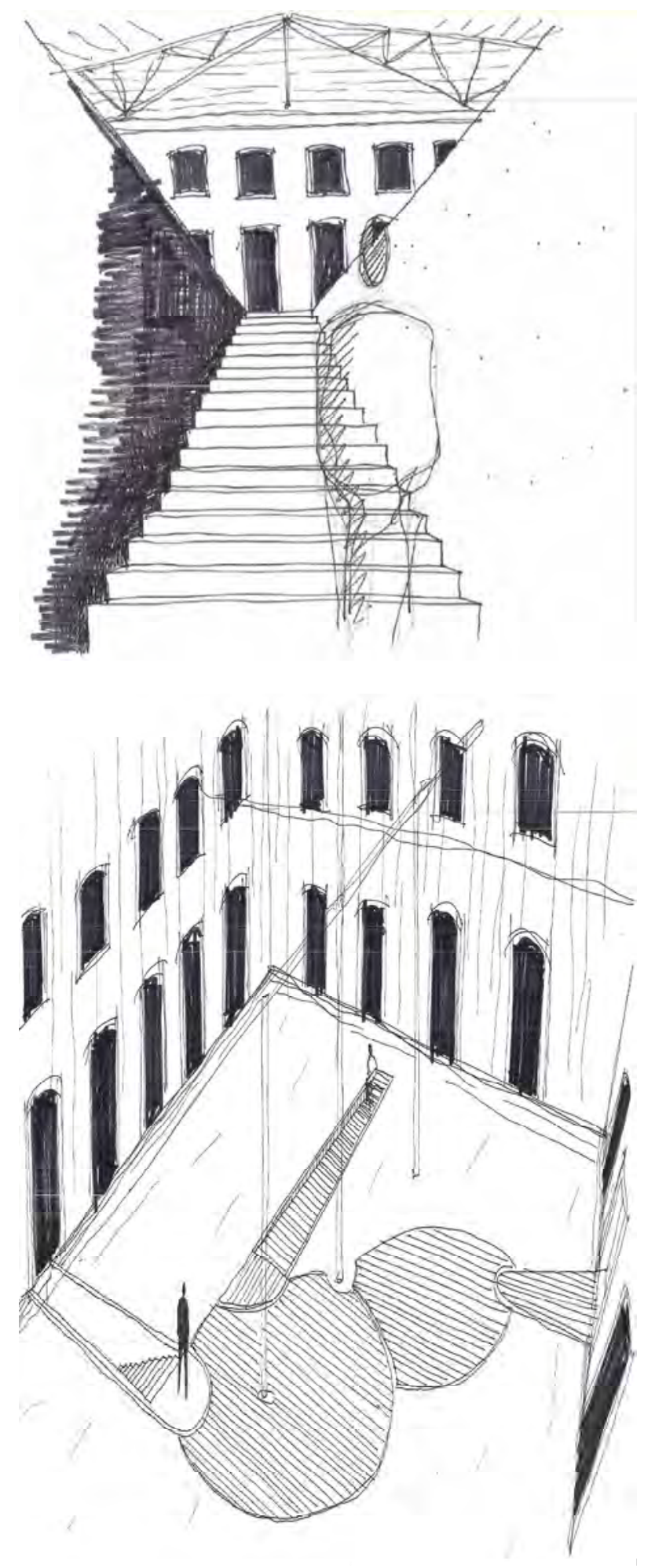

(159). Nuno Ramos. Projeto para a obra Cabaré Chinelo, 2009. Manaus / Rio Negro. (Fonte: arquivo do artista). 

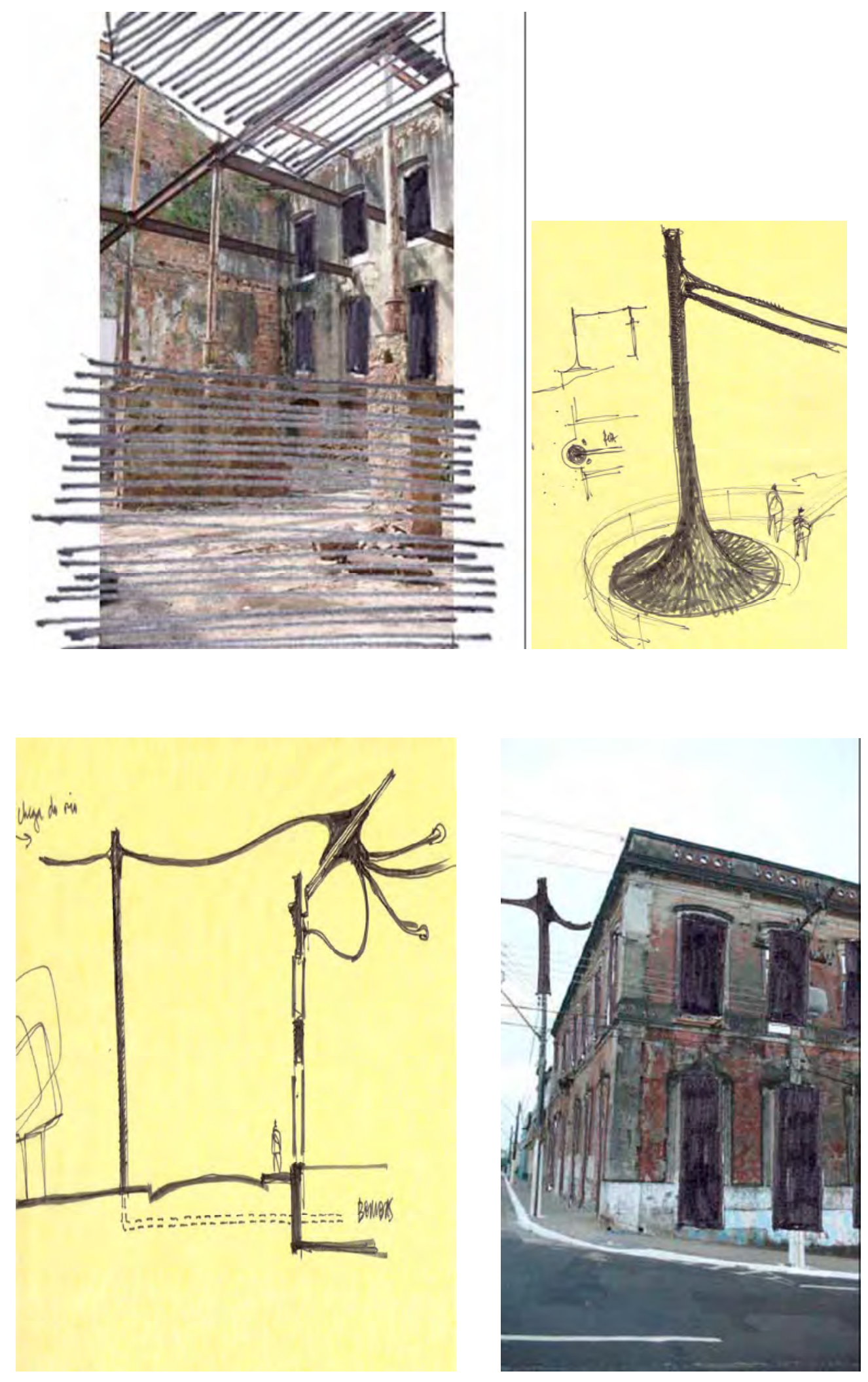

(158). Nuno Ramos. Projeto para a obra Cabaré Chinelo, 2009. Manaus / Rio Negro.

(Fonte imagem: arquivo do artista) 
Nuno Ramos, no debate Práticas de Arte Pública Site-Specific ${ }^{540}$, expõe que, no Brasil, há uma certa imprecisão em relação ao lugar, como se tivéssemos voltado ao "indeterminado" ou "geral" do Modernismo, quando uma obra é projetada para diferentes lugares, não sendo parte integrante do lugar e vice-versa, uma vez que não há "um acento, uma concretude no lugar, no site", que caracterizou o Minimalismo norte-americano e que influenciaria a land art. Ele explica, "voltamos para uma indeterminação [...] há uma grande liberdade e ao mesmo tempo uma grande indiferença". Estes fatores naturalmente se infiltram na obra que "interioriza a falta de espaço público".

A fala do artista provoca uma profunda reflexão sobre as características e contornos da arte contemporânea da paisagem no Brasil. Ramos sintetiza um entendimento - já iniciado com a análise das obras de Fronteiras - de que o lugar não é determinante para a nossa arte. As obras enfrentam imprecisões que vão desde as premissas dos projetos de exposição, incluem a discussão sobre apropriação pública ou não dos lugares, e lidam com "não-lugares". Por vezes, as obras parecem referir-se mais a espaços da memória, do imaginário ou de uma projeção - espaços mentais -, e menos na concretude do espaço físico e factual do lugar, e então a paisagem permanece aquela da memória ou de um vir-a-ser.

Se considerarmos o pensamento de Albuquerque: "No Brasil, fora o Rio e São Paulo, tudo o mais é paisagem" ${ }^{1541}$, ou seja, o que não é civilizado, culto, produzido pela técnica e erudição seria resumido à natureza, e paisagem assume o significado de natureza; e com este pensamento fizermos uma analogia com as obras de Fronteiras, parece ter havido uma mudança de paradigma na percepção ou compreensão de paisagem através da experiência de Fronteiras, pois as áreas de escassa urbanização ocupadas por suas obras não são facilmente apreendidas como paisagem.

Aparte natureza e cidades com contornos bem delimitados, podemos, em uma primeira aproximação, conceber como paisagens estas de transição ou transformação,

\footnotetext{
540 RAMOS, Nuno no segundo dia do Seminário Internacional de Arte Pública. As cidades e suas margens. Debate: Práticas de Arte Pública Site-Specific. (17/09/2009). (DVD IC EVCE FV486). Acervo Midiateca, Itaú cultural. A fala do artista assemelha-se ao que Nelson Félix acenou como característica própria desta arte.
}

541 Frase do escritor português ALBUQUERQUE, Matheus de citada in MURARI, Luciana. Natureza e Cultura, 2002. 
apresentadas por Fronteiras e Margem? ${ }^{542}$ Podemos conceber como paisagem a São Paulo de Errante?

Duas obras apontam para o debate sobre como a paisagem pode interferir na concepção ou na leitura da obra, uma vez que lhe empresta significados:

A primeira é o sólido e geométrico volume de Sem título (1993/2001), de Carlos Fajardo - obra já projetada para outros lugares -, pois ao abarcar a paisagem rarefeita de ocupação imprecisa, onde predominam o silêncio e os vazios da beira-mar de Laguna, parece diluir-se na paisagem.

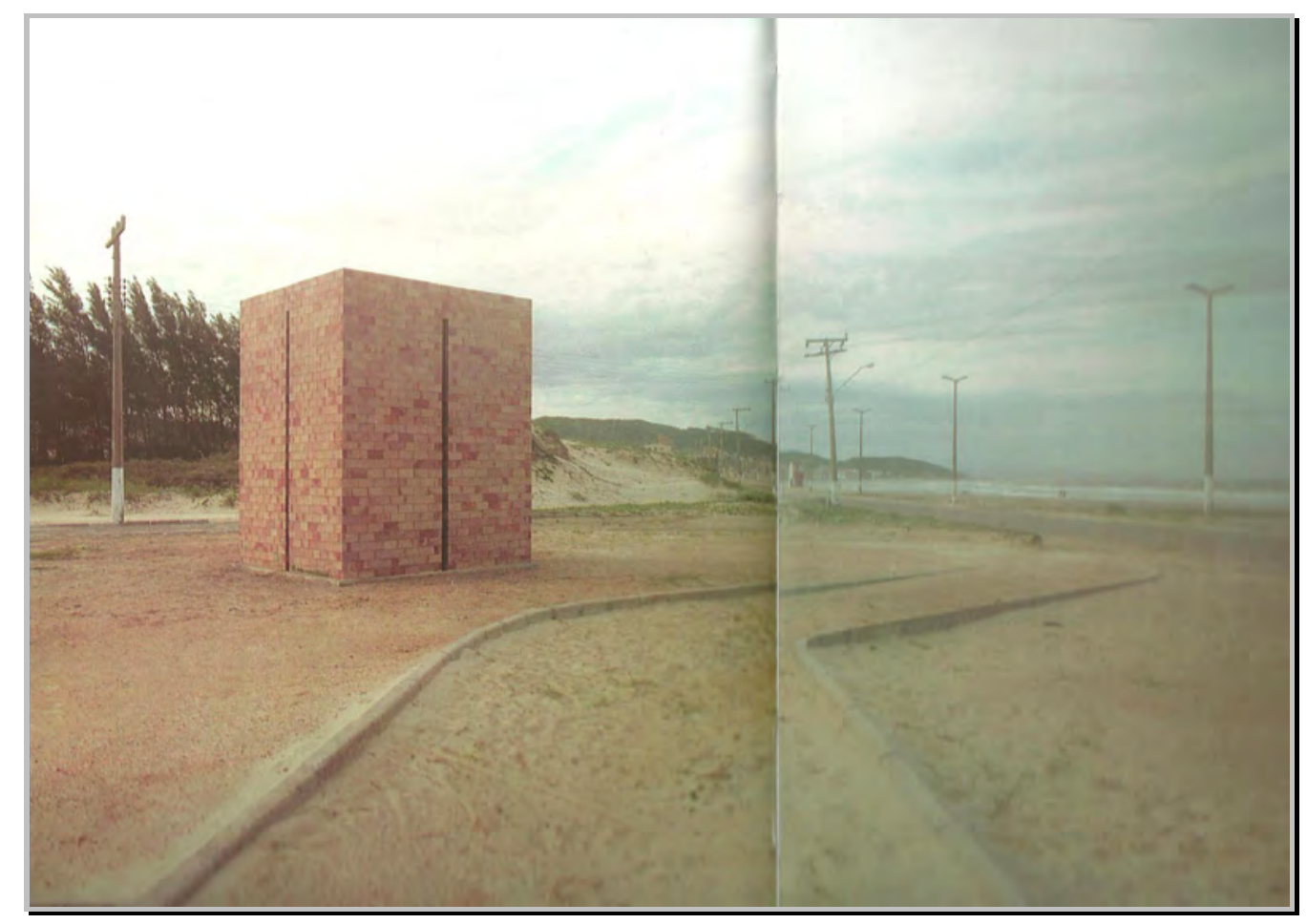

(137.) Carlos Fajardo. Sem Título, 1993/2001. 13 mil tijolos de barro. 340x280x280. Laguna, SC (Fonte: Fronteiras, 2005,p. 84).

542 Robert Smithson, como vimos no Capítulo 2, parece ter indicado que, para o reconhecimento de paisagens de refugo, de transição entre o urbanizado e o abandonado ou aquelas industriais sem apelo estético, fora necessário um exercício contínuo de pensá-las até que estas formassem também parte do repertório da arte. 
E, a segunda, é a escultura Momento de fronteira (2000) que segue a poética de Waltércio Caldas, mas ao mesmo tempo não se opõem à paisagem das margens do Rio Uruguai, plena de natureza e densa em visualidade. Nela, o rio, a mata e o céu são intensamente marcantes e a experiência estética da paisagem é sensível de tal modo, que o artista preenche os vazios da obra e os intervalos - espaços de tempo do pensamento - com a própria paisagem.

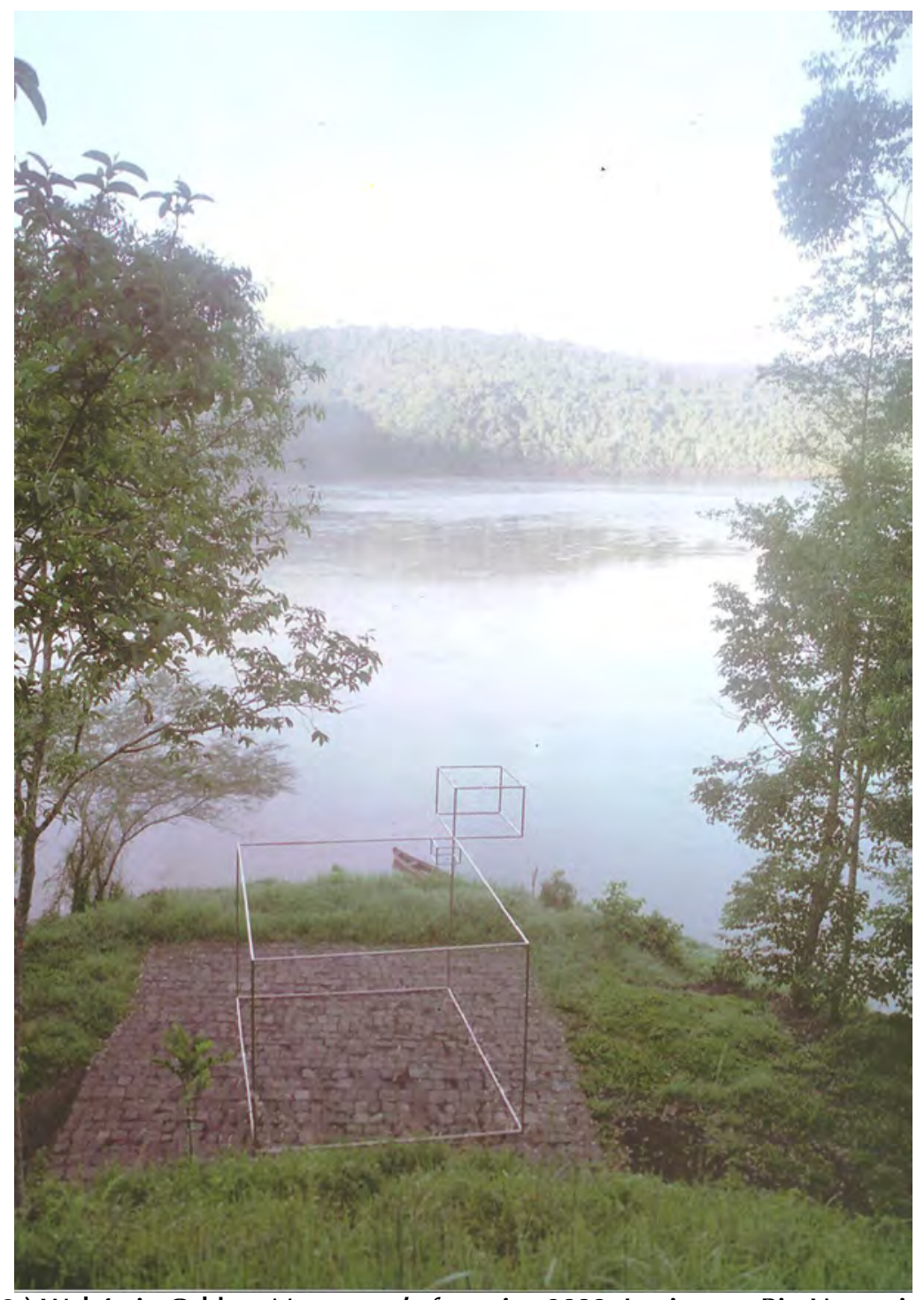

(143.) Waltércio Caldas. Momento de fronteira, 2000. Itapiranga, Rio Uruguai, SC.

Em tempo, a construção da arte da paisagem passa pela promoção cultural. Imagens, textos críticos, debates, tudo o que constitui a divulgação é de extrema importância, pois estes 
meios também constituem o tecido cultural. Archer ${ }^{543}$ expõe a importância que a divulgação da obra, tanto quanto ela mesma, assume a partir da Pop Art. Pelo mesmo motivo, ao apresentar a obra plástica de land art de Christo e Jeanne-Claude, Beardsley ${ }^{54}$ inclui os trâmites e documentos que integram a obra. Não saberíamos sobre as paisagens de Passaic e a que se propunha a arte da paisagem de Robert Smithson se não fossem seus registros.

$\mathrm{Na}$ arte contemporânea da paisagem, vimos obras diversas quanto à forma, escala, tipo de ocupação espacial, materiais empregados, temporalidade. Uma escultura pode não durar até o próximo vento, mas ela permanece se sua imagem, seu debate - como fonte estética e crítica - são registrados. O que os artistas de Fronteiras (1998-2001) e de Margem (2009-2010) propuseram-se a comentar sobre a paisagem, sobre o lugar de suas obras, é essencial para darmos o contorno deste trabalho.

Vejamos algumas obras dos artistas de Fronteiras e de Margem, a fim de compreendermos que elas compartilham com as obras destes projetos afinidades conceituais, plásticas e poéticas. Salvo exceções, a arte da paisagem no contemporâneo - como bem exemplifica os trabalhos para recuperação de terras - tende a prescindir da "grafia" do artista, da autoria, e dilui-se na trama de objetos e ações da paisagem.

159. Angelo Venosa.

Baleia, 1990. Desde 1998, na praia do Leme, Rio de Janeiro

Fonte:

http://vejario.abril.com.b r/especial/site-reuneobras-de-arte-das-ruasdo-rio-729338.shtml

rioartecidade.com $\mathrm{br}$

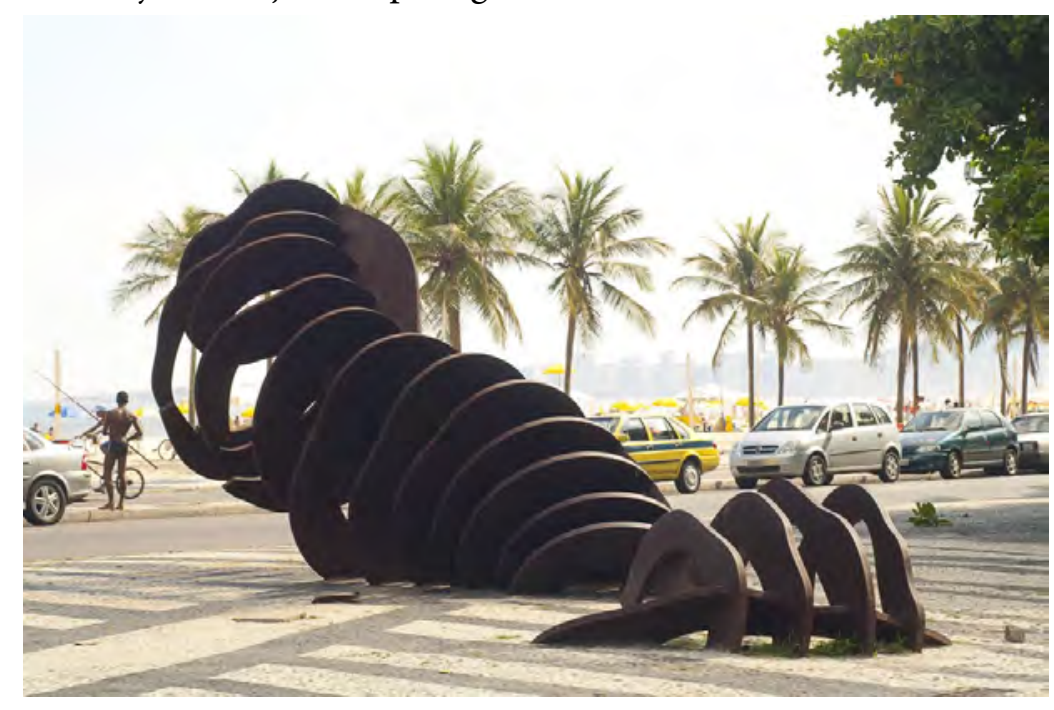

543 ARCHER, 2001, p. 86 Sobre a importância do discurso das instituições, do mercado, das editoras e da crítica que envolvem a arte cita "[...] Michael Foucault, o maior responsável pela elaboração da idéia de discurso durante este período, descreveu-o [...] como práticas que sistematicamente formam os objetos sobre os quais falam".

544 BEARDSLEY, 1998, p. 34. 
160. Waltércio Caldas. Escultura para o Rio (1996)

Av. Beira-mar, Rio de Janeiro. Pedra e concreto, $1000 \times 1000 \times 600 \mathrm{~cm}$

(Fonte imagem: http://www.facebook.com/ARTINFO Brasil.)

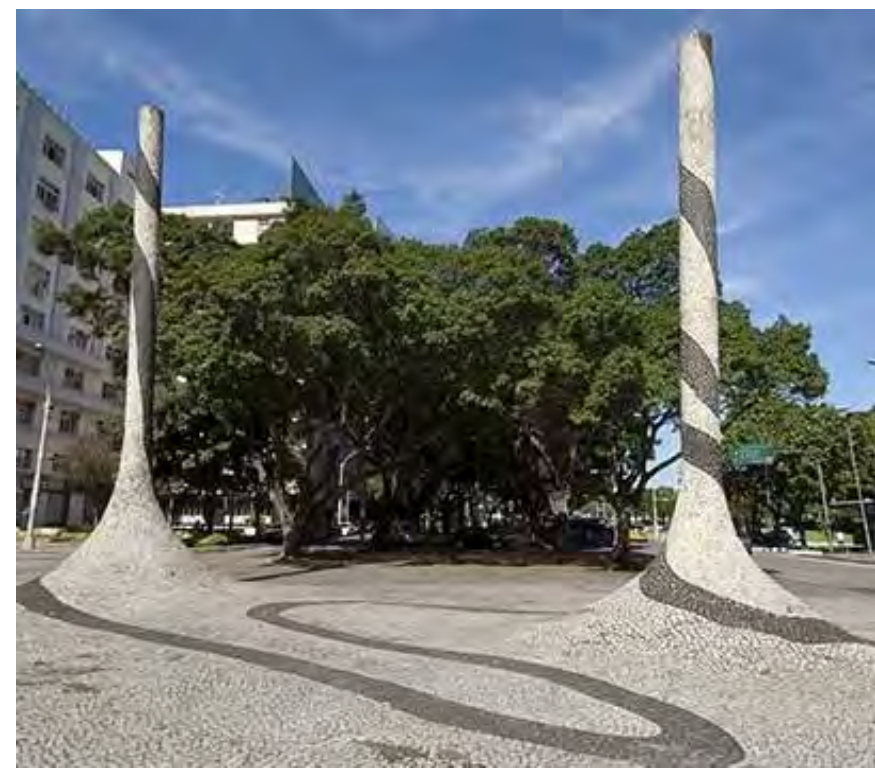

O fato de a escultura pública ser instalada em um local público não significa que ela precise gritar para ser ouvida; ela não precisa se render a uma demanda de comunicação estranha a si para ganhar dimensão pública.

O ambiente urbano engole tudo o que busca uma negociação com ele. (Waltércio Caldas. Fronteiras, 2005, p. 230 e 234)
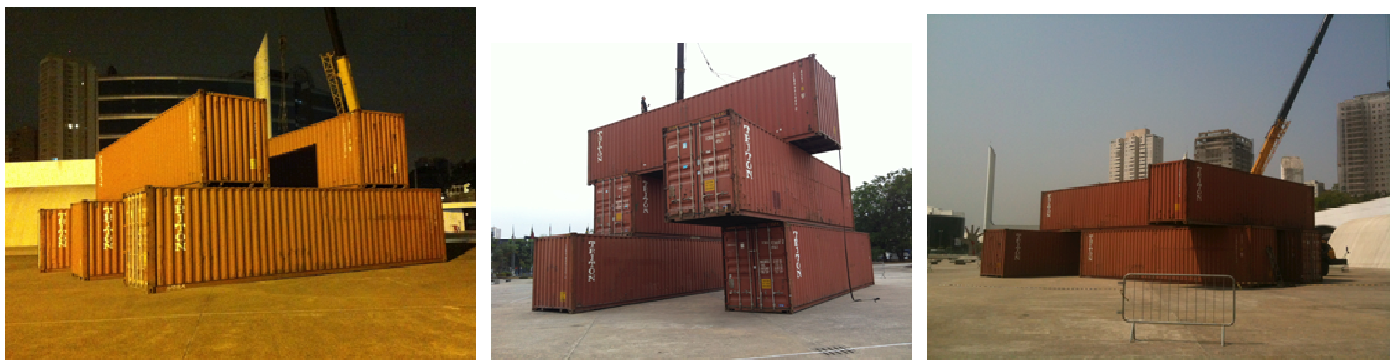

(Fonte: http://www.facebook.com/pages/Canteiro-de-Opera\%C3\%A7\%C3\%B5es/353071871440762)

No Memorial da América Latina, cinco containers de transporte de carga foram empilhados e rearranjados durante seis dias, em 18 posições diferentes. O experimento testou diferentes modos de estruturação e equilíbrio. Paralelamente, no ramal ferroviário da Mooca, os vagões abandonados ao longo dos trilhos, entre as estações Mooca e Ipiranga, serão cobertos com tela sintética, como a usada para cobrir a fachada de prédios em reforma, destacando-os da paisagem de muros e galpões industriais. 


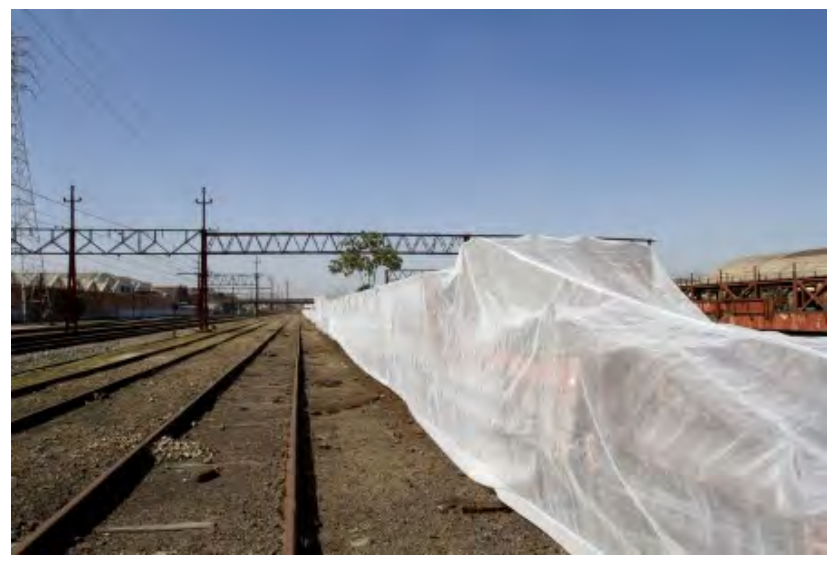

\section{José Resende. Canteiro de Operações.}

11 a 16 set., 2012. e 11 a 16 de setembro, na Praça Cívica, Memorial da América Latina e Mooca, linha férrea.

José Resende, Nelson Brissac Peixoto e Heloísa Maringoni
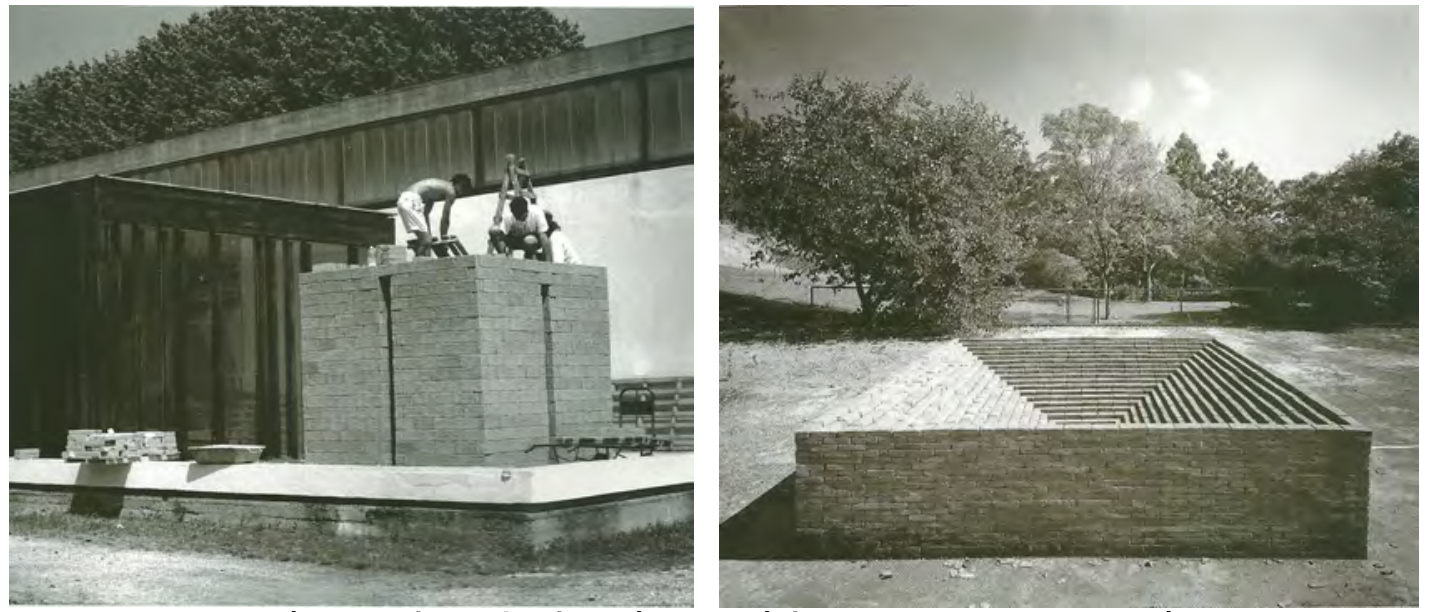

162. Carlos Fajardo. Cubo de tijolos. Bienal de Veneza, 1993 e tijolos, 1989

(Fonte: catálogo Carlos Fajardo. Petrobrás. São Paulo, 2003)

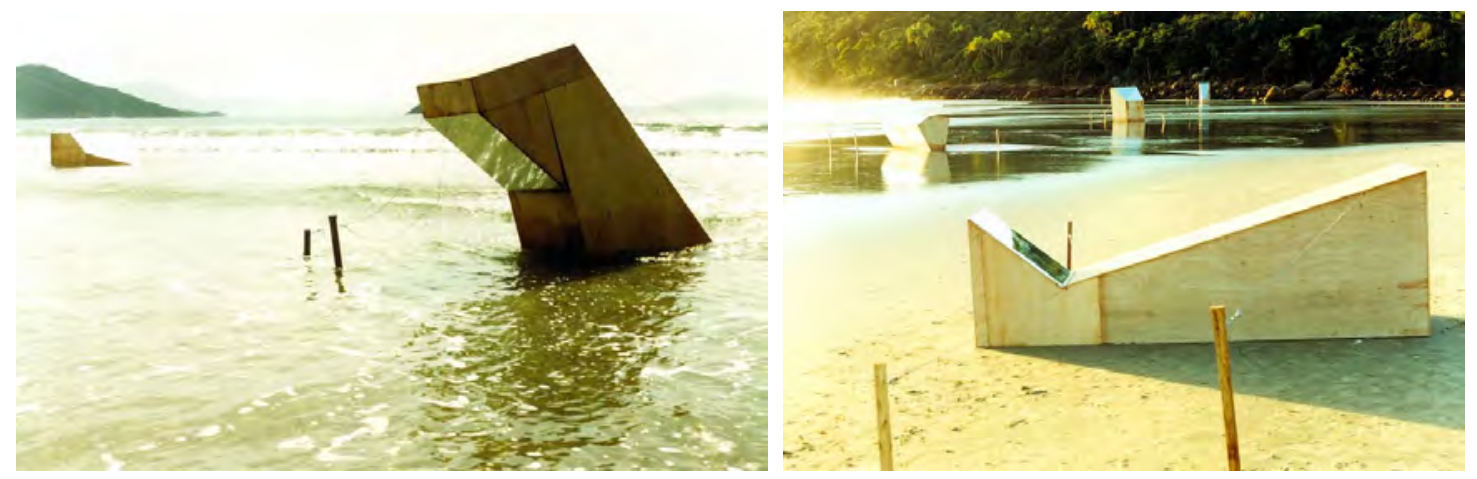

163. Nuno Ramos. Marécaixão, 2000.

Na maré baixa, esculturas de compensado e espelho são presas à areia por cabos de aço. Com a subida da maré, as esculturas são parcialmente submersas

(Fonte: http://www.nunoramos.com.br/portu/comercio.asp?flg_Lingua=1\&cod_Artista=100

\&coSerie $=47$ ) 


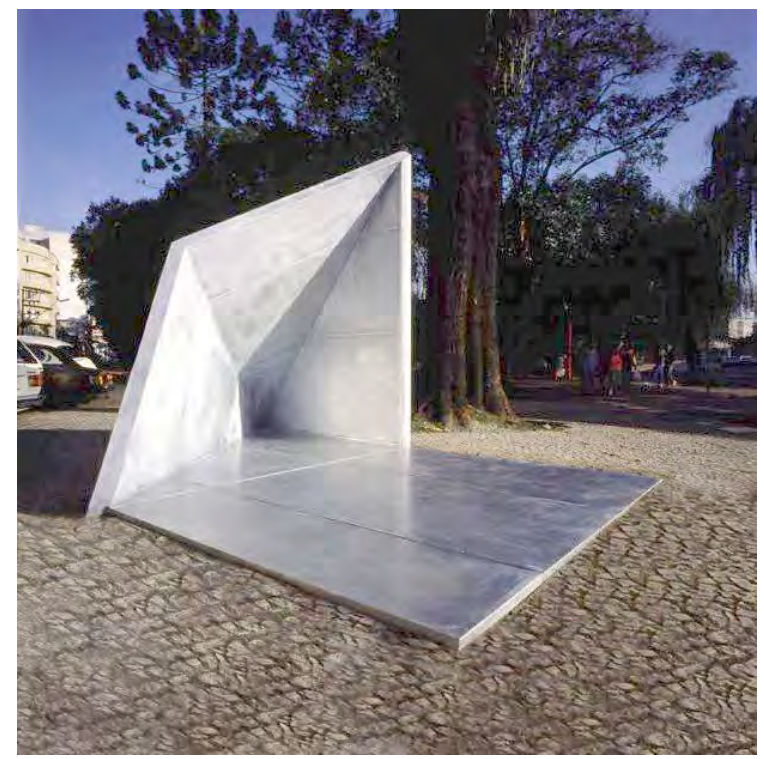

164. Eliane Prolik. Canto I, 1992.

(Fonte: <http://www.muvi.advant.com.br/artistas/e/eliane_prolik// escultura_publica.htm>. Acesso em: 20/12/12).

Os Cantos, poeticamente, eram uma espécie de acontecimento ou lugar contrário à ideologia de circulação encontrada nas metrópoles, pois neles podia existir o devaneio, o silêncio, a parada. [...] Cantos foram realizados entre a escala do corpo humano e a arquitetura da cidade e foram instalados em ilhas de calçamento ou sobras urbanas de modo a estabelecer laços com o cidadão. Eles envolviam o corpo do sujeito. Propunham a experiência de uma interioridade citadina [...]. (Eliane Prolik, Corpo escultórico. Fonte texto e imagem:http://www.muvi.advant.com.br/artistas/e/eliane_prolik// escultura_publica.htm> Ascesso em 20/12/12
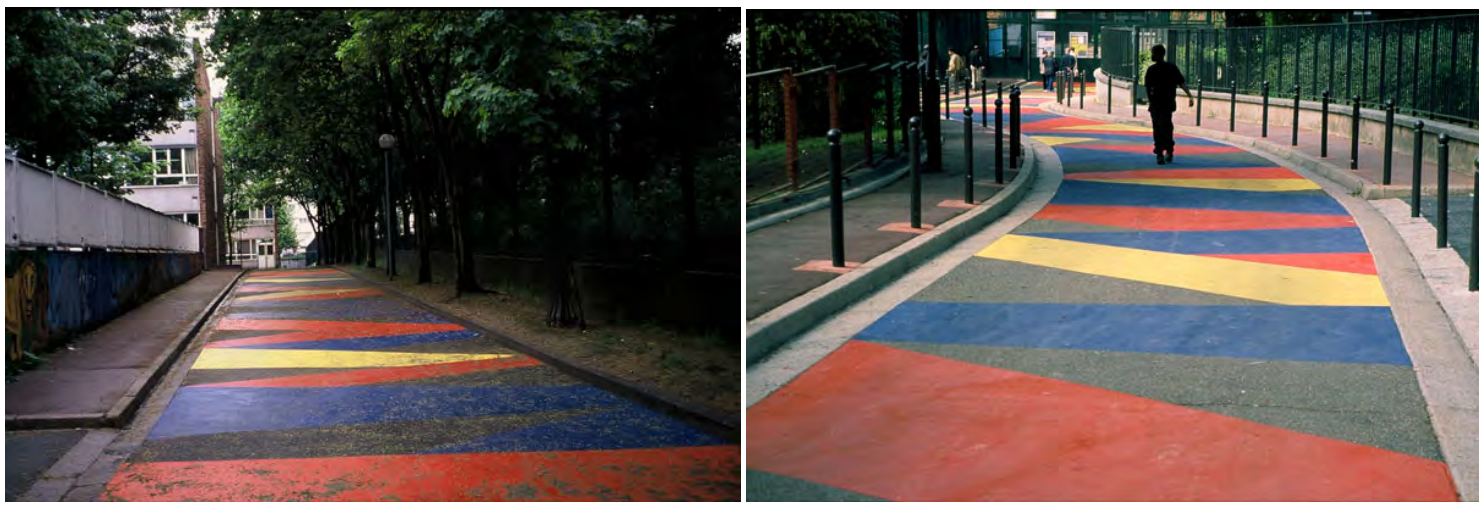

165. Carmela Gross. BLEUJAUNEROUGEROUGE, 2004. Intervenção arquitetônica permanente na fachada e nos arredores do edifício da Escola René Binet, na cidade de Paris, França.

(Fonte: www.carmelagross.com.br) 


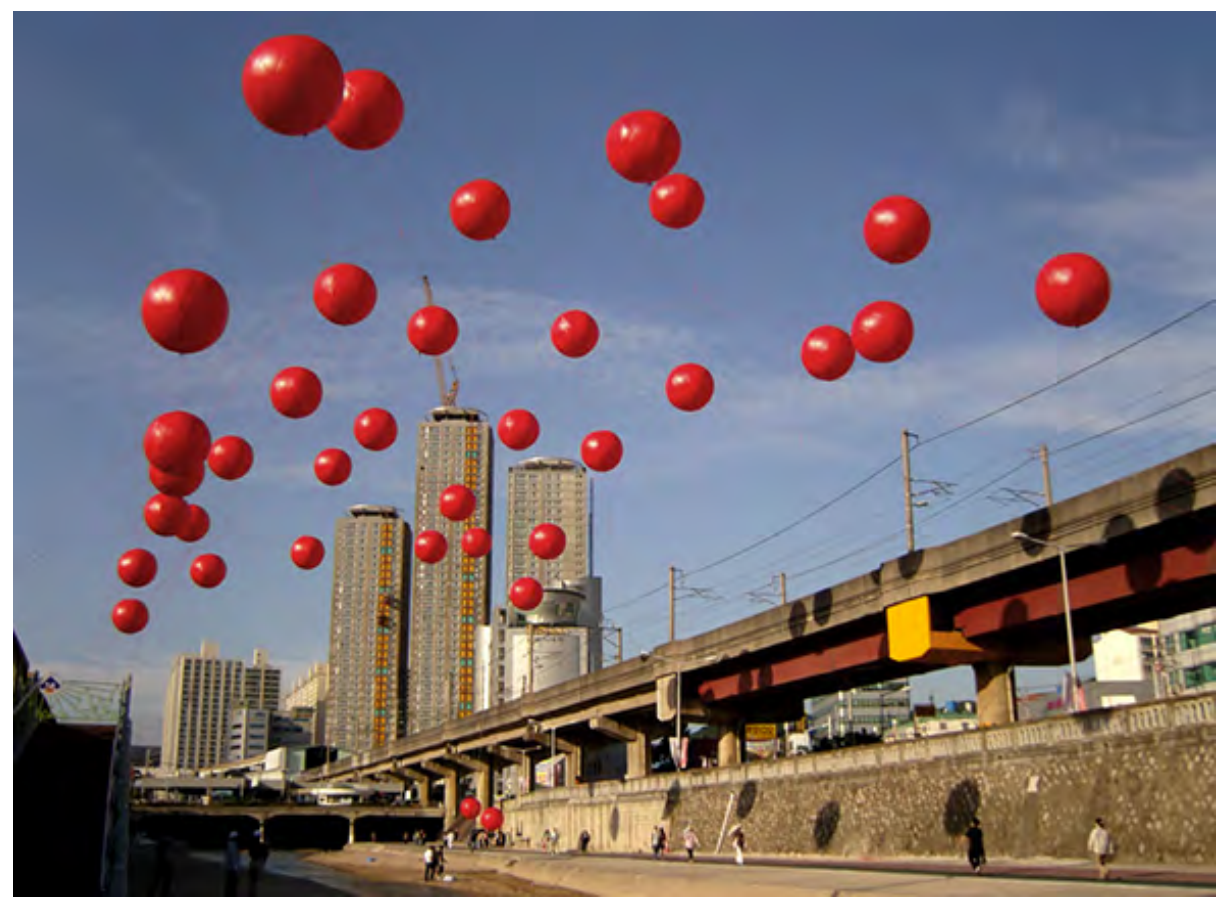

166. Hector Zamora. Topografia Volátil. Coréia do Sul, 2006. (Fonte imagem: <http://www.scapebiennial.org.nz/scape/>) 


\title{
Considerações Finais. A paisagem em debate na arte.
}

\begin{abstract}
$\mathrm{Na}$ arte visual, o momento estético é aquele instante fugaz, tão breve a ponto de ser quase infinito, em que o espectador está de acordo com a obra de arte que está olhando, ou com a realidade de qualquer espécie que o próprio espectador vê em termos de arte, como forma e cor. Ele deixa de ser seu eu comum, e o quadro ou construção, estátua, paisagem ou realidade estética não mais está fora dele. Os dois tornam-se uma entidade; o tempo e o espaço são abolidos e o espectador é possuído por uma percepção. Quando recobra a consciência rotineira é como se tivesse sido iniciado em mistérios iluminadores, exaltadores e formativos. Em resumo, o momento estético é um momento de visão mística. (BERENSON, Bernard. Estética e História. São Paulo: Perspectiva, 1972, p. 82)
\end{abstract}

$\mathrm{Na}$ arte contemporânea da paisagem, a expansão da sensibilidade que podemos experimentar na presença imediata do mundo ${ }^{545}$ ou o momento estético - conforme apresenta Berenson - nasce da convergência entre a experiência da paisagem e da apreciação estética da arte que, juntas, reforçam o sentimento de presença e de pertencimento do indivíduo no mundo, diante da natureza e dos históricos processos que a transformam.

Mas não é só a experiência estética que esta arte suscita-nos. Principalmente, ela leva a refletir sobre valores e dinâmicas culturais que são formadores da paisagem, espelhando a "complexidade de nossa relação com a paisagem e natureza" ${ }^{546}$. Uma vez apreendidas, arte e paisagem, se permanecerem em nossa memória, nutrirão nosso repertório de pensamentos, ações, percepção - nossa matriz cultural, nos termos de Berque ${ }^{547}$, novamente formadora da paisagem.

A paisagem na pintura - do Renascimento ao Neoclássico - evocava a composição harmônica, o Belo, modelando-se em equilíbrio entre o natural e o construído. Nela, podíamos repousar nosso olhar, nossa consciência. Com a paisagem Romântica, a natureza e seus fenômenos sobressaem-se sobre o construído e a apreciação evoca o Sublime. Na arte contemporânea da paisagem, a partir da segunda metade do século XX, a paisagem deixa de ser apenas uma composição a ser contemplada e passa a ser também o suporte da própria obra que, além de dialogar com os aspectos formais e estéticos, aborda os processos econômicos, políticos e culturais da mesma.

\footnotetext{
545 BESSE, 2006, p. 7. "a experiência imediata da presença do mundo supõe uma expansão da sensibilidade".

546 TUFNELL, 2006, p. 15.

547 BERQUE in CORRÊA, RODENDHAL, 1998, p. 85.
} 
Por vezes, esta arte evidencia os aspectos mais incômodos da formação da paisagem. Assim, Errante e Cabaré Chinelo, de Margem, mostram-nos como os elementos naturais têm sido reduzidos a fonte de recurso e como são tecnicamente subjugados na produção das paisagens brasileiras. Fronteira, Fonte, Foz e Pálio I e II, de Fronteiras, acabam por evidenciar que muitos de nossos espaços públicos são nesgas de terrenos desenhados conforme interesses (ou desinteresses) imobiliários, viários.

É possível a arte da paisagem desenvolver-se em lugares que não acolhem, lugares que nos são indiferentes? Ou em lugares cujo histórico de construção e organização do espaço esvaziou-se de referenciais culturais, simbólicos, em favor da técnica e do utilitário? Vimos que os lugares qualificam a paisagem e lhes conferem um caráter distintivo. Sem elos com o espaço significativo, praticado, permaneceremos presos a paisagens como a Passaic de Robert Smithson, à margem da arte, ou restaremos com imagens "ligadas a expectativas vagas e distantes $^{1548}$ de cartões-postais.

Algumas das obras dos projetos Fronteiras e Margem inseriram-se em "nãolugares ${ }^{449}$. Mas, de modo surpreendente, mesmo dentro deste contexto, por meio da ação e do olhar artístico (que cria significado, tece relações, e investiga origens) elas não evitaram conformar a paisagem. Esta, impregnada pela natureza esquiva destes lugares, pouco ou ainda não artializados, permaneceu mais no campo das ideias configurando-se, principalmente, no nosso espaço mental.

A aderência da obra em relação ao lugar é fator que diferencia a arte contemporânea brasileira ligada às questões da paisagem das obras da land art. As obras brasileiras pouco solicitam as especificidades do lugar, físicas ou culturais. Como sintetiza Nuno Ramos, a arte pública contemporânea no Brasil, da qual a arte da paisagem participa, aproxima-se de "uma indeterminação que era própria do modernismo" ${ }^{n 50}$. Se por um lado algumas obras de Fronteiras e Margem não atentaram para as questões do lugar em específico, por outro, a maioria buscou na atmosfera da paisagem, essência que a singulariza e a distingue da

\footnotetext{
548 LEITE, 1998, p. 79.

549 Lugares que não são identitários, relacionais, históricos. AUGÉ, Marc. Não-lugares. Introdução a uma antropologia da supermodernidade. Campinas: Ed. Papyrus, 2007, p.73.

550 Nuno Ramos. Seminário Internacional de Arte Pública. 17/09/2009. O artista cita como exemplo de obras ligadas ao lugar a Spiral Jetty, 1970, e a obras de Richard Serra, como Tilted Arc, 1981. ITAÚ CULTURAL. Seminário Internacional de Arte Pública: A cidade e suas margens, 17/09/2009. DVD IC EVE FV 486. Acervo Midiateca Itaú Cultural.
} 
natureza bruta, seus pontos de contato. Esta imaterialidade que circunscreve a paisagem é similar àquela que emana da arte.

Elos entre a paisagem e as obras estão principalmente nos elementos naturais, que se mostraram estruturadores, tanto para a concepção, como para leitura das obras. Os referenciais da natureza foram e continuam sendo poderosos símbolos para a arte. Diante do descampado e do desconhecido, o movimento do sol como referência ritmada continua a amparar nossa percepção do meio.

Vimos que em países onde há uma cultura paisagística formou-se o que conhecemos por land ou environmental art, uma arte que incorpora a paisagem em seus aspectos naturais $\mathrm{e}$ culturais e que, há aproximadamente quarenta anos, tem se transformado e reinventado. Esta arte se desenvolve onde a produção artística é valorizada na medida em que se valoriza a paisagem. Percebemos que o que cria um forte elo entre a arte e a paisagem é o fato destas paisagens já serem simbólicas, mesmo que rarefeitas ou silenciosas. São assim o deserto de Nevada e as pedreiras abandonadas (diante da necessidade de recuperação de terras) para as obras de Robert Smithson, a Cordilheira do Himalaia nas andanças de Richard Long e a área rural e bosques escoceses para a escultura de Goldsworthy. Paisagens já preenchidas de história, já artializadas, pela fotografia, pintura, cinema ou literatura, pelas ciências humanas e nossas vontades.

No Brasil, esta arte acontece graças a motivações individuais e em uma produção esparsa, assim como em raras exposições temáticas que a incentivam, como foram Fronteiras e Margem. Talvez, para compreendermos melhor nossa arte contemporânea da paisagem, seja necessário determo-nos em profundidade nas obras de Frans Krajcberg e Helio Oiticica, que têm muito a dizer sobre a maneira como nos apropriamos de nossas paisagens e como não a queremos ver. Estes artistas expõem o paradoxo brasileiro que, "enquanto valoriza as imagens da natureza e as suas paisagens, assiste com condescendência à degradação de suas paisagens". ${ }^{551}$

No decorrer deste trabalho, revelou-se uma outra problemática, que diz respeito às acepções do termo paisagem. Por remeter a uma pintura histórica que, de um modo geral, exaltava a natureza brasileira como recurso, o tema da paisagem é evitado ou considerado anacrônico ${ }^{552}$ em relação à arte contemporânea brasileira. As camadas históricas da pintura

551 CASTRO, Iná Elias. Paisagem e turismo. De estética, nostalgia e política. In: YÁZIGI, 2002, p. 122. 552 Conforme vimos no Capítulo 1, e mais adiante no Anexo I. 
de paisagem parecem distanciar arte e paisagem na produção contemporânea. Mas por que atrelarmos a paisagem ainda à sua condição de representação ou pintura de natureza?

Ponderamos o quanto nossas paisagens carecem de transformações e reflexões promovidas pela arte. Temos na pintura de paisagem, desde o séc. XIX até a Vanguarda Modernista, muitos exemplos de artializações in visu, mas tais transformações (ou padrões) através da arte parecem não terem seguido o ritmo das transformações de nossas paisagens. Encontramos mais facilmente dentro de museus e galerias exposições temáticas sobre Natureza e Paisagem.

Apenas no período em que se desenvolveu este trabalho, aconteceram cinco importantes exposições, que também propuseram debates sobre a temática natureza $e$ paisagem -, incluindo o próprio projeto Margem (2009-2010) Estas evidenciam uma tendência presente em outros países, que apresentam suas retrospectivas da land art e refletem sobre a arte, que nas últimas quatro décadas, percorreu "da arte da terra à arte ecológica"553. São elas:

Ecológica (MAM-SP), 2010, sob curadoria de Felipe Chaimovich que escreve:

[...] a arte contemporânea tem responsabilidade sobre os equívocos atuais da política ecológica, pois foi a arte que gerou o jardim ocidental, gênese da ilusão do proletariado urbano de que o mundo deve permanecer como um lugar harmônico. (Catálogo ECO lógica, 2010:13)

I Seminário Internacional Arte e Natureza (Instituto Goethe), 2011, sob coordenação do Prof. Dr. Hugo Fortes, que abordou a natureza como produção cultural e a relação arte e meio ambiente:

[...] A arte, como forma de conhecimento sensível, oferece sua contribuição para a tomada de consciência das possibilidades e das dificuldades de relacionamento do homem com o meio ambiente. No atual contexto tecno-científico, a arte incorpora a ciência e seus procedimentos, produzindo imagens de mundo contaminadas pelas percepções culturais, midiáticas e científicas. Olhar e discutir a natureza a partir deste novo paradigma é nosso objetivo. (FORTES, Hugo. org.)

553 Em 2008, a Cornell University promoveu uma exposição em homenagem aos 40 anos da Land Art: From earth art to eco art (Da arte da terra à arte ecológica). (Nota no Capítulo 2). 
A mostra Poética da Natureza (MAC-USP), 2009, que "discutiu a partir dos módulos, A natureza da Paisagem, Águas e Umidades, Denúncia e Reconstrução e Natureza Inventada, a paisagem pela perspectiva de 48 artistas contemporâneos." ${ }^{554}$ Aqui, a "paisagem" adquire uma elasticidade de significados e, principalmente, apresenta-se como representação na pintura e na fotografia. Semelhante ao projeto Margem, esta exposição propõe a aproximação da arte contemporânea brasileira com meio ambiente, através de uma reflexão entre as interações entre eles ${ }^{555}$.

A mostra Arte Frágil Resistências (MAC-USP), 2009, apresentou artistas brasileiros e franceses, cujas reflexões fossem ligadas "direta ou indiretamente a temas da natureza em sociedades urbanas e industriais" ${ }^{\prime 56}$. Sob organização de Lisbeth Gonçalves e Jacques Leenhardt, que escreve:

\footnotetext{
Nossa exposição realiza-se sob o auspício de Frans Krajcberg e Pierre Restany, que por meio da produção do Manifesto Do Rio Negro (1978), abriram uma nova perspectiva na história da relação dos artistas com a natureza. (Arte Frágil Resistências, 2009:27. MAC-USP)
}

Vimos que há semelhanças formais e conceituais entre as obras da land art agrupadas nas vertentes integração, interrupção, envolvimento, imaginação com as de Fronteiras e Margem. Contudo, não há exemplos que se enquadrem na vertente implementação, cujas obras abordam ou intervêm em questões ambientais ou urbanas, e para as quais a natureza "não é uma tela em branco ou uma fonte de exploração infinita, mas um sistema dinâmico que interage com as estruturas sócio-políticas" ${ }^{1557}$. Elas tratam da expansão urbana, desperdício, terrenos degradados, entre outras questões. Dentro desta temática, há aproximações com a proposta do projeto Margem, contudo, a exposição brasileira restringiu-se ao papel crítico desta situação, enquanto boa parte das obras desta vertente "combinam uma crítica incisiva com práticas e estratégias remissórias (de melhoria) que podem ser realizadas pelo indivíduo." ${ }^{\text {558 }}$

\footnotetext{
554 CANTON, Kátia (org.). Poéticas da Natureza. MAC-USP, 2009.

555 Ibidem.

556 GONÇALVES, Lisbeth R.; LEENHARDT, Jacques (org.). Arte Frágil. Resistências, Catálogo, São Paulo, MAC-USP, 2009

557 KASTNER; WALLIS, 1998, p. 17.

558 Ibidem, p. 136.
} 
Segundo Yázigi ${ }^{599}$, a arte potencializa a relação paisagem e história e apenas ela "consegue vivificar o sentimento que nos liga ao meio". A arte contemporânea da paisagem, portanto, é um forte indício para analisarmos a relação do indivíduo ou de uma sociedade com a paisagem, em determinada época. Este trabalho propôs-se a estudar, através de alguns exemplos da arte contemporânea brasileira, sentimentos que matizam esse meio que compreendemos como paisagem.

No Brasil, a arte contemporânea da paisagem espera por mais brechas a ocupar, por possibilidades de se enraizar, para que possa elaborar paisagens que criem elos de identidade com indivíduos ou com a sociedade. Estas paisagens, aquelas que simplesmente gostamos ${ }^{560}$, seja pela artilização, seja pela apreciação desinteressada, são repertório estético e simbólico para novos projetos.

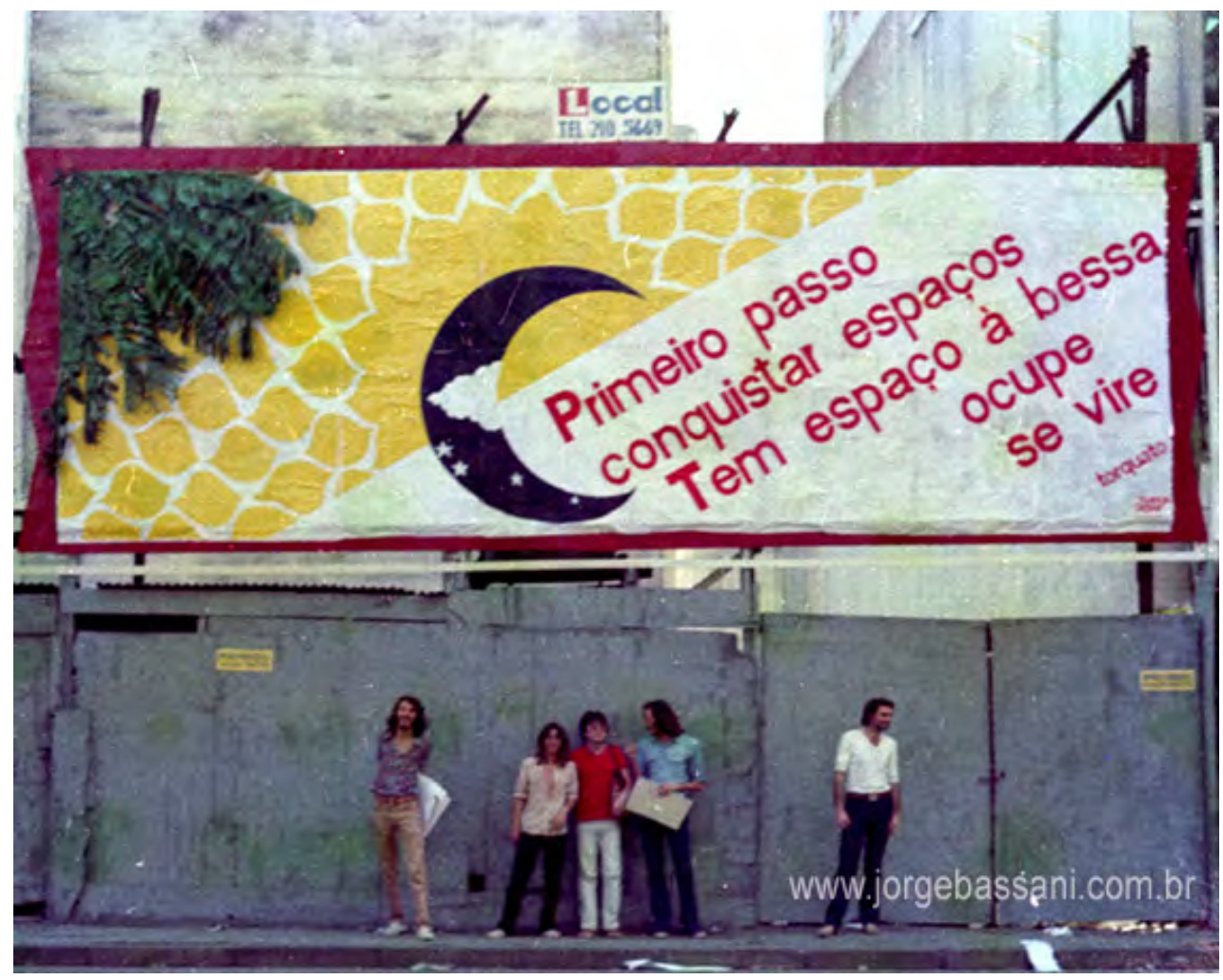

167. Grupo Manga Rosa e artistas convidados Ao ar livre.

Projeto de ocupação sistemática de placa de outdoor. Rua da Consolação, São Paulo. 1981-82.

(Fonte: <http://www.jorgebassani.com.br/port.php>)

559 YÁZIGI, 2002, p. 14.

560 Como Appleton instiga-nos a pensar sobre a paisagem perguntando por que gostamos dela. Ver APPLETON, 1975. 
ANEXO I

ENTREVISTAS 


\section{Sônia Salzstein, maio de 2012.}

NOTA: Antes de iniciar a conversa, Sônia Salzstein explica que paisagem e arte contemporânea são "anacrônicas". Expus algumas definições de paisagem adotadas para esse trabalho, e a convergência de ambas na arte contemporânea da paisagem que tem como expoente histórico a land art, mas ela faz ressalvas quanto a esta abordagem, pelo termo se "referir à pintura".

. O que o Itaú Cultural, intentava com o projeto Fronteiras (1998-2001), algo como uma comemoração do descobrimento do Brasil? Ampliar os pólos da arte além de São Paulo, Rio de Janeiro? Quais diretrizes antecedem a escolha do tema, artistas e lugares? Na introdução do Ricardo Ribenboim para o Catálogo Eixo Curatorial 98, Itaú Cultural, Fronteiras propunha refletir sobre "imagens de identidade nacional" e "possibilidades de elaboração dos valores culturais", contribuindo para "o conhecimento do Brasil."

Entrei no projeto depois do seu andamento, para escrever o catálogo [a publicação Fronteiras, 2005] apenas, porque já havia escrito sobre o trabalho de alguns artistas participantes.

. O nosso histórico de urbanização parece ser uma justificativa dessa "ação interiorizada" das obras, e do fato delas apontarem para "outros lugares", tenderem ao espaço interior, intimista (arredias ao espaço público,). Quando você fala do nosso modelo de urbanização a partir dos anos 1970 - ampliando vias, implantando rodovias, desmatando, buscando resultados funcionalistas e tecnocratas que respondiam à ideologia da nossa industrialização "pseudo-desenvolvimentista".

Seria isso que nos "amortiza" da paisagem? Parece que é aí que se torna difícil esse olhar "para fora" e se relacionar com o lugar e com o entorno? É a partir daí que nossa arte contemporânea não se integra ou não abarca a paisagem facilmente, diretamente?

No Brasil, é escassa a presença da arte no nosso meio até mesmo na arquitetura, diferente da cultura européia onde desde a Art Noveau, por exemplo, já existe um debate sobre a arte estar na vida moderna [...] A presença da escultura nas cidades brasileiras é muito escassa, a inserção da arte se dá de maneira paroquial.

A iniciativa para a inserção da arte no meio urbano se dá nos anos 1970 - como no exemplo da Praça da Sé, mas a isso não se seguiu uma ocupação. Antes disso devemos, certamente, considerar as obras e projetos de Hélio Oiticica. 
- Sobre a obra que foi retirada do local, $\boldsymbol{O}$ Aleph, como se dá a política de divulgação, de manutenção?

Os trabalhos oferecem uma possibilidade de escala, linha do horizonte... Era desejável que fossem preservados, criando um ambiente cultural. $\mathrm{O}$ acervo deve permanecer, não importa o quão acessível está o trabalho... Para se falar de manutenção, talvez somente quando a cultura da arte contemporânea tiver reconhecimento no Brasil como vitalidade, como cultura. Deveria haver uma ligação deles [dos trabalhos] com os museus mais próximos, um circuito institucional... A dificuldade de acessos deveria ser acolhida dentro de uma política institucional. Não se preservou por uma incúria, uma história brasileira.

- Apesar dos procedimentos industriais, das grandes distâncias vencidas para sua implantação, você com freqüência se refere a "um espaço mais interior", que os trabalhos sugerem um espaço "interiorizado". Gostaria de entender melhor... ou ainda a "interiorização do espaço público"

Os trabalhos tematizam um estranhamento de estarem na amplitude [...] Waltércio Caldas faz um movimento de "recuo", por exemplo. Os trabalhos estão nessas localidades sem pertencimento... porque não há nexos, vínculos entre município, política cultural, etc.

\section{. Como também Mesa...}

Para Felix o espaço geográfico é como um espaço mental.

- Você escreve que as obras de Fronteiras - de um modo geral - foram percebidas como experiências do ilimitado, da indeterminação e da relativização. Quais obras ressaltam a paisagem, ou poderíamos pensar como acontece a relação dos trabalhos com a paisagem? (paisagem compreendida como as transformações da natureza, ao longo do tempo, através da cultura). Vejo em Fronteira, Fonte, Foz analogias com os aspectos físicos da paisagem, simbólicos, o mosaico português na orla...

O Trabalho de Gross não é celebrar a paisagem.

(Salzstein frisa que não há relação com "paisagem", esta não está na essência daqueles trabalhos, e sim a questão pública, de arte pública [...] na "abertura" das obras para aquela escala geográfica em continuidade com a poética de cada artista)

. Até que ponto o texto (de Fronteiras, 2005) é poético, idealizado e perpetua uma idéia de Brasil "a perder de vista"? Por exemplo, você se refere a uma destas paisagens de fronteiras 
como "essa exterioridade irrecorrível, que só se pode oferecer sob a forma de horizontes vazios e resistentes à escala humana".

Não intentei em reforçar este imaginário, como algo romântico se houve essa interpretação...

- De uma maneira geral, apresenta os trabalhos de Fronteiras "arredios à face abstrata e genérica de espaço público", esta que é uma característica da arte pública brasileira. Existe em algumas obras, uma resistência ou uma crítica implícita em relação a ocupar o espaço público e de torná-lo público? De modo a sugerir, então, um lugar de interioridade?

Não considero como um "afrontamento" ou uma crítica, mas como decorrência natural, sintoma, de uma situação extrema para um trabalho... Os artistas trabalharam com uma relação com o espaço que é rara. Pense o artista naquele contexto... ele nem sabe a quem se dirigir, quem será o público, o observador. É neste sentido que a paisagem é rarefeita, é imaginada... No sentido de não haver naquelas localidades, usos culturais institucionalizados, culturais aqui me refiro ao que é relativo ao público da arte. Daí, para o artista, não mudaria se esse ambiente é rarefeito por ser uma fazenda ou um deserto.

\section{2 Angelo Venosa, abril de 2012.}

- Apesar do projeto Fronteiras ter sido uma exposição de grande alcance, não há informações de fácil acesso sobre as obras, por exemplo, saber como estão hoje, o que o público local pensou sobre elas e assim por diante... Pesquisando na net, encontrei o texto do José Francisco Alves (No Limite: Obras Públicas na fronteira co Rio Grande do Sul, 2010) que diz que $\boldsymbol{O}$ Aleph não está mais no Parque do Batuva, isso é verdade?

A informação sobre o sumiço do Aleph é verdadeira. O próprio José Francisco me contou. O projeto Fronteiras faz parte da tese de Doutorado dele e ele esteve lá em 2010, constatando que não sobrou um pedregulho. Na época ele me pediu informações sobre o projeto e gente de lá para contatar e este foi o e-mail que enviei a ele [...] Se você acessar o Google Earth usando a opção de data passada você verá que até meados de 2003 o Aleph era visível no lago do Batuva.

- Há influência da paisagem - seja dos Pampas, de Santana do Livramento ou do parque na criação de O Aleph?

Há influência sim. Histórica não sei te dizer. Há quem perceba (gente do lugar) referência aos muros de pedra catada construídos pelos escravos e usados para demarcar os limites das propriedades rurais. Não houve essa intenção e nem sei 
se estou dando a referência de forma correta. No entanto a idéia de fronteira era algo muito impalpável para mim, algo muito abstrato . Não coisificável.

. Havia uma idéia - uma imagem mental - de "paisagem da fronteira" antes de chegar aos lugares? Uma maneira de ver esse "lugar" ?

Havia o esforço de enxergar alguma coisa que eu não conhecia e não conseguia sentir, perceber. Houve uma primeira idéia que era muito complicada de se produzir e manter e que tentava dar conta desse lugar estranho para mim. Consistiria em ter, em algum ponto da linha de fronteira, uma câmera que olhava para a "fronteira", o lado de lá. As imagens dessa câmera eram transmitidas para uma grande video wall no saguão de um aeroporto internacional (Porto Alegre?). Essa imagem, constante, em tempo real, era dividida em faixas verticais. Digamos... 12 faixas. Cada faixa tinha uma diferença de duas horas em relação à outra, o resultado era que se veria esse "quadro" da fronteira inteiro com diferenças de luz e de tempo. A imagem era uma só mas guardava instantaneamente uma passagem de tempo nela, e essa passagem era constantemente alterada, em tempo real. Estar no aeroporto era marcar a idéia de fronteira como uma linha de separação. O aeroporto é um tipo de experiência de fronteira. Entramos pela porta do finger, sentamos, esperamos e saímos do lado de lá. Dá pra imaginar que não havia grana pra produzir esse trabalho. Aliás, a altura do muro de pedra do Aleph foi definido pela grana.

. A paisagem incorporada em algumas obras da land art parece já ter significados simbólicos e míticos enraizados, que são reiterados pela arte ou repensados por ela, como o deserto norte-americano e os significados de conquista de novos territórios, etc que no momento da contracultura emergem com os earthworks e seus artistas; ou como as montanhas nas paisagens ermas de Richard Long, de modo que tais paisagens já por si evocam significados e associações.

Você comentou, para o catálogo Fronteiras, não querer um lugar que "já tem uma imagem a priori, uma forte conotação simbólica que marca de antemão o trabalho" ${ }^{11}$ É uma busca por um lugar de neutralidade? Uma busca por uma paisagem a ser descoberta? (por um novo olhar ou ainda não reconhecível?). Pois ao mesmo tempo teu trabalho parece não se "impor" sobre o entorno, parece se adequar e incorporar as características deste ambiente e entorno...

Acho que o trabalho quer de um jeito humilde experimentar a fronteira. Aliás, o curioso é que eu imaginava que havia uma espécie the "blur" na fronteira. Uma área de fusão entre paisagem física e humana. Pois bem... fisicamente não há (naquele caso) diferença. Pelo menos quanto à natureza. Já quanto à paisagem humana... Tudo marca a diferença. Cada lado da fronteira usa a sua língua

1 VENOSA, Angelo In Fronteiras, 2005, p. 36. 
mesmo entendendo a do outro. Há uma rua que de um lado é Brasil do outro Uruguai: o meio fio já é diferente, o calçamento. É como água e óleo!

- A experiência sensorial de estar ao ar livre e a experiência estética dos elementos da natureza se somam, no caso da arte na paisagem (uma land art), à experiência estética da arte?

Não sei se somam... Para somar deveria estar separado. E nesse caso é constitutivo. Acho que estamos falando de escala e lugar. De que a escala humana não é só dada pelo corpo mas também pelo construído. Pela arquitetura. Por aquilo que é próprio do homem e se opõe a natureza. E o espaço "natural", imaginado que isso seja possível, natural e intocado pela cultura, pelo homem e sua escala, pode nos propor uma outra escala, um outro lugar. Estamos desabrigados, vulneráveis. Inclusive esteticamente.

\section{3 Nelson Felix, junho de 2012}

Comento sobre as acepções de paisagem para esta pesquisa e sobre a Land Art, que para o artista rompeu e estabeleceu uma nova estrutura para a arte, além de ter sido um "período feliz de exploração do pensamento ... um ganho do pensamento artístico que a apartir de então se desenvolveria". Ele cita artistas que abriram campos para se pensar arte como Mark Rothko, Yves Klein e Joseph Beuys e explica, já de início, sobre a relevância de um trabalho ser ou não site-specifc, como se ao sê-lo a obra se "enquadrasse" em uma certa categoria, em uma premissa de exposição ao invés da pesquisa artística buscar sua essência.

De início, e ao final, Nelson Félix diz que o que importa é a "construção do pensamento plástico". As questões, deste modo, não estão fora da arte - sejam questões do lugar ou da paisagem. Esta, por sinal, adentra "sem querer" o trabalho do artista, pois de início ela é negada para não incorrer na composição e, depois, pelo acaso, é reencontrada em $\mathbf{C r u z} \boldsymbol{n a}$ América.

- Você comenta sobre não tomar o lugar como dado a priori , e assim, evitar fazer uma "composição", por isso escolhe aleatoriamente o lugar, mas mesmo assim Mesa se relacionaria com a paisagem (teve que lidar com os imprevistos de uma área de fazenda, etc)...? a obra faz contato / analogias com o lugar e seu entorno?

Não se trata apenas da composição como forma, como configuração, é a composição como resultado de um processo exterior ...Como um objeto, ou ação que atenda a determinada solicitação (pode ser da instituição, de uma exposição) e então a arte passaria a funcionar como apenas mais uma vírgula no meio do 
texto. Esse texto já está escrito, ou sendo escrito por necessidades alheias à arte, por vezes até antagônicas a ela. Parte daí também questionar os limites da composição

Fronteiras propiciou dar continuidade a um trabalho, "o grande Budha" (19852000) que é a obra mais diretamente ligada à Mesa, e que desencadeou questões que eu trabalharia nos pampas... Se no pampa gaúcho há o "vazio" você vê uma pessoa chegando durante dez minutos... e a amplitude...; na floresta amazônica onde está Budha, no Acre, ao contrário, tudo é matéria, a cada centímetro você esbarra em matéria.

. Mesmo a escolha aleatória do paralelo $30^{\circ}$, que você sabia passar pelas planícies do Sul, trazia já algumas informações sobre o lugar que não são abstraídas... Vemos que Mesa (1999) ressalta a horizontalidade, erguerá sua chapa alinhando-a com a linha do horizonte, ou seja, faz referências às características do pampa como sua horizontalidade e a presença constante da linha do horizonte.

A obra trabalha com o espaço mental que é indiferenciado como experiência de lugar porque não existe essa categoria de espaço - seja na amplitude sem referenciais, nem na floresta, onde está o grande Budha aliás em uma árvore, que é uma unidade, em milhares de iguais. Do mesmo modo, é o espaço que só pode ser mental ${ }^{2}$ - pois não há percepção dele, não o abarcamos, nem percepção do tempo... Mesa (1999) se desenvolverá ao longo dos séculos, pelos processos naturais os quais o homem não interfere e não prevê. $O$ trabalho é a floresta e não se sabe onde vai acabar! Ponto importante é a não ação que fica implícita no processo de transformação do trabalho, uma não ação na paisagem onde o latão (faz analogia ao) é metáfora do pensamento.

Assim como tempo do relógio, as coordenadas são convenções de medição e controle que não existem fora da mente, são "acordos" da mente para reter o incomensurável.

( Nelson Félix fala sobre imaginar o caminho trilhado pelo bandeirante, (não podemos imaginar tal como o bandeirante) uma analogia a trilhar um terreno virgem de pensamento)

\footnotetext{
2 (Sobre essa "categoria", o espaço mental, Nelson Felix contextualiza na história da arte os tipos de espaço com que a obra se relaciona. Quando a obra tem uma forma muito forte (como exemplo escultura de Brancusi) o olho e toda nossa atenção vai ao encontro dessa forma é como se o espaço circundante desaparecesse, a obra situa-se em um "buraco negro" é indiferente ao espaço (lugar e entorno) pois ela tem em si uma enorme concentração de força e pensamento. $O$ espaço circundante, a posição da obra passa a ser relevante com artistas como Rothko, Yves Klein, Helio Oiticica. Com o primeiro, é através da pintura, da superfície de sua obra, que o artista pensa nesse conjunto de ambiente, iluminação, seqüências, criando uma ambientação. Fala-se então na arte ambiental ou ambiente. O trabalho dele está numa terceira categoria, ou dimensão, é mental. Toda a obra é produzida, desenhada na mente, e o "observador" pode imaginá-la, mas não podemos acompanhar.
} 
. Você viajou pelos lugares de fronteira, escolhendo... e decidiu, depois, escolher pelo paralelo 10 e depois 30 ? Ou já foi assim desde o início?

Não, primeiro deu-se a escolha das coordenadas geográficas tal como acontece em o grande Buddha, de onde veio a idéia de trabalhar partindo abstratamente de paralelos.

- Ver a paisagem é ver, talvez, o lugar - com seus elementos naturais e culturais - com significados históricos, afetivos... você, naquele "ponto $29^{\circ}$, reconhecia uma paisagem ou seria, ao contrário, trabalhar com a abstração do lugar?

[...] na arte há a necessidade simbólica de questionar, além de ser impossível obviamente desconsiderar as características do lugar por completo... de modo que ao eleger o paralelo 30 e saber que incidiria no extremo sul, já imaginava a horizontalidade da paisagem. Contudo, tais imagens mentais têm peso muito diverso de relacionar com a realidade dos elementos e fatos do lugar quando ele é ponto de partida para uma obra, para uma intervenção.

O lugar são as camadas de pensamento, o momento em que se vive...sensações aglomeradas de acontecimentos... é mais compreendido como o que vai ser percebido, solicitando sensações e memória e menos como realidade exterior (...) são pensamentos filosóficos sobre o local. Coordenadas também não existem, nem as horas, são acordos de tempo.

Por exatamente evitar a composição, adotando coordenadas geográficas em uma relação filosófica (ou abstrata) com o lugar, e ao demarcar a cruz sobre a superfície terrestre há uma descoberta, uma surpresa de que os quatro vértices incidem sobre paisagens muito distintas e emblemáticas: floresta, pampa, deserto e litoral. Sem querer eu voltei para as paisagens, que era a negação do início, mas neste retorno está a poesia e essa negação era necessária para chegar a elas novamente ... a negação volta como certeza!

É como o jogo de xadrez com a Morte do filme $O$ Último Selo ... se toda a ação vai resultar em composição é como querer adiar esse encontro, ludibriar, e nesse decorrer, nesse adiamento, refletir sobre ele é uma relação mais profunda... vou deixar que essa paisagem entre em mim. Nesse embate com a composição, com o lugar ou paisagem, procura vencer uma estrutura fundamental da vida da arte: a própria composição.

- Creio que Mesa, tem afinidades com algumas obras da arte da paisagem (ou land art como é dita no exterior )- pela relevância que atribui à natureza, aos processos naturais... Você acha que essa interpretação tem a ver? A natureza como processo que se "sobrepõe" ao da arte? ... A apreciação estética (ela ainda existe?) vai em direção à natureza ou à tecnologia? 
A apreciação estética na arte está no sentido de compor um pensamento plástico, na composição do pensamento. A beleza está na estrutura do pensamento, tanto faz se da ciência, filosofia ou arte... É sobre esse pensamento - que se refere e é parte da história da Cultura - se tem a experiência estética[...] Tanto a experiência estética quanto a mística transgridem a natureza, desconsideram , interpretam ou buscam os limites das leis da natureza.

. ... faço uma referência à Maritime Alps (1968) de Giuseppe Penone com o grande Budha, como ambos inserem o metal em um tronco de árvore e esta é um símbolo do tempo, do crescimento, é símbolo e matéria-prima para a arte há séculos. Através da árvore ele transgride a natureza...

A intenção no Grande Budha, não foi usar a árvore propriamente dita. Como em Penone, por exemplo, aliás artista que tenho profunda admiração, mas sim, a floresta, esta extensão de iguais, este espaço cheio, mas sem referência. Para isto tive que utilizar a árvore, elemento formador da floresta, centrar o olhar sobre a árvore. Criar esta referência, para perdê-la nas garras e tornar a perdê-la, já no espaço, depois no tempo,etc, etc.....Vejo ai a poesia do trabalho.

. Fronteiras(1998-2001) foi a oportunidade de dar continuidade, de experimentar algo que você já vinha fazendo? Dá a impressão que tuas obras estão muito ligadas, em continuidade...

(...) Mesa não poderia ter partido de uma idéia de ir fazer uma composição, nos moldes de intervenções "site-specific" conforme anunciado pela instituição e que podem se tornar meros meios para inserir ou compor uma obra. Então, em paralelo com pensamento e poética que já me ocorria, o trabalho compartilha com outros um mesmo tempo (que se perde à nossa percepção e pertence mais às forças da natureza e seus processos).

. Há alguma espécie de visão do sublime nessas paisagens inóspitas, simbólicas.

[Nelson Félix não acha que tem a ver, a visão do sublime é minha, tais acepções do belo estão muito ligadas a moldes já assimilados é querer enquadrar em uma visão que pertence a história da arte.

- Mesa como arte do lado de fora da galeria, do museu, suscitaria no observador uma experiência sensível do lugar, da amplitude, etc... ou não foi pensada para essa aproximação concreta?

A experiência se faz no meu pensamento. Não é uma condição para a obra a experiência do observador na paisagem.

. Por que você comenta que a paisagem do pampa gaúcho é "violenta"? Qual foi a sensação?

...é por ser impactante em sua vastidão, de imediato te interioriza, te esvazia, se você está com um certo pensamento, ele vai sumindo da cabeça ...e há uma relação com solidão. 


\section{4 Carlos Fajardo, junho de 2012.}

O artista comenta sobre os dois primeiros projetos para Fronteiras e sobre a obra instalada em Laguna, relacionando-a com outras obras da sua trajetória e suas impressões sobre a cidade. Falamos sobre land art. Procuramos Sem Título (1993/2001) no Google Earth e o encontramos em uma foto de 2009.

. Você descreve a paisagem de Laguna de maneiras muito diversas de "belíssima" a uma "anti-paisagem"'.

Minhas impressões de Laguna remetem a um "não-lugar". Quando me aproximei da cidade a noite vendo ao longe as luzes dos barcos pesqueiros e pensei que eram as luzes da cidade...é uma paisagem belíssima. É também uma cidade de ocupação sazonal, as referências na paisagem são móveis como as dunas ...não é uma paisagem portentosa... Parece ser "um lugar perdido.

(Nota: As impressões e memórias do artista são ricas em imagens, e parecem configurar uma paisagem imprecisa. Em Fronteiras (2005), o artista descreve bem mais a paisagem, lá interessou-lhe a "atmosfera de rarefação", uma certa noção de vazio imersa em silêncio na maior parte do ano. $\mathrm{O}$ cubo de tijolos "dialogaria bem com aquele ambiente ralo, onde predominam a distância e o vazio do horizonte" ${ }^{\text {"4 }}$ )

. Os dois primeiros projetos tiravam partido da paisagem, estabeleciam mais de um contato com a paisagem. Como eram? E como você acabou escolhendo o lugar para a obra em Laguna?

De início já estava descartada a associação de fronteira com limite geográfico, e sim, foi adotada a idéia de "fronteira" como limite de uma experiência. A primeira proposta foi para as Cataratas de Foz do Iguaçu (PR), fronteira entre Argentina, Paraguai e Brasil, mas que é um lugar tombado, é Patrimônio Natural e depois descobri que não poderia intervir, mas antes disso já havia me desinteressado ao descobrir que o ruído da água não competia com a visualidade da paisagem.

Buscava por uma paisagem impactante e ao mesmo tempo ruidosa - "um barulho pleno e intenso" - para nela instalar uma caixa de vidro com isolamento acústico onde de dentro não se ouviria o som da paisagem: ficaríamos em suspenso e isolados na visibilidade que ganharia, então, potência como superfície. Ao excluir a ação e o som da paisagem a experiência da visibilidade ficaria como que "congelada".

\footnotetext{
3 SALZSTEIN, 2005: 86 e 89, respectivamente.

4 FAJARDO in SALZSTEIN, S. Fronteiras, 2005, p. 87
} 
Essa idéia migrou para a usina hidrelétrica de Itaipu (PR) onde a paisagem, ao contrário de Iguaçu, não é pitoresca, mas igualmente "eloqüente" e o cubo estaria suspenso sobre o vertedouro. Esta proposta também recebeu impedimentos como até, por exemplo, a oposição do Governo do Paraguai que associou a intervenção com espionagem.

Laguna é, então, a cidade sugerida pela instituição, lugar por onde passa a linha fronteiriça do Tratado de Tordesilhas. Não seria mais o cubo de vidro mas o cubo de tijolos de barro, com frestas finas nas superfícies que já havia sido montado em outras exposições. ${ }^{5}$

. O projeto da caixa de vidro ${ }^{6}$ e o cubo de tijolos, formas pré-concebidas e tão particulares na sua trajetória foram capazes de se fundir à paisagem pois foram incorporados pela paisagem, seja como superfície desta "extrema visibilidade, seja pela disposição deslocada naquela paisagem de elementos desconexos.... Tal fato me fez refletir que a obra que atenta às características, ações e objetos da paisagem não necessariamente tem como ponto de partida a própria paisagem, não necessariamente a obra é concebida para determinada paisagem ou lugar.

(Fajardo concorda, diz que é mesmo esta coexistência entre ser autônoma, um "corpo estranho" e se diluir na paisagem, não se impor sobre ela)

. Em Fronteiras (2005) você diz que preferiu Itaipu às cataratas do Iguaçu (também lá percebera que o som da queda d'água não concorria com a visibilidade), pois você não estava interessado no lado "pitoresco da natureza" e buscava o lado "não eloqüente da natureza". Aquela visualidade impositiva (p.80) - da força impactante da natureza - carrega algo do Romântico? Daí referir-se como pitoresco? ( O termo carrega uma conotação "piegas" para a arte contemporânea?

(Mudamos de assunto e Carlos Fajardo comenta sobre a land art não ter na paisagem sua intenção, sua motivação, mas se ela foi para lugares ermos teria sido, sim, uma contestação política e em relação aos donos de galerias que eram a direita política)

. Há influência da paisagem no projeto da caixa de vidro, tanto em Iguaçu quanto em Itaipu, pois exatamente você procurava uma paisagem de "intensa visualidade", mas "impura", ruidosa, além de dizer que a obra é o lugar. No cubo de Laguna, como é a relação com a paisagem? Você comenta algo muito relevante sobre modos da arte se aproximar da

5 Entre elas na Bienal de Veneza (1993) numa versão com 6.380 tijolos 220x220x240 cm e no Paço das Artes, São Paulo,(1997)

6 Fajardo me explica que desde os anos 1960 trabalha com o cubo e com caixas. 
paisagem quando fala que o cubo "ganhou significado ali precisamente por não pressupor uma autonomia escultórica, um valor prévio..." Isso me faz pensar se o simples fato de uma obra não ter essa autonomia, ou narrativa, ela ficaria, então, aberta para incorporar o lugar e entorno...

O cubo não é um monumento e também não apresenta nenhuma condição narrativa, ele permanece na paisagem como um "intruso", quase um monolito - a escultura é subtração da matéria do monolito. Uma solidez, uma "presença monolítica" que contrasta com a paisagem rarefeita, de esparsas construções.

(a paisagem de) Laguna não tem uma afetividade afirmada. Essa afetividade, como vínculo que atribui significados, é também rarefeita e de igual modo o cubo não possui uma dimensão simbólica...

- Você buscou algum referencial simbólico da paisagem, como o farol, para escolher o lugar, a proximidade da obra? (o cubo está na Praia do Mar Grosso, Sul de Laguna quase alinhado com o Farol, distante no mar)

O farol não é um elemento simbólico, é real, tanto se pensarmos a respeito da econômica da cidade que depende da pesca, seja como referência para o turista.

. Parece que a paisagem incorporada por estas obras já têm significados simbólicos e míticos enraizados que são, então, reiterados pela arte ou repensados por ela.

Não vejo associação desta arte com "paisagens simbólicas". Aquelas de Robert Smithson, do subúrbio de Passaic ou os projetos com refugos, estão na "idéia do desprezível"8. A land art foi para o deserto ou lugares urbanos não por valores paisagísticos (o que implicaria refletir como a natureza tem sido transformada pela sociedade, e novos modos de aproximação com essa natureza cultivada), mas, como comentado anteriormente, uma contrapartida ao sistema econômico que manipulava a arte. Ir para longe (do mercado) como uma atitude radical.

\footnotetext{
7 Fajardo, 2005, p. 89.

8 Seria interessante estender essa discussão sobre a paisagem ser ou não simbólica (ou para quem?). Os Monumentos de Passaic descritos por Smithson são anti-monumentos, são objetos sem singularidade ou poesia, portanto não simbólicos. Contudo, eu compreendo que mesmo Passaic como o deserto com sua ocupação histórica são paisagens simbólicas, que expressam valores de uma época ou sociedade, que corporificam anseios e frustrações do homem em relação meio: "todas paisagens possuem significados simbólicos porque são o produto da apropriação e transformação do meio ambiente pelo homem" (COSGROVE in CORREA; ROSENDHAL, 1998: 108).
} 


\section{5 Nuno Ramos, maio de 2012.}

. Por que Barra do Quaraí ou Quaraí? Era necessário que o trabalho estivesse em uma área pública urbana para esse "acervo de arte pública permanente"?

(porque em Ensaio Geral você expõe que em Barra do Quaraí não tem lugar público)

Por que a fazenda, o pasto? É uma reação a essa exigência de público?

(...) é meio impositivo e arbitrário essa proposta de "arte na fronteira". Das opções existentes - dentre as cidades de fronteira - fiquei com Barra do Quaraí, lá por perto, por ter uma paisagem bonita e porque lá nessa estância do Getúlio as pessoas podem ter acesso.

Uma coisa é pensar a fronteira que tem uma questão social intensa ou cultural como a fronteira EAU e México... Tem muitos trabalhos sendo feitos em Tijuana, nessa fronteira, por exemplo. A nossa fronteira não tenciona nada.

- Você vê em Minuano (2000) reflexos da paisagem - literalmente há os do espelho, refletindo o horizonte, sol, as outras pedras, até o gado - mas de uma maneira mais profunda você buscou analogias entre paisagem e obra? Talvez a dispersão - que você frisa o perder de vista, a superfície, esse lugar sem perspectiva, tudo muito parado e então você propõe reflexos, o transitório.... Ou, ao contrário, a paisagem lhe provocou tal incômodo, desprazer, um não pertencimento - às vezes você se refere com irritação à cidade, aos pampas, às pessoas... - a obra estaria alheia à paisagem?

Minuano é uma presença vertical nessa horizontalidade, reflete a paisagem, e a si própria. Minuano é a tentativa de ser uma obra em vários lugares... ele reflete, lança essa imagem, a luz, para além do lugar que ocupa...uma obra independente dos lugares. [...] Nessa arbitrariedade, nessa escassez de recursos, possibilidades, busquei a possibilidade de criar nexos.

. Sobre as obras americanas da land art - você e Salzstein em Fronteiras (2005) falam sobre o trabalho do Michael Heizer e depois sobre o trabalho do Robert Smithson ser visivelmente "americano"... As obras deles são muito ligadas à paisagem, as paisagens são significativas, os representam culturalmente. No nosso caso talvez falte um envolvimento, um reconhecimento da nossa natureza, e por decorrência, das nossas paisagens?

Eu não acho que a land art americana (ou talvez se refira em específico aos earthworks) está ligada à paisagem, que haja um gosto pela paisagem. Há, sim, uma ação extremada de contestar e "cair fora" das instituições de arte - que é exatamente o que nós não temos (as instituições da arte bem desenvolvidas, 
influentes) [...] ou o que começou a ser feito no Brasil há uns $\mathbf{1 0}$ anos mais ou menos. A land art é um deslocamento do lugar da obra, ela vira uma fotografia, etc... "é para ser longe".

A diferença está na resposta política de ir contra essas instituições e mercado da arte em Nova lorque. Então é "pegar uma motocicleta e desenhar círculos no deserto" (se refere a uma ação de Michael Heizer em 1968) não vejo um gosto pela paisagem aí...

. Há sim a vontade de romper, de dar um novo rumo à arte para além de um "objeto de valor", no exemplo do Heizer fala mais alto a transgressão mas, após ações "radicais", floresce rapidamente uma arte ligada à paisagem- há um gosto pela natureza que nós não tenhamos talvez... O Smithson propôs uma arte para conciliar indústria e natureza, e assim também o fez Robert Morris com as "land reclamations", quer dizer, eles sequer separavam cultura e natureza! E logo vem a environmental art, e aí vem outros que como você comentou voltam a natureza para fazer "coisas bonitas" ... Para nós, a arte ligada à paisagem parece ser ligada ao "romântico", enfim, não tem a ver com as vanguardas?

Realmente não vejo a questão da land art como um gosto ou uma ligação com a paisagem mas são outras motivações... Talvez nossa relação com a terra seja mais virgem, é mais como para Euclides da Cunha!

Existe esta ligação, por exemplo, em Frank Lloyd Wright que já integrava sua obra com a natureza muito antes. Já existe na música ... Acho que nossa "land art" é Brasília, é ir para aquele "planalto neutro" e lá fazer um desenho.

. Mas talvez esse "desenho" de Brasília não se integra à paisagem, até se contrapõe a ela...

Sim, se contrapõe mas o que o Heizer faz hoje lá no deserto também não tem a ver com essa "comunhão com a paisagem"...

- Você assinalou algo que acho muito relevante, sobre as obras se inserirem timidamente, e o fato da natureza continua resistindo firmemente.

(Ramos não responde diretamente a essa pergunta e chama a atenção para que seja analisada a estrutura institucional e cultural que propõe e media a arte nesta escala (todo o projeto Fronteiras). A dificuldade nas relações, em criar nexos, debater, com relação à verba, etc... Comenta sobre o "despropositado, essa natureza falha" que ele buscou traduzir por escrito em Diário de Um Trabalho, em Ensaio Geral (2007)

. Você fez projetos para o Fronteiras antes de Minuano? E de onde vem a idéia de Megalitos? 
Sempre gostei desse tema, do arcaico, já tinha muitos livros a respeito... mas não lembro se já era uma motivação para realizar o trabalho de Fronteiras (uma imagem na cabeça antes de chegar lá). Mas antes... eu havia pensado em bombardear um trecho da fronteira e de trabalhar em um pântano afundando uma casa pré-fabricada... Quaraí foi a primeira cidade das possíveis para o trabalho que visitei e já aceitei, apenas não concordo em "fazer uma arte pública" no sentido de obra exposta em espaço público urbano...

. Sobre projeto Margem. Você deu uma Palestra no Itaú Cultural, qual era a idéia do trabalho? Há registros, desenhos que você poderia mostrar?

Chegamos até a um projeto executivo. Esse sim me deixou triste de ser "cortado"... O tema era denso, interessante. Eu trabalharia em Manaus e com o Rio Negro (mas, essas coisas desconectadas, ninguém assume nada...) Comentei com o curador "que idéia boa! Mas acho que vai morrer na praia, na palestra" e dito e feito, depois da palestra já encerraram. Eu tinha dois projetos: um seria com enormes pedras de gelo - 2x3 m- de água do Rio Negro, que seriam enviadas congeladas para cidades como Brasília, Londrina, etc... (a se definir) colocadas em praças públicas, onde derreteriam... Chamava-se Cartas do Negro.

Outro era levar água do Rio para um casarão em ruínas à sua margem e fazer escorrer a água pelas paredes, um apelo cenográfico...

(Comentei a respeito daquela obra do Mark Dion sobre o Tâmisa que teve apoio do Educacional do Museu Tate Galery, que envolveu a população, teve palestras, etc... o quão diferentes são propostas de ligar a arte ao contexto da cultura, da paisagem)

Aqui depois da palestra é como se falassem "já tá bom". (Ramos fala algo sobre posturas...sobre este arbitrário e falho).

\section{6 Eliane Prolik, junho de 2012.}

. Gostaria de saber sobre os trabalhos, primeiramente, em que lugar estão nessa avenida que "divide" Brasil e Paraguai, em qual canteiro pois gostaria de encontrá-las no Google Earth até, para saber "como estão". Você tem uma referência do lugar?

Este canteiro central entre duas avenidas, do lado brasileiro, Rua Paraguai, no lado paraguaio, Av. Dr. Francia demarca exatamente a fronteira entre os dois países. Ele atravessa em extensão as duas cidades. Instalei cada um dos conjuntos em área próxima ao centro, mas em pontos opostos segundo as estradas de acesso 
a Ponta Porã. (uma ficava próxima ao Cassino Paraguaio e a outra próxima ao Hotel Barcelona).

- O que mais me chama a atenção em relação a teu trabalho e Fronteiras, é que Pálio parece ser o que mais lidou com o aspecto político de se inserir na fronteira - com a demarcação política, econômica - pois você escolheu uma cidade com vida nessa fronteira, com comércio e quis se inserir nessa "linha", na dinâmica de lá...Este mesmo fato parece - seja pela mobilidade, trânsito do lugar, etc...-pelas mesmas questões econômicas ou políticas "diluir" a obra parece dificultar fazer uma arte da paisagem, mais que numa área de descampado (considerando cada um com suas adversidades). Como você vê esse "diluir", ou não concorda? (Você teve uma fase de fazer trabalhos mais politizados, fazendo parte de um grupo, tem a ver com isso?)

Pálio já havia sido instalado em outros dois lugares com especificidades diferentes, no último andar a céu aberto junto à silhueta da cidade, no Centro Cultural São Paulo e na calçada junto ao transito de pedestres e veículos da Avenida Paulista. Nesse sentido é uma escultura ambulante, que se adequou bem a essa diversidade de situações. No primeiro caso, inserido num jardim de esculturas, o individuo a percebe recortando a solidez dos edifícios, no segundo, a presença do trânsito acelera o passar entre seus elementos.

Sua visualidade rarefeita está na forma, na matéria e no espaço permeável composto por vários elementos. Em Pálio a ideia de lugar é a tessitura de um 'entre', o que, ao mesmo tempo, promove um diluir-se, deixar-se transpassar junto ao entorno e a realidade. A instalação no contexto urbano de duas cidades que se costuram uma de frente a outra cria uma nova similitude com a obra e a circunstancia viva de demarcações avaliadas nos diversos atos desse cotidiano citadino de fronteira. Talvez o som produzido nas pás alçadas de Pálio (ação do volume vazio, da altura e da flexibilidade de suas hastes e do seixo no interior das pás), desempenhe o papel de tornar esse campo público imantado e propagado.

. Há um dado importante sobre a relação com a paisagem que é o mimetismo que você comenta sobre a obra em São Paulo parecer ou "fazer lembrar" elementos naturais, vegetais e em Ponta Porã as hastes lembram elementos urbanos. Como você vê Pálio nestas duas paisagens? Há estranhamento como um "corpo estranho" ou é esse mimetismo? (Obs.: estou considerando paisagem na sua totalidade de elementos humanos e físicos, culturais e naturais, inclui a ação humana).

Simultaneamente há estranhamento (aquela causada por uma obra de arte) e mimetismo (provocada entre outras coisas por sua visualidade rarefeita).

. Ao escolher o lugar, essa praça ou canteiro central - em Ponta Porã você já tinha em mente instalar Pálio? 
Já, foi me solicitado instalar Pálio, então escolhi essa situação específica de fronteira. Onde a fronteira está presente a cada ato do cotidiano, na vida entre duas cidades de frente uma para outra. Justamente porque ali, se desfaz uma ideia fixa e formal de fronteira, ela é refeita constantemente na vivência das pessoas. Cito um exemplo, o cimento paraguaio era mais barato, então não se vendia cimento no lado brasileiro, todos os artigos eram assim avaliados e de certo modo corrompidos (carros, artigos importados, gasolina, produtos agrícolas e industriais, gado, etc.). Passar para o outro país significava apenas uma quadra de distancia, o outro lado desse canteiro.

. Havia alguma "paisagem de fronteira" em mente antes de chegar /visitar os lugares?

Havia a ideia de ocupação do canteiro central onde a linha de fronteira dos dois países serpenteia, ora mais para cá, ora mais para lá. Interessava-me instalar o trabalho numa espécie de não-lugar, um lugar ainda sem destinação ou uso específico, a prefeitura me indicava a praça onde ficava a biblioteca próximo tb a fronteira, mas não caberia fisicamente nem conceitualmente. Em visita ao local, percebi uma informalidade nas relações, na ocupação, uma urbanidade tímida típica das cidades menores. Havia barracos de comércio em torno, algumas áreas destinadas ao esporte, lixo e falta de arborização ou paisagismo que amenizasse o forte sol e o calor. De qualquer modo, se confirmava que essa grande extensão do canteiro central abrigaria Pálio e dividi-lo em dois conjuntos reiterava a importância da extensão dessa faixa fronteiriça de área urbana, constituindo um paralelo com o movimento perceptivo de seus elementos.

- Você diz:. "A idéia dessa escultura é que as pessoas possam estar dentro dela, possam percorrê-la" Você mostrou um interesse pelo o que os outros - os moradores - pensaram, comentaram sobre a obra depois de pronta, a estória sobre a escola participar do evento...Qual o peso desse "outro" numa obra no espaço público? Como é determinante essa participação, ação humana?

Não havia barreira, pedestal que impedisse ou obstaculizasse o acesso à obra e cada um dos conjuntos instalados se estendia por cerca de uma área de 60 metros quadrados. Seu piso de pedras ou seixos brancos, por coincidência, também era encontrado comumente nas calçadas da cidade, feitas de áreas de cimento intercaladas com esses seixos brancos. Tive contato com funcionários da prefeitura, da secretaria de turismo e esporte (infelizmente no período de dezembro quando ela foi instalada as escolas estavam de recesso) e com o público em geral que circulava no local e acompanhou sua instalação. Ao mesmo tempo, que eles percebiam algo sendo entregue a eles com certa admiração e reconhecimento receavam condições para mantê-lo. Alguns percebiam o som, outras a semelhança com pás de ferro ou ainda associavam a escultura ao universo orgânico. 
Entendo a concepção de um corpo escultórico em relação e interação ao corpo humano, é desse embate e interesse que deriva a poética, a dimensão e a própria questão da obra. Pensando a escala pública, a obra era composta por várias unidades que somavam um coletivo e com isso deixar-se permear e não impor monumentalidade de um volume absoluto e fechado. Pálio foi um título cunhado da ação de se suspender hastes em cultos ou atos coletivos e, derivou também de uma imagem jornalística forte na época do movimento dos sem terra que empunhavam suas pás e ferramentas agrícolas em manifestação. Por me utilizar da matéria do ferro e seu processo de ferrugem no tempo e, do agrupamento de pedras-seixos em seu piso, a obra denota natureza e paisagem.

. O que é determinante na paisagem, na escolha do canteiro central, para decidir onde iria estar a obra?

Um lugar ainda sem função determinada, próximo ao fluxo urbano.

\section{7 Carmela Gross, junho de 2012}

. Tem um trecho da entrevista em Fronteiras (2005) que a mim gera muita dúvida, quando Salzstein (2005, p. 102) comenta que você quis "distanciar-se de uma relação com a paisagem como natureza" e você concorda...

(Carmela remonta à tradição da paisagem na arte, como gênero da pintura, contextualizando-a )... A natureza na pintura brasileira aparece como registro, como documento histórico, para ser reconhecida como território de cultivo, exploração...paisagem para ser apropriada ou como um bibelô para ser apreciada esteticamente....Falar em "paisagem" dá margem a esta produção acrítica. (...)A arte tem natureza social e urbana, se produz nesse meio e a ele se destina.

PS.: No decorrer da conversa, a artista frisa a condição urbana da arte e cita Argan, "História da Arte como História da Cidade", talvez buscando afastar-se de uma interpretação que ligasse obra à paisagem ou natureza. Busco, então, no autor, as referência do pensamento a artista:

Como atividade ligada desde as mais remotas origens (da primeira oposição do ferreiro ao guerreiro, ou, recuando um pouco mais no tempo, do cultivador ao caçador) à burguesia, a arte aparece como uma atividade tipicamente urbana, $\mathrm{E}$ não apenas inerente, mas constitutiva da cidade. ARGAN, 1993: 43) 
(Carmela Gross antes de comentar sobre Fronteira, Fonte, Foz, explica que para participar do projeto fez a exigência de que sua obra tivesse um uso social, e que fosse uma praça e que, de antemão, enviou uma carta à Instituição Itaú Cultural discordando das premissas do projeto Fronteiras e expondo a necessidade da arte em relacionar-se com o lugar, entorno, de entrelaçar-se aos sentidos humanos e usos sociais).

\section{Projeto "Fronteiras"}

Itaú Cultural 1999

Recebi o material relativo ao levantamento geográfico, histórico, topográfico, numérico.. do projeto "Fronteiras". Examinei-o atentamente, encontrando dados importantes que podem ajudar como pano de fundo informacional, mas que me dizem pouco enquanto experiência sensível e visual da situação em questão.

Por este motivo não me senti capaz, ainda, de determinar um lugar, um espaço, um recorte para desenvolver meu projeto (esta dificuldade, aliás, já havia sido transmitida pessoalmente). Falta o contato, o contágio, um respirar "a paisagem" pelo lado de dentro, possuí-la e deixar-se possuir por ela.

Mesmo assim, tenho trabalhado assiduamente na elaboração de pressupostos que constituirão, certamente, o plano de consistência do meu projeto, avaliando algumas referências, conceitos, formalizações, possibilidades..., chegando às consideraçőes que se seguem:

1. para mim, só é possivel "pensar arte" como máquina social e urbana, que se produz nesse meio e a ele se destina, em suas trocas ativas e múltiplas; daí o meu interêsse maior pelas cidades de fronteira, do que pela geografia, uma vez que o trabalho a ser realizado deverá "pertencer" à fronteira em questão.

2. não consigo "pensar arte à distância"; preciso da experiência concreta, direta, corporal, visual, com o espaço que "receberá" a obra, ou se "transformará" na obra - suas vizinhanças, entornos, sombras, que serão componentes indissociáveis dela.

3. penso que toda obra de arte deve ser erigida como monumento (acepção esta que exclui aquela do senso comum que pensa o monumento como o marco da praça pública, comemorativo ou homenagem histórica referencial) e independe da escala, ou melhor, a escala, o lugar, sua materialidade e resoluçōes técnicas formam um único bloco poético.

4. a proposta, que inclui extensão territorial, estados, países, linhas demarcatórias, interfaces geográficas, limites, divisas.. constitui abstração de um macro-desenho que chamamos mapa, mas que diz pouco das trocas pessoais, fluxos inter-subjetivos, sentidos e sentimentos humanos, construções do possivel. 
5. em escala planetária, pensando em uma geografia extensível, qualquer interferência artística envolveria um alto custo, cujo montante não é nem de longe ajustável ao orçamento proposto no projeto.

Daí alguns vetores:

- No sentido de amplitude de atuação, a primeira possibilidade foi pensar a multiplicidade, isto é, produzir o objeto de arte como múltipio, talvez uma espécie de moeda que passasse de mão em mão e que pudesse significar algum valor, não monetário, mas cultural, fenomenal, comunicacional, poético, virtual.

- Outro questionamento importante é a mobilidade; neste caso, usar a estrada como suporte ou veículo para uma interferência artistica, que implicaria em um "olhador" que está sempre em movimento, de passagem, na velocidade.

- Mais ainda, ligar o objeto de arte às construções urbanas que já săo monumentos porque são histórica e socialmente significativos e reconheciveis, funcionando como espelhos coletivos, religiosos, institucionais, grupais, lúdicos - edificios públicos, igrejas, praças...

- Fazer sobressair em edificaçōes urbanas (como a casa, o edificio comercial) relaçōes poéticas pela cor, por interferências simples, buscando uma marca, uma singularizaçăo, um diferencial; fazer funcionar a fragilidade pela repetição e reverberaçāo de sentido.

(Com a carta, reforcei minha interpretação de que Fronteira Fonte Foz se relaciona intensamente com a paisagem, com seus aspectos físicos e humanos, uma vez que a obra se destina "às trocas pessoais, sentidos e sentimentos humanos", além de abarcar "suas vizinhanças, entornos e sombras, que serão componentes indissociáveis dela", assim como "a escala, o lugar, sua materialidade e resoluções técnicas formam um único bloco poético". Carmela Gross faz lembrar que não há paisagem de sobrevôo ${ }^{9}$. A artista se refere a "paisagem"10 vivenciada., a se possuir, a "se respirar pelo lado de dentro").

- Deste modo, é posto em xeque a incongruência e arbitrariedade da proposta da exposição em relacionar a arte com a idéia de "território" e fronteira geográfica, espaços não vivenciais, não perceptíveis.

\footnotetext{
9 BESSE, 2006, p. 92.
}

10 Notar que ela emprega o termo entre aspas para não tomá-la no sentido da visualidade, talvez. 
A obra não está nesta abstração do espaço e tampouco aludiria a uma "fronteira" do Mercosul - uma entidade econômica e política.

. Sobre o desenho no piso e o material.

A figura foi retirada de uma pintura de Piero della Franchesca (1415-1492), e distorcida. O mosaico português, não é porque tem a ver com calçamento de passeios públicos, etc... mas sim pela facilidade de reproduzir - naquela ampla escala - o desenho de curvas concêntricas. Os construtores transpuseram o desenho do papel para o piso utilizando aqueles cabos flexíveis de elétrica, desenhando com os conduítes no piso, um quadrante por vez, assentavam as pedras, um metro de cada vez, acompanhando o desenho. Outro material não traduziria a maleabilidade das linhas daquele desenho. Por exemplo, não daria para ter aquele resultado utilizando concreto.

- Eu interpretava, até então, que as linhas orgânicas da obra tinham a ver com a materialidade fluída e instável da paisagem: a cambiante linha do horizonte entre o céu e o mar, as linhas nas dunas formadas pelo vento, das ondas, enfim, dos elementos visíveis da paisagem (e remete até mesmo às curvas de nível em uma topografia inexistente)... Fazendo reverberar esses movimentos tênues e certa indeterminação da fisionomia da cidade. E interpreto como uma obra muito atenta e generosa para com a paisagem, por não adicionar esse "objeto a mais", uma obra que não se impõe na paisagem. E o fato de usar o mosaico português relacionava com aspectos culturais da paisagem, pois remete ao calçamento à beira mar de Burle Marx, e aqueles das praças secas ibéricas cuja tradição herdamos. Observava uma estreita ligação de Fronteira, Fonte, Foz com o lugar e seu entorno.

Mas a interpretação não está errada... Tem uma autora (Cecília Almeida Salles) que escreve sobre crítica genética ${ }^{11}$ [...] e são interpretações possíveis. Em relação com o mosaico português como elemento simbólico, que remete à calçadão, etc.. sim (ela acena com a cabeça como uma possibilidade) está aí...mas quanto às "curvas", não: curvas sinuosas podem estar em qualquer outra paisagem.

. Não se impor "numa paisagem, a princípio, estrangeira" parece conter algo de reverência à paisagem, uma atenção que está voltada mais para "fora" que para si, para a obra, embora o desenho seja muito forte ...

Mas não é essa a postura, a intenção ...é o fato de querer fazer uma praça, uma arte inserida na vida das pessoas. Interessou-me a condição da obra como

11 SALLES, Cecília Almeida . Gesto Inacabado. Processo de criação artística.São Paulo: Annablume, 2004 
acontecimento urbano e daí, então, a praça...tornar o espaço público vivo, habitável.

NOTA: Já abordamos nesta dissertação que paisagem, por mais que tenha sua essência na natureza, não lhe é sinônimo, ela envolve reconhecer mais profundamente as transformações sociais ou do indivíduo sobre o meio e a percepção do meio. O próprio Argan (1994) desfaz a dicotomia entre urbano e natural ao descrever as paisagens que se estendem modificadas por todo o globo terrestre: " A natureza não está mais além dos muros da cidade, as cidades não tem mais muros, estendem-se [...]". Mas, na entrevista com Carmela Gross, percebemos que paisagem para nossa arte contemporânea carrega o estigma de referência à natureza (na pintura) que lhe fora conferido historicamente. Está em concordância com a fala de Sônia Salzstein. Estas entrevistas indicaram-me que a paisagem pode estar distante da arte contemporânea não apenas como suporte e realidade para ser projetado, pensada; mas, enquanto idéia, devido as acepções do termo.

\section{8 José Resende, setembro de 2012.}

- Salzstein comenta que principalmente após os anos 80 sua escultura se contamina com o espaço da cidade - poderia pensar aí em paisagem - "um espaço fragmentário e incapaz de protagonizar uma condição pública". Você vê motivações/desafios ao relacionar a arte com esse espaço "do lado de fora"? Também vê empecilhos?

A meu ver a cidade esteve sempre presente no meu trabalho, desde o vocabulário de materiais empregados, oriundos de um repertório que é comum na construção civil, defeito quem sabe de minha formação como arquiteto, mas também a relação com o espaço que não é nunca indiferente e em grande parte aliás é o que lhe atribui sentidos, ao ocupar um lugar e uma disposição que não lhe é indiferente. O que ocorreu em 1978, que acredito seja ao que a Sônia se refere, foi a oportunidade de pela primeira vez realizar um trabalho em espaço público na Praça da Sé. Uma placa de concreto pigmentado de preto, uma espécie de quadro negro inclinado, onde esperava houvessem intervenções. Além disso seria uma tarja preta em frente do edifício do Fórum, embora esta locação não tenha sido no final permitida. Ou seja, trata-se de um depoimento passados mais de trinta anos de indiferença total a sua presença ali e da incapacidade de se tornar uma obra pública. Ou seja, a simples presença de um trabalho de arte em um espaço público não faz dessa obra um bem público. 
- Com Evanescente, ${ }^{12}$ você não se relaciona, ao menos não diretamente, com 'espaço urbano", com o lugar mas, com "espaço sem fronteiras do capital globalizado". Acho muito bonito você ao invés de discutir coisas como lugar, ou site-specific, ou questões já que viraram uma "categoria", falar desse espaço do capital e de um "espaço ampliado da cultura" (uso o termo de Salzstein, p. 146). Mas como você o abordou? Você faz uma crítica, sutil e indireta, ao não participar seguindo as premissas da Instituição? Como podemos compreender estas moedas ou a ação de trocá-las, guardá-las como arte?

O "Evanescente" foi uma solução depois de uma sucessão grande de propostas para o projeto Fronteiras que não foram possíveis. A primeira seria intervir no curso de um rio de fronteira, dividindo o curso das águas em dois canais, um de cada lado de suas margens, de forma que uma visão aérea do conjunto seria como ver no solo o sorriso do Man Ray ao pigmentar de vermelho as águas. Dada a impossibilidade de execução pensamos no lago de Itaipu, fronteiriço entre Brasil, Paraguai e Argentina, realizar os mesmos lábios com jorros de água. Seria imaginar dois dos jeux d'au que havia no lago do Ibirapuera, só que inclinados, lançando água um contra outro. No alto conformariam o contorno do lábio superior e seu reflexo na água, o lábio inferior. Com luz ambos coloridos de vermelho. Mas também não foi permitido. Por fim veio a idéia da moeda, pois em se tratando do Banco Itaú, a fariam circular através de suas agências fronteiriças nos três países. Uma das faces seria com a forma de um suspiro, com o nome evanescente que tem a mesma grafia nas duas línguas gravado, e na outra face um polígono que unia o nome dos três países. "Evanescente" tinha a evocação da eliminação das fronteiras, a vontade de uma moeda comum, entretanto o processo inflacionário daquele momento trouxe um sentido critico inesperado relativo a "evanescência", mas dos valores das moedas circulantes no Mercosul. Acho que o Itaú não gostou nada disso.

. Como ocorreu a ação de evanescente? No dia de abertura da exposição colocaram em circulação as 7000 moedas? Onde e quem as deu início a essa ação? Você acompanhou esta circulação das moedas, sabe se elas adquiriram outros valores?

Acredito que não aconteceu. Eu pelo menos não soube. Depois de um bom tempo foi feito um catálogo de capa dura onde inseriram as moedas. Uma solução gráfica horrível a meu ver.

. Sobre tuas propostas para o Fronteiras, gostaria que você comentasse o que achar relevante para entendermos como se dá o fazer arte nesta escala da paisagem.. Ainda sobre a pergunta

12 São 7000 moedas distribuídas no evento da Exposição. De um lado, cunhado evanescente manuscrito "com letra infantil para mostrar que algo está nascendo" e na outra face o mapa do Brasil, com a indicação das capitais do Mercosul. 
anterior, surge uma dúvida, quando você comenta ser um pouco absurdo a obra ter "significado" - como a figura de boca no trabalho de Man Ray (?) - em um trabalho que lida com a paisagem.

"...desse modo, a referência absurda a um "significado" - no caso, a figura do trabalho de Man Ray - em um trabalho que lida com a paisagem desfaz a noção de controle como intenção, embora a realize, mesmo assim, em um outro nível..." (RESENDE, 2005, p.149)

Que significados têm as obras que se integram à paisagem? A paisagem "empresta" sentidos à obra?

A idéia de fronteira é abstrata. Uma linha imaginária. Muitas vezes se concretiza por coincidir com um rio por exemplo. Acredito que salvo em locais muito determinados o noção de fronteira se constitui com clareza. Para a maioria no Brasil o oceano é um limite à leste muito evidente, já à oeste não se dá o mesmo. Relacionar fronteira com paisagem não é uma premissa que seja convincente para mim. Haja vista Brasília que é uma cruz no meio do mapa. O Cildo se desligou desse projeto por que o exército proibiu que ele considerasse "fronteira" e interviesse no Pico da Fumaça, o de maior altitude no país. E não se tratava de uma ação a favor da liberação da maconha. Até aí a noção de fronteira foi mais política do que paisagem.

- Pelas tuas considerações de como implantar a obra que teria o curso do rio desenhando a boca - parece que você já estava na fase de estudos integrados com engenharia, etc... Como foi o estudo pré-implantação na paisagem? E as parcerias com equipes de engenharia, topografia, outras. Gostaria que você descrevesse essas etapas de preparação. Estes projetos com água chegaram a ser negociados para implantação?

Para todo trabalho que ganha proporções maiores a intervenção da técnica se faz necessária em todos os sentidos: desde o cálculo e dimensionamento, até a manufatura e muitas vezes uma engenharia de estratégias de trânsito e montagem.

. John Beardsley em "Earthworks and Beyond", evidencia através da obra Valley Curtain, de Christo, a necessidade da arte da paisagem - seja sua escala a geográfica ou mais pontual integrar uma rede de setores (do político, administrativo ao cultural). Beardsley comenta que as documentações para implantar a "cortina", os alvarás, etc... são também a obra que os artistas documentam. A arte não fica restringida ao seu circuito... Uma vez na paisagem, ela une outros saberes, funções... Gostaria que você comentasse sobre isso, tendo em vista tua experiência em obras que se integram à paisagem considerando suas necessidades, valores 
sociais, culturais, como você bem considerou em "Olhos Atentos" no Guaíba (RS), ou até tuas obras para o Arte Cidade, em São Paulo. Parece que você começa a falar sobre isso em "não se pode averiguar a sociabilidade de um trabalho"13.

As implicações de ordem institucionais sempre se fazem presentes e influentes quando o trabalho de arte disputa locais que extravasam àqueles convencionados para este fim, mesmo no interior em instituições destinadas a abrigá-los. O que se dirá em espaços públicos. Aliás que pese em contrário e muitas vezes com razão, pois certas intervenções acobertadas pela denominação de "obras de arte" ocupam com freqüência de forma prepotente e irresponsável espaços urbanos.

. Como ou por que a arte pode ou consegue se integrar com a paisagem? Quando então, a obra, incorpora seus elementos naturais e/ou culturais e a dinâmica daquela paisagem... Você comenta sobre a escultura que você fizera para a Praça da Sé, e os outros trabalhos, "estão ali, soltos no mundo de maneira insignificante"14 ...Existe um limiar para que a arte esteja assim solta ou fazendo parte da paisagem?

Como comentário final acho importante que se faça uma definição mais precisa de "paisagem". A "Land Art" americana se relaciona a uma tradição daquele pais muito específica, seja uma razão ligada à história (a conquista do oeste), à sociologia e à política como idéia de Nação e inclusive arraigada na literatura (Wall Whilman). Natureza e Paisagem são atributos muito específicos daquela cultura. Aqui natureza e paisagem ainda estão mais para Macunaíma. Dorival Caymmi fala, mas só do mar ou de uma Copacabana que já não existe mais. E, como o pais é muito desigual, a paisagem que é urbana, talvez esteja mais para Blade Runner.

\section{9 Hector Zamora, maio de 2012.}

- O curador comentou que você tinha, primeiro, um projeto para o Edifício São Vito, gostaria que você comentasse suas motivações, inspirações para este projeto.

O projeto consistia em construir um restaurante de alto padrão na cobertura do São Vito. A ideia era que fosse um espaço exclusivo para a elite de São Paulo, o acesso seria só pelo ar, de helicóptero, tudo chegaria ao restaurante pelo ar, incluindo a comida, água, etc.. para mantê-lo funcionando, o contato com o

\footnotetext{
13 RESENDE, 2005, p. 150

14 Ibidem.
} 
chão não existiria, eletricidade seria gerada por geradores...enfim uma ilha para milionários naquele contexto.

Sim foi a primeira proposta que desenvolvi para o projeto margem, acho que com a descrição do projeto ficam claras as minhas motivações e inspirações..claro que o itaú não topou fazer porque a critica atingia eles mesmos...

. Havia necessidade de intervir diretamente nos rios?

não

. Como "migrou" para a proposta para o Tamanduateí?

Foi resultado do trabalho de pesquisa no local e da adaptação de uma ideia que já havia estudado em um projeto anterior na Bienal de Busan 2006, onde também fui convidado para trabalhar em torno a um rio.

.Vendo como se deu a formação da paisagem paulistana - pensando paisagem como as transformações da natureza pela cultura ao longo dos tempos - as sucessivas degradações da natureza, nosso ambiente tão tecnocrata, ...tudo isso vem à tona em Errante - a meu ver... que faz uma crítica ácida a essas apropriações da paisagem....

OK

. De que maneira teu trabalho foi influenciado pela paisagem (seus elementos, sua dinâmica, história)?

A paisagem lá é das mais interessante de São Paulo, e o centro o coração da cidade, e acho que ele mostra de um jeito muito real o que é São Paulo e o Brasil em geral.

. Você gerou essa imagem de "jardim suspenso" antes, ou ele nasceu ali no

Tamanduateí?

Ele nasceu na Coréia do Sul, em um outro contexto, mas ele se acoplou perfeitamente para gerar um discurso mas rico e interessante no Tamanduateí.

. Uma paisagem tão agressiva, onde prevalecem as vias para automóveis, caminhões... Como você pensou a visualidade e experiência do trabalho? É importante ele ser visto, ou como num trabalho de land art/conceitual, ele pode ser visto em imagem, como idéia e não na experiência no lugar, na paisagem?

Uns dos principais motivos que me levou a escolher aquele local é que lá o transito pedestre é muito grande, na passarela do parque Dom Pedro e na ponte da Av. Mercúrio e contando com um fluxo pedestre menor mas constante nas duas margens, sempre pensei a visualidade desde o ponto de vista das pessoas 
que cruzam diariamente naquela região, gosto de confrontar a escala das pessoas, isso não acontece sentado em um caminhão ou carro...

. O curador escreveu sobre a obra não "propor remédio para esse pesadelo", uma crítica a certa visão da arte como algo para "remediar", "amenizar" feiúras, falhas, injustiças... Ali, Av. do Estado, Tamanduateí é tão desumano! Como se inserir, intervir?... Você acredita numa arte, pensando como exemplo Joseph Beuys e os 7000 carvalhos, que intente por mediar certos problemas urbanos/ambientais?

Acredito na arte como uma linguagem que pode trazer problemáticas de ordem social, cultural, político ou econômica à discussão publica, mas estou seguro que o papel da arte não é brindar soluções, a força transformadora da arte está na arte mesmo e não em querer fazer trabalho social ou político através dela.

. O que é hoje uma arte em uma cidade/lugar tecnocrata, desumano?

Para mim uma cidade não pode ser desumana por mais que sua realidade seja muito complexa, A arte que tenta interagir com essas realidades é mais uma reação aos estímulos que vem daquela estimulação urbana.

- Você teve retorno das pessoas que passam por lá, trabalham lá?... Algo que te marcou?

Sim tive retorno, do melhor foi dos moradores de rua que chapados pela realidade e pelos entorpecentes achavam que o trabalho mais um elemento da viagem na que eles estavam.. frases, como "que barato" são minha melhores lembranças, elas foram faladas por moradores de rua e até pelos engenheiros envolvidos no projeto. 


\section{Referências Bibliográficas}

ADORNO, Theodor W. Teoria Estética. Coimbra: Edições 70, 2008. (original de 1970).

ALEX, Sun. Água e paisagem: questões de paisagismo em torno de um reservatório de abastecimento na grande São Paulo. Dissertação de Mestrado FAU-USP, São Paulo, 1985.

ALVES, José Francisco. No limite: Obras Públicas na fronteira do Rio Grande do Sul. In: CONGRESSO INTERNACIONAL DA ASSOCIAÇÃO DE PESQUISADORES EM CRÍTICA GENÉTICA, 2010.

A especificidade da Arte Pública na $5^{\mathrm{a}}$ Bienal do Mercosul. Tese de Doutoramento Instituto de Artes UFRGS, Porto Alegre, 2011.

AMARAL, Aracy. A Arte Pública em São Paulo In: MIRANDA, Danilo S. (org.) Arte Pública. São Paulo, SESC SP, 1998, p. 46-53.

APPLETON, Jay. The experience of Landscape. London: John Wiley \& Sons, 1975.

ARCHER, Michael. Arte Contemporânea: Uma história concisa. São Paulo: Martins Fontes, 2001.

ARGAN, Giulio Carlo. História da Arte como História da Cidade. São Paulo: Martins Fontes, 1993.

ARNHEIM, Rudolf. Arte e Percepção Visual: Uma Psicologia da visão criadora. São Paulo: Ed. Pioneira, 1991.

AUGÉ, Marc. Não Lugares. Introdução a uma antropologia da supermodernidade. Campinas: Papirus, 1994

BASSANI, Jorge. As linguagens artísticas e a cidade. Cultura urbana do século XX. São Paulo: FormARTE, 2003

BEARDSLEY, John. Earthworks and Beyond: contemporary art in the landscape. NY: Abeville, 1998.

BERENSON, Bernard. Estética e História. São Paulo: Perspectiva, 1972.

BERLEANT, Arnold. The aesthetics of art and nature. In: KEMAL \& GASKELL (org.). Landscape, natural beauty and the arts. Cambridge: Cambridge University Press, 1995, p. 228-243.

BESSE, Jean- Marc. Ver a Terra: Seis ensaios sobre a geografia e a paisagem.São Paulo: Perspectiva, 2006. 
BOBERG, Jochen. About the rebirth of a new world In: STRELOW, Heike; DAVID, Vera (org.). Ecological Aesthetics. Art in Environmental Design: Theory and Practic. Berlin, Basel: Birkhäuser, 2004, p. 7-9.

BÜRGUER, Peter. Teoria da Vanguarda. Lisboa: Veja, 1993.

CARPENTER, Jonathan. Alan Sonfist's Public Sculptures. In: SONFIST, Alan (org.). Art in the Land: A Critical Anthology of Environmental Art. New York: Dutton, 1983, p. 149.

CAUQUELIN, Anne. A Invenção da Paisagem. São Paulo: Martins Fontes, 2007.

CLARK, Kenneth. Paisagem na arte. Lisboa: Ulisseia, 1961.

CORRÊA, Roberto Lobato \& ROSENDAHL, Zeny (org.) Paisagem, Tempo e Cultura. Rio de Janeiro: EdUERJ, 1998. Série Geografia Cultural, n².

COELHO, Teixeira. Moderno, Pós-Moderno.São Paulo: Iluminuras, 1995

COSGROVE, Denis. A Geografia está em toda parte: cultura e simbolismo nas paisagens humanas, 1989. In: CORREAA, Roberto Lobato \& ROSENDAHL, Zeny (org.) Paisagem, Tempo e Cultura. Rio de Janeiro: Ed. UERJ, n. 2, 1998, p. 98. (Série Geografia Cultural)

COSTA, Carlos Zibel. Além das formas: introdução ao pensamento contemporâneo no design, nas artes e na arquitetura.São Paulo: Ed. Annablume, 2010.

CRAWFORD, Donald W. Comparing natural and artistic beauty. In: KEMAL \& GASKELL. Landscape, natural beauty and the arts. Cambridge: Cambridge University Press, 1995.

D'ANGELO, Martha. Educação estética e crítica de arte na obra de Mario Pedrosa. Rio de Janeiro: Editora NAU, 2011.

FLAM, Jack. Robert Smithson: The Collected Writtings. Berkeley: University of California Press, 1996.

FERREIRA, Glória. Land art: paisagem como meio da obra de arte. In:SALGUEIRO, Heliana Angotti. Paisagem e Arte: a invenção da natureza, a evolução do olhar. São Paulo: CNPq/FAPESP/CBHA, 1999 - 2000. ; COTRIM, Cecília. Escritos dos artistas: Anos 60/70. Rio de Janeiro: Editora Zahar, 2006.

FERRIOLO, Massimo Venturi. Landscape Ethics. In: STRELOW, Heike; DAVID, Vera (org.). Ecological Aesthetics. Art in Environmental Design: Theory and Practic. Berlin, Basel: Birkhäuser, 2004, p. 16-19. 
FORTES, Hugo. Poéticas Líquidas: a água na arte contemporânea. Tese de Doutoramento ECA-USP, São Paulo, 2006.

FREDERICO, Maria Elvira B. Guarapiranga - paisagem e natureza filtradas pela cultura ou Arte e Meio Ambiente como expressão cultural, educacional, comunicacional e ecológica. Tese de Doutoramento FAU-USP, São Paulo, 1998.

FREIRE, Cristina. Espaço e Lugar: os registros da paisagem urbana na arte contemporânea, 1999. In: SALGUEIRO, Heliana Angotti. Paisagem e Arte: A invenção da natureza, a evolução do olhar. São Paulo: CNPq/FAPESP/CBHA, 1999 - 2000.

FUREGATTI, Sylvia. Arte e Meio Urbano: Elementos de formação da estética extramuros no Brasil. Tese de Doutoramento FAU-USP, São Paulo, 2007.

GOMBRICH, Ernst Hans. A história da Arte. Rio de Janeiro: Ed. Guanabara, 1988.

GOMES Filho, João. Gestalt do objeto: sistema de leitura visual da forma. São Paulo: Escrituras, 2009.

HALL, Carol. Environmental Artists: Sources and directions. In: SONFIST, Alan (org.). Art in the Land: A Critical Anthology of Environmental Art. New York: Dutton, 1983, p. 55.

HENRI, Adrian. Total art: environmetns, happenings and performance. New York: Praeger, 1974.

HOGAN, Erin. Spiral Jetta. A Road Trip throuh the Land Art of the American West. Chicago: University of Chicago Press, 2008.

HONNEF, Klaus. Arte contemporânea. São Paulo: Taschen, 1992.

KASTNER, Jeffrey; WALLIS, Brian. Land and Environmental Art. Londres: Phaidon Press, 1998.

KEMAL, Salim; GASKELL, Ivan (org.) Landscape, natural beauty and the arts. Cambridge: Cambridge University Press,1995.

KRAUSS, Rosalind E. Caminhos da escultura moderna. 2a ed. São Paulo: Martins Fontes, 2007. Texto original de 1977.

A Escultura no campo ampliado. Tradução Elizabeth Carbone Baez. Revista Gávea, Rio de Janeiro, n. 1, p. 87-93, 1984. Original: Sculpture in The Expanded Field In: The Anti-Aesthetic: Essays on PostModern Culture. Washington: Bay Press, 1979.

LEENHARDT, Jacques (org.). Nos Jardins de Burle Marx. São Paulo: Ed. Perspectiva, 1996. 
LENOBLE, Robert. História da Idéia de Natureza. Lisboa: Edições 70, 1990.

LEITE, Maria Angela Faggin Pereira. Destruição ou Desconstrução? Questões da paisagem e tendências de regionalização. São Paulo: Hucitec, 2006.

. As Tramas da Segregação: Privatização do Espaço Público. Tese de Livre-Docência FAU-USP, São Paulo, 1998.

. Natureza e cultura: paisagem, objetos e imagens. Revista Paisagem e Ambiente, São Paulo, FAU-USP, n.18, 2004.

. Natureza e cidade: rediscutindo suas relações. In: SOUZA, Maria Adélia Aparecida de (org.) Natureza e Sociedade de Hoje: uma leitura geográfica. São Paulo: HUCITEC/ANPUR, 1993.

LIMA, Catharina Pinheiro Cordeiro dos Santos. Paisagem em metamorfose: a cidade de Natal. Dissertação de Mestrado, FAU-USP, São Paulo, 1987.

LIPPARD, Lucy. Overlay contemporary art and the art of Pre-history. New York : Pantheon Books, 1983.

The lure of the local senses of place in a multicentered society. New York: New Press, 1997.

MACEDO, Silvio S. São Paulo, paisagem e habitação verticalizada: os espaços livres como elementos de desenho urbano. Tese de Doutoramento FAU-USP, São Paulo, 1988.

MARIA, Yanci Ladeira. Paisagem entre o sensível e o factual uma abordagem a partir da geografia cultura. Dissertação de Mestrado FFLCH-USP, São Paulo, 2010.

MENESES, Ulpiano Bezerra. A paisagem como fato cultural. In: YÁZIGI, Eduardo (org.) Paisagem e Turismo. São Paulo: Contexto, 2002.

MOORHOUSE, Paul; HOOKER, Denise. Richard Long. Walking the line. London: Thames\&Hudson, 2002.

MORI, Klára Kaiser. Brasil: urbanização e fronteiras. Tese de Doutoramento FAU- USP, São Paulo, 1997.

MURARI, Luciana. Tudo o mais é paisagem. Representações da Natureza na Cultura Brasileira. Tese de Doutoramento FFLCH-USP, São Paulo, 2002.

MYANAKI, Jacqueline. A paisagem no ensino de geografia: uma estratégia didática a partir da arte. Dissertação de Mestrado FFLCH-USP, São Paulo, 2003. 
NUNES, Lilian do Amaral. Derivações da Arte Pública Contemporânea. Tese de Doutoramento ECA-USP, São Paulo, 2010.

PALHARES, Taisa Helena Pascale. Modernidade, Tradição e Caráter Nacional na Obra de Alberto da Veiga Guignard. Tese de Doutoramento FFLCH-USP, São Paulo, 2010.

PALLAMIN, Vera M. Arte Urbana: Aspectos Contemporâneos. Revista Sinopses, São Paulo, n. 22, dez. 1994, p. 24-32.

PAREYSON, Luigi. Os Problemas da Estética. São Paulo: Martins Fontes, 2001.

PEDROSA, Mário. Arte ambiental, arte pós-moderna, Helio Oiticica, 1966. In: OITICICA, Hélio. Aspiro ao grande labirinto. Rio de Janeiro: Ed. Rocco, 1986.

PINHEIRO, Maria Lúcia B.; D’AGOSTINO, Mário Henrique S.. A noção do pitoresco no debate cultural das primeiras décadas do séc. XX no Brasil. Anais do XXIII Colóquio de História da Arte. Rio de Janeiro: CBHA/UERJ/UFRJ , 2004, p. 339-351.

POTTEIGER, Matthew; PURITON, Jamie. Landscape Narrative: Design Practices for Telling Stories. New York: J. Wiley, 1988.

RAMIREZ, Mari Carmen. Blueprint Circuits: Conceptual Art and Politics in Latin America. In: RAMUSSEN, Waldo; BRECHT, Fatima (ed.). Latin American Artists of the Twentieth Century. NY: Museum of Modern Art, 1993, p. 156-167.

RAMOS, Nuno. Ensaio Geral. Projetos, roteiros, ensaios, memórias. São Paulo: Ed. Globo, 2007.

RIBENBOIM, Ricardo. In: ITAÚ CULTURAL. Eixo Curatorial 98: Catálogo, São Paulo, Itaú Cultural, 1998.

RITTER, Joachim. Paisagem: Função estética na sociedade moderna. Tradução francêsportuguês Vladimir Bartalini. Texto para o uso exclusivo na disciplina da pós-graduação da FAU AUP 5882 Paisagem e Arte - Intervenções contemporâneas (original em alemão de 1963, tradução para o francês em 1997).

ROGER, Alain. O Nascimento da Paisagem no Ocidente. In: $1^{\circ}$ COLÓQUIO INTERNACIONAL DE HISTÓRIA DA ARTE, 1999. Tradução Prof. Dr. Vladimir Bartalini para disciplina AUP 5834, do curso de Pós-graduação da FAU-USP, São Paulo, 2009. In: SALGUEIRO, Helena Angotti (org.). Paisagem e Arte: a invenção da natureza, a evolução do olhar. São Paulo: CNPq/FAPESP/CBHA, 1999 - 2000. 
ROSENBERG, Harold. Time and Space Concepts in Environmental Art. In: SONFIST, Alan (org.). Art in the Land: A Critical Anthology of Environmental Art. New York: Dutton, 1983, p. 210.

ROSENTHAL, Mark. Some attitudes of Earth Art: from Competition to Adoration. In: SONFIST, Alan (org.). Art in the Land: A Critical Anthology of Environmental Art. New York: Dutton, 1983, p. 60-72.

SALGUEIRO, Helena Angotti (org.). Paisagem e Arte: a invenção da natureza, a evolução do olhar. São Paulo: CNPq/FAPESP/CBHA, 1999 - 2000.

SALZSTEIN, Sônia. Fronteiras. Rio de Janeiro: Itaú Cultural/Contra-Capa, 2005.

SAQUET, Marcos Aurélio. Abordagens e Concepções de Território. São Paulo: Editora Expressão popular, 2007.

SARAIVA, Maria da Graça Amaral Neto. O Rio como Paisagem: Gestão de corredores fluviais no quadro do ordenamento do território. Lisboa: Fundação Calouste Gulbenkian, 1999. (Coleção Textos Universitários de Ciências Sociais e Humanas).

SCHAMA, Simon. Paisagem e Memória. São Paulo: Companhia das Letras, 1996

SCHULZ, Christian Norberg. The Phenomenon of Place, 1976. In: NESBITT, Kate (org.) Uma Nova Agenda para a Arquitetura. São Paulo: Cosac\&Naify, 2008, p. 459.

SILVA, Luciana Bosco. Spiral Jetty: o sublime na obra de Robert Smithson. In: CANTON, Kátia (org.) Poéticas da Natureza. São Paulo: MAC-USP, 2009.

SILVEIRA, Flávio Leonel Abreu da Silveira. A paisagem como fenômeno complexo, relações sobre um tema interdisciplinar. In: ; CANCELA, Cristina Donza (org.). Paisagem e cultura: dinâmica do patrimônio e da memória na atualidade. Belém: UFPA, 2009, p. 71-83.

SIMMEL, Georg. Filosofia da Paisagem. Tradução Prof. Dr. Vladimir Bartalini. Para uso exclusivo da disciplina da pós-graduação AUP 5882 Paisagem e Arte, 2011. (texto original de 1913)

HEIZER, Michael; Oppenheim, Dennis; SMITHSON, Robert. Discussões com Heizer, Oppenheim, Smithson, 1970. In: FERREIRA, Glória; COTRIM, Cecília. Escritos dos artistas: Anos 60/70. Rio de Janeiro: Editora Zahar, 2006, p. 275-288

SMITHSON, Robert. A Sedimentation of the Mind: earth projects, 1968. In: FERREIRA, Glória; COTRIM, Cecília. Escritos dos artistas: Anos 60/70. Rio de Janeiro: Editora Zahar, 2006, p.184. 
SMITHSON, Robert. Um passeio pelos monumentos de Passaic, Nova Jersey. In: FARIAS, Agnaldo. Robert Smithson: o artista como viajante. Revista Espaço e Debates, São Paulo, v.23, jan/dez, p 120-128, 2003.

SONFIST, Alan (org.). Art in the Land: A Critical Anthology of Environmental Art. New York: Dutton, 1983.

SPIRN, Anne W. O Jardim de Granito. São Paulo: Edusp, 1995.

STANGOS, Nikos (org.). Conceitos da Arte Moderna. Rio de Janeiro: Jorge Zahar Editor, 2000.

STRELOW, Heike; DAVID, Vera (org.). Ecological Aesthetics: Art in Environmental Design. Theory and practice. Basel, Berlin, Boston: Birkhaüser, 2003.

TAYLOR, Joshua C. A Land for Landscapes. In: SONFIST, Alan (org.). Art in the Land: A Critical Anthology of Environmental Art. New York: Dutton, 1983, p. 1-7.

TUAN, Yi-fu. Topofilia: Um estudo da percepção, atitudes e valores do meio ambiente. São Paulo: Difel, 1980.

TUFNELL, Ben. Land Art. London: Tate Publishing, 2006.

WEILACHER, Udo. Between Landscape Architecture and Land Art. Basel, Berlin, Boston: Birkhaüser, 1999.

YÁZIGI, Eduardo (org.). Turismo e Paisagem. São Paulo: Ed. Contexto, 2002.

\section{Catálogos:}

ALVES, José Francisco. Histórias da Arte e do Espaço: Transformações do espaço público. Porto Alegre: Fundação Bienal de Artes Visuais do Mercosul, 2006. (Catálogo 5a Bienal do Mercosul) BRITO, Ronaldo; FÉLIX, Nelson; FLORIDO, Marisa. Concerto para encanto e anel. Rio de Janeiro: Susy Produções, 2011.

; CORONA, Joana; MARQUES, Rodrigo F. Eliane Prolik. Curitiba: Simões de Assis Galeria de Arte, 2011.

CANTON, Kátia. Poéticas da Natureza. Catálogo, São Paulo, MAC-USP, 2009.

CHAIMOVICH, Felipe. ECO lógica: Catálogo, São Paulo: MAM-SP. 2010. 
FAJARDO, Carlos; SALZSTEIN, Sônia. Carlos Fajardo. Poéticas da distância. São Paulo: Pinacoteca do Estado de São Paulo, 2003.

FARIAS, Agnaldo A. C. Amélia Toledo: As naturezas do artifício. São Paulo: W11, 2004.

FARKAS, Solange O. (Curadoria) Joseph Beuys. A Revolução somos nós. SESC Pompéia. Set. 15 - Nov. 28, 2010.

Frans Krajcberg: Natura. MAM-SP, de 16.10 a 14.12.2008.

GONÇALVES, Lisbeth R.; LEENHARDT, Jacques (org.). Arte Frágil. Resistências: Catálogo, São Paulo, MAC-USP, 2009.

ITAÚ CULTURAL. Ações Prospectivas. Fronteiras. Reprodução xerográfica de dados dos projetos dos artistas e fotos das obras em andamento. São Paulo, 2000. Acervo Midiateca, Itaú Cultural.

LAGO, Pedro Corrêa. Olhar Distante.A paisagem Brasileira vista pelos Grandes Artistas Estrangeiros. In: FUNDAÇÃO BIENAL DE SÃO PAULO. Olhar Distante. Mostra do Redescobrimento. Brasil +500: Catálogo, São Paulo: Fundação Bienal de São Paulo, 2000.

MIGLIACCIO, Luciano. O Século XIX In: FUNDAÇÃO BIENAL DE SÃO PAULO. Arte do Século XIX. Mostra do Redescobrimento. Brasil +500: Catálogo, São Paulo: Fundação Bienal de São Paulo, 2000.

NAVES, Rodrigo. Nelson Félix. São Paulo: Cosac\&Naify, 1998.

PINACOTECA DO ESTADO. Carmela Gross. um corpo de idéias. São Paulo: Pinacoteca do Estado, 2010.

RIBENBOIM, Ricardo. In: ITAÚ CULTURAL. Eixo Curatorial 98. São Paulo, Itaú Cultural, 1998.

\section{Bibliografia complementar:}

AMARAL, Aracy. Hélio Oiticica: tentativa de um diálogo, 1977. In: AMARAL, Aracy. Textos dos Trópicos de Capricórnio: artigos e ensaios (1980-2005). São Paulo: Editora 34, v. 3, 2006.

BATCHELOR, David. Arte Minimalista. São Paulo: Cosac\&Naify, 1999.

CANTON, Kátia (org.). Espaço e lugar. Temas da arte contemporânea. São Paulo: Martins Fontes, 2009. 
CACCIA-GOUVEIA, Isabel C. M. Da originalidade do sítio urbano de São Paulo às formas antrópicas: aplicação da abordagem da Geomorfologia Antropogênica da Bacia Hidrográfica do Rio Tamanduateí na Região Metropolitana de São Paulo. Tese de Doutoramento FFLCH-USP, São Paulo, 2010.

CASSIRER, Ernst. Ensaio sobre o homem. Introdução a uma filosofia da cultura humana. São Paulo: Martins Fontes, 1994

CHRISTOV-BAKARGIEV, Carolyn. Arte Povera. London: Phaidon Press, 1999.

FABRIS, Annateresa. Antônio Lizárraga: uma poética da radicalidade. São Paulo: Edusp, 2000.

FARIAS, Agnaldo A. C. Esculpindo o Espaço. A escultura contemporânea e a busca de novos modos de relação com o espaço. Tese de Doutoramento FAU-USP, São Paulo, 1997.

FAVARETTO, Celso Fernando. A invenção de Helio Oiticica. São Paulo: EDUSP/FAPESP, 1992.

FERREIRA, Glória. A coisa é ar. In: BRISSAC, Nelson; FERREIRA, Glória; SALZSTEIN, Sônia. Nelson Félix. Rio de Janeiro: Casa da Palavra, 2001.

FURQUIM, Laércio Jr. Fronteiras Terrestres e Marítimas do Brasil: um contorno dinâmico. Dissertação de Mestrado. FFLCH-USP, São Paulo, 2007.

JACQUES, Paola Berenstein. Estética da ginga: A arquitetura das favelas através da estética de Hélio Oiticica. 2a ed. Rio de Janeiro: Casa da Palavra, 2003.

OITICICA, Hélio. Aspiro ao grande labirinto. Rio de Janeiro: Ed. Rocco, 1986.

ROSSI, Aldo. A arquitetura da cidade. São Paulo: Martins Fontes, 1995.

VENTRELLA, Roseli; BORTOLOZZO, Sílvia. Frans Krajcberg: arte e o meio ambiente. São Paulo: Ed. Moderna, 2006.

WOOD, Paul. Arte Conceitual. São Paulo: Cosac \&Naify, 2002. 


\section{Diversos:}

\section{DVDs projeto Margem:}

ITAÚ CULTURAL. Seminário Internacional de Arte Pública: A cidade e suas margens, 16/09/2009. DVD . Seminário Internacional de Arte Pública: A cidade e suas margens, 16/09/2009. DVD IC EVE FV 485. Acervo Midiateca Itaú Cultural.

Seminário Internacional de Arte Pública: A cidade e suas margens, 17/09/2009.

DVD IC EVE FV 486. Acervo Midiateca Itaú Cultural.

Seminário Internacional de Arte Pública: A cidade e suas margens, 18/09/2009.

DVD IC EVE 487 pt.2 e FV 488 pt. 1. Acervo Midiateca Itaú Cultural.

FORTES, Hugo (org) Seminário Arte e Natureza. 8 a 9 junho, 2011. Instituto Goethe. São Paulo, 2011.

\section{Folders:}

ITAÚ CULTURAL. Margem e Seminário Internacional de Arte Pública: As Cidades e suas Margens (16 a 19/09/2009). Folder, Acervo Gráfico Itaú Cultural.

ITAÚ CULTURAL. MARGEM. Hector Zamora -Errante. 09 out. a 28.nov. Folder, Itaú Cultural, 2010.

\section{Documentos disponíveis por meio eletrônico:}

ANDRÉS, Maria Helena. Guignard, o mestre, 1996. Disponível em:

$<$ http://www.scielo.br/scielo.php?pid=S0103-40141996000300014\&script=sci_arttext $>$. Acesso em:15/05/2012.

BARTALINI, Vladimir. Arte e paisagem: uma união instável e sempre renovada. Jun. 2008. Disponível em: <www.vitruvius.com.br/revistas/read/arquitextos/09.097/133>. Acesso em: 10/05/2010

CAMPOS, Haroldo de. Tarsila, anos 20, 1997, p. 111. Disponível em: $<$ http://www.macvirtual.usp.br/mac/templates/projetos/roteiro/PDF/02.pdf >. Acesso em: 10/12/2012

CHIARELII, Tadeu. De Anita à academia: para repensar a história da arte no Brasil. Novos estudos CEBRAP, São Paulo, n. 88, dez. 2010.Disponível em: <http://www.scielo.br/scielo.php?pid=S010133002010000300007\&script=sci_arttext $>$. Acesso: 07/01/2013 
CORNELL UNIVERSITY. From Earth Art to Eco Art' marks 40th anniversary of historic Cornell exhibit. Outubro, 2008.Disponível em: < http://aap.cornell.edu/news/newsitem.cfm?customel_datapageid_2892=112900 >. Acesso em: 12/02/2013

EDUARDO SRUR.Caiaques. Março, 2009. Disponível em: $<$ http://eduardosrur.tumblr.com/post/806940635/caiaques $>$. Acesso em: 05/12/12.

FISKE, Tina; BOTINELLI, Giorgia. Tate Thames Dig. Fev. 2002. Disponível em: $<$ http://www.tate.org.uk/art/artworks/dion-tate-thames-dig-t07669/text-summary>. Acesso em:18/06/2011.

ITAÚ CULTURAL. Projeto Fronteiras: Proposta de trabalho, 1998. Disponível em: <http://www.itaucultural.org.br/fronteiras/projeto/proposta.htm>. Acesso em: 19/05/2012.

Projeto Fronteiras. Ações Prospextivas, 1998 Disponível em: http://www.itaucultural.org.br/fronteiras/pros.htm

Projeto Fronteiras. Pesquisa: Formação do Território Brasileiro, 1998 Disponível em: $<$ http://www.itaucultural.org.br/fronteiras/projeto/territorio/Divisao.htm> Acesso em: 20/06/2011.

Artes Visuais: Projeto Fronteiras é finalizado com livro: Release, 1998. Disponível em: $<$ http://www.itaucultural.org.br/index.cfm?cd_pagina=2716\&cd_noticia=5741 >. Acesso em: 19/05/2012

. Projeto Margem, 2010. Disponível em: < http://177.71.252.105/explore/artes-

visuais/projetos/hotsite/?id=61850>. Acesso em: 10/02/2013

Quase Líquido, 2008. Dismponível em: <

http://www.itaucultural.org.br/quaseliquido/index1.cfm > Acesso em 05/02/12).

KATO, Gisele. Muito Além dos Jardins, dez. 2008. Disponível em: <http://bravonline.abril.com.br>. Acesso em: abril/2011.

KRAJCBERG, Frans. Site do artista / Cronologia. Disponível em: <http://www.franskrajcberg.com/fkchronologieportugues.html>. Acesso em: 20/05/12.

LATIN ART MUSEUM. Disponível em: <http://www.latinartmuseum.com/amaral.htm>. Acesso em:09/07/2012.

LIMA, Catharina P.C. dos Santos. Natureza e cultura: o conflito de Gilgamesh. Revista Paisagem e Ambiente, São Paulo, FAU-USP, n.18, 2004. Disponível em: < $<$ http://revistasusp.br/paam/article/view/40210/43076 > cessado em: 20/06/2011.

LONGMAN, Gabriela. Carmela Gross prepara obra que “pede passagem”. Folha de São Paulo, São Paulo, 23 fev. 2006. Caderno Ilustrada. Entrevista com a artista Carmela Gross. Disponível em: <http://www1.folha.uol.com.br/fsp/ilustrad/fq2302200626.htm>. Acesso em:11/12/2012.

MATEVSKI, Nikola. Krajcberg-versus-Curitiba. Gazeta Do Povo, Curitiba, 2 set. 2006. Caderno G. Disponível em: <http://www.gazetadopovo.com.br/cadernog/conteudo.phtml?id=595705\&tit=Krajcberg-versusCuritiba>. Acesso 12/10/2012. 
OHIO HISTORICAL SOCIETY. Serpent Mound. Disponível em: <http:/ http://www.ohiohistory.org/museums-and-historic-sites/museum--historic-sites-by-name/serpent-mound $>$. Acesso em: 10/05/2011

PORTAL 200 ANOS MINISTÉRIO DA FAZENDA. Ciclo da borracha. Disponível em: <http://200anos.fazenda.gov.br/linha-do-tempo/1800-1899/1882-ciclo-da-borracha>. Acesso em: 08/07/2012

PROLIK, Eliane. Corpo escultórico. Disponível em:

<http://www.muvi.advant.com.br/artistas/e/eliane_prolik// escultura_publica.htm>. Acesso em: 20/12/12.

RASOR, Mitchell. Revisiting Hours: Robert Smithson's Passaic. Disponível em: $<$ www.mrld.net/pdfs/Smithson_by_Rasor.pdf >. Acesso em: 05/06/2010.

SCENIC HUDSON, On The Waterfront: New Sculpture Connects People with the RiverNov. 2007. Disponível em:<:http://www.scenichudson.org/whatwedo/ourtowns/beacon/trakas>Acesso em: 11/10/2012

SMITHSON, Robert. Cultural Confinement. 1972. Disponível em: <http://www.robertsmithson.com/essays/cultural.htm>. Acesso em: 15/01/2013. 


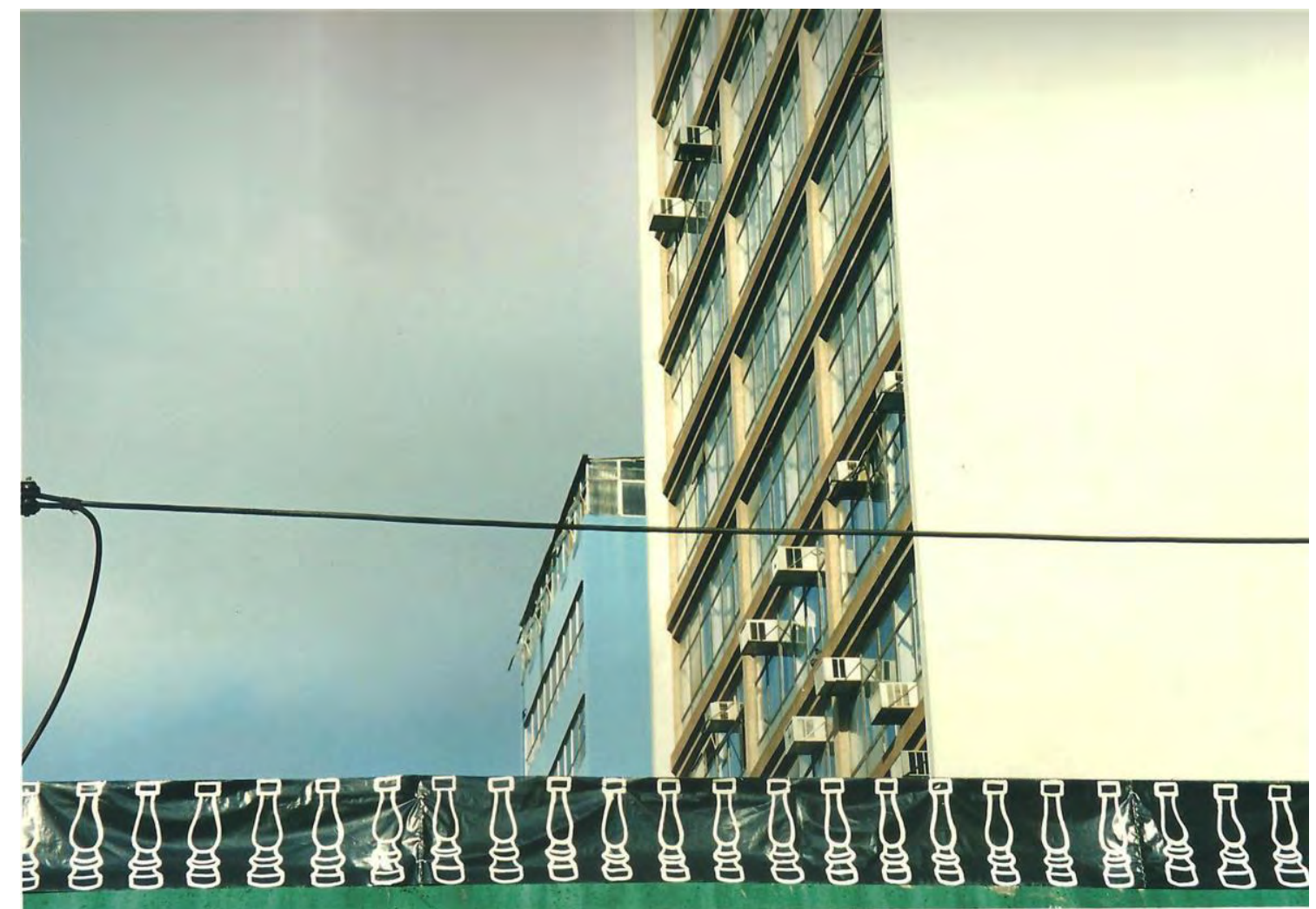

Cristiana Bernardi Isaac. Varanda-Minhocão. Rua kaguaribe, São Paulo. Março, abril 2002. Desenho s/ Iona. 0,63 x 24m.

\section{Arte e Paisagem.}

Estudo de obras contemporâneas brasileiras. 